\author{
UNIVERSIDADE DE SÃO PAULO \\ ESCOLA DE ENGENHARIA DE SÃO CARLOS \\ DEPARTAMENTO DE ENGENHARIA DE ESTRUTURAS
}

\title{
REFORÇO DE VIGAS DE CONCRETO ARMADO SUBMETIDAS A PRÉ-CARREGAMENTO E AÇÕES DE LONGA DURAÇÃO COM APLICAÇÃO DE CONCRETOS DE ALTA RESISTÊNCIA E CONCRETOS COM FIBRAS DE AÇO
}

Andréa Prado Abreu Reis

Tese apresentada à Escola de Engenharia de São Carlos da Universidade de São Paulo, como parte dos requisitos para obtenção do Título de Doutor em Engenharia de Estruturas.

Orientador: Prof. Titular João Bento de Hanai

São Carlos

2003 
Ficha catalográfica preparada pela Seção de Tratamento da Informação do Serviço de Biblioteca - EESC/USP

Reis, Andréa Prado Abreu

R375r Reforço de vigas de concreto armado submetidas a pré-carregamento e ações de longa duração com aplicação de concretos de alta resistência e concretos com fibras de aço / Andréa Prado Abreu Reis. -- São Carlos, 2003.

Tese (Doutorado) -- Escola de Engenharia de São Carlos-Universidade de São Paulo, 2003

Área : Engenharia de Estruturas.

Orientador: Prof. Titular João Bento de Hanai.

1. Vigas de concreto armado. 2. Reabilitação. 3. Reforço. 4. Fibras de aço. 5. Deformações diferidas. 6. Pré-carregamento. 7. Peças compostas. I. Título. 
A meus pais, Ronan e Leila, a minha tia Carmem e a meu irmão Ricardo que me incentivaram sempre. 


\section{AGRADECIMENTOS}

A Deus, por estar sempre presente ao meu lado, possibilitando a concretização de mais uma etapa da minha vida.

Ao Prof. João Bento de Hanai pelo inestimável incentivo, amizade, apoio e pela excelente orientação que foram fundamentais para a elaboração deste trabalho.

Aos professores Ronaldo Barros Gomes e Mounir Khalil el Debs pelas contribuições dadas no Exame de Qualificação.

Aos professores da COPPE/UFRJ, UFF e UNB que ajudaram a complementar minha pesquisa bibliográfica. Em especial ao Prof. Antonio R. Marí Bernat, da Universidade Politécnica da Catalunya, apesar de não tê-lo conhecido pessoalmente, sua atenção e disponibilidade no esclarecimento de dúvidas sobre a utilização do programa CONSNOU, usado na simulação numérica, foram indispensáveis ao bom desenvolvimento deste trabalho.

Aos técnicos do Laboratório de Estruturas pela dedicação dispensada durante a realização dos ensaios experimentais.

A FURNAS Centrais Elétricas S.A. especialmente à equipe técnica do Laboratório de Concreto desta instituição, que acreditou e apoiou este trabalho de pesquisa fornecendo toda a mão-de-obra necessária para a realização dos ensaios de longa duração requisitados.

Às firmas BELGO MINEIRA, que doou as fibras de aço, HOLDECIM CIMINAS, que doou o cimento de alta resistência inicial e MBT do Brasil, que doou o superplastificante, materiais estes utilizados na moldagem dos modelos ensaiados.

À FAPESP pela concessão da bolsa de doutorado e pelo apoio financeiro, sem o qual este trabalho não poderia ter sido realizado.

Ao amigo Adilson Roberto Takeuti, pela companhia em muitas das reflexões que contribuíram para o bom andamento deste trabalho.

Aos amigos, Anamaria M. Miotto, Vanessa Cristina de Castilho e Suzana Campana Peleteiro, pelo incentivo e paciência com que me confortaram nos momentos difíceis, tornando menos árduo o caminho a ser percorrido.

Ao Luiz Liserre, companheiro de todas as horas, pelo conforto e apoio nos momentos de dúvida e pela alegria compartilhada a cada etapa vencida.

A todos os colegas, amigos, funcionários e professores do Departamento de Engenharia de Estruturas, que contribuíram direta ou indiretamente para a realização deste trabalho de doutorado. 


\section{SUMÁRIO}

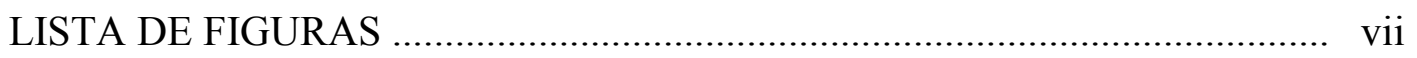

LISTA DE TABELAS ………………………………….................... xii

LISTA DE SIMBOLOS _........................................................................ xiii

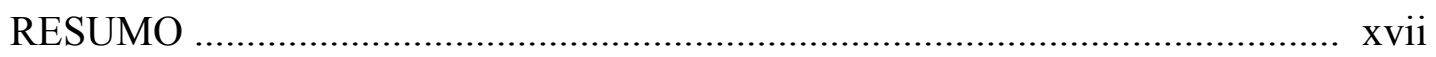

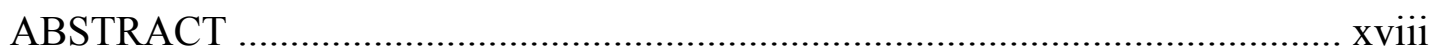

1 INTRODUÇÃO

1.1 Considerações Gerais ............................................................................. 1

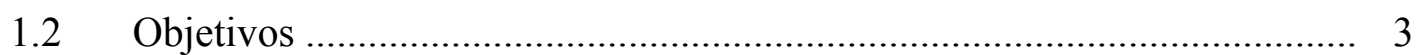

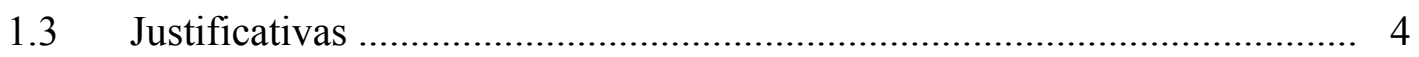

1.4 Apresentação da tese ................................................................................ 6

\section{ASPECTOS SOBRE REFORÇO DE VIGAS}

$2.1 \quad$ Considerações Gerais ............................................................................. 9

2.2 Estudos realizados por outros pesquisadores ............................................. 12

2.2.1 Estudos genéricos .................................................................. 12

2.2.2 Estudos específicos ………………………………………..... 19

2.2.2.1 Ensaios realizados por CLÍMACO (1990) ………............. 19

2.2.2.2 Ensaios realizados por PIANCASTELLI (1997) ............... 24

2.2.2.3 Ensaios realizados por REIS (1998) .................................. 34

2.2.2.4 Ensaios realizados por SÁ (1993) ………………………... 40

2.2.2.5 Ensaios realizados por SUMIE \& LOPES (2000) ............. 42

2.2.2.6 Ensaios realizados por CAMPOS (2000) ........................... 44

2.3 Metodologia usada no programa experimental desenvolvido ..................... 45

2.3.2 Descrição resumida dos ensaios principais ..................................... 45

2.3.3 Descrição resumida dos ensaios complementares ............................ 48

2.3.4 Caracterização dos materiais .......................................................... 50

\section{FUNDAMENTOS PARA O DESENVOLVIMENTO DAS TÉCNICAS DE REFORÇO PROPOSTAS}

3.1 Concreto com fibras de aço ........................................................................ 53

3.1.1 Comportamento de concretos com fibras de aço ............................... 53

3.1.2 Normas técnicas adotadas para avaliação da tenacidade .................... 55

3.1.3 Outros parâmetros usados na avaliação do desempenho de materiais

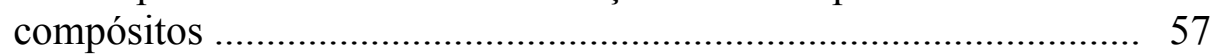

3.2 Comportamento de vigas compostas ................................................................. 61

3.2.1 Tensões de cisalhamento solicitantes e resistentes na região da junta..62

3.2.2 Avaliação dos efeitos dependentes do tempo ……………………..... 68

3.3 Efeito das fibras de aço na transmissão de esforços ............................................ 68

3.4 Deformabilidade do concreto ao longo do tempo …………………................. 70

3.4.1 Comportamento viscoelástico do concreto - formulação teórica ........ 70 
3.4.2 Análise paramétrica do comportamento viscoelástico do concreto a partir de dados experimentais

3.4.3 Tensões e deformações diferidas em vigas de concreto armado fissuradas 79

3.4.3.1 Considerações gerais 79

3.4.3.2 Procedimento de cálculo das tensões e deformações diferidas em vigas fissuradas em serviço

3.4.4 Avaliação de flechas devido aos efeitos de fluência e retração ......... 88

3.4.5 Efeito da deformabilidade ao longo do tempo em peças fletidas compostas 92

3.4.5.1 Considerações gerais 92

3.4.5.2 Procedimento para cálculo das tensões e deformações ao longo do tempo em peças de seção composta . 96

3.5 Comportamento de vigas carregadas com trechos da armadura tracionada exposta

3.5.1 Considerações adotadas na análise do comportamento 98

3.5.2 Estudos realizados por outros pesquisadores 98

3.6 Simulação Numérica - Análise teórica das vigas reforçadas 101

3.6.1 O Programa CONSNOU 104

3.6.2 Considerações sobre a simulação das vigas reforçadas VFT e VFC.. 111

4 ENSAIOS COMPLEMENTARES AO ESTUDO DA TÉCNICA DE REFORÇO N ${ }^{\circ} 1$

4.1 Ensaios de flexão em prismas 116

4.1.1 Características dos modelos ensaiados ......................................... 116

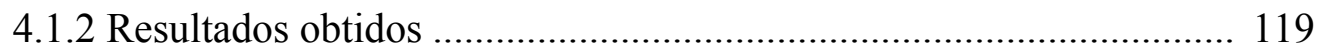

4.1.3 Análise dos resultados ................................................................. 124

4.2 Ensaios de vigas retangulares ................................................................. 128

4.2.1 Características dos modelos ensaiados ......................................... 128

4.2.2 Caracterização dos materiais .......................................................... 131

4.2.3 Moldagem das vigas e esquema de ensaio ..................................... 132

4.2.4 Apresentação e análise dos resultados ............................................. 134

4.3 - Conclusões parciais dos ensaios complementares ........................................ 144

5 VIGAS T REFORÇADAS NO BORDO TRACIONADO

5.1 Características das vigas (dimensões, detalhamento e instrumentação) .......... 147

5.2 - Caracterização dos materiais ............................................................... 150

5.3 - Moldagem, escarificação, cura e esquema de ensaio .................................. 151

5.4 - Apresentação e análise dos resultados ......................................................... 155

5.4.1 - Fissuração, capacidade portante e modo de ruptura ..................... 155

5.4 .2 - Deslocamentos verticais ...................................................... 159

5.4 .3 - Deslocamentos horizontais ...................................................... 162

5.4 .4 - Deformação do concreto .......................................................... 165

5.4.5 - Deformação das armaduras ......................................................... 166

5.5 - Dificuldades encontradas ...................................................................... 174 


\section{ENSAIOS COMPLEMENTARES AO ESTUDO DA TÉCNICA DE REFORÇO N ${ }^{\circ} 2$}

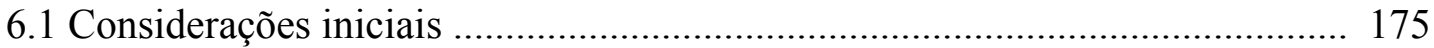

6.2 Ensaios realizados em FURNAS Centrais Elétricas S.A. ............................. 177

6.2.1 Ensaio para determinar a deformação por fluência e a deformação por retração autógena .................................................................. 178

6.2.2 Ensaios de retração por secagem ................................................. 185

6.2.3 Ensaios de compressão axial, de tração por compressão diametral e determinação do módulo de elasticidade .......................................... 188

6.2.4 Ensaios para determinação do coeficiente de dilatação térmica

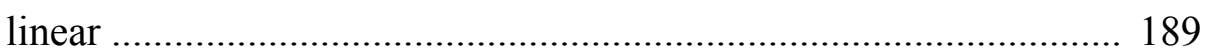

6.3 Análise dos resultados da deformabilidade do concreto ................................ 191

6.3.1 Resultados fornecidos pelo ajuste das curvas experimentais ............ 192

6.3.2 Resultados fornecidos pelas formulações teóricas ........................... 199

6.4 Conclusões parciais sobre a deformabilidade do concreto ............................... 204

\section{VIGAS T REFORÇADAS NO BORDO COMPRIMIDO}

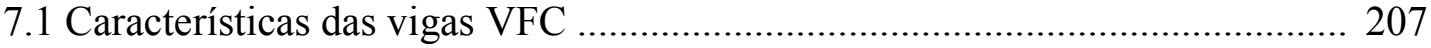

7.1.1 Dimensões, detalhamento e instrumentação usada nos modelos ....... 208

7.1.2 Sistema usado na aplicação do pré-carregamento por meio de

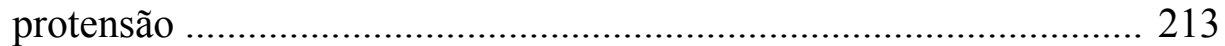

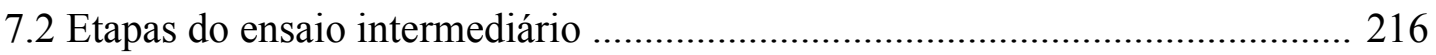

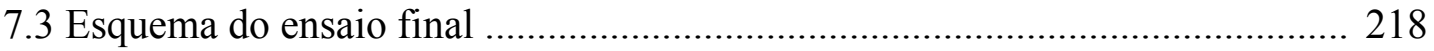

7.4 Caracterização dos materiais ......................................................................... 219

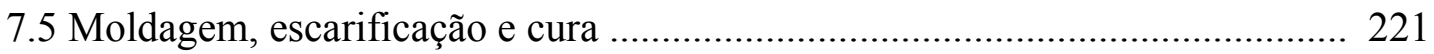

7.6 Apresentação e análise dos resultados ......................................................... 223

7.6.1 Ensaio intermediário (carregamento de longa duração) ................... 223

7.6.1.1 Esquema de fissuração ..................................................... 226

7.6.1.2 Deslocamentos verticais ................................................... 227

7.6.1.3 Deformações do concreto ................................................. 231

7.6.1.4 Deformações da armadura comprimida ............................ 240

7.6.1.5 Deformações da armadura tracionada ................................. 241

7.6.1.6 Deformações da armadura transversal ............................... 243

7.6.2 Ensaio final (carregamento de curta duração) .................................. 243

7.6.2.1 Fissuração, capacidade portante e modo de ruptura ............ 244

7.6.2.2 Deslocamentos verticais ................................................... 246

7.6.2.3 Deslocamentos horizontais na região da junta .................... 250

7.6.2.4 Deformações do concreto ................................................... 252

7.6.2.5 Deformações da armadura comprimida ............................. 258

7.6.2.6 Deformações da armadura tracionada ................................. 261

7.6.2.7 Deformações da armadura transversal ................................ 264

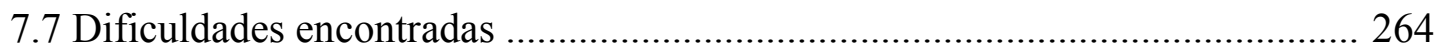




\section{CONCLUSÕES}

8.1 Sobre as técnicas de reforço de vigas por meio de adição de concreto e o comportamento geral dos ensaios experimentais realizados

8.2 Sobre os ensaios complementares ao estudo da Técnica de Reforço $\mathrm{n}^{\circ} 1$........ 267

8.3 Sobre o comportamento das vigas reforçadas pela Técnica de Reforço $\mathrm{n}^{\mathrm{o}} 1$... 269

8.4 Sobre os ensaios complementares ao estudo da Técnica de Reforço $\mathrm{n}^{\circ} 2$........ 271

8.5 Sobre o comportamento das vigas reforçadas pela Técnica de Reforço $\mathrm{n}^{\circ} 2 \ldots 272$

8.6 Sugestões para pesquisas futuras .......................................................... 274

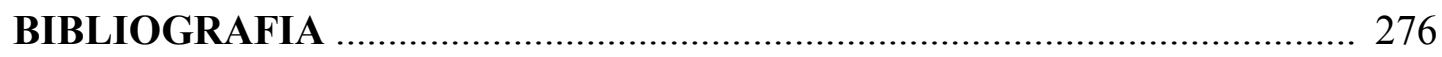

APÊNDICE A - Resultados dos ensaios dos prismas de argamassa com fibras

APÊNDICE B - Resultados dos ensaios das vigas retangulares - séries 1 e 2

APÊNDICE C - Resultados dos ensaios das vigas reforçadas no bordo tracionado

APÊNDICE D - Resultados dos ensaios realizados em Furnas Centrais Elétricas SA

APÊNDICE E - Resultados dos ensaios das vigas reforçadas no bordo comprimido 


\section{LISTA DE FIGURAS}

Figura 1.1 - Técnicas de reforço das vigas estudadas ..................................... 5

Figura 1.2 - Técnicas de reforço por adição de armadura tracionada ................ 5

Figura 2.1 - Reforço mediante adição de concreto com ou sem armadura ......... 10

Figura 2.2 - Reforço mediante colagem de chapas de aço ............................... 11

Figura 2.3 - Reforço por colagem de lâminas flexíveis de fibras de carbono .... 11

Figura 2.4 - Reforço de vigas por meio de protensão exterior ........................... 11

Figura 2.5 - Deformações de peça composta por materiais com módulos de elasticidade diferentes (ROCHA, 1997) ...................................... 15

Figura 2.6 - Estados de tensão e deformação em uma viga reforçada sob

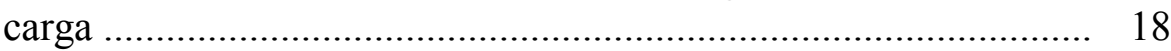

Figura 2.7 - Esquema de reforço realizado por CLÍMACO (1990) .................. 21

Figura 2.8 - Gráfico da viga V11 ensaiada por CLÍMACO (1990) .................. 24

Figura 2.9 - Detalhamento das seções longitudinais das vigas ensaiadas por PIANCASTELLI (1997) ....................................................... 26

Figura 2.10 - Detalhamento das seções transversais das vigas ensaiadas por PIANCASTELLI (1997) ......................................................... 27

Figura 2.11 - Gráfico carga x flecha (séries 3 e 5) com o pré-carregamento ....... 28

Figura 2.12- Gráfico momento x curvatura (séries 3 e 5) com o pré-carregamento ................................................................... 29

Figura 2.13 - Gráfico carga x flecha (séries 3 e 5) sem o pré-carregamento ....... 29

Figura 2.14- Gráfico momento x curvatura (série 3 e 5) sem o pré-carregamento ................................................................... $\quad 30$

Figura 2.15 - Vigas ensaiadas por REIS (1998) ............................................. 36

Figura 2.16 - Esquema de fissuração e ruptura - vigas ensaiadas por REIS (1998) ............................................................... 37

Figura 2.17- Força $\mathrm{x}$ deslocamento vertical das vigas ensaiadas por REIS ....... 37

Figura 2.18 - Gráficos das deformações das armaduras das vigas ensaiadas

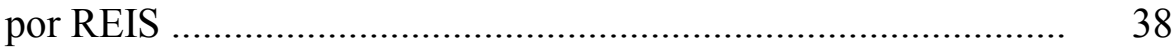

Figura 2.19- Seção transversal das vigas ensaiadas por SÁ ............................. 41

Figura 2.20 - Seção transversal das vigas ensaiadas por SUMIE \& LOPES ....... 43

Figura 2.21 - Esquema das técnicas de reforço estudadas - ensaios principais ... 47

Figura 2.22 - Esquema dos ensaios complementares de vigas retangulares ........ 49

Figura 3.1 - Efeito das fibras na distribuição de tensões na seção transversal de uma peça sujeita a flexão (NUNES, 1998) .............................. 54

Figura 3.2 - Tensões normais e cisalhantes (CLÍMACO, 1990) ....................... 64

Figura 3.3 - Esquema de treliça modificada após a reabilitação da peça ........... 69 


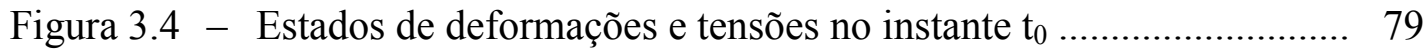

Figura 3.5 - Estados de deformações e tensões no instante $t$............................ 80

Figura 3.6 - Variação das tensões normais no concreto no decorrer do tempo .. 80

Figura 3.7 - Nomenclatura utilizada na formulação apresentada ..................... 82

Figura 3.8 - Distribuição de tensões e deformações em vigas fissuradas ........... 83

Figura 3.9 - Exemplo de análise das tensões e deformações ao longo do tempo 88

Figura 3.10 - Esquema estático usado para avaliar as flechas ............................ 89

Figura 3.11 - Comportamento de longa duração em vigas (MURCIA, 2000) ...... 92

Figura 3.12 - Deformações de retração e fluência em peças compostas................ 94

Figura 3.13 - Aumento da flecha devido à retração . ......................................... 94

Figura 3.14 - Seção das vigas ensaiadas por JOHAN SILFWERBRAND (1997) 95

Figura 3.15 - Distribuição das tensões e deformações em uma seção composta considerando as diferenças dos módulos de elasticidade ............... 97

Figura 3.16 - Comportamento de viga com trecho de armadura exposto ............ 99

Figura 3.17 - Tipos de ruptura em vigas com armadura tracionada exposta ........ 100

Figura 3.18 - Esquema de fissuração para vigas com e sem barras de aço

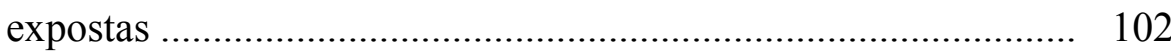

Figura 3.19 - Elemento finito de barra utilizado no programa CONSNOU ......... 106

Figura 3.20 - Equação constitutiva do concreto adotada pelo CONSNOU ......... 107

Figura 3.21 - Equação constitutiva da armadura passiva .................................... 108

Figura 3.22 - Discretização longitudinal usada na simulação das vigas VFT ...... 113

Figura 3.23 - Discretização transversal usada na simulação das vigas VFT ........ 113

Figura 3.24 - Discretização longitudinal usada na simulação das vigas VFC ...... 115

Figura 3.25 - Discretização transversal usada na simulação das vigas VFC ........ 115

Figura 4.1 - Ensaio dos prismas de concreto com fibras ................................... 118

Figura 4.2 - Variação das resistências x volume de fibras obtidas a partir de corpos-de-prova cilíndricos $10 \mathrm{~cm}$ x $20 \mathrm{~cm}$............................. 120

Figura 4.3 - Variação da resistência x volume de fibras obtidas em corpos-de-prova prismáticos .................................................... 122

Figura 4.4 - Índices de tenacidade de acordo com a norma ASTM C1018 ........ 123

Figura 4.5 - Fator de tenacidade $\left(\mathrm{f}_{\mathrm{ct}, \mathrm{eq}}\right)$ de acordo com a norma JSCE ............... 123

Figura 4.6 - Esquema de fissuração e ruptura dos prismas ................................ 124

Figura 4.7 - Seção longitudinal das vigas preliminares VP .............................. 130

Figura 4.8 - Seção transversal das vigas preliminares VP ................................. 131

Figura 4.9 - Fotos da escarificação e do esquema de ensaio das vigas VP .........134

Figura 4.10 - Esquema de fissuração e ruptura das vigas tipo VP ....................... 135

Figura 4.11 - Ganho de resistência em função do volume e tipo de fibra-série 1.138 
Figura 4.12- Ganho de resistência em função do volume e tipo de fibra-série 2.138

Figura 4.13 - Gráfico das flechas nas vigas da série 1 e série 2 .......................... 140

Figura 4.14 - Deformação do concreto e das barras de aço (vigas da série 1)....... 142

Figura 4.15 - Deformação do concreto e das barras de aço (vigas da série 2)....... 143

Figura 5.1 - Dimensões, armaduras e instrumentação das vigas VFT ................ 149

Figura 5.2 - Posicionamento do poliestireno na VFT-1 antes de sua moldagem e esquema de demolição do trecho tracionado da viga VFT-2 ….... 153

Figura 5.3 - Moldagem do reforço e aplicação do pré-carregamento na VFT-1. 154

Figura 5.4 - Esquema de fissuração das vigas antes e após o reforço ................. 157

Figura 5.5 - Gráfico da variação do pré-carregamento nas vigas VFT ................ 158

Figura 5.6 - Evolução da flecha total no meio do vão ...................................... 159

Figura 5.7 - Evolução da flecha até a força de serviço das vigas VFT ................ 161

Figura 5.8 - Variação das flechas até a força de serviço descontando-se o pré-carregamento de $50 \mathrm{kN}$................................................ 162

Figura 5.9 - Deformação do concreto no bordo mais comprimido ...................... 165

Figura 5.10 - Estados de tensão e deformação em uma viga reforçada ................ 167

Figura 5.11 - Evolução da deformação das barras de aço tracionadas .................. 170

Figura 5.12 - Comportamento real x comportamento teórico das vigas VFT ...... 171

Figura 5.13 - Deformação da armadura comprimida ......................................... 172

Figura 5.14 - Deformação da armadura transversal ............................................ 174

Figura 6.1 - Disposição dos equipamentos no interior da câmara climatizada construída no Laboratório da EESC- USP.................................... 175

Figura 6.2 - Tela principal do sistema SIMPLE Ambiental (software para coleta e controle das condições ambientais da câmara climatizada) .......... 176

Figura 6.3 - Fixação dos extensômetros Carlson e do disco metálico ................. 180

Figura 6.4 - Corpos-de-prova selados e aparelhagem usada na aplicação e manutenção de carga nos ensaios de fluência

Figura 6.5 - Função fluência para várias idades de aplicação do carregamento . 184

Figura 6.6 - Evolução da deformação por retração autógena em função do tempo para os traços analisados ............................................... 185

Figura 6.7 - Fôrma usada na moldagem dos prismas de 15 x 15 x 60 ................ 186

Figura 6.8 - Gráfico da deformação de retração por secagem dos traços ........... 187

Figura 6.9 - Evolução da resistência à compressão ao longo do tempo ............ 189

Figura 6.10 - Evolução do módulo de elasticidade dos traços analisados ............. 189

Figura 6.11 - Deformações imediatas experimentais e estimadas a partir da parcela elástica da função fluência ................................................ 195

Figura 6.12 - Curva da fluência específica $x$ idade $t_{0}$ (TS-2) ...............................196

Figura 6.13 - Curva da fluência específica $x$ idade $t_{0}$ (TR-2) ............................... 196 
Figura 6.14- Evolução dos parâmetros $\mathrm{a}\left(\mathrm{t}_{0}\right), \mathrm{b}\left(\mathrm{t}_{0}\right)$ e c $\left(\mathrm{t}_{0}\right)$ do traço do substrato.. 197

Figura 6.15 - Evolução dos parâmetros $\mathrm{a}\left(\mathrm{t}_{0}\right), \mathrm{b}\left(\mathrm{t}_{0}\right)$ e c $\left(\mathrm{t}_{0}\right)$ do traço do reforço ... 197

Figura 6.16- Exemplo de curvas da função fluência dadas pela formulação paramétrica interpoladas às curvas da função fluência experimentais... 198

Figura 6.17- Retração teórica x experimental para o substrato (traço TS-2) ...... 200

Figura 6.18 - Retração teórica x experimental para o reforço (traço TR-2) ......... 200

Figura 6.19- Função fluência para $t_{0}=7$ dias (traço TS-2) ................................. 201

Figura 6.20 - Função fluência para $t_{0}=14$ dias (traço TS-2) ............................. 202

Figura 6.21 - Função fluência para $t_{0}=50$ dias (traço TS-2) .............................. 202

Figura 6.22 - Função fluência para $t_{0}=103$ dias (traço TS-2) ............................ 202

Figura 6.23 - Função fluência para $t_{0}=7$ dias (traço TR-2) .............................. 203

Figura 6.24 - Função fluência para $t_{0}=14$ dias (traço TR-2) ............................. 203

Figura 6.25 - Função fluência para $t_{0}=126$ dias (traço TR-2) ........................... 203

Figura 6.26 - Função fluência para $t_{0}=176$ dias (traço TR-2) ........................... 204

Figura 7.1 - Dimensões das vigas VFC ....................................................... 209

Figura 7.2 - Detalhamento das armaduras das vigas VFC ............................... 210

Figura 7.3 - Instrumentação ao longo das vigas VFC ...................................... 211

Figura 7.4 - Instrumentação na seção transversal ............................................. 212

Figura 7.5 - Sistema de aplicação de carregamento de longa duração usual ...... 213

Figura 7.6 - Sistema de aplicação do pré-carregamento por protensão ............... 214

Figura 7.7 - Cordoalha não aderente usada na protensão das vigas VFC ...........2215

Figura 7.8 - Jogo de cunha, porta-cunha e desviador ..................................... 215

Figura 7.9 - Detalhe do bloco de ancoragem ............................................... 215

Figura 7.10 - Esforços gerados pela aplicação da protensão ............................... 216

Figura 7.11 - Esquema de ensaio das vigas VFC .............................................. 219

Figura 7.12 - Poliestireno fixado na extremidade da peça antes do reforço ........ 221

Figura 7.13 - Detalhes do reforço do bordo comprimido da viga ........................ 222

Figura 7.14 - Etapas do ensaio a partir dos gráficos em função do tempo ........... 223

Figura 7.15 - Evolução da força vertical nas peças ensaiadas .............................. 225

Figura 7.16- Gráficos da umidade e temperatura em função do tempo ............... 225

Figura 7.17 - Esquema de fissuração durante o pré-carregamento da VFC-1 ...... 226

Figura 7.18 - Esquema de fissuração durante o pré-carregamento da VFC-3 ...... 227

Figura 7.19 - Flechas totais e diferidas na viga VFC-1 ….................................. 229

Figura 7.20 - Flechas totais e diferidas na viga VFC-3 .................................... 230

Figura 7.21 - Tensões e deformações teóricas obtidas pelo CONSNOU na VFC-1 
Figura 7.22 - Tensões e deformações teóricas obtidas pelo CONSNOU na VFC-3

Figura 7.23 - Evolução das deformações do concreto e microconcreto da VFC-1

Figura 7.24 - Evolução das deformações do concreto e microconcreto da VFC-3

Figura 7.25 - Evolução das deformações experimentais ao longo da seção transversal do elemento no meio do vão 239

Figura 7.26 - Evolução da deformação das armaduras comprimidas 241

Figura 7.27 - Deformação da armadura longitudinal tracionada (meio do vão) ...242

Figura 7.28 - Força vertical total aplicada nos ensaios de curta duração .............. 244

Figura 7.29 - Panorama geral de fissuração das vigas VFC ................................. 245

Figura 7.30 - Detalhe da ruptura da VFC-1 (semelhante às demais vigas) .......... 246

Figura 7.31 - Deslocamentos verticais (flechas) ............................................. 248

Figura 7.32 - Comparação entre as flechas experimentais e as simuladas ........... 249

Figura 7.33 - Deslocamentos horizontais relativos entre o material do substrato e o material de reforço para a região da junta

Figura 7.34 - Comparação entre as deformações reais do substrato e do reforço. 253

Figura 7.35 - Deformação no concreto do substrato - seção do meio do vão ...... 254

Figura 7.36 - Deformação no microconcreto do reforço - seção do meio do vão. 255

Figura 7.37 - Tensões e deformações teóricas do substrato e do reforço .............. 257

Figura 7.38 - Deformação na armadura longitudinal comprimida ....................... 259

Figura 7.39 - Deformação na armadura longitudinal comprimida ........................ 260

Figura 7.40 - Deformação na armadura longitudinal tracionada ......................... 262

Figura 7.41 - Estimativa numérica da deformação da armadura tracionada .........263 


\section{LISTA DE TABELAS}

Tabela 2.1 - Características das vigas ensaiadas por CLIMACO (1990) 22

Tabela 2.2 - Características das vigas ensaiadas por PIANCASTELLI (1997) ... 25

Tabela 2.3 - Características das vigas ensaiadas por REIS (1998)

.................... 35

Tabela 2.4 - Características do concreto e da argamassa de reforço no dia do ensaio ........................................................................ 35

Tabela 2.5 - Resultados das vigas ensaiadas por REIS (1998) _........................ 35

Tabela 2.6 - Média dos resultados das vigas ensaiadas por SÁ (1993) .............. 41

Tabela 2.7 - Resultados das vigas ensaiadas por LOPES \& SUMIE (2000) ........ 43

Tabela 2.8 - Relação dos traços usados no programa experimental .................. 51

Tabela 2.9 - Dosagens dos traços usados no programa experimental ................ 51

Tabela 2.10- Características das fibras usadas na fabricação de compósitos 52

Tabela 3.1 - Tipos de transferência de esforços de cisalhamento em juntas 62

Tabela 4.1 - Resistências características médias para cada material compósito .. 119

Tabela 4.2 - Parâmetros relativos às fibras em função dos traços usados 120

Tabela 4.3 - Parâmetros calculados de acordo com a norma JSCE SF-4 121

Tabela 4.4 - Índices de tenacidade e fatores de resistência calculados pelas normas ASTM C1018 e JSCE SF-4

Tabela 4.5 - Resistência dos concretos e argamassas usados nas vigas VP ........ 132

Tabela 4.6 - Características das armaduras usadas nas vigas VP (série 2) ..........132

Tabela 4.7 - Forças de ruptura e tipo de ruptura das vigas VP ........................ 136

Tabela 5.1 - Características das vigas T ensaiadas no bordo tracionado ...............147

Tabela 5.2 - Características das vigas ensaiadas .............................................. 150

Tabela 5.3 - Propriedades mecânicas dos traços usados nas vigas VFT ............. 151

Tabela 5.4 - Propriedades mecânicas das armaduras usadas nas vigas VFT ....... 151

Tabela 5.5 - Pré-carregamento aplicado nas vigas VFT durante o reforço .......... 158

Tabela 5.6 - Avaliação das tensões tangenciais na região da junta ..................... 163

Tabela 6.1 - Expressões matemáticas das curvas experimentais ajustadas 192 
Tabela 6.2 - Equações matemáticas ajustadas através das curvas experimentais para determinação da função fluência dos traços analisados 194

Tabela 6.3 - Parâmetros da fluência específica para cada idade de aplicação de carregamento em função dos traços analisados

Tabela 7.1 - Resumo das características das vigas ensaiadas

Tabela 7.2 - Etapas do ensaio intermediário realizado nas vigas VFC 217

Tabela 7.3 - Características do concreto e do microconcreto de reforço 220

Tabela 7.4 - Características mecânicas da armadura ativa ................................... 220

Tabela 7.5 - Características mecânicas da armadura passiva .............................220

Tabela 7.6 - Evolução da força vertical aplicada em função do tempo ................224

Tabela 7.7 - Valores experimentais das flechas totais e diferidas aos 100 dias ... 231

Tabela 7.8 - Força de serviço e força de ruptura 245

Tabela 7.9 - Avaliação das tensões tangenciais na região da junta 251

\section{LISTA DE SÍMBOLOS}

\section{- Letras romanas maiúsculas}

$\mathrm{A}_{\mathrm{c}} \quad$ - área da seção de concreto resistente;

A homo - área da seção de concreto homogeneizada;

$\mathrm{A}_{\mathrm{sl}}^{\prime} \quad$ - área de aço da armadura longitudinal comprimida ou do porta-estribo;

$\mathrm{A}_{\mathrm{sl}} \quad$ - área de aço da armadura longitudinal tracionada passiva;

$\mathrm{A}_{\mathrm{sw}} \quad$ - área de aço da armadura transversal (estribos);

$\mathrm{E}_{\mathrm{co}} \quad$ - módulo de elasticidade tangente do concreto;

$\mathrm{E}_{\mathrm{c}} \quad$ - módulo de elasticidade secante do concreto na idade de análise t;

$\mathrm{E}_{\mathrm{ci}} \quad$ - módulo de elasticidade secante do concreto aos 28 dias;

$\mathrm{E}_{\mathrm{s}} \quad$ - módulo de elasticidade do aço;

$\mathrm{F}_{\text {hd }} \quad$ - força horizontal solicitante de cálculo;

I $\quad$ - momento de inércia da seção transversal;

$\mathrm{I}_{\mathrm{e}} \quad$ - momento de inércia equivalente;

$\mathrm{I}_{\mathrm{N}} \quad$ - índice de tenacidade determinado em função de múltiplos da flecha medidas

em ensaios de prismas de concreto para determinação da resistência à tração na flexão;

$\mathrm{I}_{\mathrm{I}} \quad$ - momento de inércia referente ao Estádio I; 
$\mathrm{I}_{\mathrm{II}} \quad$ - momento de inércia referente ao Estádio II;

$\mathrm{I}_{\mathrm{x}} \quad$ - momento de inércia da seção homogeneizada de concreto;

$\mathrm{J}\left(\mathrm{t}, \mathrm{t}_{0}\right)$ - função fluência;

$\mathrm{C}\left(\mathrm{t}, \mathrm{t}_{0}\right)$ - fluência específica;

M - momento fletor;

$\mathrm{R}_{\mathrm{cc} 2}$ - força de compressão no concreto moldado no local $\left(\mathrm{R}_{\mathrm{cc} 2}=0,85 \cdot \mathrm{f}_{\mathrm{cd}} \cdot \mathrm{A}_{\mathrm{c} 2}\right)$;

$\mathrm{R}_{\mathrm{cc}} \quad$ - força total de compressão na seção composta;

$\mathrm{R}_{\mathrm{a}, \mathrm{b}}$ - fator residual de resistência em relação aos valores de referência a e b;

$\mathrm{R}_{\mathrm{e}, 3}$ - fator de tenacidade determinado conforme recomendações da norma JSCE-SF4;

$\mathrm{S} \quad$ - momento estático; fator de espaçamento das fibras de aço;

$\mathrm{T}_{\mathrm{b}} \quad$ - tenacidade à flexão medida através das recomendações da JSCE-SF4;

$\mathrm{V}$ - esforço cortante atuante na seção analisada;

$\mathrm{V}_{\mathrm{f}} \quad$ - volume de fibras de aço no material compósito;

\section{- Letras romanas minúsculas}

$\mathrm{a}_{\mathrm{v}} \quad$ - distância entre os pontos de momento máximo e momento nulo;

b - largura da seção transversal na fibra em estudo; largura da viga;

$b_{\mathrm{f}} \quad$ - largura da mesa da viga de seção T;

$b_{\mathrm{w}} \quad$ - largura da alma da viga de seção T;

d - diâmetro da fibra de aço;

d' $\quad$ - altura útil da armadura comprimida em relação à fibra de concreto mais comprimida da viga;

$\mathrm{d}_{1}, \mathrm{~d}_{2}$ - altura útil das barras de aço longitudinal tracionadas respectivamente da primeira e segunda camadas em relação à fibra de concreto mais comprimida da viga;

$\mathrm{f}_{\mathrm{c}} \quad$ - resistência média à compressão do concreto;

$\mathrm{f}_{\mathrm{cd}} \quad$ - resistência de cálculo do concreto à compressão;

$\mathrm{f}_{\mathrm{cj}} \quad$ - resistência média do concreto à compressão na idade de $\mathrm{j}$ dias;

$\mathrm{f}_{\mathrm{ck}} \quad$ - resistência característica do concreto antigo à compressão em $\mathrm{MPa}$;

$\mathrm{f}_{\mathrm{ck}, \mathrm{c}} \quad$ - resistência característica do concreto medida em corpos-de-prova cúbicos;

$\mathrm{f}_{\mathrm{ct}, \mathrm{m}} \quad$ - resistência do concreto à tração na flexão;

$\mathrm{f}_{\mathrm{k}} \quad$ - valor característico das resistências dos materiais usadas na estrutura;

$\mathrm{f}_{\mathrm{t}} \quad$ - resistência média à tração do concreto;

$\mathrm{f}_{\mathrm{y}} \quad$ - resistência característica à tração do aço;

$\mathrm{f}_{\mathrm{yd}} \quad$ - resistência de cálculo do aço à tração;

h $\quad$ - altura total da viga antes do reforço; 
$\mathrm{h}_{\mathrm{f}} \quad$ - altura da mesa da viga de seção $\mathrm{T}$;

$h_{\mathrm{r}} \quad$ - espessura total do material de reforço adicionado à seção das vigas;

$h_{1} \quad$ - diferença entre a altura total " $h$ " e a altura da mesa " $h_{f}$ " da viga de seção T;

$\mathrm{h}_{2} \quad$ - posição da junta formada pela ligação entre o substrato e o reforço das vigas reabilitadas no bordo tracionado em relação à fibra de concreto mais comprimida;

$\mathrm{h}_{3}, \mathrm{~h}_{4}$ - parcela da espessura do reforço executado no bordo tracionado das vigas correspondente respectivamente à parte que não alterava a altura da viga em relação à altura original ' $h$ ' e à parte referente ao acréscimo da altura da viga após a execução do reforço;

$\mathrm{h}_{5} \quad$ - altura total da viga após o reforço;

- comprimento da fibra; comprimento do vão teórico entre apoios de vigas;

s $\quad$ - deslizamento relativo entre duas superfícies em contato;

$\mathrm{s}_{\mathrm{V}} \quad$ - espaçamento vertical entre os eixos das barras de aço longitudinais tracionadas;

x - altura da zona comprimida; Altura da linha neutra;

$\mathrm{x}_{\mathrm{e}} \quad$ - posição da linha neutra equivalente;

$\mathrm{x}_{\mathrm{I}} \quad$ - posição da linha neutra para o Estádio I;

$\mathrm{x}_{\mathrm{II}} \quad$ - posição da linha neutra para o Estádio II;

$\mathrm{Z}_{1} \quad$ - braço de alavanca da armadura inicial devido $\mathrm{M}_{\mathrm{g}}$;

$\mathrm{z}_{2} \quad$ - braço de alavanca da armadura inicial devido $\mathrm{M}_{\mathrm{q}}$;

$\mathrm{Z}_{3} \quad$ - braço de alavanca da armadura inicial devido $\mathrm{M}_{\mathrm{q}}$ e $\mathrm{M}_{\mathrm{g}}$;

$\mathrm{Z}_{\mathrm{r}} \quad$ - braço de alavanca da armadura do reforço;

\section{- Letras gregas minúsculas}

$\alpha_{e} \quad$ - relação entre os módulos de elasticidade do aço e do concreto;

$\alpha_{c} \quad$ - relação entre os módulos de elasticidade de concretos moldados em idades diferentes;

$\beta_{1}$ e $\beta_{2}$ - coeficientes multiplicadores da resistência que dependem da armadura e da superfície de contato, fornecidos pela FIP;

$\delta \quad-$ deslocamento vertical (flechas) de estruturas fletidas;

$\varepsilon_{\mathrm{c}} \quad$ - deformação específica do concreto à compressão;

$\varepsilon_{\mathrm{d}} \quad$ - deformação recuperável retardada;

$\varepsilon_{\mathrm{e}} \quad$ - deformação recuperável instantânea;

$\varepsilon_{\mathrm{s}} \quad$ - deformação específica do aço;

$\varepsilon_{\mathrm{t}} \quad$ - deformação residual;

$\varepsilon_{\mathrm{cc}}\left(\mathrm{t}, \mathrm{t}_{\mathrm{o}}\right)$ - deformação por fluência do concreto referente ao intervalo de tempo t-t $\mathrm{t}_{\mathrm{o}}$; 
$\varepsilon_{\mathrm{ci}}\left(\mathrm{t}_{\mathrm{o}}\right)$ - deformação elástica imediata;

$\varepsilon_{\mathrm{cs}}\left(\mathrm{t}, \mathrm{t}_{\mathrm{s}}\right)$ - deformação por retração;

$\varepsilon_{\mathrm{cT}}\left(\mathrm{t}, \mathrm{t}_{\mathrm{s}}\right)$ - deformação por variação térmica;

$\phi\left(t, t_{0}\right)$ - coeficiente de fluência do concreto referente ao intervalo de tempo $t-t_{0}$;

$\gamma_{c} \quad$ - coeficiente de minoração da resistência do concreto;

$\gamma_{\mathrm{f}} \quad$ - coeficientes de segurança relativos às ações na estrutura;

$\gamma_{\mathrm{m}} \quad$ - coeficientes de segurança relativos às características resistentes dos materiais respectivamente;

$\lambda \quad$ - fator de forma da fibra;

$\tau_{\mathrm{Rd}}$ - tensão de cisalhamento resistente de cálculo na interface formada por materiais cimentícios moldados em idades distintas;

$\tau_{\mathrm{Sd}} \quad$ - tensão de cisalhamento solicitante na interface formada por materiais cimentícios moldados em idades distintas;

$\tau_{\mathrm{u}} \quad$ - tensão de cisalhamento última na interface;

$\sigma_{\mathrm{c}} \quad$ - tensão normal de compressão no concreto;

$\sigma_{0} \quad$ - tensão correspondente ao surgimento da primeira fissura observada nos ensaios de prismas para determinação da resistência à tração na flexão;

$\sigma_{\mathrm{u}} \quad$ - módulo ou tensão de ruptura dos prismas ensaiados para determinação da resistência à tração na flexão;

$\sigma_{\mathrm{s}} \quad$ - tensão normal de tração na armadura;

- abreviaturas

ABNT - Associação Brasileira de Normas Técnicas;

ACI - Norma americana - American Concrete Institute;

ASTM - Norma americana - American Society for Testing and Materials;

BS - Norma britânica - British Standard;

CAD - Concreto de alto desempenho;

CEB - Commite Euro-International du Beton;

CFA - Concreto com fibras de aço;

EESC - Escola de Engenharia de São Carlos;

FAPESP - Fundação de Amparo à Pesquisa do Estado de São Paulo;

FIP - Federal Internationale de la Precontrainte;

JSCE - Norma Japonesa - Japan Society of Civil Engineers;

NBR - Norma Brasileira;

PCI - Prestressed / Precast Concrete Institute;

TR - Traço do reforço; 


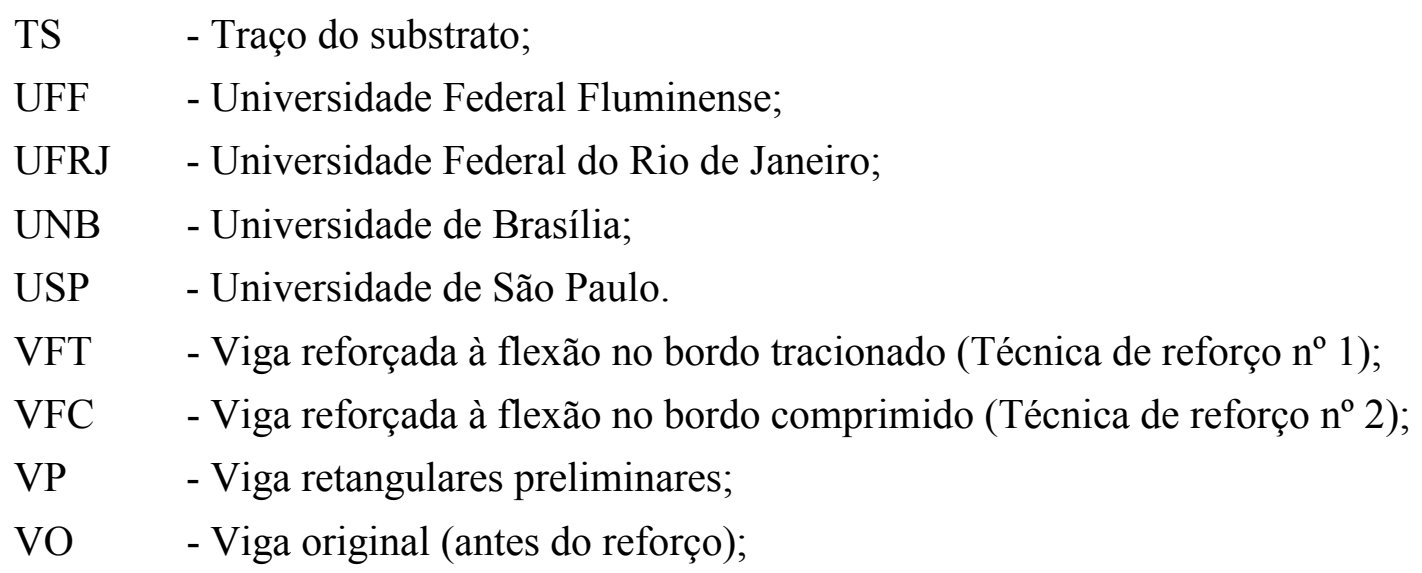




\section{RESUMO}

REIS, A. P. A. (2003). Reforço de vigas de concreto armado submetidas a précarregamento e ações de longa duração com aplicação de concretos de alta resistência e concretos com fibras de aço. São Carlos, 286p. Tese (Doutorado) - Escola de Engenharia de São Carlos, Universidade de São Paulo.

Neste trabalho estudou-se o reforço de vigas " $T$ " de concreto armado tanto por meio de adição de armadura longitudinal ao bordo tracionado envolvida por um material compósito (argamassa com fibras curtas de aço), quanto pela aplicação de uma capa de pequena espessura de microconcreto de alta resistência ao bordo comprimido. Para estudar as possibilidades da aplicação prática destas duas técnicas de reforço avaliou-se o comportamento das vigas reabilitadas verificando a influência: da atuação de um pré-carregamento durante a execução do reforço, das deformações diferidas diferenciais (fluência e retração) existentes entre os materiais novos e antigos e, dos mecanismos de resistência mobilizados na transmissão de esforços na junta - formada pela ligação do substrato ao concreto do reforço - ou entre as barras de aço tracionadas preexistentes e adicionadas em função da ausência de estribos envolvendo-as. Para redimensionar as peças reforçadas no bordo tracionado foram realizados ensaios complementares para identificar, dentre as várias fibras disponíveis comercialmente, qual a que proporcionaria ao material compósito, um confinamento suficiente que evitasse a ruptura prematura da viga pela tendência de deslizamento relativo entre as barras de aço tracionadas devida à ausência de estribos neste local. Para redimensionar as peças reforçadas no bordo comprimido realizou-se ensaios complementares para determinar as propriedades viscoelásticas dos materiais usados no substrato e no reforço, tornando possível estimar as descontinuidades geradas nos estados de tensão e deformação ao longo do tempo já que tais materiais são moldados e submetidos a carregamentos em idades distintas. Os resultados dos ensaios das vigas reforçadas de seção $\mathrm{T}$ foram analisados e comparados com previsões teóricas feitas a partir da adaptação de métodos analíticos convencionais recomendados por norma para estruturas novas, e a partir de simulações numéricas usando um programa computacional baseado no método dos elementos finitos. Do estudo realizado foi possível: comprovar a eficiência das técnicas de reforço propostas estando as peças submetidas ou não a um pré-carregamento durante a execução da intervenção, compatibilizar alguns dos conhecimentos teóricos existentes a fim de poder usá-los na análise teórica das vigas reabilitadas, além de reunir uma série de informações úteis que podem ser exploradas na definição de estratégias e procedimentos de projeto de estruturas reabilitadas semelhantes.

Palavras chaves: vigas de concreto armado, reabilitação, reforço, fibras de aço, deformações diferidas, pré-carregamento, peças compostas. 


\begin{abstract}
REIS, A. P. A. (2003). Strengthening of reinforced concrete beams subjected to preloading forces and long-term loads: application of high strength concrete and steel fiber reinforced concrete. São Carlos, 286p. Thesis (PhD). School of Engineering at São Carlos, University of São Paulo.
\end{abstract}

This paper reports on the results of a study about the behavior of reinforced concrete T-beams rehabilitated using two different techniques. The first technique consists of the addition of longitudinal reinforcement embedded in a steel fiber reinforced highperformance mortar at the bottom face of the member. The second technique consists of rehabilitation by adding a thin overlay of high-strength concrete to the compression zone. The parameters analyzed to verify the possibilities of practical applications of these techniques were: the effect of a pre-loading acting on the beams during their rehabilitation, the differential time-dependent deformations (creep and shrinkage) between the new concrete and existing base, the mechanisms of resistance mobilized along the interface formed by old and new concrete or between preexistent steel bars and added steel bars that are not involved by stirrups. Previous tests were carried out to make it possible to redesign the intervention adequately. Theses tests yield useful information about which type and volume of steel fibers need to be added to composite mortar to avoid the premature rupture of the strengthened beam caused by relative slipping between the layers of steel tensioned bars. These tests also give information about the viscoelastic properties of the materials used to manufacture the T-beams. The test results were analyzed and compared with the results of analytic models and numeric models based on the method of the finite elements. Based on this study, it can be stated that the proposed techniques are really efficient even if the beams are submitted to a pre-loading during the process of rehabilitation. Also, existing theoretical knowledge was organized to support the theoretical analysis of the rehabilitated beams, besides gathering useful information that can be explored in the definition of strategies and procedures of similar projects of rehabilitated structures.

Keywords: reinforced concrete beams, rehabilitation, strengthening, steel fibers, timedependent deformations, long-term loading, pre-loading, composite elements, 


\section{1 - Introdução}

\subsection{Considerações Gerais}

Até há relativamente pouco tempo, considerava-se que as estruturas de concreto armado poderiam ser eternas, ou seja, que elas ofereciam uma perspectiva de vida útil que extrapolava todas as previsões de longo prazo. Entretanto, sabe-se hoje que elas podem tornar-se inadequadas ao uso em prazo relativamente curto. Dentre os motivos capazes de provocar tal degradação ou inadequação ao uso podese citar erros de projeto e de execução, utilização indevida da estrutura, ausência de manutenção, danos acidentais (incêndios ou colisões) e outros. Além destes fatores, as mudanças de uso, como por exemplo aquelas que acarretam aumento dos esforços solicitantes, também podem gerar a necessidade de reabilitação da estrutura.

Como forma de sanar os problemas existentes constata-se, nos últimos anos, um grande aumento no número de estudos direcionados à reabilitação de elementos estruturais com objetivo de melhorar o conhecimento sobre o seu comportamento. Entretanto, apesar deste ramo da Engenharia estar se desenvolvendo com relativa rapidez, os profissionais ainda contam apenas com técnicas baseadas na experiência empírica acumulada. Isto ocorre porque os processos de reabilitação apresentam, em sua maioria, um caráter artesanal e particular, pois cada problema enfrentado tem características próprias. Além disto, não existe uma metodologia específica de análise do comportamento estrutural da peça reabilitada nem diretrizes que orientem o projetista durante o processo de redimensionamento e reprojeto. Portanto, apesar de várias obras terem sido reabilitadas com sucesso, ainda existem vários fatores que merecem ser investigados para avaliar melhor o comportamento após a intervenção.

No campo dos elementos estruturais de concreto armado sujeitos à flexão como as vigas, que são o objeto principal do presente trabalho, pode-se dizer que 
existe um considerável número de investigações concluídas, sendo grande parte delas de caráter experimental. Todavia, ainda há muitas questões a serem respondidas e, sobretudo, conhecimentos existentes a serem compatibilizados e sistematizados. Para confirmar esta relativa "carência" de conhecimento sobre o comportamento de estruturas reforçadas fez-se, ao dar início a este trabalho, a seguinte pergunta:

Quais são as lacunas de conhecimento, ou seja, o que ainda não se sabe e o que está ou parece incompleto a respeito do reforço estrutural de elementos sujeitos à flexão?

Com este questionamento estabeleceu-se, a priori, algumas premissas como referências iniciais e portanto consideradas como o ponto de partida do trabalho. Tais premissas estão descritas a seguir:

- Existe um significativo conhecimento empírico sobre técnicas de reabilitação de estruturas de concreto, em que predominam dados sobre a escolha de materiais e as técnicas de execução.

- Faltam informações sobre o comportamento conjunto dos materiais (material original, material de reparo, material de reforço, material de substituição, etc.), a variação de suas propriedades ao longo do tempo (retração e fluência do concreto, módulo de elasticidade, fluência do aço, etc.), os campos de tensões no material original e no reparo ou reforço (em particular na interface), a ordem de carregamento, etc.

- Existe a possibilidade de desenvolvimento de métodos de análise que se incorporem ao conhecimento empírico existente.

- Existe a possibilidade de elaboração de estratégias e projetos de reabilitação com maior confiabilidade.

A partir destas premissas desenvolveu-se o trabalho de busca de novas informações, de esclarecimento de dúvidas, de produção de novos dados, etc., e a confirmação ou não dessas próprias premissas. Diante disto procurou-se definir o conjunto de parâmetros a serem abordados, estabelecendo-se como área principal de 
estudo o reforço de vigas devido à ação do momento fletor ${ }^{1}$ por meio de adição de concreto/argamassa e armadura.

\subsection{Objetivos}

Diante da 'carência' de conhecimento observada e da necessidade permanente de racionalização e melhoria da confiabilidade na definição de estratégias de reabilitação e no projeto tecnológico (conjugando a análise estrutural com os procedimentos de seleção de materiais, processos de execução, etc.) no campo do reforço estrutural, estabeleceu-se como objetivo principal, elaborar subsídios para o estabelecimento de estratégias, métodos e procedimentos de projeto para a reabilitação de estruturas de concreto, particularmente no que se refere ao reforço de elementos estruturais sujeitos à flexão combinada com cisalhamento. Como objetivos específicos, foram selecionados os seguintes aspectos:

- Avaliação da eficiência de duas técnicas de reforço de vigas ao momento fletor e a forma de torná-las mais confiáveis para solucionar um caso específico.

- Estudo do comportamento conjunto dos diferentes materiais presentes nas peças reabilitadas e o estabelecimento de referências para o estudo de situações similares.

- Identificação dos mecanismos de resistência e da transferência de esforços entre a região recuperada e o substrato através de investigação experimental e analítica do comportamento da interface concreto novo/concreto antigo e do uso de concreto com fibras de aço.

- Estudo das descontinuidades provocadas pelo reforço nos estados de tensão e deformação da estrutura em função das deformações dependentes do tempo tais como a retração e fluência, na região recuperada e no elemento estrutural como um todo. Estes fatores podem alterar a eficiência do reforço, pois a estrutura a ser reabilitada normalmente já foi submetida a carregamentos que geram deformações enquanto que os materiais utilizados no reforço ainda não sofreram estes tipos de solicitações e acomodações.

- Análise do efeito de ações já atuantes (pré-carregamento) na peça durante a execução da reabilitação.

\footnotetext{
${ }^{1} \mathrm{O}$ reforço de vigas devido à ação do esforço cortante não foi abordado neste trabalho.
} 
Portanto, pretendeu-se elaborar estudos que possibilitassem avaliar o comportamento estrutural de peças fletidas durante e após o processo de reabilitação, bem como indicar os processos de dimensionamento, indicar novas alternativas para reabilitação de estruturas e aprimorar algumas das técnicas de uso corrente.

Devido ao elevado número de variáveis que interferem nos processos de reforço estudados foram estabelecidas algumas limitações de abrangência, especialmente quanto ao número de situações analisadas experimentalmente.

\subsection{Justificativas}

Como a reabilitação de estruturas é um campo bastante complexo e de muitas alternativas, selecionou-se duas técnicas de reforço de vigas (ver Figura 1.1) para serem estudadas mais aprofundadamente.

$\mathrm{Na}$ primeira, denominada Técnica de reforço $n^{o} 1$, tenta-se aumentar a resistência ao momento fletor da viga adicionando-se mais barras de aço ao banzo tracionado da peça e posteriormente envolvendo-as com argamassa de alto desempenho com ou sem fibras de aço. Na segunda, denominada Técnica de reforço $n^{\circ} 2$, realiza-se a intervenção na viga mediante aumento da altura da seção transversal acrescentando-se uma camada de microconcreto à face superior (banzo comprimido). Em ambos os casos aumenta-se a capacidade resistente do banzo e também o braço de alavanca do momento resistente e, conseqüentemente, a capacidade portante da viga.

Optou-se pelo estudo de técnicas de reforço executadas adicionando-se concreto armado ou simples aos elementos estruturais porque no Brasil são justamente o concreto e outros produtos à base de cimento os principais materiais empregados na Construção Civil. Portanto, a realização de pesquisa e a formação de recursos humanos na área de reabilitação das estruturas de concreto são de grande importância e capazes de produzir reflexos econômicos imediatos.

No caso do estudo de reforço de vigas mediante adição de armadura convencional ao banzo tracionado envolvidas por concreto, apesar da técnica empregada carregar consigo algum inconveniente devido ao aumento das dimensões do elemento a ser reforçado e por precisar de um certo tempo para que o concreto 
adicionado adquira a resistência necessária antes de entrar em serviço, este é um dos métodos mais empregados no Brasil. Mesmo assim, constata-se que ainda são necessários estudos teóricos e experimentais para avaliar melhor o comportamento de peças reforçadas por estes métodos.

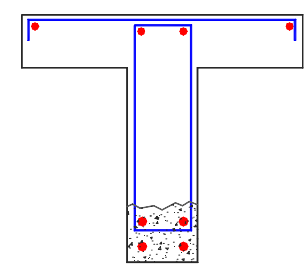

(a) Reforço $n^{\circ} 1$ - bordo tracionado

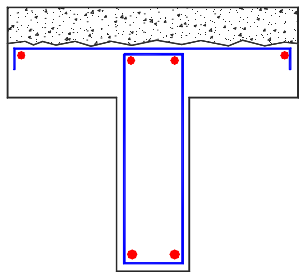

(b) Reforço $n^{\circ} 2$ - bordo comprimido

Figura 1.1 - Técnicas de reforço das vigas estudadas

Todavia, deve-se esclarecer que a técnica ${ }^{2}$ aqui analisada difere da usada na prática, pois nela se substituem os estribos, que deveriam ser adicionados ao bordo tracionado da viga a fim de envolver a nova armadura de tração, por uma argamassa de alta resistência com fibras de aço. O novo conceito aqui explorado refere-se à reconstituição do banzo tracionado na forma de compósito com fibras de aço. Os estribos existentes permanecem ancorados nesse banzo e a ruptura interna por cisalhamento longitudinal é evitada pela adição adequada de fibras de aço.

O uso desta técnica pode ser vantajosa pois facilita a reconstituição do banzo tracionado, já que não é preciso escarificar nem aumentar a largura da seção transversal da peça a ser reabilitada para alocar novos estribos (ver Figura 1.2).

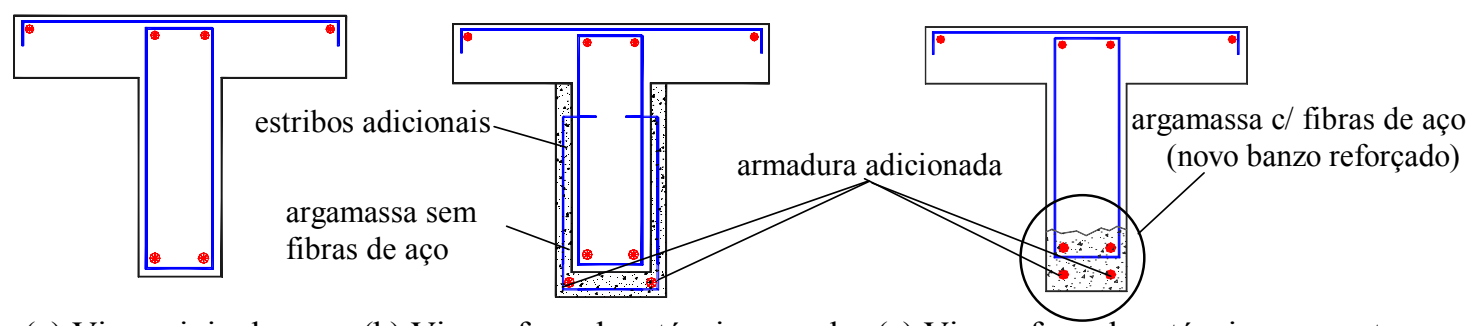

(a) Viga original

(b) Viga reforçada - técnica usual

(c) Viga reforçada - técnica proposta

Figura 1.2 - Técnicas de reforço por adição de armadura tracionada

\footnotetext{
2 Peças reforçadas por esta técnica já foram ensaiadas por REIS (1998) e os resultados de tais ensaios estão apresentados no Capítulo 2.
} 
Quanto ao estudo do reforço de vigas adicionando-se uma camada de microconcreto ao banzo comprimido, acredita-se que os resultados permitirão avaliar melhor a conveniência do uso de concretos de alta resistência no reforço de vigas e lajes, já que neste caso tal atributo de alto desempenho é explorado de modo mais efetivo. Isto não ocorre nos reforços executados no banzo tracionado devido à fissuração do concreto adicionado. Além disso, este tipo de reforço pode ser uma nova opção para se reforçar painéis pré-moldados tipo $\pi$ ou vigas de pontes, podendo ser estendido ao caso de reforço de lajes com capas de pequena espessura. Quanto à preocupação em não descaracterizar arquitetonicamente o ambiente, pode-se considerar que boa parte das edificações possui um contrapiso do pavimento da ordem de $4 \mathrm{~cm}$, espaço este que poderá ser usado para realizar tal reforço de maneira que o acréscimo em sua seção transversal (com concreto de alta resistência) seja menos problemático. Além disso, este estudo também é importante para esclarecer como as tensões se redistribuem na seção transversal de um elemento reabilitado por tal técnica. Estas tensões são muito influenciadas pelos efeitos de retração e fluência, sendo essencial este conhecimento para a realização de um dimensionamento adequado do elemento estrutural.

Outra justificativa para o estudo destes dois tipos de reforço é que ambos podem ser realizados simultaneamente em uma única peça devendo-se, contudo, verificar a resistência ao cisalhamento do elemento.

\subsection{Apresentação da tese}

Para alcançar os objetivos pretendidos neste trabalho foi necessário ter conhecimentos sobre assuntos bastante distintos. Por isso optou-se por descrever, de maneira sucinta, a metodologia empregada para o desenvolvimento desta pesquisa.

a) Realização de uma pesquisa bibliográfica analisando-se os principais trabalhos sobre reforços de vigas e os métodos de avaliação do comportamento estrutural de peças reabilitadas;

b) Estudo de assuntos aparentemente independentes da área de reabilitação de estruturas, mas que se correlacionavam com a área pesquisada tais como: efeito da presença de fibras de aço em elementos fletidos, avaliação da deformabilidade ao longo do tempo 
(fluência e retração) em vigas compostas, tipos de mecanismos de resistência mobilizados na transferência de esforços em peças monolíticas e compostas, e outros temas complementares;

c) Realização de ensaios complementares específicos destinados à avaliação de determinadas características necessárias para se ter um melhor entendimento do comportamento das vigas reforçadas pelas técnicas propostas;

d) Realização de ensaios de modelos físicos em escala real representando situações de reforços de vigas de seção $\mathrm{T}$ de forma a tentar obter uma validação das técnicas propostas para uso prático;

e) Análise dos dados experimentais de maneira a avaliar o potencial que as técnicas de reforço empregadas proporcionaram à estrutura a ser reabilitada;

f) Realização de análise teórica baseada em métodos analíticos simplificados utilizando os dados experimentais obtidos;

g) Avaliação dos resultados efetivamente alcançados em função dos dados experimentais obtidos e das conclusões estabelecidas comparando-as com os objetivos inicialmente propostos.

Dentro deste contexto o corpo do trabalho está dividido da seguinte forma:

No Capítulo 2 são descritos os principais conceitos e aspectos a respeito da execução e avaliação do comportamento de vigas reforçadas à ação do momento fletor. Descrevem-se ensaios realizados por outros pesquisadores, tecendo-se comentários sucintos sobre os resultados encontrados por cada um deles. Apresenta-se também, de maneira bastante resumida, o programa experimental referente às duas técnicas de reforço propostas que foi realizado no Laboratório de Estruturas da EESC-USP.

No Capítulo 3 aborda-se vários temas que nem sempre se relacionam diretamente com a questão do reforço estrutural. Entretanto foi com base nestes estudos que se tentou prever e avaliar teoricamente o comportamento das peças reforçadas pelas técnicas propostas.

No Capítulo 4 descreve-se ensaios complementares em prismas de argamassa e em vigas retangulares de pequenas dimensões. Tais ensaios foram necessários para identificar os principais mecanismos de resistência mobilizados e as características das fibra de aço mais adequadas a serem usadas nas vigas de seção $\mathrm{T}$ reabilitadas pela Técnica de Reforço ${ }^{0} 1$. 
Os ensaios das vigas $\mathrm{T}$ reabilitadas por intervenção no bordo tracionado conforme a Técnicas de Reforço $\mathrm{n}^{0} 1$ são apresentados mais detalhadamente no Capítulo 5. Neste descreve-se os resultados obtidos e as análises dos elementos, fazendo-se comentários sobre as principais dificuldades encontradas durante a realização desta parte do programa experimental.

No Capítulo 6 são abordados os ensaios complementares feitos em vários tipos de corpos-de-prova no Laboratório de Concreto de Furnas Centrais Elétricas SA., localizado em Aparecida de Goiânia - GO. Tais ensaios foram necessários para caracterizar experimentalmente a deformabilidade ao longo do tempo dos materiais usados na confecção das vigas reabilitadas pelo bordo comprimido (Técnica de reforço $n^{\circ} 2$ ).

No Capítulo 7 descreve-se os ensaios das vigas T reabilitadas por intervenção no bordo comprimido conforme a Técnica de Reforço $\mathrm{n}^{\mathrm{o}} 2$, os resultados obtidos e as análises do comportamento deste tipo de elemento estrutural. Tece-se também comentários sobre as principais dificuldades encontradas durante o planejamento e desenvolvimento destes ensaios.

No Capítulo $\boldsymbol{8}$ apresenta-se as conclusões obtidas a partir dos estudos realizados na revisão bibliográfica e pela análise dos resultados experimentais. Compara-se os objetivos propostos com os atingidos e a viabilidade de aplicação práticas das duas técnicas de reforço propostas dentro das limitações de abrangência do trabalho. Neste capítulo também são propostos alguns temas de estudo para trabalhos futuros. Logo após lista-se a Bibliografia consultada e coloca-se os Apêndices $\boldsymbol{A}$ a $\boldsymbol{E}$, nos quais se apresenta em forma de tabelas e gráficos, todos os dados experimentais coletados nos ensaios realizados no Laboratório de Estruturas da USP de São Carlos e nos ensaios realizados no Laboratório de Concreto de FURNAS Centrais Elétricas SA. 


\section{2 - Aspectos sobre reforço de vigas}

\subsection{Considerações Gerais}

Para entender melhor alguns conceitos utilizados na área de Patologia $e$ Terapia de Estruturas e o tipo de intervenção a que a estrutura está sendo submetida, apresentam-se as seguintes definições:

- Avaliação: processo de verificação das condições físicas e ambientais, das características mecânicas, e do desempenho efetivo de uma estrutura.

- Durabilidade: é a aptidão de uma construção em desempenhar as funções para as quais foi concebida durante um determinado período de tempo, sem que, para isso, sejam necessários gastos imprevistos para manutenção e reabilitação.

- Reparo: é a correção localizada de problemas patológicos.

- Recuperação: é a correção dos problemas patológicos de forma a restituir total ou parcialmente o desempenho original da peça.

- Reforço: é a correção de problemas patológicos com aumento da resistência ou ampliação da capacidade portante da estrutura.

- Reabilitação ou Intervenção: abrange situações em geral, envolvendo tanto o reparo simples, como a recuperação e o reforço. Sendo assim, pode ser definida com sendo a ação necessária para habilitar a estrutura a cumprir novamente suas funções originais ou habilitar a estrutura a responder a novas condições de uso.

No presente trabalho aborda-se especificamente o estudo de vigas de concreto armado reforçadas, ou seja, que tiveram sua capacidade portante aumentada. O aumento da capacidade portante de vigas pode ser alterada em função de basicamente três tipos de esforços solicitantes: o momento fletor, o esforço cortante e o esforço de torção. Entretanto, conforme já mencionado no Capítulo 1, será analisado neste trabalho exclusivamente o comportamento de vigas reforçadas à ação 
do momento fletor. Dentre as principais técnicas de reforço de elementos à ação do momento fletor (ver figuras 2.1 a 2.4 ) pode-se citar:

a) Reforço mediante adição de concreto simples ou armado, moldado ou projetado;

b) Reforço por adição de chapas e perfis metálicos;

c) Reforço por colagem de lâminas de compósito de fibras de carbono;

d) Reforço por protensão exterior.
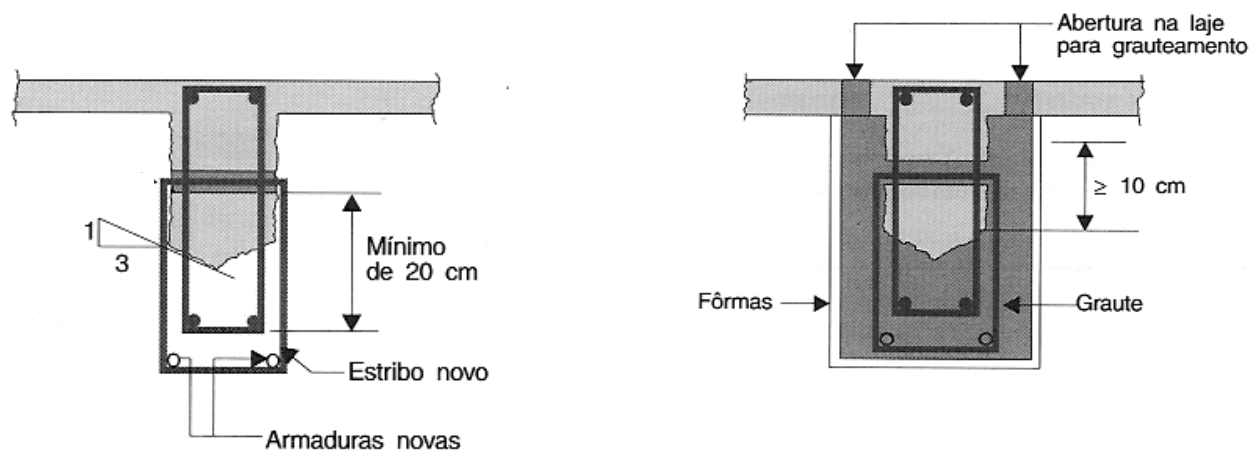

(a) reforço por adição de armadura convencional (bordo tracionado)
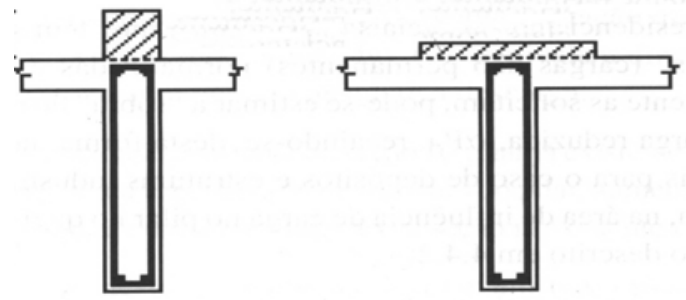

(b) reforço por aumento da altura h com concreto (bordo comprimido)

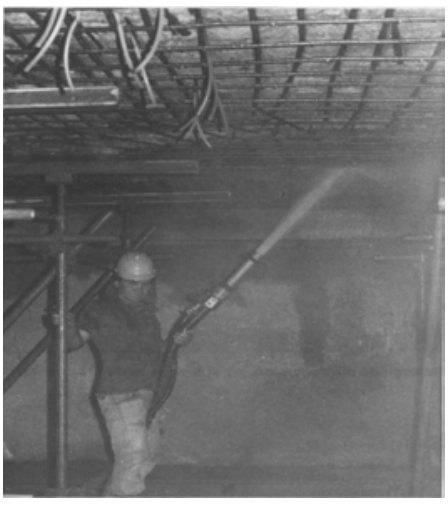

(c) reforço com concreto projetado

Figura 2.1 - Reforço mediante adição de concreto com ou sem armadura na peça 

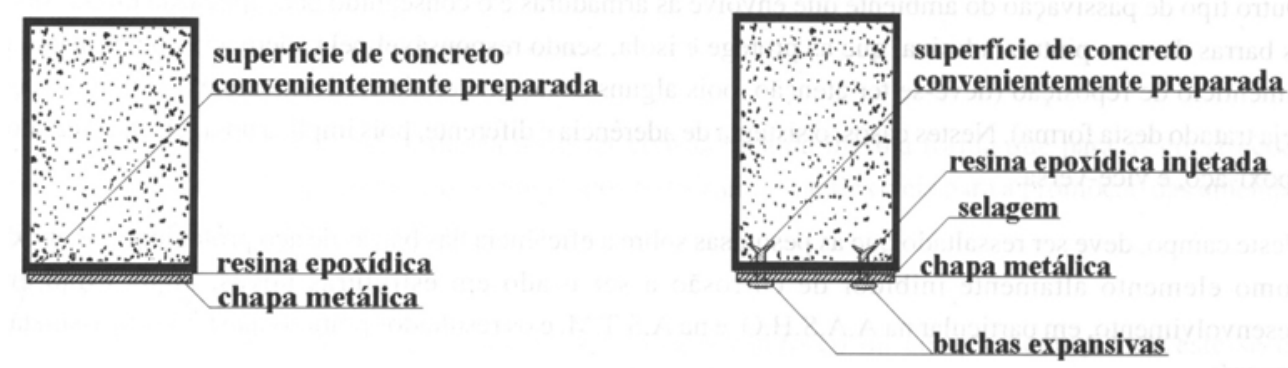

Figura 2.2 - Reforço mediante colagem de chapas de aço

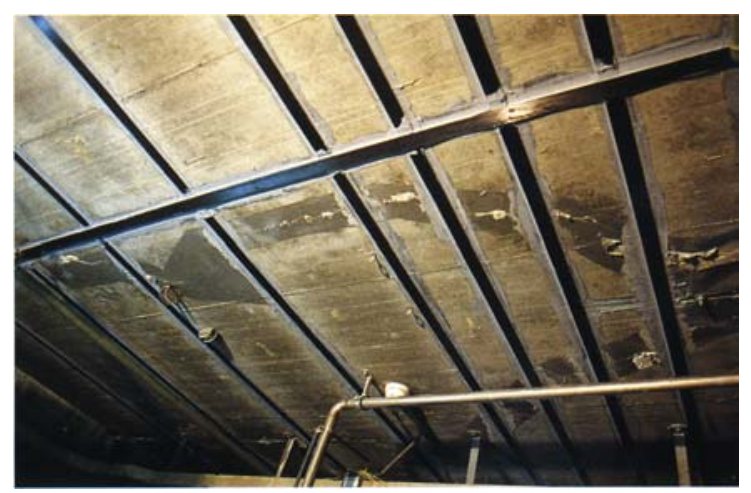

Figura 2.3 - Reforço por colagem de lâminas flexíveis de fibras de carbono

Cabo de protensão usado no reforço de viga $\mathrm{T}$

Desviador usado para mudar a direção do cabo de protensão

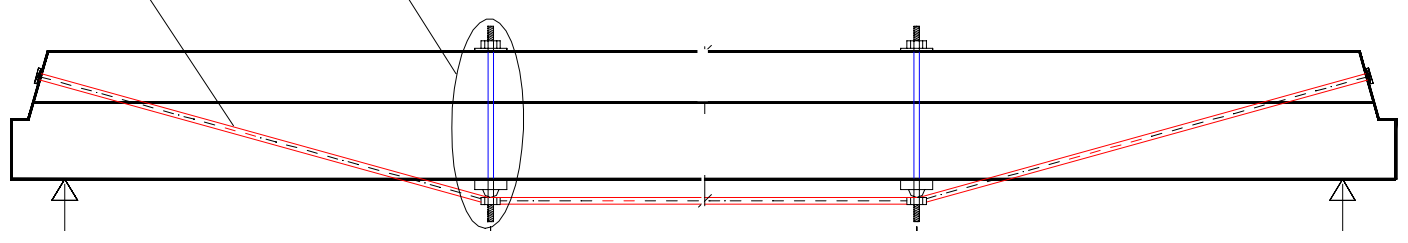

seção longitudinal

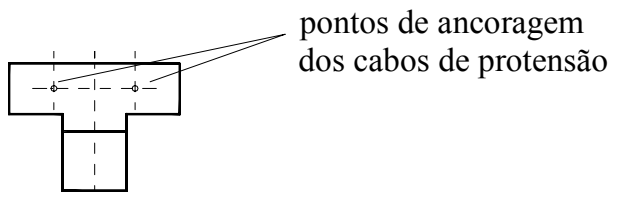

seção transversal

Figura 2.4 - Reforço de vigas por meio de protensão exterior (ALMEIDA, 2001)

Dentre as várias possibilidades de reforço devido à ação do momento fletor, optou-se por avaliar o comportamento estrutural de peças reforçadas adicionando-se concreto armado ou concreto simples. 


\subsection{Estudos realizados por outros pesquisadores}

Apesar de vários profissionais questionarem a execução de reforço mediante adição de concreto por causa da necessidade de se demolir parte do elemento estrutural e de se ter que esperar o material adicionado atingir a resistência adequada, esta ainda é uma das técnicas mais utilizadas no Brasil. Isso se deve principalmente pelo baixo custo dos materiais de reposição e à tradição de seu uso.

A necessidade de escarificação do elemento por si só também não é uma justificativa bastante forte para inviabilizar a utilização de tal técnica de reforço já que nos casos de corrosão de armaduras é inevitável a demolição de trechos do elemento estrutural para limpeza e até mesmo a reposição de armadura.

Para indicar o estágio de conhecimento disponível a respeito deste tipo de reforço, descreveu-se a seguir alguns aspectos importantes a serem considerados durante a execução deste tipo de reabilitação bem como alguns estudos realizados por diversos pesquisadores. Tais estudos foram subdivididos em: estudos genéricos e estudos específicos.

No item estudos genéricos abordam-se de maneira geral as principais observações quanto às características que devem apresentar o material do reforço, a forma de preparo do substrato, a maneira de prever o comportamento de peças reabilitadas além de outros fatores relevantes a serem considerados antes e durante o redimensionamento e reprojeto de tais elementos.

No item estudos específicos descrevem-se individualmente alguns ensaios experimentais de peças reforçadas ou reparadas realizados por diversos pesquisadores e comentários a respeito das conclusões obtidas por cada um deles.

\subsubsection{Estudos genéricos}

Antes de escolher determinado produto de reparo e/ou reforço é preciso verificar a compatibilidade entre os materiais novos e o substrato. Como se deve escolher materiais que apresentem propriedades similares às do substrato, geralmente a escolha de concreto de cimento portland ou qualquer outra composição cimentícia semelhante é uma boa escolha. Todavia, o concreto é um material de estrutura 
interna e propriedades complexas, o que dificulta a previsão do seu comportamento imediato e ao longo do tempo, e conseqüentemente, a avaliação da confiabilidade das estruturas quanto à resistência e à durabilidade. No caso particular de reabilitação de estruturas de concreto, a ação que se venha a programar para corrigir uma manifestação patológica torna-se ainda mais complexa, pois além de se partir de uma origem problemática, outros materiais estão sendo adicionados. Por este motivo todas as propriedades do concreto, tanto aquele da estrutura original como o do reparo ou reforço, devem ser criteriosamente analisadas e estimadas, especialmente aquelas relacionadas à resistência, durabilidade, aderência e deformabilidade.

Para melhorar a aderência entre superfícies de concretos moldados em idades diferentes estão disponíveis comercialmente um grande número de produtos denominados de adesivos e "primers" e que são aplicados na superfície do substrato antes de se adicionar o material cimentício novo, funcionando como pontes de aderência. Entretanto, pesquisas desenvolvidas nos últimos anos têm mostrado que quando se tem um substrato devidamente limpo e previamente umedecido (mas sem presença de água superficial) e uma dosagem do concreto adicionado ${ }^{1}$ adequada, o uso de pontes de aderência geralmente não é necessária. CASTRO et al. (1999) apresentaram um trabalho sobre a real necessidade do uso de resina epóxi na ligação entre concreto remanescente e a argamassa de reforço e concluíram que se for feita uma dosagem adequada da argamassa utilizando superplastificante e sílica ativa, este material fornece uma resistência de aderência na junta superior à obtida com a resina. Este estudo foi realizado ensaiando-se corpos-de-prova cilíndricos. CLÍMACO (1990) também realizou um estudo avaliando diversos tipos de materiais usados como pontes de aderência e constatou a ineficiência de alguns deles. Entretanto alguns profissionais recomendam a aplicação de uma pasta de cimento na superfície do substrato devidamente limpo e seco instantes antes da moldagem do reforço ao invés de se umedecer a superfície e aplicar diretamente o material do reforço.

Além das características do material do reforço, deve-se lembrar que o correto preparo do substrato é decisivo para garantir boa aderência entre superfícies.

\footnotetext{
${ }^{1}$ Para melhorar as características do material cimentício pode-se incorporar à pasta alguns aditivos e/ou adições. As adições minerais mais utilizadas são as pozolanas, cinzas volantes, a escória de alto forno e a sílica ativa e os aditivos são os plastificantes, aceleradores ou retardadores de pega, redutores de permeabilidade, expansores, inibidores da corrosão nas armaduras, etc.
} 
Procedimentos de preparo de substrato podem ser encontrados em diversas publicações bastante conhecidas do meio técnico podendo-se citar, dentre elas HELENE (1992).

De qualquer forma, é importante verificar o nível de tensões tangenciais atuantes na região da junta para definir se é ou não necessário ter uma armadura cruzando tal superfície independentemente se foi ou não utilizado pontes de aderência. Esta verificação pode ser feita utilizando-se normas destinadas ao dimensionamento de peças compostas (ex.: NBR-9062 - "Projeto e execução de estruturas de concreto pré-moldado") que fornecem formulações específicas para se determinar a taxa de armadura a ser adicionada em função das solicitações existentes na região da junta. No trabalho desenvolvido por ARAÚJO (1997) aborda-se várias maneiras de avaliar a resistência ao cisalhamento da interface formada por duas superfícies de concreto moldadas em idades distintas atravessadas por armadura para elementos estruturais submetidos à flexão. Maiores detalhes sobre os métodos de avaliação das tensões tangenciais na junta estão no item 3.2 do Capítulo 3.

Durante um processo de reabilitação, o conhecimento das propriedades de deformação dos diferentes concretos é extremamente importante pois deformações diferenciais entre o concreto do reparo e o substrato podem gerar tensões consideráveis na interface de ligação. Isto porque na estrutura a ser recuperada, essas variações de volume e deformações já ocorreram quase totalmente, enquanto que no material de reparo esses fenômenos ainda irão se processar, interferindo na redistribuição de tensões.

A deformabilidade do concreto engloba o estudo das deformações intrínsecas tais como a retração, as variações de volume causadas pela variação da umidade e da temperatura e as deformações provocadas por ações externas (deformação imediata e fluência). A estimativa dessa deformabilidade depende dos valores do módulo de deformação longitudinal, do coeficiente de dilatação térmica, do coeficiente de Poisson, de complexas relações entre as propriedades dos materiais constituintes, da estrutura interna do concreto, e ainda da sua interação com o meio ambiente.

O efeito causado pela deformação diferencial em peças confeccionadas por materiais com diferentes módulos de elasticidade pode ser observado na Figura 2.5. Verifica-se que ocorrem concentrações de tensões em determinados trechos do 
elemento e, dependendo da posição da junta em relação ao carregamento aplicado, é possível haver ruptura tanto no material de menor quanto no de maior módulo. Tendo em vista este comportamento, pode-se dizer que o módulo de elasticidade do material a ser adicionado deve ser próximo ao do concreto da estrutura original de modo a minimizar as tensões originadas por fenômenos diferenciais. O CEB Bulletim d'Information $\mathrm{n}^{\circ} 162$ complementa que a fluência diferencial (differential creep) entre concreto novo e antigo é mais evidente no reforço de paredes, pilares ou vigas/lajes reforçadas no bordo comprimido.

O trabalho de MENDES (1993), apesar de se destinado à análise de peças de concreto protendido, fornece uma boa fundamentação teórica que pode ser adaptada para avaliar as deformações diferidas ao longo do tempo em elementos reabilitados sob carga. Mais detalhes sobre a avaliação dos efeitos das deformações de longa duração em estruturas reabilitadas estão apresentados no item 3.4 do Capítulo 3.

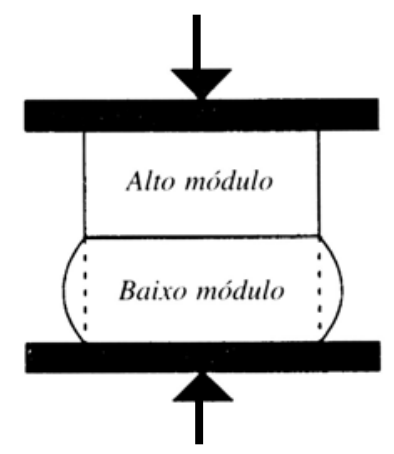

a) carregamento perpendicular à junta

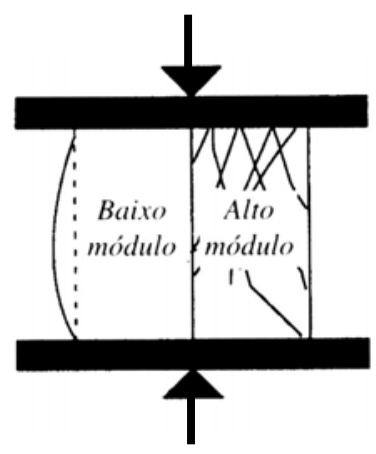

b) carregamento na direção da junta

\section{Figura 2.5 - Deformações de peça composta por materiais com módulos de elasticidade diferentes (ROCHA, 1996)}

A respeito do dimensionamento e previsão do comportamento de vigas reforçadas por adição de concreto é praticamente consenso entre os pesquisadores que se a intervenção for executada de maneira adequada, é possível usar os princípios básicos válidos para estruturas novas, desde que se garanta o respeito aos Estados Limites Últimos e Estados Limites de Serviço pelo uso de coeficientes parciais de segurança específicos. Tais coeficientes dependem das características particulares do elemento a ser reforçado devendo ser estabelecidos caso a caso. Os trabalhos desenvolvidos por SOUZA et al.(1998), SOUZA (1990) e o CEB Bulletim 
d'Information $\mathrm{n}^{\mathrm{0}} 162$ apresentam mais informações sobre como determinar tais coeficientes.

Para avaliar o quanto o nível de fissuração existente na peça danificada afeta o comportamento do elemento após a reabilitação, PARAMASIVAM \& LIM et al. (1998) ensaiaram vigas pré-fissuradas e reforçadas por meio de acréscimo de argamassa armada ao bordo tracionado, sem injeção das fissuras. Tais autores verificaram que mesmo para um nível de dano razoável, a viga não teve sua resistência última significativamente afetada para um carregamento monotônico de curta duração. Isto também foi observado por REIS (1998), que estudou vigas reforçadas por adição de chapas de aço e também por adição de barras de aço ao bordo tracionado. Por outro lado, deve-se esclarecer que apesar da intensa fissuração, a armadura de flexão das vigas ensaiadas por ambos os pesquisadores armadura responsável pelo limite da capacidade portante das peças - não atingiu o escoamento durante a pré-danificação do elemento antes da execução da intervenção. Ressalta-se ainda que o não fechamento das fissuras em um elemento estrutural prejudica sua durabilidade, razão pela qual se recomenda que mesmo não sendo necessário estruturalmente, deve-se sempre tentar vedar as fissuras pré-existentes.

Outro aspecto que normalmente gera dúvidas durante o reprojeto de um elemento reforçado refere-se à existência de um pré-carregamento atuante durante a execução da intervenção. Geralmente ao realizar uma reabilitação estrutural tenta-se descarregar ao máximo a estrutura para neutralizar as solicitações provenientes do carregamento atuante. Este procedimento é feito antes de executar a reabilitação a fim de garantir que a intervenção contribua efetivamente na resistência e controle de deformações causadas pelas ações permanentes e variáveis. Contudo, nem sempre se consegue fazer tal descarregamento, ficando a estrutura submetida a um estado de solicitação inicial que poderá afetar o desempenho do reforço, uma vez que as tensões existentes antes da reabilitação poderão não ser adequadamente absorvidas pelo material adicionado. Um reforço estrutural executado em uma peça fortemente solicitada só vai exercer sua influência quando aumentarem as solicitações ou os deslocamentos originais.

Um exemplo é o caso de uma viga na qual se pretende reforçar adicionando novas barras de aço ao bordo tracionado. Se a viga estiver pré-carregada durante a 
execução da reabilitação, dependendo da solicitação atuante naquele instante, a armadura longitudinal remanescente poderá ficar sujeita a tensões (e conseqüentemente a deformações) muito maiores que a armadura adicionada quando a peça for novamente colocada em serviço. Dependendo da ordem de grandeza destas tensões, poderá ocorrer desde fissuração e deslocamentos inaceitáveis, até a ruptura inesperada da peça devido ao escoamento prematuro das barras de aço antigas.

Apesar de se recomendar a consideração do efeito da existência de um précarregamento no dimensionamento de elementos reforçados, encontrou-se na bibliografia pouquíssimos estudos que analisassem o comportamento de peças reforçadas submetidas a um pré-carregamento durante a execução do reforço, bem como poucos procedimentos indicando a maneira de se considerar tais esforços no redimensionamento e reprojeto do elemento danificado. Dentre os autores que investigaram tal fenômeno pode-se citar CAIRNS \& HUTT $^{2}$, apud CLIMACO (1990), que analisaram a influência das "tensões que ficam de fora do reforço" durante a intervenção. Tais autores ensaiaram três vigas sendo duas reforçadas sob uma carga de $25 \%$ da capacidade última e outra reforçada sem carga alguma. Após a análise dos resultados, os autores observaram que as tensões que não foram absorvidas pela armadura adicionada não prejudicaram o comportamento das estruturas reforçadas, já que o comportamento de vigas reabilitadas foi semelhante. Entretanto, não se conseguiu obter maiores detalhes sobre a forma de reforço destas vigas, nem como tais ensaios foram realizados e nem os valores dos dados experimentais coletados.

PIANCASTELLI (1997) também estudou o comportamento de vigas reabilitadas à flexão adicionando armadura ao bordo tracionado sujeitas a précarregamento. Algumas vigas foram reforçadas sob ação somente do peso próprio e outras vigas foram reforçadas sob ação de $91 \%$ da carga de serviço, mais o peso próprio e mais o peso do reforço. De acordo com este autor, aparentemente não foram observadas diferenças significativas entre as resistências finais destas vigas, mas deve-se considerar, no cálculo da reabilitação, as deformações e deslocamentos

${ }^{2}$ CAIRNS J. \& HUTT C. (1983)- "Replacement of corroded reinforcement: locked-out stresses", Proceedings of The First International Conference Structural Faults \& Repair - apud CLIMACO (1990). 
existentes no instante do reforço. Maiores detalhes sobre os ensaios realizados por PIANCASTELLI estão no item 2.2.2 - "Estudos específicos".

Para tentar avaliar teoricamente o comportamento de peças reforçadas sob carregamento atuante no bordo tracionado, CÁNOVAS (1988) apresentou um método de dimensionamento baseado nos diagramas de tensão e de deformação ao longo da altura da seção transversal de peças fletidas (ver Figura 2.6). Estes diagramas foram obtidos considerando que a viga seja solicitada por um momento fletor final $\mathrm{M}_{3}$ composto de duas parcelas. A primeira corresponde ao momento $\mathrm{M}_{1}$, existente durante a execução da reabilitação, e a segunda parcela corresponde ao momento fletor $\mathrm{M}_{2}$, que atuará na peça em função do acréscimo de carga aplicado após o reforço. Como o dimensionamento é feito no Estádio III (tensões não são lineares), para determinar as tensões finais inicialmente faz-se a superposição dos diagramas de deformações atuantes na peça. A partir do estado de deformações final da estrutura, determina-se as tensões na fibra de concreto mais comprimida e nas armaduras, comparando-as com os valores das tensões limites destes materiais já multiplicados pelos respectivos coeficientes de segurança.

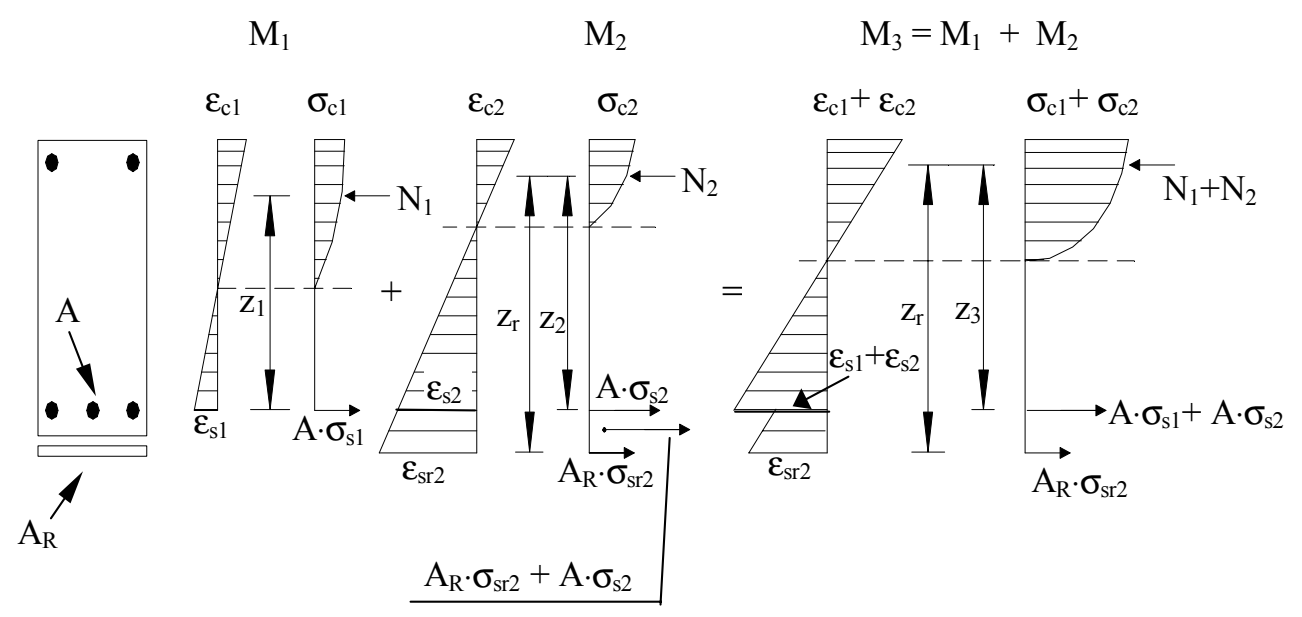

Figura 2.6 - Estados de tensão e deformação em uma viga reforçada sob carga onde:

$\mathrm{M}_{1} \quad$ - momento gerado pela aplicação do pré-carregamento;

$\mathrm{M}_{2} \quad$ - momento gerado pelo acréscimo de carga aplicado após a execução do reforço;

$\mathrm{M}_{3} \quad$ - momento total (pré-carregamento + acréscimo de carga após o reforço);

$\mathrm{A}=\mathrm{A}_{\mathrm{sl1}} \quad$ - Área de aço do substrato;

$\mathrm{A}_{\mathrm{R}}=\mathrm{A}_{\mathrm{s} 12}$ - Área de aço do reforço;

$\varepsilon_{\mathrm{c} 1}$ e $\sigma_{\mathrm{c} 1}$ - Deformação e tensão do concreto gerados pelo pré-carregamento;

$\varepsilon_{\mathrm{s} 1}$ e $\sigma_{\mathrm{s} 1}$ - Deformação e tensão do aço do substrato gerados pelo pré-carregamento;

$\varepsilon_{\mathrm{c} 2}$ e $\sigma_{\mathrm{c} 2}$ - Deformação e tensão do concreto gerados pelo acréscimo de carga após o reforço; 


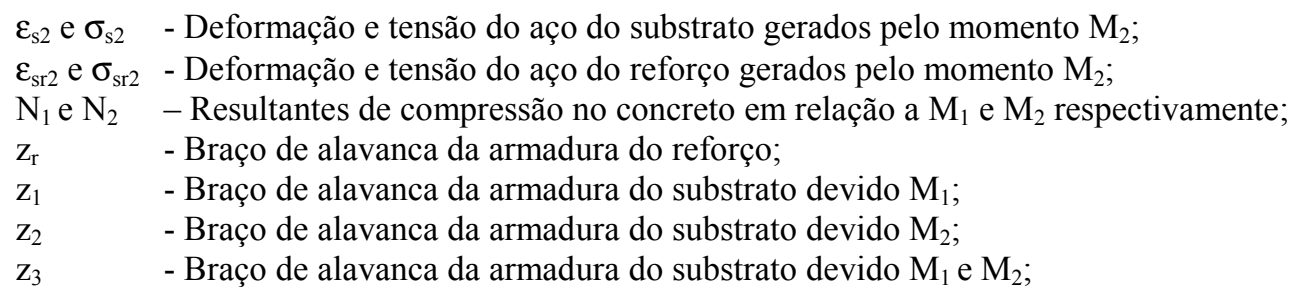

A estimativa correta dos valores destes diagramas ajuda a simular o estado de solicitação que pode ser aplicado à viga antes $\mathrm{e}$ após a reabilitação e conseqüentemente permite que se dimensione de maneira mais coerente o reforço.

\subsubsection{Estudos específicos}

Fazendo-se a revisão bibliográfica foram encontradas poucas pesquisas que tivessem averiguado alguns dos aspectos abordados neste trabalho, como por exemplo, o reforço sob carga e o efeito da deformabilidade do concreto sob ações de longa duração no desempenho do reforço estrutural. Mesmo as pesquisas que adotaram processo de reforço similar ao do presente estudo, apresentaram, em relação a ele, importantes diferenças quanto à seção transversal e vão das vigas, aos tipos de concreto utilizados e aos procedimentos de reforço. Em função disso, procurou-se fazer um resumo dos trabalhos encontrados que mais se assemelhavam à proposta deste estudo de maneira que se pudesse avaliar tais diferenças e também confirmar, quando possível, algumas das conclusões já observadas por tais pesquisadores.

\subsubsection{Ensaios realizados por CLÍMACO (1990) ${ }^{3}$}

CLÍMACO analisou o comportamento de onze vigas biapoiadas sendo oito reforçadas por adição de novas armaduras de tração envolvidas por um concreto novo através da remoldagem de sua seção transversal, uma reparada por remoldagem do bordo comprimido enquanto submetida a um pré-carregamento durante a execução da intervenção, e as demais sendo peças monolíticas. No caso do primeiro tipo de reforço, para evitar a colocação de novas armaduras transversais para envolver as barras de aço adicionadas, os estribos foram confeccionados com uma dimensão adequada ao tamanho final da seção transversal da peça após o reforço.

\footnotetext{
${ }^{3}$ Não houve aumento na seção transversal das vigas reabilitadas por CLÍMACO.
} 
Desta maneira foi possível posicionar as barras adicionadas abaixo da armadura longitudinal original deixando entre seus eixos uma distância de $4 \mathrm{~cm}$. Não foram aplicados materiais que funcionassem como ponte de aderência na superfície de ligação entre concretos moldados em idades diferentes em nenhuma viga reforçada, nem se umedeceu o substrato antes de executar o reforço. Com os ensaios das vigas avaliou-se a forma de colocar e compactar o novo material cimentício, o efeito do tamanho do vão de cisalhamento e as condições de carregamento (estático ou dinâmico) no desempenho do elemento reabilitado. As características das peças ensaiadas por CLÍMACO estão na Tabela 2.1 e na Figura 2.7.

As vigas V1 a V7 foram ensaiadas normalmente até a ruptura por meio de aplicação de um carregamento estático crescente por incrementos de força. A viga V8, submetida a carregamento cíclico, foi carregada até o surgimento de fissuras horizontais na junta e descarregadas até $10 \mathrm{kN}$. Feito isso, aplicou-se um carregamento repetido composto por 15 ciclos de $10-100-10 \mathrm{kN} ; 10$ ciclos de $10-120-10 \mathrm{kN} ; 10$ ciclos de $10-140-10 \mathrm{kN}$ e 50 ciclos de $10-160-10 \mathrm{kN}$. As vigas V9 e V10 foram submetidas a um carregamento dinâmico após se aplicar um carregamento estático de $120 \mathrm{kN}$ (correspondente a 3/4 da carga teórica última) o qual produziu fissuras de cisalhamento e flexão. O carregamento dinâmico variou entre 20 e $120 \mathrm{kN}$, sendo controlado automaticamente a uma taxa de 60 ciclos por minuto até se atingir a ruptura da peça por fadiga. A viga V11 foi submetida a um pré-carregamento de $70 \mathrm{kN}$ (35\% da capacidade portante de flexão) que foi mantido constante durante a execução do reforço e por mais 15 dias até a data de ensaio. Para evitar a perda de pressão do óleo durante este período travou-se o macaco hidráulico, mas de qualquer forma, observou-se uma perda de $10 \%$ em relação à carga aplicada inicialmente. 


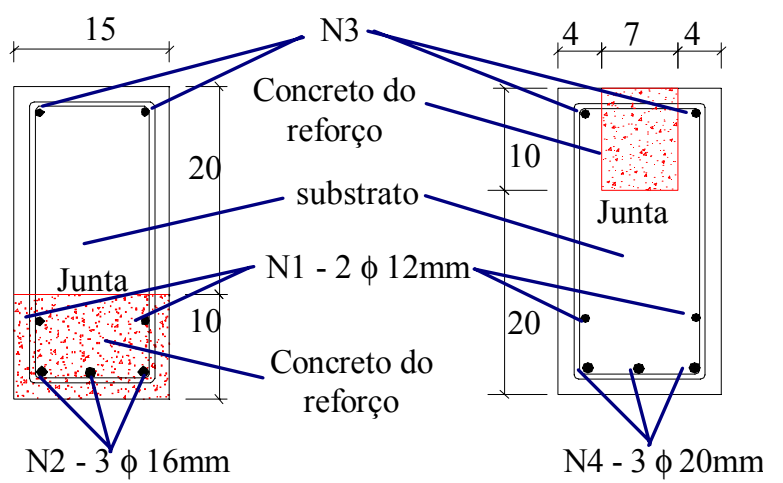

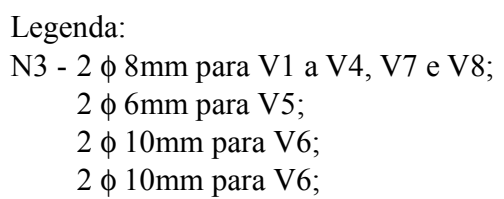

Legenda:

N3 - 2 ф 8mm para V1 a V4, V7 e V8; $2 \phi 6 \mathrm{~mm}$ para V5;

$2 \phi 10 \mathrm{~mm}$ para $\mathrm{V} 6$;

$2 \phi 10 \mathrm{~mm}$ para $\mathrm{V} 6$;

N2 - armadura de reforço posicionada abaixo da armadura pré-existente.

OBS. Unidades em $\mathrm{cm}$

\section{$\mathrm{V1}, \mathrm{V} 2, \mathrm{~V} 3, \mathrm{~V} 4, \mathrm{V8}, \mathrm{V9}, \mathrm{V} 10$ e V11 - a/d = 4}

(a) seção transversal

$17 \phi 8 \mathrm{~mm} \mathrm{c/} 18 \mathrm{~cm}$ ou $21 \phi 8 \mathrm{~mm} \mathrm{c} / 14 \mathrm{~cm}$ (só na V11)

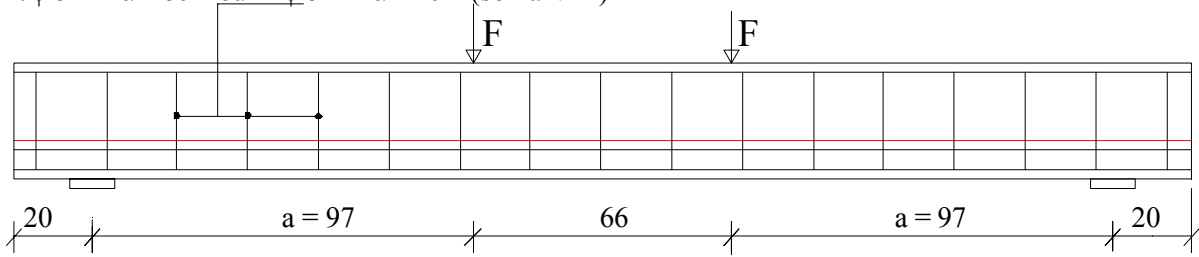

$\underline{\mathrm{V} 5-\mathrm{a} / \mathrm{d}=\mathbf{5}}$
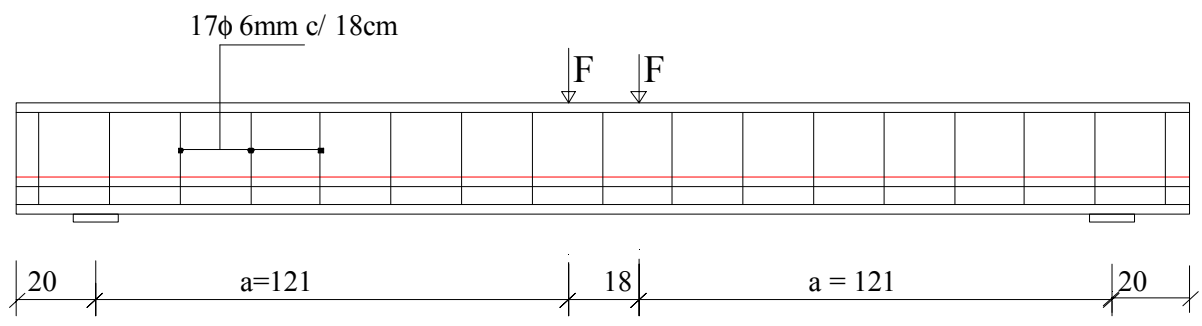

$\underline{\mathrm{V} 6}-\mathbf{a} / \mathrm{d}=\mathbf{2}$
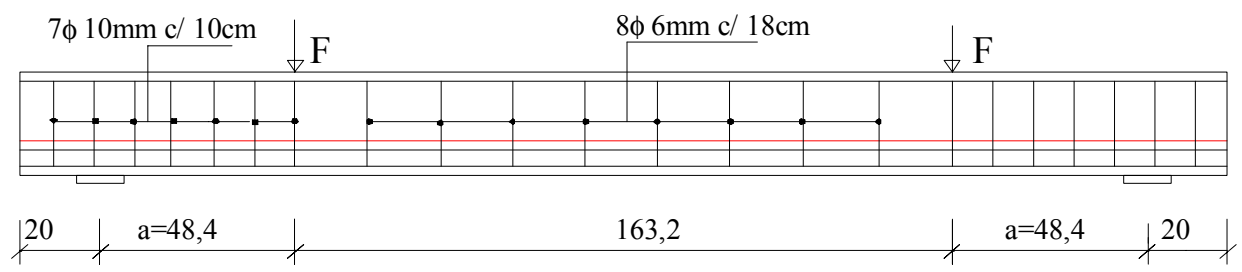

$\underline{\mathrm{V} 7-\mathrm{a} / \mathrm{d}=\mathbf{3}}$

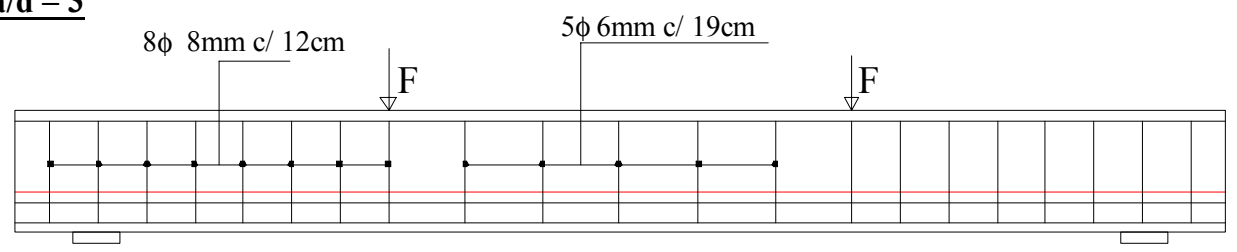

$\nmid 20 \nmid \mathrm{a}=72,6 \quad 114,8 \quad \mathrm{a}=72,6 \quad \nmid 20$

(b) seção longitudinal

Figura 2.7 - Esquema de reforço realizado por CLÍMACO (1990) 
Tabela 2.1 - Características das vigas ensaiadas por CLIMACO (1990)

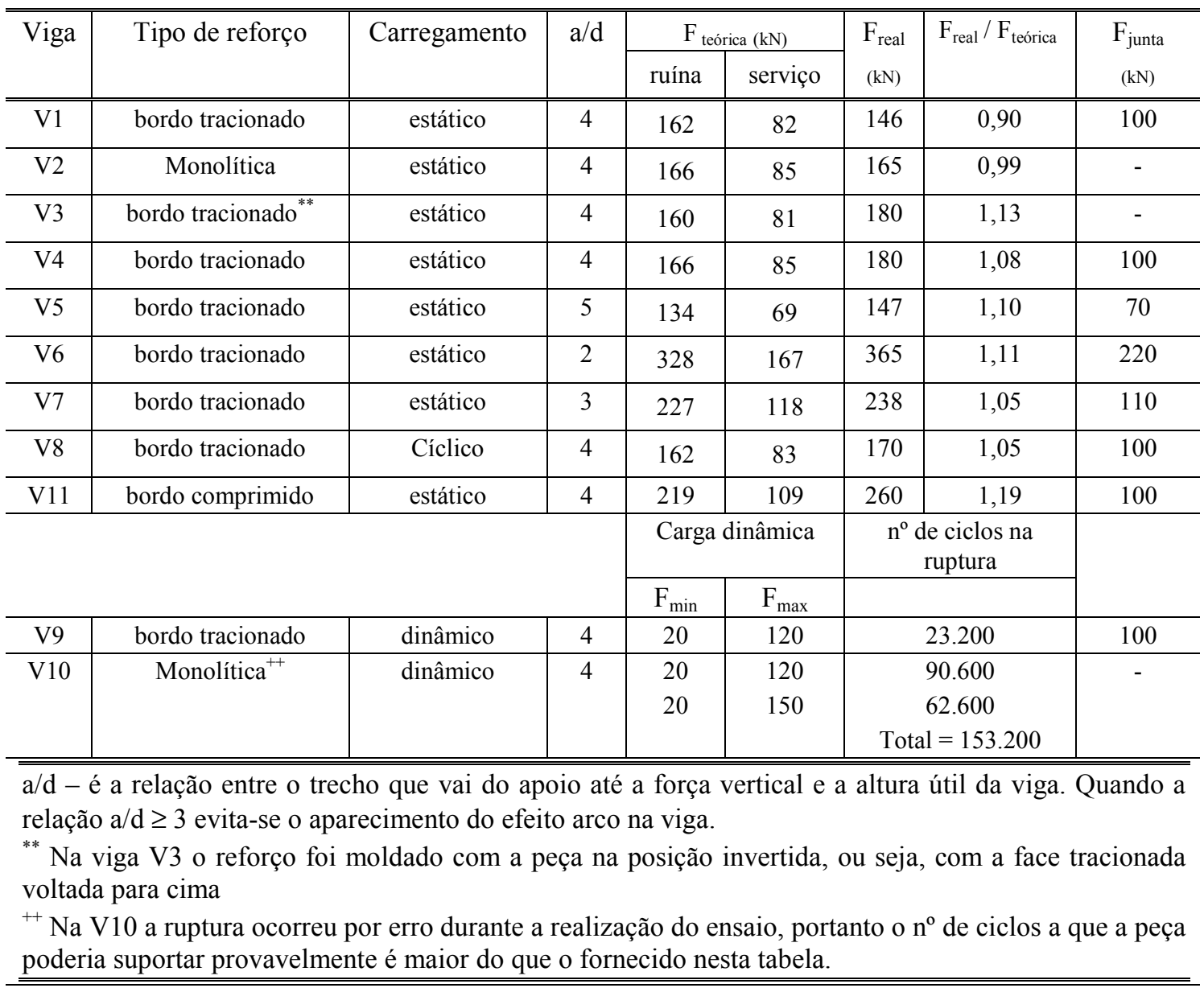

Após a análise dos resultados das vigas reabilitadas CLÍMACO observou que:

$\checkmark$ as técnicas de reforço estudadas foram eficientes para carregamento estático, podendo-se dimensionar e prever o comportamento das peças reabilitadas usando os princípios válidos para elementos monolíticos.

$\checkmark$ todas as peças carregadas estaticamente romperam por flexão ${ }^{4}$ apesar de ter surgido fissuras horizontais na junta para trechos dentro do vão de cisalhamento “ $a$ ”. Entretanto, essa perda parcial de aderência não reduziu a capacidade portante das vigas reabilitadas. Por outro lado, embora a fissuração na junta não

4 A ruptura por flexão corresponde à deformação plástica excessiva da armadura tracionada e do esmagamento do concreto comprimido. 
tenha prejudicado o desempenho estrutural, esse é um problema a ser enfrentado no que se refere à durabilidade da peça reforçada.

$\checkmark$ o bom desempenho das vigas reforçadas foi obtido mesmo sem se adotar as recomendações a respeito do uso de superplastificantes, concretos de elevada resistência, umedecimento da superfície antes da moldagem do concreto do reforço, utilização de aditivos compensadores de retração e pontes de aderência. Por outro lado, tais recomendações devem ser seguidas pois evitam ou retardam o surgimento de fissuras na região da junta.

$\checkmark$ comparando as vigas V9 e V10, que romperam por fadiga, percebe-se que o número de ciclos que a peça reabilitada suportou foi de apenas $15 \%$ em relação ao suportado pela peça monolítica. Na V9 houve uma ruptura prematura por perda de aderência entre os materiais cimentícios da junta seguido do esmagamento do concreto na face comprimida. Já na V10 houve a ruptura por flexão aos $163 \mathrm{kN}$ que corresponde a capacidade teórica máxima.

$\checkmark$ a viga V11 (reabilitada no bordo comprimido) comportou-se como monolítica, pois o concreto novo e antigo esmagaram praticamente ao mesmo tempo no meio do vão, mesmo o elemento estando pré-carregado durante a execução do reforço. Além disso, a carga de ruptura experimental foi 19\% superior à carga teórica prevista, apesar de terem surgido fissuras na região da junta. CLÍMACO constatou ainda que o concreto do substrato já possuía uma deformação $\varepsilon_{\mathrm{c}}=\frac{1}{3} \varepsilon_{\mathrm{cmáxima}}$ antes de se aumentar o carregamento da V11 após a execução do reparo. Pelo gráfico da Figura 2.8 percebe-se que há uma tendência das deformações dos dois concretos se igualarem. 


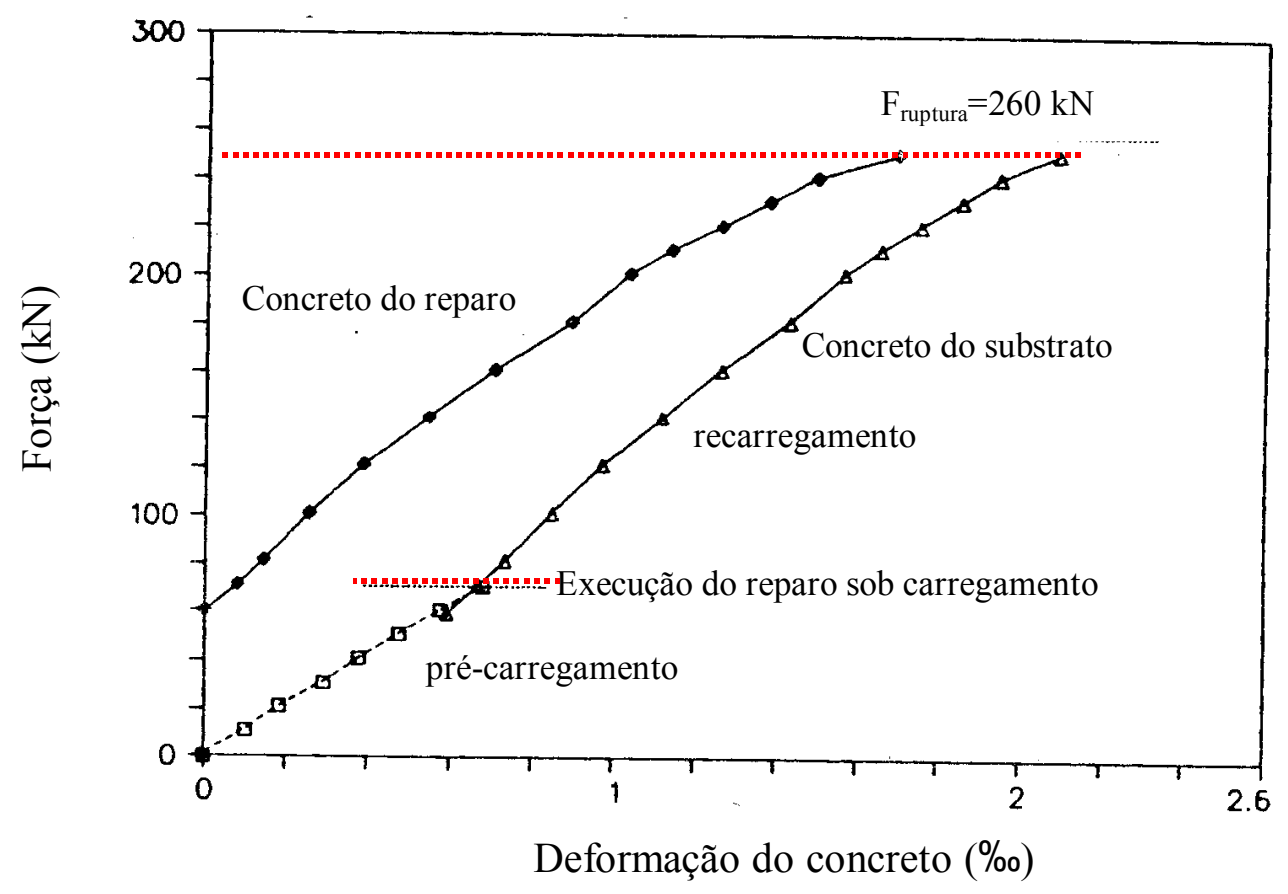

Figura 2.8 - Gráfico da viga V11 ensaiada por CLÍMACO (1990)

\subsubsection{Ensaios realizados por PIANCASTELLI (1997)}

PIANCASTELLI ensaiou doze vigas de concreto armado, divididas em seis séries de duas peças cada, conforme se apresenta na Tabela 2.2, a fim de estudar o reforço de vigas aumentando as seções de concreto e de aço, conforme Figuras 2.9 e 2.10. As doze vigas foram concretadas originalmente com as mesmas características, sendo denominadas de vigas originais. As duas vigas da série 1 foram ensaiadas mantendo-se as características iniciais para servirem de referência ao se comparar com as peças reforçadas e as demais foram reforçadas constituindo as séries 2 a 6 .

As séries 2 e 4, ambas com vinte e seis estribos na posição N3, se diferenciaram em função do tamanho do reforço adicionado à seção transversal. As séries 3 e 5, ambas com apenas dez estribos na posição N3, se diferenciavam apenas pela ação atuante no instante da execução do reforço. As vigas da série 3 foram reforçadas apenas sob a ação do seu peso próprio, e do peso do reforço e as da série 5 foram submetidas a um carregamento de aproximadamente $20 \mathrm{kN}$ (45\% da carga de ruptura teórica da série 1 ou 18,5\% da carga de ruptura prevista da série 3), além do peso próprio e do peso do reforço. As vigas da série 6 (vigas monolíticas de referência) foram moldadas em uma só etapa e apresentavam as mesmas 
características das peças da série 2 depois de reforçadas, inclusive com relação ao número de estribos prolongados.

Nas peças armadas com dez estribos envolvendo a armadura do reforço, colocaram-se três estribos nas extremidades da viga, ficando os quatro estribos restantes distribuídos ao longo da peça para possibilitar a fixação da armadura adicionada. Os estribos do tipo N3 foram maiores que a seção transversal da peça para evitar operações de prolongamento destas armaduras durante a execução do reforço. Nas posições onde não se desejava tal armadura, estes estribos foram cortados. Para permitir deslocamento relativo entre o reforço e o substrato foram utilizadas chapas de poliestireno expandido entre estes materiais. Não foi utilizado nenhum adesivo estrutural na ligação substrato/concreto novo, nem se umedeceu o substrato antes da execução do reforço. As peças reforçadas foram ensaiadas para baixa idade do concreto do reforço, porque em situações reais é freqüente a necessidade de se colocar rapidamente em uso as estruturas reforçadas.

Tabela 2.2- Características das vigas ensaiadas por PIANCASTELLI (1997)

\begin{tabular}{|c|c|c|c|c|}
\hline Série & Tipo de reforço & Viga & 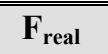 & 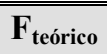 \\
\hline \multirow[t]{2}{*}{1} & \multirow{2}{*}{$\begin{array}{l}\text { Vigas monolíticas de referência com seção transversal } \\
\text { anterior ao reforço }\end{array}$} & $\mathrm{V} 3$ & 43,0 & \multirow{2}{*}{42,3} \\
\hline & & V7 & 43,0 & \\
\hline \multirow{2}{*}{2} & \multirow{2}{*}{ Vigas reforçadas com prolongamento total dos estribos } & "V4 & 102,9 & \multirow{2}{*}{108,4} \\
\hline & & V10 & 108,3 & \\
\hline \multirow[t]{2}{*}{3} & \multirow{2}{*}{ Vigas reforçadas com prolongamento parcial dos estribos } & V2 & 100,2 & \multirow{2}{*}{108,4} \\
\hline & & V9 & 100,2 & \\
\hline \multirow[t]{2}{*}{4} & \multirow{2}{*}{$\begin{array}{l}\text { Vigas reforçadas com prolongamento total dos estribos } \\
\text { (difere-se da série } 2 \text { pelo tamanho do reforço executado) }\end{array}$} & V5 & 111,9 & \multirow{2}{*}{108,4} \\
\hline & & V8 & 111,9 & \\
\hline \multirow{2}{*}{5} & \multirow{2}{*}{$\begin{array}{c}\text { Vigas reforçadas com prolongamento parcial dos estribos } \\
\text { e pré-carregadas }(20 \mathrm{kN}) \text { durante execução do reforço }\end{array}$} & V1 & 109,2 & \multirow{2}{*}{108,4} \\
\hline & & V6 & 109,2 & \\
\hline \multirow[t]{2}{*}{6} & \multirow{2}{*}{$\begin{array}{l}\text { Vigas monolíticas de referência com seção transversal } \\
\text { posterior ao reforço }\end{array}$} & VR1 & 111,0 & \multirow{2}{*}{108,4} \\
\hline & & VR2 & 105,6 & \\
\hline
\end{tabular}


$26 \mathrm{~N} 3 \mathrm{c} / 10 \mathrm{~cm}$ e $26 \mathrm{~N} 4 \mathrm{c} / 10 \mathrm{~cm}$

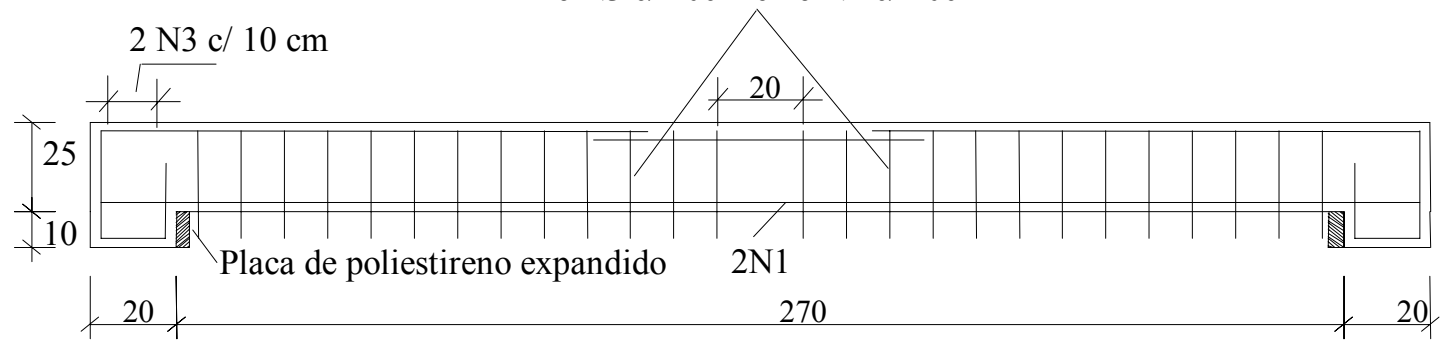

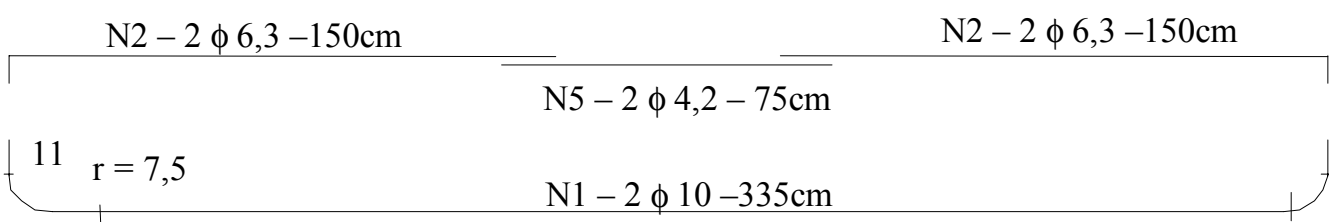

a) série 1 (vigas originais)

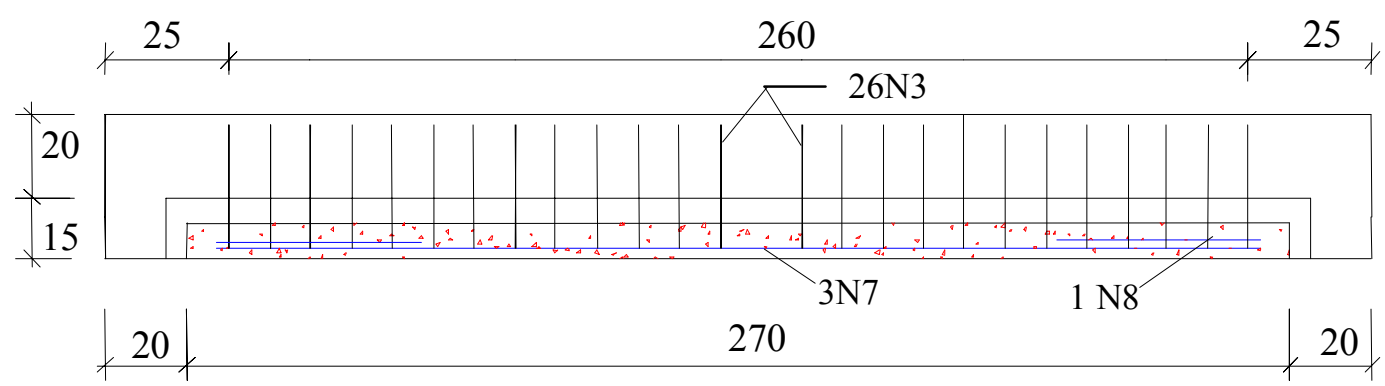

b) série 2,4 e 6

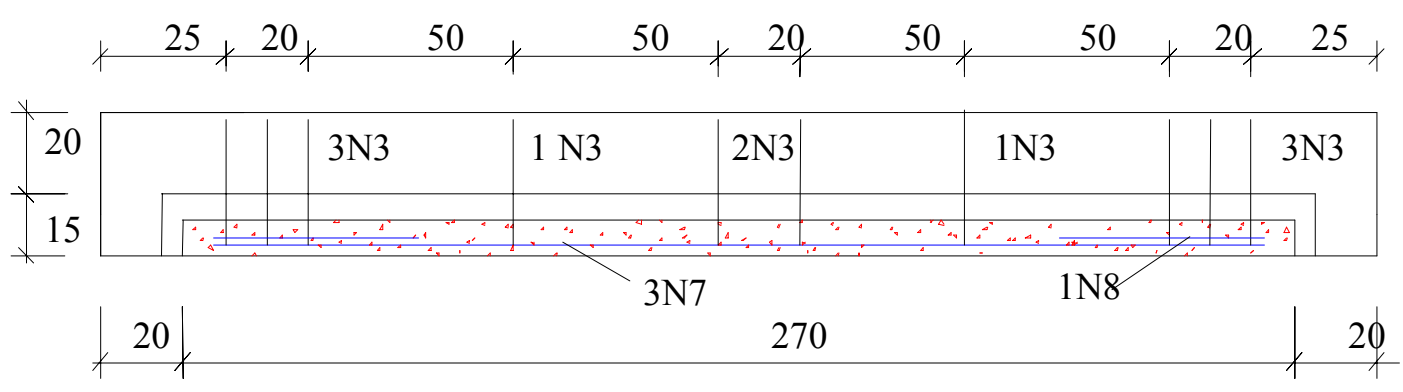

c) série 3 e 5

$$
\mathrm{N} 8-2 \phi 10-120 \mathrm{~cm}-3 \phi 10-267 \mathrm{~cm}
$$

d) detalhamento da armadura do reforço

Figura 2.9 - Detalhamento das seções longitudinais das vigas ensaiadas por PIANCASTELLI (1997) 


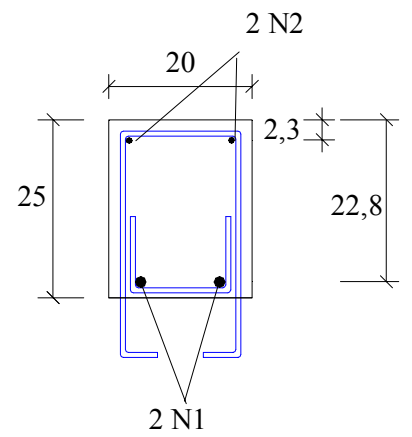

Seção original série 1

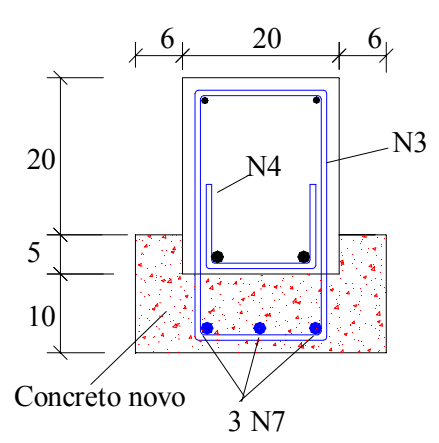

Seção $n^{\circ} 1$ série $2,3,5$ e 6

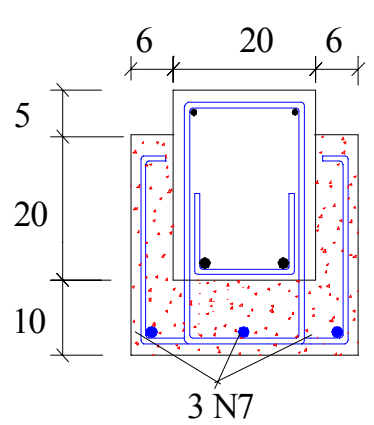

Seção $n^{\circ} 2$ serie 4

a) Tipos de seções transversais

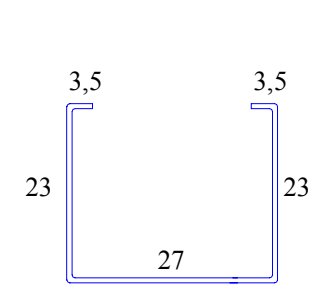

N9 - $26 \phi 6.3 \mathrm{c} / 10 \mathrm{~cm}$

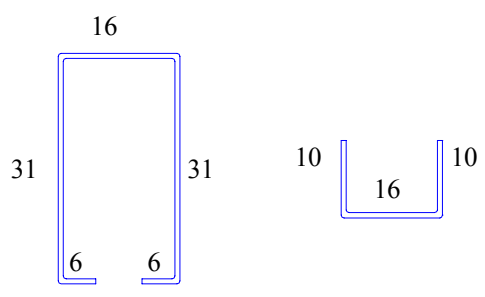

$\mathrm{N} 3-30 \phi 6.3 \mathrm{c} / 10 \mathrm{~cm} \quad \mathrm{~N} 4-26 \phi 4.2 \mathrm{c} / 10 \mathrm{~cm}$

b) detalhamento dos estribos utilizados

Figura 2.10 - Detalhamento das seções transversais das vigas ensaiadas por PIANCASTELLI (1997)

As vigas foram ensaiadas em duas etapas, sendo que na primeira (antes da execução do reforço), carregava-se as vigas para simular os danos estruturais existentes em um elemento a ser reforçado. Após este pré-carregamento, as peças foram descarregadas (exceto as da série 5) e suas faces inferiores foram apicoadas e lavadas para fixar a armadura de reforço. No instante da concretagem do reforço, o substrato estava propositadamente seco para que se pudesse avaliar a necessidade do umedecimento superficial na qualidade de aderência entre concretos moldados em idades diferentes.

No caso das vigas da série 5, que estavam submetidas a uma solicitação durante a execução do reforço, o carregamento foi mantido constante através do bombeamento do macaco hidráulico desde o dia da concretagem do reforço até 24 horas antes do início do ensaio final. Durante estas 24 horas o macaco continuou aplicando carga só que sem serem feitas correções para mantê-la constante. Neste período observou-se um aumento do carregamento, que o autor justificou como 
sendo devido a uma flexão invertida causada pela retração do concreto do reforço. $\mathrm{O}$ comportamento da série 5 foi comparado ao da série 3 por serem vigas semelhantes quanto à seção transversal e podem ser observados pelos gráficos das Figuras $2.11 \mathrm{a}$ 2.14. O ensaio final das peças reforçadas ocorreu após quatro dias da execução da intervenção. As vigas da série 6 (monolíticas) foram ensaiadas em uma única etapa.

Pelos gráficos força x flecha e momento x curvatura (Figura 2.11 e 2.12) o autor constatou que apesar das diferenças de comportamento impostas pelas distintas condições de solicitação inicial, as curvas apresentaram o mesmo aspecto. Ao se eliminar os efeitos do pré-carregamento observou-se que o comportamento em serviço das vigas da série 5 foi análogo ao das vigas da série 3 (ver Figura 2.13 e 2.14). Por outro lado, a carga de ruptura de vigas reforçadas sob carga depende fundamentalmente dos níveis de tensão atuantes na armadura original tracionada e no concreto comprimido.

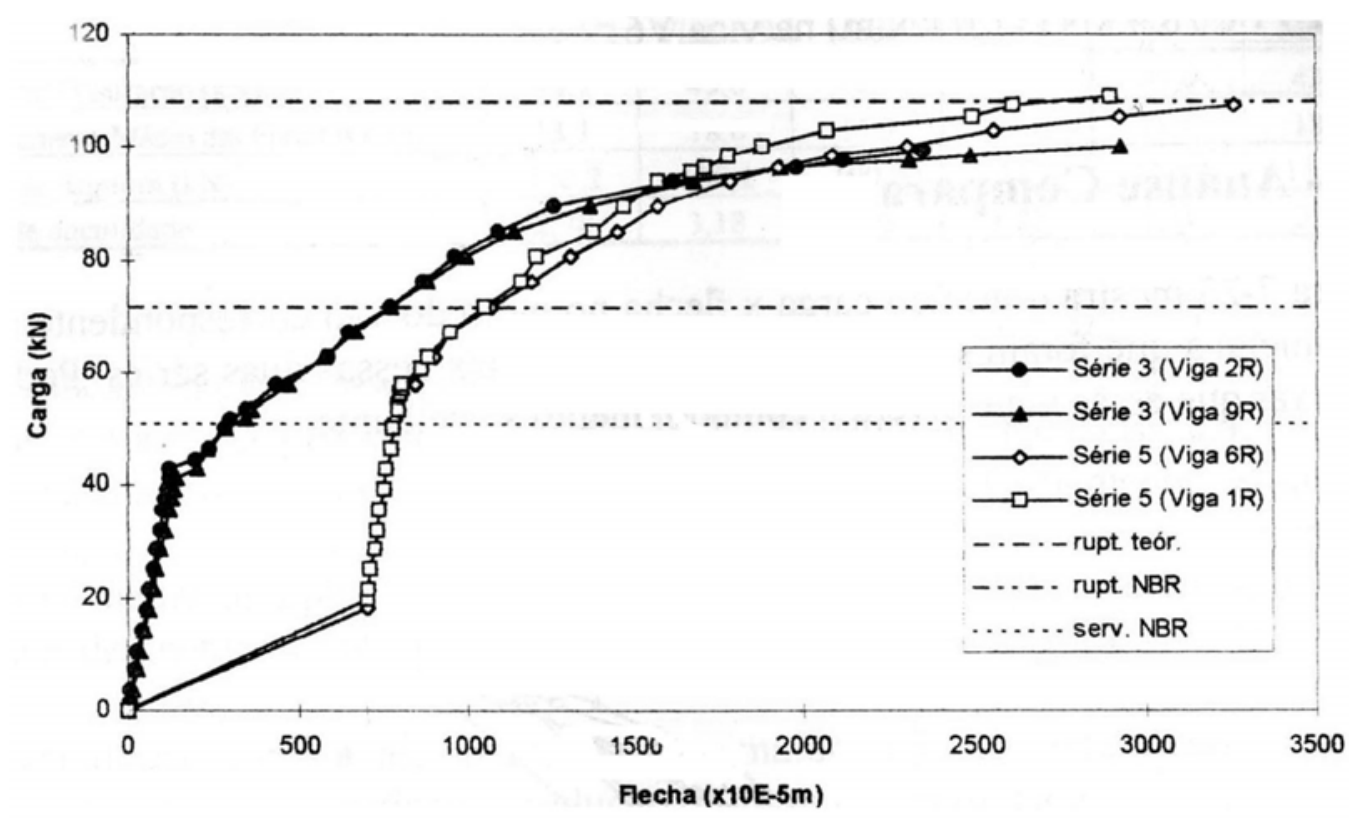

Figura 2.11 - Gráfico carga x flecha (séries 3 e 5) com o pré-carregamento 


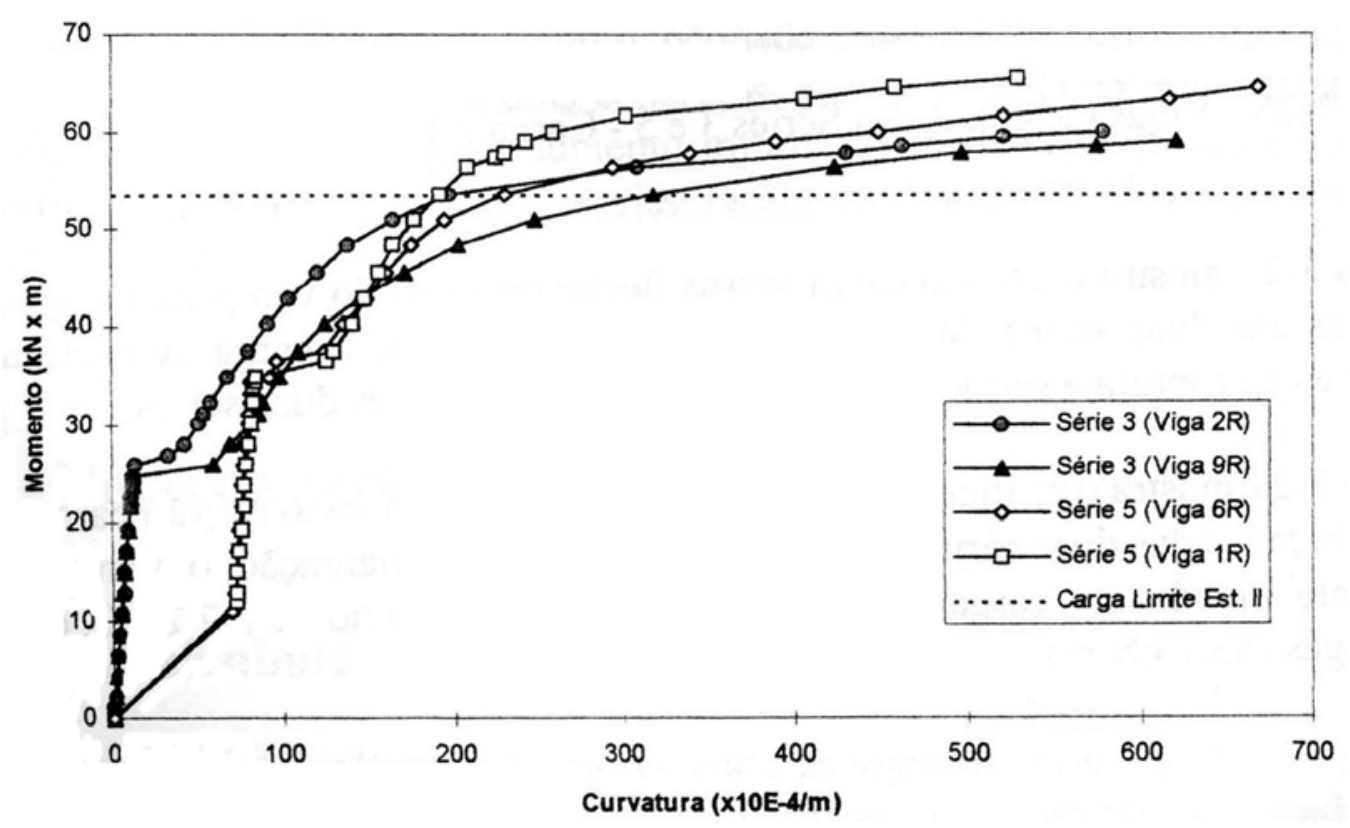

Figura 2.12 - Gráfico momento x curvatura (séries 3 e 5) com o précarregamento

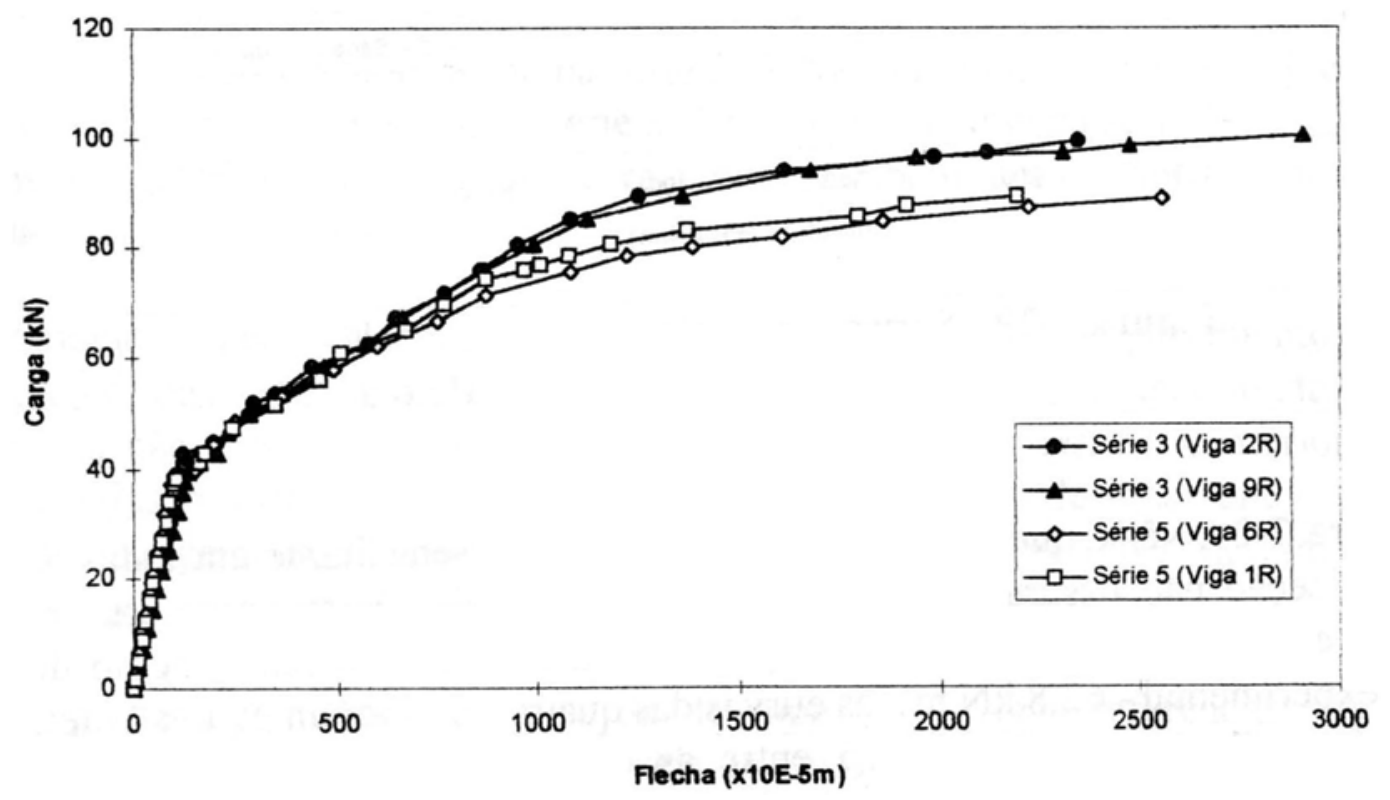

Figura 2.13 - Gráfico carga x flecha (séries 3 e 5) sem o pré-carregamento 


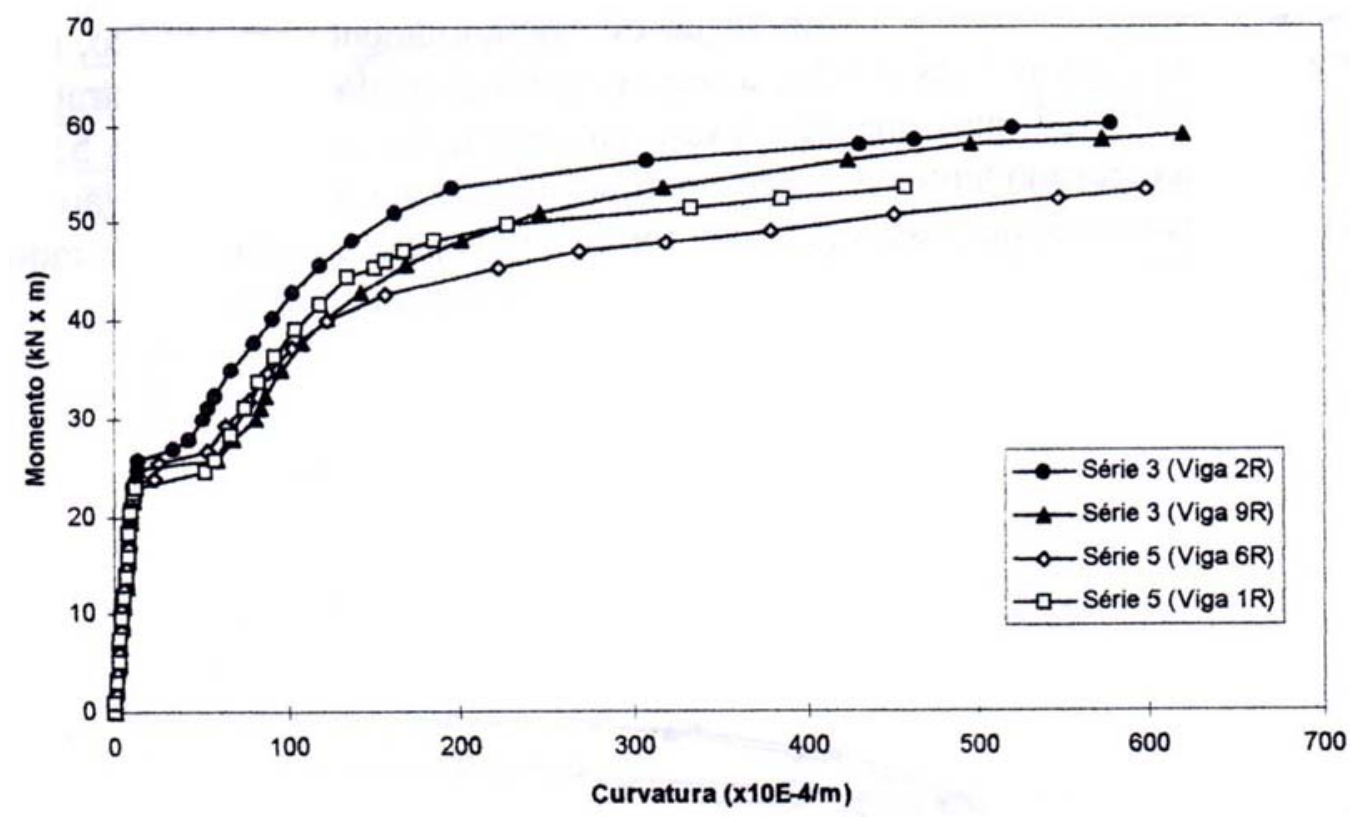

Figura 2.14 - Gráfico momento x curvatura (série 3 e 5) sem o précarregamento

De acordo com PIANCASTELLI, para se ter, na ruptura, uma peça reforçada sob carga com mesmo desempenho de outra reforçada sem estar solicitada, é preciso que a distância entre a armadura da viga original e a do reforço seja tal que a deformação de escoamento desta última seja atingida antes da armadura original e do concreto alcançarem suas respectivas deformações de ruptura. Desta forma, o autor relacionou o desempenho das vigas reforçadas sob pré-carregamento simplesmente ao acréscimo da seção transversal adotada durante o reforço, ou seja, ao tamanho do braço de alavanca da armadura adicionada. Entretanto, é importante esclarecer que, ao contrário do que PIANCASTELLI afirma, acredita-se que outros fatores também influenciam no valor da tensão suportada pela armadura adicionada, além da que é contabilizar apenas pelo efeito do braço de alavanca.

De acordo com as análises feitas, PIANCASTELLI constatou que:

a técnica de reforço estudada foi eficiente, mesmo solicitando-se as peças reabilitadas com o material do reforço ainda "jovem", pois todas as peças romperam por escoamento da armadura tracionada. Isso foi possível pois se adotou uma dosagem adequada do concreto do reforço em função das propriedades que este material deveria apresentar durante a realização do ensaio das peças. 
a quantidade de estribos prolongados não afetou as forças de fissuração e de ruptura das vigas reforçadas, pois as vigas da série 2 e 3 tiveram comportamentos semelhantes, indicando que a resistência de aderência da junta formada pelos concretos moldados em idades distintas foi satisfatória.

$\checkmark$ a tentativa de se aumentar a resistência de aderência do concreto do reforço com o concreto do substrato por meio do envolvimento de um trecho maior das faces laterais das vigas originais (seção $\mathrm{n}^{\circ} 2$ ) não alterou o comportamento conjunto dos dois concretos, apesar de ter se observado um melhor desempenho das vigas da série 4 em serviço e na ruptura.

$\checkmark$ as vigas recuperadas apresentaram início de fissuração para forças mais elevadas do que as vigas monolíticas por terem uma resistência à tração maior no bordo tracionado em função do concreto do reforço adicionado. Entretanto não houve diferenças significativas em relação à força de ruptura.

$\checkmark$ As vigas reforçadas sob carga apresentaram flechas maiores que as descarregadas durante a execução do reforço em função exclusivamente dos deslocamentos já existentes antes do reforço. Ao se desconsiderar tais deslocamentos, o comportamento das peças reforçadas com e sem carga foram equivalentes.

$\checkmark$ Para que as vigas reforçadas sob carga tenham um desempenho semelhante ao de peças reforçadas descarregadas, deve-se posicionar a armadura de flexão do reforço em um local tal que seu escoamento ocorra antes do escoamento da armadura pré-existente na viga. Aqui novamente se faz uma ressalva, pois se acredita que a armadura adicionada tende, até certo ponto, a retardar o início do escoamento da armadura longitudinal pré-existente.

$\checkmark$ O comportamento das vigas reforçadas pode ser estimado com segurança pela norma NBR-6118, estando a peça solicitada ou não no instante da execução do reforço. De qualquer forma, é fundamental estimar as deformações e deslocamentos existentes no instante da execução do reforço para se avaliar corretamente o desempenho da peça reabilitada.

$\checkmark$ A fissuração não alterou o comportamento das peças reabilitadas.

$\checkmark$ Nem sempre é necessário utilizar adesivos estruturais nas ligações entre concreto antigo e novo e nem umedecer o substrato para obter resultados satisfatórios nos trabalhos de reabilitação. 
Analisando as conclusões descritas por CLÍMACO (1990) e PIANCASTELLI (1997) deve-se fazer algumas ressalvas:

$>$ As peças ensaiadas por estes autores foram confeccionadas com o estribo já no tamanho adaptado à seção da peça reforçada, não havendo necessidade de adicionar novos estribos para evitar a ruptura por cisalhamento horizontal, que pode ocorrer entre as camadas de armadura tracionada devido à falta de confinamento do local.

Nos estudos realizados por estes autores, a superfície do concreto antigo antes da moldagem do material de reforço estava propositalmente seca, contrariando as recomendações usuais destinadas à confecção de estruturas compostas. Inicialmente CLÍMACO adotou este procedimento para simular uma situação mais desfavorável. Entretanto, durante o estudo de aderência feito através de ensaios de compressão-cisalhamento (slant shear test) em prismas de junta inclinada moldados com concretos em idades distintas, o autor constatou que os prismas moldados com a superfície do substrato seca apresentaram maior resistência de aderência que os com superfície úmida. Segundo CLÍMACO, “a superfície extremamente seca do concreto do substrato melhora a aderência na interface, possivelmente pela migração e penetração de cristais de cimento hidratado na superfície escarificada do concreto antigo associado a um decréscimo do fator água/cimento do concreto vizinho à junta". PIANCASTELLI também realizou ensaios semelhantes para avaliação da aderência, chegando à mesma conclusão. Daí optou pela utilização do substrato seco, salientando que este procedimento, além de favorecer a aderência, facilita a execução do reforço, pois além do grau de umedecimento da superfície ser de difícil controle, também é difícil retirar a água que cai dentro da fôrma "tipo cachimbo", uma vez que esta deve ser estanque devido à alta fluidez do concreto de reforço utilizado.

Por outro lado, deve-se salientar que a aderência da junta das vigas ensaiadas por CLÍMACO não foi perfeita, pois apesar de não se constatar nenhuma redução da capacidade portante das vigas ensaiadas, surgiram várias fissuras na região da junta formada pela ligação entre 
substrato e reforço. Este tipo de fissuração não foi observado por PIANCASTELLI, talvez porque nos ensaios deste autor houve uma pequena exsudação do concreto do reforço, que provavelmente foi favorável à aderência dos dois concretos, visto que o substrato estava seco. Convém ressaltar também que a resistência da junta ${ }^{1}$ não depende apenas da parcela da aderência existente entre os concretos em contato, mas também de uma parcela referente à taxa de armadura transversal que cruza tal superfície. Contudo, não foi realizado nenhum ensaio específico para quantificar esta parcela nos estudos realizados por PIANCASTELLI e CLÍMACO. De qualquer maneira, é importante esclarecer que o estudo da aderência é bastante complexo, dependendo de vários fatores que nem sempre são perfeitamente controláveis, sendo necessários outros estudos para que se possa definir em que tipos de situações o umedecimento do substrato é favorável ou prejudicial à aderência.

Quanto às peças reforçadas pré-carregadas, PIANCASTELLI só avaliou o comportamento de duas peças idênticas (série 5) reforçadas pelo bordo tracionado e mesmo assim de uma maneira que dificilmente ocorreria na prática, pois tais peças foram reabilitadas sem a necessidade de se deixar trechos expostos da armadura longitudinal, uma vez que os estribos usados já tinham o tamanho adequado à seção final da peça após a intervenção. Já a intervenção feita no bordo comprimido da viga précarregada ensaiada por CLÍMACO (V11) constituiu apenas um reparo, já que somente se substituiu parte do concreto comprimido por outro sem modificar a seção inicial do elemento estrutural. De qualquer maneira, este estudo mostrou que o pré-carregamento aplicado não foi suficientemente grande para que ocorresse a ruptura prematura da peça reabilitada sob carga devido à diferença de tensões e deformações existente nos materiais novos e antigos.

\footnotetext{
${ }^{1}$ No Capítulo 3 estão apresentadas algumas formulações teóricas sobre como avaliar a resistência de juntas formadas por concretos moldados em idades distintas.
} 
$>$ Por último ressalta-se que nenhum destes trabalhos mostrou, de maneira detalhada, um roteiro de dimensionamento a ser seguido durante o reprojeto de peças reforçadas por estas técnicas, e nem se avaliou o efeito da deformabilidade do concreto devida às ações de longa duração no desempenho dos reforços estudados.

\subsubsection{Ensaios realizados por REIS (1998)}

O trabalho realizado por REIS abordou o estudo de duas técnicas de reforço de vigas. Na primeira estudou-se o comportamento de vigas reforçadas por meio da adição de barras de aço convencionais, no banzo tracionado envolvidas por uma argamassa de alto desempenho com e sem adição de fibras de aço. Na segunda estudou-se o comportamento de vigas reforçadas por meio da adição de uma chapa de aço no bordo inferior.

Foi abordada aqui somente a parte do trabalho referente ao estudo do reforço por adição de barras de aço convencionais, na qual se verificou a viabilidade de se adicionar fibras curtas de aço à argamassa de reforço como forma de substituir os estribos necessários para envolver a armadura adicionada à viga, em função da existência de solicitações tangenciais neste local.

Para realizar este estudo REIS ensaiou quatro vigas de seção $\mathrm{T}$ sendo três reforçadas, denominadas de VA-1, VA-2 e VA-3, e uma viga monolítica (VM) para servir de referência. As dimensões, o detalhamento e o esquema de ensaio destas peças estão na Figura 2.15 .

As vigas foram concretadas em duas etapas: primeiro, a parte correspondente à viga original e depois, a parte correspondente ao reforço. Após a concretagem, as vigas VA-1 e VA-2 tiveram a face tracionada apicoada para que se retirasse o concreto até a altura desejada para execução da junta. Ressalta-se que na viga VA-2, o comprimento da armadura de reforço foi reduzido, simulando a presença de um pilar que impedisse o prolongamento da armadura. A viga VA-3 correspondia ao reensaio da VA-1 após ser novamente reforçada pela remoção da argamassa e da armadura tracionada adicionada e pela retirada de parte do substrato para que a junta ficasse posicionada $10 \mathrm{~cm}$ acima do fundo da viga. Como não foi adotado nenhum 
procedimento para vedar as fissuras pré-existentes devido ao ensaio anterior, a VA-3 era na verdade uma viga pré-danificada.

Quanto à presença ou não de fibras, adicionou-se $1 \%$ de fibras de aço à argamassa usada na reconstituição do bordo tracionado das vigas VA-2 e VA-3. Foram usadas fibras de aço da marca HAREX, do tipo HSCF-25 com ganchos nas extremidades. As características destas fibras estão apresentadas na Tabela 2.10.

Em todos os casos, as superfícies de concreto do substrato foram escarificadas, limpas com jato de ar comprimido e umedecidas antes da aplicação da argamassa de alto desempenho. Todas as vigas foram dimensionadas para atingir a ruína por deformação plástica excessiva da armadura longitudinal.

Tabela 2.3 - Características das vigas ensaiadas por REIS (1998)

\begin{tabular}{||l|l|l|c||}
\hline \multicolumn{1}{|c|}{ Viga } & \multicolumn{1}{c|}{$\mathbf{A}_{\text {sir }}$} & \multicolumn{1}{c|}{ Reforço } & Condição de ensaio \\
\hline VM & $3 \phi 16-\ell=317$ & - & Monolítica \\
\hline VA-1 & $3 \phi 16-\ell=317$ & Argamassa sem fibras de aço & Sem dano \\
\hline VA-2 & $3 \phi 16-\ell=280$ & Argamassa com $1 \%$ de fibras de aço & Sem dano \\
\hline VA-3 & $3 \phi 16-\ell=317$ & Argamassa com $1 \%$ de fibras de aço & Viga VA-1 reabilitada \\
\hline
\end{tabular}

Tabela 2.4 - Características do concreto e da argamassa de reforço no dia do ensaio

\begin{tabular}{|c|c|c|c|c|c|c|c|c|c|c||}
\hline \hline \multirow{2}{*}{ Viga } & \multicolumn{1}{|c|}{ Idade (dias) } & \multicolumn{1}{c|}{ Substrato } & \multicolumn{4}{c||}{ Reforco } \\
\cline { 2 - 13 } & subs. & ref. & $\begin{array}{c}\mathbf{E}_{\mathbf{c o}} \\
\mathbf{M P a}\end{array}$ & $\begin{array}{c}\mathbf{E}_{\mathbf{c}} \\
\mathbf{M P a}\end{array}$ & $\begin{array}{c}\mathbf{f}_{\mathbf{c j}} \\
\mathbf{M P a}\end{array}$ & $\begin{array}{c}\mathbf{f}_{\mathbf{t j}} \\
\mathbf{M P a}\end{array}$ & $\begin{array}{c}\mathbf{E}_{\mathbf{c o}} \\
\mathbf{M P a}\end{array}$ & $\begin{array}{c}\mathbf{E}_{\mathbf{c}} \\
\mathbf{M P a}\end{array}$ & $\begin{array}{c}\mathbf{f}_{\mathbf{c j}} \\
\mathbf{M P a}\end{array}$ & $\begin{array}{c}\mathbf{f}_{\mathbf{t j}} \\
\mathbf{M P a}\end{array}$ \\
\hline \hline VM & 14 & - & 25.996 & 22.139 & 24,76 & 2,39 & - & - & - & - \\
\hline VA-1 & 12 & 8 & 26.834 & 20.457 & 34,03 & 2,75 & 27.837 & 19.473 & 46,02 & 3,87 \\
\hline VA-2 & 13 & 8 & 35.468 & 30.218 & 26,32 & 2,76 & 28.808 & 26.483 & 58,70 & 4,95 \\
\hline VA-3 & 175 & 7 & 36.454 & 32719 & 46,04 & 3,46 & 30.215 & 28.335 & 60,23 & 4,87 \\
\hline \hline
\end{tabular}

Tabela 2.5 - Resultados das vigas ensaiadas por REIS (1998)

\begin{tabular}{|c|c|c|c|c|}
\hline \multirow[t]{2}{*}{ Viga } & \multicolumn{2}{|c|}{ Força de ruína $(\mathrm{kN})$} & \multirow[t]{2}{*}{$\mathbf{F}_{\text {real }} / \mathbf{F}_{\text {teórica }}$} & \multirow[t]{2}{*}{ Modo de ruína } \\
\hline & $\mathbf{F}_{\text {real }}$ & $F_{\text {teórica }}$ & & \\
\hline $\mathrm{VM}$ & 160 & 153 & 1,05 & $\begin{array}{l}\text { Fissura horizontal na interface substrato/reforço, por falta de } \\
\text { ligação com estribos e início do escoamento de } \mathrm{A}_{\text {slr }}\end{array}$ \\
\hline VA-1 & 160 & 204 & 0,78 & Perda de aderência entre as camadas substrato/reforço \\
\hline VA-2 & 130 & 185 & 0,70 & Deficiência de ancoragem da armadura principal \\
\hline VA-3 & 202 & 194 & 1,04 & $\begin{array}{l}\text { Escoamento da armadura de flexão e esmagamento do } \\
\text { concreto comprimido }\end{array}$ \\
\hline
\end{tabular}




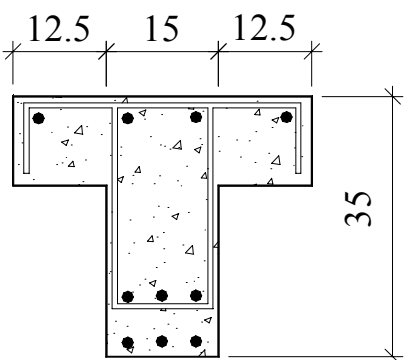

VM

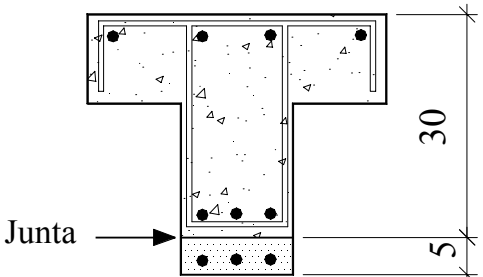

VA-1

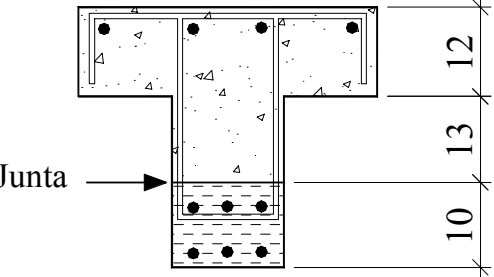

VA-2 e VA-3

Legenda:

Concreto

Argamassa de alto desempenho

Argamassa de alto desempenho com fibra

(a) seção transversal

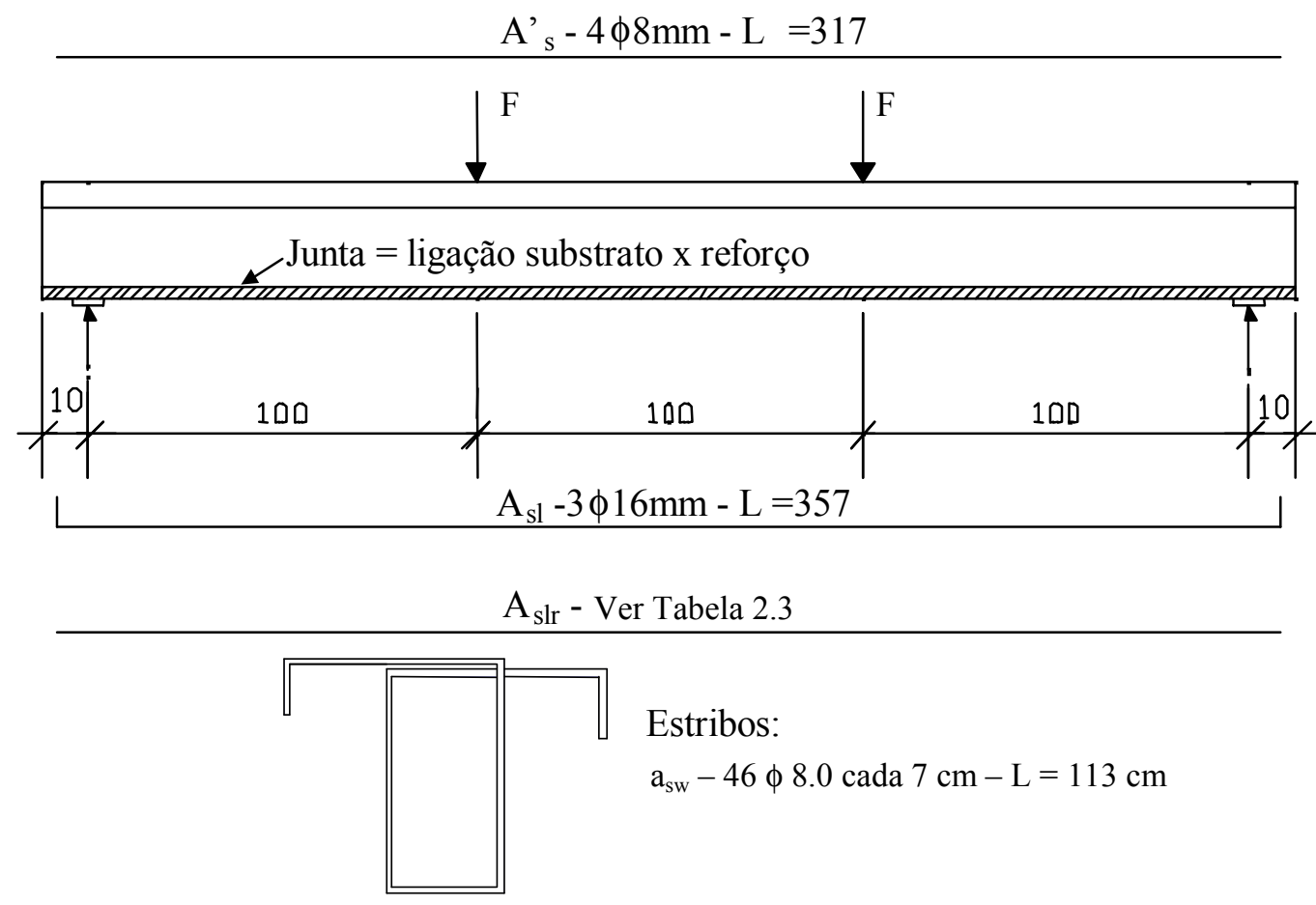

(b) seção longitudinal

Figura 2.15 - Vigas ensaiadas por REIS (1998) 

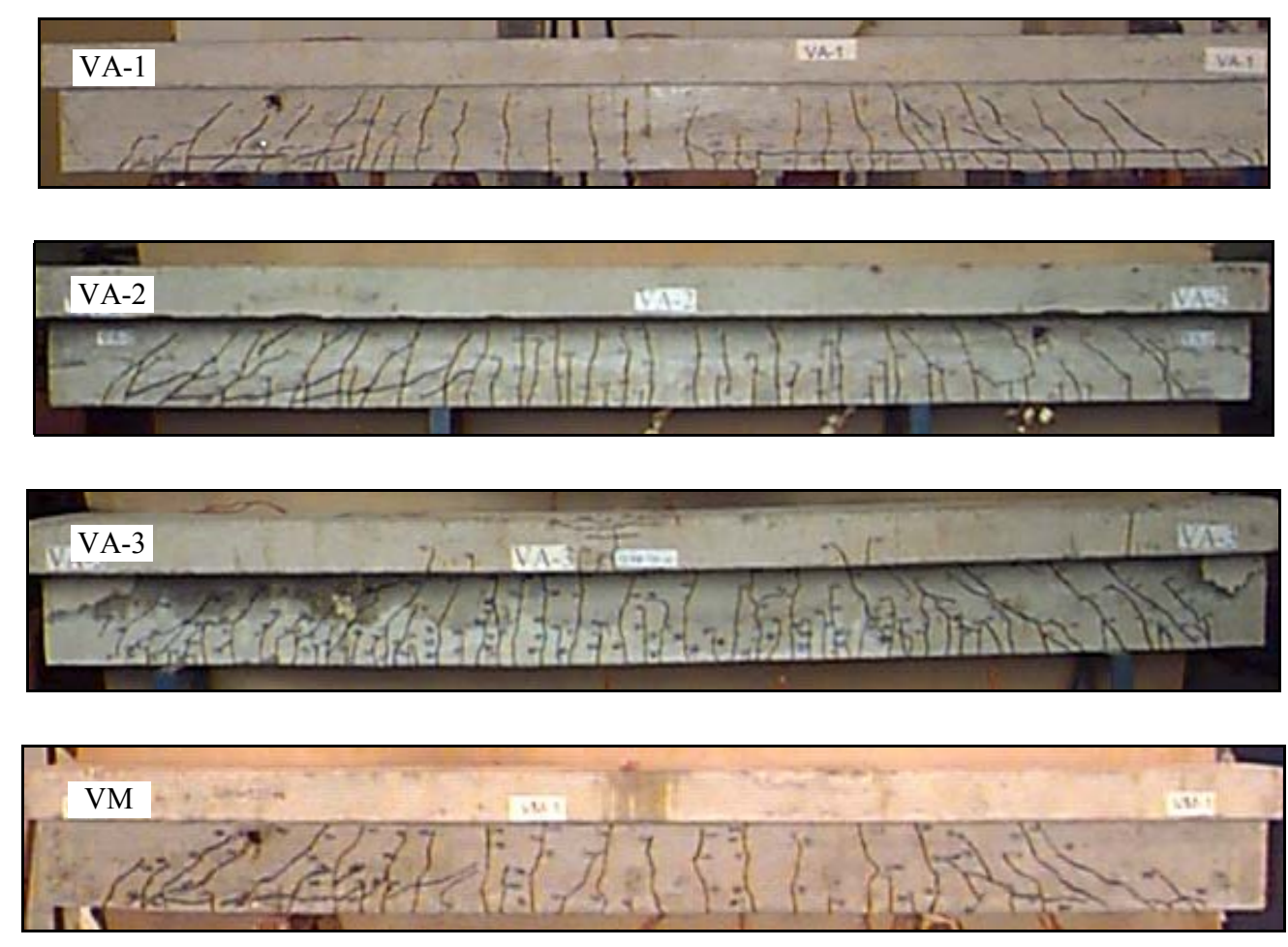

Figura 2.16 - Esquema de fissuração e ruptura - vigas ensaiadas por REIS (1998)

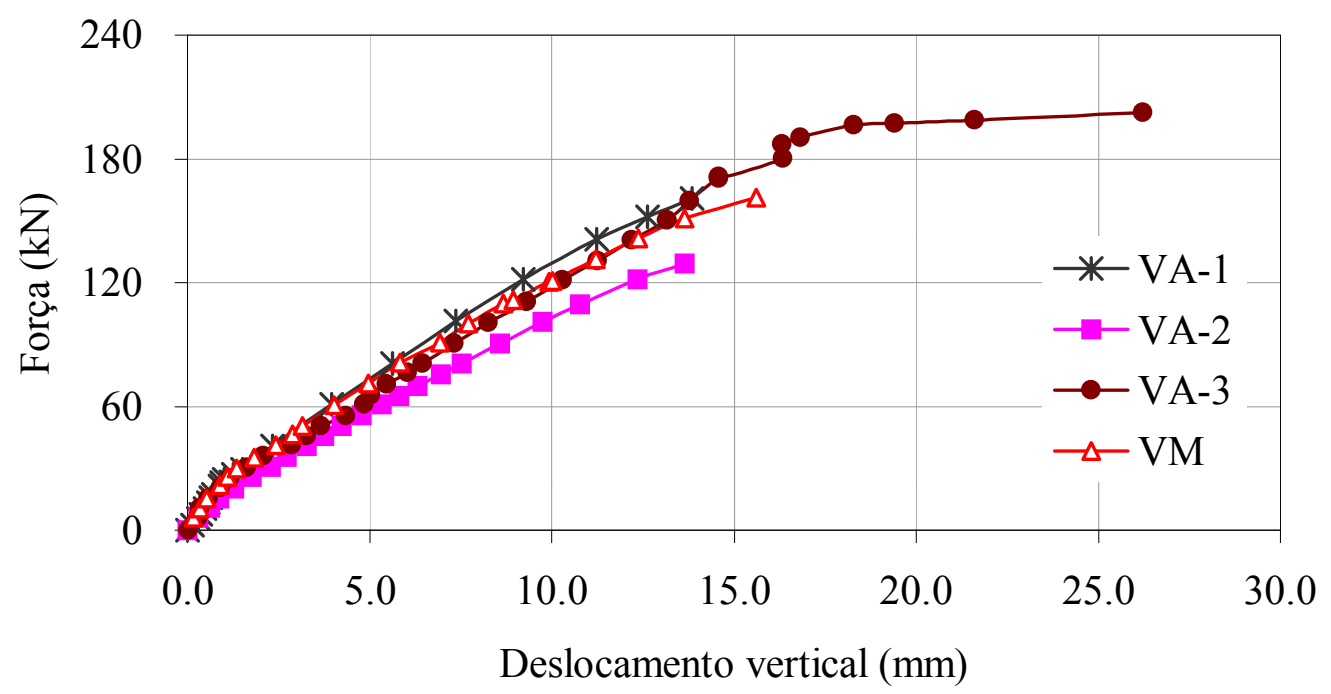

Figura 2.17 - Força x deslocamento vertical das vigas ensaiadas por REIS (1998) 

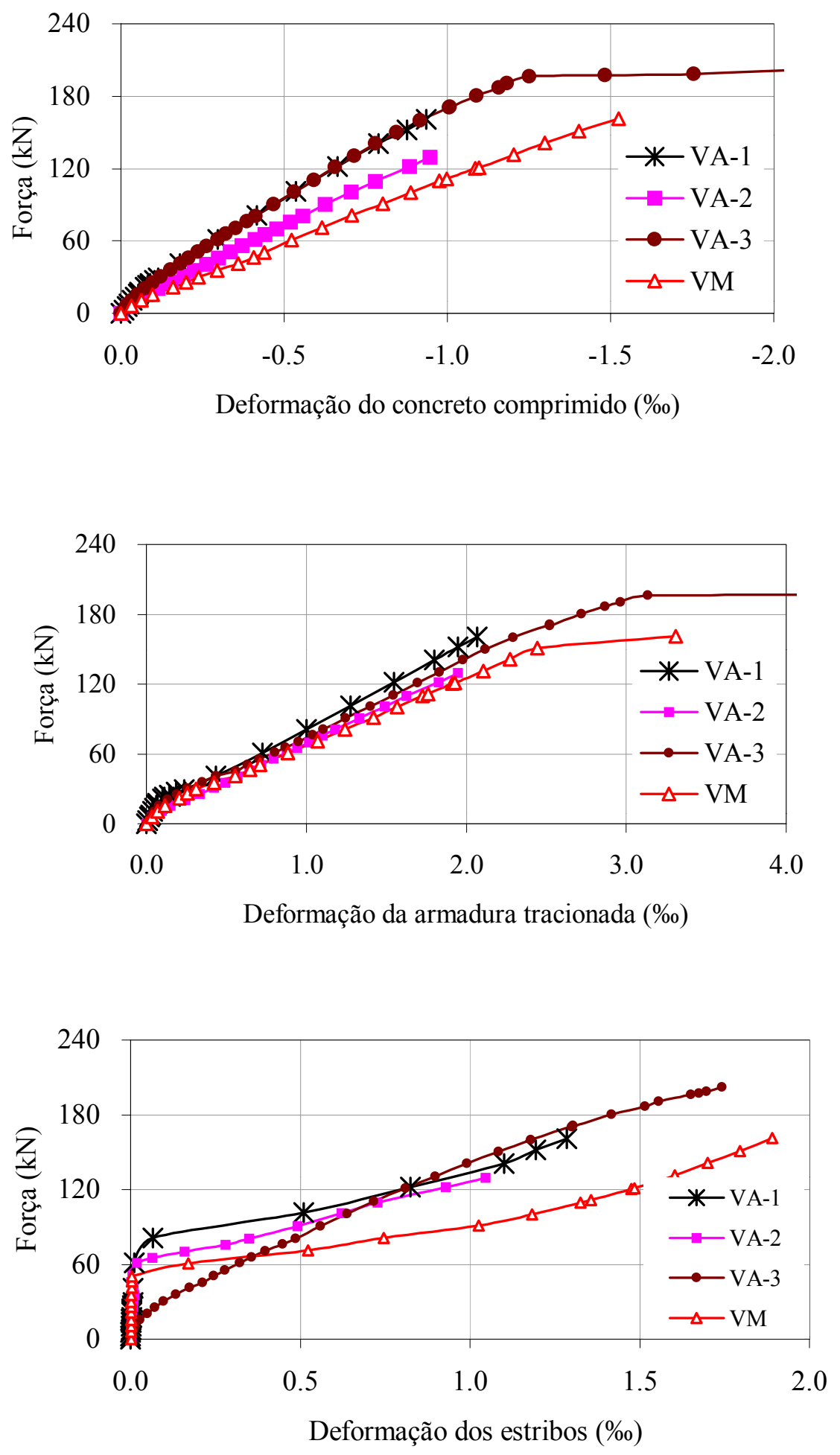

Figura 2.18 - Gráficos das deformações das armaduras das vigas ensaiadas por REIS (1998) 
Os ensaios foram executados de acordo com a seguinte metodologia:

○ inicialmente se ensaiou a viga VA-1 que possuía a junta em um trecho não atravessado por armadura transversal e empregou-se uma argamassa sem adição de fibras de aço para envolver a armadura longitudinal de reforço. Durante o ensaio observou-se que a peça rompeu prematuramente por cisalhamento horizontal devido à falhas de aderência entre o substrato e o reforço;

- para evitar a ocorrência deste tipo de ruptura nas outras vigas reabilitadas, optou-se por escarificar um pouco mais a face tracionada da viga original de maneira que fosse possível usar os estribos já existentes no elemento original como uma armadura de costura a fim de aumentar a resistência ao cisalhamento da junta;

○ avaliou-se também se o fato da armadura de reforço não estar envolvida por estribos prejudicaria o desempenho da estrutura reabilitada. Para isso ensaiou-se a viga monolítica VM usando o mesmo detalhamento das peças reforçadas;

○ a viga VM também rompeu prematuramente por cisalhamento horizontal indicando que é preciso envolver as barras de aço do reforço com algum tipo de armadura para evitar o deslizamento relativo entre as barras tracionadas da primeira e da segunda camada devido à falta de confinamento do local;

○ foram então adicionadas fibras curtas de aço à argamassa de reforço para tentar garantir uma adequada transmissão de esforço entre as barras de aço originais e adicionadas a fim de evitar o tipo de ruptura observado na VM;

- ensaiou-se a viga VA-2 na qual se usou argamassa com fibras e junta mais profunda. Entretanto, como o comprimento da armadura de tração adicionada foi menor para tentar simular a presença de pilares nas extremidades do elemento, a peça rompeu prematuramente. Contudo esta ruptura prematura se deu por falhas de ancoragem e não por deficiências do método de reforço empregado;

- Para tentar confirmar a eficiência do método de reforço proposto, ensaiou-se a VA-3 utilizando-se como base a viga VA-1 já ensaiada, mas fazendo-se as modificações no método de reforço já mencionadas anteriormente. Tal peça 
atingiu a resistência máxima esperada pois rompeu por escoamento da armadura de flexão seguido do esmagamento do concreto comprimido mesmo apesar de já estar pré-fissurada.

Pelos resultados obtidos por REIS (1998) constatou-se que:

$\checkmark$ a técnica de reforço proposta é potencialmente viável caso se posicione a junta em uma região atravessada por estribos e caso se consiga garantir uma boa transmissão de esforços entre as barras de aço adicionadas e as pré-existentes na peça reabilitada, pela adição de fibras curtas de aço à argamassa de reforço;

$\checkmark$ as fibras de aço conseguem, em parte, substituir a função das armaduras transversais e promover uma boa transmissão de esforços entre a armadura adicional e o banzo a ser reforçado. Esse efeito pode ter ser associado a uma "ligação contínua", como uma costura proporcionada pelas fibras;

$\checkmark$ devido à pequena quantidade de ensaios realizados, não foi possível contabilizar como as fibras contribuem nesta transmissão de esforços, sendo necessário realizar novos testes para avaliar com segurança o desempenho das vigas reforçadas por essa técnica. É preciso também estabelecer um método que possibilite selecionar qual o tipo e o teor de fibras de aço mais indicado a ser adicionado na argamassa de reforço para que se tenha uma boa transmissão de esforços entre as barras adicionadas e as já existentes na peça, além de verificar se o fato da armadura longitudinal no reforço não ter sido envolvida por estribos, mas por fibras, altera o posicionamento do banzo tracionado e a inclinação das bielas comprimidas;

$\checkmark \quad \mathrm{O}$ fato de ser possível reforçar uma viga pela técnica de reforço proposta, na qual não há a necessidade de adicionar novos estribos nem aumentar a largura da seção, é particularmente interessante em casos de elementos com elevadas taxas de armadura, pois a intervenção se torna mais simples de ser executada.

\subsubsection{Ensaios realizados por SÁ (1993)}

SÁ ensaiou 15 vigas de concreto armado para avaliar a técnica de reforço mediante acréscimo de altura útil no bordo comprimido por adição de concreto de resistência normal, verificando basicamente a eficiência da ligação entre os dois concretos sem o emprego de adesivos e com ou sem armadura cruzando a interface. 
O tratamento dado à superfície de ligação entre os concretos foi um apicoamento manual seguido de escovação e lavagem.

As vigas foram subdivididas em três séries ${ }^{1}$ com cinco peças cada, sendo que cada série tinha vigas com as seções transversais apresentadas na Figura 2.19. Estas seções tinham basicamente dimensões de $10 \times 30 \mathrm{~cm}^{2}$ e de $10 \times 40 \mathrm{~cm}^{2}$. De acordo com o autor, todas as vigas tiveram um comportamento de peça subarmada, sendo a ruptura iniciada por escoamento da armadura de tração seguida pelo esmagamento do concreto comprimido, apesar de às vezes terem aparecido fissuras na superfície de ligação. O concreto usado para aumentar a altura do bordo comprimido foi projetado para ter a mesma resistência do concreto do substrato, no caso de $15 \mathrm{MPa}$, no dia do ensaio da peça reforçada.

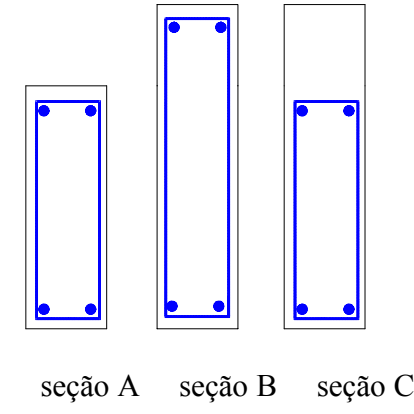

Vigas monolíticas

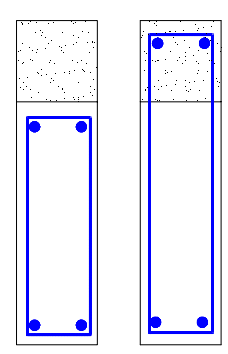

seção D seção E

Vigas reforçadas

Figura 2.19 - Tipos de seção transversal das vigas ensaiadas por SÁ (1993)

Tabela 2.6 - Médias dos resultados das vigas ensaiadas por SÁ (1993)

\begin{tabular}{|c|c|c|c|}
\hline Tipo de seção & $F_{\text {ruptura }}$ & (1) & (2) \\
\hline $\mathrm{A}$ & 44.0 & 1.00 & - \\
\hline $\mathrm{B}$ & 62.7 & 1.42 & - \\
\hline $\mathrm{C}$ & 62.4 & 1.42 & - \\
\hline $\mathrm{D}$ & 56.1 & 1.27 & 0.90 \\
\hline $\mathrm{E}$ & 58.5 & 1.33 & 0.93 \\
\hline \multicolumn{4}{|c|}{$\begin{array}{l}\text { OBS. } \\
\text { (1) relação entre a força de ruptura da seção tipo considerada e a força na seção tipo A } \\
\text { (2) relação entre a força de ruptura da seção tipo considerada e a força na seção monolítica } \\
\text { correspondente. }\end{array}$} \\
\hline
\end{tabular}

Os resultados obtidos mostraram que para o estado limite de utilização, a ligação executada nas vigas com seção D e E foram eficientes, pois tiveram comportamentos semelhantes aos das vigas monolíticas (seções B e C). Para o

\footnotetext{
${ }^{1}$ A única diferença entre as séries foi a data de execução dos serviços de recuperação.
} 
estado limite último, apesar de ter ocorrido o esmagamento do concreto comprimido em ambas as peças, as vigas com seção D apresentaram deformações bem maiores que todas as outras vigas de mesma altura. No entanto, não houve ruptura na superfície de ligação, indicando que a tensão de aderência foi maior que a tensão de deslizamento. Por estes resultados, percebe-se que nem sempre é preciso ter uma armadura cruzando a interface para garantir a monoliticidade da peça reforçada.

\subsubsection{Ensaios realizados por SUMIE \& LOPES (2000)}

SUMIE \& LOPES avaliaram o reforço de vigas em concreto armado pelo acréscimo de uma camada de apenas $5 \mathrm{~cm}$ de concreto de alta resistência na região comprimida. Foram ensaiadas 3 vigas de seção retangular sendo duas reforçadas e uma monolítica. A viga monolítica, VT, foi moldada em uma única etapa usando somente o traço do concreto do substrato. A viga reabilitada, VR-PRE, foi moldada em uma única etapa, mas usando tanto o traço do concreto do reforço quanto o traço do concreto do substrato (não existe junta devido ao processo de moldagem em uma só etapa). Já a viga reabilitada VR-POS, foi confeccionada em duas etapas, uma para cada tipo de concreto utilizado. As peças reforçadas foram perfuradas ao longo de sua altura para introdução de uma armadura transversal de conexão para ligar a armadura transversal já existente à nova camada de concreto do reforço (ver Figura 2.20). Não foram usadas pontes de aderência para melhorar a ligação entre concreto novo e substrato. No dia do ensaio o concreto do substrato apresentava uma resistência de $35 \mathrm{MPa}$ e o do reforço de $75 \mathrm{MPa}$. A armadura de costura usada na região da junta nas vigas reforçadas foi dimensionada para que a mesma fosse efetivamente solicitada para carregamentos próximos ao escoamento da armadura longitudinal, de maneira que a ligação entre as camadas e, conseqüentemente, os procedimentos de ligação adotados fossem analisados de forma efetiva. 


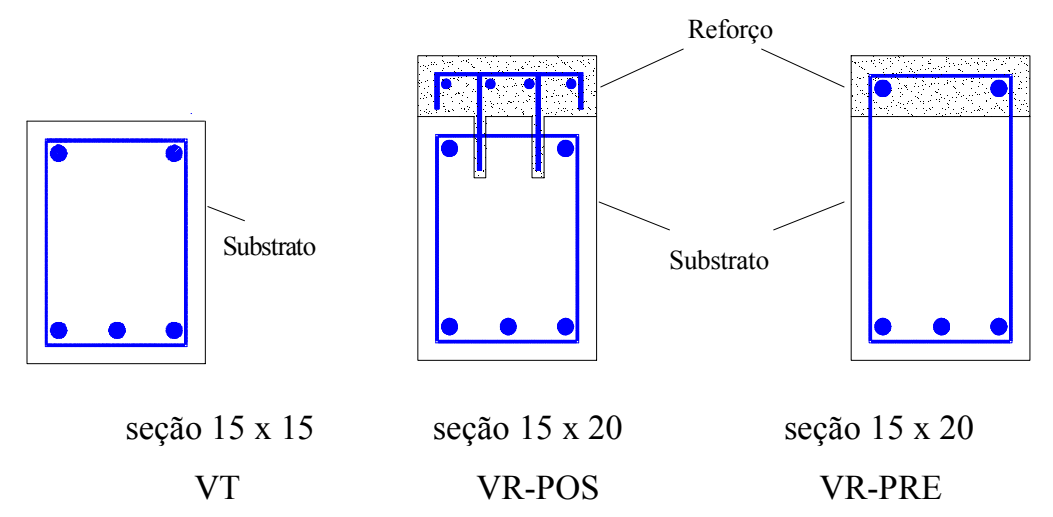

Figura 2.20 - Seção transversal das vigas ensaiadas por SUMIE \& LOPES (2000)

Tabela 2.7 - Resultados das vigas ensaiadas por SUMIE \& LOPES (2000)

\begin{tabular}{l|c|c|c}
\hline Viga & $\mathbf{M}_{\text {real }}$ & $\mathbf{M}_{\text {teorico }}$ & Tipo de Ruptura \\
\hline VT & 53,10 & 50,03 & Escoamento da armadura longitudinal \\
\hline VR-POS & 78,38 & 87,15 & Escoamento da armadura transversal seguida do esmagamento do \\
VR-PRE & 78,11 & 87,15 & concreto comprimido \\
\hline
\end{tabular}

Pelos resultados os autores concluíram que o acréscimo do momento fletor suportado pelas peças reforçadas foi de $46 \%$ em relação à peça antes do reforço, indicando que é possível utilizar uma camada de pequena espessura de concreto de alta resistência para reforçar vigas. Como não se constatou nenhuma movimentação relativa na região da junta, pode-se dizer que os procedimentos adotados para se fazer a ligação concreto novo/concreto velho e que os adotados para se dimensionar a armadura de costura (usando a mesma bitola da armadura de cisalhamento) foram eficientes. Os autores ressaltam ainda a importância de se realizar mais estudos que avaliem as influências de variáveis como taxa de armadura longitudinal, de armadura transversal, relação entre alturas das camadas de concreto velho e concreto novo entre outras.

Analisando este estudo, convém ressaltar que a viga VT deveria ter sido dimensionada para romper por esmagamento do concreto no bordo comprimido. Da forma como foi feito o dimensionamento, o aumento da resistência ocorreu basicamente em função do aumento do braço de alavanca, sem considerar a real influência do uso do concreto de alta resistência. 


\subsubsection{Ensaios realizados por CAMPOS (2000)}

CAMPOS $^{2}$ avaliou o comportamento experimental de quatro lajes maciças de concreto armado, sendo uma delas monolítica e as outras três reforçadas pela face superior por adição de uma camada de concreto de alto desempenho com espessura variável. Essa variação na espessura confere à camada de reforço uma forma de lente plano-convexa de bordos delgados com pequena espessura nos bordos $(2 \mathrm{~cm}) \mathrm{e}$ maior espessura no centro $(4 \mathrm{~cm})$, calculada considerando o vão, taxa de armadura e solicitações. Nestes ensaios avaliou-se a deficiência da resistência do concreto e a deficiência de armadura longitudinal.

Quanto à forma de preparação da superfície para receber o reforço, CAMPOS optou pelo umedecimento justificando que se a reabilitação for à base de produtos de cimento Portland, o substrato deve estar saturado para que este não retire água do novo sistema, geralmente dosado com baixo fator água/cimento. Isso porque se o substrato estiver muito seco, ao se retirar água do material de reforço adicionada, será tirada uma zona de interface em que faltará água para hidratação da pasta do concreto que está sendo aplicado, prejudicando a aderência entre os materiais. Além disso, para melhorar ainda mais a aderência optou-se pelo uso de concreto de alto desempenho (50 MPa) com sílica ativa. Portanto, a escolha deste material de reforço se prende não à resistência, e sim ao poder de aderência que o concreto de alto desempenho tem em relação a outros concretos convencionais sem adições e com fator água/cimento alto.

Após a realização dos ensaios CAMPOS constatou que:

- todas as lajes romperam por escoamento da armadura longitudinal sem o esmagamento do concreto no bordo comprimido. Entretanto, nas lajes com insuficiência de armadura longitudinal, o reforço, apesar de elevar a carga última de ruptura, não demonstrou o mesmo grau de eficiência, pois a capacidade portante do elemento ficou limitada pela quantidade de armadura. Sendo assim, é preciso verificar a quantidade de armadura existente do elemento a ser reforçado para avaliar a viabilidade ou não de se usar este processo de reforço. Portanto a técnica de

\footnotetext{
${ }^{2}$ Apesar deste trabalho se referir ao reforço de lajes, acredita-se que algumas conclusões possam se aplicadas ao reforço de vigas, já que ambos elementos são predominantemente solicitados à flexão.
} 
reforço empregada é eficiente para os casos em que há uma taxa mínima de armadura;

- nas peças onde havia deficiência na resistência do concreto, observou-se um ganho na capacidade portante de $30 \%$ a $32 \%$ com a aplicação do concreto ao bordo comprimido em relação à uma laje de referência sem o reforço. Constatou-se ainda que o ganho gerado pelo aumento da altura útil foi preponderante ao ganho de resistência do elemento reforçado em relação à resistência do concreto;

- a maneira de preparo da superfície foi satisfatória, pois não se percebeu nenhuma falha na aderência entre os concretos moldados em idades distintas para nenhum modelo ensaiado, o que foi confirmado pelo comportamento monolítico observado nas peças reforçadas.

\subsection{Metodologia usada no Programa Experimental desenvolvido}

Neste item apresenta-se resumidamente a metodologia usada na definição dos modelos ensaiados no programa experimental desenvolvido no Laboratório de Estruturas da Escola de Engenharia de São Carlos - USP, referente ao presente trabalho.

Inicialmente definiu-se que seria estudado o reforço de vigas aumentando-se a capacidade portante em relação ao momento fletor. Identificou-se o tipo de reforço mais utilizado no Brasil e fez-se um levantamento do conhecimento técnico disponível sobre tal método de reabilitação. De posse deste levantamento, definiu-se as lacunas de conhecimento, identificando os tópicos que ainda geravam dúvidas durante o redimensionamento e reprojeto de elementos estruturais usando este tipo de intervenção.

\subsubsection{Descrição resumida dos ensaios principais}

Para tentar sanar tais dúvidas selecionou-se duas técnicas de reforço de vigas de seção T para serem estudadas mais aprofundadamente caracterizadas pela:

- Adição de armaduras longitudinais ao banzo tracionado por encamisamento com argamassa de alto desempenho com fibras de aço (Técnica de Reforço n⿳0 1);

- Adição de microconcreto de alta resistência ao banzo comprimido da viga (Técnica de $\operatorname{Reforço~} \mathbf{n}^{\circ} \mathbf{2}$ ); 
As características das vigas foram escolhidas para permitir a análise das seguintes variáveis:

- Eficiência dos tipos de reforço realizados

- Influência de um pré-carregamento atuante na peça durante a execução do reforço

- Verificação da necessidade do uso de armaduras de solidarização ${ }^{3}$

- Avaliação do efeito da fluência e retração na viga reabilitada para reforços no bordo comprimido

A nomenclatura adotada para representar as vigas de seção $\mathrm{T}$ analisadas foi:

"nome da viga" $=\mathrm{V} \underline{\mathrm{a}} \underline{\mathrm{b}} \underline{\mathrm{c}}$

onde:

$\mathbf{V}$ : tipo de elemento estudado que corresponde a uma viga;

a : indica se a viga foi ou não reforçada

$\mathrm{F}=$ refere-se às vigas reforçadas aumentando-se a resistência ao momento fletor;

$\mathrm{O}=$ refere-se às vigas originais de referência antes da execução do reforço;

$\underline{\mathbf{b}}$ : localização do bordo no qual foi executado o reforço:

$\mathrm{C}=$ bordo comprimido

$\mathrm{T}=$ bordo tracionado

c : número do modelo ensaiado em função do programa experimental realizado.

No total foram ensaiadas cinco vigas, sendo duas reforçadas no bordo tracionado e três no bordo comprimido. Para maiores informações a respeito das dimensões, detalhamento, esquema de ensaio, tipo e duração do carregamento aplicado e outros detalhes específicos dos modelos de vigas $\mathrm{T}$ reforçados deve-se consultar os Capítulos 5 e 7 respectivamente.

\footnotetext{
3 O termo armadura de solidarização (FUSCO, 1994) é usado na definição de armaduras responsáveis pelo equilíbrio local das peças estruturais, ou seja, pela transmissão de esforços entre concreto $\mathrm{x}$ concreto, concreto $\mathrm{x}$ armadura e/ou armadura $\mathrm{x}$ armadura.
} 


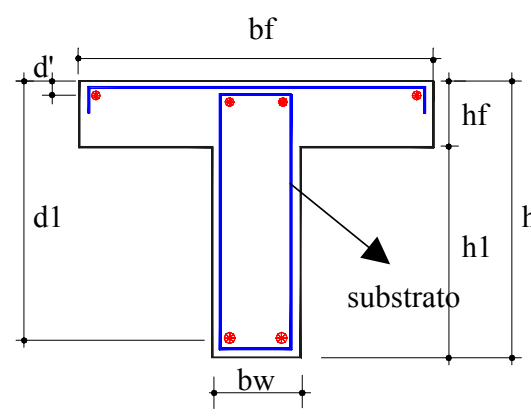

VO-1 = VO-2

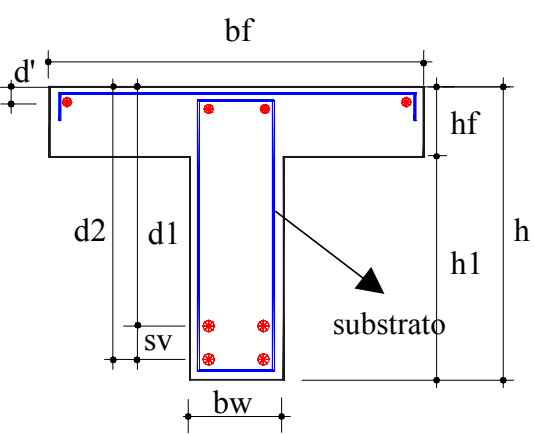

VO-3 $=$ VO-4 = VO-5

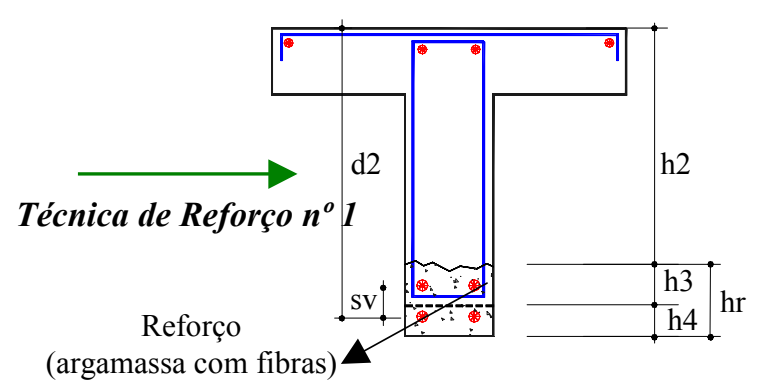

VFT-1 e VFT-2

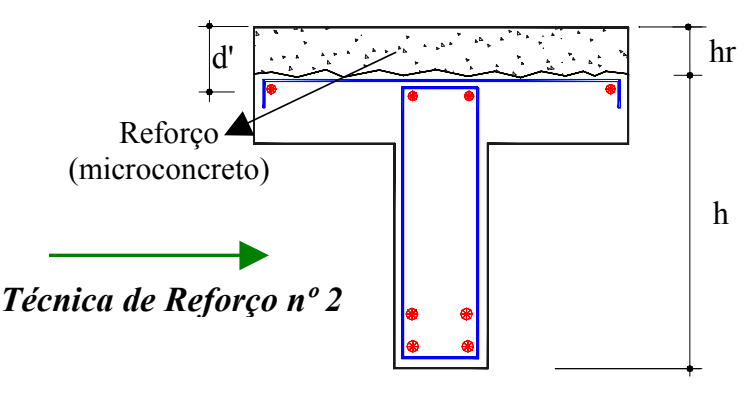

VFC-1; VFC-2 e VFC-3

Figura 2.21 - Esquema das Técnicas de reforço estudadas - ensaios principais

Cada técnica de reforço envolvia dois dimensionamentos diferentes, ambos baseados nos procedimentos de cálculo recomendados pela NBR-6118. O primeiro correspondia ao dimensionamento da viga original (VO) confeccionada antes de se executar o reforço, e o segundo correspondia ao dimensionamento da peça após a reabilitação (VFT ou VFC). As vigas originais a serem reforçadas no bordo tracionado (VO-1 e VO-2) foram dimensionadas para se comportarem como peças subarmadas, ou seja, caso houvesse ruptura, esta ocorreria por deformação plástica excessiva da armadura de flexão (domínio 2). Já para o reforço no bordo comprimido partiu-se do princípio de que se tinha vigas originais superarmadas (VO-3; VO-4 e VO-5), de forma que se houvesse uma ruptura, esta ocorreria por esmagamento do concreto comprimido de maneira frágil (domínio 4). Todavia, após a execução da intervenção todas as vigas reforçadas deveriam romper por deformação plástica excessiva da armadura longitudinal e esmagamento do concreto comprimido (domínio 3). Como não se desejava que as vigas reforçadas rompessem 
por ação do esforço cortante, superdimensionou-se a taxa de armadura transversal utilizada.

Os cálculos da força de ruptura das vigas após o reforço foram feitos de acordo com as recomendações da NBR 6118, mas sem utilizar os coeficientes de segurança.

Para simular as situações encontradas na prática, todas as vigas (exceto a VFC-2) foram pré-fissuradas antes da intervenção e estavam pré-carregadas durante a execução do reforço.

O efeito da fluência foi analisado somente para as vigas reforçadas no bordo comprimido (vigas VFC), já que nos modelos reabilitados pelo bordo tracionado (vigas VFT) o material do reforço, por hipótese de dimensionamento, encontra-se fissurado fazendo com que os efeitos de longa duração não afetem tão significativamente o desempenho do elemento estrutural reabilitado. Como o fenômeno de retração é bastante difícil de ser controlado, tentou-se evitar ao máximo sua ocorrência fazendo uma cura adequada das peças.

Definidas as características geométricas das vigas $\mathrm{T}$ a serem reforçadas, percebeu-se que nem todos os parâmetros necessários à avaliação do comportamento delas podiam ser estimados teoricamente, sendo preciso realizar ensaios complementares específicos.

\subsubsection{Descrição resumida dos ensaios complementares}

\section{Ensaios complementares das vigas do tipo VFT}

Em relação às vigas reforçadas no bordo tracionado, realizou-se ensaios complementares para selecionar qual o tipo de fibra de aço disponível comercialmente apresentaria um melhor desempenho quando adicionada à argamassa do reforço. Foi preciso também verificar a viabilidade de se utilizar tal material compósito (argamassa com fibras de aço) na reconstrução do banzo tracionado, de maneira que não ocorresse a ruptura interna por cisalhamento longitudinal entre as camadas das barras de aço pelo não envolvimento da última camada por estribos. Para isso foram realizados dois tipos de ensaios complementares: 
a) ensaios de flexão em prismas de argamassa com fibras de aço;

b) ensaios de vigas preliminares retangulares de pequenas dimensões.

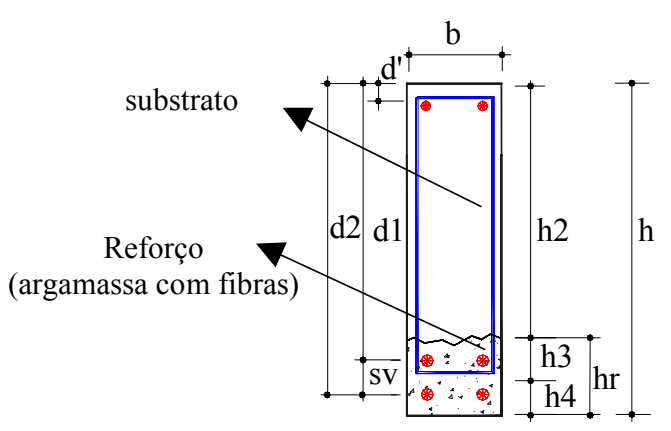

VP (série 1)

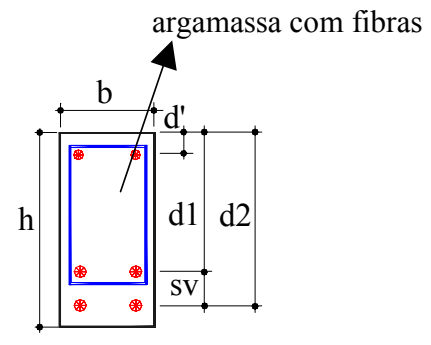

VP (série 2)

Vigas preliminares

\section{Figura 2.22 - Esquema dos ensaios complementares de vigas retangulares}

Somente após a obtenção dos resultados destes ensaios é que se pôde definir o tipo e a taxa de fibra a ser adicionada à argamassa do reforço das vigas reabilitadas pela Técnica de Reforço $\mathrm{n}^{\mathrm{o}} 1$. Os detalhes destes ensaios estão apresentados no

\section{Capítulo 4.}

\section{Ensaios complementares das vigas do tipo VFC}

Em relação às vigas reforçadas no bordo comprimido foi necessário realizar vários ensaios complementares em corpos-de-prova para caracterizar a deformabilidade ao longo do tempo dos traços usados para moldar o substrato e o reforço.

Inicialmente tentou-se realizar tais ensaios no Laboratório de Estruturas da EESC-USP. Entretanto, constatou-se que as deformações a serem monitoradas eram muito pequenas e difíceis de serem medidas, necessitando de equipamentos especiais e muita experiência para se ter resultados satisfatórios.

Cientes da excelente capacidade do Centro Tecnológico de Engenharia Civil de Furnas Centrais Elétricas S.A., localizado em Aparecida de Goiânia - GO, e do seu domínio sobre a realização de ensaios e estudo das propriedades e das características do concreto, fez-se uma parceria com o Laboratório de Concreto desta 
Instituição para que a caracterização da deformabilidade do concreto ao longo do tempo fosse realizada lá.

Os detalhes dos ensaios realizados em FURNAS bem como as análises dos resultados estão apresentadas no Capítulo 6.

\subsubsection{Caracterização dos materiais}

Tanto nos ensaios principais quanto nos ensaios complementares foram utilizados os mesmos traços de concretos e procedimentos semelhantes para caracterizar as propriedades mecânicas dos materiais. Sendo assim, optou-se por apresentar aqui tais características e procedimentos a fim de evitar repetições desnecessárias durante a leitura do texto.

\section{- $\quad \underline{\text { Concreto e argamassa }}$}

Para facilitar a identificação do tipo de traço usado na confecção de cada modelo ensaiado montou-se as Tabelas 2.8 e 2.9.

As propriedades mecânicas dos traços foram determinadas usando corpos-deprova cilíndricos de $10 \mathrm{~cm}$ de diâmetro por $20 \mathrm{~cm}$ de altura, adensados em mesa vibratória e ensaiados à compressão axial simples ${ }^{4}$ e à tração por compressão diametral. Estes ensaios foram realizados na máquina de compressão ELE Auto-test com capacidade de $3000 \mathrm{kN}$ e com controle de velocidade de carregamento por incremento de força.

Os valores da resistência mecânica e do módulo de elasticidade dos concretos usados na confecção dos modelos no dia do ensaio estão apresentados nos capítulos referentes à descrição detalhada de cada elemento estudado.

O traço TS-1 foi idealizado para ser bastante sensível à fluência e à retração, ou seja, traços com elevada relação a/c e pouca quantidade de agregado graúdo.

\footnotetext{
${ }^{4}$ Como a resistência usada nos cálculos teóricos refere-se a corpos-de-prova cilíndricos de $15 \mathrm{~cm}$ x 30 $\mathrm{cm}$, minorou-se em $5 \%$ os valores experimentais das resistências obtidas para considerar o efeito de escala.
} 
Tabela 2.8 - Relação dos traços usados no programa experimental

\begin{tabular}{c|c|l}
\hline \hline Local & Nome & \multicolumn{1}{c}{ Descrição das características do traço } \\
\hline \hline \multirow{3}{*}{ Reforço } & TR-1a & $\begin{array}{l}\text { argamassa de alta resistência reforçada com vários teores e tipos de fibras de } \\
\text { aço usada nos prismas da série 1, nas vigas VP da série 1 e no reforço das } \\
\text { vigas VFT. }\end{array}$ \\
\cline { 2 - 3 } & TR-1b & $\begin{array}{l}\text { argamassa de resistência normal reforçada com vários teores e tipos de fibras } \\
\text { de aço usado nos prismas da série 2 e nas vigas VP da série 2 }\end{array}$ \\
\cline { 2 - 3 } Substrato & TR-2 & $\begin{array}{l}\text { microconcreto usado em alguns corpos-de-prova ensaiados em FURNAS e no } \\
\text { reforço das vigas VFC }\end{array}$ \\
\cline { 2 - 3 } & TS-1 & $\begin{array}{l}\text { concreto de resistência normal usado no substrato das vigas VP (série 1) e das } \\
\text { vigas VFT }\end{array}$ \\
\hline \hline
\end{tabular}

Tabela 2.9 - Dosagens dos traços usados no programa experimental

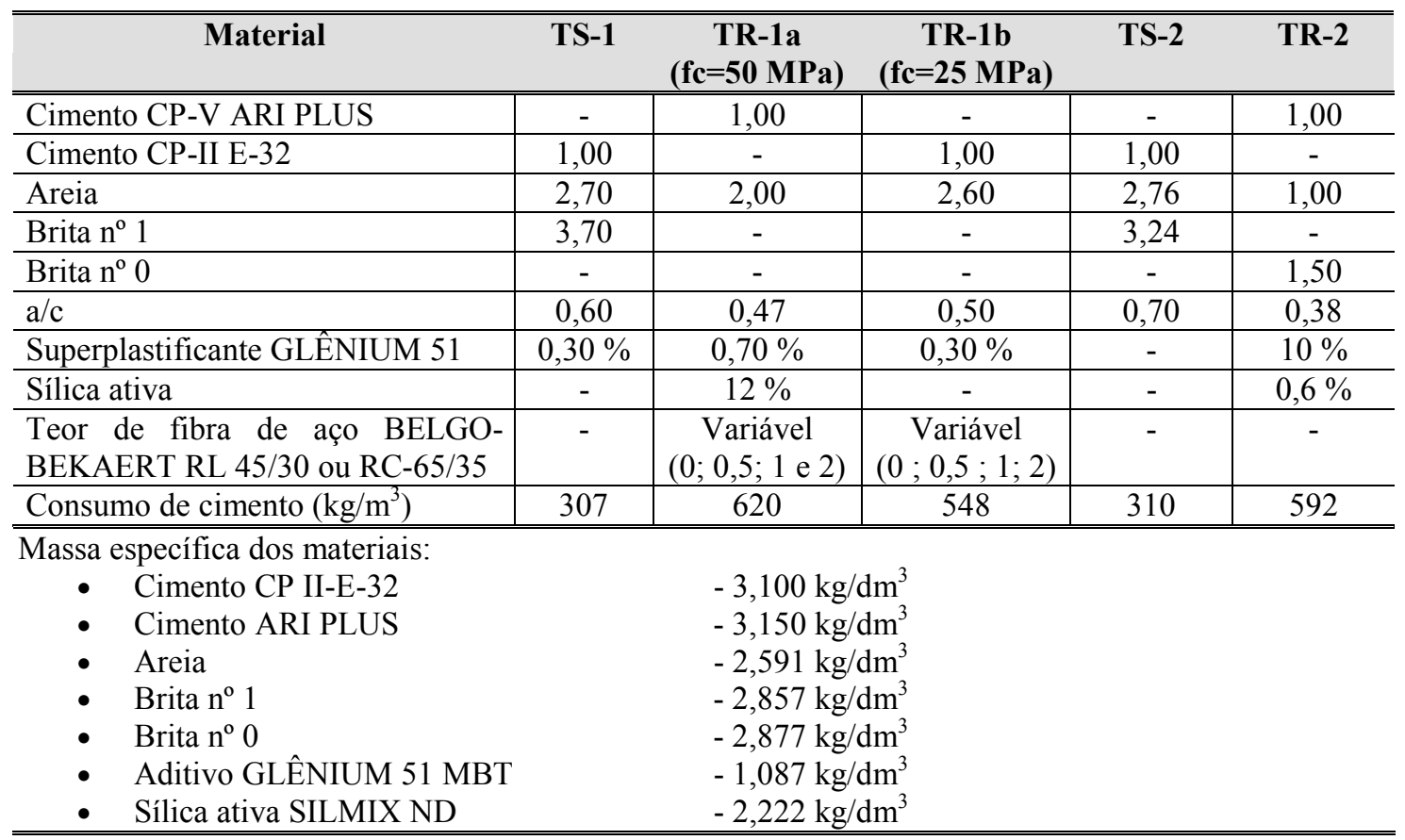

\section{$\underline{\text { Armadura }}$}

As armaduras utilizadas nos modelos ensaiados foram classificadas em:

a) barras de aço CA-50 ou CA-60 - armadura discreta convencional;

b) fibras de aço - armadura difusa;

As resistências de escoamento e de ruptura à tração das barras de aço foram obtidas por ensaios de tração axial conforme recomendações da norma NBR-6152 
(1980) executados na Máquina Universal INSTRON do Laboratório de Estruturas da EESC-USP, com capacidade de $2500 \mathrm{kN}$. Durante a realização destes ensaios também foram obtidos os módulos de elasticidade, $\mathrm{E}_{\mathrm{s}}$, das barras de aço construindose o gráfico tensão $\mathrm{x}$ deformação. $\mathrm{O}$ módulo de elasticidade foi determinado dividindo-se a tensão da barra $\left(\sigma_{\mathrm{s}}\right)$ pela deformação $\left(\varepsilon_{\mathrm{s}}\right)$ correspondente ao trecho linear deste diagrama. A tensão $\sigma_{\mathrm{s}}$ na barra foi calculada dividindo-se a força de tração aplicada na barra, $\mathrm{F}_{\mathrm{s}}$, pela sua área de aço, $\mathrm{A}_{\mathrm{s}}$, e a deformação correspondente, $\varepsilon_{\mathrm{s}}$, foi obtida dividindo-se a variação do alongamento $(\Delta \ell)$ da barra por um comprimento específico, $\ell$, definido em função do "clip-gauge" usado.

Como as barras de aço foram adquiridas separadamente para cada um dos modelos ensaiados, foi preciso fazer ensaios de tração em vários lotes de barras de aço mesmo quanto tais barras possuíam diâmetros iguais. As propriedades das barras de aço usadas em cada modelo estão nos capítulos específicos de cada ensaio.

Quanto às fibras curtas de aço foram selecionados as do tipo RL 45/30 BN e RC 65/35 BN, ambas da marca DRAMIX fornecidas pela BELGO MINEIRA BEKAERT S.A. As características geométricas destas fibras estão apresentadas na Tabela 2.10 e o processo para selecioná-las bem como os ensaios para determinação das características mecânicas dos compósitos produzidos com elas (traços TR-1a e TR-1b) foram apresentados no Capítulo 4.

Como os resultados das vigas VFT foram comparados com os de REIS(1998), optou-se por apresentar as características das fibras de aço usadas por tal pesquisador também na Tabela 2.10 a título de comparação. No caso, as fibras usadas por REIS (1998) foram da marca HAREX do tipo HSCF-25

Tabela 2.10 - Características das fibras usadas na fabricação de compósitos

\begin{tabular}{||lc|c|c|c||}
\hline \multicolumn{2}{|c|}{ Dados das fibras } & RL 45/30 BN & RC 65/35 BN & HSCF-25 \\
\hline \hline Comprimento nominal $1_{\mathrm{n}}$ & $(\mathrm{mm})$ & 30 & 35 & 25 \\
\hline Diâmetro nominal equivalente $\mathrm{d}_{\mathrm{c}}$ & $(\mathrm{mm})$ & 0,62 & 0,55 & 0,67 \\
\hline Fator de forma $\left(\lambda_{\mathrm{n}}=1 / \mathrm{d}\right)$ & & 45 & 65 & 38 \\
\hline Área da seção transversal & $\left(\mathrm{mm}^{2}\right)$ & 0,3019 & 0,2376 & 0,4900 \\
\hline Peso específico $\gamma_{\mathrm{e}}$ & $\left(\mathrm{kg} / \mathrm{m}^{3}\right)$ & 7850 & 7850 & 7850 \\
\hline Tipo de seção transversal & & Circular & Circular & Retangular \\
\hline Tensão máxima de tração $\sigma_{\mathrm{fu}}$ & $(\mathrm{MPa})$ & 1100 & 1150 & 1100 \\
\hline
\end{tabular}

\footnotetext{
${ }^{5}$ Este instrumento apresenta uma base de medida específica dentro da qual se consegue medir o incremento do alongamento da barra de aço até antes de seu escoamento.
} 


\section{3 - Fundamentos para o desenvolvimento das técnicas de reforço propostas}

Como o trabalho em questão aborda dois tipos de reforços distintos e o estudo de vários temas aparentemente independentes da área de reabilitação de estruturas, mas que se correlacionam com o tema pesquisado, optou-se por descrever aqui os principais fundamentos para se realizar as análises teóricas das vigas reforçadas.

\subsection{Concreto com fibras de aço}

\subsubsection{Comportamento de concretos com fibras de aço}

Para analisar o comportamento de materiais confeccionados com fibras de aço, baseou-se principalmente nos trabalhos desenvolvidos por NUNES (1998), FIQUEIREDO (1995), FURLAN (1995) e BENTUR \& MINDESS (1990). De acordo com estes autores, o desempenho de um material compósito pode ser avaliado pelos mecanismos envolvidos na sua ruptura e a quantificação do gasto energético envolvido na fratura deste material, cujas fontes de dissipação de energia são:

- Deformação elástica da fibra devida à transferência de tensão da matriz fissurada para as fibras;

- Trabalho realizado para descolamento da fibra da matriz,

- Trabalho de arrancamento da fibra contra a força de atrito no escorregamento fibramatriz. 
Como a maior parte do trabalho total para a ruptura do compósito deve-se à energia dissipada durante a ruptura da aderência entre fibra e matriz e seu posterior arrancamento, pode-se avaliar o desempenho das fibras em um compósito por meio da sua tenacidade* . Esse parâmetro é influenciado pela resistência da matriz e pela resistência ao arrancamento das fibras.

Matrizes com microestrutura mais compacta e resistência mecânica elevada, como por exemplo o CAD, conduzem a um comportamento mais frágil do compósito, pois parte das fibras se rompe antes de escorregar devido à melhora da aderência com a matriz e à maior carga transferida a elas no momento da ruptura da matriz. Como o gasto energético para a ruptura da fibra é menor para seu arrancamento, a tenacidade dos compósitos de alta resistência tende a ser menor (NUNES, 1998).

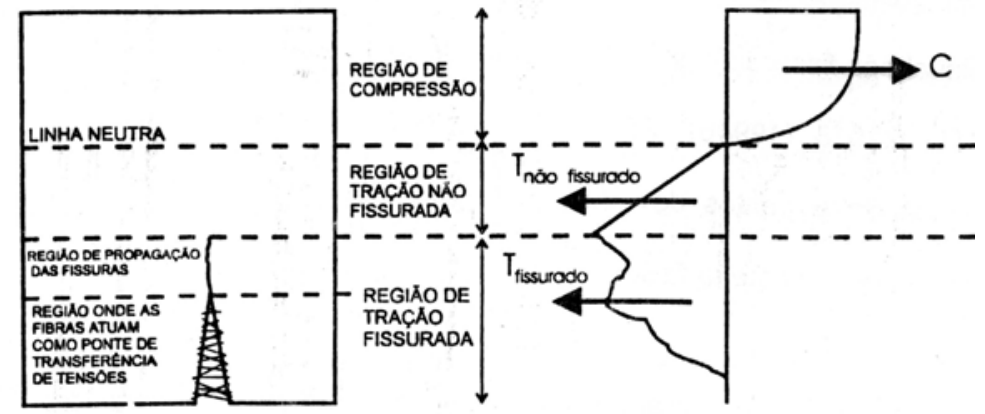

Figura 3.1 - Efeito das fibras na distribuição de tensões na seção transversal de uma peça sujeita a flexão (NUNES, 1998)

Outro aspecto que prejudica a tenacidade do compósito é que as fibras que ficam inclinadas em relação à superfície da fissura sofrem efeitos de flexão quando se tem matriz de alta resistência em vez de ocorrer o esmagamento da matriz, fato que normalmente ocorre em concretos menos resistentes (ARMELIN \& BANTHIA, 1997, apud NUNES, 1998). Nestas condições, desenvolvem-se tensões adicionais de cisalhamento que reduzem as resistências de escoamento e ruptura da fibra e aumentam a probabilidade de sua ruptura. Entretanto, como a resistência ao

\footnotetext{
* A tenacidade corresponde à medida da energia total absorvida pelo compósito até sua fratura. Tal energia pode ser quantificada pela área sob a curva tensão x deformação. Entretanto, como nos CFA é difícil determinar a tensão pós-fissuração, pode-se obter a tenacidade calculando a área sob a curva carga $\mathrm{x}$ deslocamento vertical.
} 
arrancamento depende da geometria da fibra, pode-se dizer que o uso de fibras com ganchos na extremidade aumentam a tenacidade do compósito.

\subsubsection{Normas técnicas adotadas para avaliação da tenacidade}

Existem vários métodos usados para avaliar a tenacidade de materiais compósitos. Dentre eles optou-se pela utilização das normas ASTM - C1018 (1994) recomendada pela American Society for Testing and Materials, e pela JSCE - SF4 (1984) recomendada pela Japan Society of Civil Engineers. Ambos os métodos avaliam a tenacidade a partir de ensaios experimentais de prismas de concreto reforçados com fibras, aplicando-se forças concentradas em seus terços médios.

\section{- Método da ASTM-C1018}

Este método baseia-se na determinação da quantidade de energia necessária para gerar a primeira fissura em um prisma de concreto reforçado com fibras, e posteriormente relacionar esta energia com aquela determinada em pontos prédeterminados em função de múltiplos da flecha existente no instante do surgimento da primeira fissura. Inicialmente determina-se o deslocamento correspondente à primeira fissura, admitindo-se que esta ocorra quando a curva força-deslocamento deixa de ser linear. Em seguida determina-se a área sob a curva compreendida entre a origem até os pontos $3 \delta ; 5,5 \delta ; 10,5 \delta$ e $15,5 \delta$, sendo $\delta$ o deslocamento vertical relativo à primeira fissura. Feito isso se calcula os Índices de tenacidade, $\mathrm{I}_{\mathrm{N}}$, dividindo a área sob a curva para cada flecha especificada anteriormente pela área sob a curva até a flecha correspondente à primeira fissura, obtendo-se os índices $\mathrm{I}_{5}$, $\mathrm{I}_{10}, \mathrm{I}_{20}$ e $\mathrm{I}_{30}$ respectivamente. Posteriormente determina-se os Fatores Residuais de Resistência, $\mathrm{R}_{\mathrm{a}, \mathrm{b}}$, através da expressão 3.1.

Os índices de tenacidade e os fatores de resistência residual fornecem informações a respeito da curva força $\mathrm{x}$ flecha, sendo independentes do tamanho do prisma e de outras variáveis de ensaio. Os índices de tenacidade têm a vantagem de avaliar o comportamento conjunto da fibra com a matriz, mas a desvantagem de depender excessivamente da flecha referente à primeira fissura do corpo-de-prova. Tal flecha deve ser avaliada de maneira bastante precisa, pois uma pequena diferença 
na definição dela acarreta uma enorme diferença nos valores dos índices de tenacidade calculados.

$$
\begin{aligned}
& \mathrm{I}_{\mathrm{N}}=\frac{\text { Energia absorvida até um certo valor de flecha (múltiplo da flecha de primeira fissura) }}{\text { Energia absorvida até a flecha que gerou a primeira fissura }} \\
& \mathrm{R}_{\mathrm{a}, \mathrm{b}}=\frac{100}{\mathrm{~b}-\mathrm{a}} \cdot\left(\mathrm{I}_{\mathrm{b}}-\mathrm{I}_{\mathrm{a}}\right)
\end{aligned}
$$

Para avaliar o desempenho do material compósito compara-se os valores dos índices de tenacidade $\left(\mathrm{I}_{\mathrm{N}}\right)$ e dos fatores residuais $\left(\mathrm{R}_{\mathrm{a}, \mathrm{b}}\right)$ com valores de referência já conhecidos. Quando se tem valores de 5, 10, 20 e 30 para os índices $\mathrm{I}_{5}, \mathrm{I}_{10}, \mathrm{I}_{20}$ e $\mathrm{I}_{30}$ respectivamente, pode-se dizer que o material usado na confecção dos prismas apresentam comportamento elástico linear antes do surgimento da primeira fissura e comportamento perfeitamente plástico após esta fissura. Para um material com curva ascendente na etapa pós-fissuração, os índices de tenacidade são maiores que para um material elastoplástico perfeito.

Como os fatores de resistência residual $\mathrm{R}_{\mathrm{a}, \mathrm{b}}$ indicam o nível médio de resistência suportado pelo prisma após o surgimento da primeira fissura como uma percentagem da resistência, para fatores iguais a 100 tem-se comportamento perfeitamente plástico e para valores menores tem-se material elastoplástico. No caso dos concretos sem fibras este fator corresponde a zero.

\section{- Método da JSCE - SF4}

Por este método, a tenacidade é medida pela Tenacidade à Flexão, $\mathrm{T}_{\mathrm{b}}$, que corresponde à área total sob a curva força x deslocamento até uma flecha de l/150. Deve-se determinar ainda a Resistência Equivalente à Tração na Flexão, $\mathrm{f}_{\mathrm{ct}, \mathrm{eq}}$, a Tensão de Fissuração à Tração na Flexão, $\sigma_{0}$, o Módulo de Ruptura, $\sigma_{\mathrm{u}}$, e o Fator de Tenacidade, $\mathrm{R}_{\mathrm{e}, 3}$, usando-se respectivamente as equações 3.2 a 3.5. Os parâmetros $\mathrm{f}_{\mathrm{ct}, \mathrm{eq}}$, e $\mathrm{R}_{\mathrm{e}, 3}$ foram calculados tomando-se como referência uma flecha de $3 \mathrm{~mm}$.

O Fator de Tenacidade, que depende da geometria do corpo-de-prova e de outras variáveis do ensaio, tem unidade de tensão e indica a resistência residual da matriz pós-fissuração do material analisado para uma flecha correspondente à $\ell / 150$. 
Já o módulo de ruptura corresponde à resistência máxima à tração na flexão do compósito.

$$
\begin{aligned}
& \mathrm{f}_{\mathrm{ct}, \mathrm{eq}}=\frac{\mathrm{T}_{\mathrm{b}}}{\delta_{\mathrm{Tb}}} \cdot \frac{\ell}{\mathrm{b} \cdot \mathrm{h}^{2}} \\
& \sigma_{0}=\frac{\mathrm{F}_{\text {fissuração }} \cdot \ell}{\mathrm{b} \cdot \mathrm{h}^{2}} \\
& \sigma_{\mathrm{u}}=\frac{\mathrm{F}_{\text {ruptura }} \cdot \ell}{\mathrm{b} \cdot \mathrm{h}^{2}} \\
& \mathrm{R}_{\mathrm{e}, 3}=\frac{\mathrm{f}_{\mathrm{ct}, \mathrm{eq}}}{\sigma_{0}}
\end{aligned}
$$

Onde:

$\mathrm{T}_{\mathrm{b}} \quad$ - tenacidade na flexão (N.mm);

$\delta_{\mathrm{Tb}} \quad$ - valor de deslocamento correspondente a $\ell / 150$;

$\mathrm{b} ; \mathrm{h}$ - correspondem ao comprimento e a altura dos prismas;

- corresponde ao vão teórico entre os apoios que neste caso é $45 \mathrm{~cm}$;

$\mathrm{F}_{\text {fissuração }} ; \mathrm{F}_{\text {ruptura }}$ - força referente à fissuração ou ruptura do prisma.

\subsubsection{Outros parâmetros usados na avaliação do desempenho de materiais compósitos}

Além da tenacidade, que é um parâmetro determinado experimentalmente, existem também parâmetros teóricos para avaliar o desempenho de materiais compósitos.

O Fator de Forma ${ }^{\dagger}$, determinado pela expressão 3.6, permite avaliar a influência do comprimento da fibra e do número de fibras por unidade de volume do compósito.

$$
\lambda=\frac{\ell}{\mathrm{d}}
$$

Onde:

$\ell$ - comprimento da fibra;

d - diâmetro da fibra.

\footnotetext{
${ }^{\dagger} \mathrm{O}$ fator de forma (coeficiente de aspecto) é a relação entre o comprimento da fibra e o diâmetro da circunferência com área equivalente a seção transversal. É um índice capaz de indicar com apenas um número o grau de eficiência da fibra em função de sua geometria.
} 
Para um volume constante de fibras de mesma seção transversal, o aumento no fator de forma corresponde ao aumento do comprimento da fibra e, portanto, a área superficial da fibra em contato com a matriz será maior. Como a resistência ao arrancamento da fibra é proporcional a esta área, maior será a força necessária para o seu arrancamento (NUNES, 1998).

Segundo BENTUR e MINDESS (1990), um outro parâmetro geométrico útil na avaliação do desempenho do compósito é o Fator de Espaçamento das Fibras, S, que indica a distância média entre fibras curtas distribuídas aleatoriamente nas três direções na matriz, é determinado pela expressão 3.7 .

$$
S=2,76 \cdot r \cdot \sqrt{\left(1 / V_{f}\right)}
$$

onde:

r : raio da fibra

$\mathrm{V}_{\mathrm{f}}$ : volume de fibras no compósito

Analisando esta expressão percebe-se que, para um mesmo volume de fibras, quanto menor seu raio, menor o espaçamento entre elas e, conseqüentemente, maior a quantidade linear de fibras por unidade de volume. Portanto, a probabilidade de uma fissura ser interceptada por uma fibra é maior. Como o aumento do fator de forma de fibras de mesmo comprimento representa redução no seu diâmetro, nestes casos tem-se um maior número de fibras atuando como ponte de transferência de tensões por unidade de volume de compósito. Isso pode gerar uma melhoria do comportamento pós-fissuração do compósito, ou seja, aumento da tenacidade.

Em geral o aumento na quantidade de fibras usadas em um material compósito eleva sua tenacidade. Entretanto, convém esclarecer que o uso de volume muito alto pode dificultar a compactação do material e trazer prejuízos para a resistência mecânica do compósito em vez de benefícios.

Um conceito importante relacionado à influência do teor de fibras na tenacidade refere-se ao Volume Crítico, que corresponde ao volume de fibras para o qual o compósito mantém uma resistência residual pós-fissuração igual à resistência da matriz. Tal volume pode ser calculado pela equação 3.8 ou 3.9 conforme diferentes autores. 
- Para BENTUR E MINDESS (1990) calcula-se o volume crítico por:

$\mathrm{V}_{\mathrm{f}, \text { critico }}=2 \cdot \frac{\sigma_{\mathrm{mu}}^{\prime}}{\tau_{\mathrm{fu}}} \cdot \frac{1}{\ell / \mathrm{d}}$

- Para AVESTON, COOPER \& KELLY (1971), apud NUNES (1998), tem-se:

$\mathrm{V}_{\mathrm{f}, \text { critico }}=0,82 \cdot \frac{\sigma_{\mathrm{t}}}{\tau_{\mathrm{fu}}} \cdot \frac{1}{\ell / \mathrm{d}}$

onde:

$\mathrm{V}_{\mathrm{f}, \text { critico }}=$ volume crítico de fibras;

$\sigma_{\mathrm{t}} \quad=$ resistência última à tração do compósito (na zona pós-fissuração);

$\sigma_{\mathrm{mu}}^{\prime}=$ resistência à tração da matriz na ausência de fibras;

$\tau_{\mathrm{fu}} \quad=$ tensão de aderência entre a fibra e a matriz;

l/d = fator de forma da fibra;

O volume crítico é influenciado pela resistência da matriz pois, dependendo do nível de tensões suportado por esta após a ruptura, haverá um maior ou menor nível de carregamento das fibras devido à distribuição de tensões entre estes materiais. Desta maneira os concretos mais resistentes precisam de maior volume de fibras para manter a tenacidade. Analogamente ao conceito do volume crítico, podese definir o Comprimento Crítico da fibra como sendo aquele que proporciona tenacidade máxima antes que as fibras se rompam. Tal parâmetro pode ser determinado por:

$\ell_{\text {critico }}=\frac{\sigma_{\mathrm{fu}} \cdot(\mathrm{d} / 2)}{\tau_{\mathrm{fu}}}$

Sendo:

$\tau_{f u}=\frac{\sigma_{c t, u}-\gamma \cdot \sigma_{m} \cdot V_{m}}{2 \cdot \alpha \cdot \beta \cdot(\ell / d) \cdot V_{f}}$

Onde:

$\ell_{\text {critico }}:$ comprimento crítico da fibra;

: comprimento da fibra;

d : diâmetro da fibra;

$\ell / d \quad$ : fator de forma da fibra;

$\sigma_{c t, u}$ : resistência à tração direta do compósito. Corresponde à $90 \%$ da resistência à tração por compressão diametral; 
$\sigma_{f u} \quad$ : tensão resistente da fibra fornecida no catálogo do fabricante;

$\sigma_{m}$ : resistência à tração direta da matriz na ausência das fibras de aço que corresponde à $90 \%$ da resistência à tração por compressão diametral;

$\tau_{f u} \quad$ : tensão de aderência entre a fibra e a matriz (BENTUR \& MINDESS, 1990);

$V_{m} \quad$ : volume da matriz de concreto dado por $V_{\mathrm{m}}=1-V_{\mathrm{f}}$;

$V_{f} \quad$ : volume de fibras adicionado ao compósito;

$\alpha ; \beta$ : coeficientes adotados iguais a 0,41 conforme CATELLI JR. (1998);

$\gamma \quad$ : coeficiente adotado igual a 1 conforme CATELLI JR. (1998).

Quando não se tem valores experimentais, pode-se estimar as resistências à compressão e à tração direta de materiais compósitos usando as expressões $3.12 \mathrm{e}$ 3.13 propostas por SOROUSHIAM \& LEE (1989) apud CATELLI JR. (1998). Já para materiais sem adição de fibras de aço, é possível estimar a resistência à tração direta $\mathrm{f}_{\mathrm{ct}}$ como sendo igual a $0,9 \mathrm{f}_{\mathrm{ct}, \mathrm{sp}}$ (resistência à tração indireta determinada por ensaios de compressão diametral), ou $0,7 \mathrm{f}_{\mathrm{ct}, \mathrm{f}}$ (resistência à tração na flexão) conforme recomendações da NBR-6118 (2003).

$$
\begin{aligned}
& \mathrm{f}_{\mathrm{t}}=\sigma_{\mathrm{tm}}\left[1+0,016 \cdot\left(\beta \cdot \mathrm{V}_{\mathrm{f}} / \mathrm{A}_{\mathrm{f}}\right)^{1 / 3}+0,05 \pi \cdot \mathrm{d}_{\mathrm{f}} \cdot \ell_{\mathrm{f}} \cdot\left(\beta \cdot \mathrm{V}_{\mathrm{f}} / \mathrm{A}_{\mathrm{f}}\right)\right] \\
& \mathrm{f}_{\mathrm{c}}=\sigma_{\mathrm{cm}}+\left(3,6 \cdot \mathrm{V}_{\mathrm{f}} \cdot \ell_{\mathrm{f}}\right) / \mathrm{d}_{\mathrm{f}}
\end{aligned}
$$

Onde:

$f_{t}=$ resistência à tração direta do concreto com fibras;

$\mathrm{f}_{\mathrm{c}}=$ resistência à compressão do concreto com fibras;

$\sigma_{\mathrm{tm}}=$ resistência à tração direta do concreto sem fibras (matriz);

$\sigma_{\mathrm{cm}}=$ resistência à compressão do concreto sem fibras (matriz);

$\beta=$ fator de orientação das fibras adotado igual a 1 ;

$\mathrm{A}_{\mathrm{f}}=$ área da seção transversal da fibra;

$\ell_{\mathrm{f}}=$ comprimento da fibra;

$\mathrm{V}_{\mathrm{f}}=$ volume de fibras;

$\mathrm{d}_{\mathrm{f}}=$ diâmetro da fibra.

$\$$ SOROUSHIAN, P \& LEE, C. (1989). Constitutive modeling of steel fiber reinforced concrete under direct tension and compression. In: Swamy, R.N.; Barr, B. Fiber Reinforced Cements and Concretes: recent developments. Elsevier Applied Science, USA, p. 363-377. 


\subsection{Comportamento de vigas compostas}

As vigas reforçadas pelas duas técnicas de reforço propostas neste trabalho correspondem na verdade a elementos estruturais compostos, pois possuem uma seção transversal formada pela ligação de dois materiais cimentícios moldados em idades diferentes. Para avaliar o comportamento deste tipo de elemento é preciso verificar as descontinuidades que ocorrem no estado de tensão e de deformação da estrutura causadas principalmente pela:

a) transferência de tensões de cisalhamento através da junta formada pelo concreto novo/antigo;

b) efeitos dependentes do tempo tais como retração e fluência.

Além dos fatores citados anteriormente, deve-se considerar também as diferenças entre as propriedades mecânicas dos concretos usados na confecção do elemento composto, as alterações das dimensões da seção transversal do elemento e a existência de um pré-carregamento durante a moldagem da nova camada de concreto.

As vigas reabilitadas pela Técnica de Reforço $n^{\circ} 1$ (vigas reforçadas tipo VFT) podem ser dimensionadas considerando os parâmetros que afetam o comportamento de peças compostas, avaliando-se principalmente as descontinuidades de tensões e deformações existentes na região da junta formada pelos concretos moldados em idades distintas, já que os efeitos dependentes do tempo neste caso não são tão relevantes, pois o material adicionado está na parte tracionada da viga. Também é preciso verificar o equilíbrio interno da viga reforçada por esta técnica devido à tendência de aparecimento de um plano de ruptura por cisalhamento longitudinal causado pelo escorregamento relativo entre as armaduras tracionadas adicionadas e as preexistentes. Este plano de ruptura pode surgir por causa de falhas de confinamento da armadura de tração adicionada, uma vez que o banzo tracionado foi reconstituído usando um material compósito com fibras de aço (armadura difusa) em substituição aos estribos que, a princípio, seriam os responsáveis pela transferência de esforços neste local. Sendo assim, é 
imprescindível considerar a contribuição das fibras de aço na argamassa do reforço nos mecanismos de resistência mobilizados nesta região (ver item 3.3).

No caso da Técnica de Reforço $\mathrm{n}^{\mathrm{o}} 2$ (vigas reforçadas tipo VFC), deve-se avaliar as descontinuidades de tensões e deformações existentes na região da junta por causa das tensões de cisalhamento e também os efeitos dependentes do tempo, já que o reforço foi feito no bordo comprimido da peça, ou seja, os materiais do substrato e do reforço não estão fissurados.

\subsubsection{Tensões de cisalhamento solicitantes e resistentes na região da junta}

Como o comportamento de uma peça composta é governado fundamentalmente pela transferência das tensões de cisalhamento na interface entre os concretos moldados em idades distintas, neste tipo de peça é preciso verificar se as tensões tangenciais solicitantes na região da junta são compatíveis com a resistência ao cisalhamento deste local, ou seja, se $\tau_{\mathrm{Sd}} \leq \tau_{\mathrm{Rd}}$. sendo:

$$
\begin{aligned}
& \tau_{\mathrm{Sd}}: \text { tensão de cisalhamento solicitante na junta; } \\
& \tau_{\mathrm{Rd}}: \text { tensão de cisalhamento resistente da junta. }
\end{aligned}
$$

Para fazer esta verificação é preciso conhecer: os mecanismos de resistência mobilizados durante a transferência de esforços por esta interface (ver Tabela 3.1), os principais fatores que influenciam a resistência ao cisalhamento da junta e se há ou não deslizamento na junta formada pelos concretos novo e antigo.

\begin{tabular}{|c|c|c|}
\hline & \multicolumn{2}{|c|}{ Transferência de tensões por } \\
\hline & Contato entre superfícies & Armaduras que cruzam a interface \\
\hline 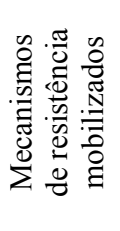 & $\begin{array}{l}\text { - Aderência por adesão; } \\
\text { - Aderência por atrito; } \\
\text { - Aderência mecânica (engrenamento dos agregados); } \\
\text { - Aderência devido ao uso de materiais especiais que } \\
\text { atuam como ponte de aderência; }\end{array}$ & $\begin{array}{ll}\text { - } & \text { Efeito de pino; } \\
\text { - } & \text { Efeito de costura ou confinamento; }\end{array}$ \\
\hline
\end{tabular}

\section{Tabela 3.1 - Tipos de transferência de esforços de cisalhamento em juntas}

Quanto aos principais fatores que afetam a resistência ao cisalhamento, podese citar: a resistência do concreto, a rugosidade da superfície de contato, a taxa de armadura que cruza a interface, a tensão normal à interface e a existência de ações cíclicas. 
Caso haja deslizamento entre as superfícies, então está ocorrendo uma transferência parcial de esforços através da junta. Neste caso deve-se considerar a deformabilidade ao cisalhamento da ligação entre os dois concretos para estimar o comportamento do elemento composto. Isso é feito estabelecendo-se uma relação entre a tensão de cisalhamento, $\tau_{\mathrm{Sd}}$, e o deslizamento, $s$, da junta considerando $\mathrm{o}$ efeito do engrenamento dos agregados, da ação de pino e da tensão normal ao plano de cisalhamento. No trabalho desenvolvido por ARAÚJO (1997) estão apresentados vários métodos empíricos e analíticos, propostos por diferentes pesquisadores, para determinar a tensão de cisalhamento $\tau_{\mathrm{Sd}}$ de vigas compostas fletidas com o deslizamento horizontal observado na junta.

A não ocorrência de deslizamento na interface formada pelos concretos moldados em idades distintas indica que está ocorrendo uma transferência total de esforços por meio da junta, de maneira que a seção composta tenha comportamento semelhante ao de uma seção integra. Este é o tipo de transferência de esforços que normalmente se deseja.

De qualquer forma, em ambos os casos deve-se sempre considerar as diferenças das características mecânicas dos concretos, principalmente aquelas relacionadas aos módulos de elasticidade.

Existem várias maneiras de se determinar as tensões de cisalhamento solicitantes e resistentes em juntas de concreto. Como não é intenção deste trabalho estudá-las mais a fundo, optou-se por descrevê-las resumidamente, dando-se prioridade para os casos de transferência total de esforços de cisalhamento na junta.

\section{a) Recomendações do CEB - Bulletin d'Information $n^{\circ} 162$}

Esta referência, específica para estruturas reabilitadas, recomenda que as tensões de cisalhamento solicitantes e resistência na junta sejam calculadas respectivamente pelas expressões (3.14) e (3.15) sem considerar a influência de armaduras cruzando a interface. No caso de peças com inversão da flexão ou submetidas a solicitações dinâmicas, recomenda-se que toda a força de cisalhamento na interface seja transferida para o substrato por conectores de cisalhamento, limitando-se a tensão cisalhante máxima em $2 / 3$ da resistência à tração do concreto antigo. 


$$
\begin{aligned}
& \tau_{\mathrm{Sd}}=\frac{\mathrm{V}_{\mathrm{d}}}{\mathrm{b} \cdot \mathrm{z}_{2} \cdot\left(1+\frac{\mathrm{A}_{\mathrm{s}, 1}}{\mathrm{~A}_{\mathrm{s}, 2}} \cdot \frac{\mathrm{d}_{1}-\mathrm{x}}{\mathrm{d}_{2}-\mathrm{x}} \cdot \frac{\mathrm{z}_{1}}{\mathrm{z}_{2}}\right)} \cong \frac{\mathrm{V}_{\mathrm{d}}}{\mathrm{b} \cdot \mathrm{z}_{2} \cdot\left(1+0,85 \frac{\mathrm{A}_{\mathrm{s}, 1}}{\mathrm{~A}_{\mathrm{s}, 2}}\right)} \\
& \tau_{\mathrm{Rd}}=\frac{1}{\gamma_{\mathrm{c}}} \cdot \frac{2}{3} \cdot \mathrm{f}_{\mathrm{ct}, \mathrm{m}} \cong \frac{1}{\gamma_{\mathrm{c}}} \cdot \frac{2}{10} \cdot \mathrm{f}_{\mathrm{ck}}{ }^{2 / 3}(\mathrm{em} \mathrm{MPa}) ;
\end{aligned}
$$

onde:

$\mathrm{V}_{\mathrm{d}}$ : $\quad$ é a força cortante de cálculo existente no elemento após o reforço

$\mathrm{A}_{\mathrm{s}, 1}$ e $\mathrm{A}_{\mathrm{s}, 2}$ : áreas de aço original e do reforço respectivamente

x : $\quad$ altura da linha neutra em relação ao bordo comprimido

$\mathrm{d}_{\mathrm{i}}$ : distância do bordo comprimido até a armadura original ou adicionada

$\mathrm{z}_{\mathrm{i}} \quad$ : $\quad$ braço de alavanca da armadura original ou adicionada

b) CLÍMACO (1990)

Conforme apresentado no item 2.2.2.1, CLÍMACO ensaiou várias vigas reforçadas por adição de armadura tracionada envolvida por concreto. Para que as vigas reabilitadas funcionassem como monolíticas, foi preciso verificar se a resistência ao cisalhamento da junta formada pelos concretos moldados em idades distintas seria suficiente para suportar as tensões tangenciais que surgiriam neste local em função da solicitação aplicada às peças. Para isso o autor separou o cálculo da tensão de cisalhamento horizontal da junta em duas regiões distintas, correspondentes respectivamente ao trecho dentro do vão de cisalhamento e ao trecho próximo ao apoio (ver Figura 3.2).

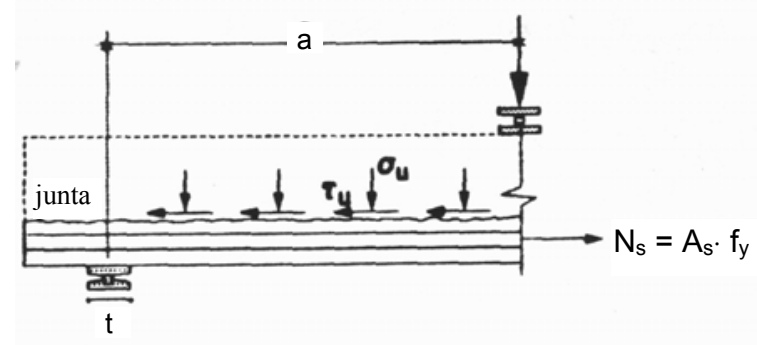

a) Região do vão de cisalhamento

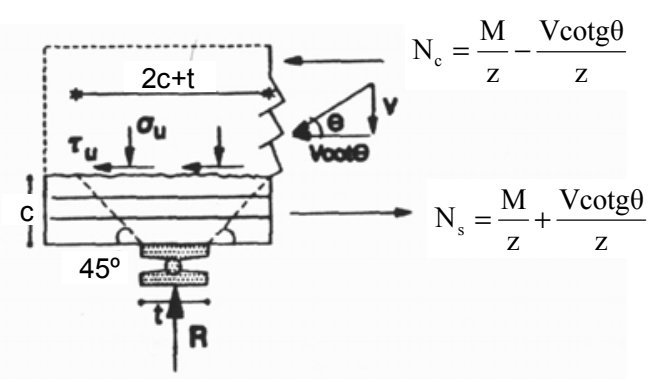

b) Região do apoio

Figura 3.2 - Tensões normais e cisalhantes (CLÍMACO, 1990) 
- Para a região do vão de cisalhamento:

$$
\begin{aligned}
& \tau_{u}=\frac{\mathrm{N}_{\mathrm{s}}}{\mathrm{a} \cdot \mathrm{b}}=\frac{\mathrm{A}_{\mathrm{s}} \cdot f_{y}}{\mathrm{a} \cdot \mathrm{b}} \\
& \sigma_{u}=\rho_{w} f_{y}=\frac{\mathrm{A}_{\mathrm{sw}}}{\mathrm{s} \cdot \mathrm{b}} \cdot f_{y}
\end{aligned}
$$

- Para a região do apoio:

$$
\begin{aligned}
& \tau_{u}=\mathrm{N}_{\mathrm{s}} \cdot \frac{1}{(2 \mathrm{c}+\mathrm{t}) \cdot \mathrm{b}} \\
& \sigma_{u}=\frac{\mathrm{M}_{\max }}{\mathrm{a}} \cdot \frac{1}{(2 \mathrm{c}+\mathrm{t}) \cdot \mathrm{b}} \\
& \mathrm{N}_{\mathrm{s}}=\frac{\mathrm{M}_{\mathrm{u}}}{\mathrm{z}}+\frac{\mathrm{V}_{\mathrm{u}} \cdot \cot g \theta}{2}=\frac{\mathrm{M}_{\text {max }}(2 \mathrm{c}+\mathrm{t})}{2 \mathrm{az}}+\frac{\mathrm{M}_{\text {max }} \cdot \cot g \theta}{2 \mathrm{a}} \\
& \cot g \theta=\frac{\mathrm{V}_{\mathrm{u}} \cdot}{\mathrm{A}_{\mathrm{sw}} f_{y}} \cdot \frac{\mathrm{s}}{\mathrm{z}}
\end{aligned}
$$

onde:

$\tau_{\mathrm{u}}$ : tensão de cisalhamento horizontal última

a : vão de cisalhamento

b : largura da viga

$\sigma_{\mathrm{u}}$ : tensão de compressão última mobilizada pelo efeito de aperto (clamping effect) dos estribos que cruzam a interface

$\mathrm{S}$ : espaçamento entre estribos

$\rho_{\mathrm{w}}$ : taxa de estribos que cruzam a interface

$\mathrm{N}_{\mathrm{s}}$ : força normal na armadura longitudinal tracionada

c : altura do material de reforço (fundo da viga até a junta)

$\mathrm{t}$ : largura do apoio

$\theta$ : ângulo da biela de compressão no apoio com a horizontal

$\mathrm{s}:$ espaçamento entre estribos 


\section{c) $E L D E B S(2000)$}

O trabalho desenvolvido por este autor apresenta várias equações para o cálculo das tensões de cisalhamento $\tau_{\mathrm{Sd}}$ em juntas de vigas compostas fletidas, bem como as recomendações de norma nacionais e internacionais para se estimar a resistência ao cisalhamento, $\tau_{\mathrm{Rd}}$, destes elementos.

\section{$\underline{\text { Avaliacãa das tensões solicitantes }\left(\tau_{\text {Sd }}\right)}$}

- Avaliação da tensão $\tau_{\mathrm{Sd}}$ usando a Teoria da Resistência dos Materiais:

$$
\text { Estado não fissurado: } \quad \tau_{\mathrm{sd}}=\frac{\text { V.S }}{\mathrm{I} . \mathrm{b}}
$$

- Avaliação da tensão $\tau_{\mathrm{Sd}}$ na interface através da transferência de forças de cisalhamento horizontais geradas pela ação de forças de compressão ou tração atuantes em uma viga.

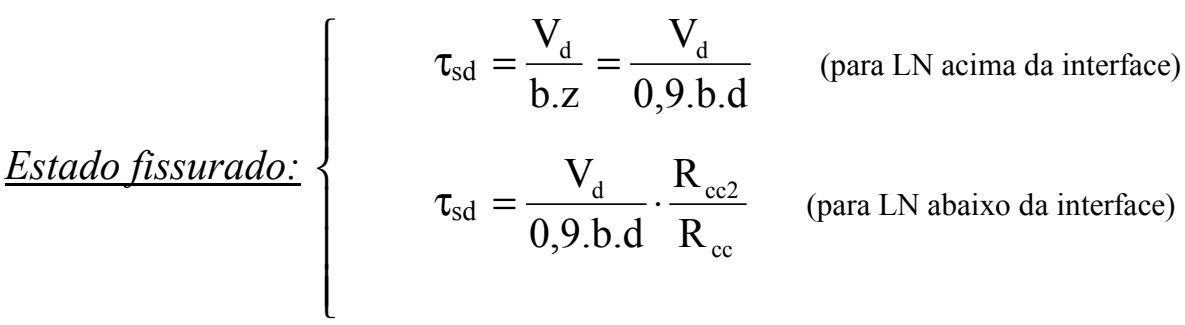

onde:

$\mathrm{V}_{\mathrm{d}}$ : esforço cortante de cálculo existente na seção;

S : momento estático da área acima da fibra em estudo com relação ao centróide da seção transversal;

I : momento de inércia da seção transversal composta homogeneizada;

b : largura da seção transversal na fibra em estudo, ou seja, largura da interface;

d : altura útil da seção;

z : distância entre a resultante das forças internas de tração e de compressão existente na seção transversal do elemento devido ao carregamento aplicado;

$\mathrm{R}_{\mathrm{cc} 2}$ : força de compressão no concreto moldado no local

$\mathrm{R}_{\mathrm{cc}}$ : força total de compressão na seção composta 


\section{$\underline{\text { Avaliação das tensões resistentes }\left(\tau_{\mathrm{Rd}}\right)}$}

As normas FIP (1992) e NBR-9062 (1985) usam a mesma expressão para o cálculo da tensão de resistência na junta. Entretanto, os valores das tensões solicitantes que devem ser comparadas com a resistência da junta são distintas (ver equações 3.26 e 3.27$)$.

\section{Tensão resistente}

$\tau_{\mathrm{Rd}}=\beta_{\mathrm{s}} \rho \mathrm{f}_{\mathrm{yd}}+\beta_{\mathrm{c}} \mathrm{f}_{\mathrm{td}} \leq 0,31 \mathrm{f}_{\mathrm{ck}}$

\begin{tabular}{lll}
\hline & Tensão solicitante & \\
\hline Para a FIP*: & $\tau_{\mathrm{Sd}}=\frac{\mathrm{V}_{\mathrm{d}}}{\mathrm{b} \cdot \mathrm{d}}$ \\
\hline Para a NBR-9062: & $\tau_{\mathrm{Sd}}=\frac{\mathrm{F}_{\mathrm{hd}}}{\mathrm{b} \cdot \ell_{0}}$
\end{tabular}

Onde:

$\beta_{\mathrm{s}}$ e $\beta_{\mathrm{c}}$ - fatores multiplicativos para as parcelas da resistência do aço e do concreto fornecidos de acordo com a norma adotada;

$\mathrm{f}_{\mathrm{td}} \quad$ - resistência de cálculo do concreto à tração;

$\rho \quad$ - taxa de armadura transversal que cruza a interface;

$\mathrm{F}_{\text {hd }} \quad$ - força horizontal solicitante de cálculo;

$l_{0} \quad$ - distância entre os pontos de momento nulo e momento máximo;

Já o PCI - Precast/Prestressed Concrete Institute (1992) indica três limites diferentes para verificar a resistência da junta em função ou não da necessidade de se colocar uma armadura de costura nesta superfície. Estes limites são:

Limite 1 - Não é necessário usar armadura

$$
\rightarrow \frac{\mathrm{F}_{\mathrm{hd}}}{\mathrm{b} \cdot \ell_{0}} \leq 0,56 \mathrm{MPa}
$$

Limite 2 - Deve-se usar uma armadura mínima

$$
\rightarrow 0,56<\frac{\mathrm{F}_{\mathrm{hd}}}{\mathrm{b} \cdot \ell_{0}} \leq 2,45
$$

Limite 3 - Deve-se usar uma armadura calculada pela teoria do atrito-cisalhamento

$$
\rightarrow \frac{\mathrm{F}_{\mathrm{hd}}}{\mathrm{b} \cdot \ell_{0}}>2,45(\mathrm{MPa})
$$

\footnotetext{
* O procedimento recomendado pela FIP é válido somente para elementos simplesmente apoiados, com seções dentro de determinados padrões (para maiores informações deve-se consultar EL DEBS[2000] ou FIP[1992]).
} 


\subsubsection{Avaliação dos efeitos dependentes do tempo}

Como a avaliação dos efeitos dependentes do tempo está relacionada com a deformabilidade do concreto, optou-se por abordá-la separadamente no tópico 3.4.

\subsection{Efeito das fibras de aço na transmissão de esforços}

Denomina-se armadura de solidarização aquela responsável pela manutenção do equilíbrio dos esforços internos no elemento estrutural pela transmissão de esforços entre: concreto x concreto, armadura x concreto e/ou armadura x armadura. Tais armaduras não participam explicitamente dos esquemas resistentes básicos ${ }^{\dagger} \mathrm{e}$ tem como exemplos típicos conhecidos as: armaduras de costura e de fendilhamento. A primeira é usada para absorver esforços tangenciais atuando ao longo de um plano ou superfície interna da peça (ex.: ancoragem e emendas de barras retas) e a outra é usada para absorver esforços de tração gerados por uma compressão localizada (ex.: esforços gerados pela ancoragem de barras dobradas ou ganchos).

Conforme dito anteriormente, é preciso verificar o equilíbrio interno das vigas reforçadas pela Técnica de Reforço $\mathrm{n}^{\mathrm{o}} 1$ devido à tendência de aparecimento de um plano de ruptura horizontal devido ao cisalhamento longitudinal. Este plano de ruptura é causado pelo escorregamento relativo entre as armaduras tracionadas adicionadas e as preexistentes em função da redução do confinamento desta região pela ausência de armadura transversal (estribos). Para evitar a ruptura prematura das vigas reforçadas por esta técnica, o banzo tracionado destas peças foi reconstituído usando um material compósito com fibras de aço em substituição aos estribos. Dessa maneira, pretendia-se que as fibras de aço existentes no material compósito funcionassem como armadura de solidarização, pois seriam as responsáveis pela transferência de tensões entre as barras de aço envolvidas por estribos (primeira camada) e as barras de aço não envolvida por estribos (segunda camada).

Inicialmente foi proposto um modelo resistente considerando que a transferência de esforços ocorresse por meio de "ligações contínuas" existentes entre

\footnotetext{
${ }^{\dagger}$ Em vigas de concreto armado fissuradas usa-se o modelo resistente de viga e de treliça para dimensionar respectivamente as armaduras longitudinais (solicitações normais) e transversais (solicitações tangenciais).
} 
as barras de aço da primeira e da segunda camada devido ao "efeito de costura" gerado pelas fibras. Este modelo foi posteriormente substituído por outro no qual se admitia que o bordo tracionado não fosse mais representado individualmente por cada uma das camadas das barras longitudinais tracionadas, mas sim representado por um banzo único formado pelo material compósito. Este material compósito corresponderia à associação da primeira e segunda camada da armadura longitudinal com a argamassa de alto desempenho e com as fibras de aço (ver Figura 3.3).

Como até o presente momento não há normas específicas nem formulações teóricas para se dimensionar peças confeccionadas com concreto reforçado com fibras, e como os modelos propostos também não permitem determinar as características das fibras a serem adicionadas à argamassa de reforço das vigas $\mathrm{T}$, foi necessário determiná-las empiricamente a partir do ensaio de duas séries de vigas retangulares tipo VP que estão apresentadas no Capítulo 4.

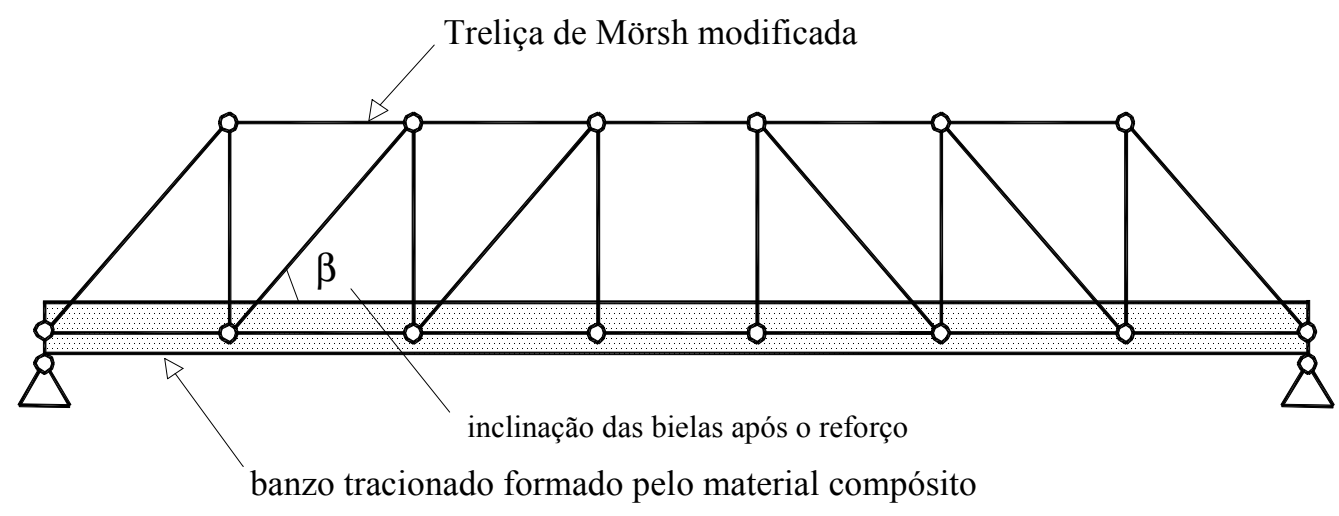

a) banzo tracionado representado por material compósito

Figura 3.3 - Esquema de treliça modificada após a reabilitação da peça 


\subsection{Deformabilidade do concreto ao longo do tempo}

\subsubsection{Comportamento viscoelástico do concreto - formulação teórica}

As deformações do concreto dependentes do tempo, também chamadas de deformações diferidas, podem ser classificadas, segundo a fib bulletin 1 (1999) em:

Deformações dependentes do tempo:
(deformações diferidas) $\left\{\begin{array}{l}\text { dependentes da tensão }-\{\text { fluência } \\ \text { independentes da tensão }-\left\{\begin{array}{l}\text { retração } \\ \text { expansão } \\ \text { efeito da temperatura }\end{array}\right.\end{array}\right.$

As deformações dependentes do tempo e independentes das tensões são as causadas por mudanças de volume, tais como a retração e a expansão (shrinkage e swelling). Estes fenômenos são influenciados principalmente pela perda ou ganho de umidade da peça de concreto não sujeita a tensões externas e com temperatura constante. Quando se tem temperatura variável ao longo do tempo é preciso computar ainda a deformação referente à variação térmica observada.

A deformação dependente do tempo e da tensão é denominada fluência (creep). Tal deformação é definida como sendo a diferença entre a deformação em dado tempo de uma peça submetida a tensões por longos períodos de tempo, e a deformação imediata que surge nesta peça assim que ela é carregada.

Correntemente, a literatura científica aborda apenas a fluência do concreto sujeito a um estado de compressão uniaxial, mas cabe ressaltar que esse fenômeno manifesta-se sob os diversos estados de solicitação do concreto, como na tração, cisalhamento, aderência, e nos estados combinados.

Como as formulações teóricas para avaliação das deformações por fluência são bastante conhecidas do meio técnico, optou-se por apresentar de maneira resumida as principais definições e formulações básicas disponíveis na literatura.

\section{- Deformação total do concreto $\varepsilon_{\mathrm{c}}$ em um instante de tempo t}

A deformação total $\varepsilon_{\mathrm{c}}(\mathrm{t})$ ocorrida no tempo $t$ em uma peça de concreto submetido a tensão uniaxial pode ser expressa pelas equações 3.35 e 3.36. 


$$
\begin{gathered}
\varepsilon_{c}(t)=\varepsilon_{c i}\left(t_{0}\right)+\varepsilon_{c c}(t)+\varepsilon_{c s}(t)+\varepsilon_{c T}(t, T) \\
\varepsilon_{c}(t)=\varepsilon_{c \sigma}(t)+\varepsilon_{c n}(t)
\end{gathered}
$$

onde:

$\varepsilon_{\mathrm{c}}(\mathrm{t}) \quad$ : deformação total na peça de concreto;

$\varepsilon_{\mathrm{ci}}\left(\mathrm{t}_{0}\right)$ : deformação inicial dependente da tensão no momento de aplicação da ação;

$\varepsilon_{\mathrm{cc}}(\mathrm{t}) \quad:$ deformação devido a fluência para um concreto com idade $t \geq t_{o}$;

$\varepsilon_{\mathrm{cs}}(\mathrm{t})$ : deformação devido a retração ou expansão para um concreto com idade $t$,

$\varepsilon_{\mathrm{cT}}(\mathrm{t}, \mathrm{T})$ : deformação térmica no concreto com idade $t$,

$\varepsilon_{\mathrm{c \sigma}}(\mathrm{t}) \quad$ : deformação total dependente da tensão para um concreto com idade $t$, ou seja, é a soma de $\varepsilon_{\text {ci }}\left(\mathrm{t}_{0}\right)$ e $\varepsilon_{\mathrm{cc}}(\mathrm{t})$;

$\varepsilon_{\mathrm{cn}}(\mathrm{t}) \quad$ : deformação total independente da tensão para um concreto com idade $t$, ou seja, é a soma de $\varepsilon_{\mathrm{cs}}\left(\mathrm{t}_{0}\right)$ e $\varepsilon_{\mathrm{cT}}(\mathrm{t}, \mathrm{T})$;

\section{- Deformação dependente da tensão $-\varepsilon_{\mathrm{c} \sigma}$}

Para determinar a deformação do concreto dependente da tensão, $\varepsilon_{\mathrm{c} \sigma}(\mathrm{t})$, em uma peça carregada deve-se conhecer os seguintes parâmetros:

\section{a) Coeficiente de fluência}

Para tensões inferiores a $\sigma_{\mathrm{c}} \leq 0,4 f_{\mathrm{cm}}$, as deformações de fluência podem ser linearmente relacionadas com as tensões (material viscoelástico linear). Esta relação é obtida introduzindo-se o coeficiente de fluência $\phi$.

Encontra-se na bibliografia duas maneiras distintas de se determinar o coeficiente de fluência. A primeira é obtida conforme a equação 3.37, dividindo-se a deformação por fluência no tempo t e a deformação inicial gerada pela aplicação de tensões no tempo $\mathrm{t}_{0}$, tal como apresentada nos modelos do ACI - American Concrete Institute e de BAZANT \& PANULA, apud MENDES (1993). A segunda é obtida dividindo-se a deformação por fluência no tempo t pela deformação inicial gerada por tensões aplicadas aos 28 dias (usada nos modelos do CEB e NBR-7197), e não será apresentada aqui.

Não havendo restrições às deformações específicas do concreto, calcula-se a deformação de fluência por 3.38 . 


$$
\begin{aligned}
& \phi\left(t, t_{0}\right)=\frac{\varepsilon_{c c}\left(t, t_{0}\right)}{\varepsilon_{c i}\left(t_{0}\right)}=\frac{\varepsilon_{c c}\left(t, t_{0}\right)}{\sigma_{c}\left(t_{0}\right) / E_{c}\left(t_{0}\right)} \\
& \varepsilon_{c c}\left(t, t_{0}\right)=\phi\left(t, t_{0}\right) \frac{\sigma_{c}\left(t_{0}\right)}{E_{c}\left(t_{0}\right)} \\
& \varepsilon_{c i}\left(t_{0}\right)=\frac{\sigma_{c}\left(t_{0}\right)}{E_{c}\left(t_{0}\right)}
\end{aligned}
$$

onde:

$\mathrm{t}$ : idade da peça desde sua moldagem até o instante de análise;

$\mathrm{t}_{0}$ : idade em que foi aplicado o carregamento na peça;

$\phi\left(t, t_{0}\right)$ : coeficiente de fluência;

$\varepsilon_{\mathrm{cc}}\left(\mathrm{t}, \mathrm{t}_{0}\right)$ : deformação por fluência no tempo t para um concreto carregado a uma idade $\mathrm{t}_{\mathrm{o}}$;

$\varepsilon_{\text {ci }}\left(\mathrm{t}_{0}\right)$ : deformação elástica inicial gerada pela aplicação de tensões no instante $\mathrm{t}_{\mathrm{o}}$;

$\sigma_{c}\left(t_{0}\right)$ : tensões que provocam a fluência aplicadas no instante $t_{0}$;

$\mathrm{E}_{\mathrm{c}}\left(\mathrm{t}_{0}\right)$ : módulo de elasticidade do concreto a uma idade $\mathrm{t}_{0}$;

\section{b) Fluência específica}

É a razão entre o coeficiente de fluência e o módulo de deformação do concreto na idade de aplicação do carregamento.

$$
C\left(t, t_{0}\right)=\frac{\phi\left(t, t_{0}\right)}{E_{c}\left(t_{0}\right)}
$$

\section{c) Função Fluência}

Representa a deformação total dependente das tensões na idade t para uma tensão unitária atuante deste a idade $\mathrm{t}_{0}$.

$$
J\left(t, t_{0}\right)=\frac{1}{E_{c}\left(t_{0}\right)}+C\left(t, t_{0}\right)=\left[\frac{1}{E_{c}\left(t_{0}\right)}+\frac{\phi\left(t, t_{0}\right)}{E_{c}\left(t_{0}\right)}\right]
$$


d) Deformação dependente das tensões para tensão mantida constante ao longo do tempo

Esta deformação é dada pela soma de $\varepsilon_{\mathrm{ci}}\left(\mathrm{t}_{0}\right) \operatorname{com} \varepsilon_{\mathrm{cc}}(\mathrm{t})$.

$\varepsilon_{c \sigma}\left(t, t_{0}\right)=\sigma_{c}\left(t_{0}\right)\left[\frac{1}{E_{c}\left(t_{0}\right)}+\frac{\phi\left(t, t_{0}\right)}{E_{c}\left(t_{0}\right)}\right]=\sigma_{c}\left(t_{0}\right) \cdot J\left(t, t_{0}\right)$

e) Deformação dependente das tensões para tensão variável ao longo do tempo

Uma vez que se considere válida a hipótese de linearidade entre fluência e tensão aplicada, a fluência do concreto sob tensões variáveis pode ser determinada utilizando o princípio da superposição de efeitos, pelo qual a deformação causada pela história da tensão $\sigma_{\mathrm{c}}(\mathrm{t})$ pode ser obtida decompondo-se a história da tensão em pequenos incrementos $\Delta \sigma_{\mathrm{c}}$ aplicados em um tempo $\tau_{\mathrm{i}}$ e posteriormente somando suas deformações correspondentes (ver equação 3.43). Caso $\sigma_{c}(t)$ seja uma função contínua, pode-se substituir a somatória por uma integral conforme equação 3.44 .

$$
\begin{aligned}
& \varepsilon_{\mathrm{c} \sigma}\left(\mathrm{t}, \sigma_{\mathrm{c}}\right)=\mathrm{J}\left(\mathrm{t}, \mathrm{t}_{0}\right) \cdot \sigma_{\mathrm{c}}\left(\mathrm{t}_{0}\right)+\sum_{\mathrm{i}=1}^{\mathrm{n}} \mathrm{J}\left(\mathrm{t}, \tau_{\mathrm{i}}\right) \cdot \Delta \sigma_{\mathrm{c}}\left(\tau_{\mathrm{i}}\right) \\
& \varepsilon_{\mathrm{c} \sigma}\left(\mathrm{t}, \sigma_{\mathrm{c}}\right)=\mathrm{J}\left(\mathrm{t}, \mathrm{t}_{0}\right) \cdot \sigma_{\mathrm{c}}\left(\mathrm{t}_{0}\right)+\int_{\mathrm{t}_{0}}^{\mathrm{t}} \mathrm{J}\left(\mathrm{t}, \tau_{\mathrm{i}}\right) \cdot \frac{\partial \sigma_{\mathrm{c}}(\tau)}{\partial \tau} \cdot \mathrm{d} \tau
\end{aligned}
$$

\section{- Deformação independente da tensão $-\varepsilon_{\mathrm{cn}}$}

Para determinar a deformação total do concreto independentemente da tensão aplicada na peça, $\varepsilon_{\mathrm{cn}}(\mathrm{t})$, deve-se conhecer os seguintes parâmetros:

\section{f) Deformação por retração}

$\mathrm{O}$ concreto fresco sofre retração por secagem quando exposto à umidade ambiente, ou seja, ocorre quando o concreto comum endurecido é exposto ao ar com uma umidade relativa inferior a 100\%. Apesar do termo retração geralmente ser usado para abreviar o que se define como retração por secagem do concreto endurecido, existem muitos outros tipos de deformações de retração que podem 
ocorrer simultaneamente e que devem ser somados para se obter corretamente a retração total do elemento estrutural analisado. Tais tipos de retração são:

- $\quad$ Retração plástica: ocorre quando o concreto perde água enquanto ainda está no estado plástico;

- Retração autógena ou química: associada com a contínua reação de hidratação do cimento que ocorre independentemente do meio ambiente;

- Retração por carbonatação: causada pela reação da pasta de cimento hidratada com o dióxido de carbono no ar na presença de umidade;

- Retraç̃a térmica: representa a deformação devida à contração térmica que ocorre quando o concreto quente é resfriado à temperatura ambiente. Geralmente existe em elementos com grande volume de concreto.

Entretanto é a retração por secagem que tem maior importância na prática, pois a retração plástica pode ser evitada fazendo uma dosagem correta do concreto bem como moldagem e cura adequadas. Já no caso da retração autógena, a deformação a ela relacionada tem-se um valor pequeno para concretos convencionais, só sendo mais significativa para concretos de alto-desempenho. É interessante observar que a retração autógena não depende da umidade relativa nem do tamanho do elemento e que se desenvolve mais rapidamente que a retração por secagem.

Mesmo assim, a fib bulletin $n^{0} 1$ (1999) recomenda que a deformação por retração para qualquer tipo de concreto seja determinada pela soma entre a retração por secagem e a retração autógena conforme expressão 3.45 .

$\varepsilon_{\mathrm{cs}}\left(\mathrm{t}, \mathrm{t}_{\mathrm{s}}\right)=\varepsilon_{\mathrm{cs} \_ \text {secagem }}\left(\mathrm{t}, \mathrm{t}_{\mathrm{s}}\right)+\varepsilon_{\mathrm{cs} \_ \text {autógena }}(\mathrm{t})$

onde:

$\varepsilon_{\mathrm{cs}}\left(\mathrm{t}, \mathrm{t}_{\mathrm{s}}\right) \quad:$ deformação total por retração;

$\varepsilon_{\text {c__secagem }}\left(t, t_{\mathrm{s}}\right):$ deformação devida a retração por secagem;

$\varepsilon_{\mathrm{cs} \_a u t o ́ g e n a}(\mathrm{t})$ : deformação devida a retração autógena;

$\mathrm{t} \quad$ : idade da peça desde sua moldagem até o instante de análise;

$t_{\mathrm{s}} \quad$ : idade em que foi finalizada a cura da peça;

As deformações provocadas pela retração podem ser determinadas a partir das recomendações de norma ou através de ensaios em laboratório. 


\section{g) Deformação por variação térmica}

A deformação do concreto provocada pela variação da temperatura ao longo do tempo é determinada pela expressão 3.46.

$\varepsilon_{\mathrm{cT}}(\mathrm{t})=\alpha_{\mathrm{cT}} \cdot \Delta \mathrm{T}(\mathrm{t})$

onde:

$\varepsilon_{\mathrm{cT}}(\mathrm{t}) \quad$ : deformação total por variação térmica;

$\alpha_{\mathrm{cT}} \quad$ : coeficiente de dilatação térmica;

$\Delta \mathrm{T}(\mathrm{t})$ : variação da temperatura ao longo do tempo;

O coeficiente de dilatação térmica do concreto depende do tipo e do volume de agregado usado, bem como do grau de hidratação da pasta de cimento utilizada na

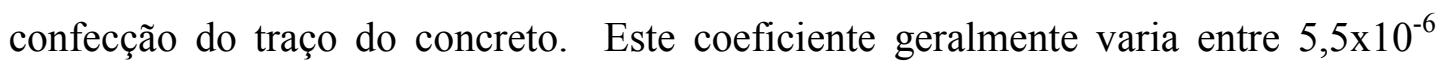
$\left(1 / \mathrm{C}^{\circ}\right)$ a $14 \times 10^{-6}\left(1 / \mathrm{C}^{\mathrm{o}}\right)$ e a norma NBR-6118 adota um valor igual à $10 \times 10^{-6}\left(1 / \mathrm{C}^{\mathrm{o}}\right)$ por atender à maior parte das situações práticas. Caso se necessite de um valor mais preciso, é possível determinar este coeficiente através de ensaios experimentais tais como os apresentados no Capítulo 6.

\subsubsection{Análise paramétrica da fluência do concreto a partir de dados experimentais}

\section{- Expressões matemáticas usadas para representar a função fluência}

Dependendo da modelagem adotada para a fluência, pode-se ter diferentes aproximações constitutivas para a função fluência $\mathrm{J}\left(\mathrm{t}, \mathrm{t}_{0}\right)$, para a fluência específica $\mathrm{C}\left(\mathrm{t}, \mathrm{t}_{0}\right)$ ou para o coeficiente de fluência $\phi\left(\mathrm{t}, \mathrm{t}_{0}\right)$. FONTOURA \& GAMBALE (1994) descreveram os resultados de um estudo feito sobre funções matemáticas usadas para representar o fenômeno de fluência do concreto ao longo do tempo, a partir do ajuste de resultados experimentais. De acordo com os autores, pode-se escolher um modelo matemático que melhor represente o comportamento viscoelástico do material a partir dos resultados dos ensaios de fluência lançados em um gráfico deformação (fluência específica) x tempo (idade após carregamento). 
Como a fluência é função da idade $(\mathrm{t})$ do concreto e da idade $\left(\mathrm{t}_{0}\right)$ em que se aplica o carregamento no elemento estudado, os modelos matemáticos usados para representar o fenômeno de fluência podem ser obtidos por meio de um estudo paramétrico empregando-se uma função do tipo $\mathrm{J}\left(\mathrm{t}, \mathrm{t}_{0}\right)$. Qualquer que seja o modelo matemático utilizado, pode-se separar a função $\mathrm{J}\left(\mathrm{t}, \mathrm{t}_{0}\right)$ em duas parcelas que são a parcela elástica, representada por $1 / \mathrm{E}_{\mathrm{c}}\left(\mathrm{t}_{0}\right)$, e a parcela viscosa representada por $\mathrm{C}\left(\mathrm{t}, \mathrm{t}_{0}\right)$.

$J\left(t, t_{0}\right)=\frac{1}{E_{c}\left(t_{0}\right)}+C\left(t, t_{0}\right)$

onde:

t - $\quad$ é a idade do concreto a partir da moldagem da peça;

$\mathrm{t}_{0}$ - $\quad$ idade do concreto no instante em que o carregamento foi aplicado na peça;

$\mathrm{J}\left(\mathrm{t}, \mathrm{t}_{0}\right)$ - função composta por uma parcela elástica e uma parcela viscosa. Corresponde à função fluência já apresentada na equação 3.41;

$\mathrm{E}_{\mathrm{c}}\left(\mathrm{t}_{0}\right)$ - é o módulo de elasticidade do concreto na idade $\mathrm{t}_{0}$. Esta função pode ser determinada por meio de uma regressão linear feita na curva experimental obtida em ensaios específicos;

$\mathrm{C}\left(\mathrm{t}, \mathrm{t}_{0}\right)$ - é determinada por ensaios de fluência, para no mínimo quatro idades de carregamentos distintos. Representa o comportamento do material viscoso, ou seja, corresponde à função da fluência específica (ver equação 3.40).

As funções que podem representar o parâmetro $\mathrm{C}\left(\mathrm{t}, \mathrm{t}_{0}\right)$ são numerosas e por este motivo, optou-se por apresentar aqui os três modelos principais usados para determiná-la.

\section{a) Modelo logarítmico:}

A equação logarítmica utilizada para o concreto massa é proposta pelo U.S. Bureal of Reclamation* apud FURNAS (1997), de acordo com a expressão (3.48).

\footnotetext{
* U.S. BUREAU OF RECLAMATION. (1956). Creep of concrete under high intensity loading. Denver, Colorado: Concrete Laboratory Report n. C-820.
} 


$$
J\left(t, t_{0}\right)=\frac{1}{E_{c}\left(t_{0}\right)}+F\left(t_{0}\right) \cdot \log \left(t-t_{0}+1\right)
$$

onde:

$\mathrm{F}\left(\mathrm{t}_{0}\right)$ - é o coeficiente de fluência na idade $\mathrm{t}_{0}$, obtido a partir de pelo menos quatro idades diferentes de carregamento. Com estas idades de carregamento consegue-se estabelecer um modelo que ajusta este parâmetro em função da idade de carregamento do concreto.

Existem basicamente duas expressões para determinar o coeficiente de fluência. A primeira é dada pela equação (3.49). Já a segunda corresponde ao modelo proposto por GUEDES ${ }^{\dagger}$ apud FURNAS (1997), que utiliza um modelo não linear dado pela equação (3.50).

$$
\begin{aligned}
& F\left(t_{0}\right)=a_{1}+\frac{b_{1}}{t_{0}} \\
& F\left(t_{0}\right)=\frac{a}{(1+x)^{m}}+b
\end{aligned}
$$

onde:

$\mathbf{a}_{1}$ e $\mathbf{b}_{1}$ - constantes determinadas pelo método dos mínimos quadrados;

a,m,b - parâmetros determinados por método iterativo durante o ajuste das curvas;

$\mathbf{x} \quad$ - relação entre a resistência à compressão do concreto em uma idade $t_{0}$ e a resistência à compressão do concreto na idade de referência $t_{r}$. A idade de referência $t_{r}$ pode ser definida pelo usuário e corresponde geralmente a uma idade onde se tem o início da estabilização da resistência mecânica à compressão do concreto (ex.: $t_{r} \geq 28$ dias).

O modelo proposto por GUEDES apud FURNAS (1997), utiliza uma equação não linear para tentar traduzir o envelhecimento do coeficiente de fluência do U.S. Bureau of Reclamation. Tal modelo depende basicamente de relações entre as resistências à compressão do concreto. Por isso pode ser usado também quando não se dispõe de ensaios de fluência. Entretanto deve-se conhecer a caracterização

\footnotetext{
$\dagger$ GUEDES Q. M (1990). Modelo unificado da viscoelasticidade linear com envelhecimento do concreto - Informações científicas: Barragens INCB5-LNEC, Lisboa - Portugal.
} 
viscoelástica de um concreto de mesmo teor de argamassa ou características semelhantes ao proposto, de forma que seja possível estimar a fluência do mesmo.

Pela expressão 3.50 percebe-se que quando $x \rightarrow \infty$ então $F\left(t_{0}\right)=b$ e que quando $\mathrm{x} \rightarrow 0$ então $\mathrm{F}\left(\mathrm{t}_{0}\right)=\mathrm{a}+\mathrm{b}$. Sendo assim, a vantagem de se usar a expressão 3.49 ao invés da expressão 3.50 consiste no fato de que, caso seja necessário extrapolar para resultados inferiores à idade mínima de ensaio, a expressão 3.49 tende para o infinito prejudicando o cálculo de tensões quando se tem um concreto jovem.

\section{b) Modelo Potencial:}

Pode-se utilizar também o modelo potencial dado pela expressão (3.51) para determinar a função fluência $\mathrm{J}\left(\mathrm{t}, \mathrm{t}_{0}\right)$.

$$
J\left(t, t_{0}\right)=\frac{1}{E\left(t_{0}\right)}+a \cdot t_{0}{ }^{n}\left(t-t_{0}\right)^{m}
$$

onde:

a, $\mathrm{n}, \mathrm{m}$ - constantes obtidas pelo método dos mínimos quadrados;

\section{d) Modelo de Boltzmann:}

Existe ainda o modelo de Boltzmann, também conhecido por cadeia de Kelvin, que é representado pela expressão 3.52. Tal modelo geralmente não é utilizado por ser bem mais complexo que os demais.

$$
\begin{aligned}
& J\left(t, t_{0}\right)=\frac{1}{E_{c}\left(t_{0}\right)}+\sum_{j=1}^{p} \frac{\left(1-\exp \left(-\frac{\left(t-t_{0}\right)}{t_{j}}\right)\right)}{E_{j}\left(t_{0}\right)} \\
& E_{j}\left(t_{0}\right)=A 1+\frac{A 2}{\left(1+t_{0} / 3\right)}+\frac{A 3}{\left(1+t_{0} / 90\right)}+\frac{A 4}{\left(1+t_{0} / 2700\right)}
\end{aligned}
$$

onde:

$\mathrm{E}_{\mathrm{j}}\left(\mathrm{t}_{0}\right)$ - corresponde ao coeficiente de mola determinado pela expressão 3.53;

A1, A2, A3 e A4 - são coeficientes determinados pelo método dos mínimos quadrados; $\mathrm{t}_{\mathrm{j}}$ - é o tempo de retardo que pode ser ajustado conforme necessidade do usuário; 
p - é o número de elementos da cadeia de Kelvin;

No Laboratório de Concreto de Furnas foram obtidos bons resultados com $\mathrm{p}=3$, ou seja, com três coeficientes de mola e com os seguintes tempos de retardo: $\mathrm{t}_{1}=0,3$ dia; $\mathrm{t}_{2}=3$ dias; $\mathrm{t}_{3}=30$ dias.

\subsubsection{Tensões e deformações diferidas em vigas de concreto armado fissuradas}

\subsubsection{Considerações gerais}

A análise do comportamento ao longo do tempo do concreto de peças fletidas fissuradas é relativamente complexa, pois além das variações de suas características mecânicas (tais como as resistências à tração, à compressão e o módulo de elasticidade) os efeitos da fluência e retração também provocam um aumento significativo da curvatura, e conseqüentemente da flecha, além da migração da linha neutra LN no sentido da armadura longitudinal de flexão tracionada. Com a movimentação da $\mathrm{LN}$, as fibras de concreto tracionadas localizadas abaixo da $\mathrm{LN}\left(\mathrm{t}_{0}\right)$ no instante $\mathrm{t}_{0}$, sofrem uma inversão de solicitação, e passam a estar sujeitas à compressão no instante $\mathrm{t}$ modificando, portanto a área de concreto comprimida (seção resistente) do elemento. Para efeito de análise, geralmente admite-se que a tensão de tração da armadura passiva não se altera com o tempo, ou seja, a tensão de tração no instante $\mathrm{t}$ é aproximadamente igual à tensão verificada no instante $\mathrm{t}_{0}$.

Desta forma percebe-se que neste tipo de estrutura, a tensão no concreto do bordo comprimido é variável ao longo do tempo mesmo quando os esforços externos aplicados não variam (ver Figuras 3.4 e 3.5).

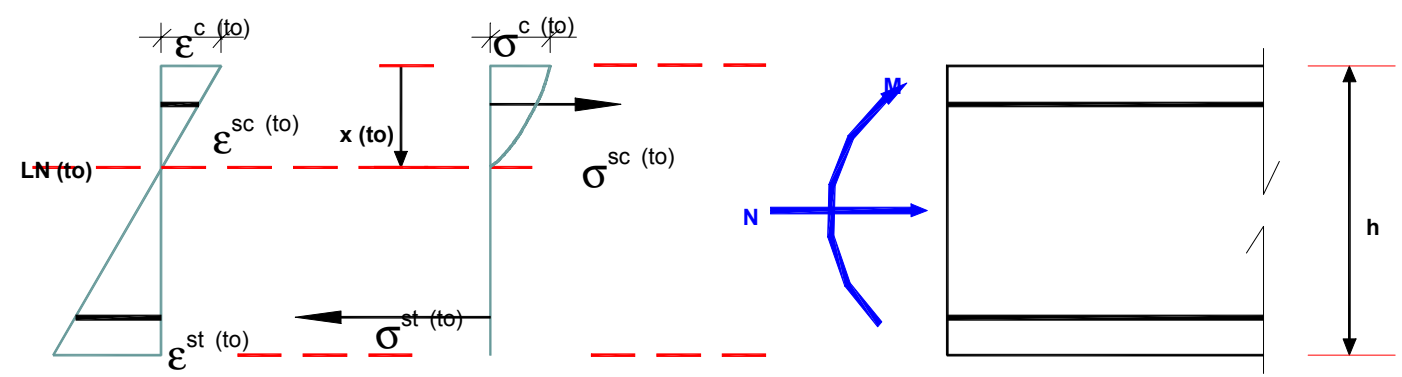

-(to) _(to)

Figura 3.4 - Estados de deformações e tensões no instante $t_{0}$ 


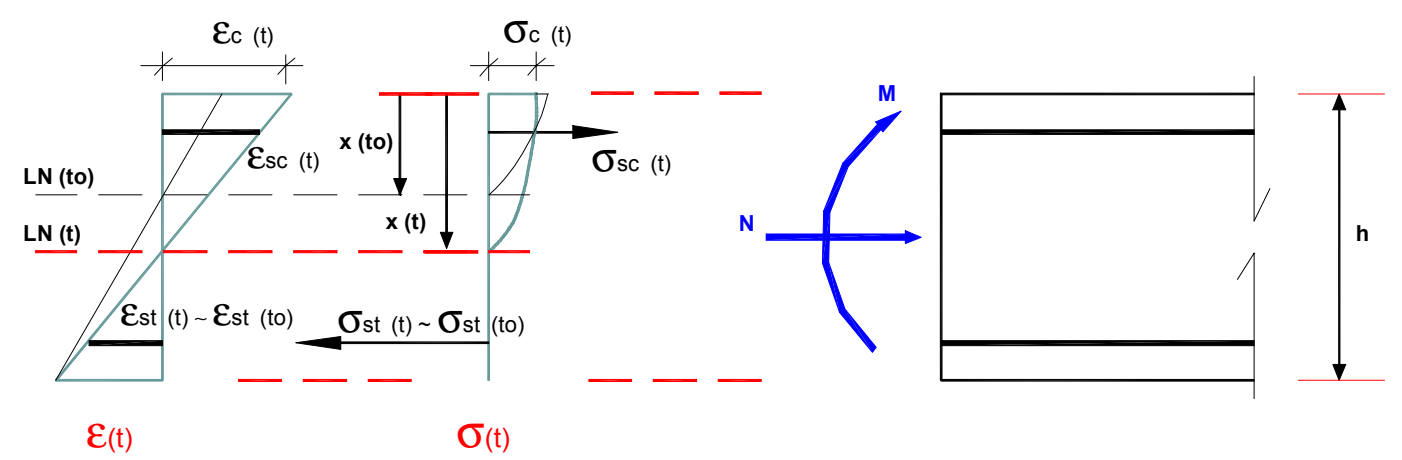

Figura 3.5 - Estados de deformações e tensões no instante t

Como as tensões são variáveis ao longo do tempo, é preciso utilizar o princípio da superposição de efeitos para avaliar as deformações do concreto a partir do cálculo da integral existente na equação 3.44. Os métodos de cálculo desta integral podem ser classificados em:

a) Método numérico por passo de tempo: baseia-se na solução numérica da equação de superposição (equação integral linear de STIELTJES) usando um procedimento de passos de tempo (ver Figura 3.6) no qual a idade $t$ da estrutura no instante da análise é dividida em $\mathrm{k}$ idades discretas $\left(\mathrm{t}_{0}, \mathrm{t}_{1}, \mathrm{t}_{2} \ldots \mathrm{t}_{\mathrm{k}}\right)$. Feito isso, calcula-se a integral para os diversos sub-intervalos $\Delta \mathrm{t}_{\mathrm{i}}=\mathrm{t}_{\mathrm{i}}-\mathrm{t}_{\mathrm{i}-1}$ admitindo-se a tensão aplicada em cada intervalo como sendo constante;

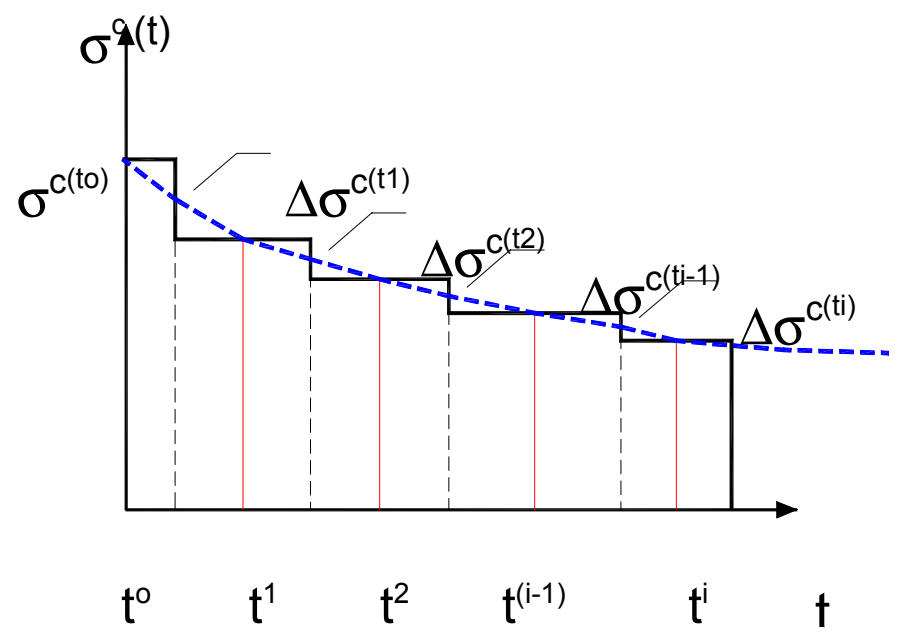

Figura 3.6 - Variação das tensões normais no concreto no decorrer do tempo 
b) Métodos simplificados: Estes métodos podem ser classificados em métodos algébricos e métodos que usam função fluência simplificada.

b.1) Métodos algébricos: consistem em soluções aproximadas para a equação de superposição integral, a qual é transformada em equações algébricas com diferentes níveis de refinamento podendo ser classificadas em:

> Método do módulo efetivo (EM),

> Método da tensão média (MS);

> Método do módulo de deformação efetivo ajustado (AAEM).

b.2) Métodos que usam função fluência simplificadas: são métodos que transformam a equação integral de superposição em equações diferenciais ordinárias, pelo uso de uma forma convenientemente simplificada para a função fluência. Tal simplificação pode ser baseada nas seguintes teorias:

$>\quad$ Teoria da hereditariedade;

> Teoria do envelhecimento;

$>\quad$ Método de Dischinger generalizado .

\subsubsection{Procedimento de cálculo das tensões e deformações diferidas em vigas fissuradas em serviço}

Para avaliar de maneira simplificada as tensões e deformações diferidas em peças fissuradas em serviço submetidas à flexão normal ou composta, GHALI \& FAVRE (1986) apresentaram uma formulação algébrica utilizando o métododo módulo de deformação efetivo ajustado.

Esta formulação, apresentada resumidamente a seguir, baseou-se nas hipóteses de que a contribuição do concreto situado na zona tracionada é desprezada e de que as seções planas permanecem planas após a deformação do elemento. Estas duas hipóteses são satisfeitas ao realizar a análise do elemento utilizando as propriedades da área da seção de concreto comprimido homogeneizada após a fissuração do elemento (Estádio II), dada por: 


$$
\mathrm{A}_{\text {homo }}=\mathrm{A}_{\mathrm{c}}+\alpha \mathrm{A}_{\mathrm{s}}
$$

onde:

$\mathrm{A}_{\text {homo }}$ : área da seção transversal homogeneizada;

$\mathrm{A}_{\mathrm{c}} \quad$ : área da seção transversal comprimida;

$\mathrm{A}_{\mathrm{s}} \quad$ : área da armadura tracionada;

$\alpha$ : relação entre os módulos de elasticidade do aço e do concreto $\left(\alpha=\mathrm{E}_{\mathrm{s}} / \mathrm{E}_{\mathrm{c}}\right)$;

$\mathrm{O}$ valor do módulo de elasticidade do concreto, $\mathrm{E}_{\mathrm{c}}$, é adotado como sendo aquele existente no instante de aplicação do carregamento quando a análise destinase a obtenção das tensões e deformações instantâneas. Quando se deseja considerar os efeitos viscoelásticos (efeitos da retração e fluência) deve-se adotar o valor de $\mathrm{E}_{\mathrm{c}}$ como sendo o módulo de elasticidade efetivo ajustado com a idade em função do módulo existente no início da aplicação do carregamento mantido constante.

A formulação apresentada baseia-se no comportamento de uma peça submetida à flexão composta em que as fibras superiores do concreto estão comprimidas e as fibras inferiores estão tracionadas. Para este caso, adota-se o momento fletor, $\mathrm{M}$, sendo positivo quando produz compressão nas fibras superiores e a força axial, N, sendo positiva quando produz tração na seção transversal. A força axial $\mathrm{N}$ é colocada em um ponto de referência $\mathrm{O}$ adotado em função da posição do centróide da área homogeneizada do concreto comprimido da seção do elemento.

\section{a) Determinação das tensões e deformações instantâneas}

Admitindo uma peça com seção transversal $\mathrm{T}$, adotou-se a nomenclatura apresentada na Figura 3.7 para desenvolver a formulação proposta.

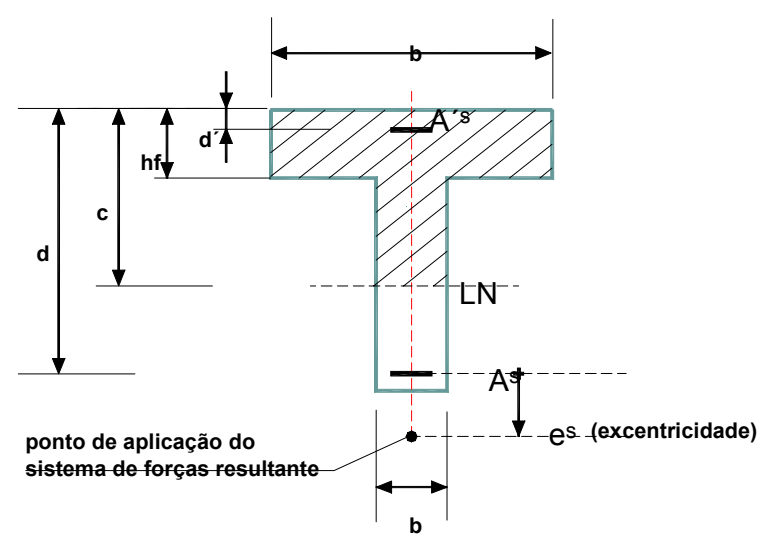

Figura 3.7 - Nomenclatura utilizada na formulação apresentada 
A Figura 3.8 apresenta a distribuição de tensões e deformações instantâneas ao longo da seção transversal de uma viga devido ao efeito combinado de $\mathrm{M}$ e $\mathrm{N}$ aplicado em um instante $\mathrm{t}_{0}$. A resultante de $\mathrm{M}$ e $\mathrm{N}$ está localizada na excentricidade $e$ determinada por:

$$
e=\mathbf{M} / \mathbf{N}
$$

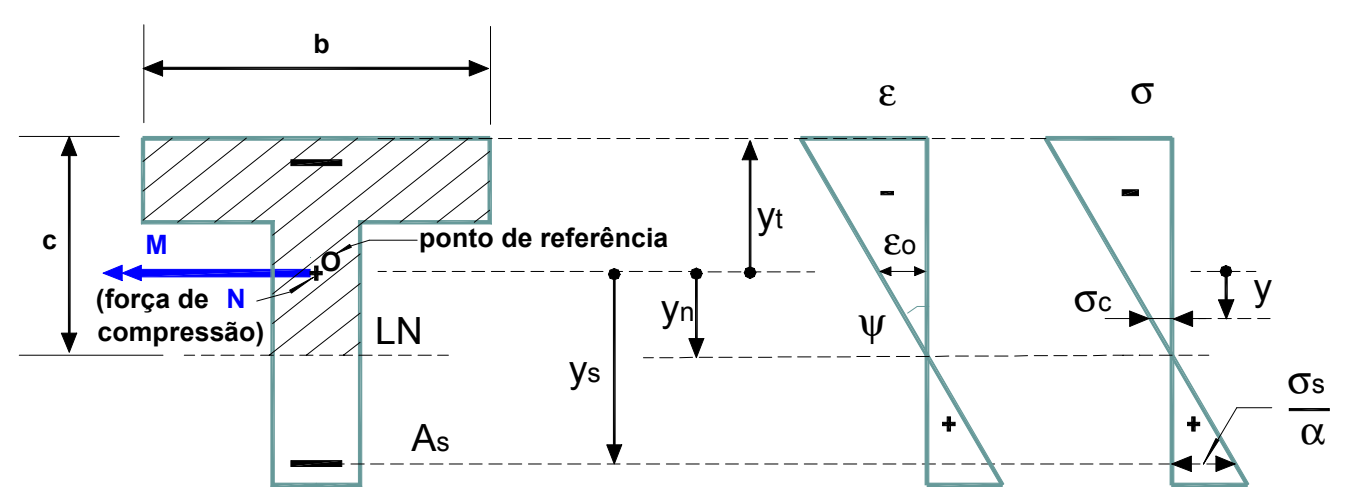
(a) seção transversal
(b) deformações
(c) tensões

\section{Figura 3.8 - Distribuição de tensões e deformações em vigas fissuradas}

Observe que a excentricidade " $e$ " e a coordenada $y$ de qualquer fibra da seção transversal do elemento é medida para baixo, a partir do ponto $\mathrm{O}$ escolhido, e que a localização da linha neutra depende não dos valores separados de M e N, mas sim do valor de $e$.

Para determinar a posição da linha neutra $c$ em uma seção genérica deve-se integrar as tensões na área e calcular o momento em torno do eixo que passa pelo ponto $\mathrm{O}$ de acordo com as expressões 3.56 e 3.57 .

$$
\begin{aligned}
& \varepsilon_{0} \cdot\left\{E_{c} \int_{y_{t}}^{y_{n}}\left(1-\frac{y}{y_{n}}\right) d A+E_{s} \sum\left[A_{s}\left(1-\frac{y_{s}}{y_{n}}\right)\right]\right\}=N \\
& \varepsilon_{0} \cdot\left\{E_{c} \int_{y_{t}}^{y_{n}} y\left(1-\frac{y}{y_{n}}\right) d A+E_{s} \sum\left[A_{s} y_{s}\left(1-\frac{y_{s}}{y_{n}}\right)\right]\right\}=M
\end{aligned}
$$

onde:

dA : elemento de área do concreto comprimido;

$\mathrm{A}_{\mathrm{s}}$ e $y_{s}$ : área de aço e posição da armadura tracionada em relação ao ponto $\mathrm{O}$; 
$\mathrm{E}_{\mathrm{c}}$ e $\mathrm{E}_{\mathrm{s}}$ : módulos de elasticidade do concreto e do aço respectivamente;

$\varepsilon$ : deformação da fibra do concreto;

$\psi$ : curvatura da seção transversal;

$y$ : posição da fibra do concreto considerada em relação do ponto de referência $\mathrm{O}$;

$y_{t}$ : posição da fibra do concreto mais comprimida;

$y_{\mathrm{n}}$ : posição da linha neutra em relação do ponto de referência $\mathrm{O}$.

Explicitando tais expressões para uma viga $\mathrm{T}$ obtém-se as equações $3.58 \mathrm{e}$ 3.59 que possibilitam determinar a altura $c$ da zona comprimida sem considerar os efeitos do tempo.

$\operatorname{Para} \mathrm{N}=0$ e $c \geq \mathrm{h}_{\mathrm{f}}$

$1 / 2 b_{w} c^{2}+\left[h_{f}\left(b-b_{w}\right)+\alpha_{s} A_{s}+\left(\alpha_{s}-1\right) A_{s}^{\prime}\right] c-\left[1 / 2\left(b-b_{w}\right) h_{f}^{2}+\alpha_{s} A_{s} d+\left(\alpha_{s}-1\right) A^{\prime}{ }_{s} d^{\prime}\right]=0$

Para $\mathrm{N} \neq 0$ e $c \geq \mathrm{h}_{\mathrm{f}}$

$\left(1 / 2 b_{w} c^{2}\right)(d-1 / 3 c)+\left(b-b_{w}\right) h_{f}\left[c\left(d-1 / 2 h_{f}\right)-1 / 2 h_{f}\left(d-2 / 3 h_{f}\right)\right]+\left(\alpha_{s}-1\right) A_{s}^{\prime}\left(c-d^{\prime}\right)\left(d-d^{\prime}\right)+$ $e_{\mathrm{s}}\left[\left(1 / 2 \mathrm{~b}_{\mathrm{w}} \mathrm{c}^{2}\right)+\left(\mathrm{b}-\mathrm{b}_{\mathrm{w}}\right) \mathrm{h}_{\mathrm{f}}\left(\mathrm{c}-1 / 2 \mathrm{~h}_{\mathrm{f}}\right)+\left(\alpha_{\mathrm{s}}-1\right) \mathrm{A}_{\mathrm{s}}^{\prime}\left(\mathrm{c}-\mathrm{d}^{\prime}\right)-\alpha_{\mathrm{s}} \mathrm{A}_{\mathrm{s}}(\mathrm{d}-\mathrm{c})\right]=0$

Quando não existe força axial $(\mathrm{N}=0)$ a posição da linha neutra, representada pela coordenada $c$ medida a partir do topo da viga, coincide com o centróide da área homogeneizada após a fissuração, ou seja, com a posição do ponto de referência $O$. Isso não ocorre quando a força axial, $\mathrm{N}$, é diferente de zero.

Determinado o valor de $c$, calcula-se as propriedades da área homogeneizada (centróide e momento de inércia em relação ao ponto $O$ ), a deformação imediata $\varepsilon_{0}$ para o ponto $\mathrm{O}$ e a curvatura $\psi$ da seção transversal. Para obter a deformação $\varepsilon_{0} \mathrm{e}$ a curvatura $\psi$ utiliza-se as expressões 3.60 e 3.61 .

$$
\varepsilon_{0}=\frac{\mathrm{N}_{\text {equivalente }}}{\mathrm{E}_{\mathrm{c}} \cdot \mathrm{A}_{\text {hom o }}}
$$




$$
\psi=\frac{\mathrm{M}_{\text {equivalente }}}{\mathrm{E}_{\mathrm{c}} \cdot \mathrm{I}_{\mathrm{x}_{-} \text {hom o }}}
$$

onde:

$\mathrm{N}_{\text {equivalente }}$ : esforço normal atuante na seção para um sistema equivalente de forças aplicado no ponto $\mathrm{O}$ (centróide da área homogeneizada);

$\mathrm{M}_{\text {equivalente }}$ : momento atuante na seção para um sistema equivalente de forças aplicado no ponto $\mathrm{O}$ (centróide da área homogeneizada);

$\mathrm{I}_{\mathrm{X} \_ \text {homo }} \quad$ : momento de inércia para um eixo $\mathrm{x}$ que passa pelo ponto $\mathrm{O}$ (centróide da área homogeneizada).

Observando a Figura 3.8 verifica-se que a deformação em qualquer fibra $\varepsilon$, as tensões $\sigma_{\mathrm{c}}$ em qualquer fibra do concreto e as tensões $\sigma_{\mathrm{s}}$ no aço podem ser determinadas respectivamente pelas equações 3.62 a 3.65 .

$$
\begin{aligned}
& \varepsilon=\varepsilon_{0}+y \cdot \psi \\
& y_{n}=-\varepsilon_{0} / \psi \\
& \sigma_{c}= \begin{cases}E_{c}\left(1-\mathrm{y} / \mathrm{y}_{\mathrm{n}}\right) \varepsilon_{0} & \mathrm{y}<\mathrm{y}_{\mathrm{n}} \\
0 & \mathrm{y} \geq \mathrm{y}_{\mathrm{n}}\end{cases} \\
& \sigma_{s}=\mathrm{E}_{\mathrm{s}}\left(1-y_{s} / y_{n}\right) \cdot \varepsilon_{0}
\end{aligned}
$$

\section{b) Determinação das tensões e deformações diferidas}

Para determinar as tensões e deformações diferidas no instante de tempo $\mathrm{t}$ devido a um carregamento aplicado em $t_{0}$ através da formulação apresentada é preciso inicialmente conhecer os valores do coeficiente de fluência do concreto, $\phi\left(t, t_{0}\right)$, do coeficiente de envelhecimento do concreto, $\chi\left(t, t_{0}\right)$, e da deformação do concreto por retração $\varepsilon_{\mathrm{cs}}\left(\mathrm{t}, \mathrm{t}_{\mathrm{s}}\right)$.

Admitindo-se que os esforços $\mathrm{M}$ e $\mathrm{N}$, introduzidos na idade $\mathrm{t}_{0}$, tenham sido mantidos constantes até a peça atingir a idade t, sabe-se que neste instante as 
distribuições das deformações e tensões na seção transversal do elemento são diferentes das existentes inicialmente devido aos efeitos da retração e da fluência do concreto

Como já foi dito, a fluência e a retração no concreto provocam alterações na posição da linha neutra ao longo do tempo, que tende a se movimentar em direção ao bordo mais tracionado da peça. Com a alteração da posição da linha neutra, altera-se também a área de concreto submetida à compressão, portanto a área $\mathrm{A}_{\mathrm{c}}$ usada na avaliação das tensões e deformações é dependente do tempo. Entretanto, para simplificar a análise das tensões e deformações no elemento ao longo do tempo, a formulação analítica apresentada aqui considerou a área $\mathrm{A}_{\mathrm{c}}$ como sendo constante $\mathrm{e}$ igual a área de concreto determinada para a zona comprimida no instante de início da aplicação do carregamento $\left(\mathrm{t}_{0}\right)$. De acordo com GHALI \& FAVRE o erro resultante desta consideração é geralmente pequeno e pode ser desprezado.

$\mathrm{O}$ ponto de referência $\mathrm{O}$ é escolhido como sendo o centróide da nova área homogeneizada em função da idade, determinada agora pela expressão 3.66.

$$
\begin{aligned}
& \mathrm{A}_{\text {homo } 2}=\mathrm{A}_{\mathrm{c}}+\bar{\alpha}\left(\mathrm{t}, \mathrm{t}_{0}\right) \mathrm{A}_{\mathrm{s}} \\
& \bar{\alpha}\left(\mathrm{t}, \mathrm{t}_{0}\right)=\frac{\mathrm{E}_{\mathrm{s}}}{\overline{\mathrm{E}}_{\mathrm{c}}\left(\mathrm{t}, \mathrm{t}_{0}\right)} \\
& \overline{\mathrm{E}}_{\mathrm{c}}\left(\mathrm{t}, \mathrm{t}_{0}\right)=\frac{\mathrm{E}_{\mathrm{c}}\left(\mathrm{t}, \mathrm{t}_{0}\right)}{1+\chi\left(\mathrm{t}, \mathrm{t}_{0}\right) \cdot \phi\left(\mathrm{t}, \mathrm{t}_{0}\right)}
\end{aligned}
$$

onde:

$\mathrm{A}_{\text {homo2 }}$ : área da seção transversal homogeneizada em função da idade;

$\mathrm{A}_{\mathrm{c}} \quad$ : área da seção transversal comprimida;

$\mathrm{A}_{\mathrm{s}} \quad$ : área da armadura tracionada;

$\bar{\alpha}\left(t, t_{0}\right)$ : relação entre os módulos de elasticidade do aço e do concreto considerando o módulo de elasticidade do concreto efetivo ajustado com a idade;

$\overline{\mathrm{E}}_{\mathrm{c}}\left(\mathrm{t}, \mathrm{t}_{0}\right)$ : módulo de elasticidade do concreto efetivo ajustado com a idade;

$\chi\left(\mathrm{t}, \mathrm{t}_{0}\right) \quad$ : coeficiente de envelhecimento do concreto;

$\phi\left(t, t_{0}\right) \quad$ : coeficiente de fluência do concreto na idade $t$ para carregamento aplicado em $t_{0} ;$

\footnotetext{
* Não se mencionou o efeito da relaxação do aço por este ser mais crítico em peças protendidas, o que não é o caso das peças analisadas aqui.
} 
De acordo com GALHI \& FAVRE as alterações em termos de deformações axiais no ponto $\mathrm{O}$, de curvatura e de tensões devidas à retração e à fluência podem ser estimadas de acordo com as expressões 3.69 a 3.74 .

$$
\begin{gathered}
\Delta \varepsilon_{0}=\eta\left[\phi\left(\mathrm{t}, \mathrm{t}_{0}\right)\left(\varepsilon_{0}+y \cdot \psi\right)+\varepsilon_{\mathrm{cs}}\left(\mathrm{t}, \mathrm{t}_{0}\right)\right] \\
\Delta \psi=\mathrm{k}\left[\phi\left(\mathrm{t}, \mathrm{t}_{0}\right)\left(\psi+\varepsilon_{0} \frac{y_{c}}{r_{c}^{2}}\right)+\varepsilon_{\mathrm{cs}}\left(\mathrm{t}, \mathrm{t}_{0}\right) \frac{y_{c}}{r_{c}^{2}}\right] \\
\Delta \sigma_{\mathrm{c}}=\overline{\mathrm{E}}_{\mathrm{c}}\left(\mathrm{t}, \mathrm{t}_{0}\right)\left[-\phi\left(\mathrm{t}, \mathrm{t}_{0}\right)\left(\varepsilon_{0}+\psi \cdot y\right)-\varepsilon_{\mathrm{cs}}\left(\mathrm{t}, \mathrm{t}_{0}\right)+\Delta \varepsilon_{0}+\Delta \psi \cdot y\right] \\
\Delta \sigma_{s}=\mathrm{E}_{\mathrm{s}}\left(\Delta \varepsilon_{0}+\Delta \psi \cdot \mathrm{y}_{\mathrm{s}}\right) \\
\eta=\frac{\mathrm{A}_{\mathrm{c}}}{\mathrm{A}_{\text {hom o } 2}} \\
\mathrm{k}=\frac{\mathrm{I}_{\mathrm{c}}}{\mathrm{I}_{\mathrm{x}_{-} \text {hom o } 2}}
\end{gathered}
$$

onde:

$\varepsilon_{\mathrm{cs}} \quad$ : deformação por retração que surgiria no concreto se este fosse livre, durante o período de tempo $\left(\mathrm{t}-\mathrm{t}_{0}\right)$;

$\varepsilon_{0} \quad$ : deformação axial do centróide da área de concreto $A_{\text {homo2 }}$ obtida usando a curvatura existente no instante $t_{0}$;

$\psi \quad$ : curvatura obtida no instante $\mathrm{t}_{0}$ imediatamente após a aplicação de $\mathrm{Me} \mathrm{N}$;

$y_{c}$ : coordenada y do centróide da área de concreto comprimido baseado na distribuição de tensões existente em $\mathrm{t}_{0}$. Esta posição é medida a partir do bordo mais tracionado da peça.

$r_{c}^{2}=\mathrm{I}_{\mathrm{x} \_ \text {homo2 }} / \mathrm{A}_{\text {homo2 }}$ : raio de giração calculado em função do momento de inércia em torno do eixo x que passa pelo ponto $\mathrm{O}$ e da área de concreto comprimido;

k e $\eta$ : fatores de redução da curvatura e da deformação axial em função da restrição gerada pela presença da área de aço existente no elemento.

$\mathrm{A}_{\text {homo2 }}$ : área de concreto homogeneizada em função da idade;

$\mathrm{I}_{\mathrm{x}_{-} \text {homo2 }}$ : momento de inércia em torno do eixo $\mathrm{x}$ que passa pelo ponto $\mathrm{O}$ (centróide da área concreto $\mathrm{A}_{\text {homo2 }}$ );

A Figura 3.9 apresenta um esquema de análise para obtenção das tensões e deformações diferidas no tempo t, para uma viga de seção $T$, a partir as tensões e 
deformações imediatas geradas pela aplicação do carregamento $\mathrm{M}$ e $\mathrm{N}$ no tempo $\mathrm{t}_{0} \mathrm{e}$ que foi mantido constante até o instante final t.
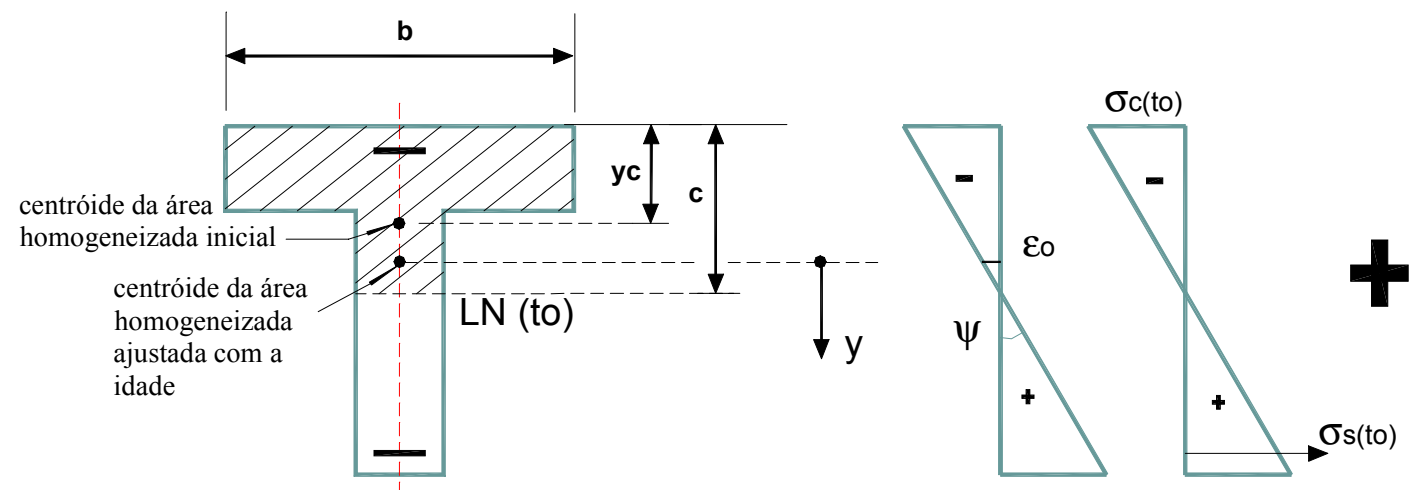

(a) seção transversal

(b) deformações e tensões no tempo $t_{0}$
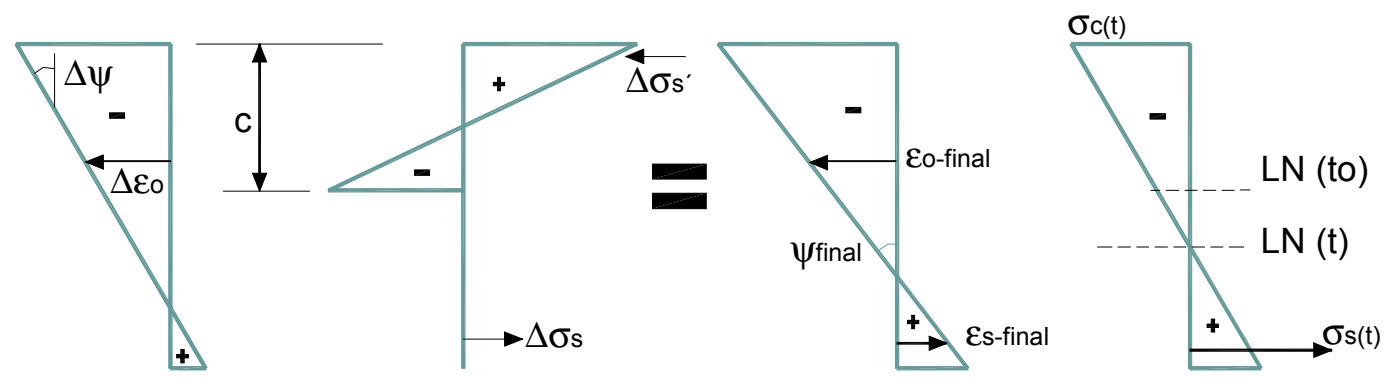

(c) variação das deformações e tensões

(d) deformações e tensões no tempo $t$

Figura 3.9 - Exemplo de análise das tensões e deformações ao longo do tempo

\subsubsection{Avaliação de flechas devido aos efeitos de fluência e retração}

O efeito da fluência e da retração em peças submetidas à flexão provoca um acréscimo da curvatura ao longo do tempo e conseqüentemente um acréscimo em seus deslocamentos verticais. Para estimar o aumento da flecha (deslocamento vertical no meio do vão) com o tempo, deve ser considerada a natureza das cargas que a provocou, ou seja, deve-se determinar a flecha gerada pela aplicação de ações de longa duração e de ações de curta duração.

As flecha para ações de curta duração são calculadas pelas expressões usuais da Resistência dos Materiais ou pelos métodos conhecidos da Teoria das Estruturas. Geralmente as fórmulas destinadas ao cálculo destas flechas (flechas elásticas), já se 
encontram tabeladas e dependem das características de vinculação, geométricas, dos esforços e do módulo de elasticidade da peça. Para o caso de viga biapoiada com duas forças concentradas aplicadas (caso estudado) a flecha elástica máxima é obtida pela equação 3.75 .

$$
\begin{aligned}
& \delta_{\text {imediata }}=\frac{\mathrm{Fa}}{24(\mathrm{EI})_{\mathrm{eq}}}\left(3 \ell^{2}-4 \mathrm{a}^{2}\right) \\
& (\mathrm{EI})_{\mathrm{eq}}=\mathrm{E}_{\mathrm{cs}}\left\{\left(\frac{\mathrm{M}_{\mathrm{r}}}{\mathrm{M}_{\mathrm{a}}}\right)^{3} \mathrm{I}_{\mathrm{c}}+\left(1-\left(\frac{\mathrm{M}_{\mathrm{r}}}{\mathrm{M}_{\mathrm{a}}}\right)^{3}\right) \mathrm{I}_{\mathrm{II}}\right\} \leq \mathrm{E}_{\mathrm{cs} \cdot \mathrm{I}_{\mathrm{c}}}
\end{aligned}
$$

onde:

F : força vertical;

a : distância da força vertical ao apoio mais próximo ;

l : vão teórico da viga;

$\mathrm{E}_{\mathrm{cs}}$ : módulo de elasticidade secante do concreto;

$I_{c} \quad$ : momento de inércia da seção bruta de concreto;

$\mathrm{I}_{\mathrm{II}}$ : momento de inércia da seção fissurada de concreto no Estádio II;

$\mathrm{M}_{\mathrm{a}}$ : momento fletor atuante na seção crítica do vão considerado;

$\mathrm{M}_{\mathrm{r}}$ : momento fletor de fissuração;

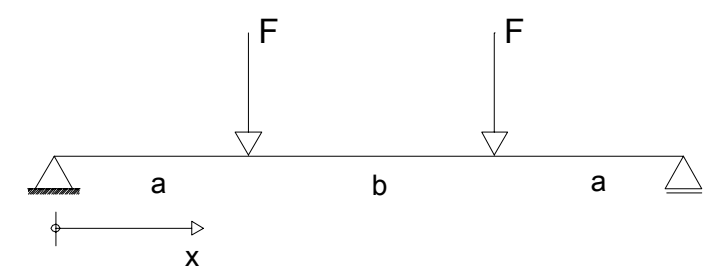

Figura 3.10 - Esquema estático usado para avaliar as flechas

As flechas geradas pelas ações de longa duração, em geral, são obtidas multiplicando-se as flechas instantâneas por um coeficiente específico que depende do método usado na previsão da retração e fluência do concreto.

Como existem muitos métodos para realizar a previsão das flechas de longa duração, optou-se por apresentar apenas alguns deles resumidamente neste texto. Caso se queira maiores informações sobre a forma de previsão das flechas de longa duração, MARÍ (1994) descreve os principais métodos usados por normas e 
pesquisadores e compara os resultados fornecidos por cada um deles com os resultados experimentais de vigas.

a) Método indicado pela NBR-6118 (1978) :

$$
\begin{aligned}
& \delta_{\text {total }}=\delta_{\text {imediada }}+\delta_{\text {diferida }}=\beta . \delta_{\text {imediata }} \\
& \beta=\frac{(1 / \mathrm{r})_{\infty}}{(1 / \mathrm{r})_{\mathrm{o}}}=\frac{\left(\mathrm{k}\left|\varepsilon_{\mathrm{c}}\right|+\varepsilon_{\mathrm{s}}\right) / \mathrm{d}}{\left(\left|\varepsilon_{\mathrm{c}}\right|+\varepsilon_{\mathrm{s}}\right) / \mathrm{d}}=\frac{\mathrm{k}\left|\varepsilon_{\mathrm{c}}\right|+\varepsilon_{\mathrm{s}}}{\left|\varepsilon_{\mathrm{c}}\right|+\varepsilon_{\mathrm{s}}}
\end{aligned}
$$

onde:

$\delta_{\text {total }} \quad$ : flecha total devida à ação de longa duração;

$\delta_{\text {imediata }}$ : flecha imediata devida à ação de longa duração;

$\delta_{\text {diferida }}:$ flecha devida a fluência gerada pela ação de longa duração;

$\beta \quad$ : coeficiente multiplicador da flecha inicial;

$\varepsilon_{\mathrm{c}} \quad$ : deformação na fibra mais comprimida do concreto;

$\varepsilon_{\mathrm{s}} \quad$ : deformação na armadura;

d : altura útil;

$\mathrm{k}$ : coeficiente de majoração da deformação do concreto por fluência estimado em:

$3 \rightarrow$ para ações de longa duração aplicadas logo após o término da construção;

$2 \rightarrow$ para ações de longa duração aplicadas seis meses ou mais após a concretagem;

b) Método indicado pela NBR-6118 (2003):

$$
\begin{array}{ll}
\delta_{\text {total }}=\delta_{\text {imediata }}+\delta_{\text {diferida }} & \rightarrow \quad \delta_{\text {total }}=\delta_{\text {imediata }} \cdot\left(1+\alpha_{\mathrm{f}}\right) \\
\alpha_{\mathrm{f}}=\frac{\Delta \xi}{1+50 \rho^{\prime}} & \\
\Delta \xi=\xi(\mathrm{t})-\xi\left(\mathrm{t}_{0}\right) & \\
\xi(\mathrm{t})=0,68 \cdot\left(0,996^{\mathrm{t}}\right) \cdot \mathrm{t}^{0,32} & \text { para } \mathrm{t} \leq 70 \text { meses } \\
\xi(\mathrm{t})=2 & \text { para } \mathrm{t}>70 \text { meses } \\
\rho^{\prime}=\frac{\mathrm{A}_{\mathrm{s}}{ }^{\prime}}{\mathrm{b} \cdot \mathrm{d}} &
\end{array}
$$

Onde: 
$\alpha_{\mathrm{f}}$ : coeficiente multiplicador das flechas imediatas, usado para determinar as flechas diferidas em função do tempo de aplicação do carregamento de longa duração;

$\xi$ : coeficiente função do tempo usado no cálculo de $\alpha_{\mathrm{f}}$;

$\rho^{\prime}$ : taxa de armadura longitudinal comprimida;

t : idade, em meses, quando se deseja o valor da flecha diferida;

$\mathrm{t}_{0}$ : idade, em meses, relativa a data de aplicação do carregamento de longa duração;

c) fib bulletin $n^{\circ} 1$ (1999) :

$\delta(t) \cong \delta_{i}\left[1+0,3 \phi\left(t, t_{o}\right)\right]$

onde:

$\delta(t) \quad$ : deslocamentos verticais da peça em função do tempo;

$\delta_{\mathrm{i}} \quad$ : deslocamento vertical inicial;

$\phi\left(t, t_{0}\right)$ : coeficiente de fluência;

d) $M U R C I A(2000)$ :

MURCIA apresentou, a partir das tensões e deformações apresentadas na Figura 3.11, uma formulação para o cálculo das flechas de longa duração em elementos fletidos. Tal formulação é separada em função do tipo de seção transversal da peça analisada.

$\delta_{\text {total }}=\delta_{\text {imediata }}+\delta_{\text {diferida }} \quad \rightarrow \quad \delta_{\text {total }}=\delta_{\text {imediata }} \cdot(1+\lambda)$

$\lambda=\frac{\mathrm{x}_{0}}{\mathrm{~d}} \cdot \frac{\phi+\frac{\varepsilon_{\mathrm{r}}}{\varepsilon_{\mathrm{c} 0}}}{1+150 \frac{\mathrm{A}_{\mathrm{s}}{ }^{\prime}}{\mathrm{bh}}}$ (para seções retangulares ou T com LN acima da mesa de compressão)

$\lambda=\frac{\mathrm{x}_{0}-\mathrm{d}^{\prime}}{\mathrm{d}-\mathrm{d}^{\prime}} \cdot \frac{\phi+\frac{\varepsilon_{\mathrm{r}}}{\varepsilon_{\mathrm{c} 0}}}{1+20 \frac{\mathrm{A}_{\mathrm{s}}{ }^{\prime}}{\mathrm{bh}_{\mathrm{c}}}}$ (para seções T com LN abaixo da mesa de compressão)

onde:

$\delta_{\text {diferida }}:$ deslocamento vertical diferida dada por $\left(\delta_{\text {diferida }}=\delta_{\text {imediata }} \cdot \lambda\right)$;

$\delta_{\text {imediata }}:$ deslocamento vertical inicial;

$\lambda \quad$ : parâmetro multiplicador das flechas;

$\varepsilon_{r} \quad$ : deformação por retração da peça 
$\varepsilon_{c 0} \quad$ : média da deformação máxima inicial do concreto, estimada em $2 \times 10^{-4}$

$\phi \quad$ : coeficiente de fluência

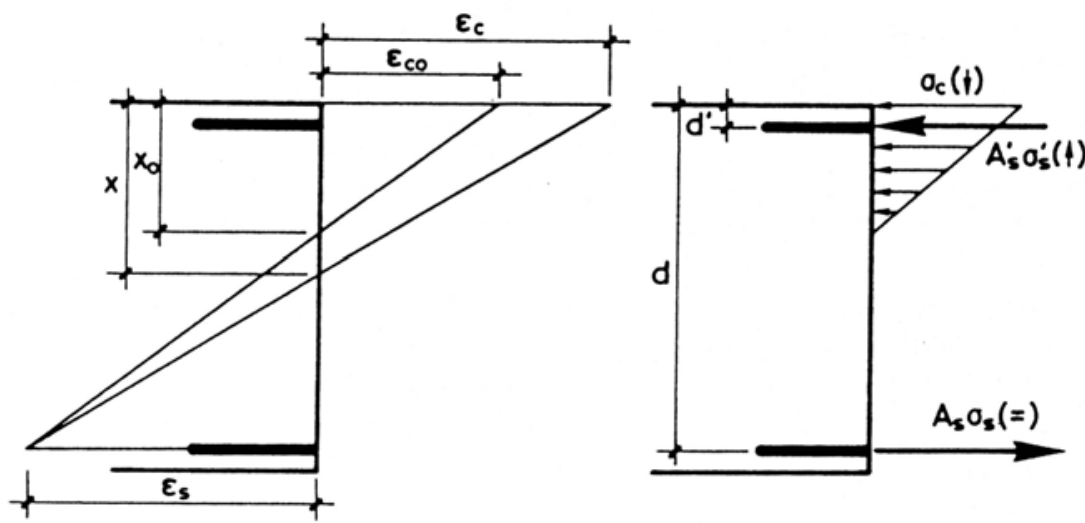

Viga de seção retangular

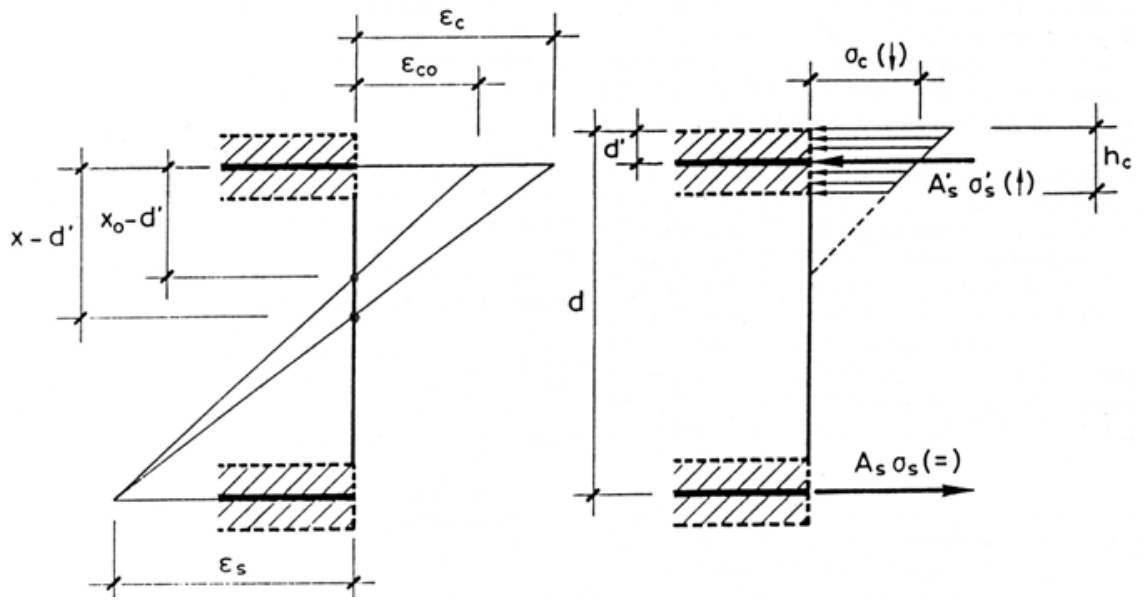

Viga de seção T

Figura 3.11- Comportamento de longa duração em vigas (MURCIA, 2000)

\subsubsection{Efeito da deformabilidade ao longo do tempo em peças fletidas compostas}

\subsubsection{Considerações gerais}

Conforme dito no item 3.2, para avaliar o comportamento de peças na qual a seção transversal é constituída por concretos moldados em idades distintas e que foram submetidas a carregamentos também em datas distintas, é preciso conhecer as descontinuidades existentes na distribuição das deformações e tensões ao longo da seção transversal do elemento. Estas descontinuidades, geradas porque os materiais 
constituintes da seção transversal possuem diferentes propriedades mecânicas e comportamentos viscoelásticos distintos, podem prejudicar o desempenho em serviço e até mesmo provocar uma redução na capacidade portante do elemento.

Quanto às propriedades mecânicas, convém ressaltar que mesmo quando se deseja que ambos os concretos tenham resistências e módulos de elasticidade próximos a longo prazo, sempre existirão diferenças de resistência iniciais entre o concreto antigo e o concreto novo, o que conduzirá a comportamentos diferentes quanto à retração e à fluência.

Quanto ao comportamento viscoelástico, no caso específico de estruturas reabilitadas por adição de concreto, normalmente o concreto do substrato, sendo antigo, já foi submetido a carregamentos que geraram deformações imediatas e diferidas, portanto apresentará fluência e retração bem menores que o material do reforço/reparo, uma vez que o material novo adicionado ainda não sofreu estes tipos de solicitações e acomodações. Isso provocará retração e fluência diferenciais entre os materiais, acentuando ainda mais as descontinuidades observadas nas tensões e deformações ao longo da seção transversal.

Para analisar o efeito das deformações ao longo do tempo geradas pela fluência e pela retração em vigas compostas simplesmente apoiadas deve-se avaliar duas situações: peça descarregada e peça carregada (Figura 3.12).

Quando não há carregamento, a retração do concreto adicionado gera tensões de compressão na parte superior do substrato do elemento composto. Em contrapartida, o concreto adicionado fica sujeito a tensões de tração devidas à restrição de seu movimento. Analisando os esforços internos no concreto adicionado, percebe-se que a deformação por fluência é oposta à deformação por retração gerada pelos esforços internos de tração. Portanto o efeito da fluência tende a reduzir os esforços de retração (EL DEBS, 2000).

Quando há carregamento atuante no elemento composto, se a capa de concreto é acrescentada ao bordo superior, os efeitos da retração e fluência se superpõem, pois neste material atuam esforços de compressão. Se a capa de concreto é acrescentada ao bordo inferior, os efeitos da retração e fluência são opostos - pois a fluência ocorre devido aos esforços de tração - proporcionando um efeito benéfico já que a deformação diferencial na junta fica minimizada. 
As deformações devidas à retração diferencial em vigas compostas podem provocar ainda um aumento das flechas porque a capa de concreto adicionada tende a se encurtar, aumentando conseqüentemente a curvatura da peça (Figura 3.13). Entretanto não há normas específicas que forneçam uma formulação para prever tais flechas.

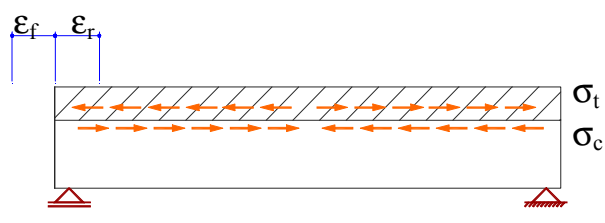

a) viga descarregada

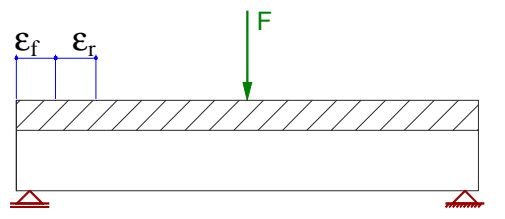

b) viga carregada - reforço no bordo comprimido
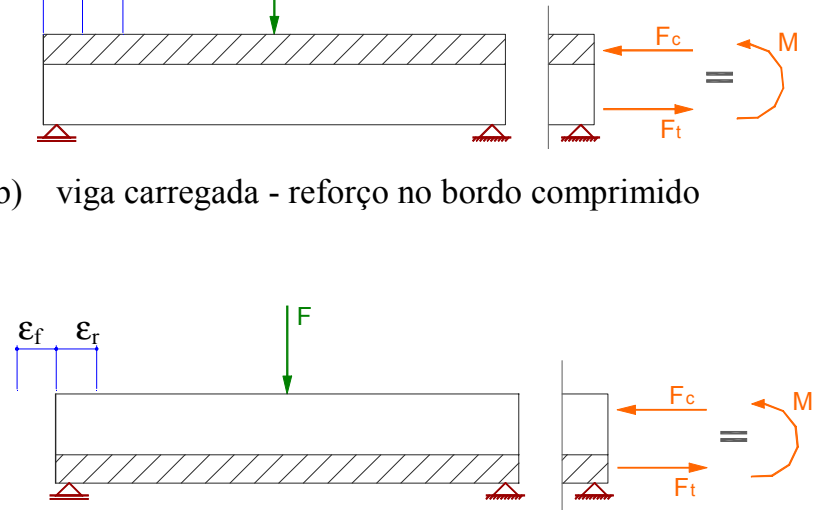

c) viga carregada - reforço no bordo tracionado

\section{Legenda:}

$\varepsilon_{\mathrm{r}}:$ deformação por retração;

$\varepsilon_{\mathrm{f}}:$ deformação por fluência;

$\sigma_{\mathrm{t}}$ : tensão de tração na capa de concreto devido à restrição da retração

$\sigma_{\mathrm{c}}:$ tensão de compressão no substrato devido à restrição da retração

$\mathrm{F}$ : força externa aplicada;

$F_{t}$ : esforços internos de tração gerado pela força $\mathrm{F}$

$\mathrm{F}_{\mathrm{c}}$ : esforços internos de compressão gerado pela força $F$

M : momento fletor gerado pela aplicação da força concentrada F.

Figura 3.12 - Deformações de retração e fluência em peças compostas

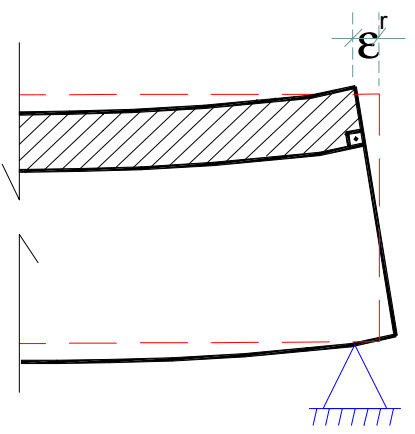

Figura 3.13 - Aumento da flecha devido à retração 
Dentre os poucos trabalhos encontrados sobre a avaliação do comportamento diferido em peças compostas devida à execução de uma reabilitação pode-se citar o trabalho desenvolvido por SILFWERBRAND (1997). Este autor desenvolveu uma metodologia para o cálculo das deformações normais, das tensões normais e das tensões de cisalhamento que surgem em vigas reabilitadas por adição de uma nova camada de concreto ao bordo comprimido, devidas exclusivamente ao efeito da retração diferencial existente entre o material adicionado e o substrato. O modelo analítico apresentado é baseado em uma relação linear entre o deslizamento e as tensões tangenciais de cisalhamento na interface, e contempla situações de deslizamento total e de aderência parcial ou total. Além disso, o modelo também consegue contabilizar o efeito da existência de uma armadura longitudinal disposta no material do reforço. O modelo apresentado é especialmente útil na análise de pavimentos de concreto e tabuleiros de concreto de pontes que precisam ter parte de sua seção reconstituída devido a algum tipo de deterioração.

Para verificar se o modelo analítico proposto fornecia resultados adequados, desenvolveu-se um programa experimental no qual se comparava o comportamento teórico com o comportamento real observado em dois ensaios de vigas biapoiadas reabilitadas por intervenção no bordo comprimido cujo substrato possuía idade superior a três anos (ver Figura 3.14).

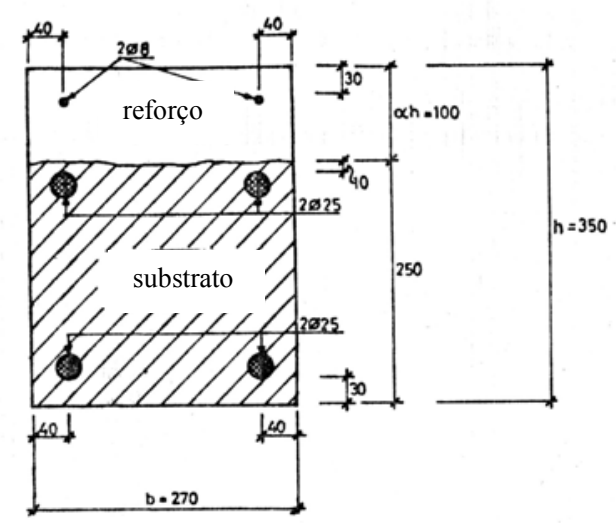

Obs.:Unidades em mm.

\section{Figura 3.14 - Seção das vigas ensaiadas por SILFWERBRAND (1997)}

Para isolar o efeito da retração diferencial no comportamento das vigas ensaiadas, estas foram apoiadas de maneira contínua ao longo de todo comprimento para que seu peso próprio fosse transferido diretamente para a fundação, não gerando 
tensões no elemento. Tais vigas foram armazenadas em ambiente protegido por 14 meses e as deformações foram monitoradas periodicamente.

Como o modelo proposto dependia das características viscoelásticas (coeficiente de fluência e deformação por retração livre) do material do reforço, estas propriedades foram obtidas experimentalmente por meio de ensaios específicos em prismas de concreto confeccionados com o material do reparo.

Os resultados obtidos mostraram que o modelo analítico proposto pode ser usado para estimar as tensões e as deformações existentes na capa de concreto adicionada ao bordo comprimido das vigas reabilitadas. Entretanto, como o método depende de um coeficiente de aderência entre as superfícies em contato, é preciso determinar com precisão este parâmetro. Contudo, nem sempre tal coeficiente é fácil de ser determinado, sendo necessário inclusive a realização de mais estudos a respeito de como a fluência do material do reparo pode alterar esta aderência.

Segundo vários pesquisadores, para evitar problemas de retração diferencial, na prática recomenda-se o uso de argamassa/concretos não retráteis ou até mesmo ligeiramente expansivos ao reabilitar um elemento mediante adição de concreto à sua seção transversal.

\subsubsection{Procedimento para cálculo das tensões e deformações ao longo do tempo em peças de seção composta}

Fazendo uma analogia com as vigas reforçadas pela técnica de reforço $\mathrm{n}^{\circ} 2$ (vigas tipo VFC) tem-se uma seção original representada apenas pelo concreto do substrato (parte 1) e uma seção final representada pelo substrato e pelo reforço (parte 2). A rigor, deve-se considerar o substrato como seção resistente não só quando ele trabalha isoladamente, mas também por alguns dias após a concretagem do reforço (parte 2), enquanto este novo concreto não possui resistência suficiente para contribuir na absorção dos esforços. Vale ressaltar que quando se concreta o reforço, o acréscimo de carga permanente é resistido somente pelo substrato.

Antes de iniciar o cálculo das tensões e deformações da seção após o reforço, deve-se conhecer as tensões e deformações finais atuantes na seção original, já considerando os efeitos da retração e da fluência. Após a concretagem do reforço é interessante calcular as tensões e deformações para uma etapa iniciando em j dias 
(com $\mathrm{j}<28$ dias, sendo $\mathrm{j}$ uma idade convencional de cura do reforço) e terminando em 28 dias, a fim de considerar a variação do módulo de elasticidade do concreto do reforço neste intervalo de tempo. No início dessa etapa o concreto do reforço possuirá tensões iniciais nulas, e ao final da etapa de duração 28 -j dias, o concreto do reforço já terá tensões oriundas do comportamento viscoelástico ocorridas neste período. Em seguida pode-se processar outra etapa, iniciando aos 28 dias e terminando na idade do carregamento seguinte ou na idade final do ensaio, considerando o módulo de elasticidade $\mathrm{E}_{\mathrm{c}}$ do reforço como constante referente ao valor do módulo aos 28 dias.

Para avaliar a distribuição de tensões e deformações ao longo de uma seção transversal composta fissurada, parte-se do princípio da igualdade das deformações na interface entre a parte 1 (substrato) e a parte 2 (reforço), obtendo-se as equações 3.88 e 3.89. Desta forma, percebe-se que as tensões na seção composta oriundas de qualquer carga adicional se faz de modo proporcional ao valor de $\alpha_{\mathrm{c}}$. A Figura 3.15 ilustra a distribuição das tensões e deformações ao longo da seção transversal de uma peça composta.

$$
\begin{aligned}
& \varepsilon_{1}=\varepsilon_{2} \rightarrow \sigma_{\mathrm{cb} 2}=\alpha_{\mathrm{c}} \sigma_{\mathrm{cb} 1} \\
& \alpha_{\mathrm{c}}=\frac{\mathrm{E}_{\mathrm{c} 2}}{\mathrm{E}_{\mathrm{c} 1}}
\end{aligned}
$$

onde:

$\alpha_{c}$ : relação entre os módulos de elasticidade dos concretos;

$\varepsilon_{\mathrm{i}}$ : deformação no concreto da parte i;

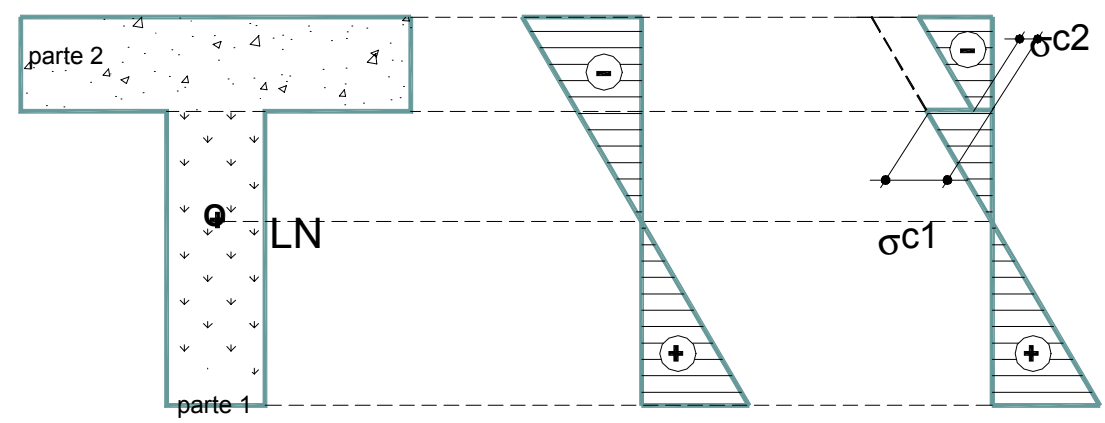

Figura 3.15 - Distribuição das tensões e deformações em uma seção composta considerando as diferenças dos módulos de elasticidade 


\subsection{Comportamento de vigas carregadas com trechos da armadura longitudinal tracionada exposta}

É comum se ter situações em que é preciso demolir trechos de vigas de concreto armado para executar um reparo e/ou reforço estrutural. Neste caso normalmente se recomenda descarregar a viga pelo uso de apoios temporários. Entretanto, este procedimento eleva bastante os custos da intervenção. Diante disso vários pesquisadores - dentre eles EYRE \& NOKHASTEH (1992) e CAIRNS \& ZHAO (1993) - estudaram o comportamento de vigas de concreto armado que possuem trechos de sua armadura tracionada expostos durante os trabalhos de reforço/reparo sem serem totalmente descarregadas.

\subsubsection{Considerações adotadas na análise do comportamento}

Quando se tem vigas com trechos de sua armadura tracionada exposta durante um processo de reparo/reforço, a seção transversal não age mais como um material compósito formado por aço e concreto, pois não existe compatibilidade de deformação entre estes materiais nesta região. Portanto, não vale mais a hipótese de que a seção plana permanece plana e a configuração das deformações na viga carregada se diferencia da de uma peça monolítica.

Alguns pesquisadores afirmam que o comportamento estrutural deste tipo de viga é semelhante ao de vigas de concreto protendido com cordoalhas não aderentes (comportamento de arco atirantado). Todavia, CAIRNS \& ZHAO salientam que apesar das semelhanças existentes entre estes dois tipos de estrutura, também existem diferenças importantes que devem ser consideradas e que tornam a extrapolação de resultados inadequada tais como:

- Em vigas protendidas com cordoalha não aderente, a ancoragem do cabo está em um ponto bem definido. O mesmo não ocorre nas vigas de concreto armado, pois a ancoragem se dá por aderência; 
○ Nas peças protendidas, as cordoalhas não aderentes geralmente ficam dentro da altura da seção transversal. Já nas vigas de concreto armado considera-se que as barras expostas ficam em um local fora da seção transversal (representada pela seção em que existe concreto);

- A hipótese de que as cordoalhas protendidas (aços de elevada resistência) são tracionadas até no máximo $70 \%$ de sua resistência característica não pode ser adotada para armaduras usadas em elementos de concreto armado (aços de baixa resistência).

Para analisar o comportamento de vigas com trechos de armadura tracionada exposta, CAIRNS \& ZHAO partiram do princípio de que se deveria inicialmente satisfazer às equações de equilíbrio de forças e de momentos e, posteriormente, adotar um estado de compatibilidade de deformações coerente, em função da existência ou não de aderência entre o aço e o concreto. Utilizando o esquema estático de uma viga biapoiada submetida a duas forças concentradas aplicadas simetricamente em relação ao vão, tais autores sugerem que a distribuição de tensão e deformação na seção transversal, ao longo de vigas com armadura exposta seja semelhante ao apresentado na Figura 3.16.

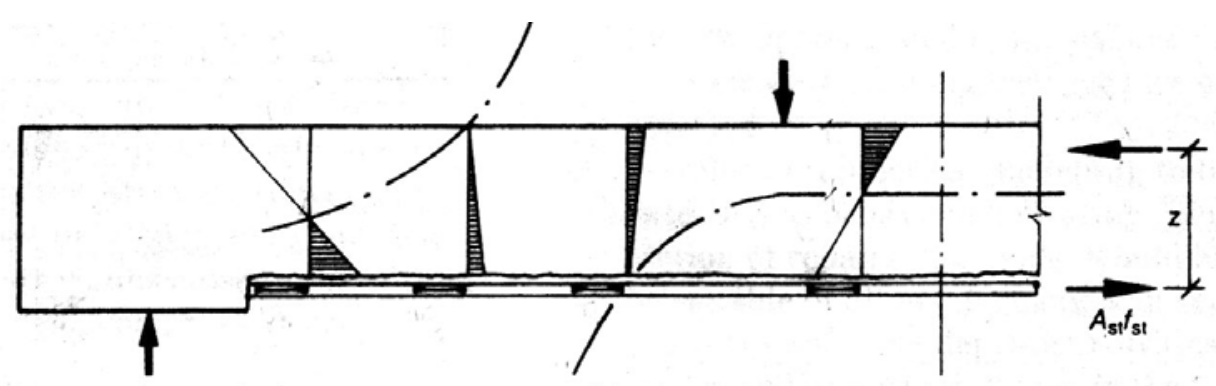

(b)

(a) Distribuição de $\underline{\text { tensões }}$ ao longo de uma viga com armadura tracionada

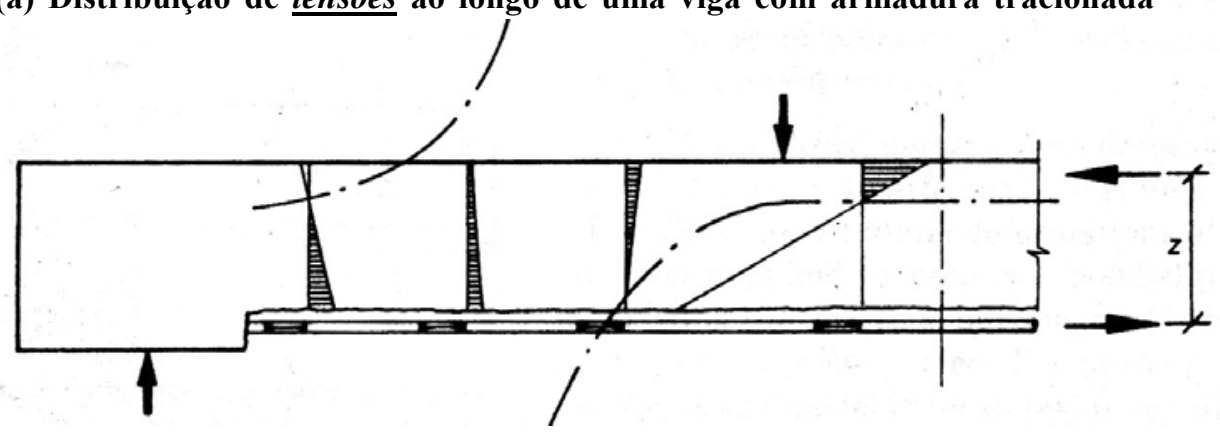

(b) Distribuição de deformaç̃oes ao longo de uma viga com armadura tracionada

Figura 3.16 - Comportamento de viga com trechos de armadura exposta 
O grau de influência da armadura exposta no comportamento da viga depende de seu comprimento de exposição. Como é evidente que o aumento no comprimento de exposição da barra provoca um aumento da deformação de compressão máxima

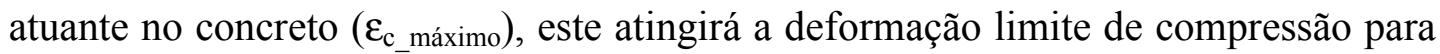
ações externas menores. A probabilidade disso afetar a capacidade portante da viga dependerá do fato da armadura tracionada escoar ou não antes do início do esmagamento do concreto, que dependerá, por sua vez, da taxa de armadura longitudinal da peça. Quando se tem uma viga dimensionada para romper no domínio 3, provavelmente esta peça irá se tornar superarmada para pequenos comprimentos de armadura exposta. Já para vigas subarmadas, provavelmente a armadura escoará antes da plastificação do concreto mesmo tendo barras expostas com comprimentos mais significativos.

Dificilmente ocorrerá a ruptura por cisalhamento dentro do vão em que as barras longitudinais estão expostas, pois as forças verticais são transmitidas diretamente ao apoio por meio de bielas de compressão inclinadas que surgem dentro do vão de cisalhamento (efeito de arco), e não mais por tensões de cisalhamento (esquema de treliça). Entretanto, se a altura de demolição do concreto da viga tiver sido muito grande fazendo com que as bielas de compressão fiquem situadas muito próximas da face inferior do concreto remanescente, pode ocorrer uma ruptura por esmagamento do concreto nas proximidades da extremidade final do comprimento de exposição da barra (ver Figura 3.17). Também fica claro que a ancoragem da armadura tracionada exposta fica prejudicada podendo ocorrer ruptura por falha de ancoragem.

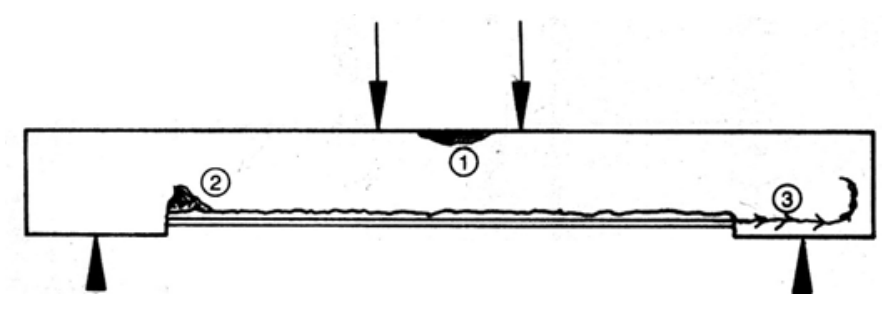

Legenda:

1 - Ruptura por esmagamento do concreto no bordo mais comprimido;

2 - Ruptura por esmagamento do concreto na extremidade do trecho com armadura exposta;

3 - Ruptura por falhas de ancoragem;

Figura 3.17- Tipos de ruptura em vigas com armadura tracionada exposta 


\subsubsection{Estudos realizados por outros pesquisadores}

EYRE \& NOKHASTEH (1992) descreveram um modelo matemático para avaliar o tamanho máximo do comprimento de exposição das barras de aço tracionadas a partir do qual a viga não tem sua capacidade portante reduzida. No desenvolvimento deste modelo adotou-se relações constitutivas simplificadas para os materiais e baseou-se no comportamento de elementos de concreto protendido usando cordoalhas não aderentes obtendo-se uma equação que relacionava a capacidade de resistência do elemento com o comprimento de armadura tracionada exposta. Entretanto, tal modelo dependia da solução de várias integrais que só poderiam ser determinadas por processo iterativo usando algum tipo de procedimento numérico. Para identificar os parâmetros que afetavam a capacidade portante das vigas com armadura tracionada exposta, os autores montaram dois ábacos específicos para uma viga biapoiada de seção retangular com carga concentrada aplicada no meio do vão ou com carga uniformemente distribuída. Pela análise destes ábacos constatou-se que as reduções na capacidade portante de vigas com armadura exposta dependiam principalmente de três fatores:

a) do comprimento de ancoragem;

b) da taxa de armadura tracionada;

A redução da capacidade portante em vigas subarmadas foi bem menor que a observada em vigas superarmadas.

c) da maneira de aplicação do carregamento.

a redução na capacidade portante é menor para carregamento uniformemente distribuído do que quando se tem uma força concentrada aplicada no meio do vão da viga.

Entretanto EYRE \& NOKHASTEH ressaltaram que o modelo matemático desenvolvido simplificava demasiadamente o comportamento dos materiais, sendo necessário realizar mais pesquisas sobre o assunto, principalmente aquelas direcionadas à modelagem destas peças usando o Método dos Elementos Finitos (MEF).

Complementando o estudo anterior, CAIRNS \& ZHAO desenvolveram um modelo numérico, baseada no MEF, para simular o comportamento de vigas carregadas com armadura exposta. Os resultados finais obtidos por tal formulação 
foram comparados com os resultados experimentais de 19 vigas biapoiadas submetidas a duas forças concentradas aplicadas simetricamente em relação ao apoio.

Para um mesmo valor de carregamento, o esquema de fissuração das vigas inicialmente carregadas com a armadura exposta foi diferente do esquema de fissuração observado nas vigas monolíticas. A Figura 3.18 ilustra as diferenças de fissuração de vigas com e sem barras tracionadas expostas.

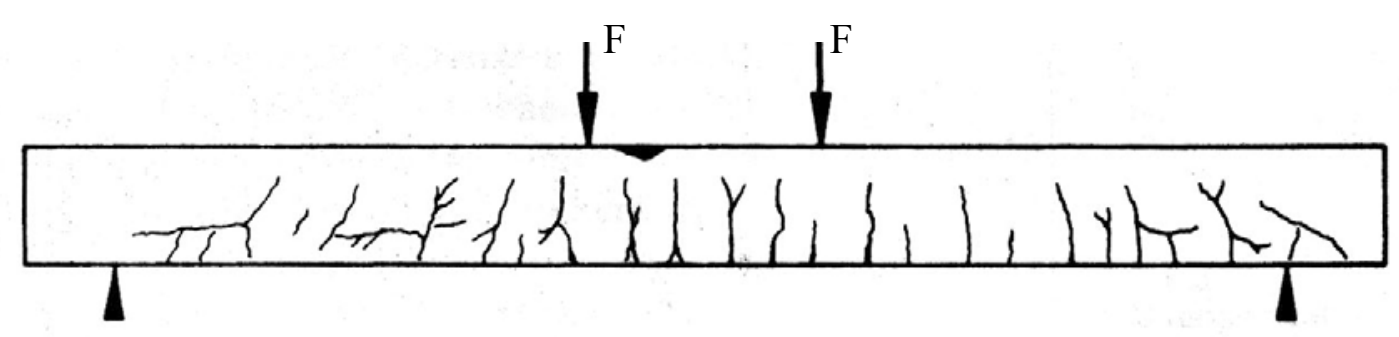

(a) Esquema de fissuração para uma peça sem armadura exposta

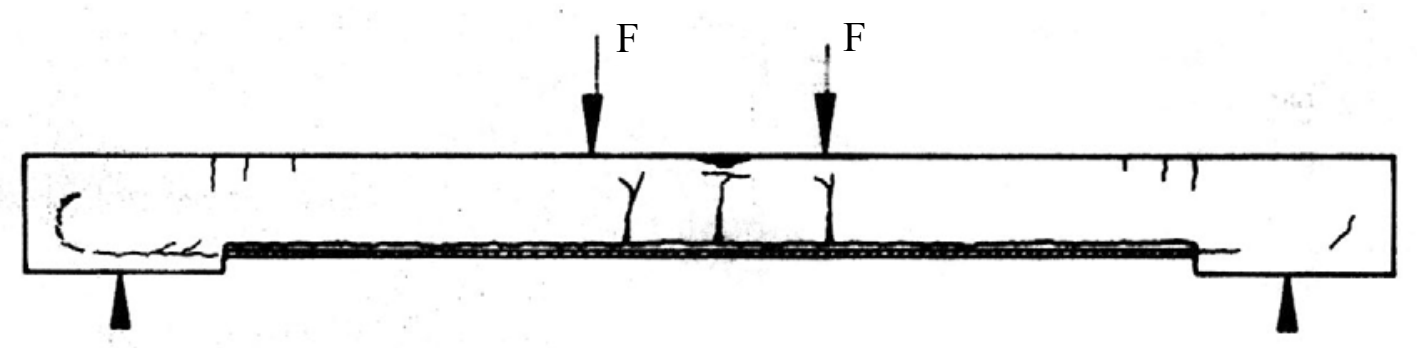

(b) Esquema de fissuração para uma peça com armadura exposta

\section{Figura 3.18 - Esquema de fissuração para vigas com e sem barras de aço expostas}

As principais diferenças observadas foram:

- maior espaçamento de fissuras dentro da região de momento constante;

- maior abertura das fissuras;

- bifurcação no topo das fissuras de flexão;

- ausência de fissuras na face tracionada fora da zona de momento constante;

- desenvolvimento de fissuras de flexão próximo das extremidades dos trechos com armadura exposta na face "comprimida" da viga;

- Fissuras de fendilhamento (bond splitting cracks) geradas por falha de ancoragem devido à redução do trecho de aderência da armadura tracionada ao concreto. 
Nas vigas com armadura exposta, o aparecimento de fissuras na região de flexão pura (entre pontos de aplicação das forças verticais) foi súbito e se iniciou para um carregamento bastante baixo, atingindo o comprimento total observado na peça quase que instantaneamente. A bifurcação das fissuras de flexão ocorreu porque ao se atingir um comprimento igual à altura da posição da $\mathrm{LN}$, elas não puderam mais aumentar verticalmente tendendo então a se propagar horizontalmente.

Em virtude da diferença de fissuração observada nestas vigas, CAIRNS \& ZHAO optaram por inicialmente pré-fissurar as vigas ensaiadas antes de se expor os trechos da armadura tracionada, pois o fato de já existirem fissuras com espaçamentos e configurações parecidas com as de uma viga de seção íntegra fez com que as novas fissuras, geradas durante a aplicação do carregamento na viga após a exposição de sua armadura, não fossem tão críticas principalmente em relação ao tamanho da abertura. Analisando os resultados experimentais e as simulações numéricas CAIRNS \& ZHAO concluíram que:

- A configuração das tensões e deformações de uma viga de concreto armado se modifica quando se tem armadura exposta em uma região de flexão simples (momento e esforço cortante atuando) de maneira semelhante ao idealizado na Figura 3.16.

- Dependendo das características da viga, nem sempre a capacidade portante é muito afetada pela exposição de parte da armadura tracionada.

- O fato de parte das barras tracionadas estarem expostas não provoca ruptura por cisalhamento na seção em função do efeito arco mobilizado. Entretanto, aumenta-se o risco de ruptura por falha de ancoragem nos locais em que as barras de aço tracionadas passam a ficar novamente aderidas ao concreto.

- Pode ocorrer uma ruptura por compressão do concreto quando o trecho final da armadura exposta está muito próximo do apoio da viga.

- Os principais parâmetros que afetam o desempenho de vigas pré-carregadas com armadura exposta são:

○ Comprimento de exposição da barra;

○ Local, em relação ao vão da viga, em que está o trecho com a armadura exposta;

○ Taxa de armadura longitudinal na seção da viga analisada; 
○ Resistência do concreto, da armadura e da aderência entre estes materiais;

- Tipo de carregamento aplicado;

○ Força resultante interna atuante no concreto comprimido da seção transversal;

- O modelo numérico desenvolvido forneceu resultados similares aos dos ensaios experimentais das vigas indicando que é viável sua utilização na determinação do comportamento de elementos fletidos solicitados com trechos de armadura tracionada expostos. Entretanto, ainda há carência de pesquisas sobre o comportamento estrutural de tais peças para se ter uma maior confiabilidade no procedimento de análise adotado.

\subsection{Simulação Numérica - Análise teórica das vigas reforçadas}

\subsubsection{O Programa CONSNOU}

Para avaliar o comportamento das vigas reforçadas no bordo tracionado (VFT) e no bordo comprimido (VFC) fez-se uma análise teórica utilizando o programa computacional CONSNOU, baseado no Método dos Elementos Finitos. Tal programa foi desenvolvido em linguagem de programação FORTRAN, a partir de pesquisas realizadas sob orientação do Prof. Antonio R. Marí Bernat do Departamento de Engenharia da Universidade Politécnica da Catalunha, situada em Barcelona - Espanha.

\section{> Campo de aplicação}

Esse programa foi desenvolvido especificamente para simular o comportamento de pórticos planos ou espaciais, de concreto armado ou concreto protendido (com cordoalhas aderentes), construídos em várias etapas. Sendo assim, permite simular as diferenças de comportamento e descontinuidades geradas em função da modificação do esquema estrutural ou das dimensões da seção transversal do elemento em função do processo evolutivo da construção ao longo do tempo. Por exemplo: concretagem de parte do elemento estrutural em diferentes datas, simulação de rótulas que podem ser bloqueadas durante o processo de construção, protensão e 
desprotensão de cabos e tirantes, instalação ou eliminação de escoramentos ou outros tipos de apoios provisórios durante o uso da estrutura, entre outras opções.

O programa permite simular o comportamento viscoelástico dos materiais causados pela retração e fluência do concreto e sua interação com o aço (passivo ou ativo) ou outros concretos que tenham diferentes idades de moldagem e aplicação de carregamento. Desta maneira consegue-se contabilizar os efeitos ao longo do tempo tais como: redistribuições de esforços no esquema estrutural adotado, redistribuições de tensões e deformações na seção transversal e o incremento diferido de flechas entre outros. Além disso o programa possibilita avaliar os efeitos da não linearidade física, pois adota curvas tensão-deformação mais realista para os materiais, e também os efeitos da não linearidade geométrica na estrutura.

\section{> Aplicacão das acõos}

Todas as ações diretas devem ser aplicadas sobre os nós da estrutura em instantes precisos, denominados passos de carga. Esse passo de carga pode ser dividido em vários incrementos conforme necessidade do usuário. O programa permite ainda a aplicação de ações indiretas, tais como deslocamentos impostos nos apoios, deformações impostas devidas à variação térmica, à retração do concreto ou à pré-deformação da armadura.

\section{$>$ Esquema de modelagem da estrutura}

Quanto à modelagem, a estrutura deve ser discretizada longitudinalmente por elementos finitos Hermitianos tipo barra com três nós, com seção constante e forma arbitrária (ver Figura 3.19). Este elemento finito possui treze graus de liberdade sendo doze nos nós extremos e um no centro (que se elimina por condensação estática), necessário para obter a matriz de rigidez à flexão e considerar a variação da linha neutra por fissuração. 


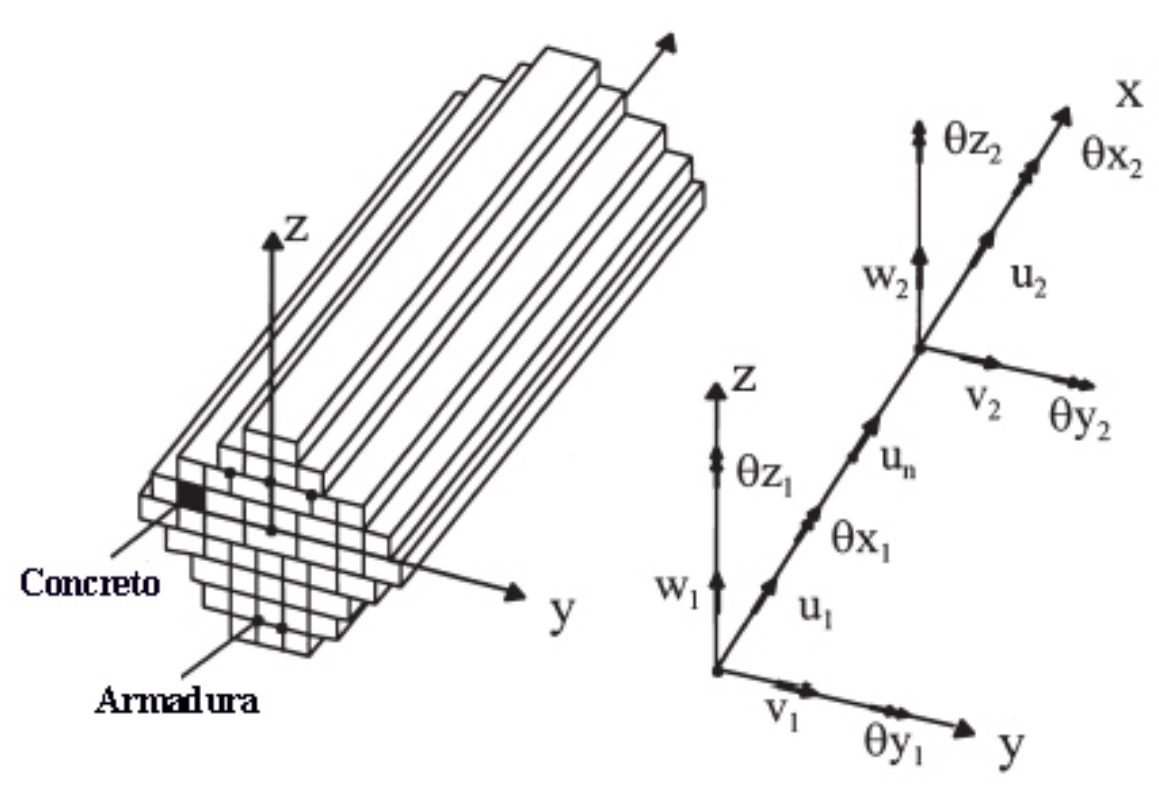

Figura 3.19 - Elemento finito de barra utilizado no programa CONSNOU

Para modelar a seção transversal da estrutura supõe-se que cada elemento componente da estrutura seja um prisma cuja seção transversal de concreto é um sólido discretizado em filamentos. As características geométricas da seção resultam da integração das áreas dos filamentos que a compõem, sendo que, quando algum destes filamentos não existe (seja por ainda não ter sido construído ou por ter sido fissurado) a contribuição de sua área diferencial será zero. Isto permite considerar o aparecimento ou desaparecimento de filamentos segundo exigências do processo construtivo, e considerar para cada um deles a equação constitutiva que lhe corresponde.

\section{> Aplicação das vinculações}

As condições de contorno se reproduzem mediante a indicação de nós de apoio (vínculos externos), que controlam as rotações e os deslocamentos da estrutura em função das rigidezes fornecidas para os seis graus de liberdade deste nó pelo usuário. Tal vinculação pode variar ao longo do tempo, permitindo que se reproduzam os processos de cimbramento, descimbramento, execução de novos apoios e/ou eliminação dos existentes. 


\section{$>$ Comportamento ao longo da seção transversal - hipóteses adotadas}

a) Deformação plana - como a estrutura é discretizada utilizando elementos finitos tipo barra adotou-se a Hipótese de Bernoulli, ou seja, o princípio de que a seção plana permanece plana, tanto para deformações mecânicas quanto não mecânicas.

b) Aderência perfeita - adotou-se que os incrementos na deformação total de um ponto são iguais para qualquer material (aço ou concreto) que se encontre nele. Isto significa que na interface entre dois materiais diferentes há compatibilidade de deformação para ambos, o que equivale a considerar que existe aderência perfeita entre aço e concreto ou entre concretos moldados em idades diferentes.

\section{$>$ Comportamento pontual - hipóteses adotadas}

a) Equação constitutiva do concreto - admite-se que o concreto esteja submetido a um estado uniaxial de tensões normais cuja equação constitutiva seja dada pelo gráfico apresentado na Figura 3.20. Por este gráfico é possível determinar a tensão do concreto, $\sigma_{\mathrm{c}}$, a partir da deformação mecânica, $\varepsilon^{\mathrm{m}}$, e do módulo de elasticidade, $\mathrm{E}_{\mathrm{c}}$, do material no instante analisado. A equação constitutiva adotada não considera a contribuição do concreto tracionado entre fissuras.

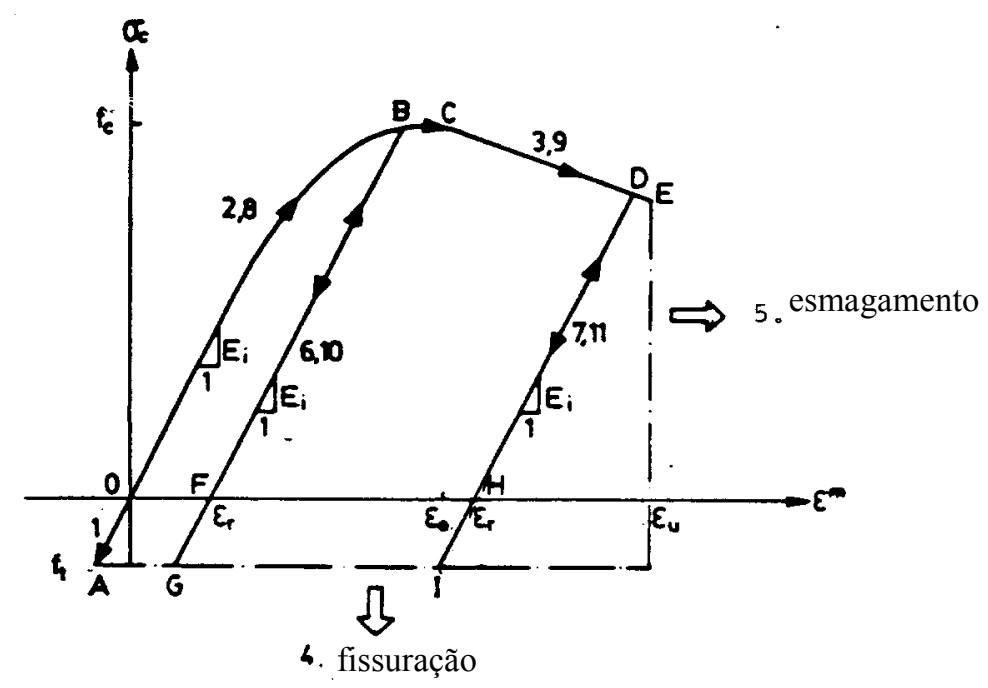

Figura 3.20 - Equação constitutiva do concreto adotada pelo CONSNOU 
b) Equação constitutiva da armadura passiva - como as propriedades mecânicas da armadura passiva não dependem do tempo e das condições ambientais (umidade e temperatura), adotou-se uma equação constitutiva obtida a partir de um diagrama bilinear simétrico em relação à origem e que permanecia constante ao longo do tempo (ver Figura 3.21).

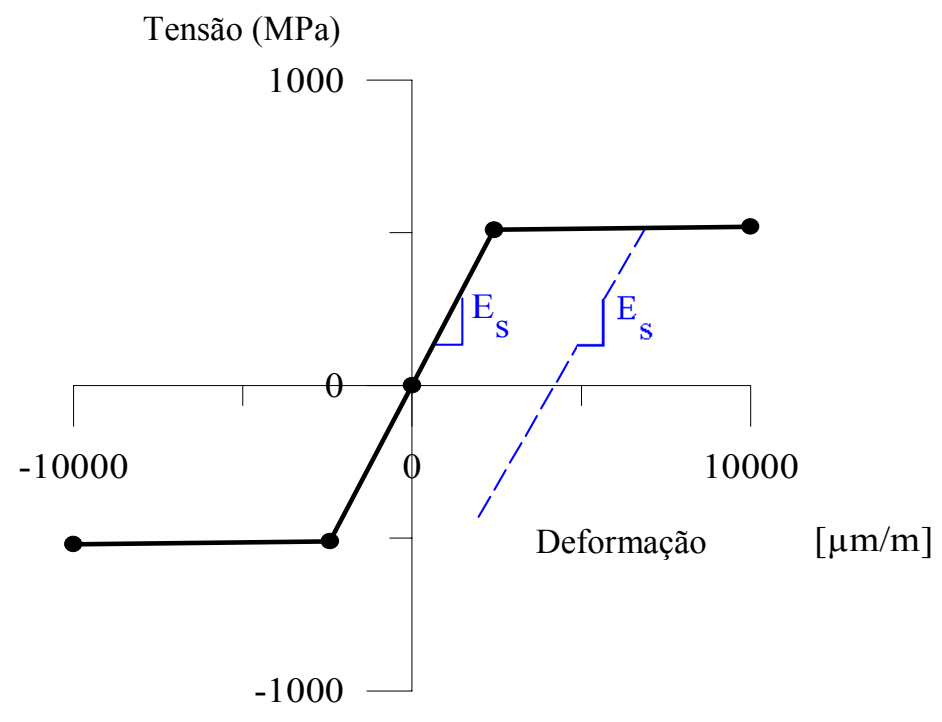

Figura 3.21 - Equação constitutiva da armadura passiva

c) Evolução da deformação e da tensão - a deformação uniaxial total em um ponto da estrutura no instante $t_{n}$ é determinada somando-se respectivamente as parcelas da deformação mecânica e não mecânica $\left(\varepsilon_{n}{ }^{\text {total }}=\varepsilon_{n}{ }^{m}+\varepsilon_{n}{ }^{n . m .}\right)$. A partir daí, determina-se a tensão em um ponto, referente ao mesmo passo de tempo $t_{n}$, calculando-se:

c.1) a deformação total no instante $t_{n}$ por: $\varepsilon_{n}=\varepsilon_{n-1}+\Delta \varepsilon_{n}$

c.2) o incremento de deformação não mecânica entre os passos de tempo $t_{n-1} \mathrm{e} t_{n}$.

$$
\begin{array}{ll}
\varepsilon_{c}^{n m}=\varepsilon_{c c}+\varepsilon_{c s}+\varepsilon_{c T}+\varepsilon_{c a} & \\
\varepsilon_{s}^{n m}=\varepsilon_{s T} & \text { (para o concreto) }
\end{array}
$$

c.3) a deformação não mecânica total em $t_{n}$ somando o incremento neste intervalo com a deformação não mecânica total do passo de tempo anterior.

$$
\varepsilon_{n}^{n m}=\varepsilon_{n-1}^{n m}+\Delta \varepsilon_{n}^{n m}
$$


c.4) a deformação mecânica subtraindo a deformação total da parcela não mecânica.

$$
\varepsilon_{n}^{m}=\varepsilon_{n}^{\text {total }}-\varepsilon_{n}{ }^{n m}
$$

c.5) a tensão no ponto desejado em função da deformação mecânica obtida por:

$$
\sigma_{n}=f\left(\varepsilon_{n}^{m}\right)=f\left(\varepsilon_{n}^{\text {total }}-\varepsilon_{n}^{n m}\right)
$$

onde:

$\varepsilon_{n}^{m} \quad$ Deformação uniaxial mecânica de um ponto no instante $\mathrm{t}_{\mathrm{n}}$;

$\varepsilon_{n}^{n . m}$ Deformação uniaxial não mecânica de um ponto no instante $\mathrm{t}_{\mathrm{n}}$;

$\varepsilon_{n-1}$ Deformação total no instante $\mathrm{t}_{\mathrm{n}-1}$;

$\Delta \varepsilon_{n}$ Incremento de deformação total no intervalo entre $\mathrm{t}_{\mathrm{n}-1}$ e $\mathrm{t}_{\mathrm{n}}$;

$\varepsilon_{c c} \quad$ Incremento de deformação por fluência do concreto no intervalo entre $\mathrm{t}_{\mathrm{n}-1}$ e $\mathrm{t}_{\mathrm{n}}$;

$\varepsilon_{c s}$ Incremento de deformação por retração do concreto no intervalo entre $\mathrm{t}_{\mathrm{n}-1}$ e $\mathrm{t}_{\mathrm{n}}$;

$\varepsilon_{c T}$ Incremento de deformação por variação de temperatura no intervalo entre $\mathrm{t}_{\mathrm{n}-1} \mathrm{et}_{\mathrm{n}}$;

$\varepsilon_{c a} \quad$ Incremento de deformação por envelhecimento do concreto no intervalo entre $\mathrm{t}_{\mathrm{n}-1}$ e $\mathrm{t}_{\mathrm{n}}$;

$\varepsilon_{s T} \quad$ Incremento de deformação no aço por variação de temperatura;

$\varepsilon_{n-1}^{n m}$ Deformação não mecânica acumulada até o instante $\mathrm{t}_{\mathrm{n}-1}$;

$\Delta \varepsilon_{n}^{n m}$ Incremento de deformação não mecânica no intervalo entre $\mathrm{t}_{\mathrm{n}-1} \mathrm{e} \mathrm{t}_{\mathrm{n}}$;

d) Comportamento diferido do concreto - a deformação dependente das tensões no concreto é determinada pela expressão 3.44, uma vez que se adota a linearidade entre tensões e deformações ao longo do tempo e, conseqüentemente, o princípio da superposição de efeitos. Para solucionar a integral existente nesta expressão sem ser necessário conhecer a história de tensões atuantes na estrutura ao longo do tempo, adotou-se um método de cálculo que utiliza uma função fluência simplificada baseada na Teoria da Hereditariedade (ver item 3.4.3.1). Essa função fluência foi desenvolvida em forma de série de Dirichlet, conforme equação 3.90. Os parâmetros usados nesta equação são obtidos automaticamente pelo programa CONSNOU mediante um ajuste, pelo processo dos mínimos quadrados, da curva da fluência adotada. Essa curva, obtida através das recomendações do CEB-FIP Model Code 90, é determinada automaticamente, sendo necessário para isso fornecer apenas alguns dados específicos durante a montagem do arquivo de dados da estrutura analisada tais como: condições ambientais (temperatura e umidade) e espessura fictícia da peça. Desta maneira, utilizando um método 
iterativo combinado com a série Dirichlet, consegue-se que cada novo incremento de deformação diferida dependa somente da tensão e de algumas outras variáveis correspondentes ao último incremento de tempo, não sendo necessário conhecer toda a história de tensão atuante na estrutura ao longo do tempo.

$$
c(t, t-\tau)=\sum_{i=1}^{m} a_{i}(\tau)\left|1-e^{-\lambda_{i} \phi(T)(t-\tau)}\right|
$$

onde:

$a_{i}(\tau)$ - Parâmetrodependente da idade de carregamento que influencia na deformação diferida final;

$\lambda_{\mathrm{i}} \quad$ - Constante que regula a evolução da fluência, adotada comosendo $\lambda_{\mathrm{i}}=10^{-i}$;

$\phi(T)$ - Função da temperatura que no programa é adotado constante e igual à unidade;

$t-\tau$ - Duração do carregamento aplicado;

\section{Procedimentos para realização da análise estrutural}

\section{a) Análise não linear}

Adotou-se um processo incremental iterativo no qual a ação externa total se divide em incrementos e, em cada um destes incrementos se faz a iteração até atingir as condições de equilíbrio. Como o processo adotado é bastante conhecido do meio técnico e por este não ser o tópico principal de estudo deste trabalho, optou-se por não descrevê-lo detalhadamente aqui.

\section{b) Análise ao longo do tempo}

Os efeitos da fluência, da retração e do envelhecimento do concreto são avaliados usando os modelos propostos pelo CEB-FIP Model Code 90. 
Para realizar essa análise, considera-se que as ações são aplicadas somente nos passos de tempo, de maneira que a tensão em cada ponto da estrutura permaneça constante durante cada intervalo de tempo analisado. Caso seja aplicado um carregamento decrescente com o tempo, deve-se lembrar de considerar que o princípio da superposição subestima a recuperação da deformação por fluência nestes casos.

Para analisar os efeitos devido à fluência, admitiu-se que os filamentos que compõem a seção transversal estavam submetidos à tensão constante em cada incremento de tempo. Como a análise parte do princípio de que se conhece o estado de tensão, deformação e deslocamento do passo anterior, é possível determinar os incrementos de tensão, deformação e deslocamento do passo atual aplicando o princípio dos trabalhos virtuais. Esse processo permite que as deformações não mecânicas sejam transformadas em um sistema de forças externas fictícias equivalentes, que produz o mesmo estado de deformação no elemento. Devido ao efeito deste sistema de forças fictício, determinam-se os incrementos de deslocamento e deformação em cada ponto mediante uma análise estrutural e conseqüentemente as tensões em cada ponto da estrutura no instante de tempo $t_{n}$.

\subsubsection{Considerações sobre a simulação das vigas reforçadas VFT e VFC}

\section{Viga reforçada no bordo tracionado - VFT}

O programa CONSNOU admite sempre que as barras de aço estão envolvidas por concreto e que existe aderência perfeita entre estes materiais. Em função disso, não foi possível simular, de maneira ideal, o comportamento das vigas VFT submetidas a um pré-carregamento durante a execução do reforço e que possuíam trechos expostos da armadura longitudinal tracionada pré-existente.

Para avaliar o comportamento das vigas VFT foi preciso inicialmente simular o comportamento da viga VO monolítica (viga original antes da execução do reforço) por incremento de passo de carga até atingir o valor do pré-carregamento atuante. Nessa parte da simulação admitia-se que a armadura tracionada estava perfeitamente aderida ao concreto, ou seja, não se considerava o efeito da exposição 
da armadura tracionada na distribuição de tensões e deformações ao longo da seção. Finalizada esta etapa, informava-se ao programa a alteração da seção transversal original mediante acréscimo de uma outra camada de concreto com novas barras de aço referente ao reforço executado no bordo tracionado e prosseguia-se a simulação por incremento de passo de carga até a peça atingir a sua capacidade portante máxima. Observe que no caso da simulação numérica, a camada de concreto acrescentada ao bordo tracionado possuía espessura constante (ver Figura 3.23), diferentemente da espessura da camada de concreto adicionada nas vigas VFT ensaiadas no programa experimental, que era variável (ver Figura 5.1).

É importante esclarecer que no programa CONSNOU não se discretiza as armaduras transversais dos elementos estruturais Portanto, não é possível avaliar usando tal programa se ocorrerá ou não a ruptura por cisalhamento horizontal entre as barras de aço pré-existentes e adicionadas pela não utilização de estribos envolvendo-as, nem se ocorrerá ruptura na região da junta formada pela ligação entre concreto do reforço e substrato devido à falta de armadura de costura ou falhas de aderência entre os materiais (o programa considera aderência perfeita entre concreto do substrato e do reforço).

Apesar dessa não ser a situação real, acredita-se que a simulação numérica é válida, pois permite avaliar qualitativamente o comportamento da peça antes e após o reforço sob carregamento. Os resultados obtidos com tal simulação encontram-se no

\section{Capítulo 5.}




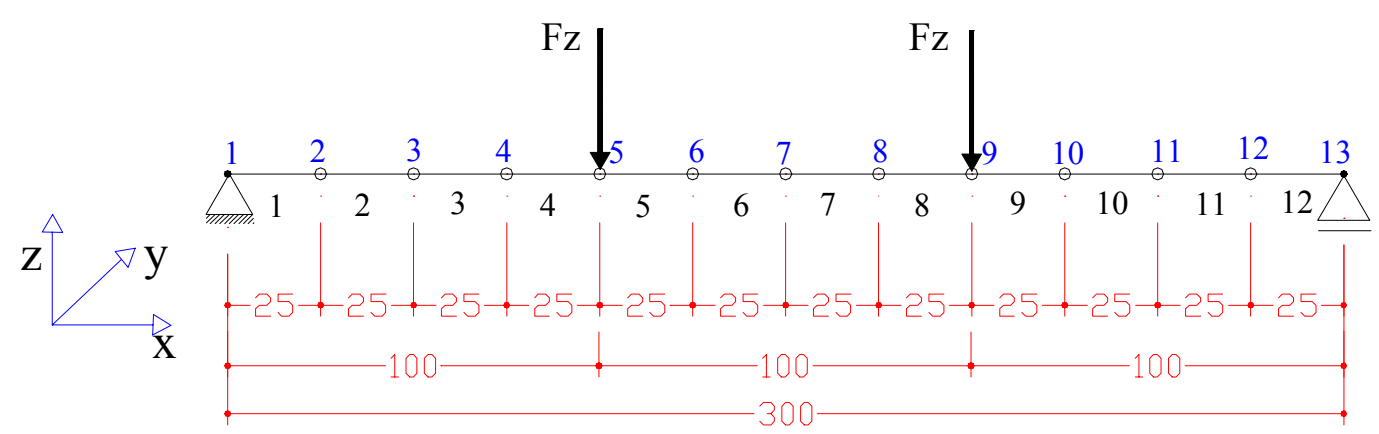

OBS.: a) Os números azul representam os nós e os números preto representam as barras;

b) Unidades: $\mathrm{cm}$

Figura 3.22 - Discretização longitudinal usada na simulação das vigas VFT

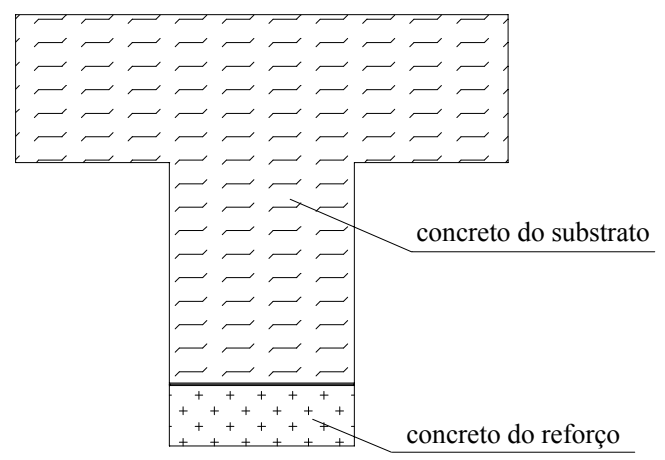

a) Tipos de concreto usado

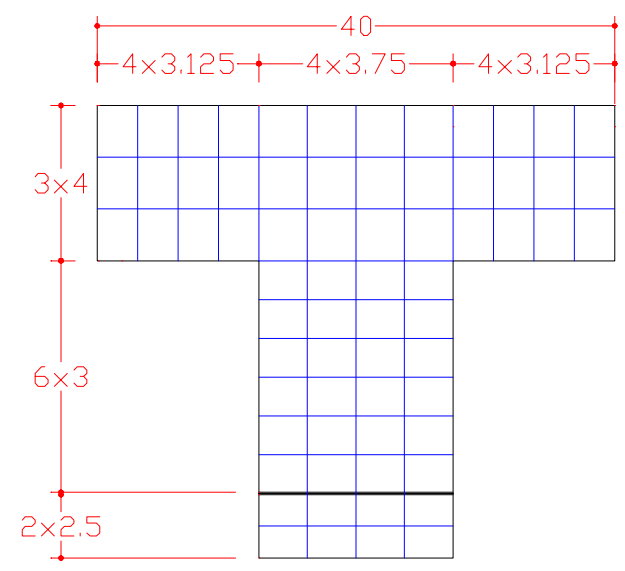

b) Posição dos filetes de concreto

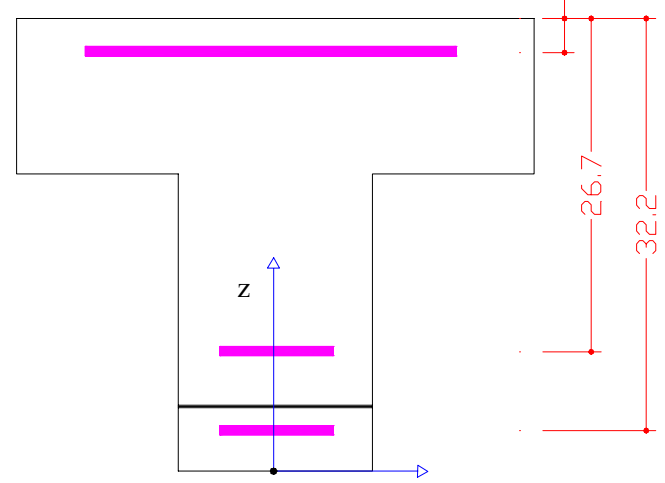

c) Posição dos filetes de aço

OBS.: Unidades: $\mathbf{c m}$

Figura 3.23 - Discretização transversal usada na simulação das vigas VFT 


\section{$\checkmark$ Viga reforçada no bordo comprimido - VFC}

Para uma análise ao longo do tempo o programa CONSNOU exige que as ações, supostas constantes, devam ser aplicadas somente nos passos de tempo, de maneira que a tensão em cada ponto da estrutura permaneça constante durante cada intervalo de tempo analisado dentro de um mesmo passo de tempo. Como nas vigas VFC o carregamento foi aplicado por meio de uma protensão externa, este se reduzia ao longo do tempo em função das perdas de protensão, portanto as vigas simuladas estavam, na realidade, sujeitas a um carregamento variável com o tempo. Para simular esta situação, foi preciso aplicar o carregamento total em vários passos de tempo aplicando-se, para cada um deles um valor específico de carregamento.

Para simular a redução do carregamento, no final de cada passo de tempo as ações externas foram corrigidas através de um passo de carga aplicado antes do início do próximo passo de tempo. Desta forma percebe-se que a simulação da redução do carregamento ao longo do tempo não ocorreu de maneira contínua conforme observado no ensaio experimental, mas sim através de perdas de carga localizadas em instantes pré-determinados.

$\mathrm{O}$ esquema de carregamento aplicado nas vigas VFC, bem como a discretização ao longo da viga, estão apresentados na Figura 3.24. Já a Figura 3.25 mostra a discretização da seção transversal e a posição das barras de aço longitudinais consideradas.

O comportamento das vigas VFC foi avaliado numericamente simulando as duas etapas observadas durante a realização do ensaio experimental real. Estas etapas correspondiam respectivamente ao ensaio intermediário (ensaio de longa duração) e ao ensaio final (ensaio de curta duração até a ruptura da peça). Os resultados das simulações numéricas para cada uma destas etapas encontram-se no

\section{Capítulo 7.}




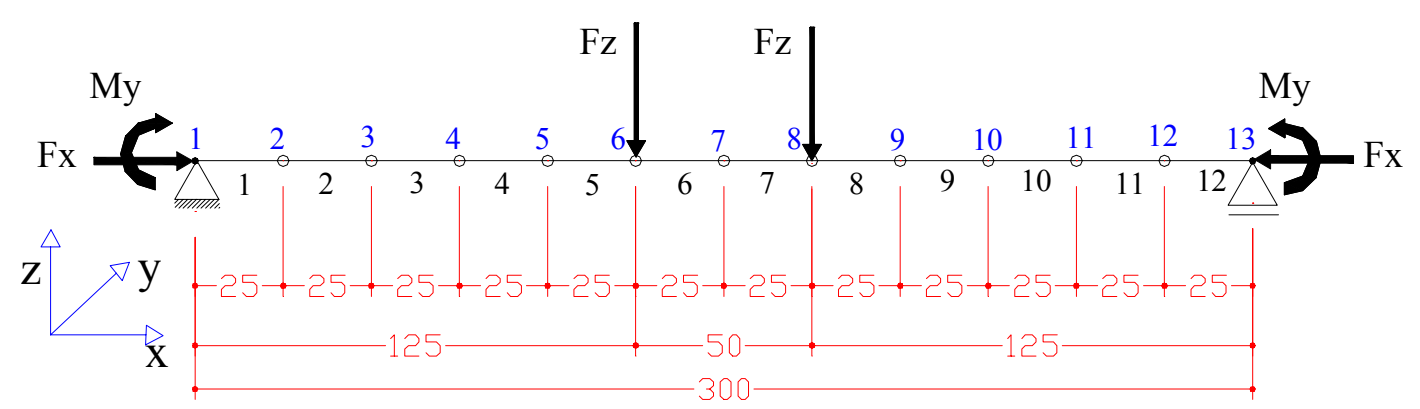

OBS.: a) Os números azul representam os nós e os números preto representam as barras;

b) Unidades: $\mathrm{cm}$

Figura 3.24 - Discretização longitudinal usada na simulação das vigas VFC

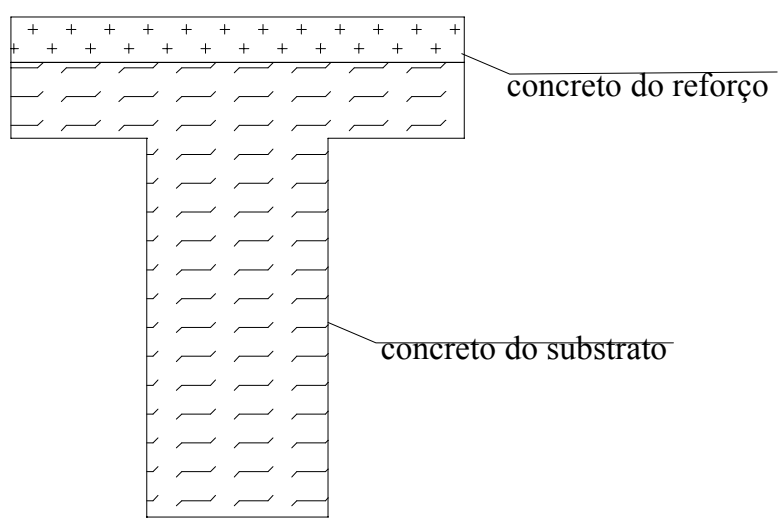

a) Tipos de concreto usado

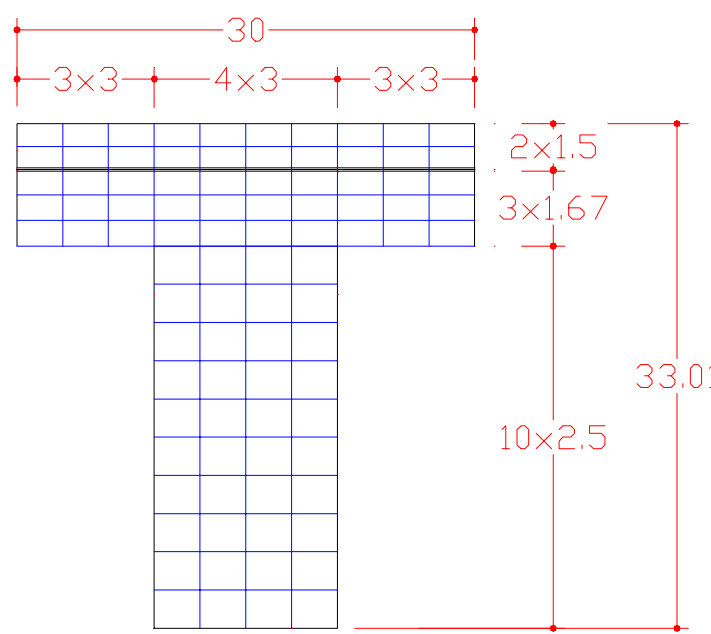

b) Posição dos filetes de concreto

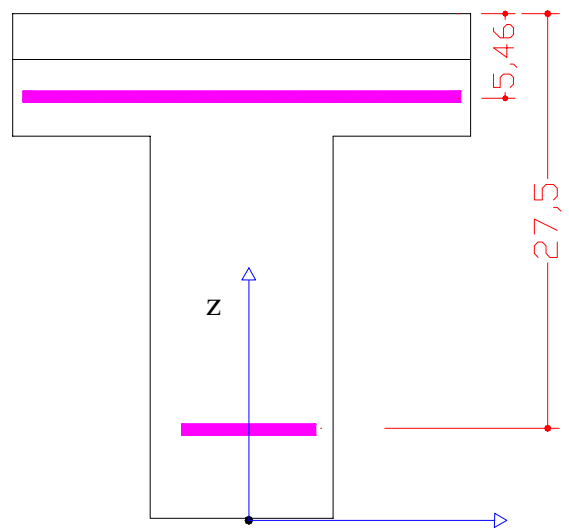

c) Posição dos filetes de aço

OBS.: Unidades: $\mathrm{cm}$

Figura 3.25 - Discretização transversal usada na simulação das vigas VFC 


\section{4 - Ensaios complementares ao estudo da Técnica de Reforço $n^{0} 1$}

\subsection{Ensaios de flexão em prismas}

\subsubsection{Características dos modelos ensaiados}

Dentre as diversas opções de fibras de aço disponíveis comercialmente, o primeiro critério usado para selecionar qual o melhor tipo de fibra para confeccionar o material compósito desejado corresponde à recomendação de que o comprimento da fibra deve ser inferior a um terço da menor dimensão do local onde se pretende aplicar tal material. Esta limitação deve ser seguida para impedir que ocorra um arranjo bidimensional das fibras durante a moldagem provocando um comportamento anisotrópico do compósito. Como a menor dimensão do banzo tracionado a ser reconstituído com o material compósito correspondia a aproximadamente $11 \mathrm{~cm}$, estabeleceu-se que o comprimento das fibras poderia ser no máximo $3,6 \mathrm{~cm}$.

Relembrando resumidamente o que já foi dito no Capítulo 3, o desempenho dos compósitos depende do tipo de ruína, que pode ocorrer por escoamento das fibras ou por seu arrancamento da matriz por falhas de aderência. Admitindo-se um volume constante de fibras adicionado ao compósito e variando-se as características geométricas das fibras, pode-se dizer que:

- $\quad$ supondo ruptura por arrancamento, para fibras de mesmo diâmetro, quanto maior o comprimento (maior fator de forma), maior é a área superficial em contato com a matriz e, portanto, mais elevada é a resistência ao arrancamento da fibra da matriz proporcionando um aumento na tenacidade do compósito;

- $\quad$ supondo ruptura por escoamento, para fibras de mesmo comprimento, quanto maior o diâmetro (menor fator de forma), mais elevada é a resistência ao escoamento da fibra e conseqüentemente a resistência à tração na flexão do compósito. Por outro lado, há uma redução no número de fibras atuando como ponte de transferência de tensões no compósito o que pode prejudicar a tenacidade do compósito. 
Com base nestas afirmações, escolheu-se fibras de aço que permitissem confeccionar compósitos com maior resistência à tração na flexão, já que é esta a característica principal que se deseja em função do uso ao qual se destina tal material, preservando-se ainda uma certa tenacidade. Para melhorar ainda mais o desempenho dos compósitos, optou-se por utilizar fibras com ganchos nas extremidades, por proporcionarem melhor aderência com a matriz do que as fibras retas e lisas.

Levando-se em consideração todos estes fatores, selecionou-se dois tipos de fibras curtas de aço (RL 45/30 BN e RC 65/35 BN) da marca DRAMIX, fornecidas pela BELGO MINEIRA - BEKAERT S.A. As características destas fibras estão na Tabela 2.10. Definidos os tipos de fibras, partiu-se para o estudo da variação da tenacidade e da resistência à tração na flexão realizando duas séries de ensaios de flexão em prismas, variando-se em cada uma delas o volume de fibra adicionados à matriz. A série 1 correspondeu aos prismas confeccionados com o traço de concreto $T R-1 a$, cuja resistência à compressão da matriz ficou na faixa de $50 \mathrm{MPa}$. A série 2 correspondeu aos prismas confeccionados com o traço de concreto $T R-1 b$, cuja resistência à compressão da matriz ficou na faixa de $25 \mathrm{MPa}$. As proporções dos traços usados na confecção do compósito de ambas as séries estão na Tabela 2.9. A preparação do material compósito foi feita de acordo com a ASTM C1116 (1995), que fornece recomendações específicas sobre a dosagem, mistura, lançamento e amostragem deste tipo de material.

Para definir o esquema de ensaio dos prismas baseou-se na norma NBR 12142 e para determinar a tenacidade baseou-se nos métodos da ASTM-C1018 (1994), proposto pela American Society for Testing and Materials, e da JSCE - SF 4 (1984) proposto pela Japan Society of Civil Engineers.

Para facilitar a identificação das características dos prismas utilizou-se a seguinte nomenclatura:

$$
\underline{\mathbf{P}} \underline{\mathbf{i}}-\underline{\mathbf{R}} \mathbf{\mathbf { j }}-\underline{\mathbf{A}}
$$

Onde:

P - corresponde ao tipo de estrutura ensaiada que no caso é um Prisma de concreto

i - indica a taxa de fibra usada na argamassa. Pode ser $0 \% ; 0,5 \% ; 1 \%$ ou $2 \%$;

$\mathrm{Rj} \quad$ - indica as iniciais do tipo de fibra usado, podendo ser RL ou RC ;

A - a letra $\mathbf{A}$ corresponde à série 1 e para os prismas da série 2 não foi usada nenhuma letra específica. 
Os detalhes das dimensões dos prismas, da fixação do relógio comparador (usado na medição das flechas) e do posicionamento no equipamento de ensaio estão apresentadas na Figura 4.1. Para evitar erros na avaliação das flechas devido ao movimento de corpo rígido foi utilizado um dispositivo denominado YOKE, que por estar fixado na altura do centro de gravidade do prisma, já fornecia leituras corretas das flechas descontando-se os deslocamentos dos apoios.

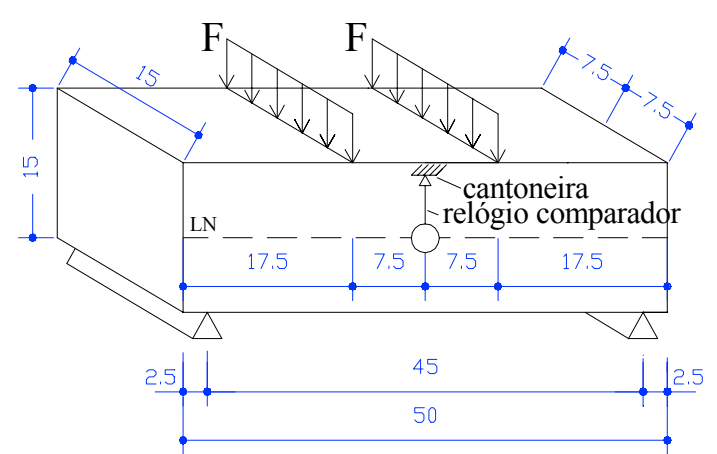

(a) dimensões, local de aplicação do carregamento e posição do relógio comparador

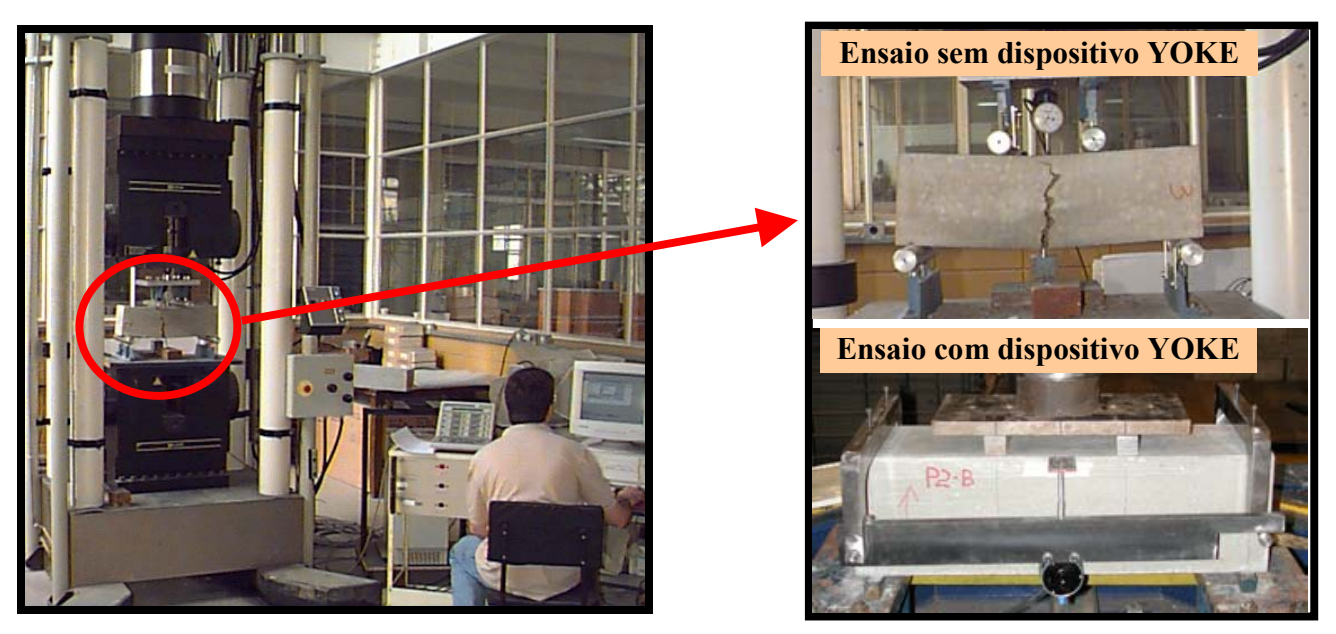

(b) Fotos dos equipamentos utilizados nos ensaios

Figura 4.1 - Ensaio dos prismas de concreto com fibras

Os prismas foram ensaiados usando uma máquina de ensaios servo-hidráulica da marca INSTRON, modelo 8506, sendo submetidos a duas forças concentradas nos terços médios. A aplicação de carregamento foi feita por incremento de deslocamento do pistão a uma velocidade constante de $0,005 \mathrm{~mm} / \mathrm{s}$, até o corpo-deprova atingir a capacidade resistente máxima. Após este instante, aumentou-se a velocidade para $0,015 \mathrm{~mm} / \mathrm{s}$ até que o deslocamento vertical do elemento atingisse 
15 vezes o valor do deslocamento lido no instante em que se atingiu o pico de resistência $\left(\mathrm{F}_{\text {máxima }}\right)$. A cada segundo registrou-se os valores representativos da força aplicada e do deslocamento lido pelo relógio comparador. Aplicou-se o carregamento por incremento de deslocamento para que se pudesse traçar o trecho descendente da curva força $x$ flecha e assim avaliar a tenacidade do compósito.

\subsubsection{Resultados obtidos}

A partir dos resultados dos ensaios de flexão dos prismas construiu-se gráficos força x flecha (ver Apêndice A), usados para determinar a tenacidade e a resistência à tração na flexão de cada material compósito analisado. As propriedades mecânicas dos materiais compósitos foram obtidas também por ensaios de compressão axial e de compressão diametral em corpos-de-prova de $10 \mathrm{~cm}$ x $20 \mathrm{~cm}$.

Como as resistências dos corpos-de-prova cilíndricos apresentaram grande variabilidade (ver Tabela 4.1) mesmo mantendo-se iguais proporções de areia, cimento e água da matriz, estimou-se os parâmetros teóricos das fibras fazendo-se algumas adaptações (ver Tabela 4.2).

Tabela 4.1 - Resistência características médias para cada material compósito

\begin{tabular}{|c|c|c|c|c|c|c|}
\hline \multirow{3}{*}{$\begin{array}{ll}\text { Traço } & \rightarrow \\
\text { Resistencia } & \rightarrow\end{array}$} & \multicolumn{3}{|c|}{ Série 1} & \multicolumn{3}{|c|}{ Série 2} \\
\hline & $\mathbf{f}_{\mathbf{c} 7}$ & $\mathbf{f}_{\mathbf{c t}, \mathrm{sp}, 7}$ & $\mathbf{f}_{\mathrm{ct}, \mathrm{f}, 7}$ & $\mathbf{f}_{\mathbf{c} 7}$ & $\mathbf{f}_{\text {ct,sp7 }}$ & $\mathbf{f}_{\mathbf{c t}, \mathbf{f}, 7}$ \\
\hline & \multicolumn{3}{|c|}{ MPa } & \multicolumn{3}{|c|}{ MPa } \\
\hline Sem fibras & 41,30 & 2,77 & 5,28 & 24,19 & 2,02 & 2,37 \\
\hline $0.5 \%$ RL- $45 / 30$ & - & - & - & 34,81 & 2,75 & 3,91 \\
\hline $1 \% \quad$ RL-45/30 & 53,08 & 5,86 & 6,38 & 21,65 & 2,13 & 4,49 \\
\hline $2 \% \quad$ RL-45/30 & 55,15 & 5,24 & 8,78 & 17,66 & 2,27 & 7,88 \\
\hline $0.5 \%$ RC- $65 / 35$ & - & - & - & 30,46 & 2,27 & 3,51 \\
\hline $1 \% \quad \mathrm{RC}-65 / 35$ & 59,67 & 5,84 & 5,86 & 30,93 & 2,65 & 3,70 \\
\hline $2 \% \quad \mathrm{RC}-65 / 35$ & 50,01 & 6,81 & 8,49 & 13,91 & 2,02 & 4,90 \\
\hline
\end{tabular}

OBS.Não se considerou a correção devido ao efeito escala nas resistências dos CP 10 x 20; Para cada traço foram ensaiados 3 prismas;

$\mathrm{f}_{\mathrm{c} 7} \quad$ - resistência média do compósito à compressão axial aos 7 dias

$\mathrm{f}_{\mathrm{ct}, \mathrm{sp}, 7}$ - resistência média do compósito à tração indireta aos 7 dias (tração por compressão diametral)

$\mathrm{f}_{\mathrm{ct}, \mathrm{f}, 7}=\sigma_{\mathrm{u}}$ - resistência média do compósito à tração na flexão aos 7 dias (módulo de resistência) 
Tabela 4.2 - Parâmetros relativos às fibras em função dos traços usados

\begin{tabular}{|c|c|c|c|c|c|c|c|c|c|c|c|c|c|}
\hline \multirow{2}{*}{\multicolumn{2}{|c|}{$\begin{array}{l}\text { Tipo fibra } \\
\text { Taxa (\%) } \rightarrow\end{array}$}} & \multicolumn{3}{|c|}{$\mathbf{S}(\mathbf{m m})$} & \multicolumn{3}{|c|}{$\tau_{\mathrm{fu}}(\mathrm{MPa})$} & \multicolumn{3}{|c|}{$\ell_{\text {critico }}(\mathbf{m m})$} & \multicolumn{3}{|c|}{$V_{\text {critico }}(\%)$} \\
\hline & & 0,5 & 1,0 & 2,0 & 0,5 & 1,0 & 2,0 & 0,5 & 1,0 & 2,0 & 0,5 & 1,0 & 2,0 \\
\hline \multirow[t]{2}{*}{ Serie 1} & RL 45/30 & 12,10 & 8,56 & 6,05 & - & 2,71 & 2,66 & - & 126 & 128 & - & 6,01 & $\overline{6,11}$ \\
\hline & RC 65/35 & 10,73 & 7,59 & 5,37 & - & 2,40 & 2,36 & - & 132 & 134 & - & 4,71 & 4,78 \\
\hline \multirow[t]{2}{*}{ Serie 2} & RL 45/30 & 12,10 & 8,56 & 6,05 & 1,75 & 1,71 & 1,68 & 194 & 200 & 203 & 5,85 & 6,01 & 6,11 \\
\hline & RC 65/35 & 10,73 & 7,59 & 5,37 & 1,54 & 1,51 & 1,49 & 205 & 210 & 213 & 4,60 & 4,71 & 4,78 \\
\hline
\end{tabular}

OBS.:

Adotou-se valores de resistência da matriz iguais $\mathrm{f}_{\mathrm{c}}=50 \mathrm{MPa}$ (Série 1) e $\mathrm{f}_{\mathrm{c}}=25 \mathrm{MPa}$ (Série 2)

Determinou-se os valores de $\mathrm{f}_{\mathrm{c}}$ e $\mathrm{f}_{\mathrm{t}}$ do compósito usando as expressões 3.12 e 3.13 .

Os parâmetros $\mathrm{S} ; \mathrm{V}_{\text {critico }} ; \tau_{\mathrm{fu}} ; \mathrm{e} \ell_{\text {critico }}$ foram calculados usando as expressões do Capítulo 3

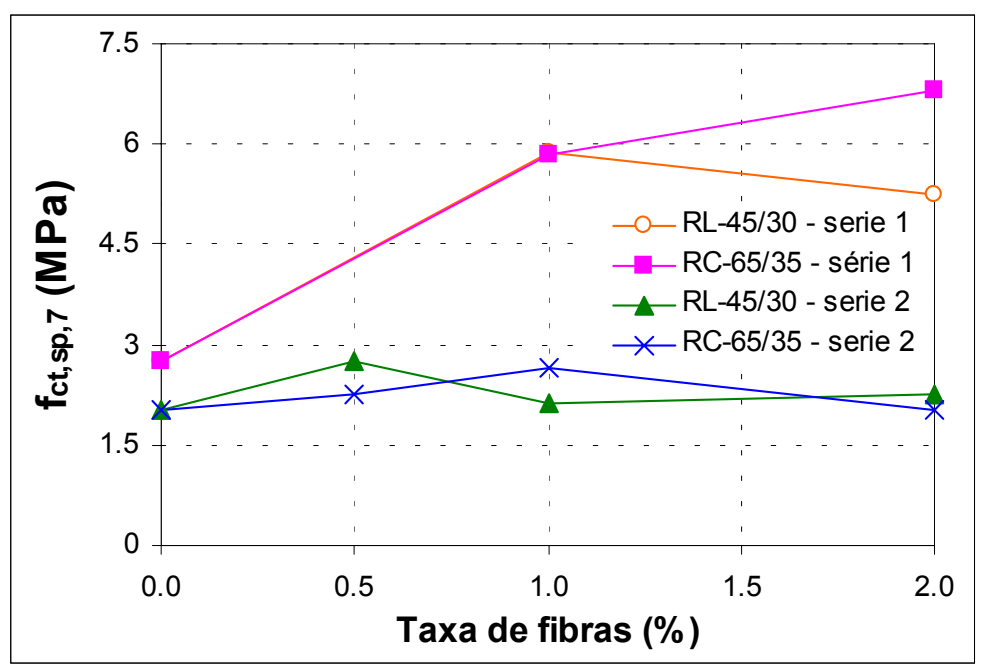

(a) Resistência à tração indireta

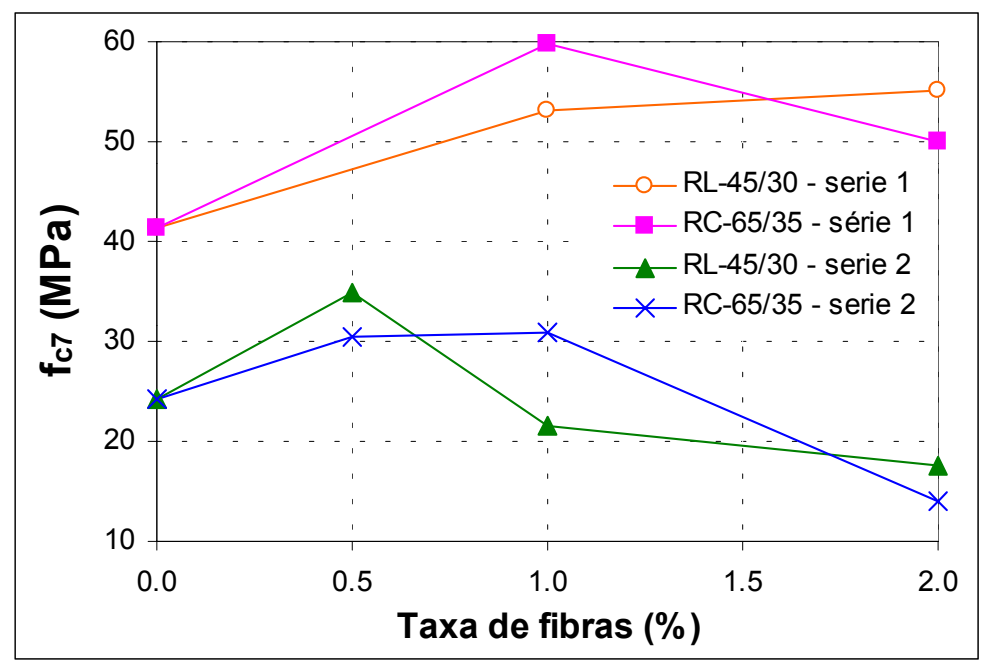

(b) Resistência à compressão

Figura 4.2 - Variação das resistências $x$ volume de fibras obtidas a partir de corpos-de-prova cilíndricos $10 \mathrm{~cm} \times 20 \mathrm{~cm}$ 
Tabela 4.3 - Parâmetros calculados de acordo com a norma JSCE SF-4

\begin{tabular}{|c|c|c|c|c|c|c|c|c|c|c|}
\hline & \multirow[t]{2}{*}{ Prismas } & \multirow{2}{*}{\begin{tabular}{|c|} 
Volume \\
$\mathbf{( \% )}$ \\
\end{tabular}} & \multicolumn{2}{|c|}{ Forças (kN) } & \multicolumn{3}{|c|}{ Tensões (MPa) } & \multicolumn{3}{|c|}{ Relações } \\
\hline & & & $\mathbf{F}_{\text {fissuração }}$ & $\mathbf{F}_{\text {ruptura }}$ & $\sigma_{0}$ & $\sigma_{\mathrm{u}}$ & $\mathbf{f}_{\mathrm{ct}, \mathrm{eq}}$ & $\sigma_{\mathrm{u}} / \sigma_{0}$ & $\sigma_{\mathrm{u}} / \mathbf{f}_{\mathrm{ct}, \mathrm{eq}}$ & $\sigma_{\mathrm{u}} / \sigma_{\mathrm{u}-\mathrm{ref}}$ \\
\hline \multirow{5}{*}{ : } & PO-A & 0 & 39,6 & 39,6 & 5,28 & 5,28 & - & 1,00 & - & 1,00 \\
\hline & P1-RL-A & 1 & 36,7 & 47,8 & 4,89 & 6,38 & 3,93 & 1,31 & 1,62 & 1,21 \\
\hline & P2-RL-A & 2 & 43,2 & 65,8 & 5,76 & 8,78 & 5,64 & 1,52 & 1,56 & 1,66 \\
\hline & P1-RC-A & 1 & 43,1 & 43,9 & 5,74 & 5,86 & 4,11 & 1,02 & 1,43 & 1,11 \\
\hline & P2-RC-A & 2 & 47,3 & 63,6 & 6,31 & 8,49 & 6,33 & 1,35 & 1,34 & 1,61 \\
\hline \multirow{7}{*}{ 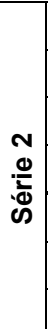 } & PO & 0 & 17,8 & 17,8 & 2,37 & 2,37 & - & 1,00 & - & 1,00 \\
\hline & P05-RL & 0,5 & 28,6 & 29,3 & 3,81 & 3,91 & 3,41 & 1,03 & 1,15 & 1,65 \\
\hline & P1-RL & 1 & 22,6 & 33,7 & 3,02 & 4,49 & 2,31 & 1,49 & 1,94 & 1,90 \\
\hline & P2-RL & 2 & 24,7 & 59,1 & 3,29 & 7,88 & 4,82 & 2,40 & 1,29 & 3,33 \\
\hline & P05-RC & 0,5 & 26,3 & 26,3 & 3,51 & 3,51 & 2,32 & 1,00 & 1,51 & 1,48 \\
\hline & P1-RC & 1 & 24,8 & 27,8 & 3,30 & 3,70 & 2,61 & 1,12 & 1,42 & 1,56 \\
\hline & P2-RC & 2 & 19,9 & 36,8 & 2,66 & 4,90 & 3,01 & 1,85 & 1,51 & 2,07 \\
\hline
\end{tabular}

OBS.:

$\mathrm{F}_{\text {fissuracão }}$ e $\mathrm{F}_{\text {ruptura }}$ - força de início de fissuração e força máxima resistida pelo compósito;

$\sigma_{0} \quad-$ resistência de fissuração à tração na flexão;

$\sigma_{\mathrm{u}} \quad$ - resistência última à tração na flexão (módulo de ruptura);

$\sigma_{\mathrm{u}-\mathrm{ref}} \quad-$ resistência última à tração na flexão para o prisma sem adição de fibras;

$\mathrm{f}_{\mathrm{cteq}} \quad-$ resistência equivalente;

Tabela 4.4 - Índices de tenacidade e fatores de resistência calculados pelas normas ASTM C1018 e JSCE SF-4

\begin{tabular}{|c|c|c|c|c|c|c|c|c|c|}
\hline \multirow[b]{2}{*}{ Prismas } & \multirow[b]{2}{*}{ Volume (\%) } & \multicolumn{4}{|c|}{ Indices de tenacidade } & \multicolumn{4}{|c|}{ Fator residual de resistência } \\
\hline & & $\mathbf{I}_{5}$ & $\mathbf{I}_{10}$ & $\mathbf{I}_{20}$ & $\mathbf{I}_{30}$ & $\mathbf{R}_{5,10}$ & $\mathbf{R}_{10,20}$ & $\mathbf{R}_{\mathbf{2 0 , 3 0}}$ & $\mathbf{R}_{\mathrm{e}, 3}$ \\
\hline P0-A & $\mathbf{0}$ & - & - & - & - & - & - & - & - \\
\hline P1-RL-A & 1 & 5,07 & 10,95 & 22,78 & 33,17 & 117,54 & 118,36 & 103,82 & 80,51 \\
\hline P2-RL-A & 2 & 5,39 & 11,87 & 24,97 & 36,07 & 129,53 & 131,01 & 111,01 & 97,79 \\
\hline P1-RC-A & 1 & 4,25 & 8,63 & 17,43 & 25,20 & 87,61 & 87,97 & 77,68 & 71,70 \\
\hline P2-RC-A & 2 & 5,17 & 11,18 & 23,08 & 34,08 & 120,13 & 119,07 & 109,94 & 100,38 \\
\hline P0 & $\mathbf{0}$ & - & - & - & - & - & - & - & - \\
\hline P05-RL & 0,5 & 4,23 & 8,25 & 17,25 & 26,78 & 80,39 & 89,97 & 95,36 & 93,89 \\
\hline P1-RL & 1 & 5,65 & 12,49 & 23,93 & 34,12 & 136,91 & 114,40 & 101,87 & 76,31 \\
\hline P2-RL & 2 & 6,64 & 16,43 & 38,88 & 59,93 & 195,72 & 224,49 & 210,58 & 186,43 \\
\hline P05-RC & 0,5 & 4,10 & 7,04 & 13,58 & 20,80 & 58,81 & 65,38 & 72,18 & 65,99 \\
\hline P1-RC & 1 & 4,24 & 8,68 & 15,60 & 23,70 & 88,88 & 69,16 & 81,03 & 78,79 \\
\hline P2-RC & 2 & 6,09 & 14,37 & 30,64 & 45,86 & 165,62 & 162,66 & 152,17 & 121,49 \\
\hline
\end{tabular}

Obs.:

$\mathrm{I}_{\mathrm{N}}$ e $\mathrm{R}_{\mathrm{a}, \mathrm{b}}$ foram determinados de acordo com expressões do Capítulo 3.

Os prismas tinham um vão livre, $\ell$, de $450 \mathrm{~mm}$ então a flecha usada no cálculo de $\mathrm{R}_{\mathrm{e}, 3}$ correspondia à $3 \mathrm{~mm}$. 


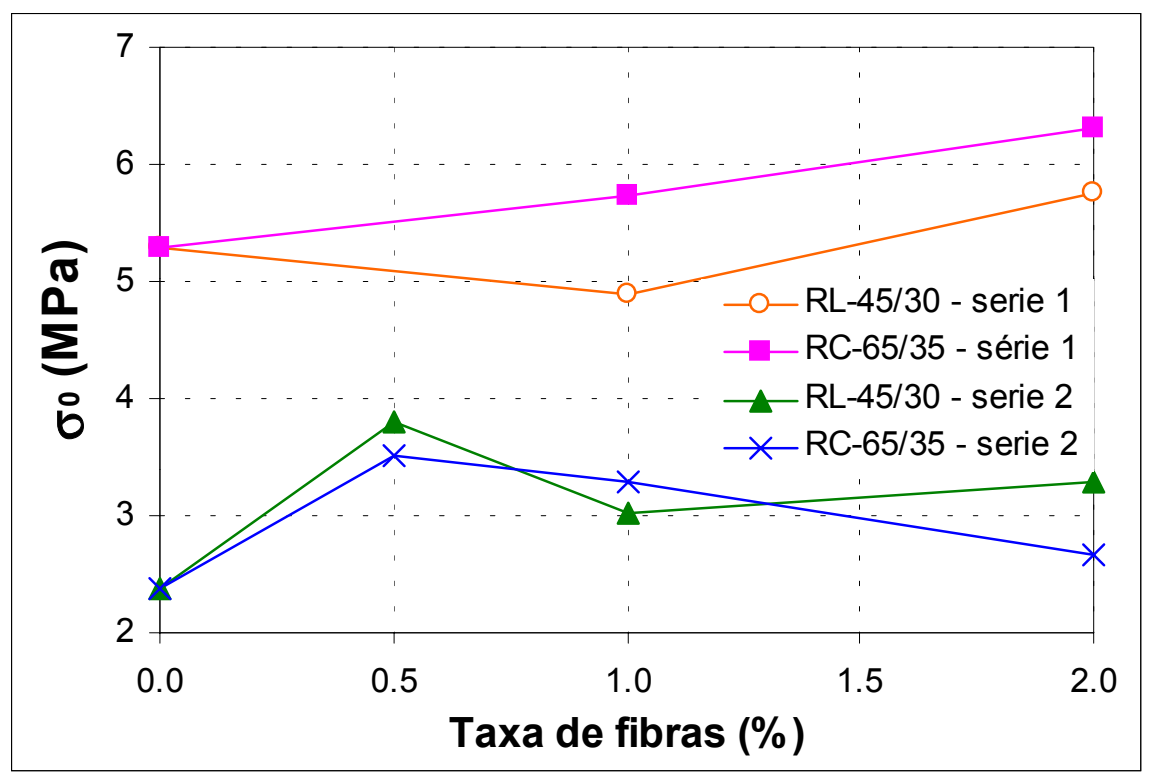

a) Resistência de fissuração à tração na flexão

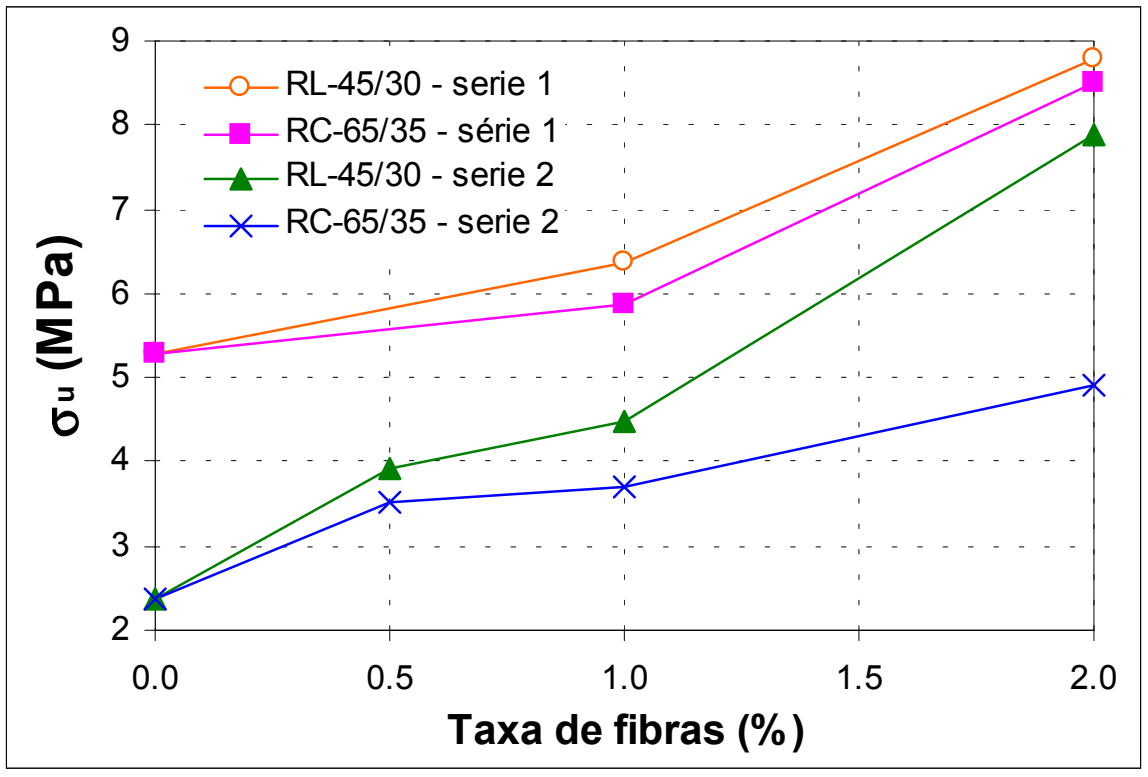

b) Resistência última à tração na flexão

Figura 4.3 - Variação da resistência $x$ volume de fibras obtidas em corpos-deprova prismáticos 


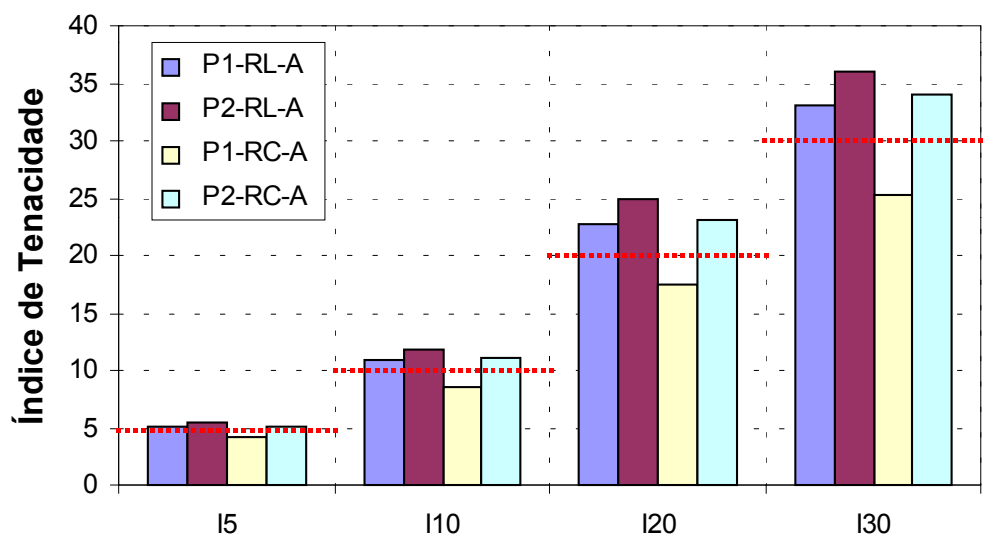

(a) prismas da série 1

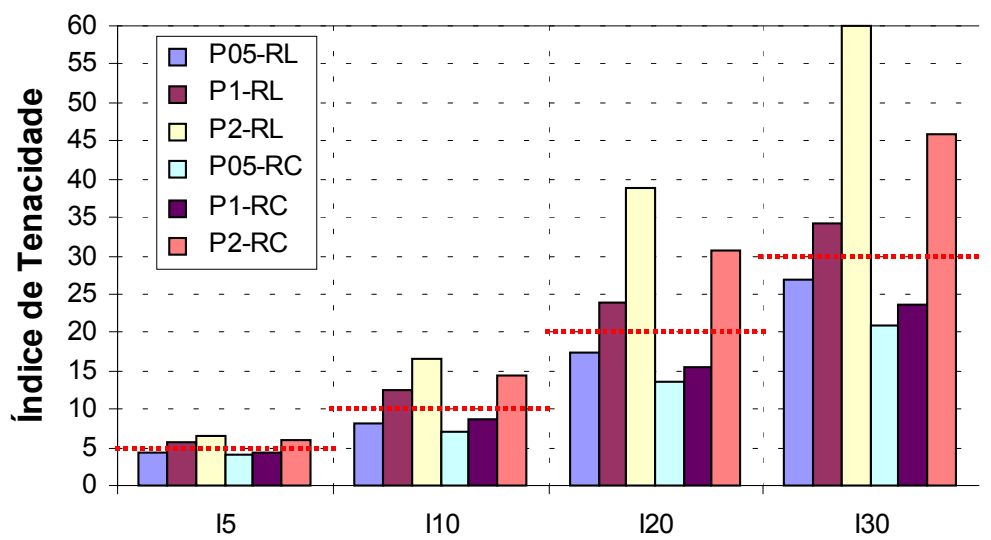

(b) prismas da série 2

Figura 4.4 - Índices de tenacidade calculados pela norma ASTM C1018

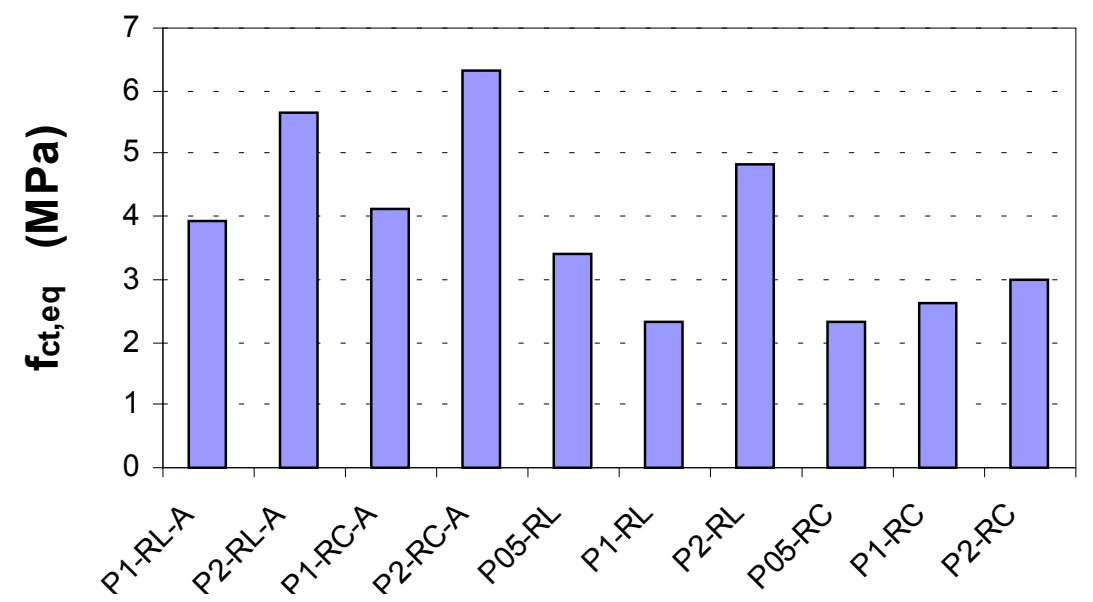

Figura 4.5 - Fator de tenacidade $\left(f_{\text {ct,eq }}\right)$ de acordo com a norma JSCE 


\subsubsection{Análise dos resultados}

\section{a) Comportamento na fissuração e na ruptura}

Os prismas moldados sem adição de fibras romperam bruscamente logo após o surgimento da primeira fissura de flexão, já os prismas com fibras de aço apresentaram certa ductilidade mesmo para uma taxa de $0,5 \%$.

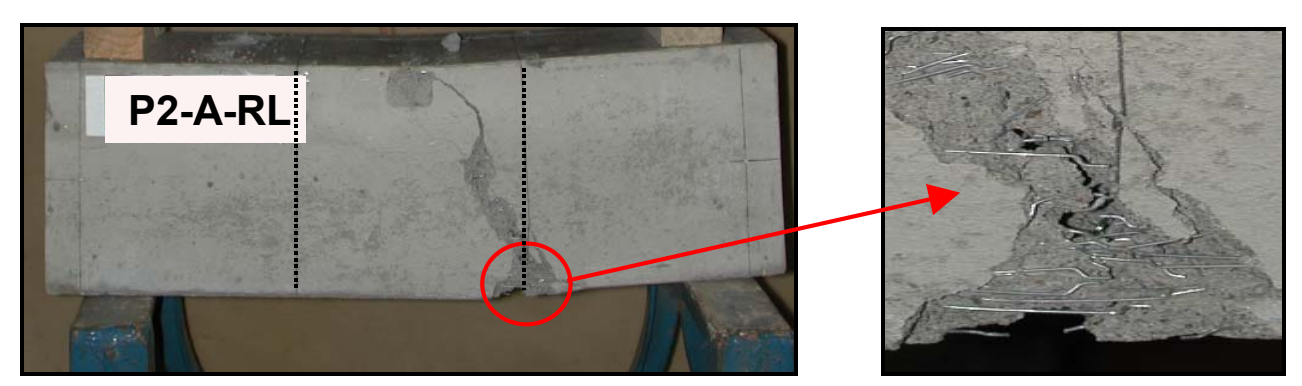

a) prisma com fibras de aço

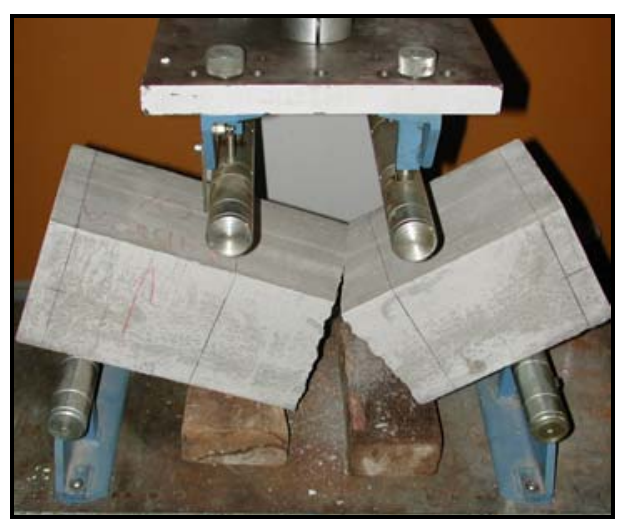

b) prisma sem fibra de aço

Figura 4.6 - Esquema de fissuração e ruptura dos prismas

Observando a configuração das fibras na região das fissuras existentes nos prismas após os ensaios, percebeu-se que estas não romperam por deformação plástica excessiva mas sim foram arrancadas da matriz por perda gradual da aderência. Isso fez com que os ganchos das extremidades das fibras ficassem praticamente retos após o final do ensaio. 


\section{b) Avaliação das resistências à compressão e à tração dos compósitos}

A grande variabilidade das resistências à compressão e à tração por compressão diametral, obtidas pelos ensaios em corpos-de-prova cilíndricos $10 \mathrm{~cm} \mathrm{x}$ $20 \mathrm{~cm}$, prejudicou um pouco a análise dos resultados e pode ter sido causada por vários fatores agindo em conjunto:

- O fato dos prismas terem sido moldados em datas diferentes permitiu que o traço do compósito sofresse influência das condições ambientais (temperatura e umidade) afetando principalmente a relação a/c, uma vez que não se fez a moldagem utilizando os materiais no estado SSS (Saturado com Superfície Seca).

- Apesar do cimento usado na confecção dos traços ser de mesmo tipo (CP-32E ou CP-ARI PLUS), nem sempre se usou cimento da mesma marca.

- A ocorrência de falhas no adensamento pode ter provocado um aumento no índice de vazios do compósito.

- Como o compósito era fluido (auto-adensável) para possibilitar sua utilização como material de reforço, pode ter ocorrido uma "segregação parcial" das fibras de aço, que podem ter se acumulado no fundo dos corpos-de-prova ao invés de ficarem distribuídas aleatoriamente, mesmo tomando-se os devidos cuidados para que isso não ocorresse. Este fato seria mais crítico nos corpos-de-prova cilíndricos em função de suas dimensões.

Por outro lado, percebeu-se que nos ensaios de flexão realizados em corposde-prova prismáticos sempre se obteve aumento da resistência última à tração na flexão $\left(\sigma_{\mathrm{u}}\right)$ com o aumento do volume de fibras (ver gráfico da Figura 4.3b).

Comparando-se os valores da relação $\sigma_{u} / \sigma_{0}$ (Tabela 4.3) constatou-se que todos os prismas com fibras continuaram suportando carga mesmo após o surgimento da primeira fissura, sendo esta relação cada vez maior em função do aumento do teor de fibras e mais significativa para os prismas da série 1 com fibra RL 45/30. Esse comportamento indica que todos compósitos analisados foram mais tenazes que um material elastoplástico perfeito.

O ganho de resistência à flexão dos modelos em função da adição de fibras foi avaliado pela relação $\sigma_{\mathbf{u}} / \sigma_{\mathbf{u}-\text { ref }}$ (Tabela 4.3 ) que adotou como referência um modelo sem fibras. Os resultados mostraram que os prismas com teores de $2 \%$ tiveram maiores aumentos da resistência última à tração na flexão $\left(\sigma_{u}\right)$ mesmo 
quando suas resistências à tração indireta eram menores que as de outros compósitos. Além disso, comparando-se prismas com mesmo teor de fibras, constatou-se que para ambas as séries, os moldados com a fibra RL 45/30 tiveram ganhos de resistência à tração na flexão mais significativos que os moldados com a RC 65/35. Isso indica uma melhor eficiência da fibra RL 45/30 provavelmente por ela ter um fator de forma menor que a fibra $\mathrm{RC} 65 / 35$. Notou-se também que a porcentagem de aumento de resistência à tração na flexão foi mais significativa para os compósitos da série 2 (compósito de menor resistência) sugerindo que a resistência da matriz influencia a eficiência da fibra.

Observando o gráfico da Figura 4.3a percebeu-se que, ao contrário do que se esperava, nem sempre o aumento da taxa de fibras proporcionou aumento da resistência à fissuração, $\sigma_{0}$. Todavia convém esclarecer que como as resistências à compressão dos compósitos foram bem diferentes umas das outras, não foi possível obter informações confiáveis sobre o efeito da taxa de fibras na resistência à fissuração, já que não se conseguiu eliminar o efeito da resistência do concreto na análise dos resultados.

\section{c) Avaliação da tenacidade}

Apesar da tenacidade normalmente ser a principal característica avaliada nos materiais compósitos, especificamente neste trabalho ela foi considerada apenas um efeito benéfico secundário proporcionado pela adição das fibras. Isto porque a principal característica mecânica considerada corresponde ao ganho de resistência à tração na flexão uma vez que o compósito está sendo usado como material de reforço estrutural que deve ser capaz de substituir os estribos necessários para impedir o deslizamento relativo entre camadas de armadura tracionada adicionadas durante o estudo da Técnica de Reforço $n^{0} 1$. De qualquer forma, a avaliação da tenacidade foi feita para se evitar produzir compósitos que rompessem bruscamente.

\section{$\underline{\text { Tenacidade avaliada pela norma ASTM - C1018 }}$}

Os índices de tenacidade, $\mathrm{I}_{\mathrm{N}}$, da série 1 e 2 (Figura 4.4), se comparados com os valores de referência, indicaram que a maioria dos compósitos teve comportamento superior ao de um material elastoplástico perfeito. Nos compósitos que apresentaram tenacidade inferior ao do material de referência convém ressaltar 
que houve instabilidade pós-pico durante a execução dos ensaios. Tal instabilidade pode ser observada nas Figuras do Apêndice $\boldsymbol{A}$.

A tenacidade obtida também sempre foi maior para os compósitos confeccionados com a matriz de menor resistência (série 2) indicando que o aumento da resistência da matriz reduz tal parâmetro conforme se previa. Percebeu-se ainda que, contrário do que se esperava, os compósitos confeccionados usando a fibra de menor fator de forma (RL 45/30) foram os que apresentaram maior tenacidade.

Em relação aos fatores residuais de resistência, $\mathrm{R}_{\mathrm{a}, \mathrm{b}}$, (Tabela 4.4) as análises confirmaram a excelente tenacidade observada nos materiais compósitos estudados uma vez que na maior parte dos ensaios, os valores foram superiores a 100 (valor de referência para um material elastoplástico perfeito). Como esse parâmetro indica o nível médio de resistência suportado pelo prisma após o surgimento da primeira fissura, pode-se dizer que na série 1 a resistência só começou a diminuir para o fator $R_{20,30}$. Já para a série 2 , o nível de resistência estimado pelos fatores $R_{5,10} ; R_{10,20}$ e $\mathrm{R}_{20,30}$ variou conforme o teor de fibras do traço analisado. Este é um parâmetro importante a ser avaliado na hora de decidir qual o tipo e a taxa de fibra a ser adicionada ao material do reforço que se deseja produzir.

\section{Tenacidade avaliada pela norma JSCE-SF 4}

Comparando-se os valores da resistência equivalente $\mathrm{f}_{\mathrm{ct}, \mathrm{eq}}$ (gráfico da Figura 4.5) percebeu-se que na série 1 , a tenacidade proporcionada pela fibra RC-65/35 foi ligeiramente maior que a proporcionada pela fibra RL 45/30. Já para a série 2 ocorreu o oposto, ou seja, os compósitos com fibra RL 45/30 tiveram maiores tenacidades, exceto o compósito P1-RL. Entretanto este compósito apresentou um comportamento estranho, pois sua tenacidade foi inferior à do compósito P0.5-RL que possuía menor teor de fibra.

$\mathrm{O}$ fator de tenacidade $\mathrm{R}_{\mathrm{e} 3}$ permitiu avaliar se o compósito possuía um comportamento semelhante ao de um material elastoplástico perfeito $\left(\mathrm{R}_{\mathrm{e} 3}=100\right)$ a partir de um deslocamento (flecha) de $3 \mathrm{~mm}$. Para ambas as séries (ver Tabela 4.4) verificou-se que apenas os compósitos com 2\% de fibras (exceto o P2-RL-A) 
apresentaram fatores maiores ou iguais a 100. Os demais compósitos apresentaram comportamento um pouco menos tenaz que o do material elastoplástico perfeito.

A relação $\sigma_{\mathbf{u}} / \mathbf{f}_{\mathbf{c t} \text {,eq }}$ (Tabela 4.3) indica a porcentagem de perda de resistência à tração na flexão do compósito para um deslocamento de $3 \mathrm{~mm}$. Por esta relação percebeu-se que na série 1 os compósitos confeccionados com fibra RC-65/35 perderam menos resistência. Já para a série 2 foram as fibras RL-45/30 que proporcionaram menores perdas (exceto no prisma P1-RL). Entretanto devida a pouca quantidade de taxas de fibras analisadas para cada série não se pode avaliar precisamente qual seria a tendência de comportamento.

\subsection{Ensaios de vigas retangulares}

\subsubsection{Características dos modelos ensaiados}

Em peças fletidas normalmente dimensiona-se e detalha-se as armaduras para que a capacidade portante (resistência máxima) seja obtida para uma ruptura por deformação plástica excessiva da armadura tracionada e esmagamento do concreto do bordo comprimido. Nas vigas VFT (ver Capítulo 5) pretendia-se adotar um detalhamento diferente do usado na prática, no qual as barras de aço tracionadas da primeira camada estavam envolvidas por estribos, enquanto que as barras da segunda camada não estavam. Como se sabia - em função dos resultados de REIS (1998) este tipo de detalhamento provocava a ruptura prematura da viga por cisalhamento horizontal (escorregamento relativo entre as camadas de barras de aço tracionadas), mas tal fenômeno poderia ser evitado se fosse utilizada uma argamassa com adição de fibras de aço envolvendo a armadura tracionada. Para que o elemento estrutural pudesse atingir sua capacidade portante plena era preciso utilizar uma argamassa com características adequadas.

Como até o momento não existem nem métodos nem normas específicas que permitam a determinação teórica das características dessa argamassa, esta teve que ser feita empiricamente. Para isso foi realizado um estudo experimental específico ensaiando-se duas séries de vigas retangulares preliminares de pequenas dimensões, a fim de avaliar o ganho de resistência de peças fletidas em função do tipo e da taxa de fibras de aço adicionadas à argamassa. 
$\mathrm{Na}$ primeira série foram ensaiadas cinco vigas retangulares de concreto reforçadas seguindo a proposta da Técnica de Reforço $\mathrm{n}^{\mathrm{o}} 1$ usando uma argamassa de alta resistência com fibras de aço somente na região do bordo tracionado do elemento. Na segunda série foram ensaiadas sete vigas moldadas em uma única etapa (monolíticas) usando argamassa de resistência normal com fibras em toda seção transversal do elemento. Adotou-se uma argamassa de menor resistência na moldagem das vigas da série 2 para tentar quantificar a influência da resistência da argamassa na resistência ao cisalhamento horizontal das vigas.

Em uma mesma série, as vigas VP se diferenciavam apenas em função da taxa e do tipo de fibras de aço adicionada à argamassa. Para facilitar a identificação das características destas vigas, utilizou-se a seguinte nomenclatura:
Para vigas preliminares $\rightarrow$
$\mathrm{VP} \underline{\mathrm{i}}-\underline{\mathrm{k}}$
Para vigas de referência $\rightarrow$
VR $\underline{w}$

Onde:

i - números impares correspondem a peças moldadas com fibras tipo RC-65/35 e números pares correspondem a peças moldadas com fibras tipo RL-45/30. Para vigas da série 1 tem-se $i=1$ ou 2 e para as vigas da série 2 tem-se $i=3$ ou 4 ;

$\mathrm{k} \quad$ - indica o teor de fibras em \% usado na peça, podendo ser $0,5,1$ ou 2;

w - número que se relaciona com a peça de referência da série 1 ou 2 respectivamente

Apesar de não existir estudos teóricos específicos a respeito da ruptura por cisalhamento horizontal causada pelo escorregamento relativo de barras de aço tracionadas em função do detalhamento usado nas vigas VFT, acredita-se que esta ruptura dependa bastante da solidariedade existente entre a barra de aço e o concreto que a envolve.

A solidarização por aderência na interface aço-concreto mobiliza tanto tensões tangenciais $\left(\tau_{b}\right)$ quanto tensões diagonais de compressão $\left(\sigma_{c \theta}\right)$ e tensões transversais de tração $\left(\sigma_{\mathrm{tt}}\right)$. Se a distância (espaçamento) entre as barras de aço for muito próxima, se o cobrimento do concreto for relativamente pequeno ou se não houver armadura transversal suficiente ao longo das barras para absorver as tensões 
de tração $\sigma_{\mathrm{tt}}$, então surge uma intensa microfissuração do concreto em torno das barras de aço que pode provocar seu fendilhamento.

Como o fendilhamento do concreto em torno das barras de aço provavelmente afeta a resistência ao cisalhamento horizontal que está sendo estudada, utilizou-se nas vigas VP o mesmo espaçamento vertical entre as camadas de barras de aço e o mesmo cobrimento usado nas vigas VFT analisadas no Capítulo 5. Os valores destes parâmetros correspondem respectivamente a $4 \mathrm{~cm}$ e $1,5 \mathrm{~cm}$.

Há a necessidade de um espaçamento vertical deste tamanho para que se consiga garantir tanto um bom adensamento da argamassa adicionada quanto a aleatoriedade na distribuição das fibras de aço durante a moldagem.

Quanto à instrumentação, as deformações das armaduras e do concreto foram medidas com extensômetros elétricos e os deslocamentos verticais com relógios comparadores dispostos no meio do vão da viga e nos apoios. A leitura destes equipamentos foi coletada pelo sistema de aquisição de dados SYSTEM 4000 (série 1) e pelo SYSTEM 5000 (série 2). Os detalhes das dimensões, do detalhamento, da instrumentação e do esquema estático das vigas VP estão nas Figuras 4.7 e 4.8.

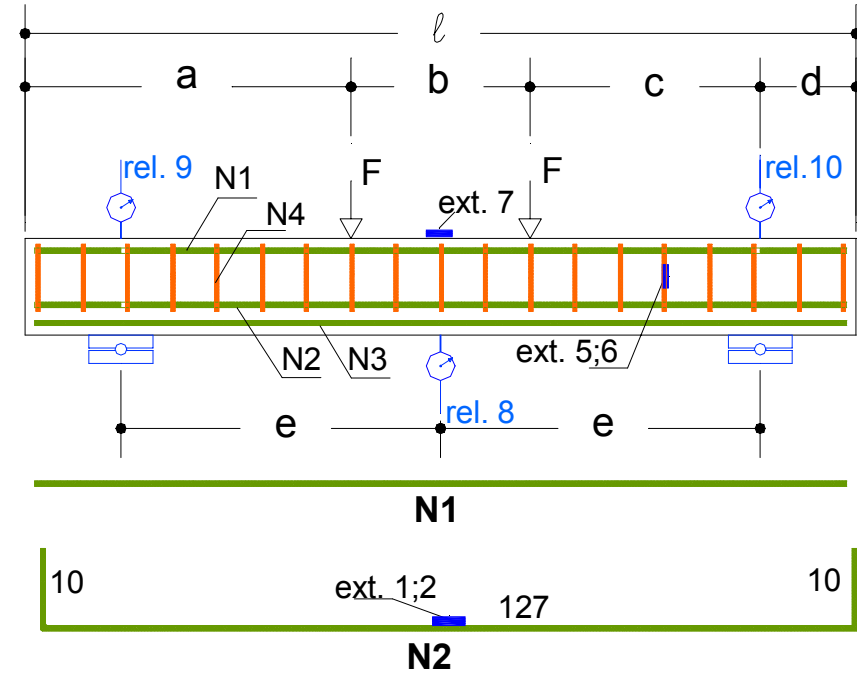

Legenda:

\begin{tabular}{l|c|c|} 
& Série 1 & Série 2 \\
\hline$\ell$ & 230 & 130 \\
\hline $\mathrm{a}$ & 65 & 51 \\
\hline $\mathrm{b}$ & 100 & 28 \\
\hline $\mathrm{c}$ & 50 & 36 \\
\hline $\mathrm{d}$ & 15 & 15 \\
\hline $\mathrm{e}$ & 100 & 50 \\
\hline $\mathrm{N} 1$ & $2 \phi \quad 8.0 \mathrm{~mm}-\mathrm{L}=227$ & $2 \phi 10.0 \mathrm{~mm}-\mathrm{L}=127$ \\
\hline $\mathrm{N} 2$ & $2 \phi \quad 8.0 \mathrm{~mm}-\mathrm{L}=250$ & $2 \phi \quad 5.0 \mathrm{~mm}-\mathrm{L}=147$ \\
\hline $\mathrm{N} 3$ & $2 \phi 16.0 \mathrm{~mm}-\mathrm{L}=227$ & $2 \phi 10.0 \mathrm{~mm}-\mathrm{L}=127$ \\
\hline As unidades de comprimento estão em $\mathrm{cm}$ \\
\hline
\end{tabular}

ext. 3,4

N3

Figura 4.7 - Seção longitudinal das vigas preliminares VP 


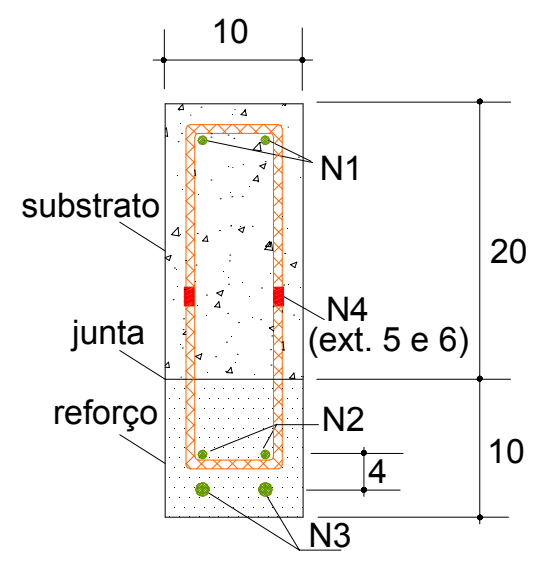

Seção B $-50 \mathrm{~cm}$ do apoio

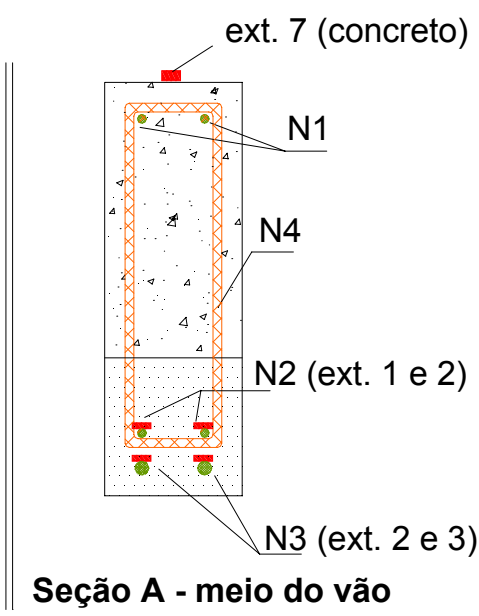

(a) vigas da série 1
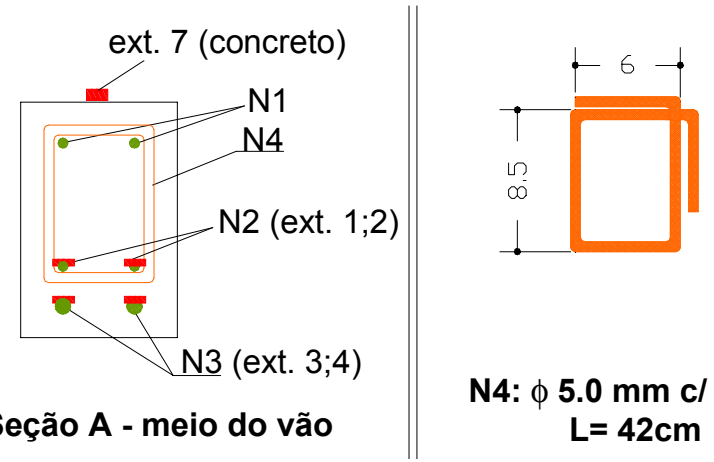

N4: $\phi 5.0 \mathrm{~mm} \mathrm{c/} 14 \mathrm{~cm}$ $\mathrm{L}=42 \mathrm{~cm}$

(b) vigas da série 2

OBS. : Unidade das cotas $-\mathrm{cm}$

Figura 4.8 - Seção transversal das vigas preliminares VP

\subsubsection{Caracterização dos materiais}

As dosagens das argamassas reforçadas com fibras de aço usadas nas vigas da série 1 e 2 foram idênticas às usadas para confeccionar os prismas (traços $T R-1 a \mathrm{e}$ $T R-1 b$ ) e a dosagem do concreto do substrato das vigas VP da série 1 (traço $T S-1$ ) foi escolhido de maneira que também pudesse ser usado para confeccionar o substrato das vigas VFT. Tais dosagens estão apresentadas na Tabela 2.9 e as resistências específicas dos ensaios das vigas VP estão na Tabela 4.5. Já as propriedades mecânicas das armaduras utilizadas estão na Tabela 4.6. 
Tabela 4.5 - Resistência dos concretos e argamassas usados nas vigas VP

\begin{tabular}{|c|c|c|c|c|c|c|c|}
\hline \multirow[t]{2}{*}{ Série } & Viga & Tipo de fibra & Taxa & $\mathbf{f}_{\mathrm{cj}}$ & $\mathbf{f}_{\mathbf{t j}}$ & $\mathbf{f}_{\mathrm{cj}}$ & $\mathbf{f}_{\mathrm{tj}}$ \\
\hline & & & & \multicolumn{2}{|c|}{ (substrato) } & \multicolumn{2}{|c|}{ (reforço) } \\
\hline \multirow{5}{*}{1} & VR1 & - & $0 \%$ & 35,20 & 3,16 & 51,32 & 3,17 \\
\hline & VP1-1 & $\mathrm{RC}-65 / 35 \mathrm{BN}$ & $1 \%$ & 41,24 & 3,45 & 47,07 & 4,68 \\
\hline & VP1-2 & $\mathrm{RC}-65 / 35 \mathrm{BN}$ & $2 \%$ & 41,24 & 3,45 & 46,91 & 4,71 \\
\hline & VP2-1 & $\mathrm{RL}-45 / 30 \mathrm{BN}$ & $1 \%$ & 35,20 & 3,16 & 44,16 & 4,30 \\
\hline & VP2-2 & $\mathrm{RL}-45 / 30 \mathrm{BN}$ & $2 \%$ & 36,34 & 3,01 & 38,99 & 5,64 \\
\hline \multirow{7}{*}{2} & VR2 & - & $0 \%$ & 22.4 & 1.36 & - & - \\
\hline & VP3-0,5 & $\mathrm{RC}-65 / 35 \mathrm{BN}$ & $0,5 \%$ & 15.7 & 1.4 & - & - \\
\hline & VP3-1 & $\mathrm{RC}-65 / 35 \mathrm{BN}$ & $1 \%$ & 16.6 & 1.58 & - & - \\
\hline & VP3-2 & $\mathrm{RC}-65 / 35 \mathrm{BN}$ & $2 \%$ & 13.8 & 1.69 & - & - \\
\hline & VP4-0,5 & $\mathrm{RL}-45 / 30 \mathrm{BN}$ & $0,5 \%$ & 18.4 & 1.89 & - & - \\
\hline & VP4-1 & $\mathrm{RL}-45 / 30 \mathrm{BN}$ & $1 \%$ & 16.7 & 1.71 & - & - \\
\hline & VP4-2 & $\mathrm{RL}-45 / 30 \mathrm{BN}$ & $2 \%$ & 20.9 & 3.41 & - & - \\
\hline
\end{tabular}

As propriedades mecânicas foram determinadas em corpos-de-prova cilíndricos de $10 \mathrm{~cm}$ x $20 \mathrm{~cm}$ ensaiados à compressão axial simples e à tração por compressão diametral. Entretanto os valores apresentados foram minorados 5\% em função do efeito escala.

Tabela 4.6 - Características das armaduras usadas nas vigas VP (série 2)

\begin{tabular}{c|c|c|c|c|c|c}
\hline \hline Série & $\phi(\mathrm{mm})$ & Armadura & Tipo de aço & $\mathrm{f}_{\mathrm{y}}(\mathrm{MPa})$ & $\mathrm{f}_{\mathrm{u}}(\mathrm{MPa})$ & $\mathrm{E}_{\mathrm{s}}(\mathrm{MPa})$ \\
\hline \hline \multirow{3}{*}{1} & 6.3 & $\mathrm{~A}_{\mathrm{sw}}$ & CA-50 B & 623 & 823 & $205000^{*}$ \\
\cline { 2 - 7 } & 8 & $\mathrm{~A}_{\mathrm{sl} 1}$ & CA-50 A & 530 & 640 & $205000^{*}$ \\
\cline { 2 - 7 } & 16 & $\mathrm{~A}_{\mathrm{sl} 2}$ & CA-50 A & 493 & 800 & $205000^{*}$ \\
\hline \multirow{3}{*}{2} & 5.0 & $\mathrm{~A}_{\mathrm{sw}}$ & CA-60 B & 698 & 767 & 203133 \\
\cline { 2 - 7 } & 6.3 & $\mathrm{~A}_{\mathrm{sl1}}$ & CA-60 B & 634 & 827 & 210300 \\
\cline { 2 - 7 } & 10 & $\mathrm{~A}_{\mathrm{s} 12} \mathrm{e} \mathrm{A}_{\mathrm{sl}}$ & CA-50 A & 562 & 700 & 210300 \\
\hline \hline
\end{tabular}

$\mathrm{A}_{\mathrm{sw}}=$ Armadura dos estribos

$\mathrm{A}_{\mathrm{sl1}}=$ armadura longitudinal tracionada da primeira camada

$\mathrm{A}_{\mathrm{s} 12}=$ armadura longitudinal tracionada da segunda camada

* Valores estimados pois não puderam ser obtidos experimentalmente

\subsubsection{Moldagem das vigas e esquema de ensaio}

A moldagem foi feita com as vigas na posição invertida devido à dificuldade de se confeccionar fôrmas suspensas necessárias nos casos das peças reforçadas (série 1). Mesmo sabendo-se que esta direção de moldagem propicia o aumento da resistência ao cisalhamento da junta formada pelos concretos do reforço e do substrato, fato que não ocorreria se a moldagem fosse feita com a peça na posição normal tal como na prática, optou-se por realizá-la desta maneira porque a intenção 
não é verificar essa resistência e sim avaliar a eficiência do uso de um compósito na reconstrução do bordo tracionado estudando-se a interação fibra $x$ estribos. Portanto, ao realizar a moldagem desta maneira, conseguiu-se minimizar a interferência de outros fatores que não estão sendo estudados, tais como falhas de aderência na junta gerada pela exsudação da argamassa adicionada, nos parâmetros analisados. Acredita-se ainda que na prática, o efeito prejudicial da exsudação do material adicionado possa ser plenamente resolvido utilizando-se dosagens do material de reforço e técnicas de execução apropriadas, além de que a presença da armadura transversal cruzando a junta também ajuda a aumentar a resistência de aderência nessa superfície.

As vigas da série 1 (peças reforçadas) foram moldadas em duas etapas e as da série 2 (monolíticas) em uma única etapa. Na primeira etapa de moldagem da série 1, concretou-se a seção transversal correspondente ao substrato, escarificando-se esta superfície com um martelete pneumático e jatos de água sob pressão logo após a sua cura. A escarificação foi feita de maneira que a junta formada pela ligação substrato/reforço ficasse a $10 \mathrm{~cm}$ de altura do bordo mais tracionado (fundo da viga) conforme ilustra a Figura 4.9. Depois de 7 dias da moldagem do substrato retirou-se toda a poeira existente sobre ele, seguindo-se o seu umedecimento sem deixar poças de água aparente e se iniciou a segunda etapa de moldagem referente ao reforço. A cura foi feita com espumas umedecidas colocadas sobre a face exposta das vigas por 5 dias após cada uma das etapas de moldagem.

Nos ensaios das vigas da série 1 o carregamento foi aplicado por meio de incrementos de força usando um macaco hidráulico. Já nas vigas da série 2 aplicouse o carregamento por meio de incremento de deformação utilizando um atuador servo-hidráulico (marca INSTRON) que possibilitava obter o comportamento póspico das vigas ensaiadas traçando-se o ramo descendente da curva força $x$ deslocamento. Tais equipamentos estavam fixados em um pórtico de reação (ver Figura 4.9) possibilitando aplicar o carregamento sobre um perfil metálico de seção duplo I, biapoiado na face superior da viga. As reações do perfil metálico na viga geravam duas forças concentradas eqüidistante $50 \mathrm{~cm}$ de cada apoio para as vigas da série 1 e $36 \mathrm{~cm}$ de cada apoio para as da série 2. Em todos os ensaios, as 
deformações e os deslocamentos gerados pelo peso próprio das vigas foram descontados das leituras dos instrumentos de medição.

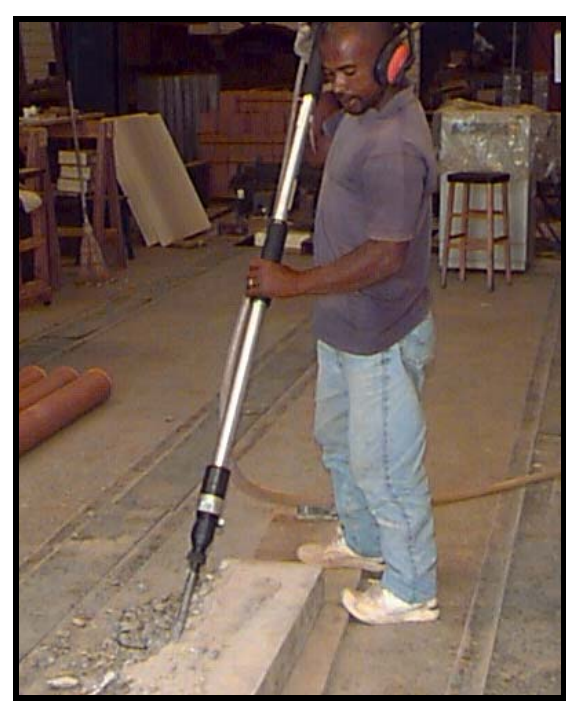

escarificação (série 1)

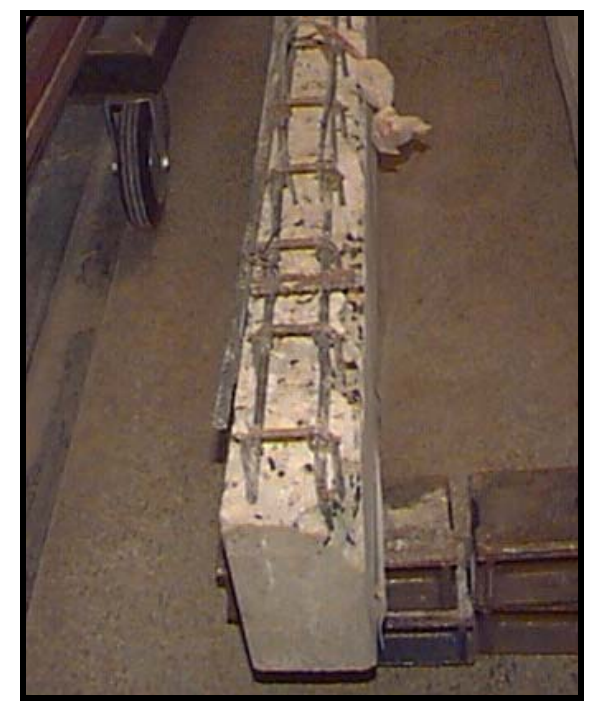

aspecto final da superfície (série 1)

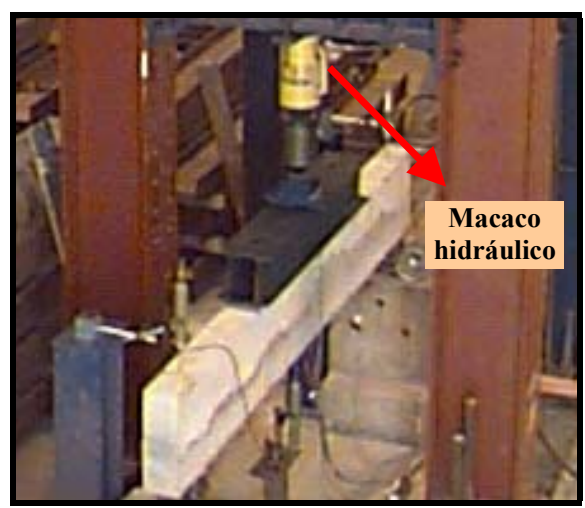

esquema de ensaio (série 1)

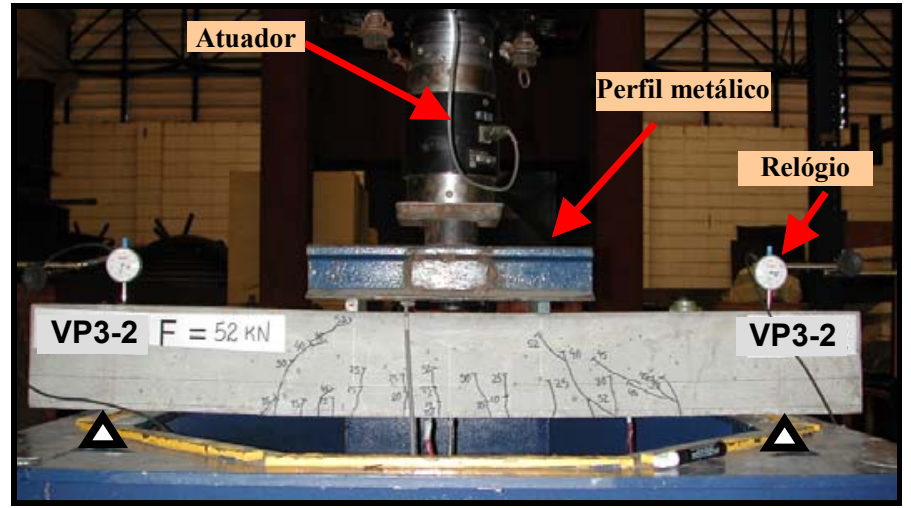

esquema de ensaio (série 2)

Figura 4.9 - Fotos da escarificação e do esquema de ensaio das vigas VP

\subsubsection{Apresentação e análise dos resultados}

\section{a) Esquema de fissuração e tipo de ruptura}

Pela Figura 4.10 percebe-se que nas vigas VP surgiram tanto fissuras de flexão quanto de cisalhamento. Entretanto, as que indicaram que a peça estava próxima de atingir sua capacidade portante foram as fissuras horizontais que 
surgiram devido ao escorregamento relativo entre as barras de aço da primeira e segunda camada da armadura longitudinal em função da ausência de confinamento gerado pela falta de estribos neste local.
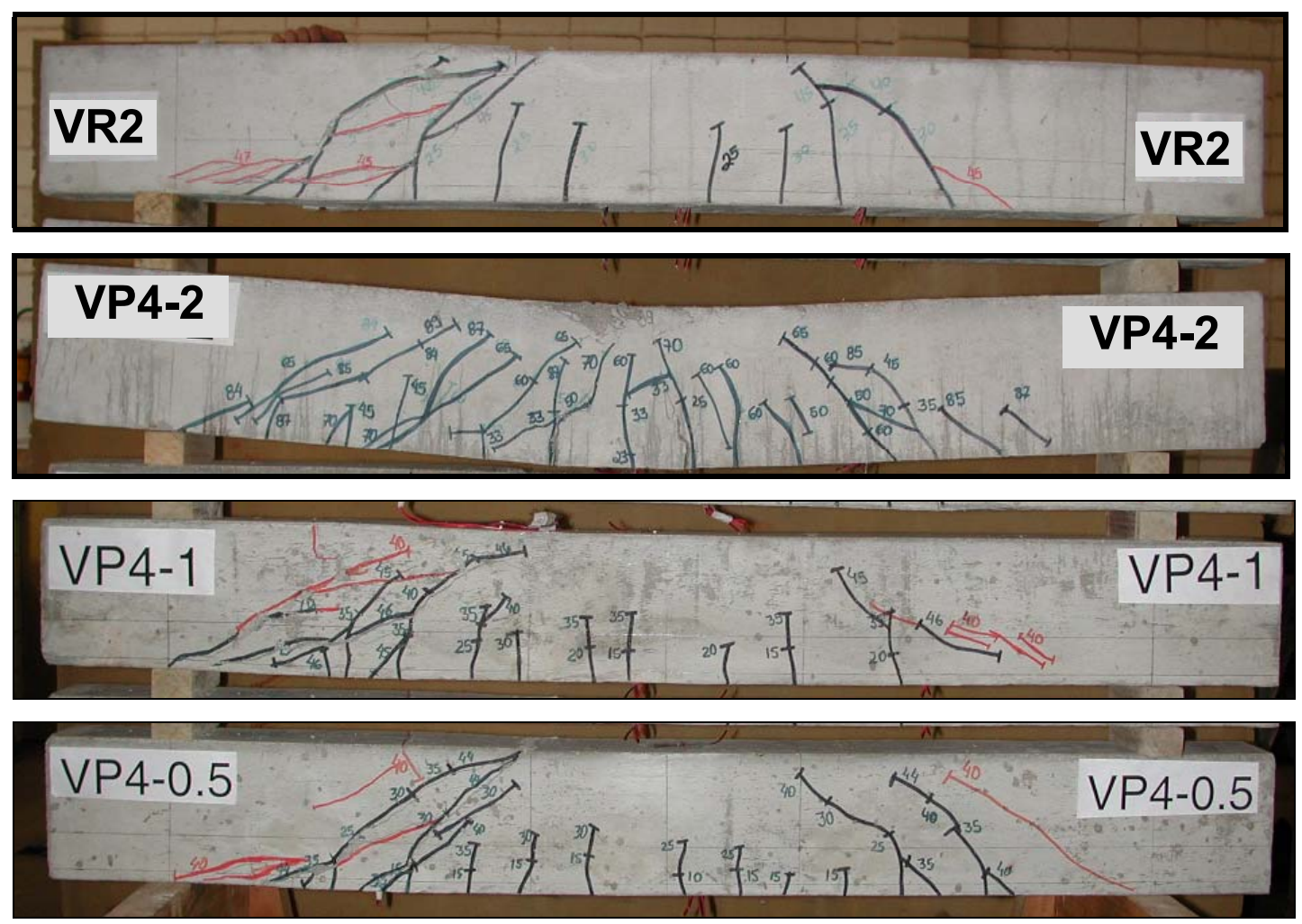

(a) vista geral da fissuração de algumas vigas da série 2
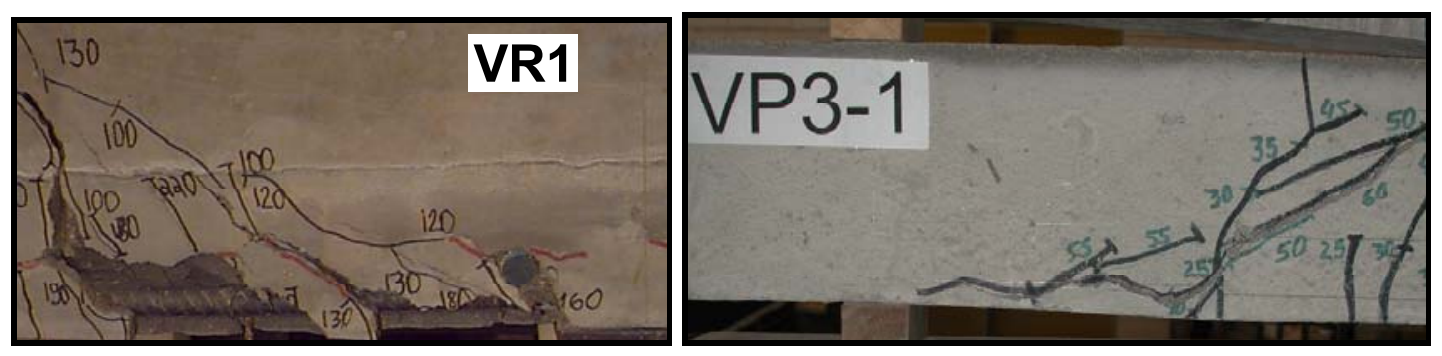

(b) Detalhes da ruptura de vigas da série 1 e 2

Figura 4.10 - Esquema de fissuração e ruptura das vigas tipo VP

\section{b) Efeito das fibras de aco na resistência das vigas VP}

Na Tabela 4.7 encontra-se a força de ruptura das peças ensaiadas, o ganho de resistência em função da taxa de fibras de aço utilizada no material compósito e o tipo de ruptura das vigas observado nos ensaios experimentais. 
Tabela 4.7 - Forças de Ruptura e tipo de ruptura das vigas VP

\begin{tabular}{l|l|c|c|c|c}
\hline \hline Série & Vigas & Fibra & $\mathbf{F}_{\mathbf{u}}(\mathbf{k N})$ & $\mathbf{V} / \mathbf{V}_{\mathbf{o}}$ & Tipo de Ruptura \\
\hline \hline \multirow{4}{*}{1} & VR1 & - & 230 & 1,00 & Cisalhamento horizontal \\
\cline { 2 - 6 } & VP1-1 & RC 65/35 & 267 & 1,16 & Cisalhamento horizontal \\
\cline { 2 - 6 } & VP1-2 & RC 65/35 & 283 & 1,23 & $\begin{array}{c}\text { deformação plástica excessiva da armadura tracionada e } \\
\text { esmagamento do concreto comprimido }\end{array}$ \\
\cline { 2 - 7 } & VP2-1 & RL 45/30 & 287 & 1,25 & $\begin{array}{c}\text { deformação plástica excessiva da armadura tracionada e } \\
\text { esmagamento do concreto comprimido }\end{array}$ \\
\cline { 2 - 7 } & VP2-2 & RL 45/30 & 287 & 1,25 & $\begin{array}{c}\text { deformaça plástica excessiva da armadura tracionada e } \\
\text { esmagamento do concreto comprimido }\end{array}$ \\
\hline \multirow{4}{*}{2} & VR2 & - & 47.8 & 1,00 & Cisalhamento horizontal \\
\cline { 2 - 6 } & VP3-0.5 & RC 65/35 & 44.5 & 0,93 & Cisalhamento horizontal \\
\cline { 2 - 6 } & VP3-1 & RC 65/35 & 46.4 & 0,97 & Cisalhamento horizontal \\
\cline { 2 - 6 } & VP3-2 & RC 65/35 & 51.5 & 1,08 & Cisalhamento horizontal \\
\cline { 2 - 6 } & VP4-0.5 & RL 45/30 & 58.0 & 1,21 & Cisalhamento horizontal \\
\cline { 2 - 6 } & VP4-1 & RL 45/30 & 64.2 & 1,34 & Cisalhamento horizontal \\
\cline { 2 - 6 } & VP4-2 & RL 45/30 & 89.7 & 1,88 & $\begin{array}{c}\text { Início do escoamento da armadura tracionada } \\
\text { seguido de cisalhamento horizontal }\end{array}$ \\
\hline \hline
\end{tabular}

Como era de se esperar, a capacidade portante quando a ruptura ocorria por cisalhamento horizontal era menor que a capacidade portante da peça quando a ruptura ocorria por deformação plástica excessiva da armadura tracionada, sendo que esta última correspondia à resistência máxima que tais vigas podiam suportar em função do dimensionamento adotado. Por este motivo, não foi possível utilizar a capacidade portante das vigas VP1-2, VP2-1 e VP2-2 da série 1 para avaliar o ganho de resistência em função do aumento da taxa de fibra incorporada à argamassa do reforço. Mesmo assim, achou-se importante traçar o gráfico da Figura 4.11, pois ele mostra que existe um limite máximo a partir do qual o aumento da taxa de fibra não aumenta mais a capacidade portante da peça, uma vez que se altera o modo de ruptura da peça.

Analisando, na Figura 4.11, a curva do comportamento das vigas com fibra RL 45/30, pode-se dizer que, caso a ruptura destas vigas não tivesse ocorrido por deformação plástica excessiva da armadura tracionada, então o coeficiente angular $\beta$ 
seria maior que o indicado no gráfico. Já na curva das vigas que utilizaram a fibra RC 65/35, o coeficiente angular está bem representado pelo valor $\alpha$ obtido no primeiro trecho desta curva, uma vez que a ruptura da viga com $1 \%$ de fibras $\mathrm{RC}$ $65 / 35$ ocorreu por cisalhamento horizontal. Sendo $\beta$ maior que $\alpha$, pode-se dizer que aparentemente a fibra RL 45/30 foi mais eficiente que a RC 65/35.

Para confirmar este comportamento foi realizada a série 2 de ensaios, na qual se tentou fazer com que as peças rompessem somente por cisalhamento horizontal. Para isso foi utilizada uma argamassa de resistência menor e uma maior variação no teor de fibras analisado. Pelos resultados da série 2 (ver gráfico da Figura 4.12) observou-se que o aumento da resistência em função do aumento da taxa de fibras é praticamente linear e que realmente a fibra RL $45 / 30$ foi mais eficiente que a RC $65 / 35$ em função das inclinações das retas obtidas ( $\beta_{2}$ maior que $\left.\alpha_{2}\right)$.

Por causa da grande diferença entre as resistências à compressão axial $\left(f_{c j}\right)$ e à tração indireta $\left(\mathrm{f}_{\mathrm{tj}}\right)$ das vigas da série 2 , o gráfico da Figura 4.12 foi construído dividindo-se o esforço cortante $\mathrm{V}$ suportado por cada viga pela raiz quadrada da resistência à compressão axial. Com este procedimento pretendia-se eliminar, pelo menos parcialmente, o efeito da variabilidade da resistência do concreto na capacidade portante das peças quando a ruptura ocorria por cisalhamento horizontal. Isso não foi feito no gráfico da Figura 4.11 porque a maioria das vigas da série 1 rompeu por deformação plástica excessiva da armadura tracionada e tal modo de ruptura não sofre tanta influência da variação da resistência à compressão do concreto.

Sendo assim, realmente se confirma que a introdução de fibras de aço na argamassa usada na reconstituição do banzo tracionado de vigas reforçadas pela Técnica de reforço $\mathrm{n}^{\mathrm{o}} 1$ afeta os mecanismos resistentes mobilizados neste local, pois é possível aumentar a resistência e até alterar o modo de ruptura da peça em função do tipo e da taxa de fibras utilizada.

O programa experimental realizado aqui não permitiu que se identificasse a taxa de fibras ideal, mas apenas o tipo de fibra que seria mais eficiente no combate ao cisalhamento horizontal. Por este motivo é importante desenvolver um método de ensaio específico que permita determinar qual o teor de fibra mais indicado, uma vez que dependendo das características da peça a ser reforçada, um aumento da taxa de 
fibras nem sempre representará um aumento da capacidade portante do elemento estrutural.

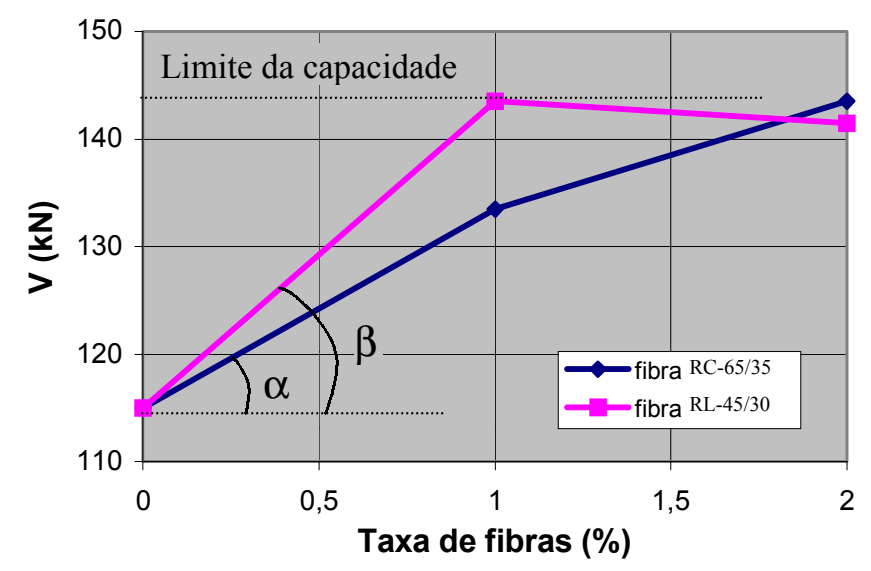

Figura 4.11 - Ganho de resistência em função do volume e tipo de fibra - série 1

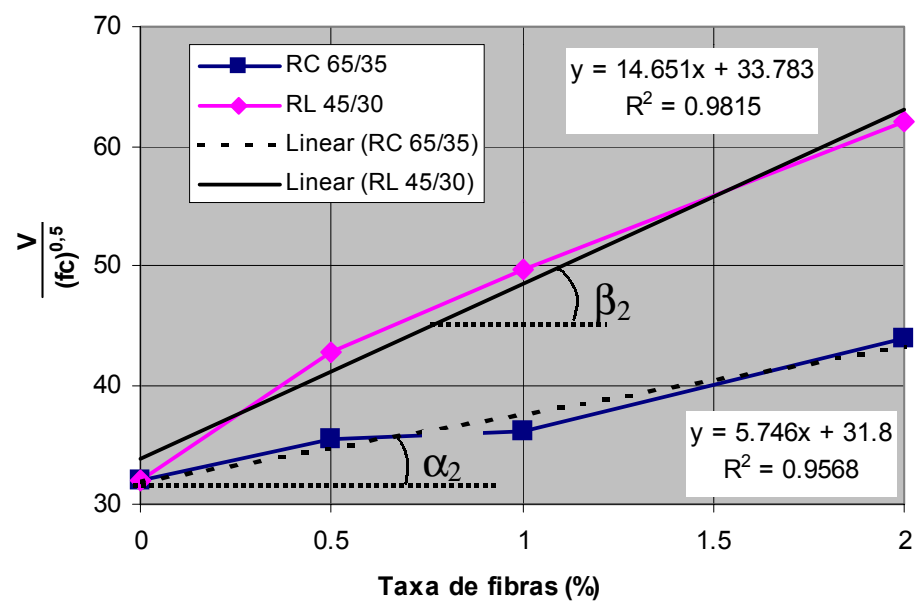

Figura 4.12 - Ganho de resistência em função do volume e tipo de fibra - série 2

\section{c) Flechas}

Analisando a evolução das flechas nas vigas da série 1 (ver Figura 4.13a) percebe-se que todas apresentaram praticamente a mesma rigidez. Isso indica que o aumento no volume de fibras praticamente não altera a rigidez do elemento estrutural. Além disso, as maiores flechas foram observadas para as vigas que romperam por deformação plástica excessiva da armadura longitudinal conforme previsto. 
Na série 2 (ver Figura 4.13b) percebeu-se uma alteração na rigidez das vigas em função do tipo e da taxa de fibras usadas na argamassa. Isso provavelmente ocorreu porque ao contrário das vigas da série 1 , nas quais a argamassa com fibra de aço foi adicionada apenas ao bordo tracionado, as vigas da série 2 foram confeccionadas usando a argamassa com fibras de aço ao longo de toda seção transversal do elemento.

Quanto ao efeito da taxa de fibras na rigidez das peças, observou-se que quanto maior a taxa de fibra, maior a rigidez do elemento. Em relação ao efeito do tipo de fibra na rigidez, aparentemente a fibra RL-45-30 proporcionou um aumento maior que a fibra RC-65-35.

Convém esclarecer que houve um descarregamento inesperado antes de se atingir a ruptura da viga VP4-2, sendo necessário recarregá-la para finalizar o ensaio. Isso provavelmente alterou a inclinação da curva das flechas desta viga e sua rigidez não deve ser adotada como parâmetro comparativo.

Como as vigas da série 2 foram ensaiadas aplicando-se um carregamento por meio de incrementos de deformação, foi possível avaliar a ductilidade pós-ruptura destas peças em função do tipo e taxa de fibras de aço utilizada.

Como todas as vigas eram armadas, inclusive a VR-2, todas apresentaram uma certa ductilidade após a ruptura, entretanto esta ductilidade se alterava com o tipo e taxa de fibras utilizada. Comparando a ductilidade verificou-se que as vigas com fibras de aço RL-45-30, apesar de resistirem a um carregamento maior, apresentaram uma perda de carga bem mais acentuada após a ruptura do que as vigas nas quais se usou fibras de aço RC-65-35. Isso sugere que apesar da fibra RL-45/30 ser mais eficiente no combate à ruptura por cisalhamento horizontal, esta é menos eficiente na garantia da ductilidade da peça pós-ruptura. 


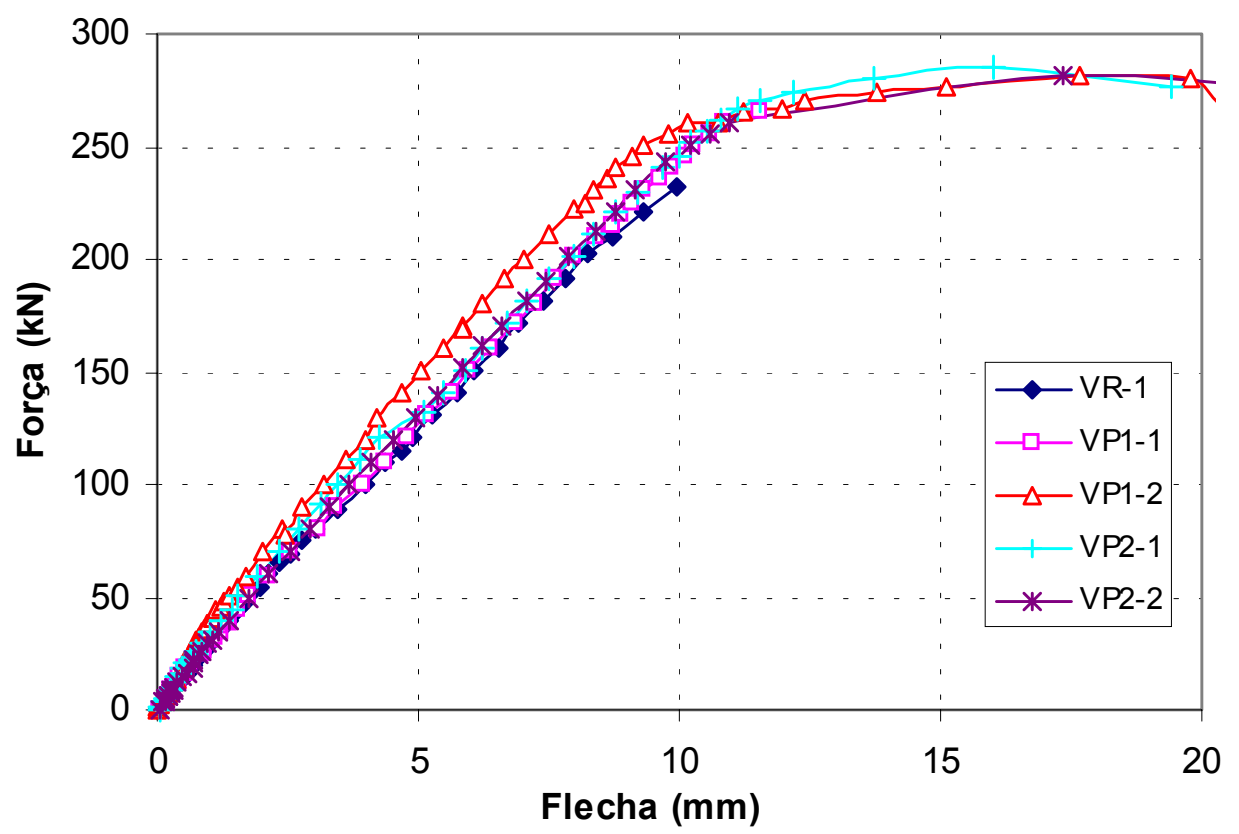

a) Série 1

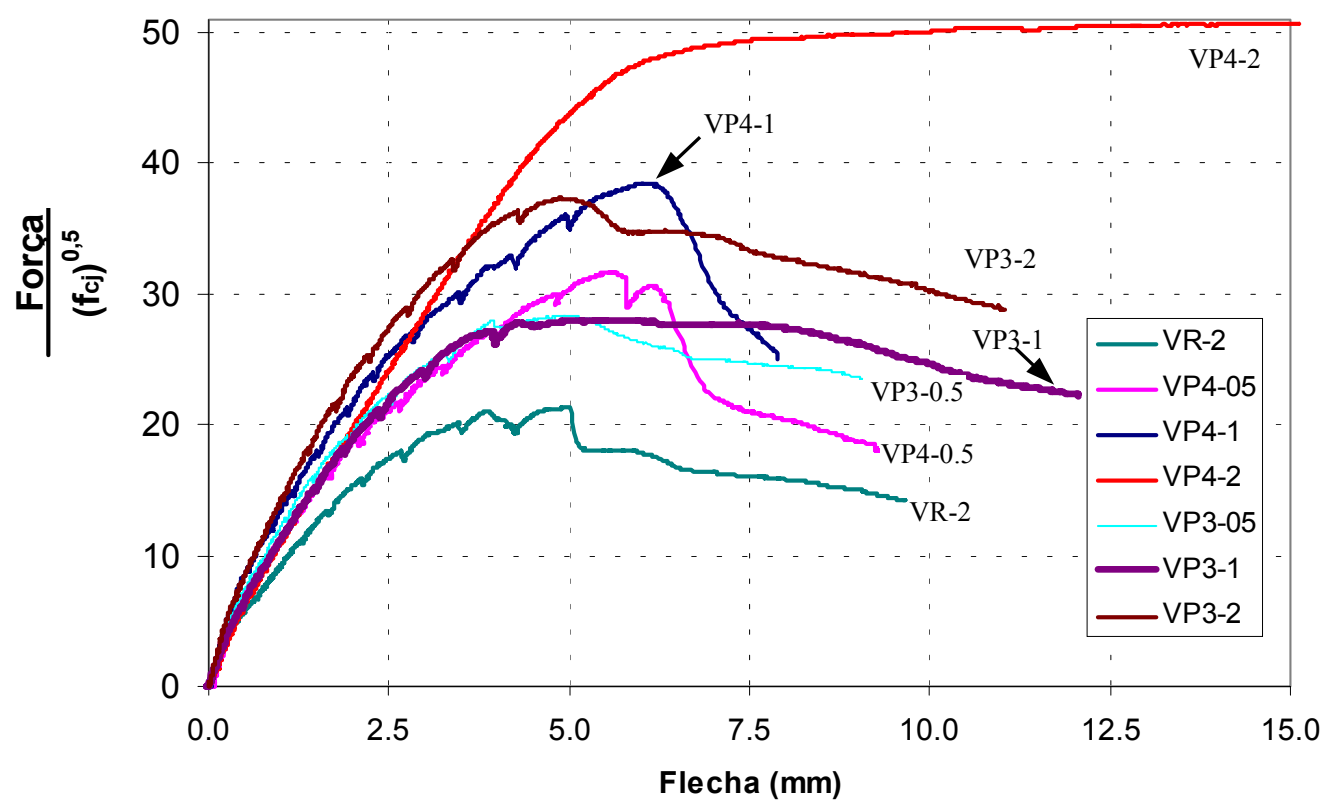

b) Série 2

Figura 4.13 - Gráficos das flechas nas vigas da série 1 e série 2 


\section{d) Deformação do concreto comprimido e da armadura longitudinal tracionada}

As Figuras 4.14 e 4.15 apresentam os gráficos da deformação do concreto no bordo mais comprimido e das barras de aço tracionadas em função do carregamento aplicado respectivamente para as vigas da série 1 e 2 .

Analisando as deformações destes materiais confirma-se o tipo de ruptura (ruptura por cisalhamento horizontal ou deformação plástica excessiva da armadura e esmagamento do concreto) observado nas vigas e descrito na Tabela 4.7. Confirmase ainda que o uso de uma argamassa reforçada com fibras de aço realmente interfere nos mecanismos resistentes mobilizados durante a tendência de deslizamento relativo entre as barras de aço tracionadas da primeira e segunda camada, alterando a resistência ao cisalhamento horizontal desta região. Essa resistência depende da taxa e do tipo de fibra utilizada e pode ser aumentada até um certo limite, a partir do qual o modo de ruptura da peça é alterado.

\section{e) Resistência ao cisalhamento da junta das vigas reforçadas (somente série 1)}

Conforme o previsto, nas vigas ensaiadas da série $1^{1}$ não surgiram fissuras na ligação entre o substrato e o reforço que indicassem perda de aderência entre estes materiais. Sendo assim, pode-se dizer que a resistência da junta foi suficiente para resistir às solicitações tangenciais de cisalhamento geradas pelo carregamento aplicado, permitindo a transferência total das tensões ao longo da junta até a peça atingir sua ruptura não afetando, portanto a capacidade portante do elemento estrutural.

Para que estas vigas não rompessem prematuramente por falhas na junta, calculou-se, em função da capacidade portante teórica, as tensões tangenciais solicitantes na junta mantendo-as menores que as tensões tangenciais resistentes mediante a adoção de uma armadura transversal adequada, seguindo as recomendações apresentadas no item 3.2. Assim pode-se afirmar que se a junta estiver em uma região cortada por estribos e se a área de aço destes estribos for adequada, não há risco de ruptura neste local, pois os ramos do estribo funcionam como armadura de costura entre as duas partes.

\footnotetext{
${ }^{1}$ Esta análise não foi feita para as vigas da série 2, por serem peças monolíticas .
} 

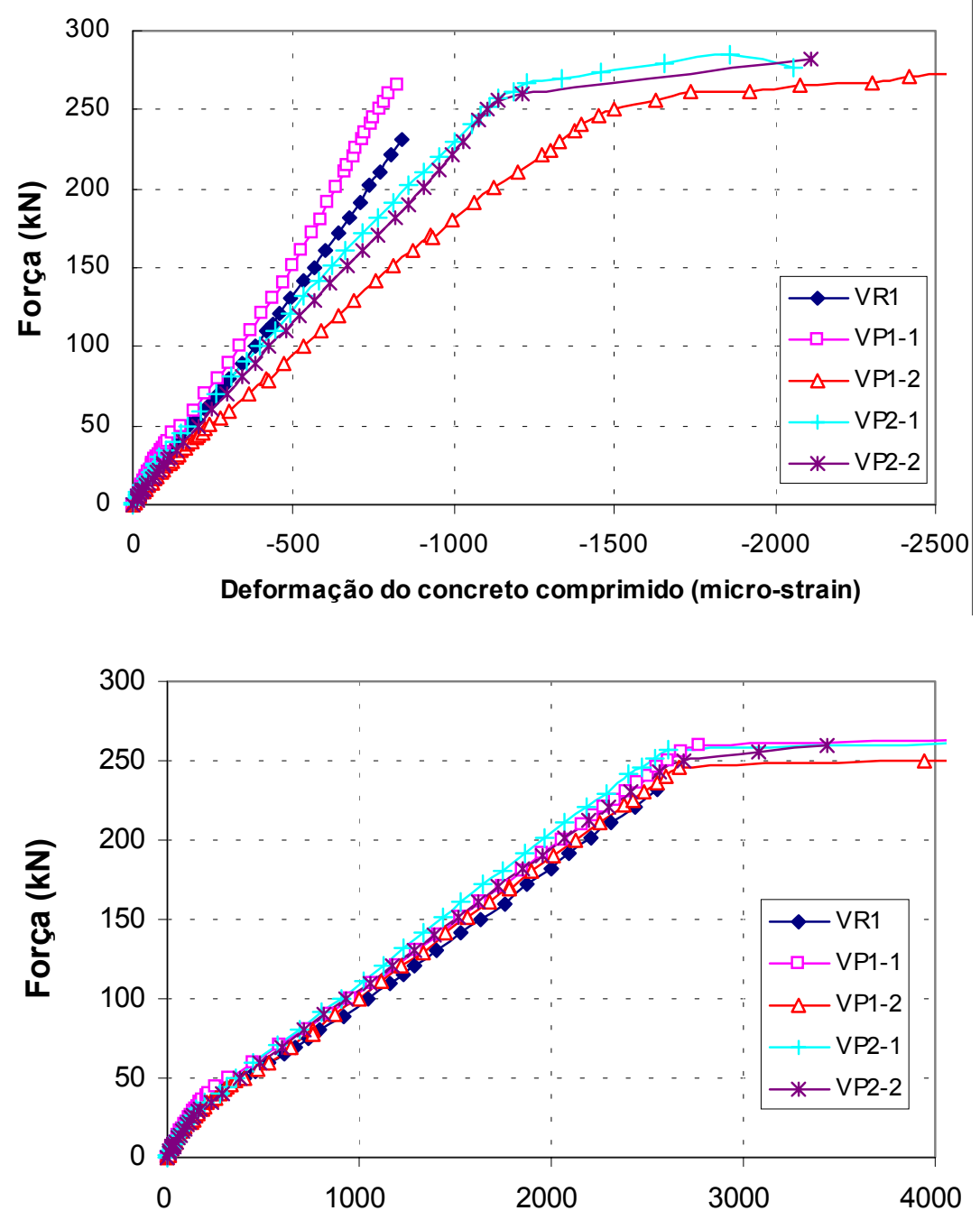

Deformação da armadura tracionada - $A_{s 11}$ (micro-strain)

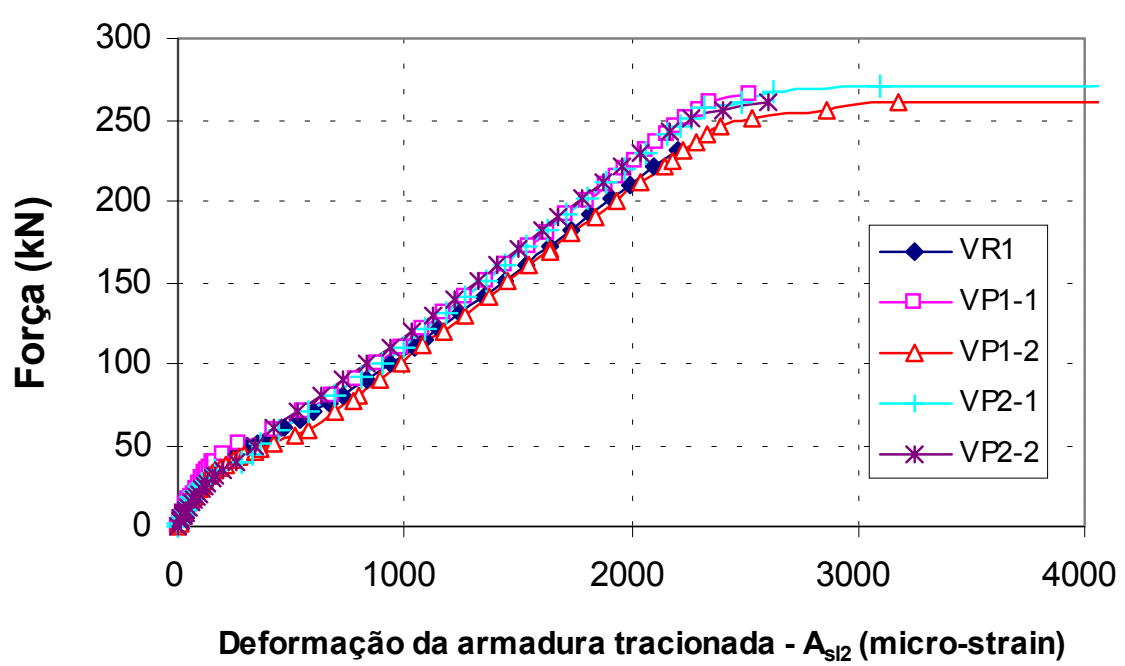

Figura 4.14 - Deformação do concreto e das barras de aço (vigas da série 1) 


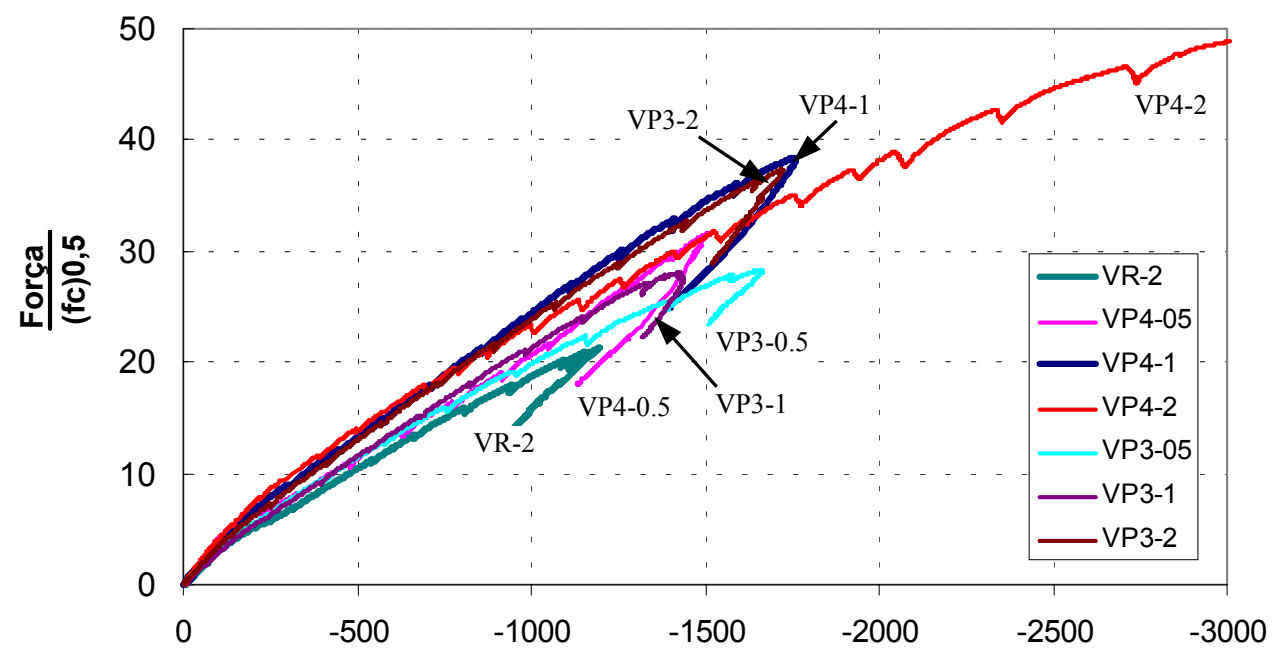

Deformação do concreto comprimido (micro-strain)
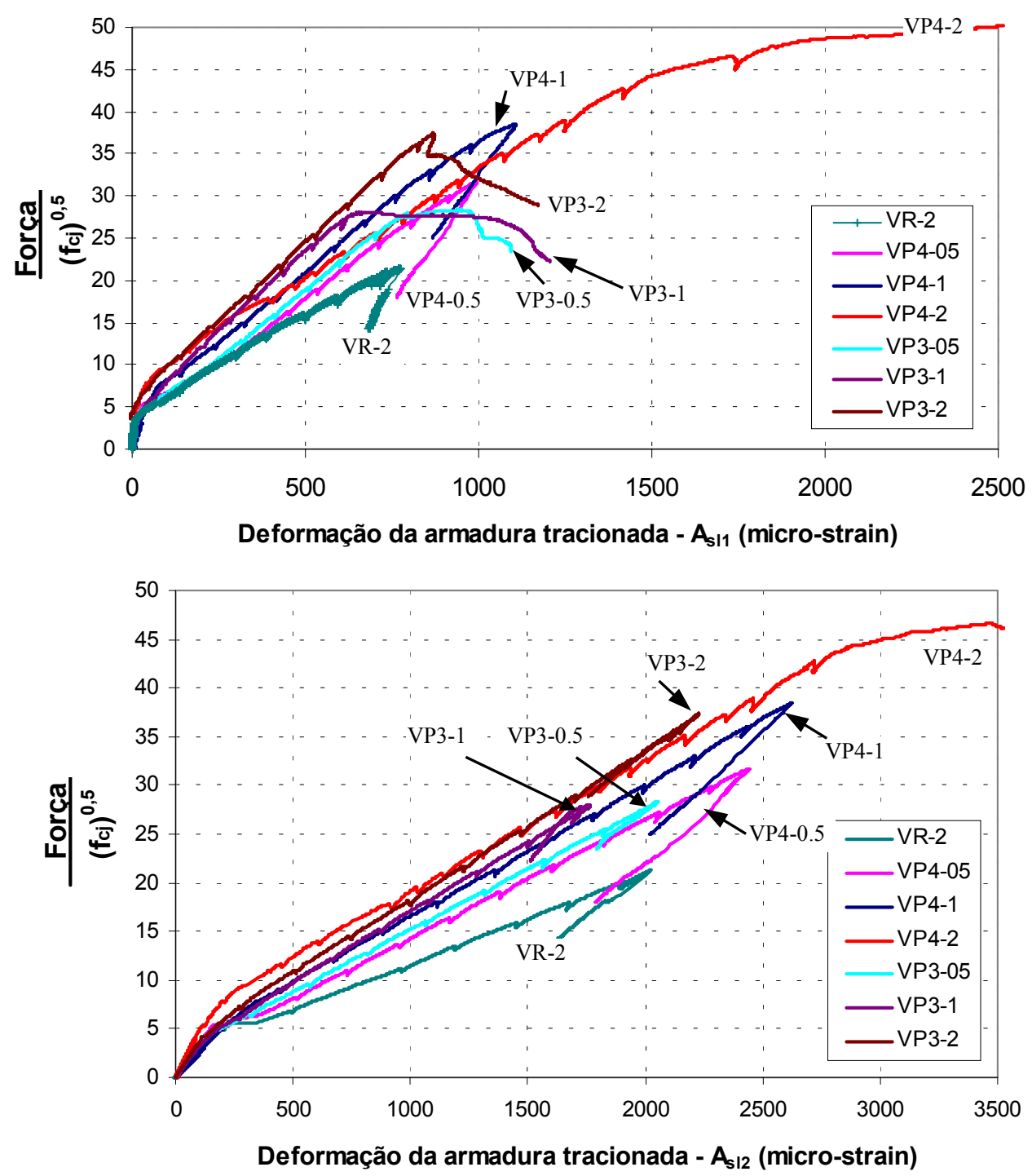

Figura 4.15 - Deformação do concreto e das barras de aço (vigas da série 2) 


\section{3 - Conclusões parciais dos ensaios complementares}

\section{Em relação ao estudo dos prismas pode-se concluir que:}

a) A estimativa da resistência à tração de um material compósito por meio de ensaios de tração indireta (ensaio de tração por compressão diametral) não é adequada, pois são mais suscetíveis a erros de execução e moldagem. Além disso, neste tipo de ensaio as solicitações aplicadas no compósito são bem diferentes daquelas que estariam atuando neste material nas aplicações práticas;

b) As variabilidades nas resistências à compressão e à tração indireta foram influenciadas pela resistência da matriz e pelo fator de forma da fibra. Quanto maior o teor de fibras e o fator de forma, menor a trabalhabilidade do material dificultando sua compactação e elevando o índice de vazios. A adição de sílica ativa pode diminuir o efeito da incorporação de vazios, pois elevam o teor de finos incorporados à matriz;

c) $\mathrm{O}$ uso do concreto com fibras de aço (CFA) pode ser uma alternativa interessante no campo de reabilitação de estruturas de concreto, pois sua adição ao concreto comum melhora algumas propriedades desse material (por ex.: a tenacidade, a retenção à propagação de fissuras e acréscimo da resistência à tração na flexão) garantindo assim um maior período de vida útil da estrutura. Isto ocorre tanto para solicitações estáticas como para solicitações dinâmicas, conferindo ao reparo maior ductilidade e durabilidade. Além disso, como o CFA tem propriedades mecânicas (resistência à compressão, resistência à tração e módulo de elasticidade) similares ao concreto convencional, esse compósito é compatível para ser usado como material de reparo/reforço;

d) Estudos realizados até o momento indicam que a influência das fibras de aço sobre a resistência à flexão de concretos e argamassas é muito maior do que sobre a resistência à tração e à compressão direta, fato que foi confirmado pelos ensaios realizados neste trabalho. O aumento da resistência à flexão pode chegar até a $100 \%$ sendo influenciado pelo volume e pelo fator de forma das fibras. Menores fatores de forma geralmente fornecem aumentos maiores da resistência à flexão, fato confirmado nos ensaios dos prismas porque foi a fibra com menor fator de forma (RL 45/30) que forneceu maiores ganhos de resistências à tração 
na flexão para ambas as séries. Para garantir a tenacidade deve-se utilizar fibras com ganchos nas extremidades já que isso melhora as características de aderência e ancoragem, aumentando a tenacidade do compósito.

e) Para compósitos confeccionados com matriz de resistência à compressão normal, a capacidade portante está próxima de ser atingida após o surgimento da primeira fissura. Já para compósitos confeccionados com uma matriz de resistência à compressão elevada, a força máxima suportada pelo prisma ainda consegue ter um ganho razoável em relação à força de início de fissuração;

f) Para estipular o traço do compósito a ser utilizado como material de reforço deve-se realizar um estudo cuidadoso para adequação dos traços de maneira a viabilizar sua correta aplicação. A exigência de um elevado nível de abatimento da argamassa de reforço entra em conflito com a necessidade de se trabalhar com valores reduzidos de relação água/materiais secos e relação água/cimento. Tal necessidade decorre do risco de segregação da fibra e exsudação do concreto que isso representa. Para minimizar o efeito da exsudação pode-se utilizar um maior conteúdo de finos que retenha a água tal como o uso de sílica ativa;

\section{Em relação ao estudo das vigas preliminares pode-se concluir que:}

a) É possível substituir os estribos complementares, que seriam necessários durante a reabilitação de peças pela Técnica de Reforço $\mathrm{n}^{\mathrm{o}} 1$, por uma argamassa reforçada com fibras de aço para evitar a ruptura por deslizamento entre as camadas da armadura tracionada devido à falta de confinamento neste local. Tal substituição não evita a ruptura por esforço cortante da seção, portanto, a verificação quanto a este tipo de solicitação sempre deve ser feita antes de realizar um reforço estrutural. Isso não foi feito nas vigas ensaiadas neste estudo porque a armadura transversal já estava superestimada, uma vez que se pretendia estudar somente o reforço devido à ação do momento fletor;

b) Apesar dos ensaios preliminares permitirem a determinação do tipo de fibra de aço mais eficiente na transmissão de esforços, ainda não foi possível desenvolver um processo capaz de fornecer dados mais precisos sobre o teor de fibras adequado a ser adicionado à argamassa do reforço em função das características da peça a ser reforçada. Para desenvolver tal processo é preciso 
realizar estudos paramétricos no qual se avaliem os efeitos da variação da taxa de armadura longitudinal das peças bem como a bitola destas barras, dos volumes e tipos de fibras, das resistências do concreto, da distância entre as camadas das armaduras tracionadas e do tamanho do cobrimento na resistência ao cisalhamento horizontal.

\section{Em relação ao material a ser usado no reforço das vigas VFT:}

Analisando tanto os resultados dos ensaios de flexão em prismas quanto os resultados das vigas preliminares VP, optou-se por usar na reconstituição do bordo tracionado das vigas VFT, uma argamassa de alta resistência com adição de $2 \%$ de fibra de aço do tipo RL 45/30.

O uso de uma argamassa de alta resistência - confeccionada utilizando cimento de alta resistência inicial e sílica ativa - foi escolhido por melhorar as condições de aderência do material de reforço ao substrato, aumentando conseqüentemente a resistência da junta às tensões tangenciais, e por melhorar as condições de aderência entre as barras de aço e o concreto que as envolve, minimizando o surgimento de microfissuras neste local e conseqüentemente aumentando a resistência ao cisalhamento horizontal. Além disso, o uso de uma matriz de alta resistência aumenta a resistência à tração na flexão do material compósito, diminuindo a probabilidade de ocorrer uma ruptura prematura da peça por cisalhamento horizontal.

Já a fibra RL-45/30 foi escolhida por ser a que se mostrou mais eficiente no combate ao deslizamento relativo entre as duas camadas de armadura tracionada devido à falta de confinamento no local.

Apesar de não ter sido possível desenvolver um processo que indicasse qual o teor de fibras adequado, mas apenas que indicasse qual o tipo de fibra mais eficiente, adotou-se um teor de $2 \%$. Este teor foi escolhido porque, apesar de não se ter dados que garantam que tal taxa será suficiente para evitar a ruptura por cisalhamento horizontal, deve-se considerar que o uso de volume de fibra muito elevado pode dificultar a compactação do material e trazer prejuízos para a resistência mecânica do material compósito, o que conseqüentemente também prejudicaria a resistência ao cisalhamento horizontal ao invés de beneficiá-la. 


\section{5 - Vigas $T$ reforçadas no bordo tracionado (Técnica de Reforço $\left.n^{0} 1\right)$}

\subsection{Características das vigas (dimensões, detalhamento e instrumentação)}

Conforme dito no item 2.3, foram ensaiadas duas vigas do tipo VFT (Viga reforçada à Flexão no bordo Tracionado), submetidas a um pré-carregamento e com parte da armadura longitudinal pré-existente ${ }^{1}$ exposta durante a execução do reforço. A diferença entre elas está descrita na Tabela 5.1 e as dimensões, o detalhamento das armaduras e a instrumentação utilizada estão na Figura 5.1.

Tabela 5.1 - Características das vigas $\mathrm{T}$ ensaiadas no bordo tracionado

\begin{tabular}{c|l}
\hline \hline Viga & \multicolumn{1}{c}{ Característica do reforço executado } \\
\hline \hline \multirow{2}{*}{ VFT-1 } & $\begin{array}{l}\text { Viga VO-1 submetida a um pré-carregamento de 30 kN durante execução do reforço. } \\
\text { A aplicação do carregamento responsável por gerar a pré-danificação na VO-1 foi feita } \\
\text { com a armadura longitudinal pré-existente exposta. }\end{array}$ \\
\hline VFT-2 & $\begin{array}{l}\text { Viga VO-2 submetida a um pré-carregamento de } 55 \mathrm{kN} \text { durante execução do reforço. } \\
\text { A aplicação do carregamento responsável por gerar a pré-danificação na VO-2 foi feita } \\
\text { antes de deixar a armadura longitudinal pré-existente exposta }\end{array}$ \\
\hline \hline
\end{tabular}

Como o comportamento das vigas VFT foi comparado com o das vigas ensaiadas por REIS (1998) (ver item 2.2.2.3), ambas tiveram características geométricas e detalhamentos semelhantes. Entretanto, para que se pudesse reforçar as vigas VFT sem descarregá-las foi preciso fazer algumas modificações em relação às peças de REIS (1998) tais como:

\footnotetext{
${ }^{1}$ Armadura longitudinal pré-existente - são as barras de aço existentes nas vigas originais (VO-1 e VO-2) e que correspondem às barras de aço da primeira camada das vigas reforçadas VFT.
} 
a) alteração do comprimento total da viga, que passou de $320 \mathrm{~cm}$ para $340 \mathrm{~cm}$, em função da necessidade de se ter blocos de concreto nas extremidades da peça para servirem de apoio enquanto se aplicava o pré-carregamento e se executava o reforço. Para não haver ruptura prematura neste bloco, colocou-se uma armadura de fretagem no local;

b) aumento da ancoragem da armadura longitudinal pré-existente na viga soldandose barras de aço transversais a ela para não ocorrer ruptura prematura por falta de ancoragem causada pela exposição destas barras de aço durante a execução do reforço. Tentou também melhorar a ancoragem da armadura adicionada, uma vez que estas não poderiam se estender até os apoios, mediante a utilização de ganchos nas extremidades dos ferros;

c) alteração do tipo e da taxa de fibras de aço incorporadas à argamassa do reforço. Estas alterações foram feitas em função dos resultados obtidos nos ensaios complementares descritos no Capítulo 4 que foram realizados para tentar definir com maior critério o uso das fibras na substituição dos estribos. Pelos resultados de tais ensaios optou-se pelo uso da fibra de aço RL-45/30 a uma taxa de $2 \%$.

d) Modificação da altura do bordo tracionado reconstituído com argamassa de alta resistência com adição de fibras de aço. No reforço feito por REIS (1998) adicionou-se uma camada de argamassa de espessura constante de aproximadamente $10 \mathrm{~cm}$ ao longo de todo bordo tracionado da viga. Já nas vigas VFT, a profundidade de reconstituição do bordo tracionado foi variável, sendo de aproximadamente $12 \mathrm{~cm}$ para os trechos submetidos a esforço cortante, e de aproximadamente $5 \mathrm{~cm}$ para o trecho central que estava sujeito apenas ao momento fletor (ver Figura 5.1).

Todavia, teve-se o cuidado de manter o mesmo esquema estático usado por REIS (1998), para garantir os mesmos esforços solicitantes em função do valor do carregamento aplicado. 

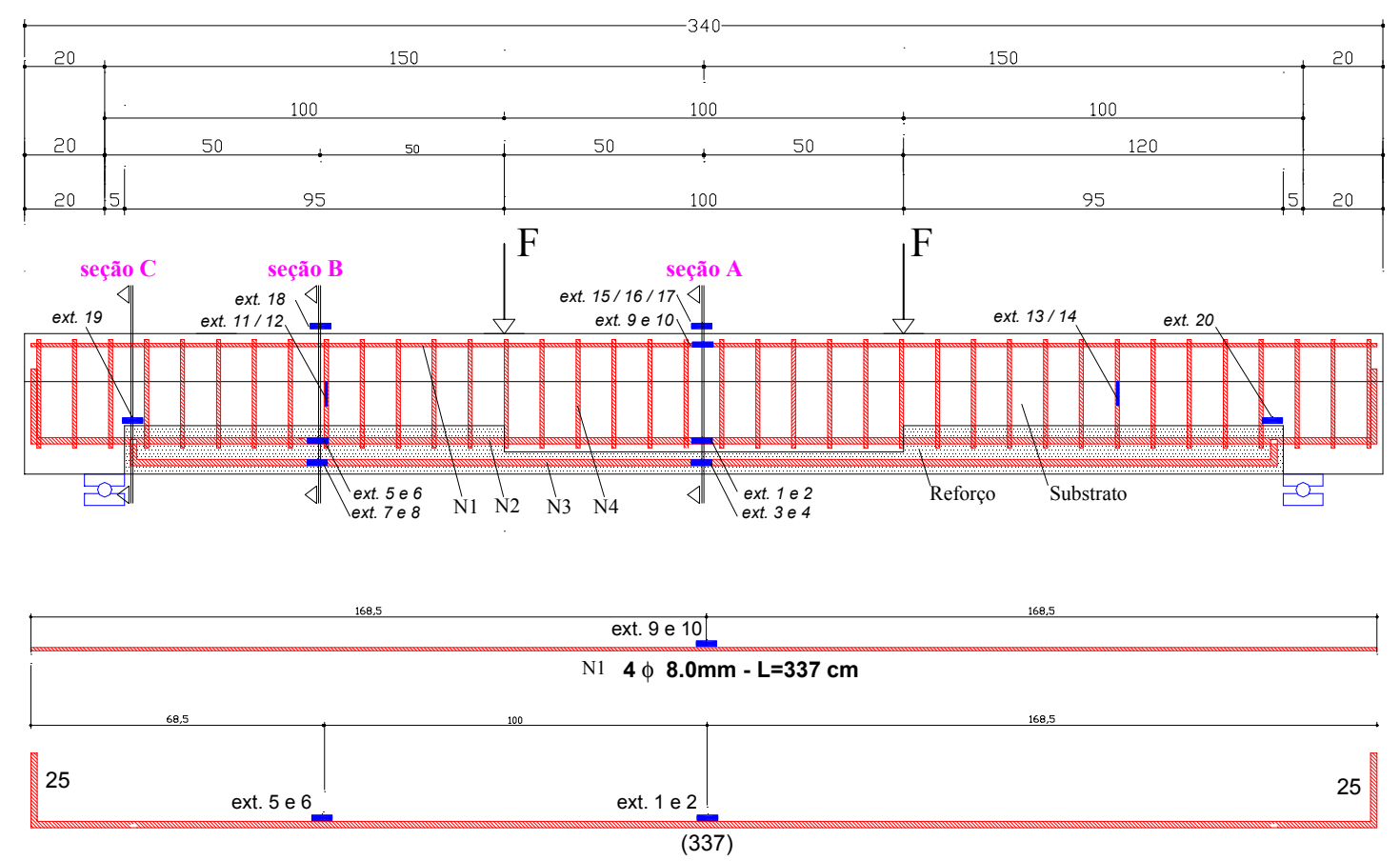

N2: $3 \phi 16.0 \mathrm{~mm}-\mathrm{L}=387 \mathrm{~cm}$

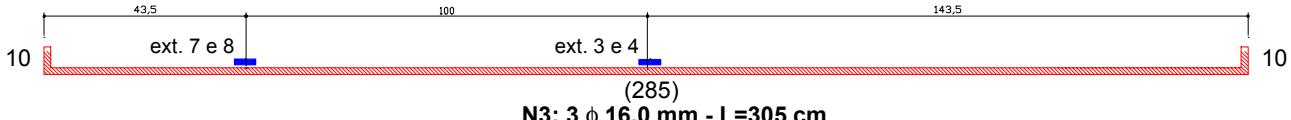

N3: $3 \phi 16.0 \mathrm{~mm}-\mathrm{L}=305 \mathrm{~cm}$

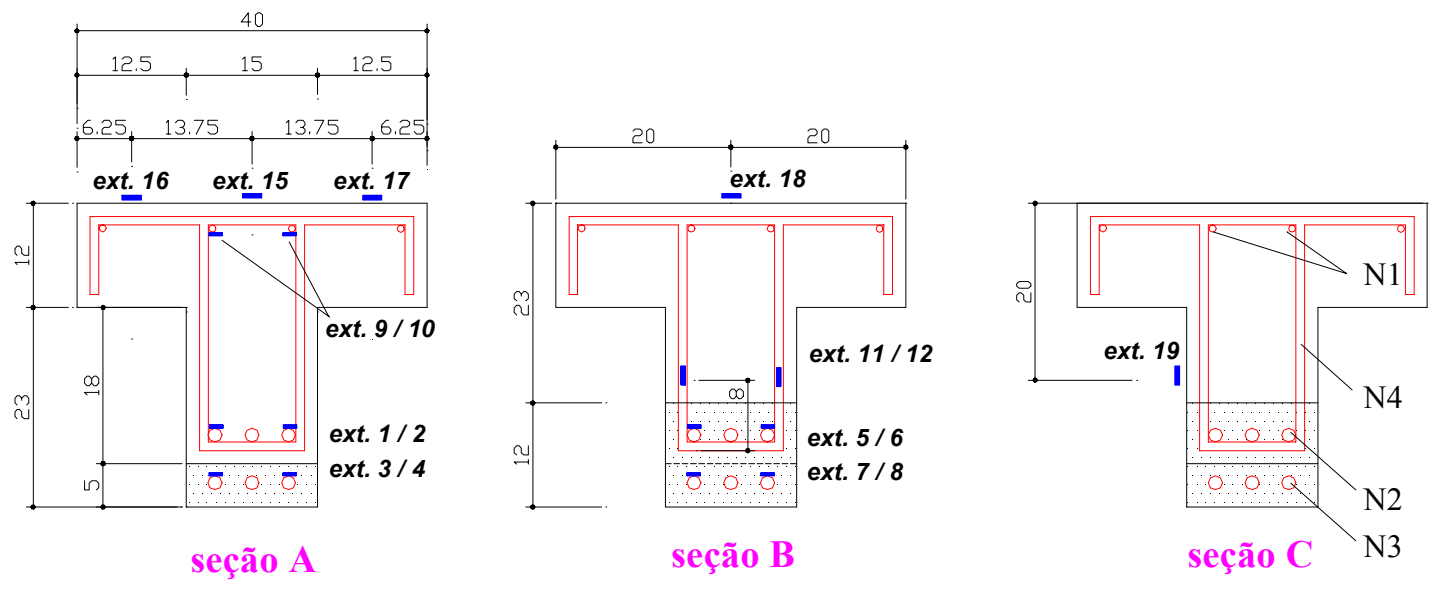

\section{Lista das armaduras:}

$$
\begin{aligned}
& \mathrm{N} 1-4 \phi 8.0-\mathrm{L}=337 \mathrm{~cm} \\
& \mathrm{~N} 2-3 \phi 16.0-\mathrm{L}=387 \mathrm{~cm} \\
& \mathrm{~N} 3-3 \phi 16.0-\mathrm{L}=305 \mathrm{~cm} \\
& \mathrm{~N} 4-50 \phi 8.0 \text { a cada } 7 \mathrm{~cm}-\mathrm{L}=113 \mathrm{~cm}
\end{aligned}
$$

Figura 5.1 - Dimensões, armaduras e instrumentação das vigas VFT 
Tabela 5.2 - Características das vigas ensaiadas

\begin{tabular}{|c|c|c|c|}
\hline Características & Vigas T & Características & Vigas $T$ \\
\hline$(\mathrm{cm})$ & 40 & $(\mathrm{~cm})$ & 4 \\
\hline$(\mathrm{cm})$ & 15 & $\mathrm{a} / \mathrm{d}($ evitar o efeito arco $\mathrm{a} / \mathrm{d} \geq 3$ ) & 3,40 \\
\hline$(\mathrm{cm})$ & 12 & 1/h (esbeltez da peça $-1 / \mathrm{h} \geq 2)$ & 8,57 \\
\hline$(\mathrm{cm})$ & 35 & $A_{s 1}-\mathrm{N} 2-3 \phi 16.0$ & 6,00 \\
\hline$(\mathrm{cm})$ & 23 & $\mathrm{~A}_{\mathrm{s} 2}-\mathrm{N} 3-3 \phi 16.0$ & 6,00 \\
\hline$(\mathrm{cm})$ & 23 & $\mathrm{~d}_{1}$ & 26,70 \\
\hline$(\mathrm{cm})$ & 7 & $(\mathrm{~cm})$ & 32,20 \\
\hline$(\mathrm{cm})$ & 5 & $\mathrm{~d}_{\text {médio }}$ & 29,45 \\
\hline Posição da junta $\left(\mathrm{h}_{\mathrm{r}}=\mathrm{h}_{3}+\mathrm{h}_{4}\right)$ & 12 & $\mathrm{~A}_{\mathrm{s}}{ }^{\prime}-\mathrm{N} 1-4 \phi 8.00$ & 2,00 \\
\hline$(\mathrm{cm})$ & 340 & d' & 2,70 \\
\hline$l_{\text {teórico }}$ & 300 & $\mathrm{a}_{\mathrm{sw}}-\mathrm{N} 4-\phi 8.00 \mathrm{c} / 7 \mathrm{~cm} \quad\left(\mathrm{~cm}^{2} / \mathrm{m}\right)$ & 7,14 \\
\hline$a=\ell / 3$ & 100 & c - cobrimento & 1,50 \\
\hline
\end{tabular}

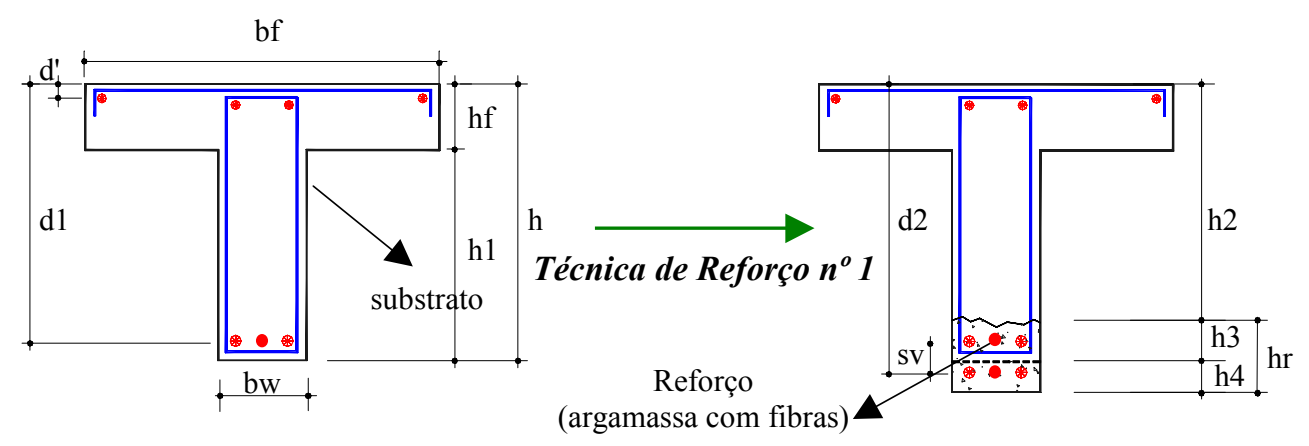

VO-1 $=$ VO-2

VFT-1 e VFT-2

\section{2 - Caracterização dos materiais}

As vigas VFT foram confeccionadas usando dois traços distintos: um para moldar o substrato (TS-1) e outro para reconstruir o bordo tracionado (TR-1a). Este último traço foi definido em função dos resultados dos ensaios complementares descritos no Capítulo 4, que indicaram que um material compósito feito de argamassa de alta resistência com adição de $2 \%$ de fibras curtas de aço do tipo RL 45/30 BN da marca DRAMIX seria o mais indicado para reforçar as vigas de seção T.

As proporções dos traços do concreto/argamassa e as características das fibras estão apresentadas respectivamente nas Tabelas 2.8 e 2.9. Já as propriedades mecânicas desses materiais bem como das barras de aço usadas nas armaduras estão nas Tabelas 5.3 e 5.4 . 
Tabela 5.3 - Propriedades mecânicas dos traços usados nas vigas VFT

\begin{tabular}{|c|c|c|c|c|c|c|c|c|c|}
\hline \multirow[b]{3}{*}{ Viga } & \multicolumn{3}{|c|}{ Idade no dia do ensaio } & \multicolumn{3}{|c|}{ Substrato } & \multicolumn{3}{|c|}{ Reforço } \\
\hline & & & & \multicolumn{6}{|c|}{ (MPa) } \\
\hline & Etapa & substrato & reforço & $\mathbf{f}_{\mathbf{c j}}$ & $\mathbf{f}_{\mathbf{t j}}$ & $\mathbf{E}_{\mathrm{c}}$ & $\mathbf{f}_{\mathbf{c j}}$ & $\mathbf{f}_{\mathbf{t j}}$ & $\mathbf{E}_{\mathrm{c}}$ \\
\hline \multirow{2}{*}{ VFT-1 } & Pré-carga & 12 & - & 28,02 & 2,95 & 31072 & - & - & - \\
\hline & Ensaio & 21 & 7 & 29,58 & 2,99 & 31175 & 38,15 & 3,94 & 21023 \\
\hline \multirow{3}{*}{ VFT-2 } & Pré-fissuração & $\overline{8}$ & - & 25,62 & 2,56 & 29573 & - & - & - \\
\hline & Pré-carga & 12 & - & 26,82 & 2,48 & 29899 & - & - & - \\
\hline & Ensaio & 22 & 8 & 29,12 & 2,69 & 31902 & 38,04 & 3,66 & 20960 \\
\hline
\end{tabular}

Tabela 5.4 - Propriedades mecânicas das armaduras usadas nas vigas VFT

\begin{tabular}{|c|c|c|c|c|c|}
\hline$\phi(\mathrm{mm})$ & Tipo de armadura & Tipo de aço & $\mathbf{f}_{\mathrm{y}}(\mathrm{MPa})$ & $\mathbf{f}_{\mathrm{u}}(\mathrm{MPa})$ & $\mathrm{E}_{\mathrm{s}}(\mathrm{MPa})$ \\
\hline 8 & $\mathrm{~A}_{\mathrm{sw}}$ e $\mathrm{A}_{\mathrm{sl}}^{\prime}$ & CA-50 A & 537 & 671 & 203600 \\
\hline 8 & $\mathrm{~A}_{\mathrm{sw}}$ (só para VFT-2) & CA-50 A & 599 & 742 & 221500 \\
\hline 16 & $\mathrm{~A}_{\mathrm{sl1} 1}$ e $A_{\mathrm{s} 12}$ & CA-50 A & 622 & 741 & 194900 \\
\hline $\begin{aligned} \mathrm{A}_{\mathrm{sw}} & =\mathrm{Arm} \\
\mathrm{A}_{\mathrm{s} 11} & =\text { Arm } \\
\mathrm{A}_{\mathrm{s} 12} & =\text { Arm }\end{aligned}$ & $\begin{array}{l}\text { dos estribos } \\
\text { longitudinal trac } \\
\text { longitudinal trac }\end{array}$ & segunda & & 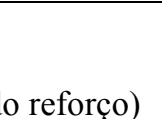 & \\
\hline
\end{tabular}

\section{3 - Moldagem, escarificação, cura e esquema de ensaio}

As vigas reforçadas foram confeccionadas de acordo com as seguintes etapas:

a) Moldagem das vigas originais VO-1 e VO-2 na posição invertida;

- Tais vigas correspondiam ao substrato das vigas VFT-1 e VFT-2 respectivamente.

- Como a viga tinha seção transversal $\mathrm{T}$, foram feitos furos de $10 \mathrm{~mm}$ a cada $50 \mathrm{~cm}$ nos trechos da fôrma que compunham as abas do modelo para evitar a formação de bolhas por aprisionamento de ar na região da mesa durante a concretagem. O adensamento foi feito em mesa vibratória;

b) Cura das vigas originais, colocando-se espuma umedecida por 5 dias após sua moldagem;

c) Realização de uma pré-danificação nos modelos;

- Para isso as vigas originais VO-1 e VO-2 foram posicionadas de maneira invertida no pórtico de reação e submetidas a um carregamento monotônico crescente por meio de incrementos de força aplicados de baixo para cima por dois macacos hidráulicos. O limite do carregamento responsável pela pré-danificação do modelo foi determinado em função das fissuras observadas nas peças e em função dos valores das deformações dos materiais (aço e concreto). 
d) Escarificação das vigas VO utilizando um martelete pneumático;

e) Reposicionamento dos modelos no pórtico de reação para aplicação de forças concentradas correspondentes ao pré-carregamento a ser mantido constante durante a execução do reforço. A aplicação destas forças foi feita de maneira idêntica à já descrita no item $c$.

- Para a viga original ser capaz de suportar as solicitações aplicadas na fase de précarregamento estando com parte da armadura longitudinal pré-existente exposta, escarificou-se apenas os trechos da viga situados entre os apoios e os pontos de aplicação das forças verticais, mantendo-se o concreto aderido à armadura no trecho central da peça.

- Para que não houvesse necessidade de escarificar um trecho muito grande do bordo tracionado e conseqüentemente reduzir os trabalhos de demolição colocou-se, na viga VO-1, pedaços de EPS (poliestireno expandido) para isolar os trechos que seriam preenchidos com a argamassa de alta resistência com fibras de aço antes de reforçá-la evitando a penetração do material do substrato nessas regiões. A princípio, acreditava-se que tal procedimento não afetaria o comportamento da peça. Entretanto, as fissuras que surgiram na VO-1 durante a fase de pré-danificação foram sensivelmente diferentes das de uma peça de seção integra pois havia trechos da armadura longitudinal inicial exposta (ver Figura 5.2). Por este motivo a VO-2 foi confeccionada sem utilizar EPS pois se desejava que a seção da viga original estivesse íntegra (sem armadura exposta) na fase de pré-danificação.

- Como parte da armadura longitudinal pré-existente na VO-1 já estava exposta durante a pré-danificação, a execução do reforço foi feita nesta fase, ou seja, o procedimento foi: pequena escarificação $\rightarrow$ pré-danificação $=$ pré-carregamento. Já na viga VO-2, seguiu-se o procedimento normal descrito, ou seja, pré-danificação $\rightarrow$ escarificação $\rightarrow$ pré-carregamento.

f) Execução do reforço no banzo tracionado do modelo logo após a aplicação do pré-carregamento. Para isso, fixou-se as novas barras de aço na viga com uso de dois espaçadores metálicos colocados próximos aos apoios, e envolveu-se essas barras com uma camada de argamassa de alto desempenho auto-adensável com adição de $2 \%$ fibras curtas de aço do tipo RL-45/30.

- Os espaçadores metálicos tinham forma de "caranguejo" e estavam presos à armadura longitudinal exposta. Por causa da quantidade e da maneira de fixação destes espaçadores, eles não trabalhavam como estribo, ficando estritamente a cargo 
das fibras de aço a função de resistir aos esforços tangenciais existentes na região reforçada.

g) Cura do material do reforço colocando-se espuma umedecida por 5 dias após sua moldagem;

h) Ensaio final da viga VFT (viga original após o reforço) aumentando-se o carregamento aplicado monotonicamente até atingir a capacidade portante máxima do modelo.

- $\mathrm{O}$ reforço foi executado quando as vigas originais tinham 12 dias de idade e o ensaio final foi executado quando o reforço atingia 7 dias de idade.

- Entre a etapa de execução do reforço até a etapa do ensaio final procurou-se manter constante o valor do pré-carregamento aplicado na peça.

A Figura 5.3 ilustra as etapas do processo de aplicação do pré-carregamento e de execução do reforço.

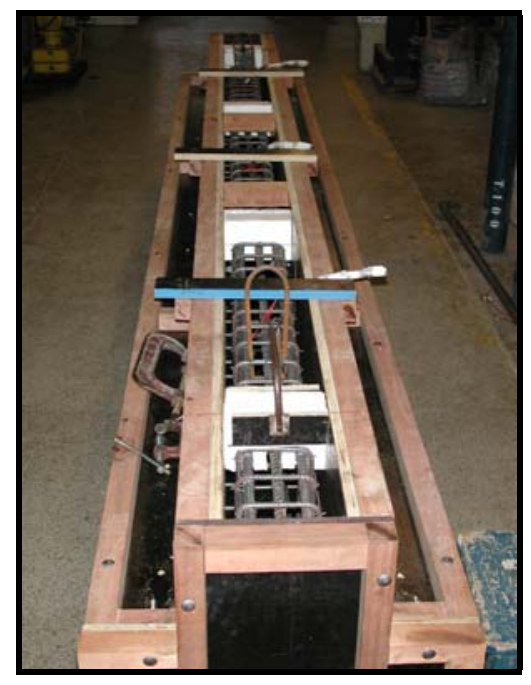

a) VFT-1

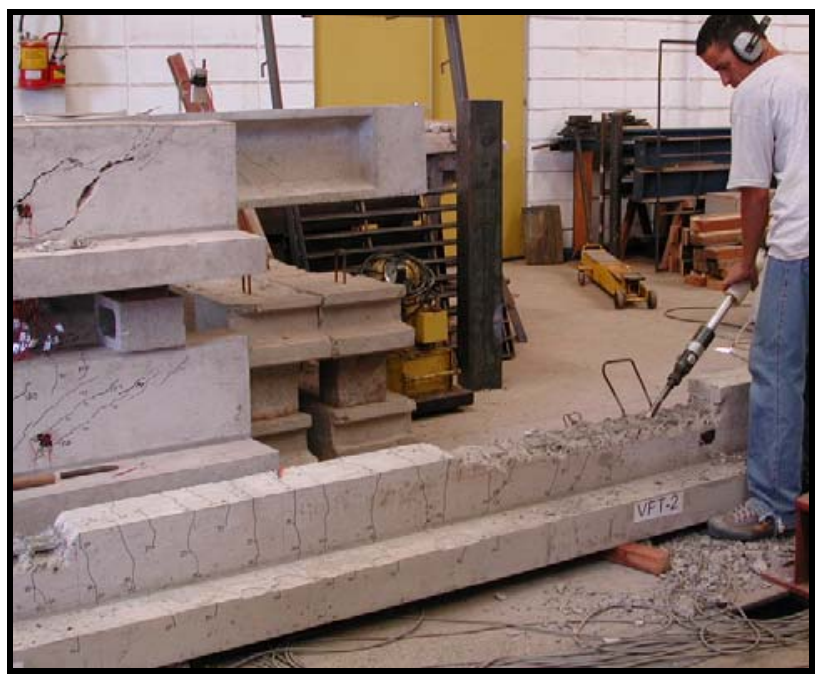

b) VFT-2

Figura 5.2 - Posicionamento do poliestireno na VFT-1 antes de sua moldagem e esquema de demolição do trecho tracionado da viga VFT-2 


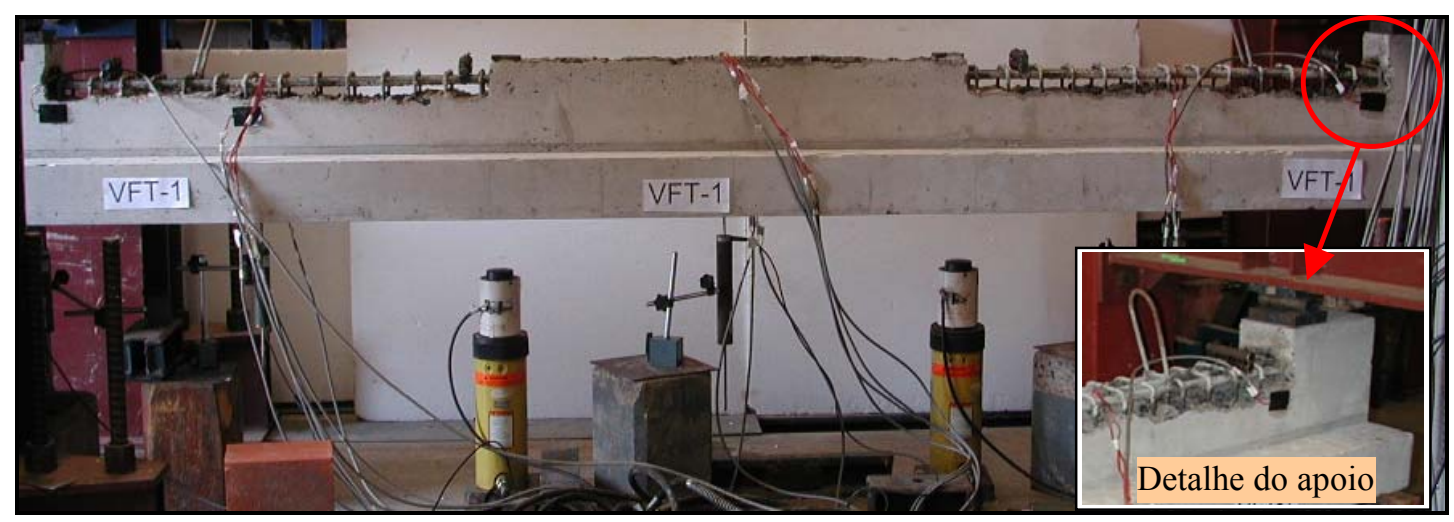

(a) Viga original com armadura exposta antes de ser pré-carregada

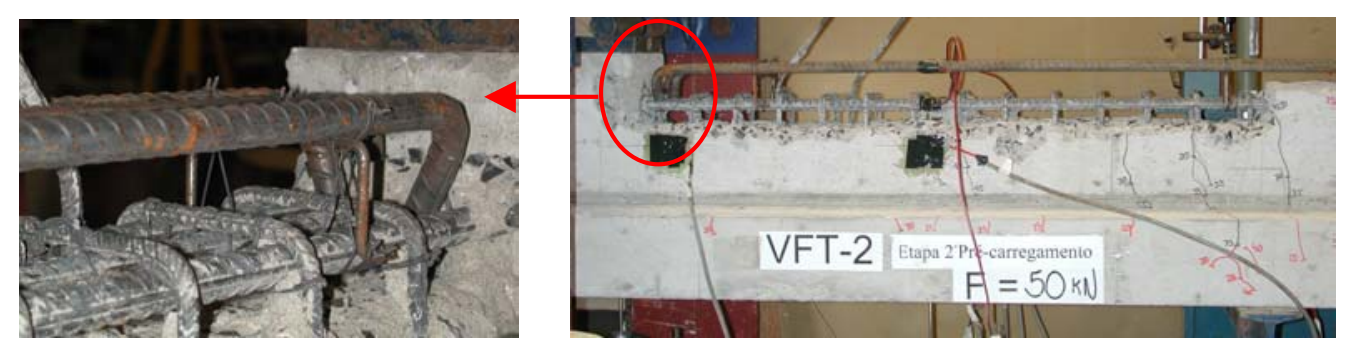

(b) Posicionamento da armadura longitudinal do reforço

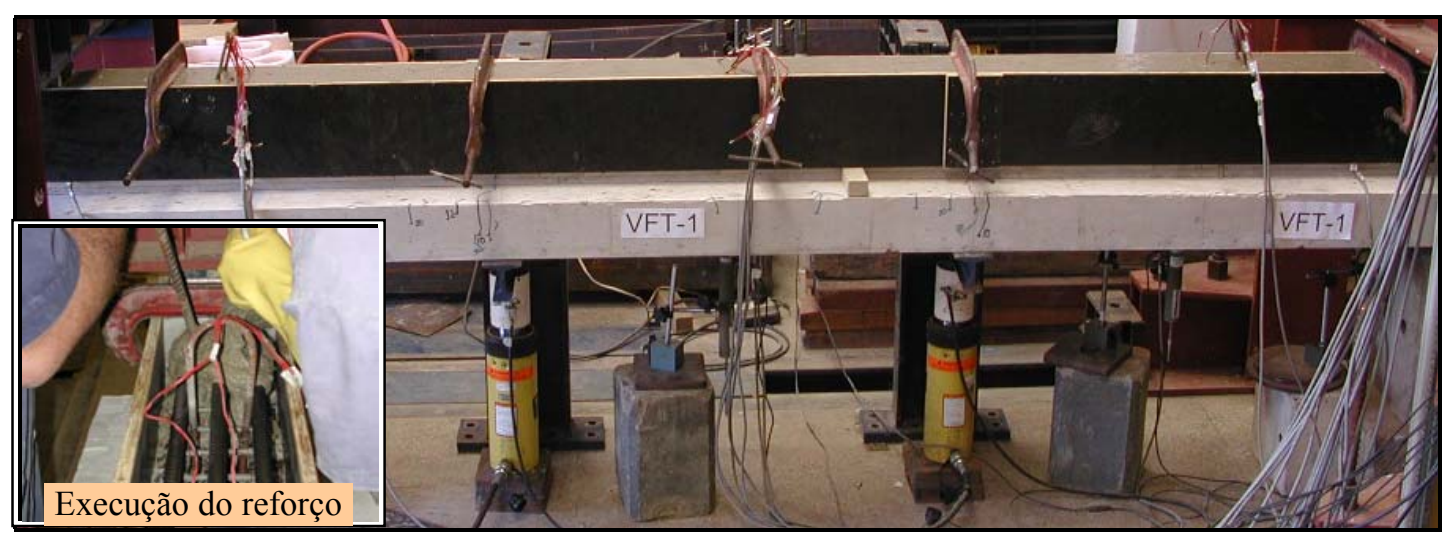

(c) Viga durante e após o reforço sob carga antes da retirada da fôrma

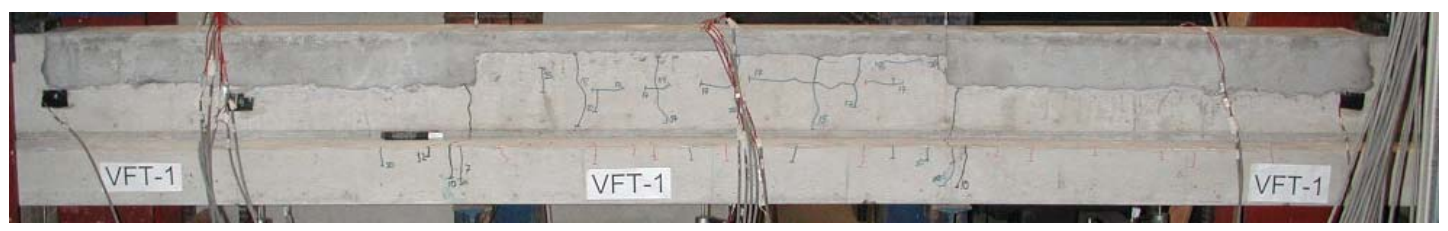

(d) Viga reforçada no dia do ensaio final (após a retirada da fôrma)

Figura 5.3 -Moldagem do reforço e aplicação do pré-carregamento na VFT-1 


\section{4 - Apresentação e análise dos resultados}

Além das comparações do comportamento entre as peças reforçadas sob diferentes intensidades de carregamento (VFT-1, VFT-2 e VA-3 ${ }^{1}$ ), também foi simulado o comportamento das vigas através do programa computacional denominado CONSNOU, baseado no Método dos Elementos Finitos. Maiores informações sobre como foi feita a simulação numérica deve-se consultar o item 3.6.2.

\subsection{1 - Fissuração, capacidade portante e modo de ruptura}

$\mathrm{O}$ esquema de fissuração observado nas vigas originais VO-1 e VO-2 foi diferente durante a fase de pré-danificação, pois a primeira possuía um trecho com a armadura tracionada exposta, enquanto a outra tinha uma seção transversal totalmente íntegra nesta fase (ver Figura 5.4).

$\mathrm{Na}$ viga original VO-1, cuja fase de pré-danificação coincidia com a fase de pré-carregamento, surgiram poucas fissuras sendo duas delas críticas por causa da redução brusca de rigidez na ligação entre o trecho com armadura exposta e o trecho central em que o concreto permanecia aderido às barras de aço. Tais fissuras apresentaram aberturas muito grandes e poderiam provocar a ruptura prematura da viga pelo escoamento localizado da armadura tracionada. Além disso, também surgiram fissuras de flexão (fissuras verticais) que a partir de determinado instante de carregamento se bifurcaram e se propagavam horizontalmente. Este esquema de fissuração foi semelhante ao observado nos ensaios realizados por CAIRNS \& ZHAO (1993) descritos no item 3.5 do Capítulo 3.

Na viga VO-2, cuja fase de pré-danificação não coincidia com a fase de précarregamento, surgiram na primeira fase inúmeras fissuras de pequena abertura causadas por cisalhamento e flexão por se ter uma peça monolítica. Por este motivo, quando se passou para a fase de pré-carregamento, na qual havia trechos de armadura

\footnotetext{
${ }^{1}$ Conforme o item 2.2.2.3, REIS (1998) ensaiou quatro vigas (três reforçadas e uma monolítica). Dessas vigas apenas a VA-3 rompeu por escoamento da armadura longitudinal (tipo de ruptura ideal). Por isso optou-se por comparar os resultados das vigas VFT apenas com os resultados da viga VA-3 em função da semelhança entre modos de ruptura.
} 
exposta, as fissuras pré-existentes voltaram a se abrir e a aumentar em função do précarregamento aplicado, impedindo o surgimento das fissuras críticas. Isso permitiu que esta viga suportasse um pré-carregamento maior que a VO-1 (ver Tabela 5.5).

Após o ensaio final, a configuração das fissuras observada nas vigas reforçadas VFT-1, VFT-2 (Figura 5.4) e VA-3 (Figura 2.16) corresponde ao surgimento de inúmeras fissuras de flexão e de cisalhamento, não se constatando nenhum tipo de perda de aderência na região da junta formada pelo concreto do substrato e argamassa do reforço. No caso das vigas VFT, nem mesmo para o trecho central, no qual não existia nenhuma uma armadura transversal cruzando a interface, não houve perda de aderência na junta. Isso indica que a transferência total de esforços através da junta foi garantida inclusive para o Estado Limite Último.

Apesar da VFT-1 possuir uma fissuração diferente da usual antes da execução do reforço, isso não influenciou o desempenho global da viga após o reforço.

Todas as vigas romperam por escoamento da armadura longitudinal seguido do esmagamento do concreto no bordo comprimido. Observando o tipo de ruptura e o esquema de fissuração concluiu-se que estas vigas funcionaram como se fossem peças monolíticas.

As forças de ruptura experimentais das vigas foram próximas (diferença máxima de apenas 5\%) constatando-se que, aparentemente, o fato delas estarem submetidas à diferentes pré-carregamentos durante a execução do reforço não afetou significativamente a capacidade portante do elemento.

O gráfico da Figura 5.5 mostra a evolução do pré-carregamento aplicado durante o período de tempo decorrido entre a execução do reforço e o ensaio final da viga reabilitada. Por esta figura verifica-se que o pré-carregamento da VFT-1, inicialmente de $30 \mathrm{kN}$, não se manteve constante em função de perdas de pressão no macaco hidráulico, sendo de apenas $10 \mathrm{kN}$ no início do ensaio final desta viga. Para isso não acontecer na VFT-2 fez-se correções manuais periódicas da pressão do óleo do macaco hidráulico, mantendo sempre um pré-carregamento de aproximadamente $55 \mathrm{kN}$. 


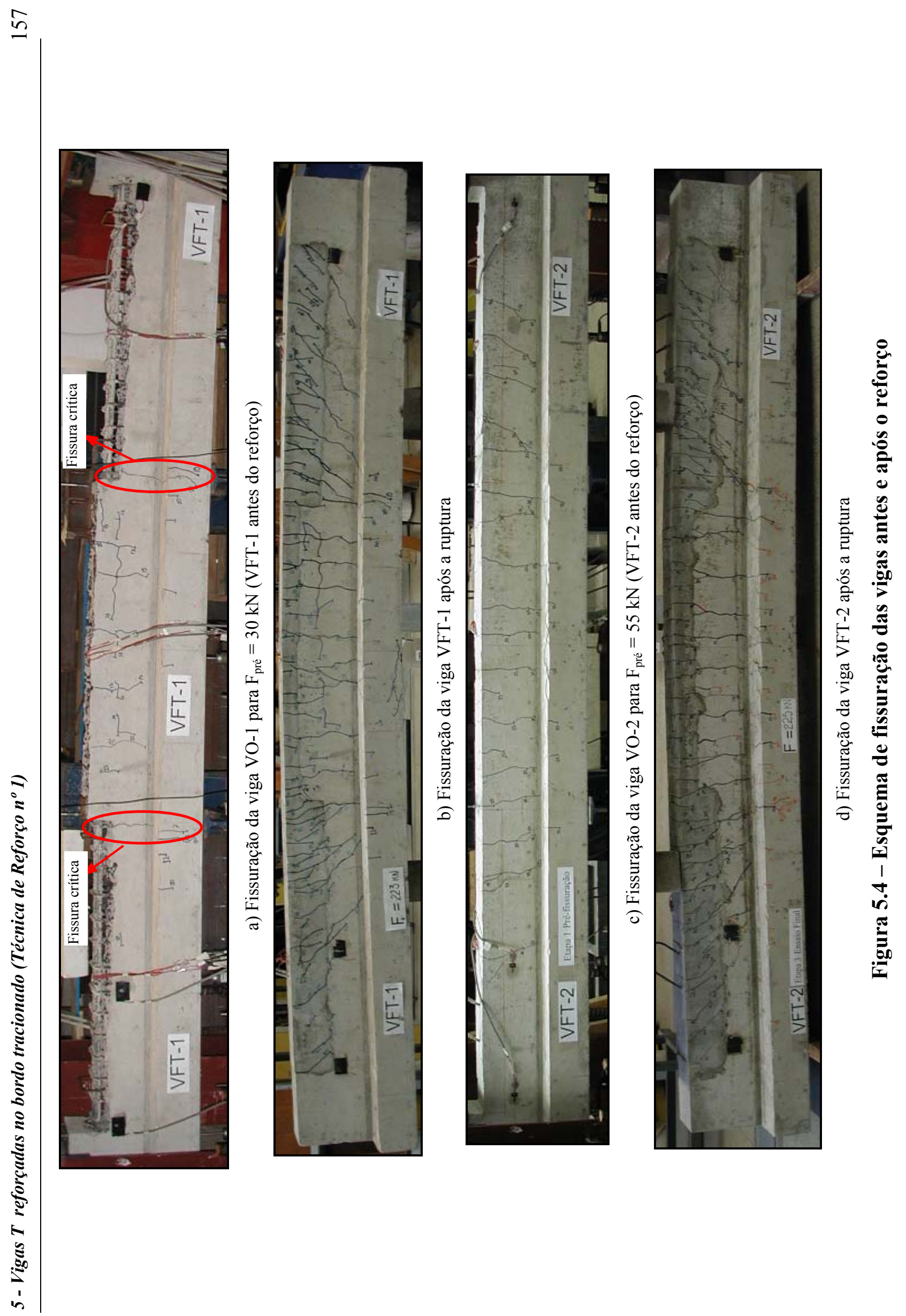


Tabela 5.5 - Pré-carregamento aplicado nas vigas VFT durante o reforço

\begin{tabular}{l|c|c|c|c|c|c|c|c|c}
\hline \hline Vigas & $\mathbf{F}_{\text {ser1 }}$ & $\mathbf{F}_{\text {rup1 }}$ & $\mathbf{F}_{\text {pré }}$ & $\mathbf{F}_{\text {ser2 }}$ & $\mathbf{F}_{\text {rup2 }}$ & $\mathbf{F}_{\text {exp }}$ & $\mathbf{F}_{\text {pré }} / \mathbf{F}_{\text {rup1 }}$ & $\mathbf{F}_{\text {pré }} / \mathbf{F}_{\text {exp }}$ & $\mathbf{F}_{\text {exp }} / \mathbf{F}_{\text {rup2 }}$ \\
\hline \hline VFT-1 & 47,6 & 75 & 30 & 123,9 & 200 & 223 & 0,40 & 0,13 & 1,12 \\
\hline VFT-2 & 47,6 & 75 & 55 & 123,9 & 205 & 225 & 0,73 & 0,24 & 1,10 \\
\hline VA-3 & - & - & - & 104,5 & 194 & 202 & - & - & 1,04 \\
\hline \hline
\end{tabular}

A unidade de força é $\mathrm{kN}$;

$\mathrm{F}_{\text {ser1 }} \quad$ - força de serviço teórica prevista de acordo com a norma NBR-6118 para as vigas originais;

$\mathrm{F}_{\text {rup1 }} \quad$ - força de ruptura teórica prevista de acordo com a norma NBR-6118 para as vigas originais;

$\mathrm{F}_{\text {pré }} \quad$ - pré-carregamento aplicado durante a execução do reforço nas vigas originais;

$\mathrm{F}_{\text {ser2 }}$ - força de serviço teórica prevista de acordo com a norma NBR-6118 para as vigas reforçadas se fossem admitidas como sendo elementos monolíticos;

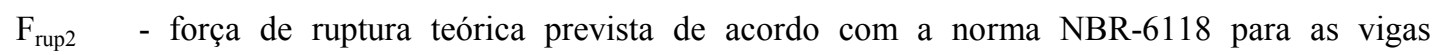
reforçadas se fossem admitidas como sendo elementos monolíticos;

$\mathrm{F}_{\exp } \quad$ - força de ruptura experimental obtida nos ensaios finais das vigas reforçadas;

As forças $\mathrm{F}$ correspondem ao valor de apenas uma das forças verticais concentradas aplicadas na viga, ou seja, corresponde é o esforço cortante $\mathrm{V}$ atuante no modelo.

A força de cálculo teórica $\left(F_{d}\right)$ de cada peça foi determinada a partir dos valores da área de aço e do concreto existentes na peça, usando as resistências dos materiais (aço e concreto) minoradas pelos respectivos coeficientes de ponderação. Após achar o valor da força de cálculo teórica, esta foi dividida por 1,4 para determinar a força de serviço $\left(\mathrm{F}_{\text {serv }}\right)$. Esta força corresponde à pior combinação de ações que se poderia considerar em estado de utilização uma vez que não se tem um conjunto de ações permanentes e variáveis a considerar, portanto, não há como definir os diversos tipos de combinação.

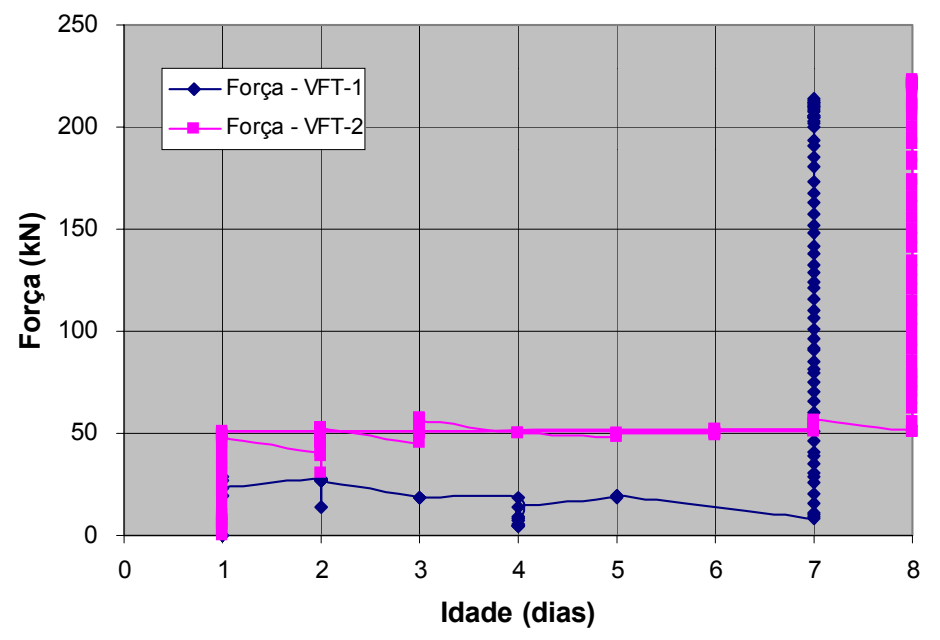

Figura 5.5 - Gráfico da variação do pré-carregamento nas vigas VFT 


\subsection{2 - Deslocamentos verticais}

Para analisar a evolução dos deslocamentos verticais (flechas) foram traçados três gráficos (ver Figuras 5.6 a 5.8).

Pelo gráfico da Figura 5.6 - que mostra a evolução total das flechas durante o ensaio a fim de ilustrar o comportamento geral das vigas - pode-se dizer as vigas originais VO-1 e VO-2 tiveram praticamente a mesma rigidez apesar de terem esquemas de fissuração diferentes neste trecho, pois as flechas correspondentes aos trechos retilíneos iniciais (fase de aplicação do pré-carregamento) foram praticamente coincidentes. Por outro lado, comparando os trechos das curvas referentes ao ensaio final (após execução do reforço) notou-se que a VFT-1 (antiga VO-1) foi um pouco menos rígida que a VFT-2 (antiga VO-2), pois suas flechas se aproximavam a medida em que o carregamento aumentava.

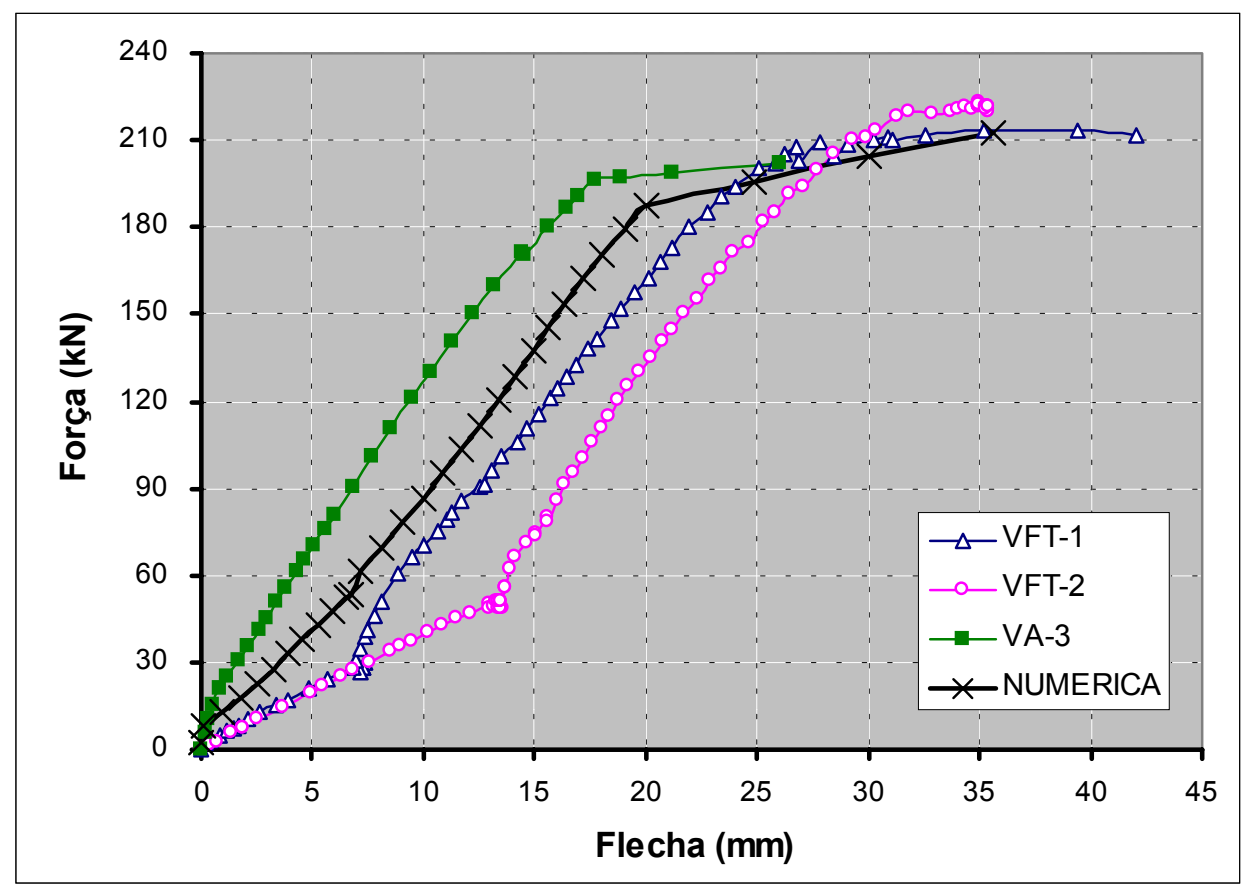

Figura 5.6 - Evolução da flecha total no meio do vão

No gráfico da Figura 5.7 apresenta-se a evolução das flechas ${ }^{2}$ teóricas e experimentais até uma força de aproximadamente $125 \mathrm{kN}$, correspondente ao

\footnotetext{
${ }^{2}$ As flechas calculadas referem-se somente a parcela da flecha imediata já que o ensaio realizado foi de curta duração.
} 
carregamento em serviço, $\mathrm{F}_{\text {ser2, }}$, das vigas VFT (ver Tabela 5.5). Isso foi feito porque na prática a análise de flechas é feita apenas para o Estado Limite de Utilização. Neste gráfico não foram avaliadas as flechas da VFT-1 por se acreditar que o comportamento teórico dela seria muito semelhante ao observado para a VFT-2.

A curva teórica obtida através da simulação numérica usando o programa CONSNOU foi denominada no gráfico de "NUMÉRICA", e a curva teórica das flechas da VFT-2 obtida pelo processo analítico convencional, usando as equações 3.75 e 3.76 foi denominada de "ANALÍTICA". A curva "ANALÍTICA-VA-3" referese à estimativa das flechas teóricas da viga VA-3 (sem pré-carregamento) utilizando o processo analítico convencional.

Para determinar as flechas referentes à viga pré-carregada VFT-2 pelo processo analítico convencional associou-se o comportamento da viga original com o da viga após o reforço através do seguinte processo:

a) cálculo das flechas teóricas da VO-2 até um carregamento de $50 \mathrm{kN}$ como se fosse uma peça monolítica. Para tentar simular a redução de rigidez devido à exposição das barras de aço utilizou-se, na equação 3.75, o momento de inércia $\mathrm{I}_{\mathrm{II}} \mathrm{e}$ o módulo de elasticidade $\mathrm{E}_{\mathrm{cs}}$ e não a relação $(\mathrm{EI})_{\mathrm{eq}}$;

b) cálculo das flechas teóricas da VFT-2 até o carregamento máximo como se fosse uma peça monolítica, usando agora a relação $(\mathrm{EI})_{\mathrm{eq}}$ dada pela equação 3.75 ;

c) somar todos os valores das flechas da VFT-2 obtidas para um carregamento maior que $50 \mathrm{kN}$ com o valor final da flecha da VO-2 obtida para a força de $50 \mathrm{kN}$;

Avaliando a curva "ANALÍTICA" obtida constatou-se que mesmo adotando uma rigidez menor que a rigidez equivalente $(\mathrm{EI})_{\mathrm{eq}}$ na determinação das flechas da VO-2, esta ainda não foi suficiente para representar toda a perda de rigidez devida à exposição das barras de aço, pois as flechas teóricas foram um pouco subestimadas. Por outro lado, a inclinação do trecho da curva após o carregamento de $50 \mathrm{kN}$ se mostrou bastante coerente com o comportamento real da peça e pode ser melhor avaliada na Figura 5.8.

Comparando-se as curvas "ANALÍTICA" e "NUMÉRICA” da Figura 5.7 verificou-se que o processo analítico representou melhor o comportamento real da peça por se possível, através dele, considerar uma rigidez da peça mais adequada do que a considerada pelo programa CONSNOU, que calculava automaticamente a 
rigidez da peça em função da sua geometria e da resistência do concreto, mas não permitia modelar elementos com trechos de armadura exposta.

A curva "ANALÍTICA-VA-3" indicou que para uma viga reabilitada sem carregamento, o modelo analítico conseguiu representar com fidelidade o comportamento real da peça, pois a curva teórica praticamente coincidiu com a experimental.

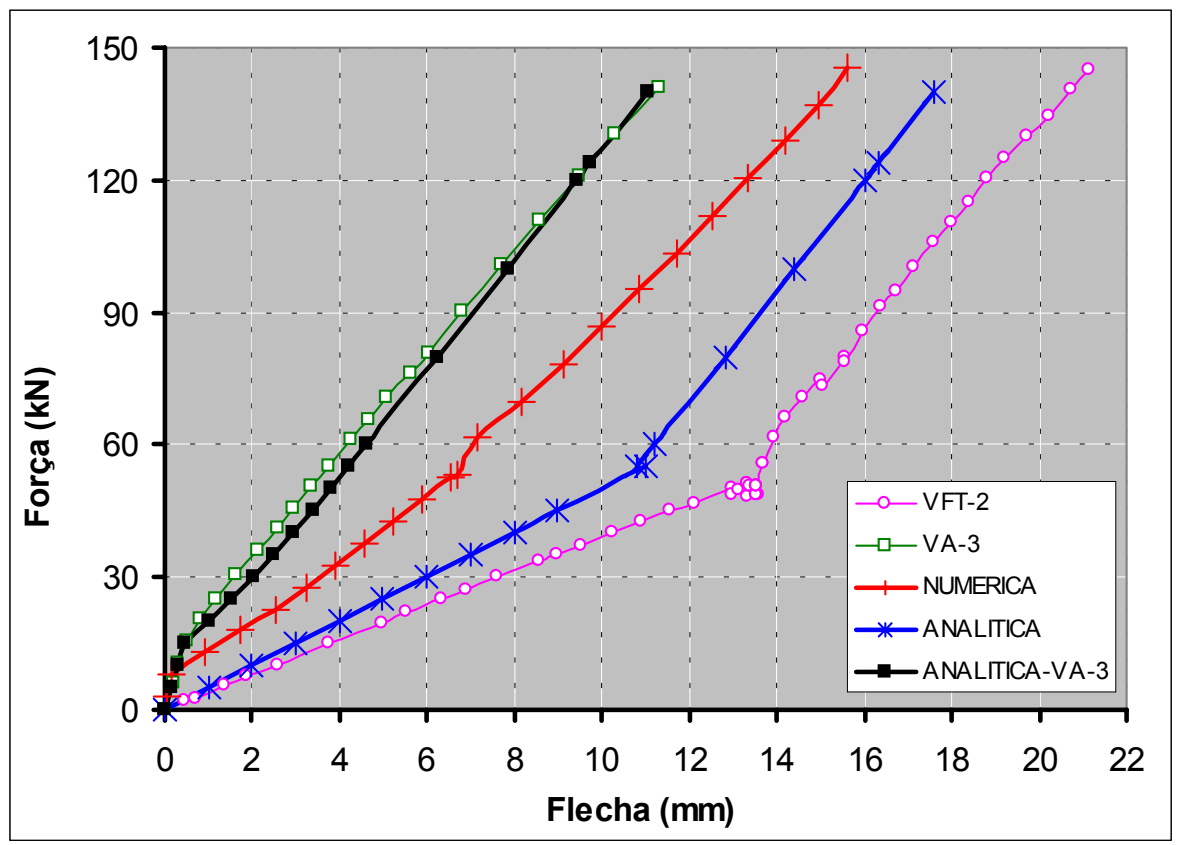

Figura 5.7 - Evolução da flecha (meio do vão) até a força de serviço da VFT

Para avaliar a coerência entre os resultados teóricos e experimentais das flechas obtidos após o reforço das vigas sem a interferência dos resultados obtidos antes desta etapa, traçou-se o gráfico da Figura 5.8 descontando-se tanto o précarregamento quanto a flecha gerada por ele. Dessa forma foi possível avaliar a taxa de crescimento das flechas em função exclusivamente do carregamento aplicado pósreforço. Neste caso verificou-se que as flechas experimentais das vigas VFT-2 e VA-3 foram praticamente iguais, indicando que independentemente das vigas terem sido reforçadas com ou sem pré-carregamento aplicado, a taxa de crescimento das flechas não se alterou. Daí pode-se dizer que a flecha final de vigas reabilitadas para o Estado Limite de Utilização depende quase que exclusivamente da flecha existente antes de se executar o reforço. 
Além disso, a avaliação do comportamento das vigas usando o método analítico foi excelente já que as curvas teóricas possuíam quase a mesma inclinação das curvas experimentais. Isso indicou que é adequada a utilização da rigidez equivalente $(E I)_{\text {eq }}$ para uma peça monolítica de seção idêntica à da seção após o reforço, na estimativa das flechas teóricas.

Já a estimativa teórica do comportamento das vigas usando o programa CONSNOU superestimou a taxa de crescimento das flechas. Isso provavelmente ocorreu porque o programa não conseguia restabelecer a rigidez total do banzo tracionado após a execução do reforço já que, pela formulação adotada, uma vez fissurado o concreto este não poderia voltar a contribuir na rigidez da peça. Entretanto, nas vigas reforçadas reais, esta rigidez se restabelecia em função da reconstituição do banzo tracionado utilizando um material que ainda não havia fissurado.

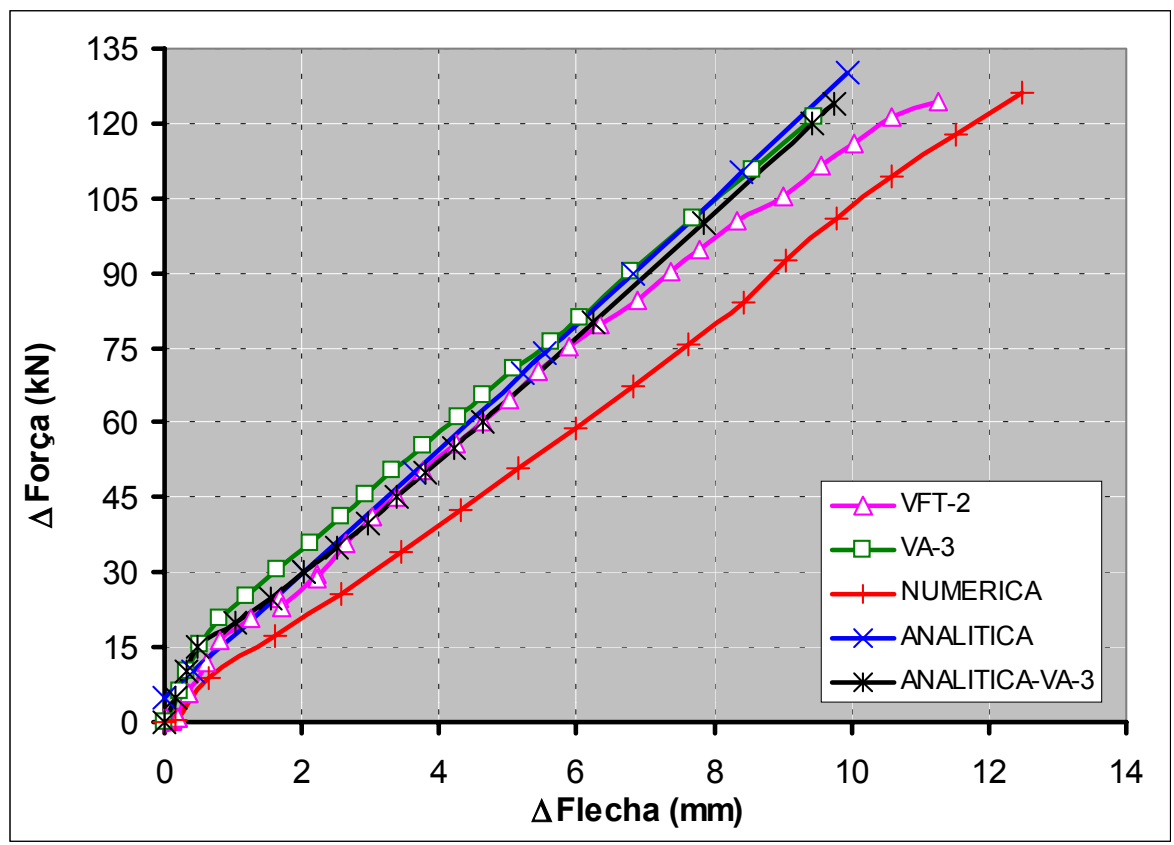

Figura 5.8 - Variação das flechas até a força de serviço descontando-se o précarregamento de $50 \mathrm{kN}$

\subsection{3 - Deslocamentos horizontais}

Nas vigas VFT podem surgir dois tipos de deslocamentos horizontais. O primeiro refere-se ao deslizamento horizontal relativo entre o material do reforço e do substrato ao longo da junta em função da perda de aderência entre estes materiais. 
Já o segundo refere-se ao deslizamento horizontal relativo entre as barras de aço da primeira e segunda camadas, devido à falta de confinamento entre a armadura longitudinal adicionada e a pré-existente em função da não utilização de estribos adicionais para envolvê-las.

Tentou-se evitar o primeiro tipo de deslocamento posicionando a junta em um local em que houvesse a possibilidade de utilizar a área de aço do estribo préexistente como armadura de costura.

Para verificar teoricamente se haverá ou não ruptura na região da junta e também para se dimensionar a área de aço da armadura de costura, deve-se calcular a tensão tangencial resistente $\left(\tau_{R}\right)$ e a tensão tangencial solicitante $\left(\tau_{S}\right)$ na junta devendo-se encontrar uma relação $\tau_{R} / \tau_{S}$ maior que 1 . Essa verificação foi feita utilizando as equações do item 3.2.1. e está apresentada na Tabela 5.6.

A tensão resistente avaliada de acordo a fórmula do CEB Bulletin d'Information $n^{\circ} 162$, contabiliza apenas a resistência do concreto na transmissão de esforços. Como as vigas ensaiadas possuem armadura de costura cruzando a interface, os valores das tensões resistentes obtidos por esta norma ficaram subestimados, não indicando a real resistência às solicitações tangenciais da junta.

Já a NBR-9062 considera tanto a contribuição da resistência do concreto quanto a contribuição da armadura de costura que cruza a interface e, portanto forneceu resultados mais adequados para a situação analisada.

Tabela 5.6 - Avaliação das tensões tangenciais na região da junta

\begin{tabular}{|c|c|c|c|c|c|c|}
\hline & $\begin{array}{c}\tau_{\mathrm{s} 1} \\
\text { eq. } 3.14\end{array}$ & $\begin{array}{c}\tau_{\mathrm{S} 3} \\
\text { eq. } 3.27\end{array}$ & $\begin{array}{c}\tau_{R 1} \\
\text { eq. } 3.15\end{array}$ & $\begin{array}{c}\tau_{\mathrm{R} 3} \\
\text { eq. } 3.25\end{array}$ & \multicolumn{2}{|c|}{$\begin{array}{c}\text { Relações } \\
\tau_{R} / \tau_{S}\end{array}$} \\
\hline & $\mathrm{MPa}$ & $\mathrm{Mpa}$ & $\mathrm{MPa}$ & $\mathrm{MPa}$ & & \\
\hline Viga & (1) & (2) & (3) & (4) & $(1) /(3)$ & $(2) /(4)$ \\
\hline VA-3 & 2.90 & 4.52 & 2.31 & 5.09 & 0.79 & 1.13 \\
\hline VFT-1 & 3.20 & 4.98 & 1.99 & 5.11 & 0.62 & 1.03 \\
\hline VFT-2 & 3.23 & 4.98 & 1.79 & 4.98 & 0.55 & 1.00 \\
\hline $\begin{array}{l}\tau_{\mathrm{S}}: \text { tensão } \\
\tau_{\mathrm{R}} \text { : tensão } \\
\text { Para avalia } \\
\text { tração do s } \\
\text { Abaixo de } \\
\text { no cálculo }\end{array}$ & $\begin{array}{l}\text { gencial } \mathrm{s} \\
\text { gencial } \mathrm{r} \\
\text { da } \tau_{\mathrm{R}} \mathrm{us} \\
\text { trato, } \mathrm{f}_{\mathrm{tj}}, \\
\text { a tensão } \\
\text { elação } \tau\end{array}$ & $\begin{array}{l}\text { icitante } n \\
\text { istente na } \\
\text { do a equa } \\
\text { btida exp } \\
\text { tá o núm } \\
\tau_{\mathrm{R}}\end{array}$ & $\begin{array}{l}\text { junta (ver } \\
\text { unta (ver } \\
\text { ão } 3.15, \mathrm{i} \\
\text { imentalm } \\
\text { o da equa }\end{array}$ & $\begin{array}{l}\text { quações d } \\
\text { uações do } \\
\text { icada pel } \\
\text { te no dia } \\
\text { o utilizad }\end{array}$ & $\begin{array}{l}\text { o } 3 \text { item } \\
3 \text { item } \\
\text { tilizou-s } \\
\text { das vig } \\
\text { lculá-la }\end{array}$ & $\begin{array}{l}\text { esistência à } \\
\text { a coluna usado }\end{array}$ \\
\hline
\end{tabular}


De acordo com os resultados teóricos obtidos, verificou-se que a estimativa das tensões utilizando a NBR-9062 indicaram que as vigas VA-3, VFT-1 e VFT-2 não romperiam por cisalhamento na região da junta, ou seja, os estribos préexistentes, utilizados como armadura de costura, possuíam área de aço suficiente para evitar a ruptura por cisalhamento horizontal. Este fato foi confirmado pelos resultados dos ensaios experimentais.

Após a realização dos ensaios não foi observado nenhum deslocamento horizontal ao longo da junta das vigas reforçadas indicando uma boa aderência e transferência de esforços entre o concreto do substrato e a argamassa do reforço. Isso confirma a idéia de que é possível e viável aproveitar os estribos pré-existentes na viga original como armadura de costura destinada a evitar a ruptura da junta por deslizamento relativo entre os materiais. Além disso, pode-se usar as normas específicas de estruturas de concreto pré-moldadas para fazer essa verificação tal como a NBR-9062.

O esquema estático usado nas vigas VFT pode ser dividido em três trechos: dois trechos de extremidade sujeitos à flexão simples e um trecho central sujeito à flexão pura. Como a tendência de deslizamento em juntas não é tão crítica para trechos submetidos à flexão pura pela ausência de solicitações tangenciais, optou-se por fazer a junta do trecho central com uma profundidade menor em relação a fundo da viga do que nos outros dois trechos (ver Figura 5.1). Apesar de não haver estribos cruzando a junta no trecho central em função da sua profundidade, não foi observado nenhum tipo de deslizamento neste local, confirmando que é possível eliminar a presença de armadura de costura (estribos) cruzando a junta, em função do nível de esforço cortante atuante na seção.

Quanto ao segundo tipo de deslizamento horizontal mencionado, tentou-se evitá-lo aumentando o confinamento entre barras de aço tracionadas pela adição de 2\% fibras de aço RL 45-30 à argamassa do reforço. As características dessa argamassa foram determinadas em função do estudo complementar apresentado no Capítulo 4, ficando dúvidas somente quanto à taxa ideal de fibras a ser usada.

Pelos ensaios verificou-se que as vigas reforçadas não apresentaram nenhum tipo de deslocamento horizontal entre as barras de aço adicionadas e pré-existentes, 
confirmando assim que a utilização de uma taxa de fibras de $2 \%$ foi suficiente para evitar tal deslizamento.

\subsection{4 - Deformação do concreto}

A ruptura das vigas VA-3, VFT-1 e VFT-2 ocorreram pelo escoamento do aço seguido do esmagamento do concreto, estando de acordo com o dimensionamento adotado que admitia a utilização máxima dos materiais, com deformações na armadura tracionada de 2,07\%o até $10 \%$ e deformações no concreto comprimido de até 3,5\%o.

Avaliando-se as medições de deformação no concreto através dos extensômetros elétricos colados na face superior das vigas (ver gráfico da Figura 5.9), verificou-se que houve o início de esmagamento do concreto para uma deformação de $\varepsilon_{\mathrm{c}} \cong 1,25 \%$ na VA-3, de $\varepsilon_{\mathrm{c}} \cong 1,75 \%$ o na VFT-1 e de $\varepsilon_{\mathrm{c}} \cong 2,75 \%$ na VFT-2. Isso indica que quanto maior o valor do pré-carregamento atuante na viga durante a execução do reforço, maior é o valor da deformação existente no bordo comprimido da peça para um mesmo nível de carregamento. Contudo, mesmo tendo-se deformações diferentes, o início de plastificação do concreto ocorreu para um mesmo patamar de carregamento (aproximadamente $200 \mathrm{kN}$ ) em todas as vigas, sugerindo que o esmagamento do concreto foi influenciado pelo início do escoamento da armadura tracionada.

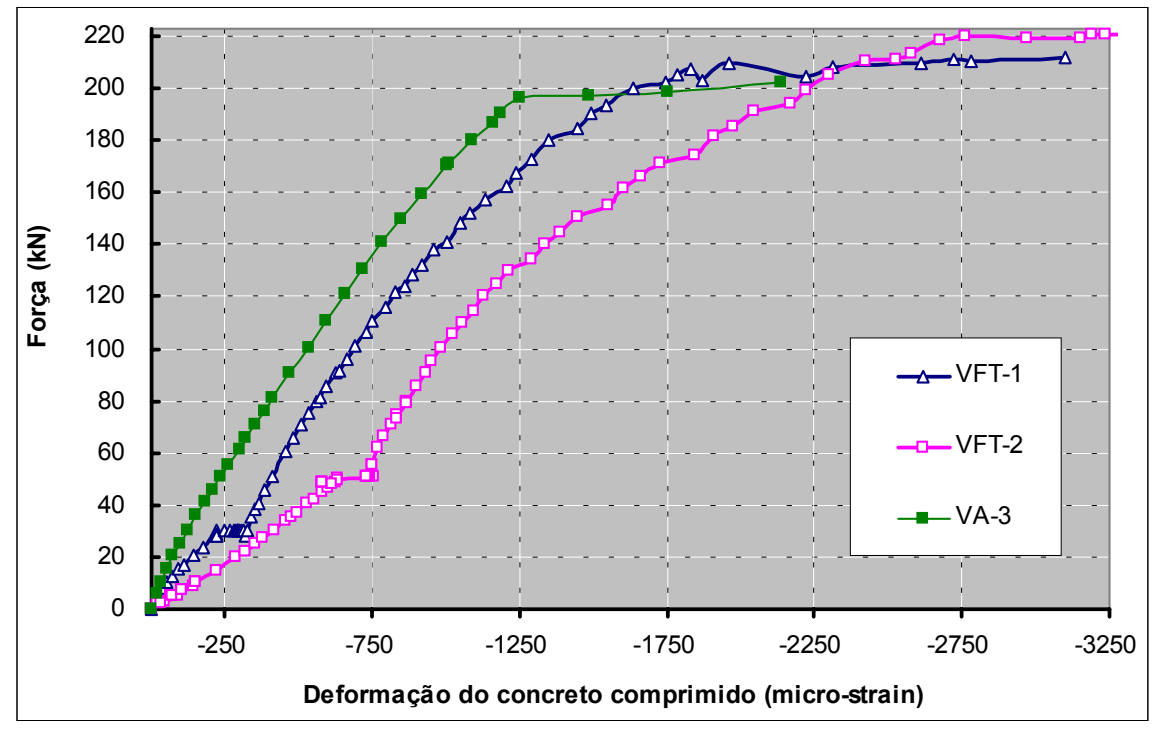

Figura 5.9 - Deformação do concreto no bordo mais comprimido 
Caso a armadura tracionada não houvesse escoado antes do concreto atingir uma deformação de 3,5\%, aí sim a capacidade portante das vigas teria sido alterada em função no nível de pré-carregamento aplicado.

As curvas teóricas obtidas através da simulação numérica pelo programa CONSNOU apresentaram inclinações bem distintas das curvas reais, portanto não foram apresentadas aqui.

\subsubsection{Deformações das armaduras}

\section{$\checkmark$ Armadura longitudinal tracionada}

Quando se executa o reforço de vigas por adição de barras de aço ocorre um deslocamento da linha neutra e um aumento da região comprimida do concreto. Isto altera o comportamento elástico da peça e conseqüentemente seu estado tensional. Outro fator que também altera o comportamento da peça reabilitada é a quantidade de carga atuante na viga durante a execução do reforço (pré-carregamento).

A Figura 5.10, idêntica à Figura 2.6 repetida aqui por conveniência, ilustra esquematicamente o estado de deformação e tensão que pode estar atuando em cada etapa do reforço da viga.

Para analisar as deformações das barras de aço tracionadas da primeira e segunda camada para o meio do vão, fez-se uma analogia com o comportamento apresentado na Figura 5.10 construindo-se os gráficos (a) e (b) da Figura 5.11. O primeiro gráfico mostra a diferença de deformação entre as barras de aço da armadura original (primeira camada $-\mathrm{A}_{\mathrm{sl1}}$ ) e da armadura adicionada (segunda camada - $\mathrm{A}_{\mathrm{s} 12}$ ) tal como no diagrama de deformações correspondente ao momento $\mathrm{M}_{3}$. O segundo gráfico mostra essa diferença tal como idealizado no diagrama de deformações para o momento $\mathrm{M}_{2}$, pois desconsidera os efeitos do pré-carregamento $\left(\mathrm{M}_{2}=\mathrm{M}_{3}-\mathrm{M}_{1}\right)$. Para comparar como seria o comportamento destas vigas caso elas tivessem sido reforçadas sem aplicação de um pré-carregamento traçou-se nestes gráficos as deformações das barras de aço da viga VA-3, ensaiada por REIS (1998). 


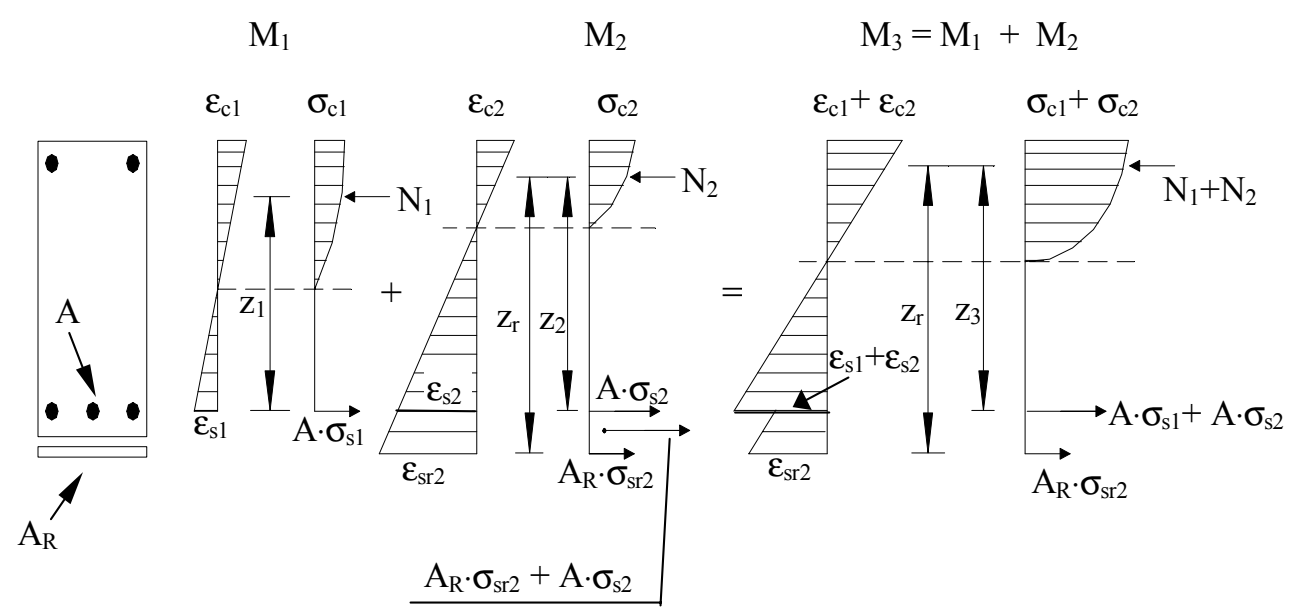

\section{Figura 5.10 - Estados de tensão e deformação em uma viga reforçada}

onde:

$\mathrm{M}_{1} \quad$ - momento gerado pela aplicação do pré-carregamento;

$\mathrm{M}_{2}$ - momento gerado pelo acréscimo de carga aplicado após a execução do reforço;

$\mathrm{M}_{3}$ - momento total (pré-carregamento + acréscimo de carga após o reforço);

$\mathrm{A}=\mathrm{A}_{\mathrm{s} 11} \quad$ - Área de aço do substrato;

$\mathrm{A}_{\mathrm{R}}=\mathrm{A}_{\mathrm{sl} 2}$ - Área de aço do reforço;

$\varepsilon_{\mathrm{c} 1}$ e $\sigma_{\mathrm{c} 1}$ - Deformação e tensão do concreto gerados pelo pré-carregamento;

$\varepsilon_{\mathrm{s} 1}$ e $\sigma_{\mathrm{s} 1}$ - Deformação e tensão do aço do substrato gerados pelo pré-carregamento;

$\varepsilon_{\mathrm{c} 2}$ e $\sigma_{\mathrm{c} 2}$ - Deformação e tensão do concreto gerados pelo acréscimo de carga após o reforço;

$\varepsilon_{\mathrm{s} 2}$ e $\sigma_{\mathrm{s} 2} \quad$ - Deformação e tensão do aço do substrato gerados pelo momento $\mathrm{M}_{2}$;

$\varepsilon_{\mathrm{sr} 2}$ e $\sigma_{\mathrm{sr} 2}$ - Deformação e tensão do aço do reforço gerados pelo momento $\mathrm{M}_{2}$;

$\mathrm{N}_{1}$ e $\mathrm{N}_{2}$ - Resultantes de compressão no concreto em relação a $\mathrm{M}_{1}$ e $\mathrm{M}_{2}$ respectivamente;

$\mathrm{Z}_{\mathrm{r}} \quad$ - Braço de alavanca da armadura do reforço;

$\mathrm{z}_{1} \quad$ - Braço de alavanca da armadura do substrato devido $\mathrm{M}_{1}$;

$\mathrm{Z}_{2} \quad$ - Braço de alavanca da armadura do substrato devido $\mathrm{M}_{2}$;

$\mathrm{Z}_{3} \quad$ - Braço de alavanca da armadura do substrato devido $\mathrm{M}_{3}$;

No gráfico da Figura 5.11a percebe-se que as curvas das deformações da armadura $A_{\text {sll }}$ das vigas VFT-1 e VFT-2 possuem uma menor inclinação no início até a força atingir o valor do pré-carregamento atuante no instante da reabilitação da peça. Após este valor de força, a inclinação das curvas aumenta devido ao aumento da seção transversal (rigidez do elemento) pelo reforço do banzo tracionado do elemento. Na viga VA-3 não existe essa diferença de inclinação na curva das deformações de $\mathrm{A}_{\text {sl1 }}$, porque o carregamento foi aplicado com a peça já reforçada, ou 
seja, não houve alteração nas dimensões da seção transversal da peça durante a aplicação de carregamento. Ainda neste gráfico, verifica-se que realmente todas as vigas analisadas romperam por escoamento das barras de aço tracionadas da primeira e da segunda camada sendo as deformações reais de início de escoamento maiores que 2,07\% (deformação convencional de escoamento para aço CA-50A).

Ao comparar as deformações das armaduras $A_{\text {sl1 }}$ com as da $A_{\text {sl2 }}$ percebe-se que, devido ao pré-carregamento atuante no instante da execução do reforço, realmente a armadura pré-existente possui deformações maiores que a armadura adicionada. Por outro lado, espera-se que com o aumento do carregamento haja uma tendência das deformações das barras de aço adicionadas se igualarem e até ultrapassarem as deformações das barras pré-existentes em função da diferença do braço de alavanca entre elas, o que faz com que a armadura $A_{s 12}$ absorva proporcionalmente mais carga que a armadura $A_{\text {sl1 }}$. Esse comportamento pode ser claramente observado nas curvas de deformação das armaduras da viga VFT-1. Já para a VFT-2 esse comportamento não ficou tão evidente.

Para avaliar melhor a taxa de crescimento das deformações das armaduras em função do braço de alavanca, construiu-se o gráfico da Figura 5.11b descontando-se o efeito do pré-carregamento. Por este gráfico verificou-se que na VFT-1 a deformação da $\mathrm{A}_{\text {s11 }}$ sempre foi menor que a da $\mathrm{A}_{\mathrm{s} 12}$ para um mesmo incremento de força. Isso está de acordo com o comportamento de uma viga convencional (ver equação 5.1), pois a armadura do reforço tem um braço de alavanca maior e conseqüentemente está sendo solicitada por uma força interna de tração também maior $\left(\mathrm{F}_{1}<\mathrm{F}_{2} \therefore \varepsilon_{1}<\varepsilon_{2}\right)$. $\mathrm{O}$ fato das deformações das armaduras $\mathrm{A}_{\mathrm{sl1}}$ e $\mathrm{A}_{\mathrm{sl} 2}$ para as vigas VFT-1 e VA-3 serem bastante próximas, além de possuírem taxas de crescimento praticamente iguais, confirma ainda mais que a equação de equilíbrio de esforços pode ser usada na previsão do comportamento dessa peça.

$$
\mathrm{M}_{\text {externo }}=\mathrm{M}_{\text {interno }} \quad \Rightarrow \mathrm{F}_{\text {total }} \cdot \mathrm{a}=\mathrm{F}_{1} \cdot \mathrm{z}_{1}+\mathrm{F}_{2} \cdot \mathrm{z}_{2}
$$

onde:

a - distância do apoio até o ponto de aplicação da força $F_{\text {total; }}$

$\mathrm{F}_{1}$ e $\mathrm{F}_{2}$ - Forças de tração na primeira e segunda camada das barras de aço; 
$\varepsilon_{1}$ e $\varepsilon_{2}$ - deformações na primeira e segunda camada das barras de aço;

$z_{1}$ e $z_{2}$ - braços de alavanca nas barras de aço da primeira e segunda camada.

Contudo, esse mesmo comportamento não foi observado na viga VFT-2, pois as deformações das barras de aço do reforço e do substrato foram praticamente coincidentes até uma valor de $\Delta \mathrm{F}$ aproximadamente igual a $117 \mathrm{kN}$. A partir deste instante, a deformação na $\mathrm{A}_{\mathrm{s} 11}$ começou a ser maior que a da $\mathrm{A}_{\mathrm{sl} 2}$, mostrando um comportamento oposto ao observado na VFT-1. Isso indica que para este patamar de $\Delta \mathrm{F}$, a deformação real existente na $\mathrm{A}_{\mathrm{s} 11}$ estava próxima do início do escoamento, fato confirmado pelas curvas da VFT-2 do gráfico 5.11a.

Isso sugere que em função da intensidade de carregamento existente durante a execução do reforço, talvez ocorra alguma redistribuição de esforços internos na viga que não possa ser avaliada apenas através da análise do braço de alavanca das armaduras. Conseqüentemente isso pode tornar inadequado o uso dos estados de deformação apresentados na Figura 5.10 como meio de se avaliar o comportamento das peças reforçadas sob carga uma vez que o valor do pré-carregamento pode afetar significativamente a evolução das deformações das armaduras tracionadas da primeira e segunda camadas. Além disso, quanto maior o valor do pré-carregamento, mais crítico será o comportamento do elemento estrutural já que as barras de aço do substrato podem escoar antes das barras do reforço.

Para complementar a análise, construiu-se o gráfico da Figura 5.12 que compara o comportamento real das vigas com o comportamento teórico simulado usando o método dos elementos finitos. Para a VFT-1, a simulação forneceu bons resultados. Entretanto, para a viga VFT-2 o comportamento teórico obtido não foi satisfatório porque, apesar das deformações reais e simuladas da armadura préexistente $\left(\mathrm{A}_{\mathrm{s} 11}\right)$ terem ficado relativamente próximas, a simulação numérica não conseguiu avaliar adequadamente o aumento de deformação da armadura adicionada $\left(\mathrm{A}_{\mathrm{s} 12}\right)$ no caso do pré-carregamento mais crítico. 


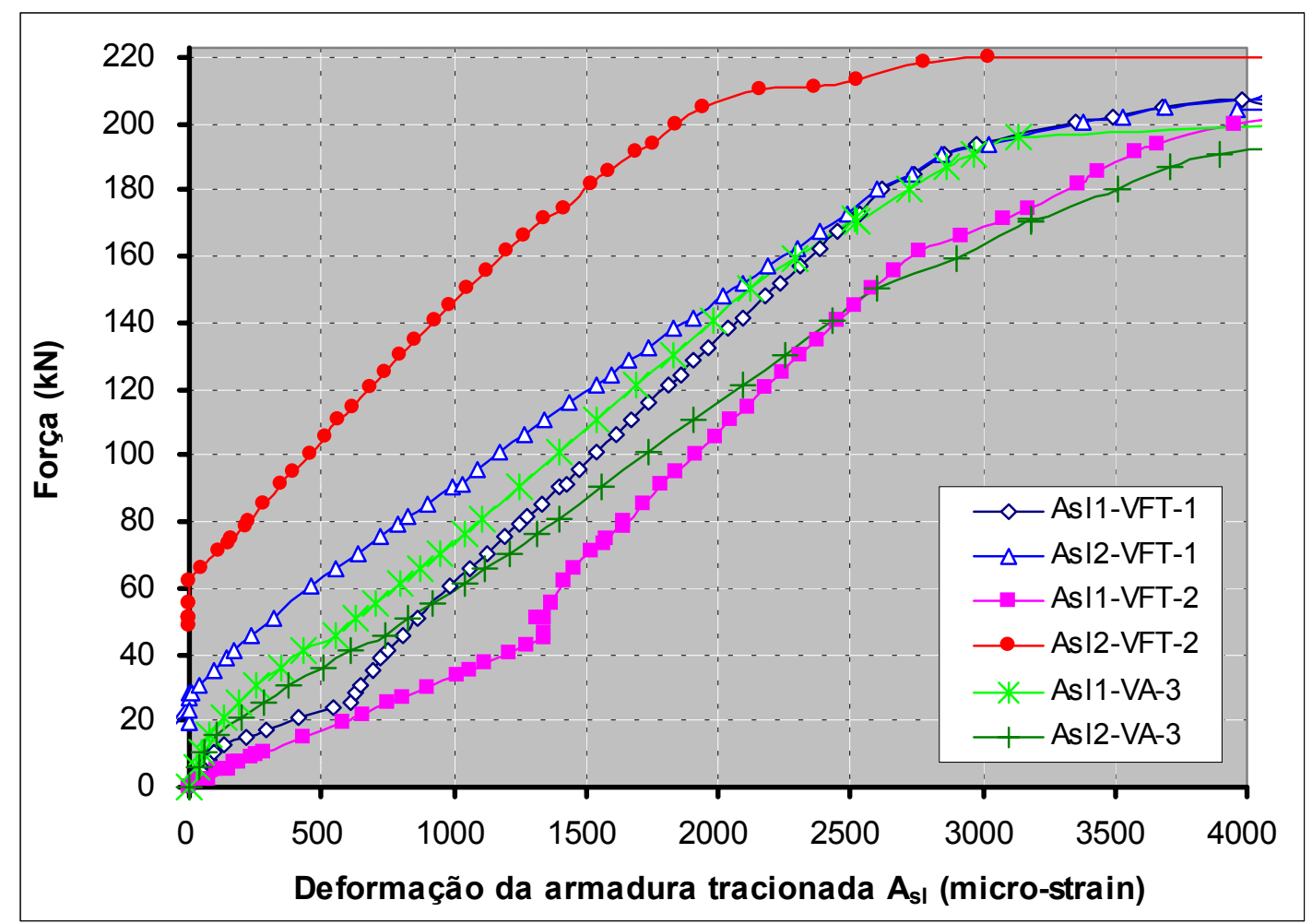

a) Evolução das deformações experimentais das vigas considerando o pré-carregamento

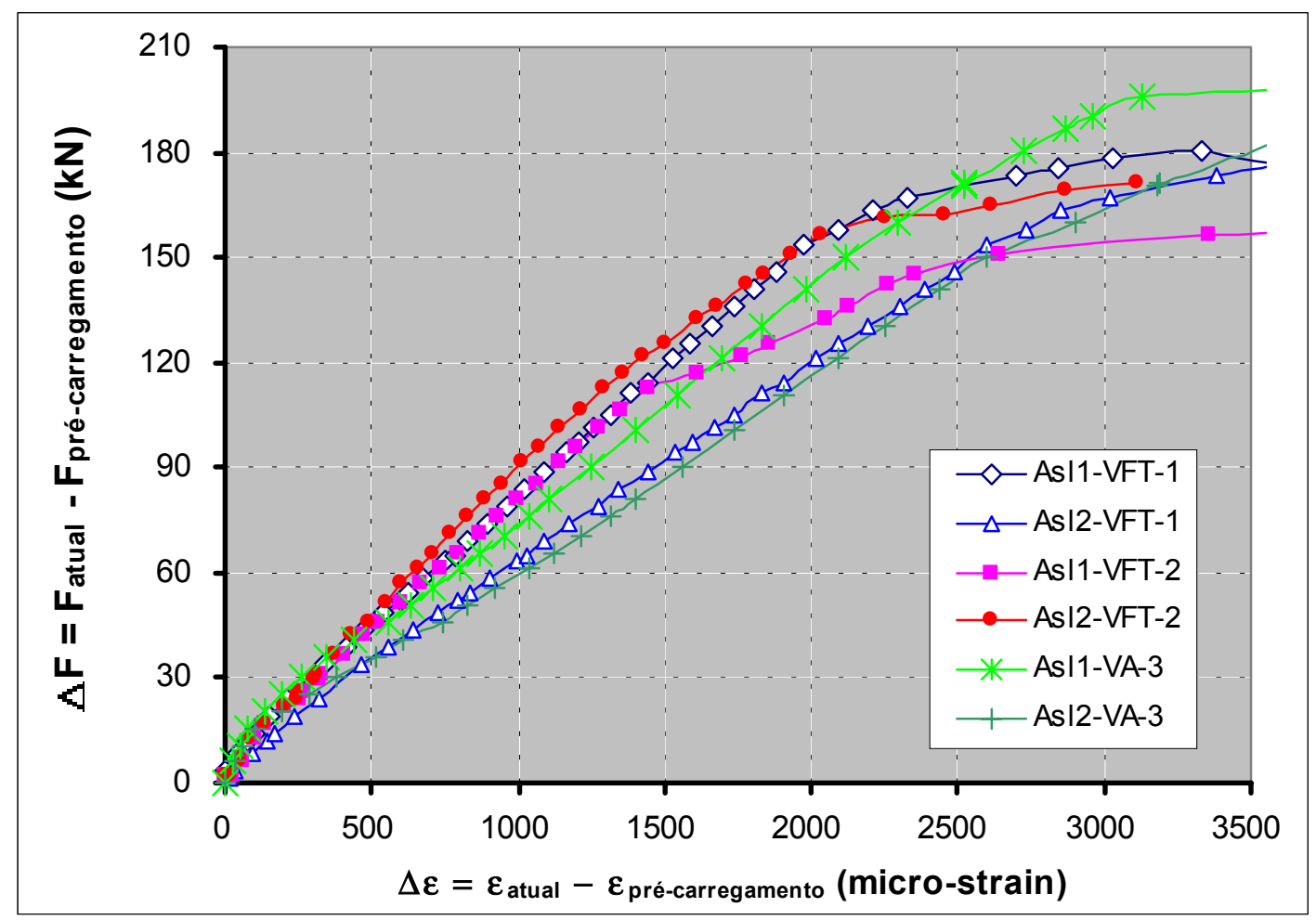

b) Evolução das deformações experimentais das vigas desconsiderando o pré-carregamento

Figura 5.11 - Evolução da deformação das barras de aço tracionadas 


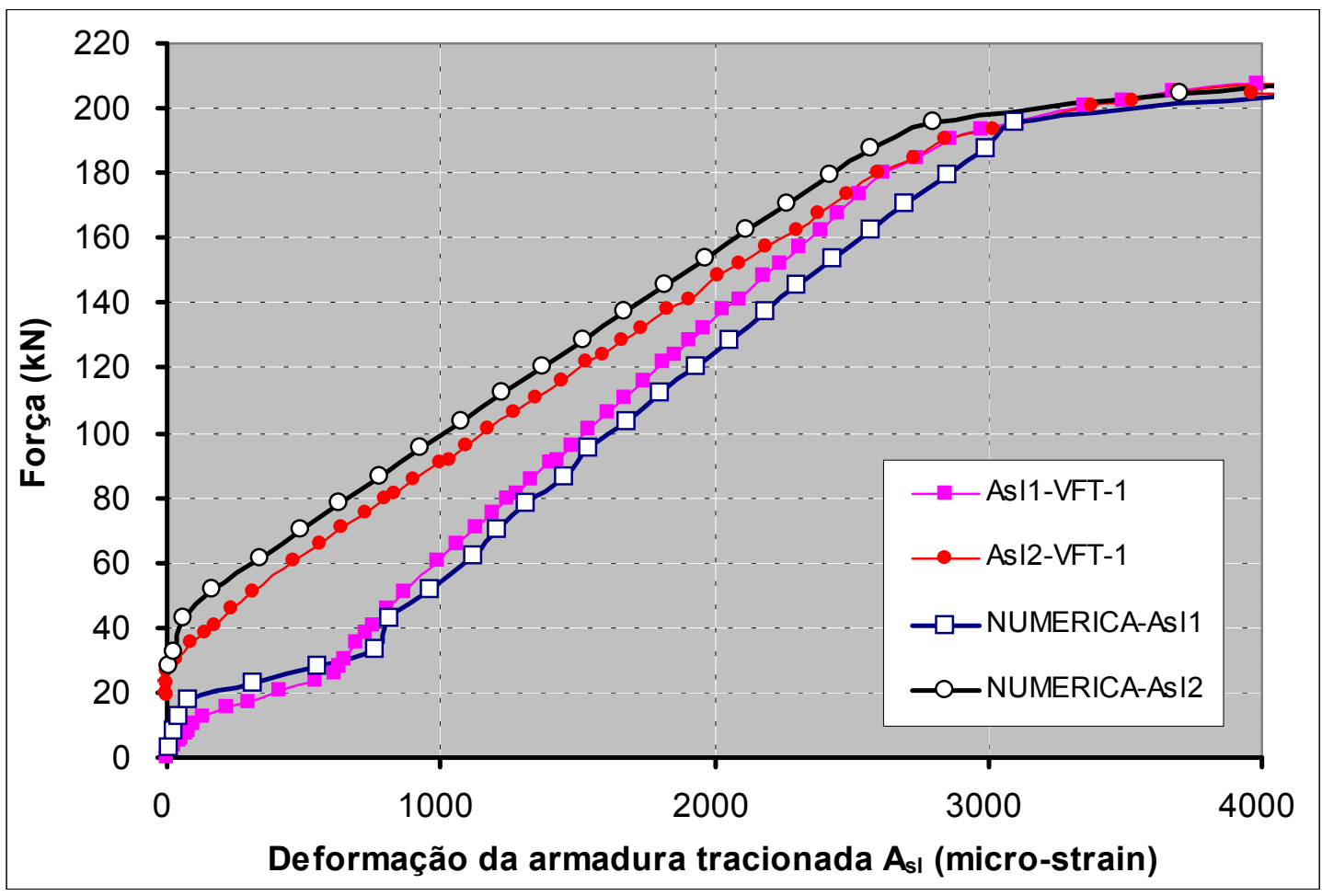

a) Comparação entre a simulação numérica e o comportamento real da VFT-1

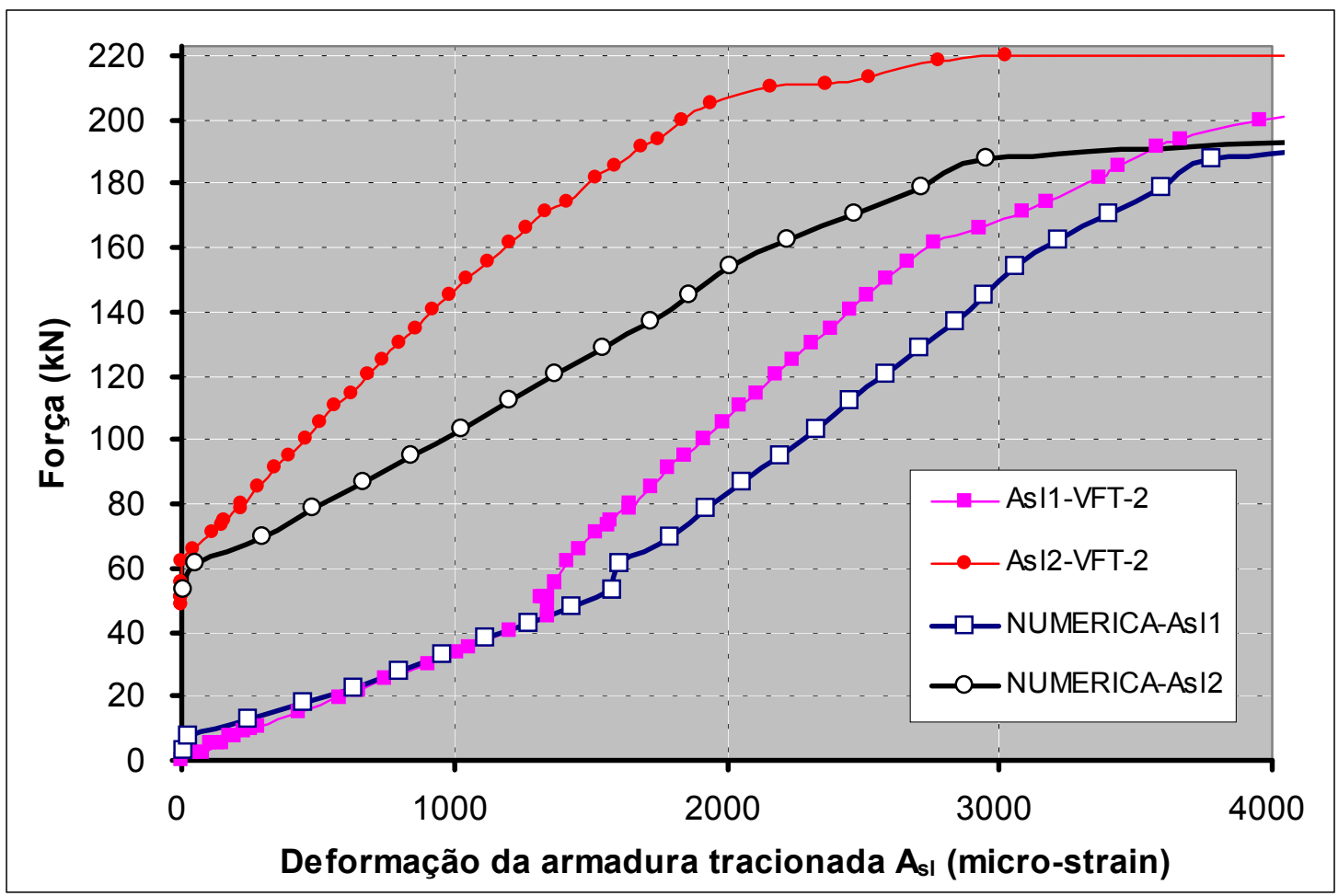

b) Comparação entre a simulação numérica e o comportamento real da VFT-2

Figura 5.12 - Comportamento real x comportamento teórico das vigas VFT 


\section{$\checkmark$ Armadura longitudinal comprimida}

Observando as deformações pré-existentes na armadura comprimida percebeuse que as curvas foram praticamente coincidentes para a VFT-1 e VFT-2, e que esta armadura escoou na ruptura, já que houve o esmagamento do concreto comprimido.

Como não se dispunha dos dados da deformação desta armadura para a viga VA-3, não foi possível comparar o comportamento entre vigas reforçadas com e sem pré-carregamento. Entretanto, como o pré-carregamento existente na VFT-1 no início do ensaio após o reforço era pequeno e mesmo assim a evolução da deformação da armadura comprimida da VFT-1 foi praticamente igual à da VFT-2, acredita-se que a execução do reforço sem o completo descarregamento da viga não deve provocar descontinuidades significativas nas deformações desta armadura em relação a uma peça reforçada sem pré-carregamento.

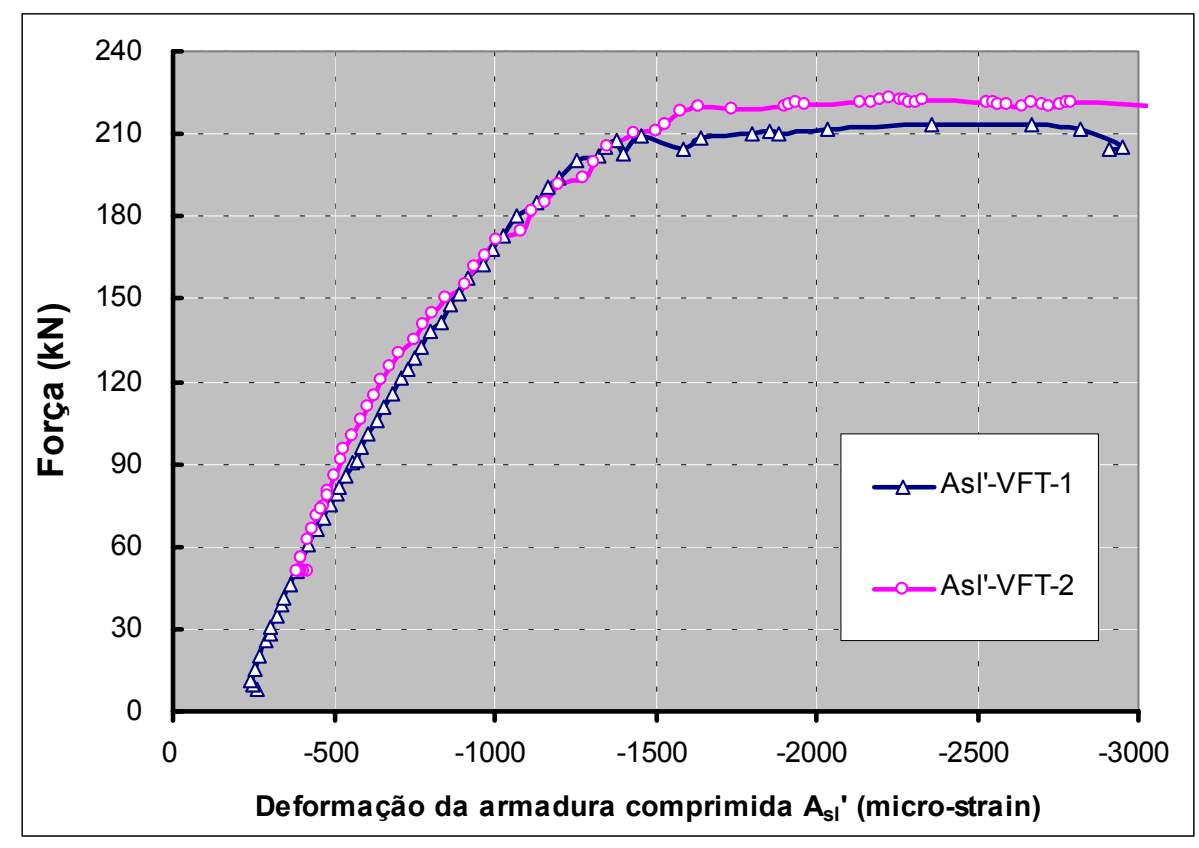

Figura 5.13 - Deformação da armadura comprimida $\mathrm{A}_{\mathrm{sl}}$,

\section{$\checkmark$ Armadura transversal}

Pelo gráfico da Figura 5.14 observou-se que a evolução das deformações experimentais dos estribos antes do reforço para as vigas VFT-1 e VFT-2 diminuíram mesmo quando o valor do pré-carregamento permanecia constante (trechos horizontais). Isso indicou que houve uma redistribuição dos esforços internos na peça, gerados pelo pré-carregamento atuante, em função do aumento de 
rigidez causado pelo aumento da seção transversal da viga e pelo ganho de resistência do material de reforço adicionado.

Essa redistribuição de esforços internos provavelmente ocorreu devido à alteração da inclinação das bielas comprimidas existentes no modelo de treliça usada no cálculo da armadura de cisalhamento de vigas em função da modificação da posição do banzo tracionado (ver Figura 3.3 - modelo b).

Na Figura 5.14 também traçou-se a evolução das deformações nos estribos das vigas reforçadas sem pré-carregamento atuante, VA-1 e VA-3, ensaiadas por REIS (1998). A diferença entre estas vigas é que a VA-1 foi reforçada e ensaiada sem ter sofrido nenhum tipo de pré-danificação, enquanto a VA-3, que correspondia à viga VA-1 reabilitada após ter sido levada a ruptura, apresentava uma pré-danificação bastante severa, mesmo depois da substituição do material do bordo tracionado da viga VA-1 para transformá-la na VA-3. Pode-se dizer inclusive que a prédanificação existente na VA-3 era muito mais crítica que a existente nas vigas VFT. Por este motivo é que as deformações dos estribos na VA-3 foram maiores que nas outras vigas analisadas.

Além disso, na VA-3 o banzo tracionado foi reconstituído utilizando um material compósito com taxa de $1,0 \%$ de fibras de aço ${ }^{3}$ da marca HAREX enquanto que nas vigas VFT o banzo foi reconstituído utilizando um material compósito com taxa de $2 \%$ de fibras de aço da marca DRAMIX. Como a variação do tipo e da taxa de fibras de aço altera significativamente a resistência à tração na flexão dos materiais compósitos (ver Capítulo 4), mesmo quando estes materiais têm aproximadamente a mesma resistência à compressão axial. Isso pode ter ressaltado ainda mais as diferenças observadas na evolução das deformações dos estribos das vigas analisadas, já que tais deformações dependem quase que exclusivamente do início da fissuração ao cisalhamento e conseqüentemente da resistência à tração do material compósito.

Comparando as deformações nos estribos das vigas VFT com as da viga VA-1 percebeu-se que as vigas pré-carregadas apresentaram deformações menores que as não pré-carregadas, porque ao substituir parte do concreto do substrato por outro

${ }^{3}$ As características das fibras de aço usadas nas vigas VFT e VA estão apresentadas na Tabela 2.10 
íntegro, o novo material não estava sujeito a nenhum esforço gerado pelo précarregamento, retardando o início da físsuração por cisalhamento em relação ao valor total da força aplicada na viga. Em função disso, pode-se dizer que a execução do reforço no bordo tracionado em peças pré-carregadas pode, até certo ponto, beneficiar a resistência ao cisalhamento do elemento.

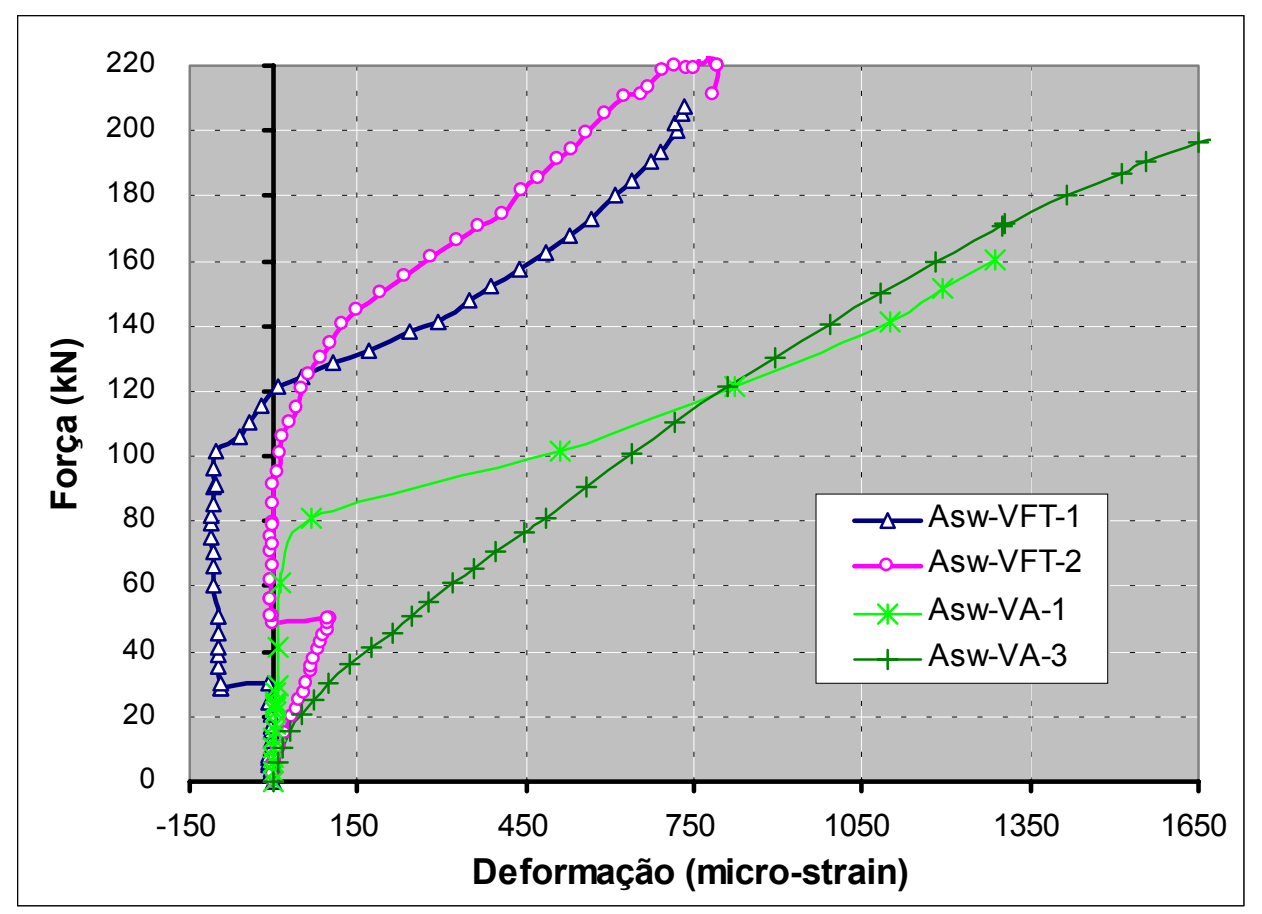

Figura 5.14 - Deformação da armadura transversal - $A_{s w}$

\section{5 - Dificuldades encontradas}

A principal dificuldade encontrada na realização deste tipo de ensaio refere-se à manutenção do pré-carregamento durante o período em que o material do reforço ainda está adquirindo resistência, pois não se conseguiu manter constante a pressão do óleo nos macacos hidráulicos. Por este motivo foram observados picos para mais ou para menos no valor do pré-carregamento atuante em função das variações de temperatura. Para evitar as variações do pré-carregamento foi preciso ajustar a força aplicada pelos macacos hidráulicos várias vezes durante o dia e de preferência nos períodos de picos de temperatura (início da noite e início da tarde). Houve dificuldade também em se realizar a escarificação do bordo tracionado da viga sem danificar os extensômetros colados à armadura. 


\section{6 - Ensaios complementares ao estudo da Técnica de Reforço $n^{0} 2$}

\subsection{Considerações iniciais}

Para avaliar de maneira mais precisa o comportamento das vigas reforçadas no bordo comprimido foi preciso realizar ensaios complementares para caracterizar a deformabilidade do concreto ao longo do tempo conforme os traços usados em sua confecção. Tais traços referem-se ao concreto do substrato (TS-2) e ao microconcreto de reforço (TR-2), cujas dosagens encontram-se na Tabela 2.9. Entretanto, como as deformações dependentes do tempo (retração e fluência) em peças de concreto são bastante influenciadas pelas condições ambientais, houve necessidade de se construir uma câmara climatizada no Laboratório de Estruturas da EESC-USP, onde se pudesse armazenar tanto os corpos-de-prova, usados nos ensaios complementares, quanto as vigas reforçadas, durante a etapa do ensaio de longa duração. Foi preciso também adquirir um software para controlar automaticamente as condições ambientais da Câmara Climatizada. As Figuras 6.1 e 6.2 ilustram algumas das características da câmara climatizada construída e do software utilizado.
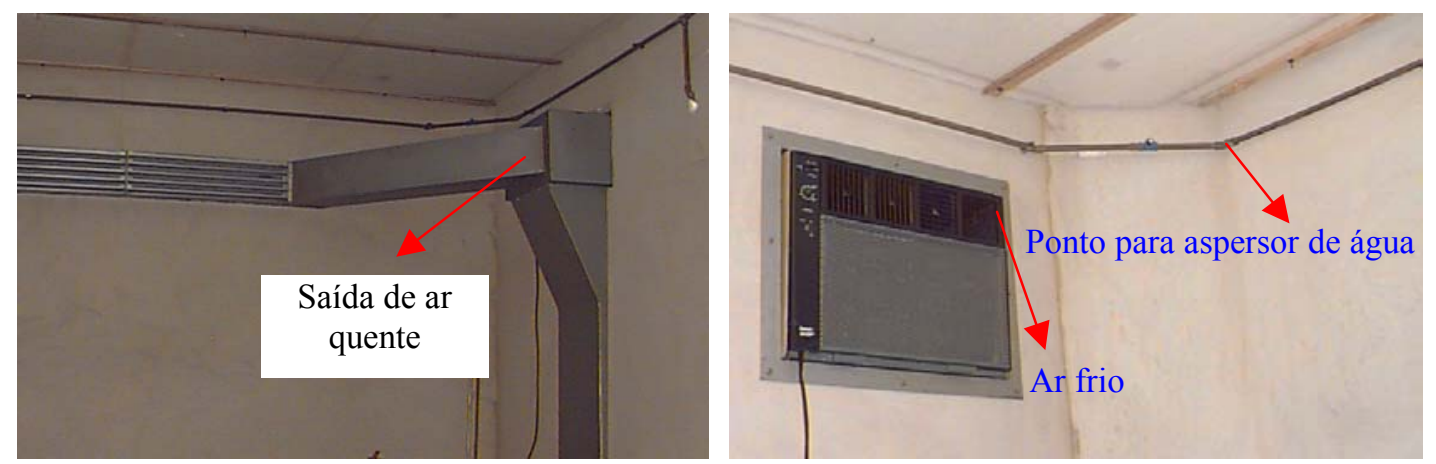

Figura 6.1 - Disposição dos equipamentos no interior da câmara climatizada Câmara Climatizada construída no Laboratório da EESC - USP 


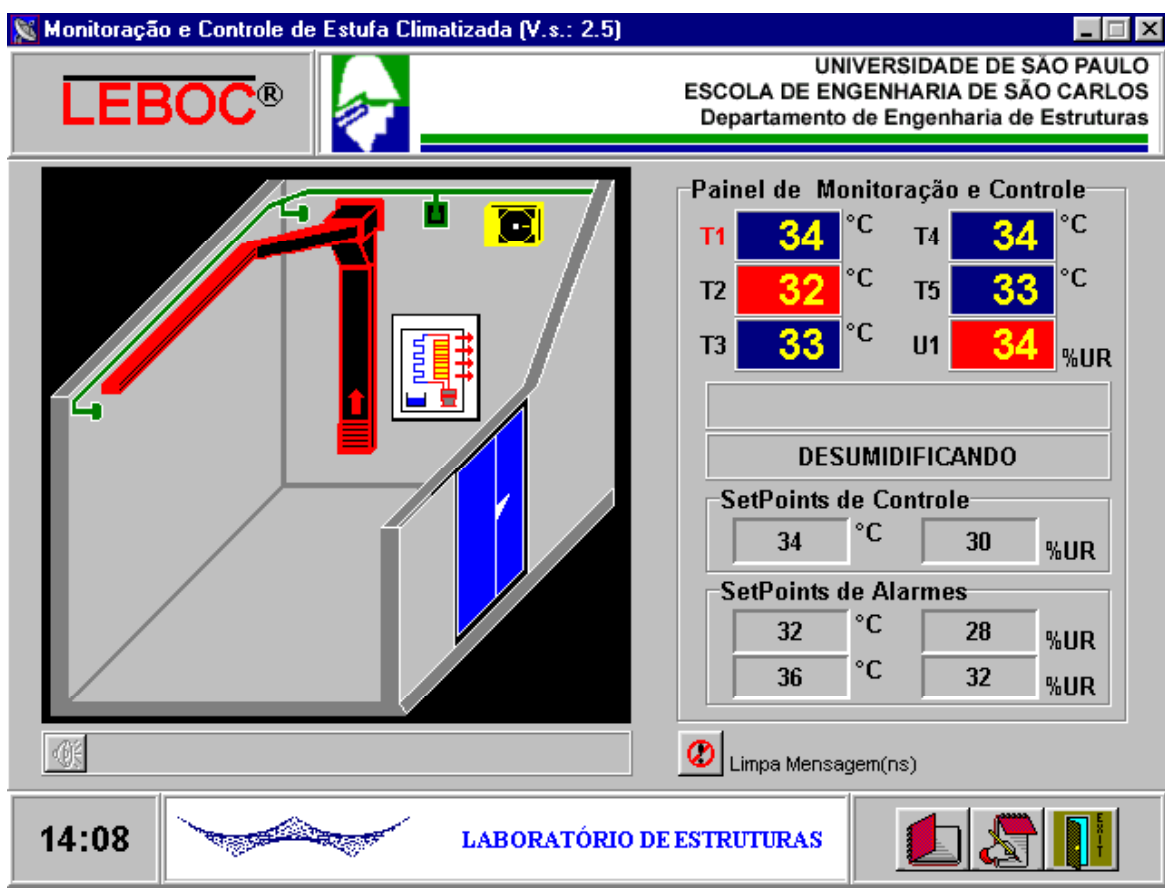

Figura 6.2- Tela principal do sistema SIMPLE Ambiental $\rightarrow$ software para monitoração e controle das condições ambientais da câmara climatizada.

Com a construção da câmara climatizada - que registrava e controlava automaticamente a temperatura e a umidade relativa do ar durante a realização dos ensaios de longa duração - tentou-se minimizar os efeitos das variações ambientais no comportamento das vigas ensaiadas facilitando assim a análise dos resultados.

Para identificar as principais dificuldades na leitura das deformações dependentes do tempo em peças de concreto armazenadas na câmara climatizada realizou-se alguns ensaios em corpos-de-prova, tentando seguir as recomendações das normas quanto à avaliação da fluência e da retração. Entretanto, os resultados obtidos não foram muito satisfatórios, pois as deformações devidas à retração e fluência são bastante pequenas e difíceis de serem medidas, necessitando de equipamentos de leitura específicos. Em virtude deste fato, para se determinar de maneira confiável os valores experimentais dos coeficientes representativos do comportamento à retração e à fluência dos concretos usados nas vigas reforçadas no bordo comprimido, fez-se uma parceria com o Centro Tecnológico de Engenharia Civil de FURNAS Centrais Elétricas S.A. (localizado em Aparecida de Goiânia GO) para se realizar lá os ensaios de caracterização da deformabilidade ao longo do tempo dos traços do substrato e do reforço usados nas vigas reforçadas do tipo VFC. 
O Laboratório de Concreto de FURNAS está credenciado junto à rede brasileira de laboratórios de ensaios do Inmetro e possui a certificação de que seu sistema de qualidade está adequado às exigências da norma ISO 9002. Possui um corpo técnico bastante experiente e dispõem de todos os equipamentos especiais necessários para executar os ensaios requeridos, tais como prensas capazes de manter constante a tensão ao longo do tempo (para ensaios de fluência), fôrmas para confecção de corpos-de-prova com dimensões indicadas por normas específicas e dispositivos de fixação dos extensômetros elétricos tipo CARLSON a serem embutidos nos corpos-de-prova para medição das deformações do concreto ao longo do tempo. Além disso, consegue garantir um ambiente com umidade e temperatura perfeitamente controladas.

Para realizar os ensaios complementares em FURNAS, foi necessário enviar para esta instituição uma certa quantidade de areia, brita, cimento, sílica ativa e superplastificante para moldar os corpos-de-prova, porque a deformabilidade dos concretos variam caso se alterem os materiais utilizados na confecção dos traços.

\subsection{Ensaios realizados em FURNAS Centrais Elétricas S.A.}

Para avaliar as características viscoelásticas de um concreto é preciso realizar vários tipos de ensaios além dos ensaios de fluência e retração. Sendo assim, foram moldados 34 corpos-de-prova para cada traço analisado (substrato e reforço) que possuíam diferentes características em função do tipo de teste ao qual seriam submetidos. Os principais ensaios realizados foram:

- Ensaios para determinação da fluência específica para 4 idades de carregamento distintas;

- Ensaios para determinação da retração autógena;

- Ensaios para determinação da retração por secagem;

- Ensaios para determinação da resistência à compressão axial;

- Ensaios para determinação da resistência à tração por compressão diametral;

- Ensaios para determinação do módulo de elasticidade do concreto;

- Ensaios para determinação do coeficiente de dilatação térmica linear. 
Os procedimentos destes ensaios estão descritos resumidamente a seguir e maiores detalhes sobre as características destes corpos-de-prova, bem como as planilhas com respectivos resultados, estão apresentados no Apêndice D.

\subsubsection{Ensaios para determinar a deformação por fluência e a deformação por retração autógena}

Define-se fluência como sendo a deformação que o concreto sofre devido a um carregamento externo que é mantido ao longo do tempo. Esta deformação é mais rápida no início e diminui com o tempo, tendendo assintoticamente a um valor limite.

A NBR-8224 prescreve o método experimental para a determinação da deformação do concreto devida à fluência em uma certa idade, estimando-se esta deformação como sendo a diferença entre a deformação total e a soma das deformações independentes da permanência do carregamento ao longo do tempo que são:

- deformação imediata, que ocorre no instante de aplicação do carregamento;

- deformação por retração autógena e por retração por secagem, que ocorrem ao longo de tempo de duração do ensaio de fluência.

A deformação imediata é obtida no instante da aplicação da carga nos corposde-prova ensaiados à fluência. Já as deformações por retração autógena ou por retração por secagem são determinadas em corpos-de-prova complementares.

Nos ensaios realizados para determinar as deformações por retração autógena, utiliza-se corpos-de-prova similares aos ensaiados à fluência, mas que não foram carregados. Tais corpos-de-prova são selados para garantir que não haja troca de umidade com o meio ambiente, indicando que a deformação observada se deve exclusivamente à retração autógena do material analisado.

Nos ensaios realizados para determinar as deformações de retração por secagem, utilizam-se corpos-de-prova prismáticos. Tais ensaios estão melhor descritos no item 6.2.2.

A deformação por fluência é afetada pela troca de umidade do concreto com o meio ambiente, ou seja, depende da superfície do elemento estrutural em contato 
com o ar. Em ensaios de fluência no qual a troca de umidade não é impedida, determina-se a chamada fluência por secagem. Para caracterizar a fluência do concreto de um elemento estrutural independentemente das dimensões e das áreas expostas ao ar, deve-se medir sua fluência básica, ou seja, aquela que surge no material quando não há troca de umidade do concreto com o meio ambiente.

Os ensaios de fluência realizados em FURNAS usam no mínimo 2 corpos-deprova cilíndricos que possuem uma relação altura/diâmetro igual ou maior que 2 , e que são selados em laboratório para evitar a troca de umidade com o meio ambiente. Para que a interpretação dos resultados dos ensaios de fluência seja correta, é essencial dispor dos resultados de ensaios de resistência à compressão, da deformação por retração autógena e do módulo de elasticidade, obtidos em corposde-prova complementares. É necessário também conhecer o coeficiente de dilatação térmica do material a fim de corrigir a deformação lida durante os ensaios de fluência em função de alguma eventual variação de temperatura.

Além dos corpos-de-prova complementares deve-se realizar ensaios de fluência em idades suficientes de carregamento (no mínimo 4 idades), de modo que, por interpolação e extrapolação, se disponha de conhecimento suficiente sobre o fenômeno da fluência no material analisado, já que este parâmetro varia em função da idade em que se aplicou o carregamento.

Os corpos-de-prova complementares e aqueles destinados aos ensaios de fluência foram moldados com o mesmo traço, sendo submetidos às mesmas condições de cura.

Para medir as deformações por fluência foram usados extensômetros de resistência elétrica tipo Carlson M4, embutidos em corpos-de-prova cilíndricos conforme Figura 6.3a. Após um dia da moldagem do corpo-de-prova, colocavam-se em sua extremidade superior, discos metálicos fixados ao concreto por meio de adição de resina epoxídica sobre a qual se aplicava uma argamassa de traço forte (1:2) que permitia o nivelamento do disco (ver Figura 6.3b).

Para o traço do substrato ${ }^{*}$ (dosagem E-9091) foram confeccionados 4 corposde-prova cilíndricos de 25 x $50 \mathrm{~cm}$ e para o traço do reforço (dosagem E-9121)

\footnotetext{
* A nomenclatura dos traços usadas em FURNAS foi diferente da adotada na Tabela 2.9 sendo que a dosagem E-9091 corresponde ao traço TS-2 e a dosagem E-9121 corresponde ao traço TR-2.
} 
foram confeccionados 4 corpos-de-prova cilíndricos de 15 x $45 \mathrm{~cm}$. Adotou-se um corpo-de-prova de seção transversal menor para o traço do reforço porque, por este traço ter uma resistência à compressão elevada, foi preciso adequar o valor da força limite que a aparelhagem usada nos ensaios de fluência seria capaz de aplicar nos corpos-de-prova, para que se conseguisse uma tensão de compressão de $40 \%$ da tensão de ruptura do corpo-de-prova.

Os corpos-de-prova ensaiados em FURNAS foram protegidos contra a perda de umidade por meio de um procedimento chamado selagem, pelo qual se envolve os corpos-de-prova com uma borracha colada com resina epóxi 24 horas após a desforma. Após o endurecimento da resina epóxi, a borracha é totalmente envolta por uma fita gomada de papel para garantir a melhor aderência da mesma ao corpode-prova. A Figura 6.4a mostra os corpos-de-prova já selados antes de se iniciar os ensaios e o instante em que se aplicou o carregamento responsável por gerar a fluência.

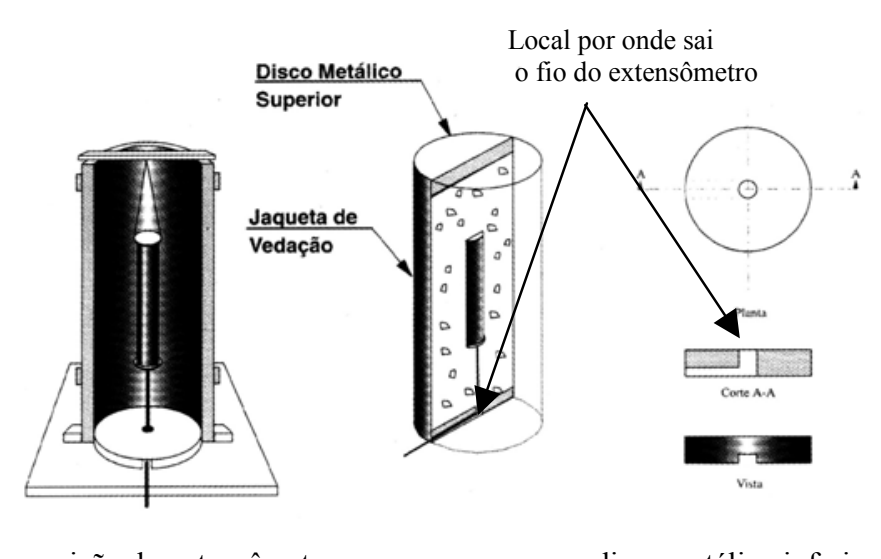

(a) Esquema de fixação do extensômetro Carlson nos corpos-de-prova
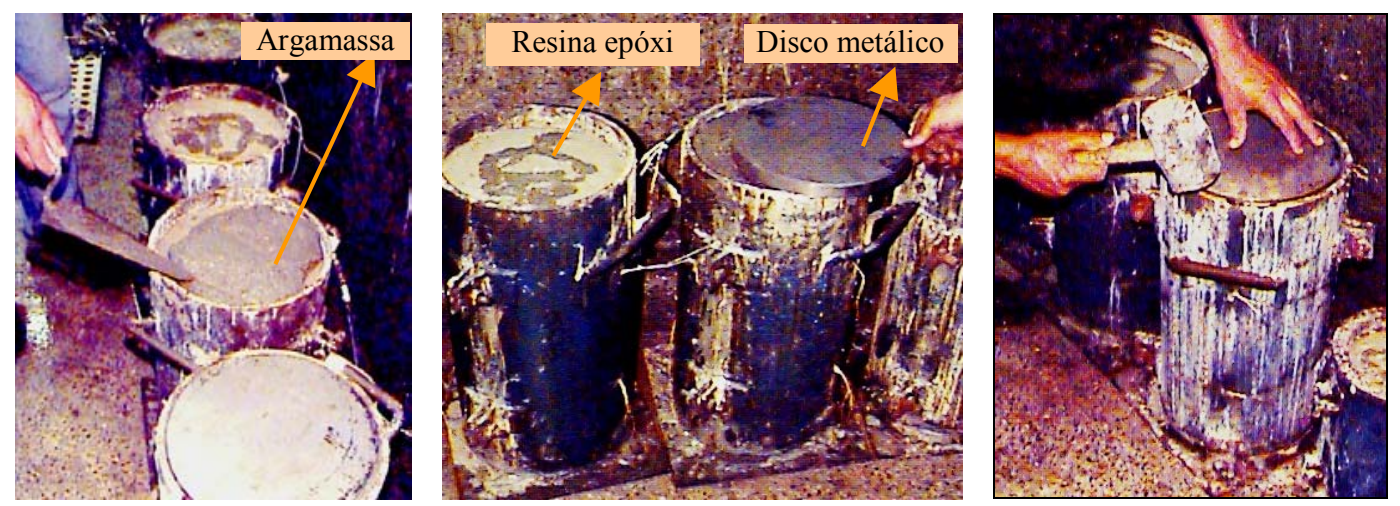

(b) Esquema de fixação do disco metálico sobre os corpos-de-prova

Figura 6.3 - Fixação dos extensômetros Carlson e do disco metálico 
Utilizou-se o Sistema Pirtz como sistema de aplicação e manutenção de carga nos ensaios de fluência. Tal sistema permite a aplicação e a manutenção de uma dada tensão em corpos-de-prova cilíndricos por um período de tempo prédeterminado, necessitando de um mínimo de ajustes manuais conseguido pelo uso de uma célula de carregamento hidráulico em conexão com um sistema de fornecimento de pressão controlada eletronicamente.

A sala onde foi feito o ensaio é climatizada, possuindo uma temperatura de $23^{\circ} \mathrm{C} \pm 2^{\circ} \mathrm{C}$ e umidade de $60 \% \pm 10 \%$. Qualquer variação de temperatura (acima ou abaixo da temperatura de início de ensaio) provocam variações volumétricas significativas, mas são corrigidas no cálculo da deformação total utilizando os resultados dos ensaios de dilatação térmica do material. Esta correção equivale à deformação dada por $\varepsilon_{\mathrm{T}}=\alpha \times \Delta \mathrm{T}$, onde $\alpha$ representa o coeficiente de dilatação térmica do concreto obtido experimentalmente e $\Delta \mathrm{T}$ representa a variação de temperatura observada durante a execução do ensaio.

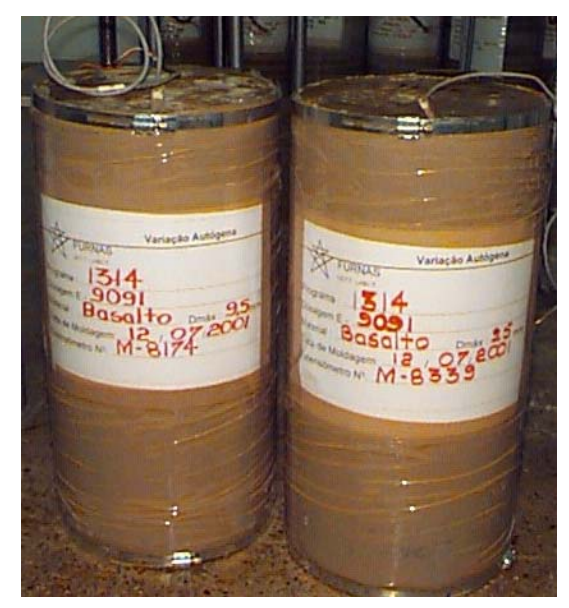

(a) Corpo-de-prova após a selagem

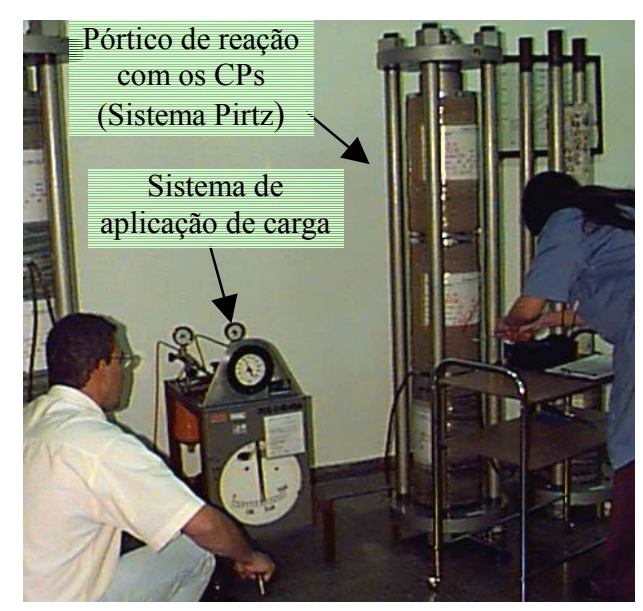

(b) Aplicação de carga - ensaio de fluência

\section{Figura 6.4 - Corpos-de-prova selados e aparelhagem usada na aplicação e manutenção de carga nos ensaios de fluência}

A tensão aplicada nos ensaios de fluência foi calculada como sendo $40 \%$ da resistência à compressão do concreto obtida experimentalmente pelos corpos-deprova complementares para cada uma das idades de ensaio de fluência. $O$ carregamento foi feito a uma velocidade tal que a carga total fosse aplicada no corpode-prova durante um período mais próximo de 30 segundos. Antes do carregamento 
definitivo, aplicou-se dois ciclos de carregamento e descarregamento simultâneos com a carga estabelecida para ensaio. Após estes ciclos, registrou-se as leituras das deformações, imediatamente antes do carregamento definitivo (leitura de referência) e em seguida aplicou-se a força prevista registrando as leituras de deformação na seguinte seqüência:

- 30 segundos após o carregamento (deformação instantânea);

- $1,2,3,5,10,15$ e 30 minutos após o carregamento;

- 1,2 e 5 horas após o carregamento;

- diariamente, por uma semana;

- duas vezes por semana, até completar um mês;

- semanalmente até completar o ensaio (mínimo de 90 dias).

A deformação por fluência foi calculada pela expressão (6.1):

$\varepsilon_{\mathrm{f}}=\varepsilon_{\mathrm{r}}-\varepsilon_{\mathrm{i}}-\varepsilon_{\mathrm{s}}$

$\varepsilon_{\mathrm{e}}=\varepsilon_{\mathrm{f}} / \sigma_{\mathrm{a}}$

Onde:

$\varepsilon_{\mathrm{f}}$ - Deformação por fluência;

$\varepsilon_{\mathrm{r}}$ - Deformação total calculada em função da leitura de referência nos corpos-de-prova carregados, na idade considerada;

$\varepsilon_{i}$ - Deformação imediata;

$\varepsilon_{\mathrm{s}}$ - Deformação média nos corpos-de-prova não carregados (deformação autógena) em $10^{-6}$ $\mathrm{cm} / \mathrm{cm}$;

$\varepsilon_{\mathrm{e}}-\quad$ Fluência específica (em $\left.10^{-6} / \mathrm{MPa}\right)$;

$\sigma_{\mathrm{a}}-\quad$ Tensão aplicada no ensaio de fluência.

Observe-se que não se mencionou aqui a deformação devida à retração por secagem, pois os ensaios de fluência foram feitos utilizando corpos-de-prova selados, ou seja, não houve troca de umidade com o meio ambiente.

Para traçar as curvas de fluência do substrato foram estabelecidos quatro idades de carregamento distintas (ver Tabela D.1 no Apêndice D). Para as idades maiores que 50 dias utilizou-se corpos-de-prova de outros ensaios tais como os da deformação autógena e os do ensaio da fluência aos 7 dias. Houve a necessidade de 
utilizar corpos-de-prova já ensaiados à fluência, pois foram adquiridos somente 8 extensômetros Carlson. Como estes extensômetros são excessivamente caros e seriam necessários no mínimo 16 (já que é preciso moldar no mínimo 2 corpos-deprova por idade de carregamento por traço), além dos 4 extensômetros usados nos ensaios de deformação autógena, optou-se por utilizar os corpos-de-prova já ensaiados à fluência para as diferentes idades de carregamento iniciais. A reutilização de corpos-de-prova já ensaiados à fluência está prevista inclusive na NBR-8224 que diz "Nos ensaios de fluência para carregamento em idades maiores que 365 dias não é permitida a utilização de corpos-de-prova que já foram utilizados nos ensaios a idades menores e cujo período de carregamento tenha sido encerrado". Como a idade que se tem é inferior a 365 dias, acredita-se que seja possível reutilizar tais corpos-de-prova sem muitos prejuízos aos resultados.

A evolução da fluência específica com o tempo, para as diversas idades de carregamento de ambos os traços estudados, está apresentada na Figura 6.5.

Os ensaios de retração por deformação autógena permitem determinar as variações de deformação que ocorrem no concreto quando este não está submetido a um carregamento e nem a trocas de umidade com o meio ambiente. De acordo como a fib Bulletin $n^{o} 1$ (1999) estas variações de deformação são mais acentuadas para corpos-de-prova com resistência elevada.

Os corpos-de-prova usados na determinação da retração por deformação autógena foram idênticos aos usados nos ensaios de fluência, ficaram armazenados em condições ambientais idênticas a estes e não foram submetidos a nenhum carregamento. Esta deformação foi observada ao longo do tempo até a sua estabilização (ver Figura 6.6) e, após a finalização dos testes, tais corpos-de-prova foram usados nos ensaios de fluência para a terceira idade de carregamento (50 dias para o traço do substrato e de 126 dias para o traço do reforço). Esta idade variou porque a estabilização da deformação autógena foi mais rápida para o concreto do substrato que para o do microconcreto do reforço, conforme já se previa. 


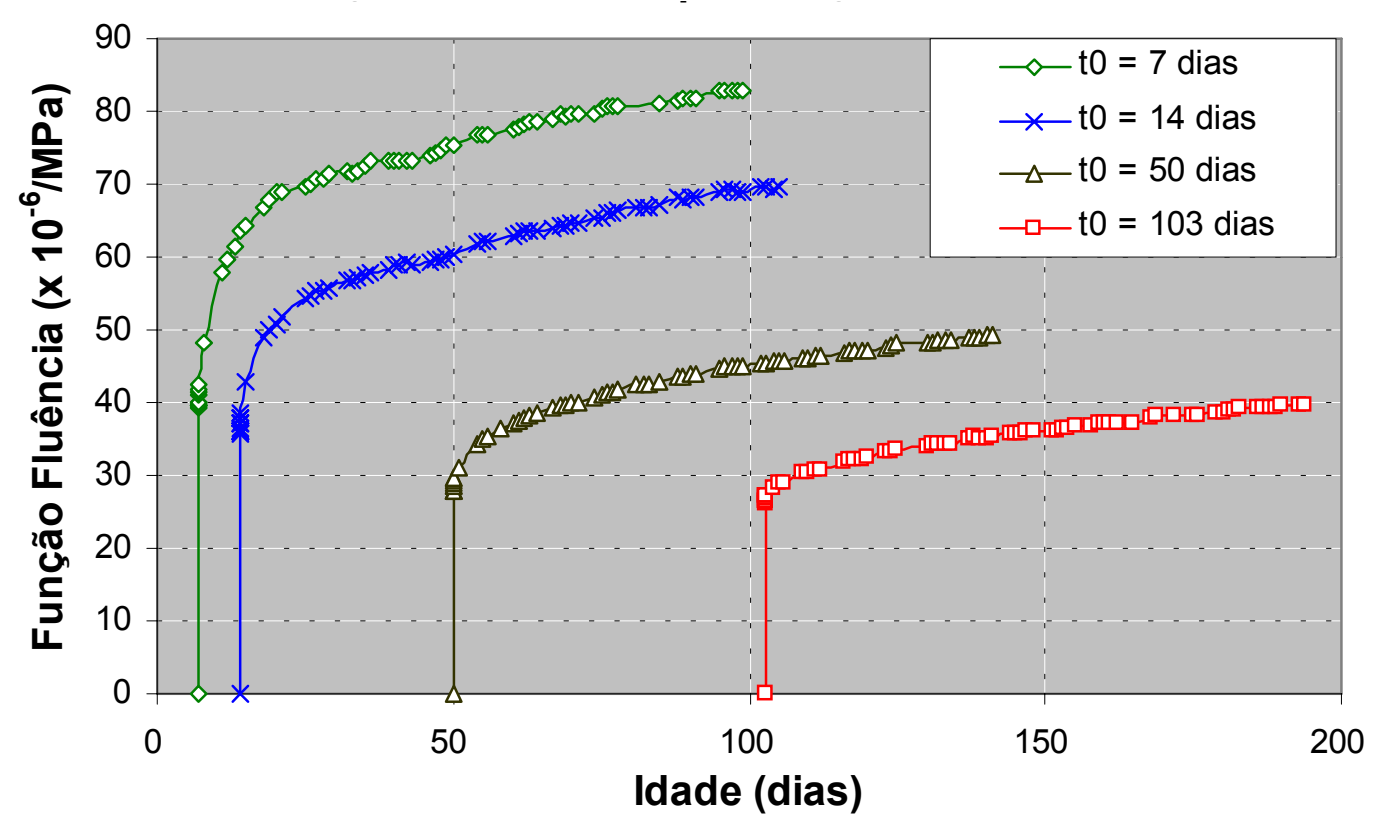

a) Curvas da função fluência para o traço do substrato (traço TS-2)

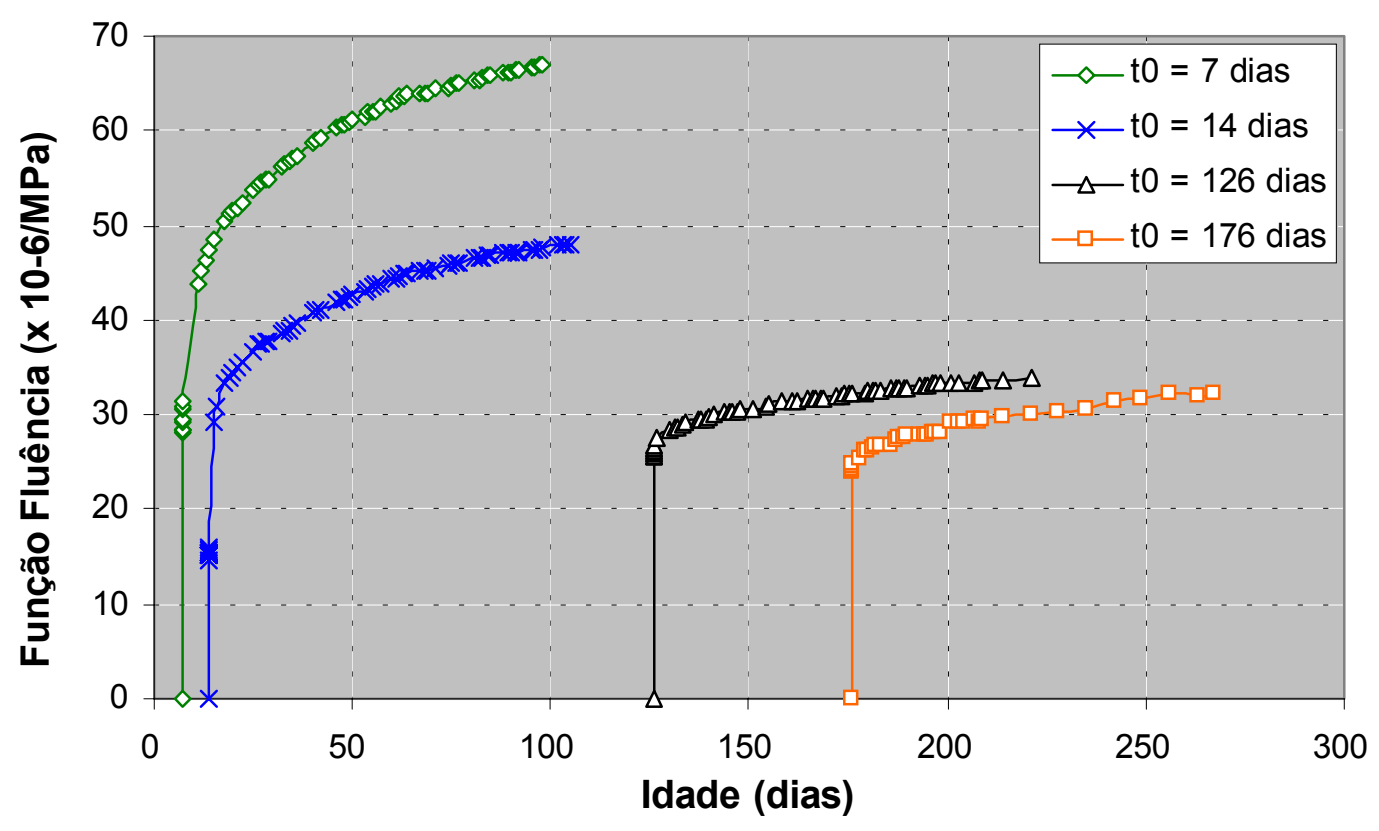

b) Curvas da função fluência para o traço do reforço (traço TR-2)

Figura 6.5 - Função fluência para várias idades $t_{0}$ de aplicação do carregamento 


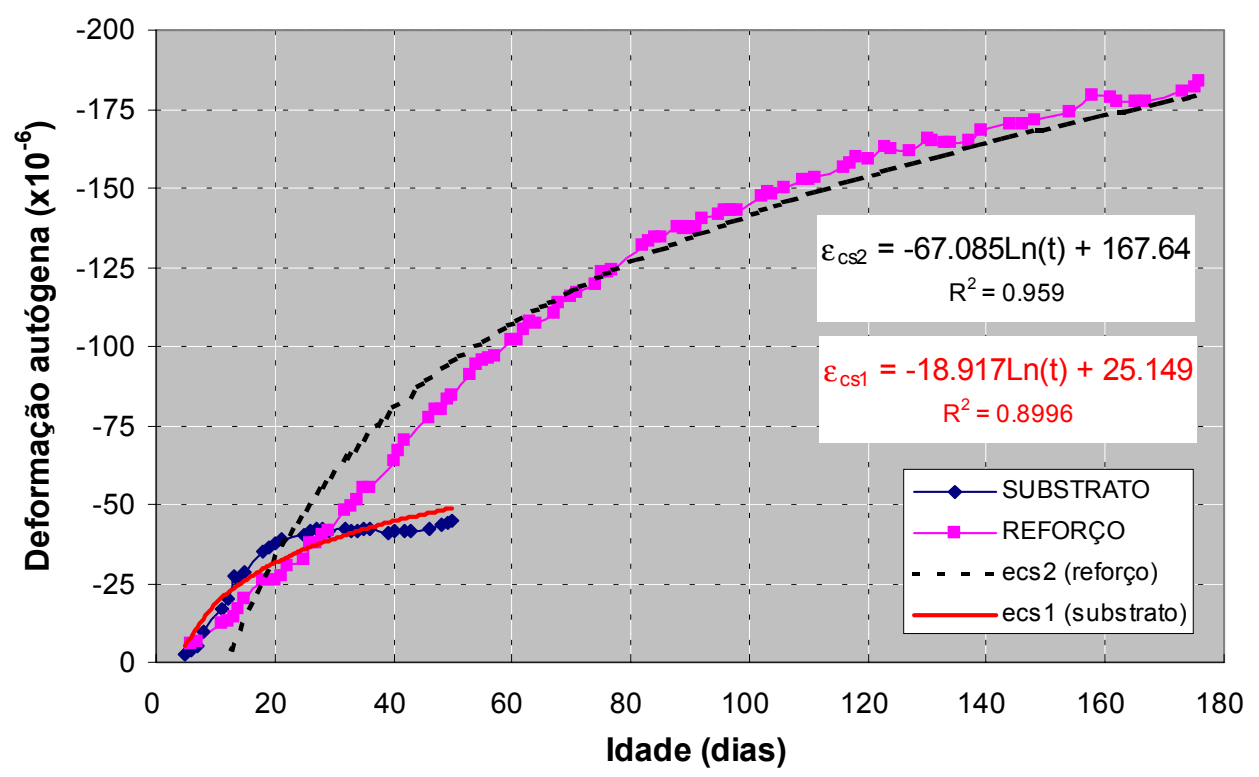

Figura 6.6 - Evolução da deformação por retração autógena em função do tempo para os traços analisados

\subsubsection{Ensaios de retração por secagem}

Retração por secagem é o fenômeno que consiste na contração decorrente da variação de umidade da pasta de cimento, argamassa ou concreto, assim como em outros materiais cuja estrutura interna seja de natureza porosa. Esse tipo de retração é inevitável em estruturas de concreto exposta à umidade abaixo da condição de saturação. Como esta é uma das principais causas da fissuração, seu conhecimento está associado à durabilidade do material.

Apesar da ABNT não apresentar nenhuma norma específica para realizar a avaliação experimental de deformação gerada pela retração por secagem de materiais cimentícios, o Laboratório de Concreto de FURNAS utiliza vários procedimentos para avaliá-la baseando-se na medição da redução de comprimento do concreto quando submetido a uma perda de umidade mantendo-se uma temperatura constante e sem nenhum tipo de carregamento aplicado. Os procedimentos usados por FURNAS para realização de tais ensaios estão descritos em ANDRADE (1997).

A realização deste ensaio é importante, pois a partir de seus dados pode-se avaliar as deformações ao longo do tempo dos traços estudados geradas não só pela fluência (corpos-de-prova selados), mas também devido à troca de umidade com o meio ambiente. Esta análise se fez necessária uma vez que as vigas ensaiadas na 
EESC-USP não foram seladas e, portanto o material que as constituía sofreu tanto os efeitos da fluência quanto os efeitos da retração por secagem.

Para avaliar a retração por secagem, ou seja, a deformação do material em função da variação da umidade do ambiente, foram confeccionados dois corpos-deprova prismáticos de $15 \times 15 \times 60 \mathrm{~cm}$ para cada traço que possuíam extensômetros elétricos (tipo KM-120 - marca Kyowa ) embutidos no concreto (ver Figura 6.7).

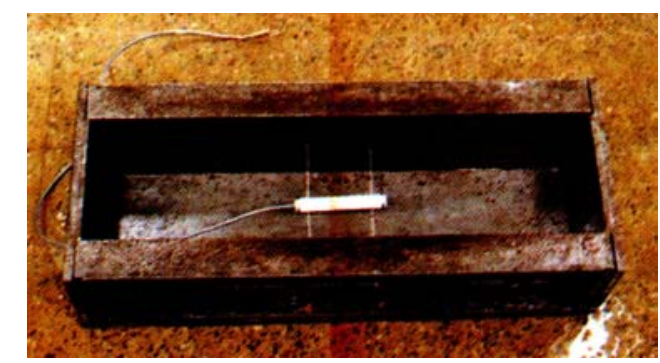

(a) Fôrmas com extensômetro

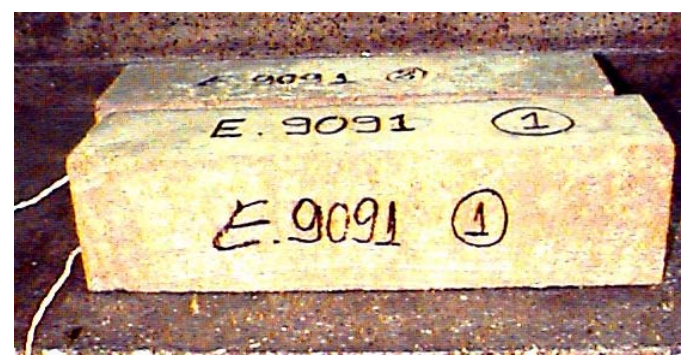

(b) Prismas moldados após a desforma

Figura 6.7 - Fôrma usada na moldagem dos prismas de 15 x 15 x 60

O ensaio de retração por secagem consistiu em, imediatamente após a moldagem, estocar os prismas ainda nas fôrmas em uma câmara úmida com temperatura de $23^{\circ} \mathrm{C}$ e umidade relativa acima de $95 \%$. Após aproximadamente 24 horas, os prismas foram removidos dos moldes e colocados em recipiente com água à temperatura de $23^{\circ} \mathrm{C}$, por um período mínimo de 30 minutos antes de se realizar a leitura do comprimento inicial. Após a leitura do comprimento inicial, estocou-se os corpos-de-prova em recipiente com água saturada de cal a uma temperatura de $23^{\circ} \mathrm{C}$ por um período de tempo contado a partir da adição da água de amassamento igual ao período de cura $t_{s}$ das vigas VFC ensaiadas na USP ${ }^{\dagger}$. A seguir, estes foram transferidos e estocados ao ar em sala climatizada $\left(23^{\circ}\right)$ e com umidade relativa igual a $50 \%$. As leituras das deformações continuaram até que esta se mantivesse praticamente constante em relação ao tempo, indicando assim a retração máxima que a amostra pode apresentar. As leituras dos extensômetros foram feitas na seguinte seqüência:

- $\quad$ Após 24 horas (desforma e medida do comprimento inicial);

- Imediatamente antes da data de início do ensaio, ainda na câmara úmida;

\footnotetext{
${ }^{\dagger}$ Em ensaios tradicionais o período de estocagem é de 28 dias.
} 
- Imediatamente após a estocagem ao ar, na câmara com umidade relativa de $50 \%$;

- Leituras diárias até a deformação se estabilizar com o tempo.

Os resultados destes ensaios estão nas planilhas do Apêndice $\boldsymbol{D}$ e as curvas obtidas estão na Figura 6.8. Nas planilhas a variação de comprimento é expressa em porcentagem de acréscimo ou decréscimo da dimensão linear, com aproximação de 0,001\%, com base na medida inicial efetuada após a remoção dos corpos-de-prova dos moldes. A variação de comprimento é calculada como:

$\varepsilon=\frac{\mathrm{L}_{1}-\mathrm{L}_{2}}{\mathrm{~L}_{1}} \times 100$

onde:

$\varepsilon$ - deformação linear específica;

$\mathrm{L}_{1}$ - leitura do comprimento da barra após a desforma e imersão em água por 30 minutos;

$\mathrm{L}_{2}$ - leitura do comprimento da barra ao fim do período de cura úmida e nos períodos de armazenamento em câmara de $50 \%$ de umidade relativa do ar.

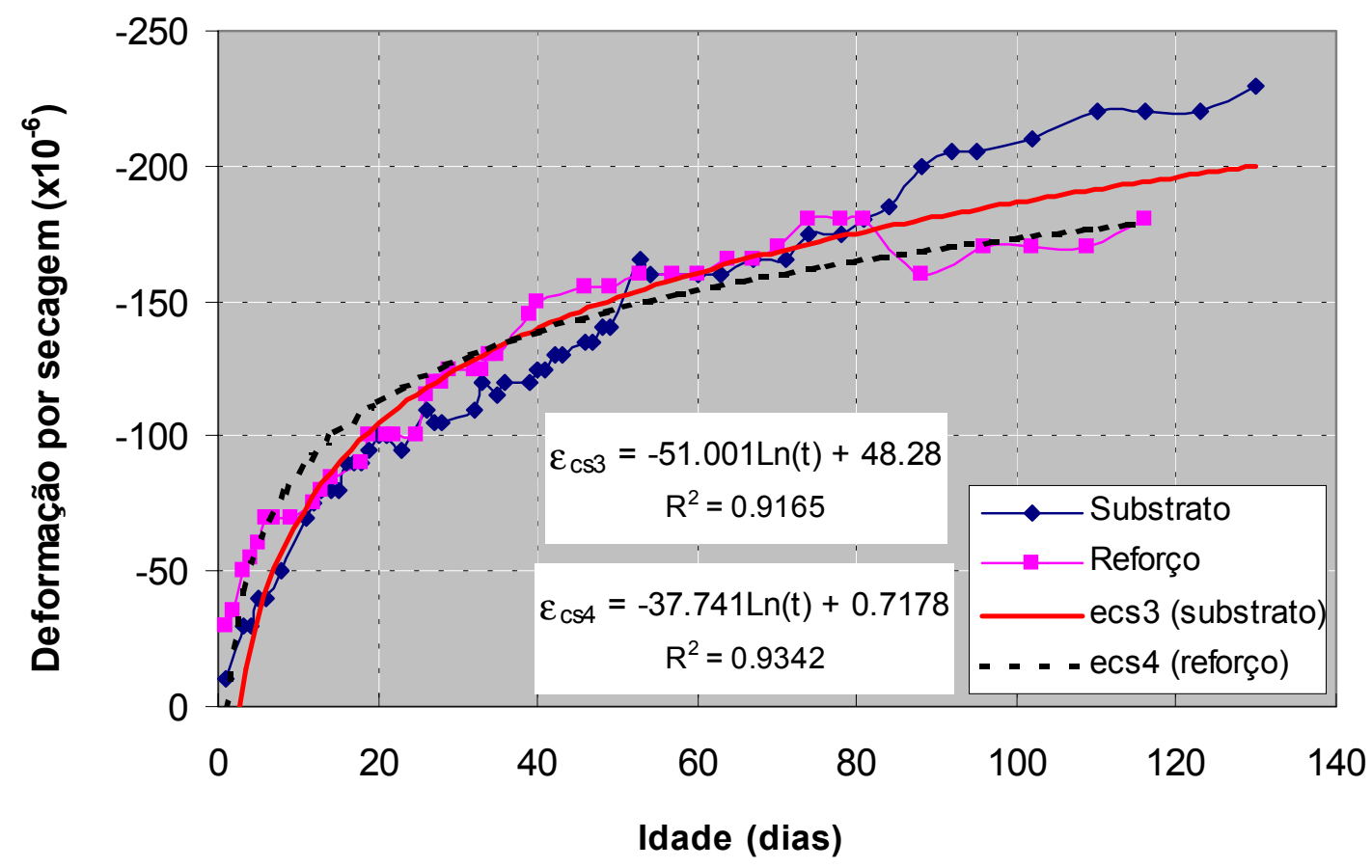

Figura 6.8 - Gráfico da deformação de retração por secagem dos traços 


\subsubsection{Ensaios de compressão axial, de tração por compressão diametral e determinação do módulo de elasticidade}

Os ensaios de compressão axial e tração por compressão diametral foram baseados nas recomendações da NBR 5739 - "Ensaio de compressão de corpos-deprova de concreto cilíndricos" e da NBR 7222 - "Argamassas e concretos determinação da resistência à tração por compressão diametral de corpos-de-prova cilíndricos".

Para traçar a evolução da resistência à compressão axial com o tempo (ver Figura 6.9), fez-se ensaios aos $3 ; 7 ; 14 ; 21 ; 28$ e 50 dias. Tais resistências foram usadas como referência para estabelecer o valor da tensão a ser aplicada nos corposde-prova nos ensaios de fluência sendo $\sigma_{\text {fluência }}=0,4 f_{c j}$. Nos ensaios de fluência com idade de carregamento maior que 50 dias, estimou-se a resistência à compressão através do ajuste da curva dos valores experimentais.

Durante a realização dos ensaios de compressão axial, determinou-se também o valor do módulo de elasticidade, pois seu conhecimento é fundamental na análise das deformações elásticas ou viscoelásticas das estruturas de concreto. O módulo de elasticidade tangente na origem, $\mathrm{E}_{\mathrm{c}}$, é utilizado para caracterizar a deformabilidade do concreto e foi calculado como sendo o coeficiente angular da tangente da curva tensão $x$ deformação para um determinado intervalo de tensão variando de $0,5 \mathrm{MPa}$ a $30 \%$ da resistência à compressão do concreto conforme recomendações da NBR 8522 - "Concreto - Determinação do Módulo de Deformação Estático e Diagrama Tensão-Deformação”.

Nos ensaios destrutivos (corpos-de-prova usados nos ensaios de compressão axial), as deformações usadas no cálculo do módulo de elasticidade foram acompanhadas usando transdutores de deslocamento indutivos tipo LVDT e nos ensaios não destrutivos (corpos-de-prova usados nos ensaios de coeficiente de dilatação térmica) essas deformações foram obtidas pelos extensômetros Carlson. 


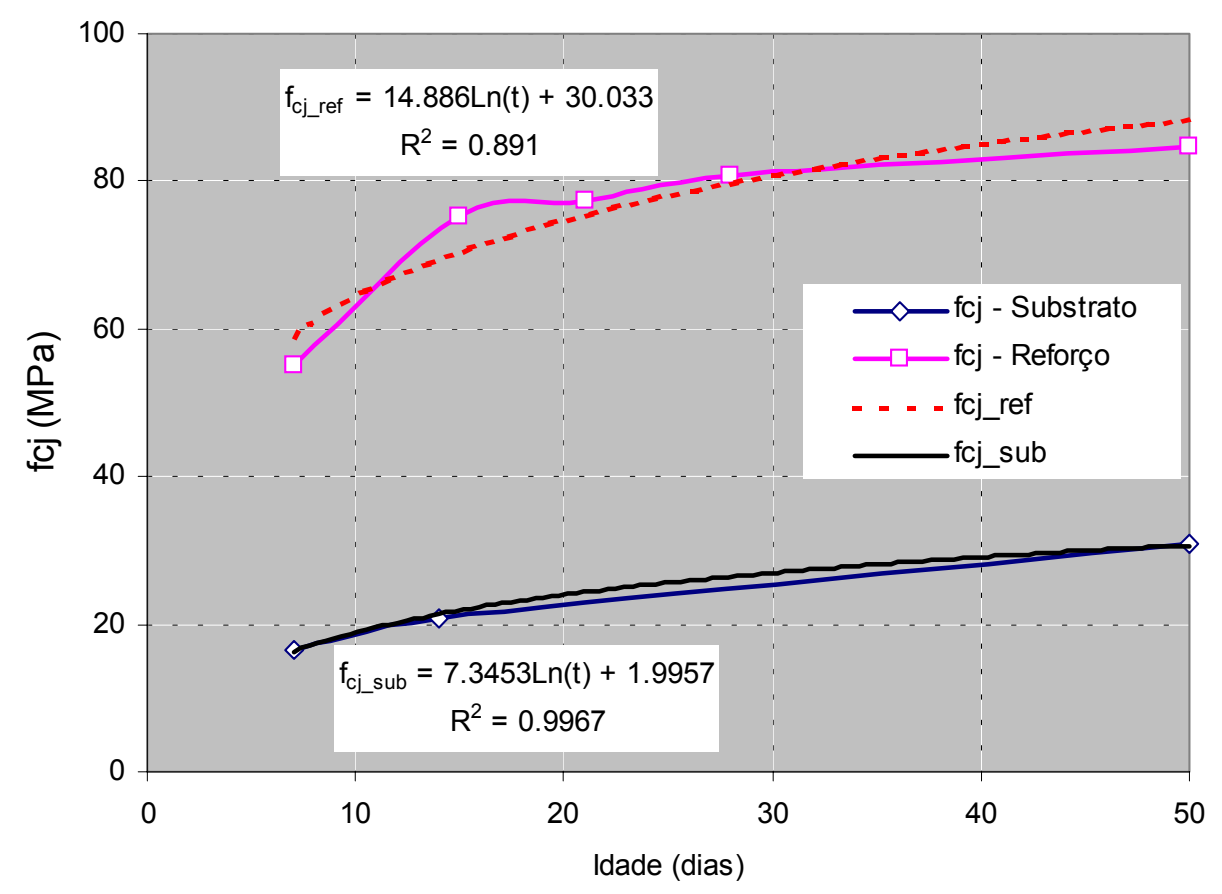

Figura 6.9 - Evolução das resistência à compressão $\left(f_{c}\right)$ ao longo do tempo

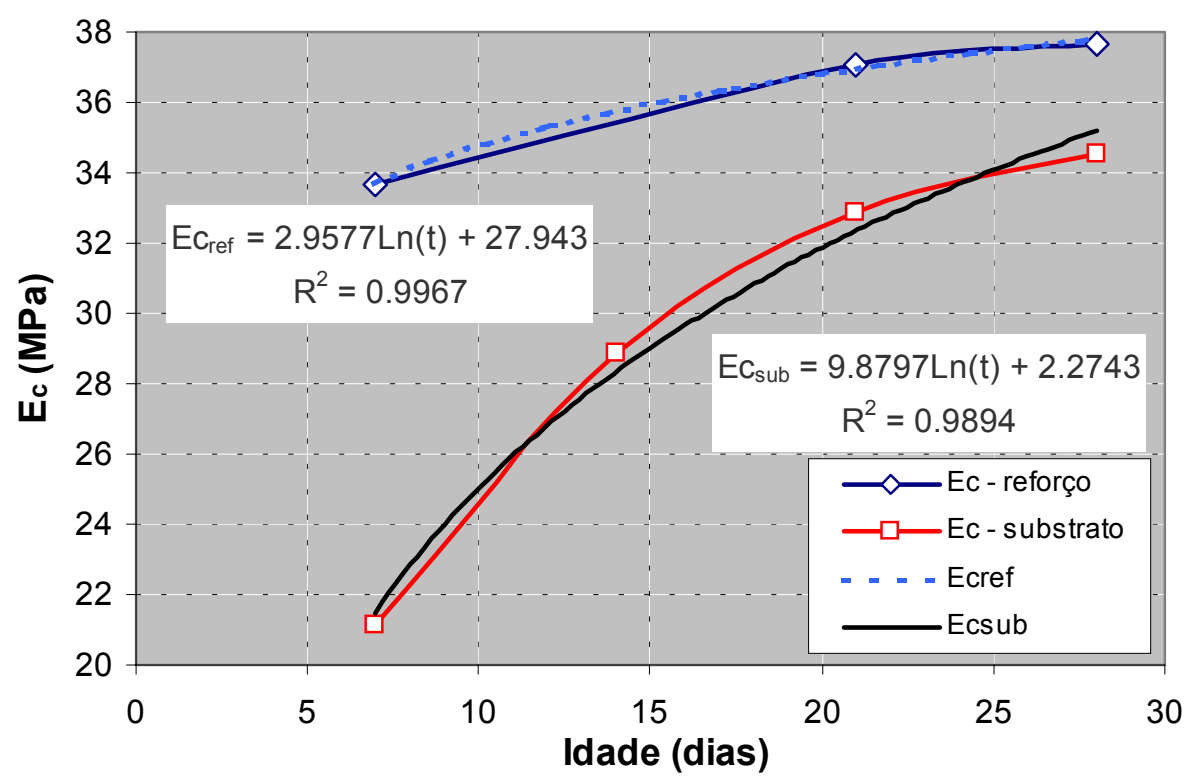

Figura 6.10 - Evolução do módulo de elasticidade $\left(\mathbf{E}_{\mathrm{c}}\right)$ dos traços analisados

\subsubsection{Ensaios para determinação do coeficiente de dilatação térmica linear}

O coeficiente de dilatação térmica $(\alpha)$ é definido como sendo a variação linear de um comprimento unitário causada por uma variação unitária de temperatura sendo normalmente expresso em termos de deformação específica por ${ }^{\circ} \mathrm{C}$. Tal propriedade é importante do ponto de vista da durabilidade do material pois, quando 
uma estrutura sofre gradientes de temperatura, as variações volumétricas decorrentes são diretamente proporcionais a este coeficiente. No caso deste trabalho, o conhecimento do coeficiente de dilatação térmica é necessário para a correção de eventuais alterações de temperatura durante os ensaios da fluência.

A determinação deste coeficiente foi feita de acordo com os procedimentos da NBR 12815 - Concreto Endurecido - Determinação do Coeficiente de Dilatação Térmica Linear, utilizando dois corpos-de-prova cilíndricos selados, com extensômetro elétrico tipo Carlson embutido, que foram submetidos a ciclos de deformações variáveis em ambientes de temperatura diferentes e controladas. Como este é um ensaio não-destrutivo, tais corpos-de-prova também foram usados para determinar o módulo de elasticidade tangente dos materiais conforme já comentado anteriormente.

Os corpos-de-prova foram estocados em várias câmaras climatizadas com temperaturas controladas em $38^{\circ} \mathrm{C}, 23^{\circ} \mathrm{C}$ e $4^{\circ} \mathrm{C}$ respectivamente. Para cada câmara climatizada em que o par de corpo-de-prova era transferido, estes ficaram armazenados por 24 horas antes de se iniciar a leitura das deformações. Após este período, fez-se feitas leituras de temperatura e deformação, perfazendo um total de três leituras diárias até sua estabilização, que geralmente ocorreu após 72 horas.

Antes de iniciar o ensaio, as deformações nos corpos-de-prova deveriam estar estabilizadas a uma temperatura de $23^{\circ} \pm 2^{\circ} \mathrm{C}$. Após a estabilização, estes elementos foram transferidos para outra sala com temperatura de $38^{\circ} \pm 2^{\circ} \mathrm{C}$. Cumprida esta etapa, retornava-se com os corpos-de-prova à sala de $23^{\circ} \pm 2^{\circ} \mathrm{C}$, aguardava-se a estabilização e transportavam-se os mesmos para a sala de $4^{\circ} \pm 2^{\circ} \mathrm{C}$, repetindo-se $\mathrm{o}$ procedimento anterior. Após o retorno dos corpos-de-prova para a sala de $23^{\circ} \pm 2^{\circ} \mathrm{C}$, o ciclo se completava. As idades de ensaio foram 7, 28, 90, 180 e 365 dias após a moldagem dos corpos-de-prova.

O cálculo do coeficiente de dilatação térmica é dado pela expressão 6.4.

$\alpha=\frac{\varepsilon_{q}-\varepsilon_{f}}{T_{q}-T_{f}}$

onde:

$\alpha$ - coeficiente de dilatação térmica linear;

$\varepsilon_{\mathrm{q}}$ - deformação linear específica dadas pela leitura de origem estabilizada; 
$\varepsilon_{\mathrm{f}}$ - deformação linear específica dadas pelas leituras do extensômetro na sala de ensaio;

$\mathrm{T}_{\mathrm{q}}$ - temperatura interna do corpo-de-prova na origem;

$\mathrm{T}_{\mathrm{f}}$-temperatura interna do corpo-de-prova na sala de ensaio;

Os resultados experimentais do coeficiente de dilatação térmica dos materiais analisados em FURNAS foram de $\alpha=10,86 \times 10^{-6} 1 /{ }^{\circ} \mathrm{C}$ para o traço do substrato e de $\alpha=11,37 \times 10^{-6} 1 /{ }^{\circ} \mathrm{C}$ para o traço do reforço. As planilhas com os resultados parciais estão apresentados em Tabelas no Apêndice $\boldsymbol{D}$.

\subsection{Análise dos resultados da deformabilidade do concreto}

O comportamento viscoelástico de um material cimentício, já comentado no item 3.4 , pode ser avaliado por sua deformação total $\varepsilon_{\mathrm{c}}(\mathrm{t})$ ocorrida no tempo $t$. Esta deformação total é composta pela parcela de deformação dependente das tensões, $\varepsilon_{\mathrm{c} \sigma}$, e da parcela de deformação independente das tensões $\varepsilon_{\mathrm{cn}}$. Por sua vez, a deformação dependente das tensões, $\varepsilon_{\mathrm{c} \sigma}$, é composta pela parcela da deformação elástica imediata, $\varepsilon_{\mathrm{ci}}$, e da deformação por fluência $\varepsilon_{\mathrm{cc}}$. Já a deformação independente das tensões, $\varepsilon_{\mathrm{cn}}$, é composta pela parcela da deformação de retração (por secagem e autógena), $\varepsilon_{\mathrm{cs}}$, e da deformação térmica $\varepsilon_{\mathrm{cT}}$.

$\varepsilon_{\mathrm{c}}(\mathrm{t})=\varepsilon_{\mathrm{c} \sigma}(\mathrm{t})+\varepsilon_{\mathrm{cn}}(\mathrm{t})$

onde:

$\varepsilon_{\mathrm{c} \sigma}(\mathrm{t})=\varepsilon_{\mathrm{ci}}\left(\mathrm{t}_{0}\right)+\varepsilon_{\mathrm{cc}}\left(\mathrm{t}, \mathrm{t}_{0}\right)$

$\varepsilon_{\mathrm{cn}}(\mathrm{t})=\varepsilon_{\mathrm{cs}}\left(\mathrm{t}, \mathrm{t}_{\mathrm{s}}\right)+\varepsilon_{\mathrm{cT}}(\mathrm{t}, \mathrm{T})$

A caracterização da deformabilidade ao longo do tempo dos traços usados nas vigas reforçadas tipo VFC foi feita a partir de:

$\checkmark$ formulação teórica baseada em recomendações de normas;

$\checkmark$ ajuste das curvas experimentais obtidos nos ensaios de FURNAS.

Várias normas nacionais e internacionais fornecem formulações teóricas para se estimar o comportamento viscoelástico do concreto. Mas como tais formulações 
são bastante aproximadas, optou-se por realizar também um estudo paramétrico para avaliar os resultados dos ensaios feitos em FURNAS e assim caracterizar, com maior confiabilidade, o comportamento viscoelástico dos traços usados nas vigas reforçadas. De posse destes resultados avaliou-se as diferenças entre os dados obtidos por algumas formulações teóricas e os obtidos por ensaios experimentais.

Ressalta-se que como todas as normas usadas na avaliação teórica da deformabilidade do concreto são bastante conhecidas do meio técnico, optou-se por não descrever neste trabalho o equacionamento e as recomendações específicas adotadas por cada uma delas.

\subsubsection{Resultados fornecidos pelo ajuste das curvas experimentais}

Pelos resultados dos ensaios de FURNAS foi possível traçar as curvas experimentais representativas de cada uma das parcelas de deformação que ocorrem ao longo do tempo nos materiais cimentícios usados no substrato e no reforço das vigas reabilitadas VFC. A partir daí, determinou-se a deformabilidade desses materiais traçando-se linhas de tendência ajustadas às curvas experimentais para obtenção de expressões matemáticas que permitissem a avaliação destas deformações para qualquer instante de tempo $t$ desejado.

As expressões matemáticas obtidas pelo programa EXCEL a partir dos ajustes das curvas experimentais da retração autógena, retração por secagem, resistência à compressão axial e módulo de elasticidade - parâmetros que dependiam apenas do tempo t no instante da análise - estão apresentadas na Tabela 6.1.

Tabela 6.1 - Expressões matemáticas das curvas experimentais ajustadas

\begin{tabular}{|c|c|c|}
\hline & Substrato & Reforço \\
\hline retração autógena $-\left(\varepsilon_{\text {cs_a }_{-}}\right)$ & $\varepsilon_{\text {cs_a }}(t)=-18.917 \ln (t)+25.149$ & $\varepsilon_{\text {cs_a }}(t)=-67.085 \ln (t)+167.64$ \\
\hline retração por secagem - $\left(\varepsilon_{\text {cs_s }}\right)$ & $\varepsilon_{\text {cs_s }_{s}}(t)=-51.001 \ln (t)+48.28$ & $\varepsilon_{\mathrm{cs} \__{-} \mathrm{s}}(\mathrm{t})=-37.741 \ln (\mathrm{t})+0.7178$ \\
\hline deformação térmica - $\left(\varepsilon_{\mathrm{cT}}\right)$ & $\varepsilon_{\mathrm{cT}}(\mathrm{t}, \mathrm{T})=\left(10.86 \times 10^{-6}\right) \Delta \mathrm{T}$ & $\varepsilon_{\mathrm{cT}}(\mathrm{t}, \mathrm{T})=\left(11.37 \times 10^{-6}\right) \Delta \mathrm{T}$ \\
\hline módulo de elasticidade - $\left(\mathrm{E}_{\mathrm{c}}\right)$ & $\mathrm{E}_{\mathrm{c}}=9.8797 \ln (\mathrm{t})+2.2743$ & $\mathrm{E}_{\mathrm{c}}=2.9577 \ln (\mathrm{t})+27.943$ \\
\hline resistência à compressão - $\left(\mathrm{f}_{\mathrm{cj}}\right)$ & $\mathrm{f}_{\mathrm{cj}}=7.3453 \ln (\mathrm{t})+1.9957$ & $\mathrm{f}_{\mathrm{cj}}=14.886 \ln (\mathrm{t})+30.033$ \\
\hline
\end{tabular}


Nesta tabela não se encontram os ajustes das curvas para a parcela da deformação dependente das tensões pois este parâmetro dependia não só do tempo t no instante de análise mas também do tempo $t_{0}$ relativo ao instante de aplicação do carregamento na peça. Para caracterizar tal deformação foi utilizado o procedimento indicando no item 3.4.2, fazendo-se o ajuste de curvas através do programa MATLAB.

Para encontrar uma equação genérica que permitisse determinar a curva da função fluência para qualquer idade de aplicação do carregamento $\left(\mathrm{t}_{0}\right)$ de cada um dos traços analisados adotou-se o seguinte procedimento:

$$
J\left(t, t_{0}\right)=E\left(t_{0}\right)+C\left(t, t_{0}\right)
$$

onde:

$\mathrm{J}\left(\mathrm{t}, \mathrm{t}_{0}\right) \rightarrow$ função fluência adotada;

$\mathrm{E}\left(\mathrm{t}_{0}\right) \rightarrow$ parcela elástica da deformação do material cimentício;

$\mathrm{C}\left(\mathrm{t}_{0}\right) \rightarrow$ parcela viscosa da deformação do material cimentício;

$\mathrm{t}_{0} \rightarrow$ idade em que o material foi carregado;

$\mathrm{t} \quad \rightarrow$ idade em que se deseja conhecer a deformação do material;

1) Utilizando o ajuste das curvas experimentais da evolução do módulo de elasticidade do concreto, $\mathrm{E}_{\mathrm{c}}\left(\mathrm{t}_{0}\right)$, em função do tempo para cada traço analisado (ver Figura 6.10 e Tabela 6.1), determinou-se a equação referente à parcela elástica da deformação do concreto, $\mathrm{E}\left(\mathrm{t}_{0}\right)$. Tal equação fornece $\mathrm{o}$ valor da deformação imediata que surge no material analisado imediatamente após a aplicação do carregamento para distintos valores de $t_{0}$. A Figura 6.11 ilustra as diferenças entre as deformações imediatas obtidas nos ensaios de fluência e as obtidas utilizando a equação da parcela elástica;

$$
E\left(t_{0}\right)=\frac{1}{E_{c}\left(t_{0}\right)} \quad \text { parcela elástica }
$$

2) Para cada traço analisado foram determinadas experimentalmente as curvas da fluência específica em quatro idades $t_{0}$ distintas (ver Figuras 6.12 e $6.13^{\ddagger}$ ). Utilizando o Modelo Potencial descrito no item 3.4.2, fez-se o ajuste destas curvas para determinar a equação da parcela viscosa da deformação do concreto, $\mathrm{C}\left(\mathrm{t}, \mathrm{t}_{0}\right)$. Desta maneira, obteve-se quatro equações de $\mathrm{C}\left(\mathrm{t}, \mathrm{t}_{0}\right)$ - uma para cada traço analisado - pois havia quatro valores distintos de $\mathrm{t}_{0}$.

* Observe que estes gráficos são diferentes dos apresentados na Figura 6.5 pois naquele está representada a função fluência e não a fluência específica em relação ao tempo. 


$$
C\left(t, t_{0}\right)=a \cdot t_{0}^{b}\left(t-t_{0}+1\right)^{c} \quad \text { parcela viscosa }
$$

3) Como os valores dos parâmetros $\boldsymbol{a}, \boldsymbol{b}$ e $\boldsymbol{c}$ obtidos para cada curva ajustada de $\mathrm{C}\left(\mathrm{t}, \mathrm{t}_{0}\right)$ traçou-se os gráficos da evolução destes parâmetros em função da idade $t_{0}$ (ver Figuras 6.14 e 6.15). Desta forma é possível determinar os valores desses parâmetros para qualquer idade de aplicação de carregamento do material $\rightarrow \boldsymbol{a}\left(\mathrm{t}_{0}\right) ; \boldsymbol{b}\left(\mathrm{t}_{0}\right)$ e $\boldsymbol{c}\left(\mathrm{t}_{0}\right)$.

4) De posse das equações de $\mathrm{E}\left(\mathrm{t}_{0}\right), \mathrm{C}\left(\mathrm{t}, \mathrm{t}_{0}\right), \boldsymbol{a}\left(\mathrm{t}_{0}\right), \boldsymbol{b}\left(\mathrm{t}_{0}\right)$ e $\boldsymbol{c}\left(\mathrm{t}_{0}\right)$ para cada um dos traços estudados, aí sim é possível traçar curvas da função fluência para qualquer idade de carregamento desejada tal como apresentado na Figura 6.16.

A Tabela 6.2 apresenta as equações $\mathrm{E}\left(\mathrm{t}_{0}\right), \mathrm{C}\left(\mathrm{t}, \mathrm{t}_{0}\right), \boldsymbol{a}\left(\mathrm{t}_{0}\right), \boldsymbol{b}\left(\mathrm{t}_{0}\right)$ e $\boldsymbol{c}\left(\mathrm{t}_{0}\right)$ obtidas para os traços do substrato e do reforço analisados neste trabalho.

Tabela 6.2 - Equações matemáticas ajustadas através das curvas experimentais para determinação da função fluência dos traços analisados

\begin{tabular}{|l|l|l|}
\cline { 2 - 3 } \multicolumn{1}{c|}{} & \multicolumn{1}{c|}{ Traço do substrato (TS-2) } & \multicolumn{1}{c|}{ Traço do reforço (TR-2) } \\
\hline Parcela elástica $\mathrm{E}\left(\mathrm{t}_{0}\right)$ & $\mathrm{E}\left(\mathrm{t}_{0}\right)=1 /\left(9,8797 \ln \left(\mathrm{t}_{0}\right)+2,2743\right)$ & $\mathrm{E}\left(\mathrm{t}_{0}\right)=1 /\left(2,9577 \ln \left(\mathrm{t}_{0}\right)+27,943\right)$ \\
\hline Parâmetro $\boldsymbol{a}$ & $\boldsymbol{a}\left(\mathrm{t}_{0}\right)=8,3901 \mathrm{t}_{0}^{(-0,9415)}$ & $\boldsymbol{a}\left(\mathrm{t}_{0}\right)=6,1617 \mathrm{t}_{0}{ }^{(-0,786)}$ \\
\hline Parâmetro $\boldsymbol{b}$ & $\boldsymbol{b}\left(\mathrm{t}_{0}\right)=1,7872 \mathrm{t}_{0}^{(-0,2378)}$ & $\boldsymbol{b}\left(\mathrm{t}_{0}\right)=1,9944 \mathrm{t}_{0}{ }^{(-0,2916)}$ \\
\hline Parâmetro $\boldsymbol{c}$ & $\boldsymbol{c}\left(\mathrm{t}_{0}\right)=0,0018 \mathrm{t}_{0}+0,2888$ & $\boldsymbol{c}\left(\mathrm{t}_{0}\right)=0,0011 \mathrm{t}_{0}+0,2515$ \\
\hline $\begin{array}{l}\text { A parcela viscosa } \mathrm{C}\left(\mathrm{t}, \mathrm{t}_{0}\right) \text { é obtida adotando-se valores específicos de } \mathrm{t}_{0} \text { a fim de encontrar os } \\
\text { parâmetros a, b e c para cada idade de aplicação do carregamento } \mathrm{t}_{0} \text { idealizado. } \\
\text { A função fluência } \mathrm{J}\left(\mathrm{t}, \mathrm{t}_{0}\right) \text { é obtida somando respectivamente as equações de } \mathrm{E}\left(\mathrm{t}_{0}\right) \text { e de } \mathrm{C}\left(\mathrm{t}, \mathrm{t}_{0}\right) \text { para } \\
\text { cada valor de } \mathrm{t}_{0} \text { idealizado. }\end{array}$ \\
\hline
\end{tabular}

A Tabela 6.3 apresenta os valores dos parâmetros da função fluência específica $\mathrm{C}\left(\mathrm{t}, \mathrm{t}_{0}\right)$ usados nos ajustes das curvas experimentais da fluência específica mostrada nas Figuras 6.12 e 6.13. Tais valores foram utilizados para traçar os gráficos das Figuras 6.14 e 6.15 . 
Tabela 6.3 - Parâmetros da fluência específica para cada idade de aplicação de carregamento em função dos traços analisados

\begin{tabular}{|c|c|c|c|}
\hline \multirow[b]{2}{*}{ Traço } & \multicolumn{3}{|c|}{ Parâmetros } \\
\hline & $\mathbf{a}$ & b & $\mathbf{c}$ \\
\hline TS- $2 \rightarrow \mathrm{t}_{0}=7$ dias & 1,309 & 1,177 & 0,273 \\
\hline $\mathrm{TS}-2 \rightarrow \mathrm{t}_{0}=14$ dias & 0,705 & 0,896 & 0,335 \\
\hline $\mathrm{TS}-2 \rightarrow \mathrm{t}_{0}=50$ dias & 0,227 & 0,707 & 0,398 \\
\hline $\mathrm{TS}-2 \rightarrow \mathrm{t}_{0}=103$ dias & 0,101 & 0,602 & 0,468 \\
\hline TR-2 $\rightarrow \mathrm{t}_{0}=7$ dias & 1,213 & 1,112 & 0,294 \\
\hline TR-2 $\rightarrow \mathrm{t}_{0}=14$ dias & 0,875 & 0,993 & 0,231 \\
\hline TR-2 $\rightarrow \mathrm{t}_{0}=126$ dias & 0,099 & 0,570 & 0,371 \\
\hline TR-2 $\rightarrow \mathrm{t}_{0}=176$ dias & 0,103 & 0,461 & 0,449 \\
\hline
\end{tabular}

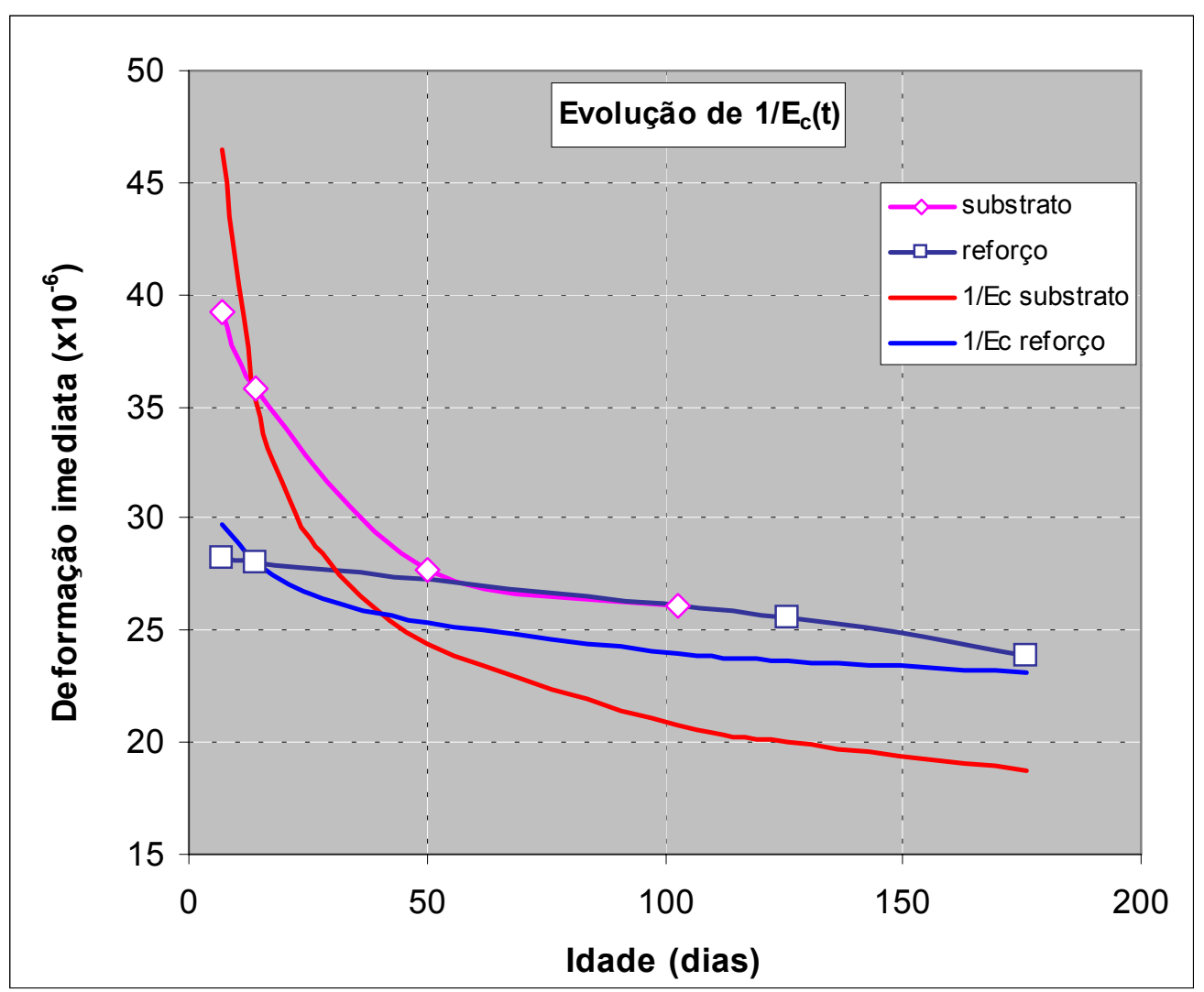

Figura 6.11 - Deformações imediatas experimentais e estimadas a partir da parcela elástica da função fluência. 


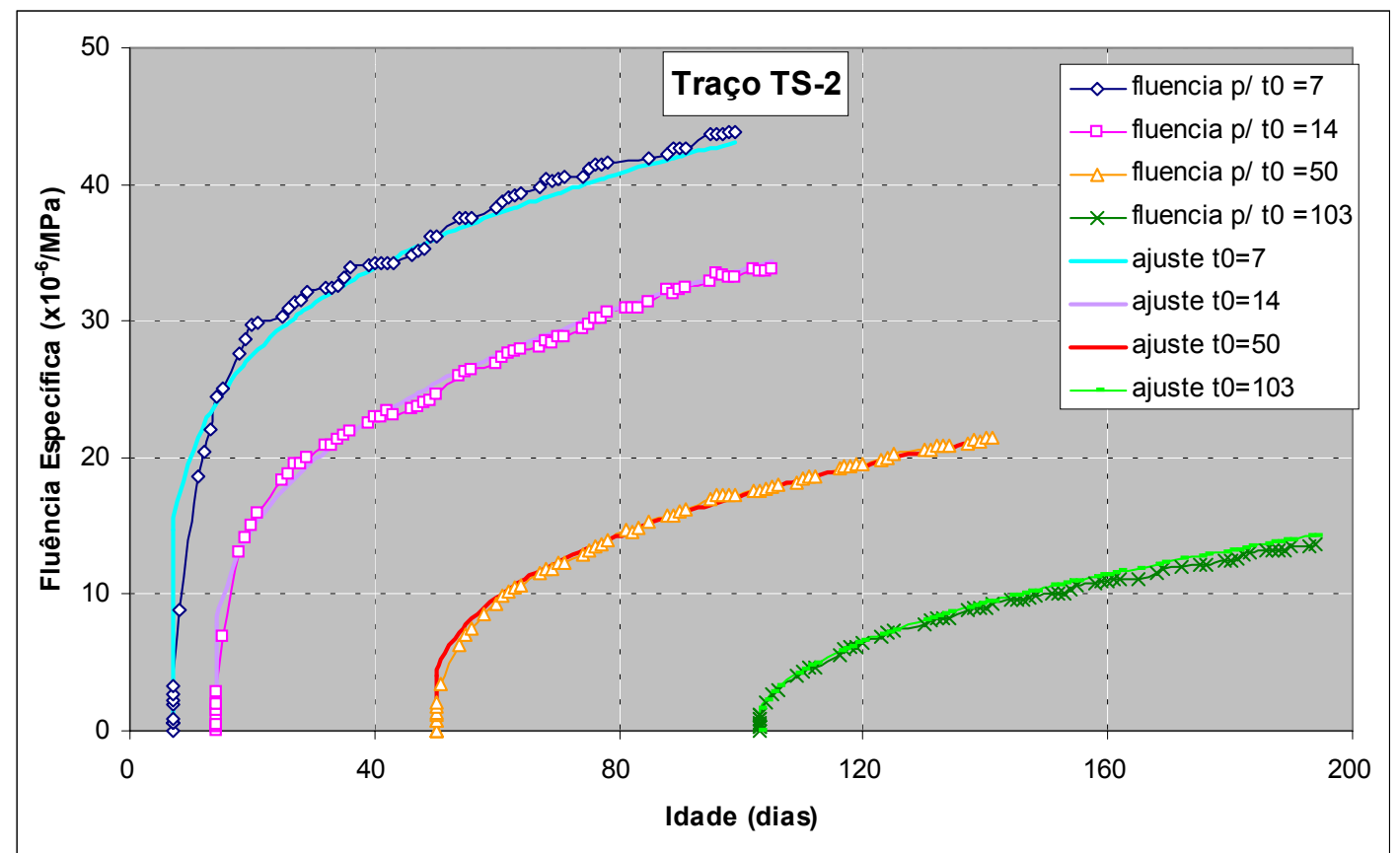

Figura 6.12 - Curva da fluência específica $x$ idade $t_{0}$ (TS-2)

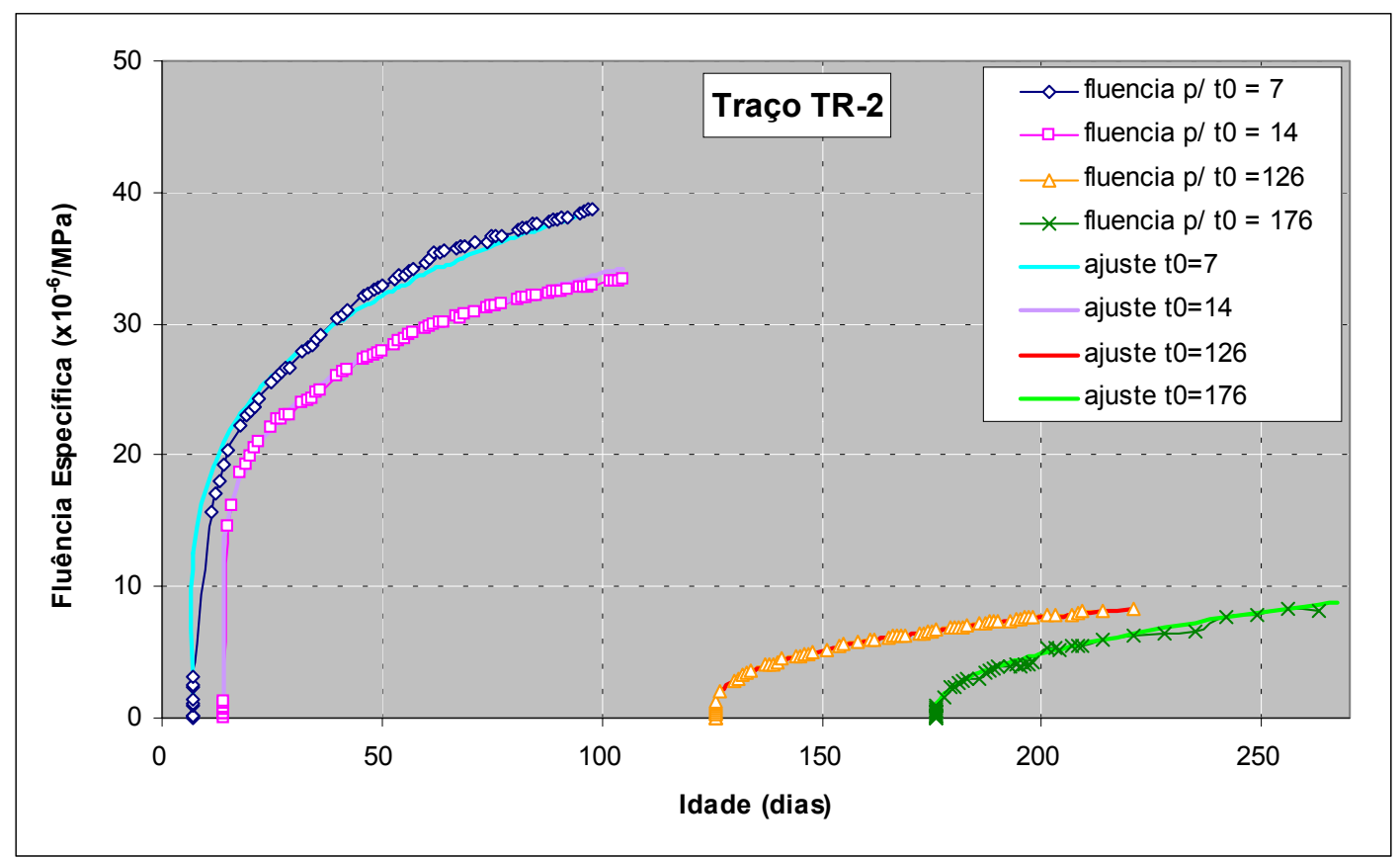

Figura 6.13-Curva da fluência específica $x$ idade $t_{0}$ (TR-2) 


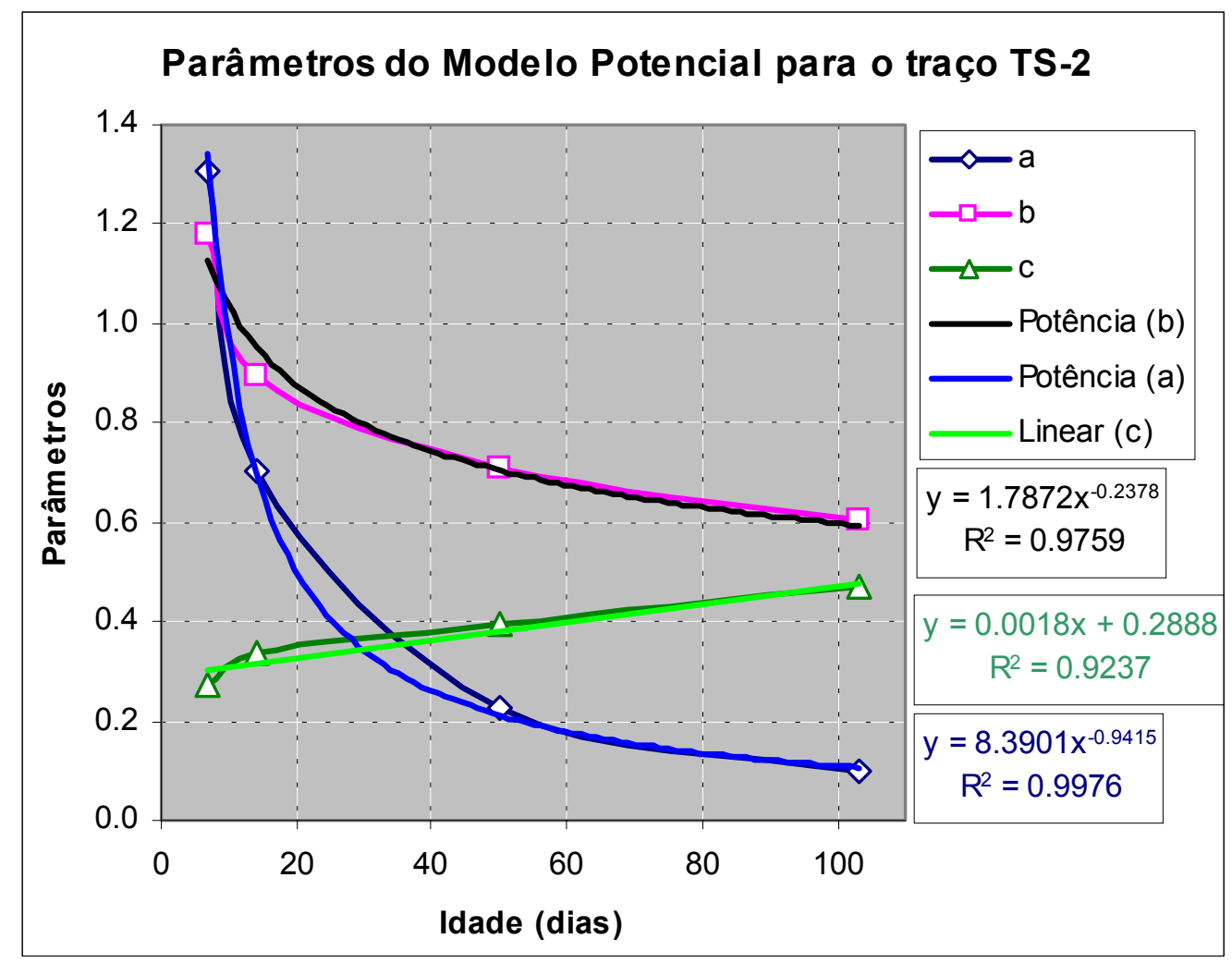

Figura 6.14 - Evolução dos parâmetros $a\left(t_{0}\right), b\left(t_{0}\right)$ e $c\left(t_{0}\right)$ do traço do substrato

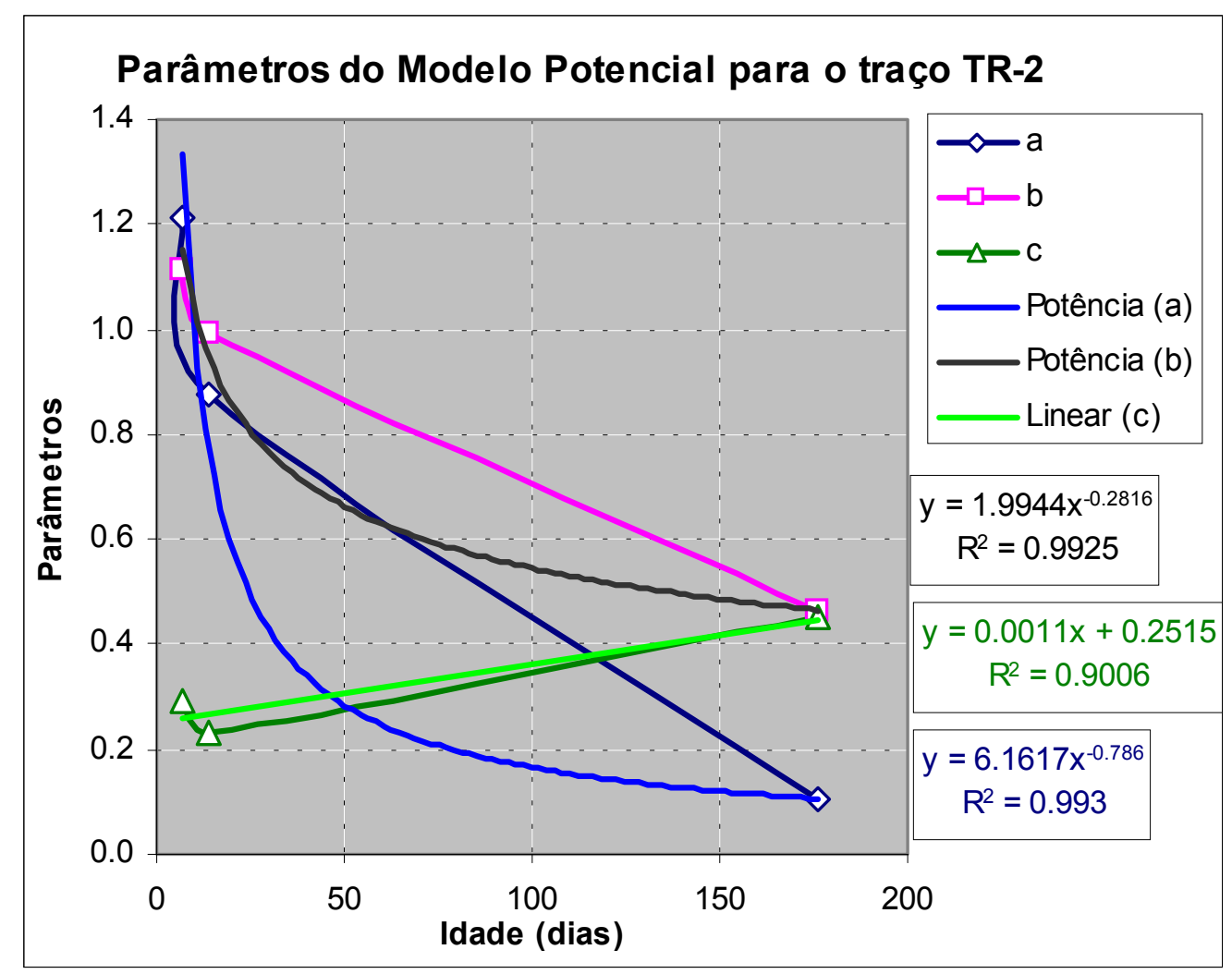

Figura 6.15 - Evolução dos parâmetros $a\left(t_{0}\right), b\left(t_{0}\right)$ e $c\left(t_{0}\right)$ do traço do reforço 


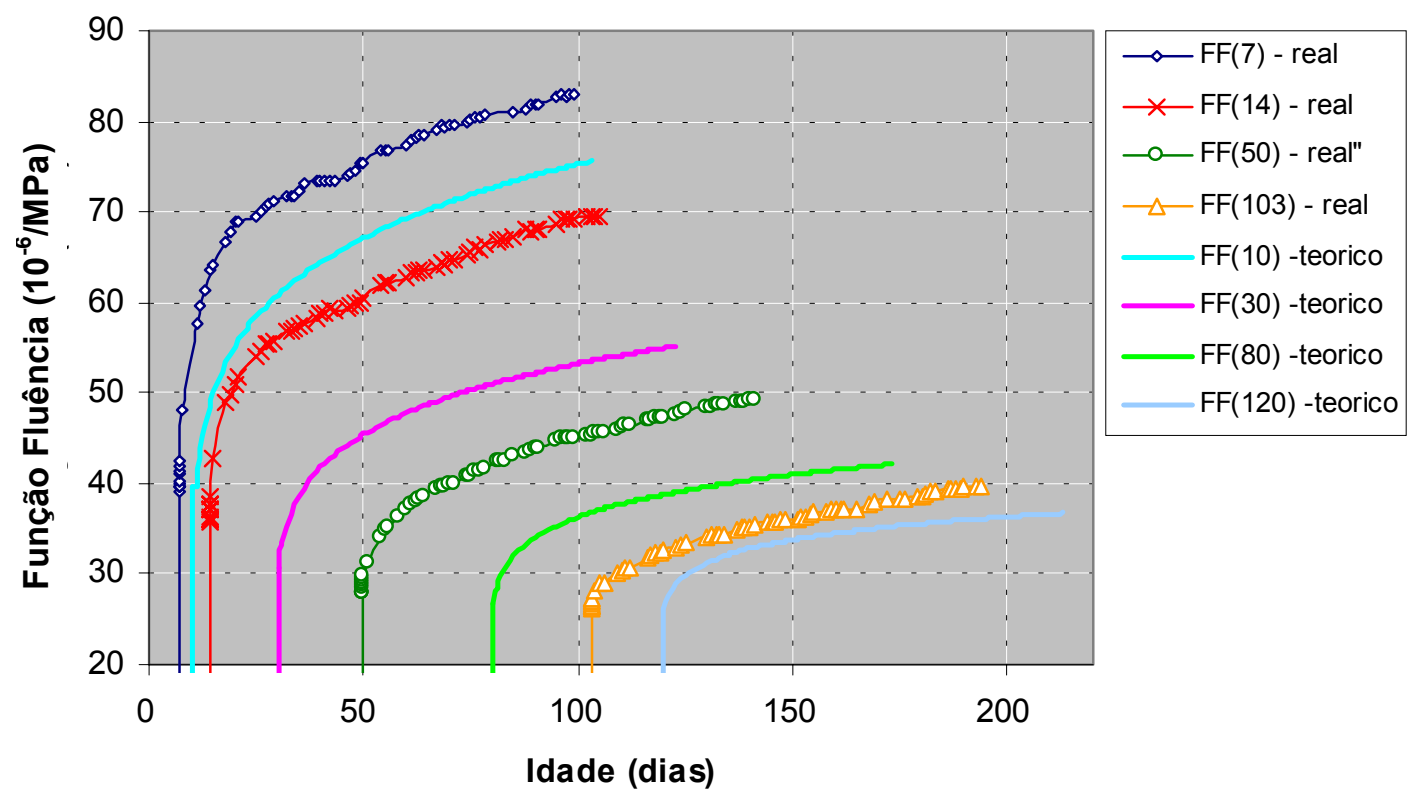

(a) Traço do substrato (TS-2)

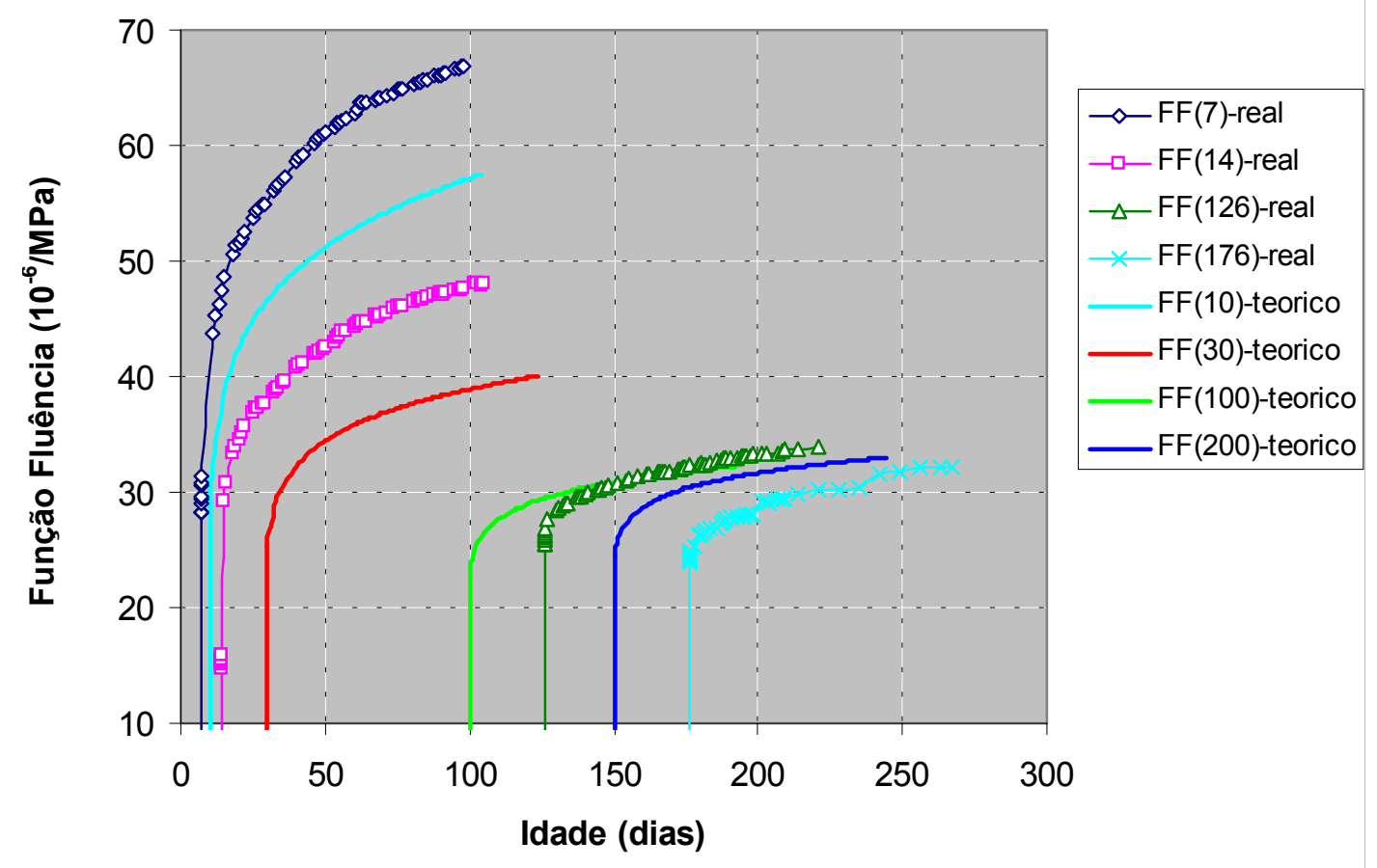

(b) Traço do reforço (TR-2)

Legenda: $\mathrm{FF}(\mathrm{N})$ = função fluência aos $\mathrm{N}$ dias de aplicação do carregamento

Figura 6.16 - Exemplo de curvas da função fluência dadas pela formulação paramétrica interpoladas às curvas da função fluência experimentais 


\subsubsection{Resultados fornecidos pelas formulações teóricas}

\section{a) Avaliação da deformação independente das tensões $\left(\varepsilon_{\mathrm{cn}}\right)$}

As formulações teóricas usadas na avaliação da deformação térmica $\left(\varepsilon_{\mathrm{cT}}\right)$ e da deformação por retração $\left(\varepsilon_{\mathrm{cs}}\right)$ foram:

- $\quad$ Fib (CEB-FIP)

- NBR-6118(2003)

Para avaliar a deformação térmica do concreto em função da variação da temperatura em uma análise estrutural a NBR-6118 (2003) recomenda a adoção de um coeficiente de dilatação térmica igual a $\alpha=10 \times 10^{-6} /{ }^{\circ} \mathrm{C}$ quando não se tem valores experimentais. Já a Fib fornece valores em função do tipo de agregado usado na confecção do material cimentício sendo que para o basalto - agregado usado na confecção do traços do reforço e substrato da VFC - o coeficiente de dilatação térmica pode assumir valores entre $8,5 \times 10^{-6} /{ }^{\circ} \mathrm{C} \leq \alpha \leq 11 \times 10^{-6} /{ }^{\circ} \mathrm{C}$. Como estes valores ficaram bastante próximos dos encontrados experimentalmente - que foram de $\alpha=10,86 \times 10^{-6} /{ }^{\circ} \mathrm{C}$ para o substrato, e de $\alpha=11,37 \times 10^{-6} /{ }^{\circ} \mathrm{C}$ para o material do reforço - constata-se que tais normas estimaram com precisão o valor do coeficiente de expansão térmica do concreto.

Quanto à retração total (correspondente à retração por secagem mais a retração autógena), foram traçados gráficos desta deformação ao longo do tempo comparando os valores teóricos com os valores experimentais obtidos nos ensaios realizados em FURNAS para cada traço analisado (ver Figuras 6.17 e 6.18). Pela análise desses gráficos, pode-se observar claramente que os resultados teóricos da deformação por retração foram subestimados por ambas as normas utilizadas. Contudo, os resultados teóricos fornecidos pela NBR-6118 (2003) ficaram bem próximos dos experimentais, principalmente para o material do substrato. Isto sugere que as recomendações desta norma, para os materiais ensaiados especificamente neste trabalho, foram mais adequadas na estimativa da deformabilidade do concreto devido aos efeitos da retração do que as recomendações indicadas pela Fib. 


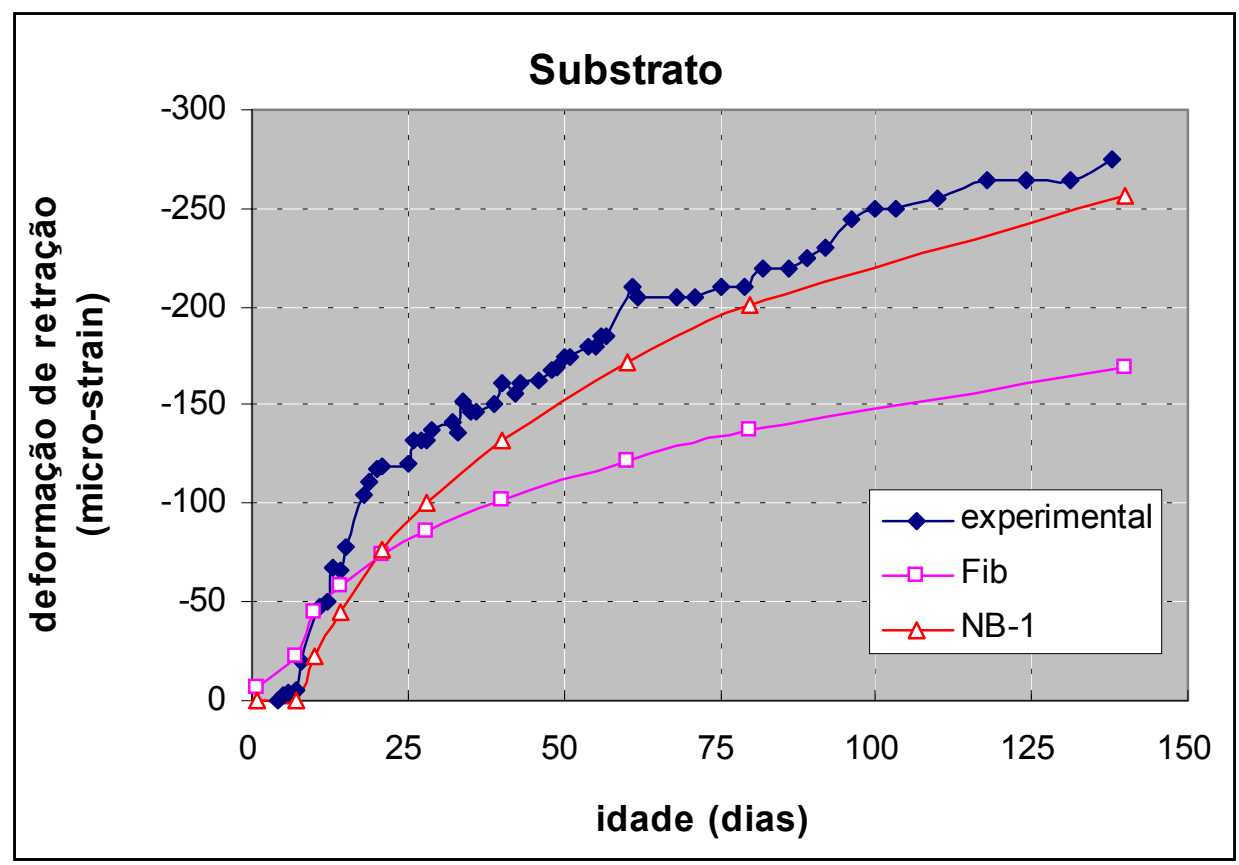

Figura 6.17 - Retração teórica x experimental para o substrato (traço TS-2)

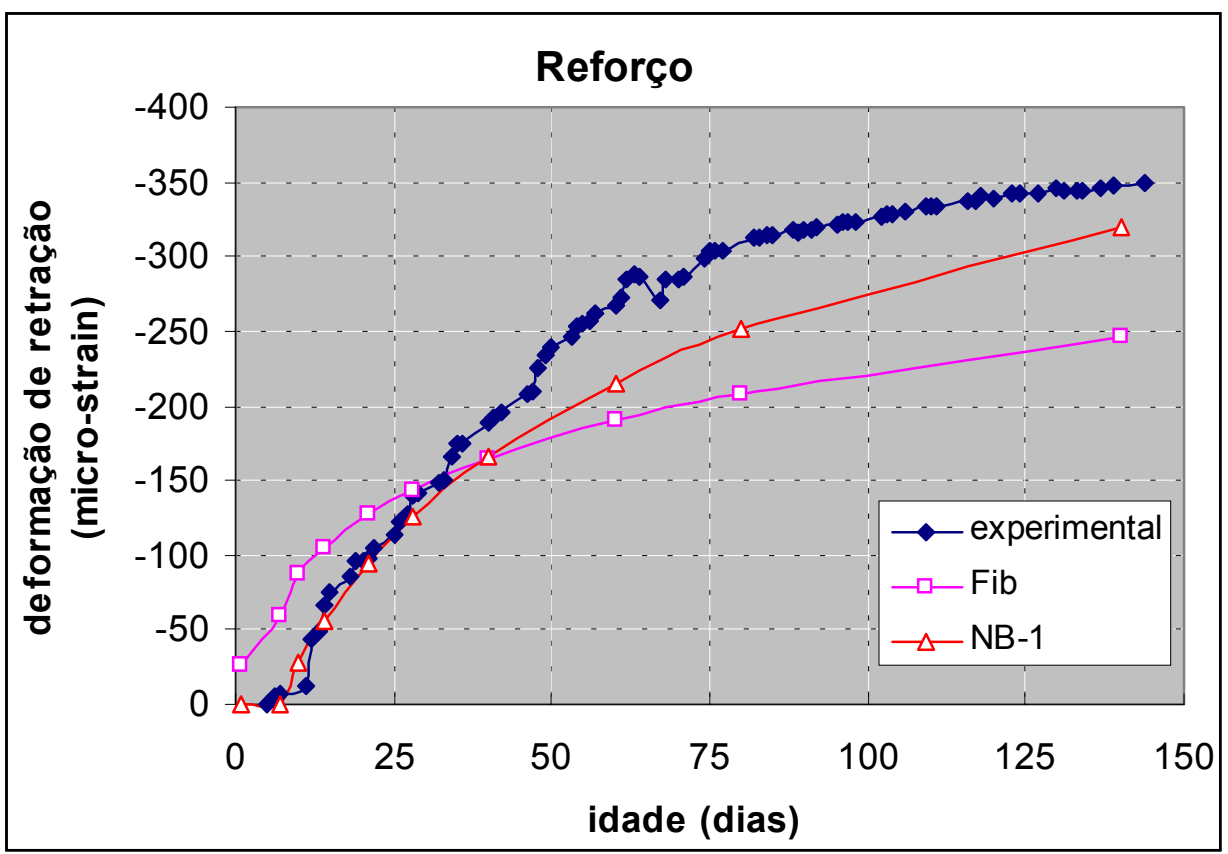

Figura 6.18 - Retração teórica x experimental para o reforço (traço TR-2) 


\section{b) Avaliação da deformação dependente das tensões $\left(\varepsilon_{c \sigma}\right)$}

As formulações teóricas usadas na avaliação da função fluência dos traços estudados correspondem às recomendadas indicadas pelas seguintes normas:

- $\quad$ CEB Model Code - 90

- $\quad$ Fib (CEB-FIP)

- EUROCODE-2

- NBR-6118 (2003)

Tais formulações teóricas adotam os conceitos apresentados no item 3.4.1 sendo que a diferença básica entre elas refere-se ao método utilizado para estimar tanto o coeficiente de fluência quanto a deformação imediata, em função das condições ambientais, dos materiais usados na confecção do traço e do valor do módulo de elasticidade do concreto $\left(\mathrm{E}_{\mathrm{c}}\right.$ aos 28 dias ou $\mathrm{E}_{\mathrm{c}}$ na data de aplicação do carregamento). O uso do módulo de elasticidade aos 28 dias implica na obtenção de deformações imediatas menores que as existentes na estrutura.

Seguindo as recomendações dessas normas traçou-se gráficos da função fluência comparando os valores teóricos com o valor experimental obtido pelos ensaios realizados em FURNAS para cada uma das idades de aplicação do carregamento $\mathrm{t}_{0}$ (ver Figuras 6.19 a 6.26).

Para avaliar a coerência entre as curvas experimentais e teóricas adotou-se as condições ambientais (umidade e temperatura) usadas nos ensaios de Furnas.

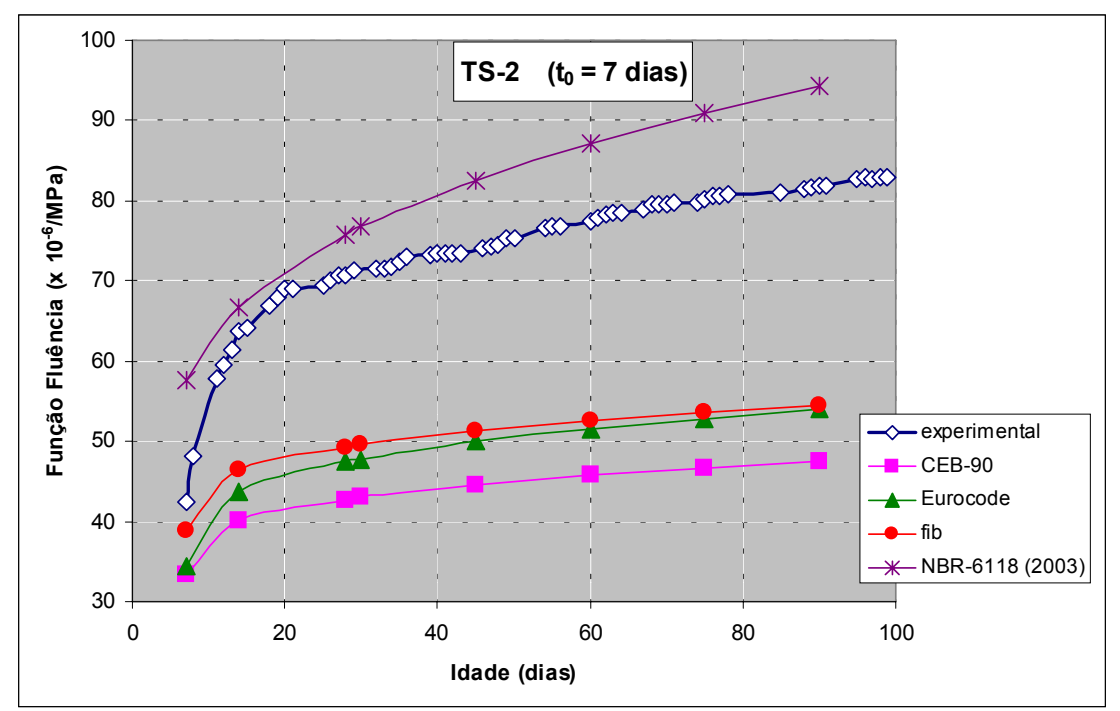

Figura 6.19 - Função fluência para $t_{0}=7$ dias (traço TS-2) 


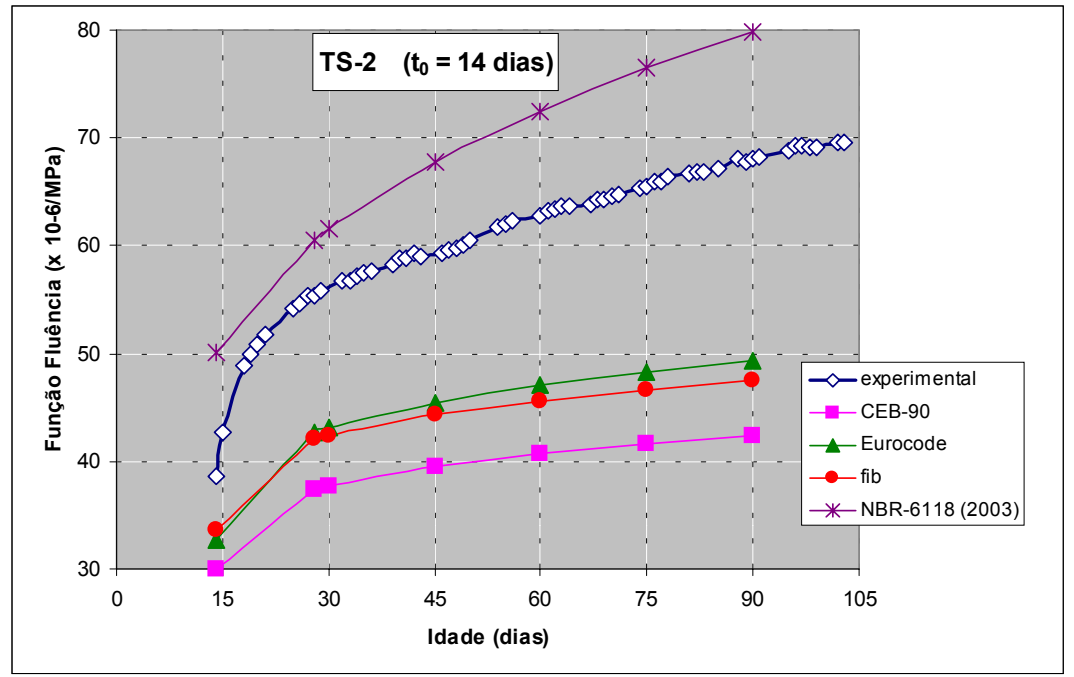

Figura 6.20 - Função fluência para $t_{0}=14$ dias (traço TS-2)

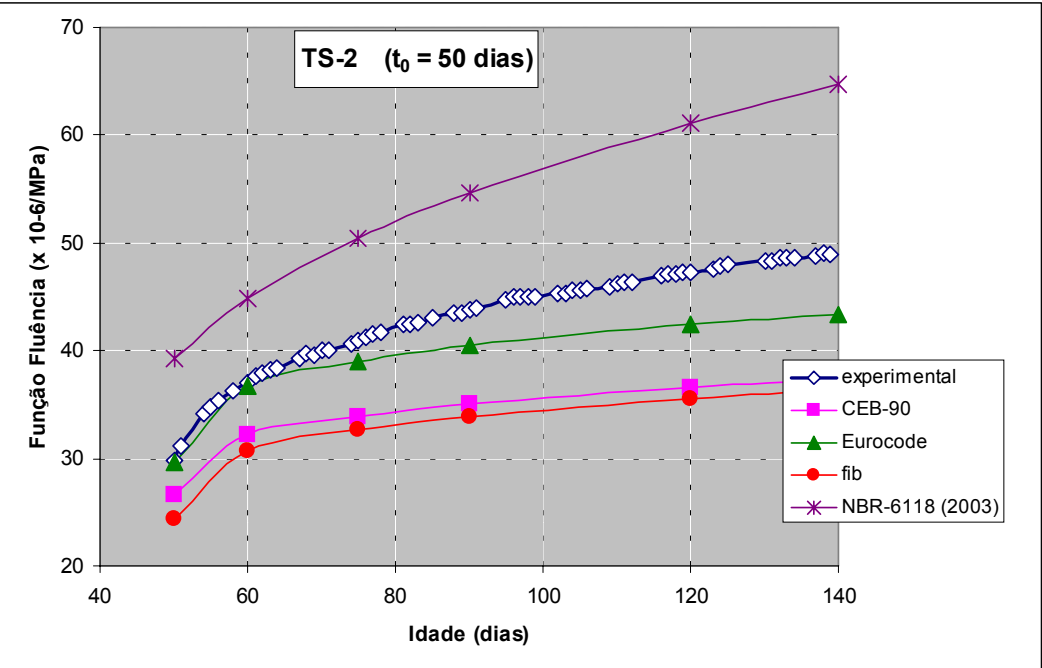

Figura 6.21 - Função fluência para $\mathbf{t}_{0}=\mathbf{5 0}$ dias (traço TS-2)

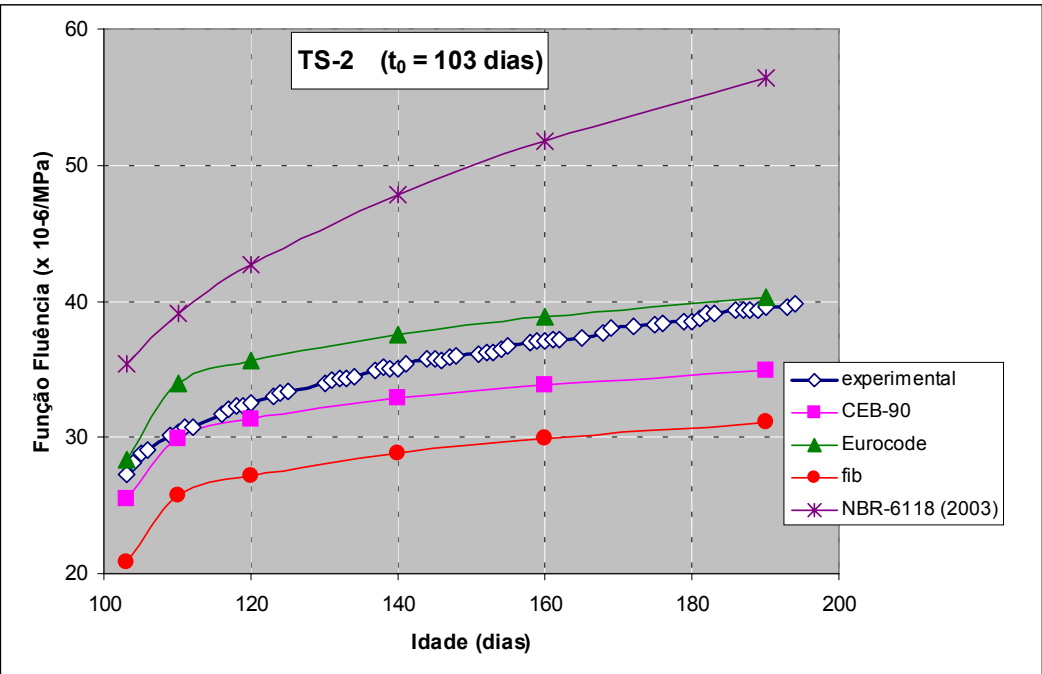

Figura 6.22 - Função fluência para $t_{0}=103$ dias (traço TS-2) 


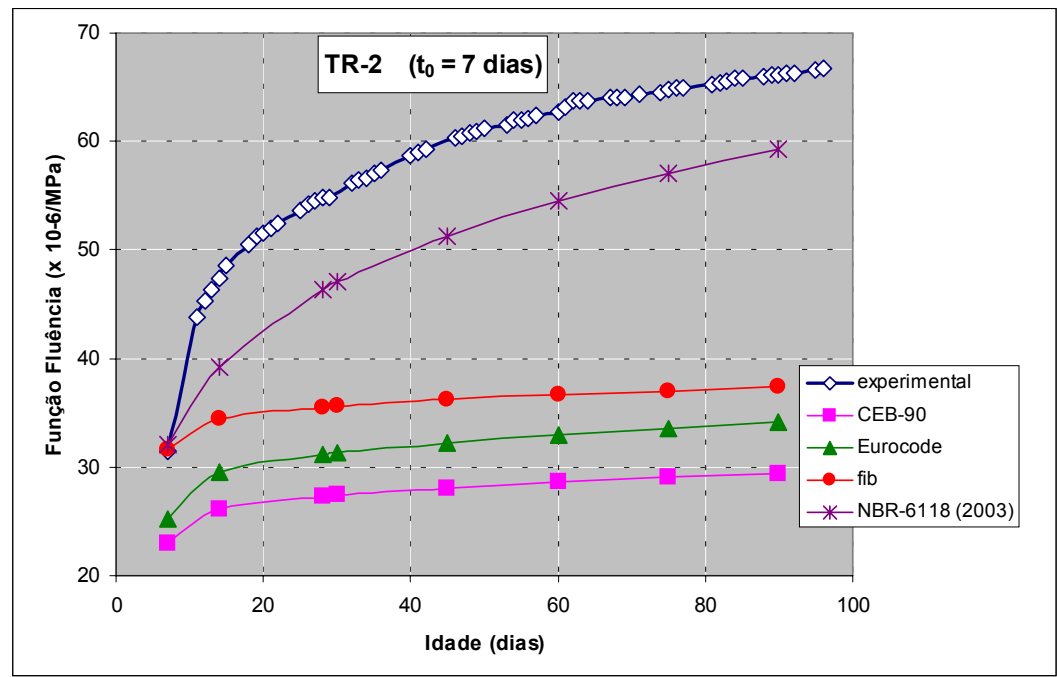

Figura 6.23 - Função fluência para $t_{0}=7$ dias (traço TR-2)

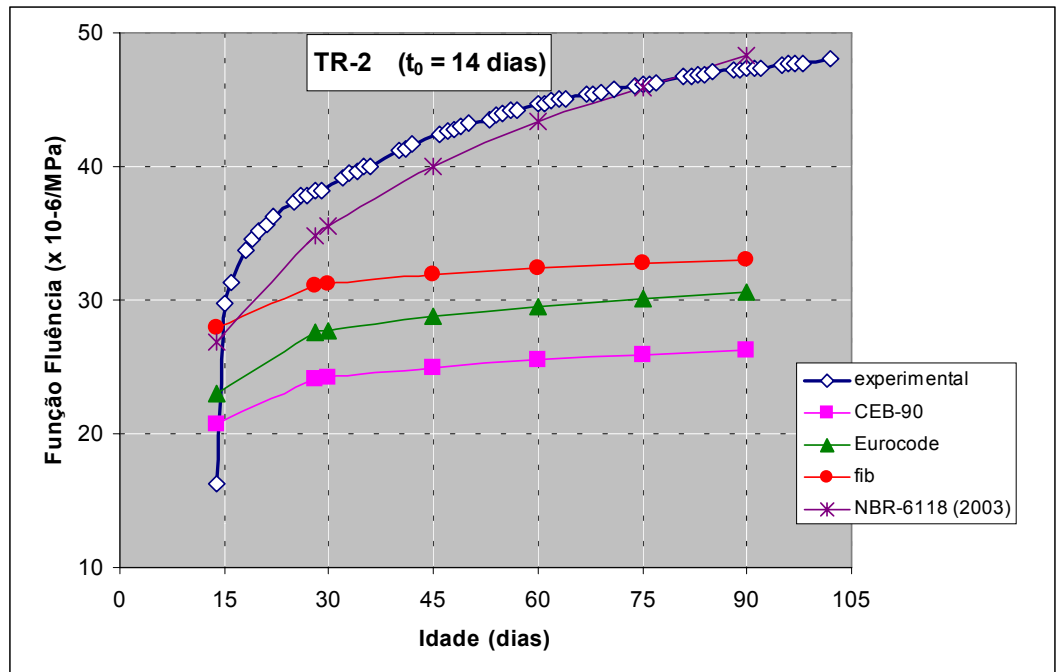

Figura 6.24 - Função fluência para $t_{0}=14$ dias (traço TS-2)

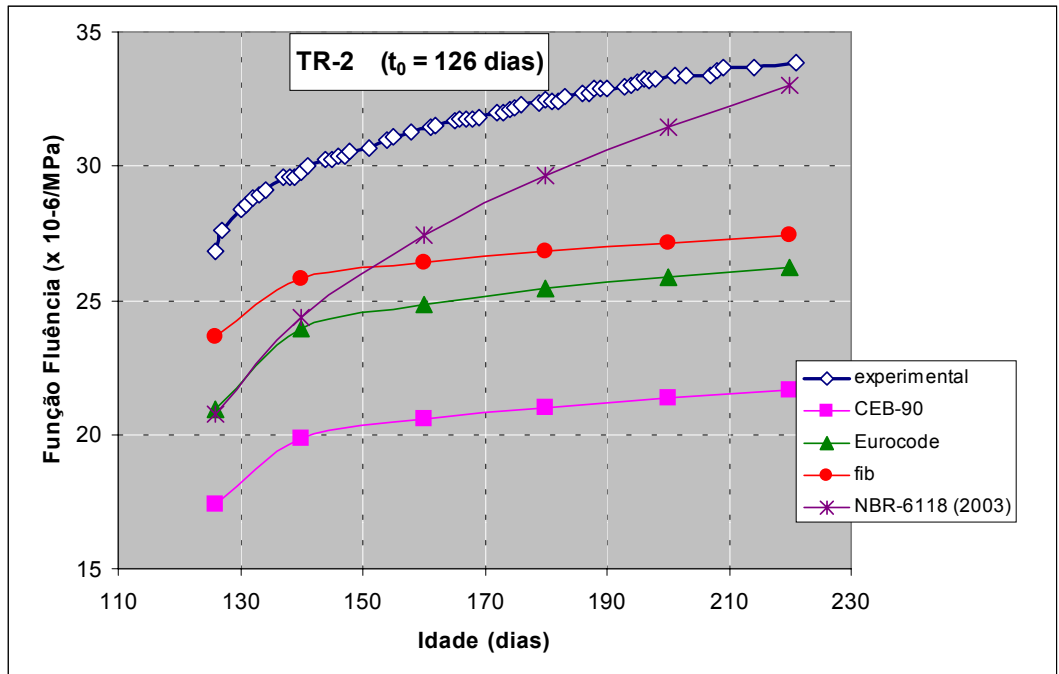

Figura 6.25 - Função fluência para $t_{0}=126$ dias (traço TR-2) 


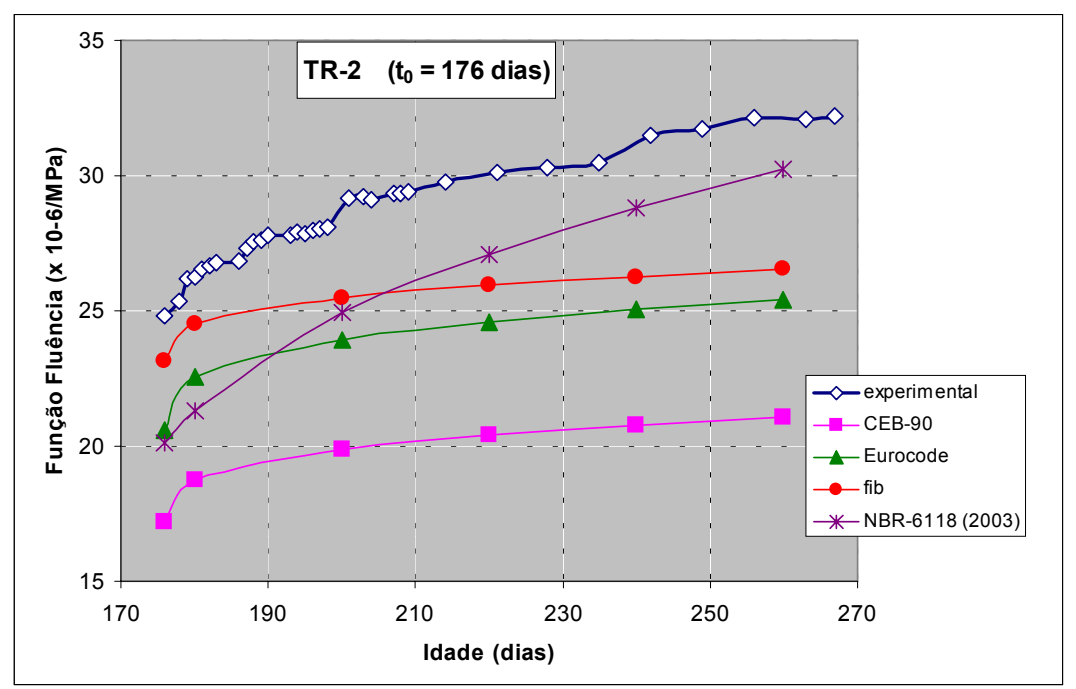

Figura 6.26 - Função fluência para $t_{0}=176$ dias (traço TR-2)

Pela análise dos gráficos da função fluência referente ao substrato (ver Figuras 6.19 a 6.22) observa-se claramente que as curvas teóricas foram subestimadas pelas normas. As únicas exceções referem-se à curva teórica obtida pelas recomendações do EUROCODE especificamente para a idade de carregamento $\mathrm{t}_{0}=103$ dias, e às curvas teóricas obtidas pelas recomendações da NBR-6118 (2003) para qualquer idade de carregamento $t_{0}$.

Para o reforço, a análise dos gráficos da função fluência (ver Figuras 6.23 a 6.26) também indicaram que as curvas teóricas foram subestimadas, não havendo desta vez nenhuma exceção. Entretanto, os resultados teóricos fornecidos pela NBR6118 (2003) foram os que ficaram mais próximos dos experimentais principalmente na estimativa das deformações para idades mais avançadas após a aplicação do carregamento.

\subsection{Conclusões parciais sobre a deformabilidade do concreto}

Antes de correlacionar os resultados obtidos por FURNAS com os dados das vigas VFC reforçadas e ensaiadas na EESC-USP deve-se lembrar que:

As vigas ensaiadas na EESC $\left(\mathrm{U}=40 \% \pm 10 \% ; \mathrm{T}=32^{\circ} \mathrm{C} \pm 4^{\circ} \mathrm{C}\right)$ estavam submetidas à umidade e temperatura diferentes daquelas dos ensaios de fluência realizados em FURNAS $\left(\mathrm{U}=60 \% \pm 10 \% ; \mathrm{T}=23^{\circ} \mathrm{C} \pm 2^{\circ} \mathrm{C}\right)$. Além 
disso, os corpos-de-prova usados na avaliação da fluência em FURNAS estavam selados, fornecendo valores da fluência básica. Já nas vigas ensaiadas na EESC, não se impediu a troca de umidade com o meio ambiente, ou seja, as peças estavam sujeitas à fluência por secagem. De posse destes valores percebe-se que as condições ambientais existentes na EESC são mais críticas, ou seja, os materiais cimentícios provavelmente terão deformações por fluência maiores que a observada em FURNAS. Contudo, na bibliografia técnica não foram encontrados estudos específicos que indicassem como fazer correções nos valores experimentais em função das variações das condições ambientais. Por este motivo achou-se melhor utilizar as curvas experimentais da função fluência sem nenhuma alteração na análise da deformabilidade das vigas VFC ensaiadas no Capítulo 7;

$\checkmark$ As tensões nas vigas ensaiadas na EESC não se mantiveram constantes como seria o ideal mas sim reduziram com o tempo. Isso ocorreu devido à maneira de aplicação do carregamento de longa duração (ver item 7.1.2);

$\checkmark$ Apesar dos corpos-de-prova de FURNAS terem sido confeccionados usando os mesmos materiais e os mesmos traços empregados nas vigas VFC, foram constatadas algumas diferenças em relação à evolução da resistência à compressão axial e ao módulo de elasticidade. Entretanto, estas diferenças foram desprezadas na análise das vigas VFC por ser impossível contabilizalas de maneira adequada.

$\checkmark$ É importante deixar claro que a determinação da deformação gerada por fluência a partir da função fluência $\mathrm{J}\left(\mathrm{t}, \mathrm{t}_{0}\right)$ corresponde apenas a uma das parcelas que compõe a deformação total existente em um elemento de concreto. Para estimar as outras parcelas da deformação foram utilizados os resultados dos ensaios para determinação da retração por secagem, da retração autógena e do coeficiente de variação térmica realizados em FURNAS.

$\checkmark$ Nem todas as expressões matemáticas adotadas na aproximação dos resultados experimentais foram satisfatórias, uma vez que a extrapolação de tais curvas além dos intervalos estudados pode fornecer resultados teóricos distintos dos que se obteria experimentalmente (ver expressão aproximada do 
módulo de elasticidade do substrato na Figura 6.10). No entanto, é possível obter ajustes mais adequados com estudos de parametrização e associação de equações diferentes.

Comparando-se os resultados teóricos, obtidos por normas nacionais e internacionais, com os resultados experimentais das deformações ao longo do tempo verificou-se que:

$\checkmark$ De todas as formulações teóricas analisadas, a norma NBR-6118 (2003) foi a que apresentou resultados mais próximos da curva experimental da função fluência e da retração. Sendo assim, optou-se por utilizar este modelo teórico para estimar as deformações por fluência, por retração e conseqüentemente as flechas das vigas VFC reforçadas e ensaiadas no laboratório da EESC-USP. Tais resultados estão apresentados no Capítulo 7.

Em relação à comparação da função fluência experimental com as funções fluência obtidas a partir do estudo paramétrico, verificou-se que:

Foram realizados os ajustes das curvas experimentais a partir dos modelos matemáticos descritos no item 3.4.2. A princípio, tentou-se fazer o ajuste adotando o Modelo Logarítmico por sua simplicidade. Entretanto, o ajuste das curvas da fluência específica foi melhor representado utilizando o Modelo Potencial, optando-se portanto por apresentar somente os resultados deste último ajuste.

$\checkmark$ A obtenção da curva da função fluência a partir do estudo paramétrico dos dados experimentais mostrou-se bastante adequada para caracterizar o comportamento viscoelástico de materiais cimentícios. Isso porque a partir deste estudo conseguia-se traçar curvas da função fluência para qualquer idade de aplicação do carregamento. Além disso, constatou-se uma excelente coincidência entre as deformações fornecidas pelas curvas traçada a partir do estudo paramétrico e as deformações dadas pelas curvas experimentais. 


\section{Vigas $T$ reforçadas no bordo comprimido (Técnica de Reforço n ${ }^{0}$ 2)}

\subsection{Características das vigas VFC}

Conforme se afirmou no item 2.3, foram ensaiadas três vigas do tipo VFC (Viga reforçada à Flexão no bordo Comprimido), de mesmas dimensões e taxas de armadura, as quais foram submetidas inicialmente a um carregamento de longa duração (denominado de pré-carregamento) e posteriormente a um carregamento monotônico de curta duração.

Em função do tipo de carregamento aplicado, o ensaio das vigas VFC foi subdividido em duas fases:

- Ensaio intermediário (carregamento de longa duração);

- Ensaio final (carregamento de curta duração);

No ensaio intermediário as vigas foram armazenadas em uma câmara climatizada, com temperatura de $\mathrm{T}=32^{\circ} \mathrm{C} \pm 2{ }^{\circ} \mathrm{C}$ e umidade de $\mathrm{U}=38 \% \pm 4 \%$, e foram submetidas a um pré-carregamento aplicado por um período de tempo superior a 90 dias, atuando tanto antes, quanto durante, e também após a execução do reforço.

$\mathrm{Na}$ fase do ensaio final, as vigas pré-carregadas foram retiradas da câmara climatizada e colocadas no sistema de reação pelo qual se aplicou o carregamento de curta duração em um único dia. Este carregamento foi o responsável por provocar a ruptura das vigas VFC.

As vigas VFC ensaiadas se diferenciavam em relação ao valor e ao período de tempo em que o pré-carregamento permaneceu atuando e as particularidades de cada uma estão especificadas no item 7.2. 


\subsubsection{Dimensões, detalhamento e instrumentação usada nos modelos}

As dimensões das vigas VFC estão na Figura 7.1. Por esta Figura percebe-se que foram moldados dois blocos de concreto nas extremidades dos modelos que serviram para ancorar o cabo de protensão responsável por gerar o pré-carregamento nas peças. Os detalhes a respeito da protensão e da ancoragem do cabo estão descritos no item 7.1.2.

O detalhamento das armaduras e o esquema estático das vigas estão especificados na Figura 7.2. Já os equipamentos usados na leitura das deformações e deslocamentos bem como seus respectivos posicionamentos nos modelos estão especificados na Figura 7.3.

Para fazer a leitura das deformações de compressão do concreto do substrato e do microconcreto do reforço para a seção do meio do vão foram usados extensômetros elétricos (strain-gauge) com base de $20 \mathrm{~mm}$ da marca Kyowa, colados na superfície do material e extensômetros elétricos encapsulados tipo KM 120 embutidos no material. Nas barras de aço longitudinais e transversais foram usados extensômetros elétricos (strain-gauge) com base de $5 \mathrm{~mm}$ da marca Kyowa e em uma das extremidades do cabo de protensão ${ }^{1}$ foi fixada uma célula de carga para que se pudesse acompanhar a variação do pré-carregamento atuante devido à perda de protensão nos cabos e ao aumento das flechas devido à fluência.

Em função da magnitude dos deslocamentos verticais no meio do vão e nos apoios gerados devido às características do carregamento aplicado, utilizou-se uma instrumentação diferenciada. Para obter os deslocamentos verticais das vigas provocados pela aplicação de um carregamento crescente por incremento de forças verticais (instante em que se executava a protensão do cabo ou instante em que se executava o ensaio final) utilizou-se transdutores de deslocamento com curso de 100 mm. Por outro lado, para medir os deslocamentos verticais gerados pela fluência durante o período em que as vigas VFC, armazenadas na câmara climatizada, ficaram submetidas a um carregamento de valor aproximadamente constante,

\footnotetext{
1 Como o Laboratório de Estruturas da EESC já tinha disponível esta cordoalha de protensão, procurou-se aproveitá-la nos ensaios das vigas VFC.
} 
utilizou-se relógios comparadores com precisão de 0,001 e com curso de $20 \mathrm{~mm}$, pois a variação dos deslocamentos verticais era muito pequena.

Como o ensaio intermediário era na verdade um ensaio de longa duração, os valores das deformações nas armaduras e nos concretos e os deslocamentos verticais (flechas) foram anotados diariamente para se traçar gráficos em função do tempo.

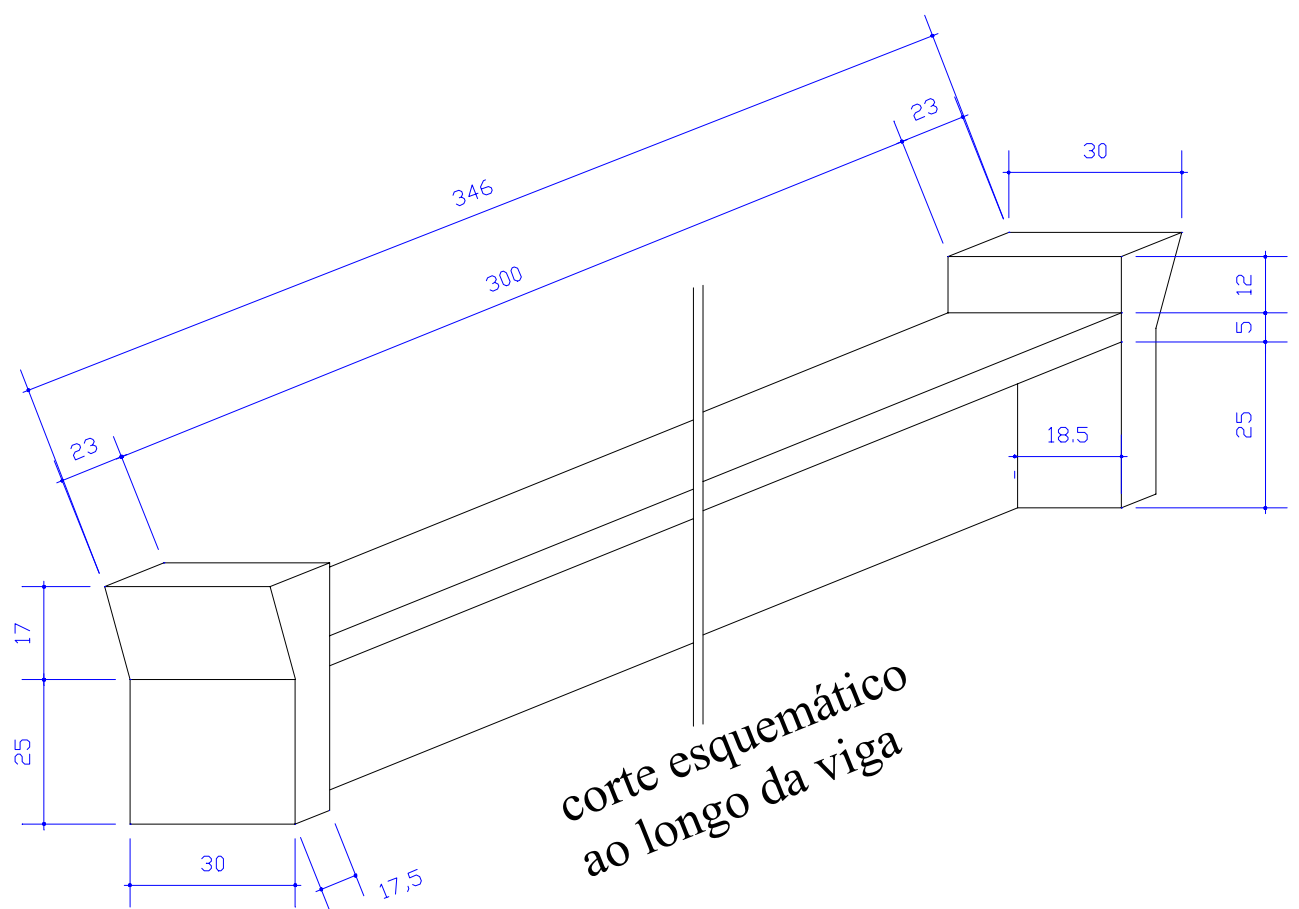

(a) Dimensões gerais da viga

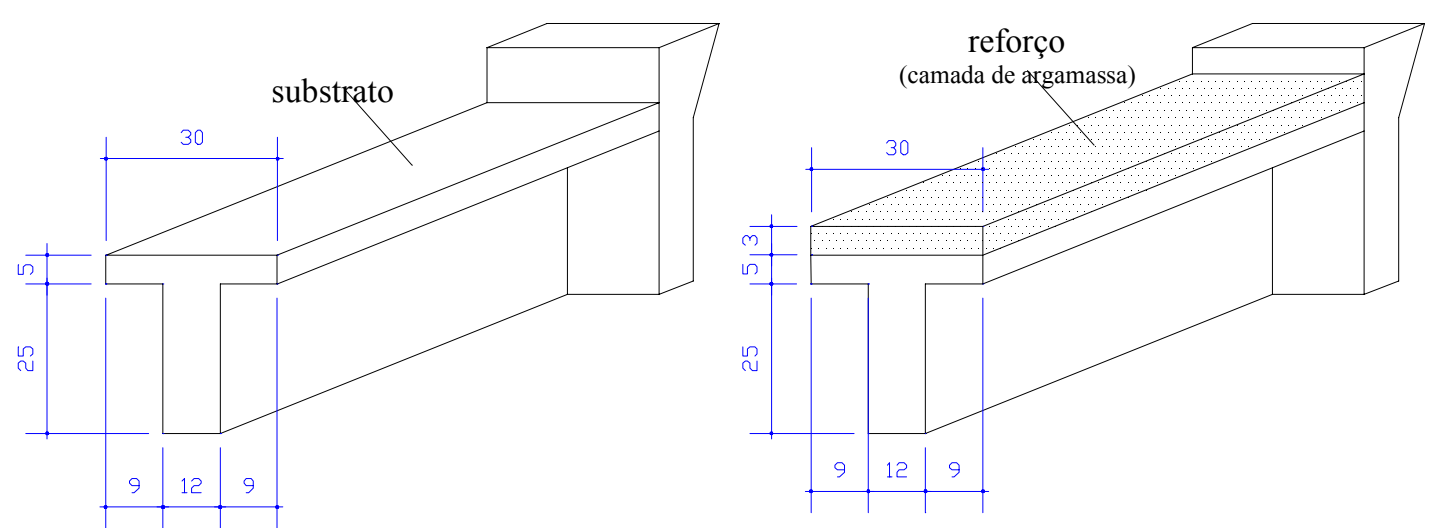

(b) Dimensões da seção transversal 


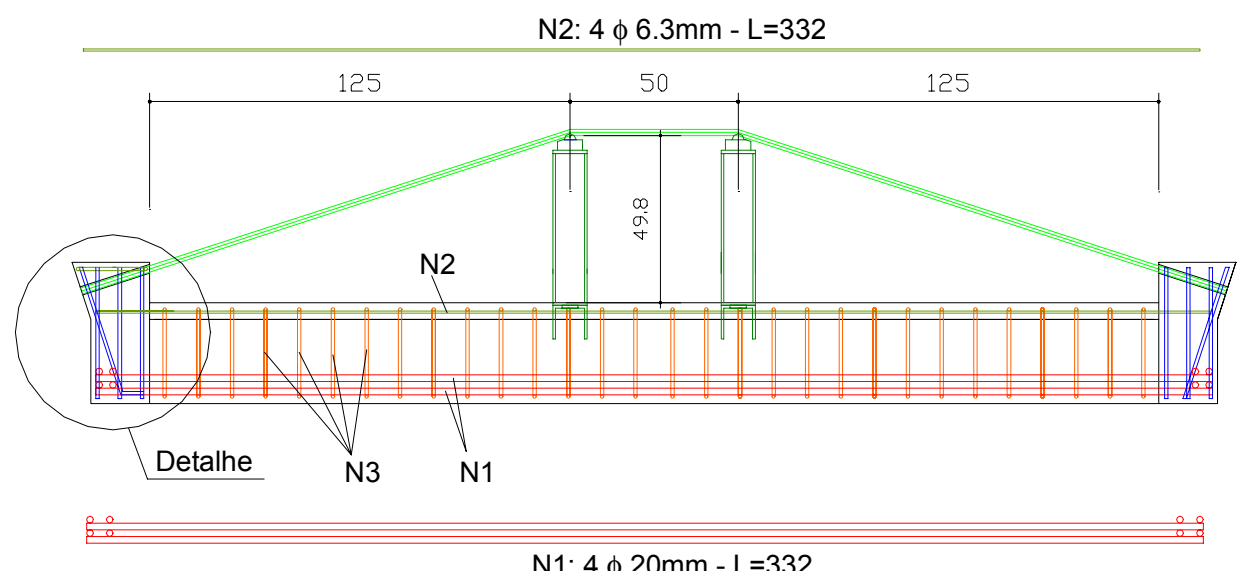

(a) Detalhe das armaduras na seção longitudinal

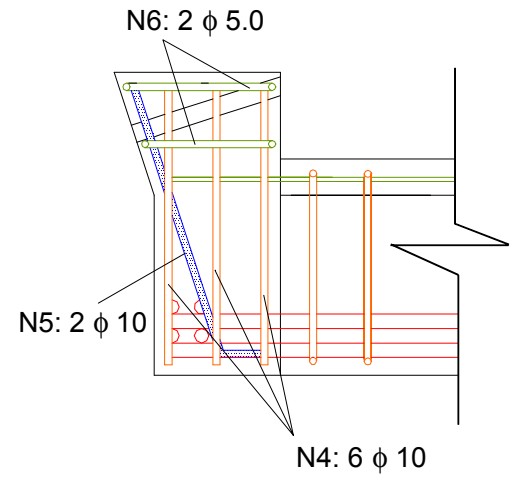

(b) Detalhe das armaduras do bloco de ancoragem

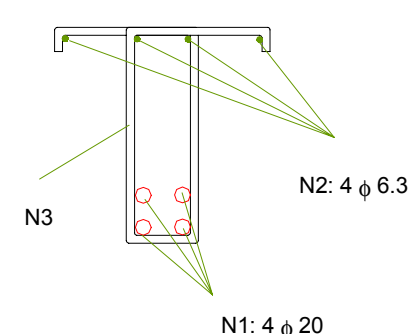

N3: 31 ф 10mm - L=105 (estribos da viga T)

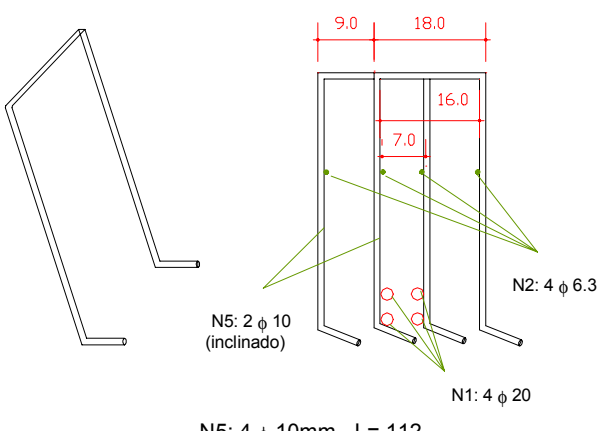

N5: $4 \phi 10 \mathrm{~mm}-\mathrm{L}=112$ (tirante duplo do consolo inclinado)
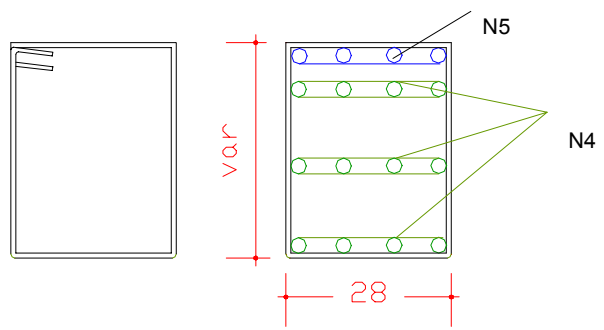

N6: $4 \phi 5 \mathrm{~mm}-\mathrm{L}=$ variável (octrihn nnnetru itiun)

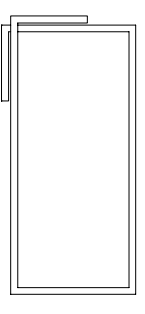

$\mathrm{N} 4: 2 \phi 10$

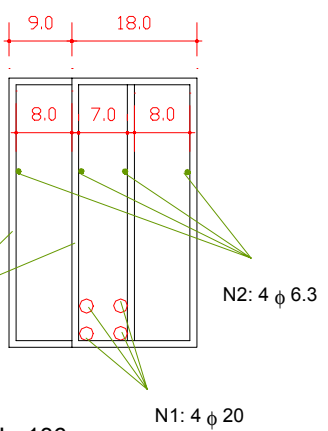

$\mathrm{N} 4: 12 \phi 10 \mathrm{~mm}-\mathrm{L}=136$ (estribo duplo vertical $\mathrm{p} /$ região do apoio)

Figura 7.2 - Detalhamento das armaduras das vigas VFC 


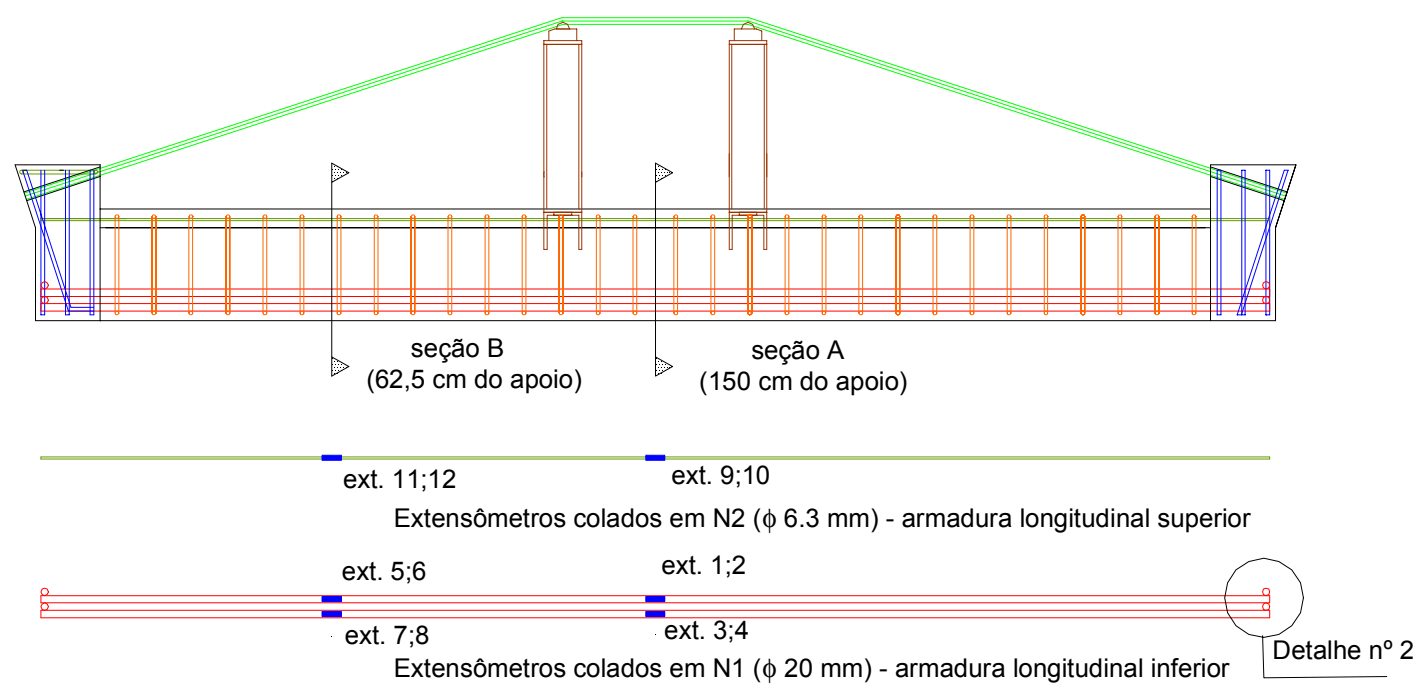

(a) posição dos extensômetros elétricos nas barras de aço tracionadas e comprimidas

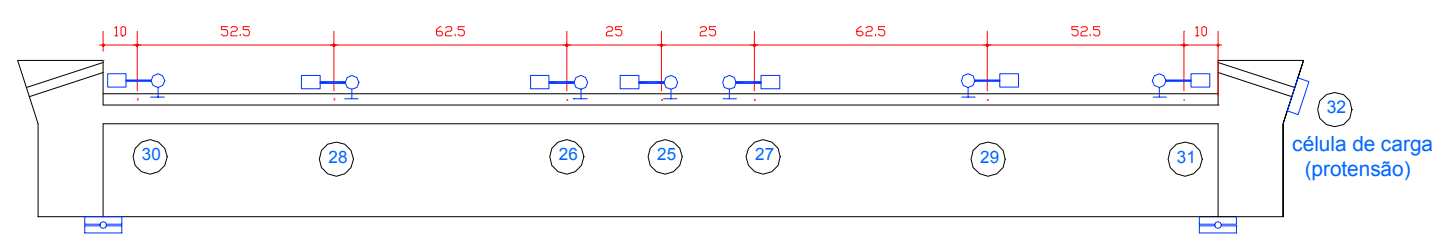

(b) relógios comparadores na região da junta reforço/substrato (usados somente durante a fase do ensaio final)

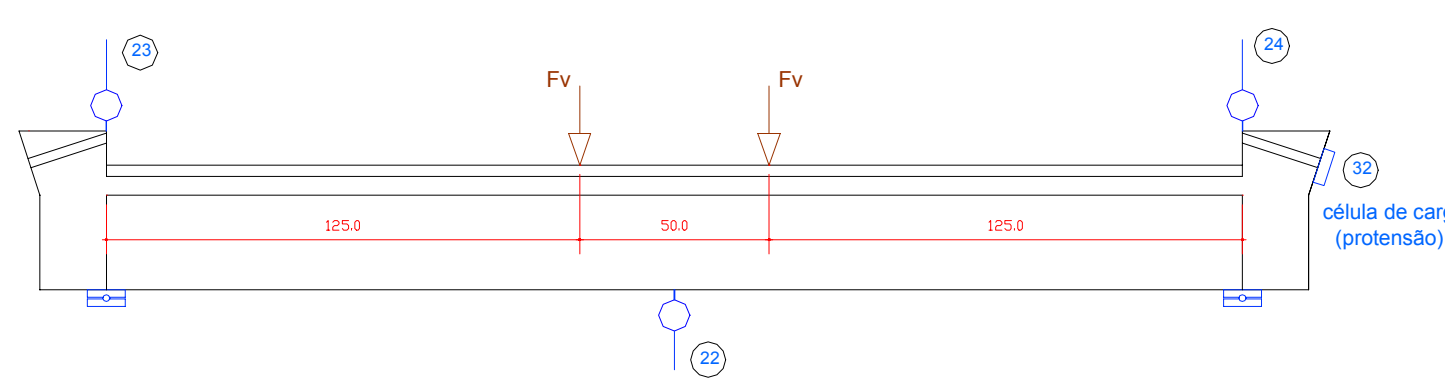

(c) posições dos transdutores de deslocamento ou dos defletômetros (em função da magnitude dos deslocamentos a serem coletados)

Figura 7.3 - Instrumentação ao longo das vigas VFC 


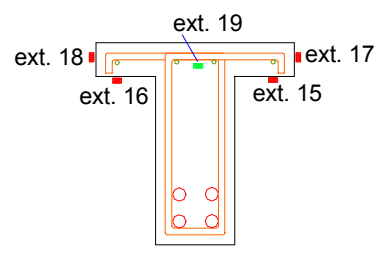

seção $A$

Seções antes do reforço (extensômetros p/ concreto)

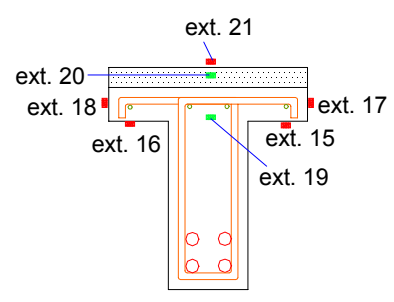

seção $A$

Seções após o reforço (extensômetros p/ concreto)

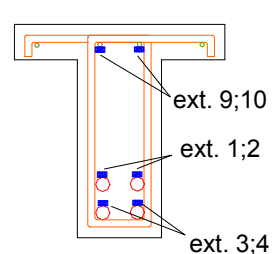

seção A

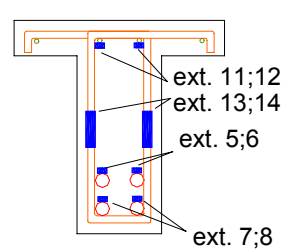

seção B

Seções antes do reforço (extensômetros p/ aço)

Legenda:

extensômetro elétrico $\mathrm{p} /$ barras de aço

extensômetro elétrico externo p/ concreto

- extensômetro embutido p/ concreto

\section{Figura 7.4 - Instrumentação na seção transversal}

Tabela 7.1- Resumo das características das vigas ensaiadas

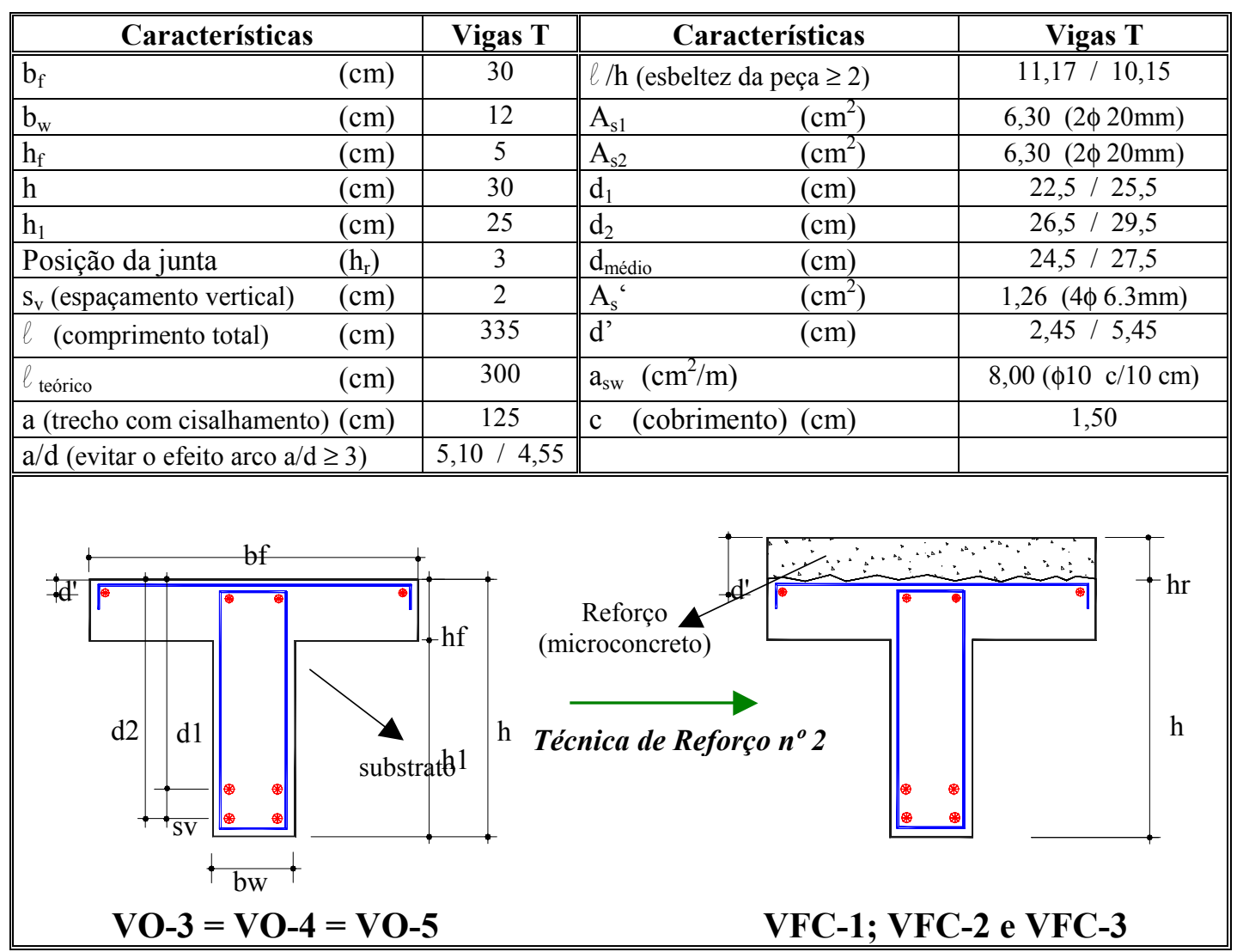




\subsubsection{Sistema usado na aplicação do pré-carregamento por meio de protensão}

Em geral para se aplicar carregamentos de longa duração em vigas utiliza-se sistemas de aplicação e manutenção de carga através de pesos fixados em um braço de alavanca tal como o apresentado na Figura 7.5.

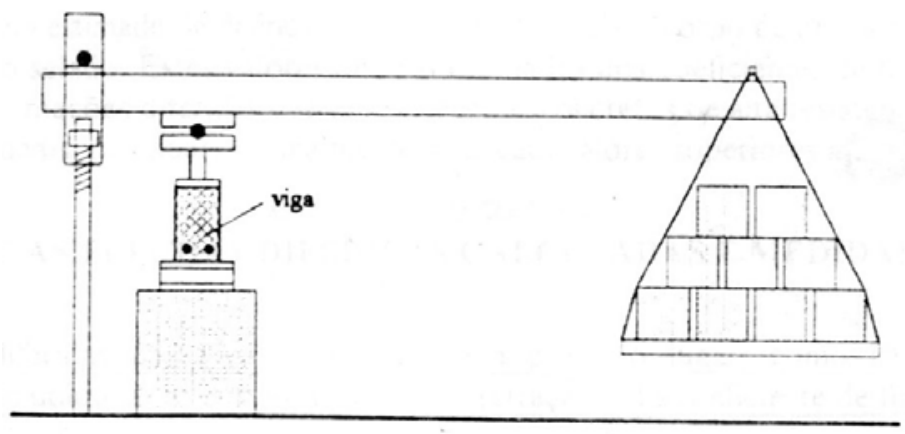

Figura 7.5 - Sistema de aplicação de carregamento de longa duração usual

Entretanto, neste trabalho, o sistema de aplicação de carga deveria permitir a execução do reforço com a viga estando carregada e também não poderia ser retirado do modelo durante seu transporte da câmara climatizada para o local do ensaio final, por isso foi inviável aplicá-lo por meio do sistema usual. Para solucionar este problema, idealizou-se um sistema no qual o pré-carregamento seria aplicado através da protensão de uma cordoalha engraxada não aderente (ver Figura 7.6) que passava externamente à viga e se ancorava em blocos de concreto moldados em suas extremidades.

Para produzir as forças verticais necessárias, adotou-se uma configuração poligonal para o cabo de protensão, que saiu da extremidade da viga com uma inclinação de $18^{\circ}$ e foi desviado a uma altura de aproximadamente $55 \mathrm{~cm}$ a partir da face superior da viga (bordo comprimido) na seção transversal situada a $125 \mathrm{~cm}$ dos apoios por meio de dois dispositivos metálicos, denominados desviadores. 


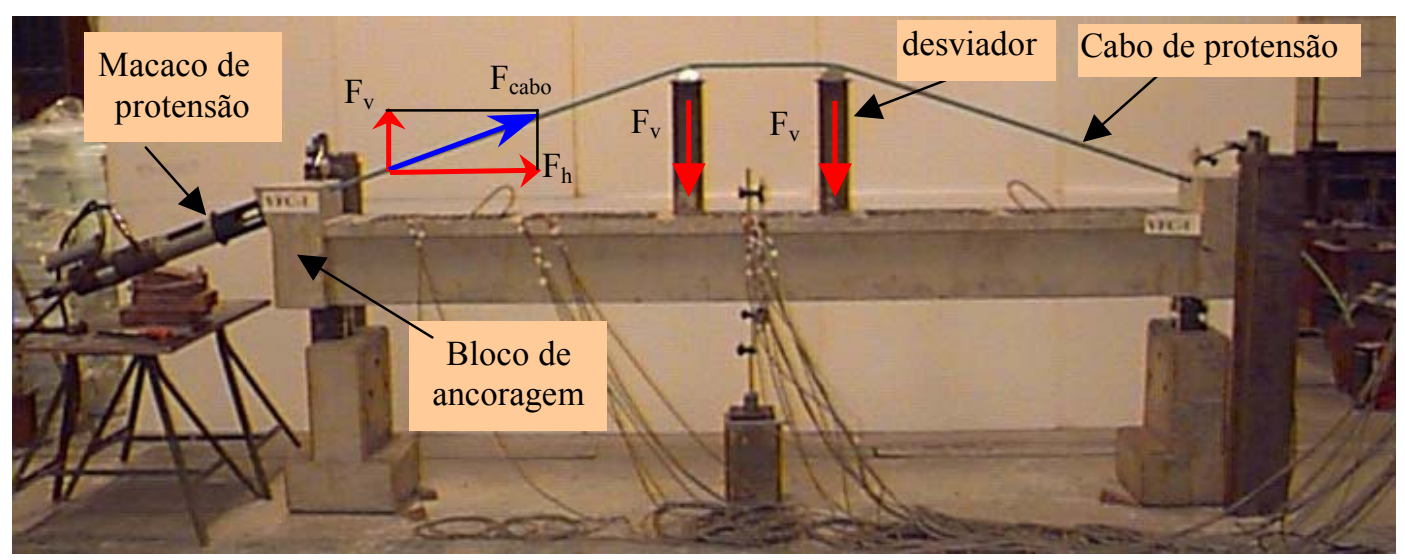

Figura 7.6 - Sistema de aplicação do pré-carregamento por protensão

Os desviadores foram fixados na viga por dois perfis metálicos chumbados à mesa da viga durante a concretagem do substrato e estão ilustrados na Figura 7.8a. A ancoragem dos cabos foi feita por um sistema convencional com porta- cunhas e cunhas individuais tripartidas fixadas nos blocos de ancoragem de concreto moldados nas extremidades das vigas. Fotos das cunhas e porta-cunhas podem ser vistas na Figura $7.8 \mathrm{~b}$ A parte externa de tais blocos foi confeccionada com certa inclinação para que a ancoragem do cabo fosse feita perpendicularmente à sua direção. O ponto exato da ancoragem do cabo ficou a $9 \mathrm{~cm}$ da face superior do bloco, ou seja, ficou acima do c.g. da peça para produzir momentos fletores positivos nas extremidades da viga e estão detalhadas na Figura 7.9.

Todavia, em função do tipo de ancoragem usado neste sistema gerou-se uma flexo-compressão na viga (flexão composta de grande excentricidade) devendo-se calcular o momento fletor pela expressão 7.1, que considera tanto o efeito da força horizontal quanto da força vertical atuante na peça.

Apesar da viga estar submetida a um esforço de compressão, não foi considerado nenhum aumento de sua resistência ao cisalhamento conforme ocorre nas peças protendidas convencionais, já que se trata de uma flexão-compressão de grande excentricidade, ou seja, a ação do momento fletor é preponderante à ação do esforço de compressão.

Tal sistema não consegue manter constante o pré-carregamento por causa dos efeitos de relaxação dos cabos de protensão e do aumento das flechas do modelo. 
Portanto, para analisar os resultados da fluência foi preciso acompanhar diariamente a variação do pré-carregamento e das flechas da viga.

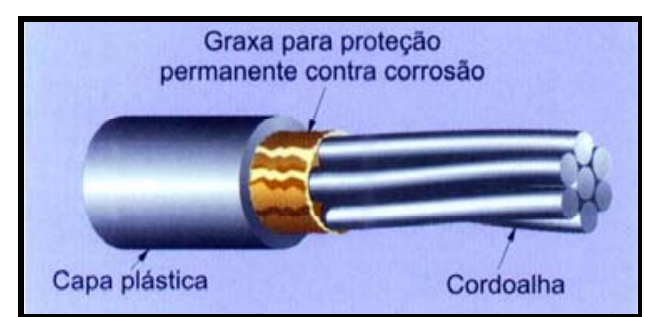

Figura 7.7 - Cordoalha não aderente usada na protensão das vigas VFC

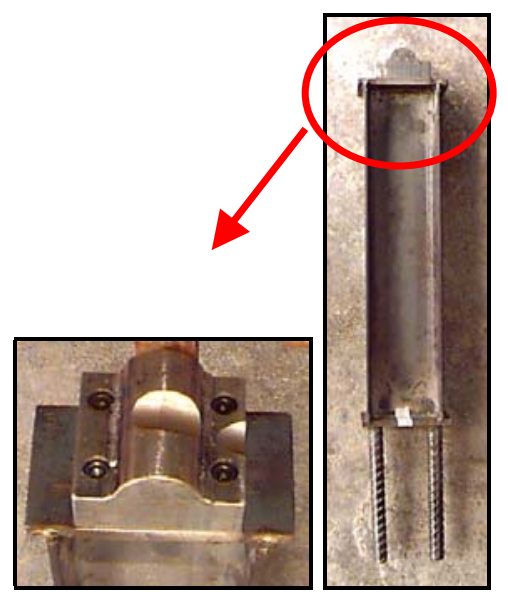

a) desviador

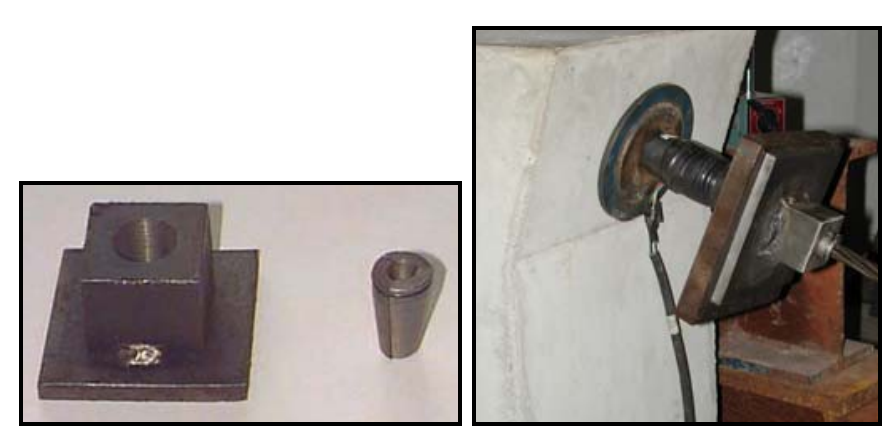

b) jogo de cunha e porta cunha

Figura 7.8- Jogo de cunha, porta-cunha e desviador

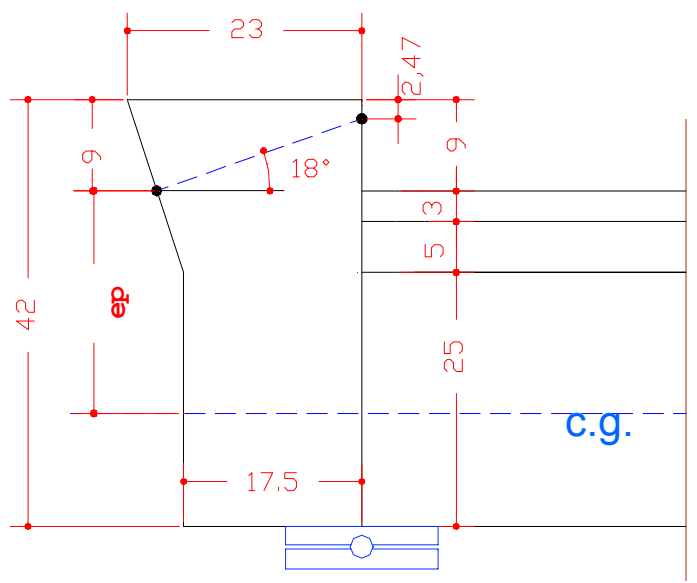

Obs.: $e_{p}=14,5 \mathrm{~cm}$ (calculado a partir da seção $\mathrm{T}$ de concreto não homogeneizada)

Figura 7.9- Detalhe do bloco de ancoragem 


$$
\mathrm{M}=\mathrm{F}_{\mathrm{H}} \cdot \mathrm{e}_{\mathrm{p}}+\mathrm{F}_{\mathrm{V} \cdot \mathrm{a}}
$$

Onde:

M : momento fletor gerado na viga pela protensão;

$\alpha \quad$ : ângulo da cordoalha de protensão com o eixo horizontal $\left(\alpha=18^{\circ}\right)$;

$e_{p}$ : excentricidade da força horizontal em relação ao c.g. da peça $\left(e_{p}=14,5 \mathrm{~cm}\right)$;

a : refere-se ao trecho com cisalhamento cuja distância vai do centro do apoio ao local de aplicação da força concentrada $(\mathrm{a}=125 \mathrm{~cm})$;

$F_{H}$ : força horizontal gerada pela protensão da cordoalha, calculada por $F_{H}=F \cdot \cos \alpha$;

$\mathrm{F}_{\mathrm{V}}$ : força vertical gerada pela protensão da cordoalha, calculada por $\mathrm{F}_{\mathrm{V}}=\mathrm{F} \cdot \operatorname{sen} \alpha$;

F : força de protensão aplicada na cordoalha, medida através de uma célula de carga;

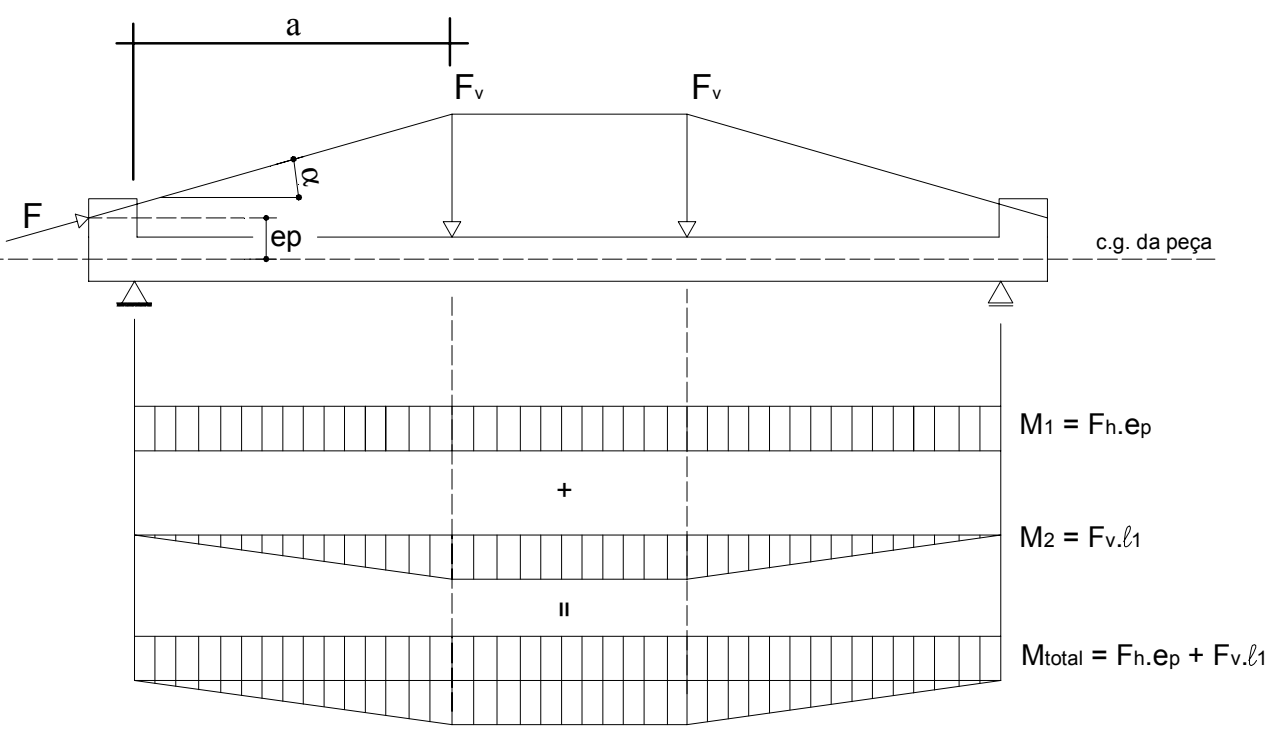

Figura 7.10 - Esforços gerados pela aplicação da protensão

\subsection{Etapas do ensaio intermediário}

As diferenças entre as vigas $\mathrm{T}$ ensaiadas no bordo comprimido, especificadas na Tabela 7.2, foram classificadas em função das etapas que compunham o ensaio intermediário. Estas etapas dependiam basicamente do número de aplicação de protensão e do intervalo de tempo em que este ficou atuando no modelo. 
Tabela 7.2 - Etapas do ensaio intermediário realizado nas vigas VFC

\begin{tabular}{|c|c|c|c|}
\hline Etapas & $\begin{array}{l}\text { Idade } \\
\text { (dias) } \\
\end{array}$ & $\begin{array}{c}\text { Intervalo de tempo após } \\
\text { início do carregamento } \\
\text { (dias) }\end{array}$ & $\begin{array}{c}\text { Intervalo de tempo } \\
\text { entre cada etapa } \\
\text { (dias) } \\
\end{array}$ \\
\hline \multicolumn{4}{|c|}{ VFC-1 - pré-carregamento aplicado em duas etapas } \\
\hline Moldagem & 0 & - & 0 \\
\hline Protensão $\mathrm{n}^{\mathrm{o}} 1$ & 7 & 1 & 7 \\
\hline Reforço no bordo comprimido & 40 & 33 & 33 \\
\hline Protensão $n^{\circ} 2$ & 75 & 68 & 35 \\
\hline Ensaio final & 104 & 97 & 29 \\
\hline \multicolumn{4}{|c|}{ VFC-2- peça não submetida a nenhum pré-carregamento } \\
\hline Moldagem & 0 & - & - \\
\hline Reforço no bordo comprimido & 40 & - & 40 \\
\hline Ensaio final & 125 & - & 85 \\
\hline \multicolumn{4}{|c|}{ VFC-3-pré-carregamento aplicado em uma única etapa } \\
\hline Moldagem & 0 & - & - \\
\hline Protensão $\mathrm{n}^{\mathrm{o}} 1$ & 7 & 1 & 7 \\
\hline Reforço no bordo comprimido & 75 & 68 & 68 \\
\hline Ensaio final & 145 & 138 & 70 \\
\hline
\end{tabular}

Para comparar os valores de pré-carregamento aplicados nas vigas antes da execução do reforço determinou-se teoricamente o carregamento máximo que a peça original (antes da intervenção) poderia suportar. Os cálculos foram feitos de acordo com as recomendações da NBR-6118, utilizando a resistência do concreto aos 28 dias. De acordo com estes cálculos obteve-se - em termos da força vertical $F_{v}$ - uma capacidade portante máxima de $78,6 \mathrm{kN}$ e uma força de serviço igual a $54,5 \mathrm{kN}$. É importante ressaltar que a ruptura prevista para a viga original ocorre no domínio 4, ou seja, se houvesse o colapso da estrutura, este se daria por esmagamento do concreto do bordo comprimido. Também foi feito o cálculo teórico da capacidade portante e da força de serviço referente à viga original após o reforço obtendo-se respectivamente $127,3 \mathrm{kN}$ e $90,9 \mathrm{kN}$.

$\mathrm{Na}$ viga VFC-1 foram aplicados dois valores de pré-carregamentos distintos. O primeiro pré-carregamento (protensão $\mathrm{n}^{\circ} 1$ ), aplicado 7 dias após a moldagem do substrato, introduzia forças verticais de 19,6 kN (36 \% da força de serviço prevista da peça original). Após 68 dias da aplicação do primeiro pré-carregamento, com a viga já reforçada, aumentou-se o pré-carregamento (protensão $n^{0} 2$ ) pelo aumento da protensão, aplicando-se forças verticais de $35,1 \mathrm{kN}$. Isto foi feito para verificar a absorção do pré-carregamento pelo material de reforço adicionado. Este novo pré- 
carregamento foi deixado por mais 29 dias e após este prazo realizou-se o ensaio final da peça.

Na VFC-3 foi aplicado apenas um único valor de pré-carregamento (protensão $\mathrm{n}^{\mathrm{o}}$ 1) de $32 \mathrm{kN}$ que correspondia a 58,7\% da força de serviço prevista da peça original. Esta solicitação foi aplicada 7 dias após a moldagem do substrato e portanto, antes da execução do reforço. Desta maneira pretendia-se analisar o fato de apenas o substrato ter sofrido fluência antes do ensaio final da peça.

As vigas VFC-1 e VFC-3 foram armazenadas na câmara climatizada por um período de tempo superior a 90 dias. Tais peças foram retiradas da câmara climatizada alguns dias antes da data marcada para realizar o ensaio final (ensaio de curta duração) para se posicionar os instrumentos de leitura referentes a este ensaio.

Na VFC-2 não se aplicou nenhum pré-carregamento para que se pudesse analisar se a existência de um pré-carregamento realmente afetava a resistência final da peça. Para que não atuasse nenhum tipo de esforço nesta peça, nem mesmo o peso próprio, esta peça ficou apoiada ao longo de todo seu comprimento. A viga VFC-2 não foi armazenada na câmara climatizada por dois motivos: o primeiro foi por falta de espaço neste local e o segundo é que por ela não estar submetida a um pré-carregamento, esta peça não apresentaria variações de deslocamento nem de deformação e, portanto seu comportamento ao longo do tempo não precisaria ser monitorado.

\subsection{Esquema do ensaio final}

Decorrido o período de tempo em que as peças permaneceram armazenadas na câmara climatizada para acompanhamento das deformações geradas por fluência, as vigas foram transportadas para o galpão de ensaio da EESC-USP onde foram ensaiadas à flexão simples até a ruptura aplicando-se, por incremento de força, duas forças concentradas verticais, de igual intensidade, distantes $125 \mathrm{~cm}$ dos apoios.

Para aplicar estas forças concentradas desenvolveu-se um sistema de aplicação de carga utilizando dois macacos hidráulicos que aplicaram as forças em dois perfis metálicos tipo I, biapoiados na mesa da viga e dispostos lateralmente à cordoalha (ver Figura 7.11), pois o cabo de protensão, responsável pela aplicação do pré-carregamento, passava externamente ao longo da parte superior da viga. 


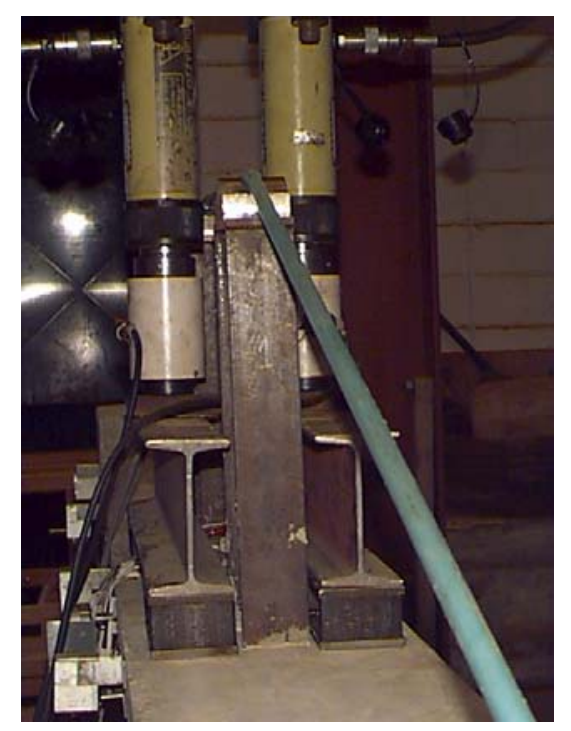

Figura 7.11 - Esquema de ensaio das vigas VFC

\subsection{Caracterização dos materiais}

Para moldar as vigas originais VO (substrato das vigas VFC), utilizou-se um traço dosado especificamente para que o concreto fosse bastante sensível ao efeito da fluência (traço $T S$-2), e que deveria apresentar uma resistência à compressão mínima de $15 \mathrm{MPa}$ aos 7 dias para possibilitar a aplicação do pré-carregamento nesta data. Para moldar o microconcreto do reforço utilizou-se um traço que não fosse tão sensível à fluência (traço $T R-2$ ). As dosagens desses traços estão Tabela 2.9 e as propriedades mecânicas na Tabela 7.3.

A armadura de protensão (armadura ativa) representada pelo cabo utilizado para aplicar o pré-carregamento, constituía-se de uma cordoalha de 7 fios tipo CP 190-RB (não aderente) com bitola de 12,7 mm fornecida pela Belgo-Mineira Bekaert Arames S.A.. De acordo com fabricante, tal cabo apresentava as características apresentadas na Tabela 7.4.

Pelas características mecânicas da armadura ativa, a cordoalha engraxada seria capaz de suportar teoricamente uma força de tração de $182 \mathrm{kN}$. Entretanto, ALMEIDA (2001), que utilizou um desviador semelhante, observou que este dispositivo não proporcionava uma mudança gradual da inclinação do cabo, resultando na ruptura prematura de um dos fios das cordoalhas devido a uma concentração de tensões nesta região. Isso fez com que a força máxima resistida pelo cabo utilizando este desviador fosse de no máximo $140 \mathrm{kN}$. Como este valor já era 
suficiente para provocar o pré-carregamento desejado não se fez nenhuma modificação no desviador. É importante esclarecer que esta ruptura prematura depende do tipo de desviador usado e não deve ser extrapolada para outros tipos de desviadores. Quanto à armadura passiva, usada no detalhamento das vigas, os ensaios de tração forneceram as propriedades mecânicas descritas na Tabela 7.4.

Tabela 7.3 - Características do concreto e do microconcreto de reforço

\begin{tabular}{|c|c|c|c|c|c|c|c|}
\hline \multirow[b]{2}{*}{ Etapas do ensaio } & \multirow[b]{2}{*}{$\begin{array}{l}\text { Idade } \\
\text { (dias) }\end{array}$} & \multicolumn{3}{|c|}{$\begin{array}{c}\text { Traço TS-2 } \\
\text { Substrato }\end{array}$} & \multicolumn{3}{|c|}{$\begin{array}{c}\text { Traço TR-2 } \\
\text { reforço }\end{array}$} \\
\hline & & $\begin{array}{c}\mathbf{f}_{\mathbf{c i}} \\
(\mathbf{M P a})\end{array}$ & $\begin{array}{c}\mathbf{f}_{\mathrm{ti}} \\
(\mathbf{M P a})\end{array}$ & $\begin{array}{c}\mathbf{E}_{\mathbf{c o}} \\
(\mathrm{MPa})\end{array}$ & $\begin{array}{c}\mathbf{f}_{\mathbf{c i}} \\
(\mathbf{M P a})\end{array}$ & $\begin{array}{c}\mathbf{f}_{\mathbf{t i}} \\
(\mathbf{M P a})\end{array}$ & $\begin{array}{c}\mathbf{E}_{\mathbf{c o}} \\
(\mathrm{MPa})\end{array}$ \\
\hline \multicolumn{8}{|c|}{ VFC-1 } \\
\hline Concretagem do substrato & 0 & - & - & - & - & - & - \\
\hline Protensão 1 & 7 & 14,61 & 1,90 & $21405^{*}$ & - & - & - \\
\hline Concretagem do reforço & 40 & 21,51 & 2,73 & 24378 & - & - & - \\
\hline Protensão 2 & 75 & 22,06 & 2,37 & 26000 & 66,24 & 5,07 & 34952 \\
\hline Ensaio da peça & 104 & 25,79 & 2,69 & 26403 & 71,55 & 5,46 & 35718 \\
\hline \multicolumn{8}{|c|}{ VFC-2 } \\
\hline Concretagem do substrato & 0 & - & - & - & - & - & - \\
\hline Concretagem do reforço & 40 & 21,53 & 1,94 & 31132 & - & - & - \\
\hline Ensaio da peça & 125 & 26,48 & 2,89 & 33378 & 87,74 & 4,91 & 34380 \\
\hline \multicolumn{8}{|c|}{ VFC-3 } \\
\hline Concretagem do substrato & 0 & - & - & - & - & - & - \\
\hline Protensão 1 & 7 & 16,19 & 1,81 & 26704 & - & - & - \\
\hline Eoncretagem do reforço & 75 & 29,90 & 2,85 & 31328 & - & - & - \\
\hline Ensaio da peça & 145 & 32,59 & 3,49 & 31772 & 90,33 & 6,03 & 34138 \\
\hline \multicolumn{8}{|c|}{$\begin{array}{l}\text { OBS.: } \\
\text { Valores assinalados com } * \text { foram calculados com as recomendações da norma }\left(\mathrm{Ec}=5600 *(\mathrm{fcj})^{0,5}\right) \\
\text { Os valores das resistências representados nesta tabela foram minorados em } 5 \% \text { para levar em } \\
\text { consideração o efeito escala }\end{array}$} \\
\hline
\end{tabular}

Tabela 7.4 - Características mecânicas da armadura ativa

\begin{tabular}{|c|c|c|c|c|c|}
\hline$\phi(\mathbf{m m})$ & $\mathbf{A}_{\mathbf{s}}\left(\mathbf{c m}^{\mathbf{2}}\right)$ & $\mathbf{E}_{\mathbf{p s}}(\mathbf{M P a})$ & $\left.\boldsymbol{f}_{\boldsymbol{p y}} \mathbf{( M P a}\right)$ & $\boldsymbol{\varepsilon}_{p y}(\mathbf{\% o})$ & $\mathbf{f}_{\mathbf{p u}}(\mathbf{M P a})$ \\
\hline 12,7 & 0,999 & 208.000 & 1.820 & 8,8 & 2.000 \\
\hline
\end{tabular}

Tabela 7.5 - Características mecânicas da armadura passiva

\begin{tabular}{|c|c|c|c|c|}
\hline$\phi(\mathrm{mm})$ & Tipo de armadura & $\mathbf{f}_{\mathrm{y}}$ (MPa) & $\mathbf{f}_{\mathrm{u}}$ (MPa) & $\varepsilon_{y}(\%)$ \\
\hline \multicolumn{5}{|c|}{ VFC-1 } \\
\hline 6.3 & CA 60B $\quad-\mathrm{A}_{\mathrm{sl}}$, & 605 & 844 & 2,95 \\
\hline 10 & CA 50A $-\mathrm{A}_{\mathrm{sw}}$ & 521 & 833 & 2,54 \\
\hline 20 & $-\mathrm{A}_{\mathrm{sl1}}$ e $\mathrm{A}_{\mathrm{sl2}}$ & 561 & 682 & 2,74 \\
\hline \multicolumn{5}{|c|}{ VFC-2 e VFC-3 } \\
\hline 6.3 & "CA 60B $-\mathrm{A}_{\mathrm{sl}}$, & 633 & 824 & 3,09 \\
\hline 10 & CA 50A $-\mathrm{A}_{\mathrm{sw}}$ & 564 & 653 & 2,75 \\
\hline 20 & $-\mathrm{A}_{\mathrm{s} 11}$ e $\mathrm{A}_{\mathrm{sl} 2}$ & 525 & 637 & 2,56 \\
\hline
\end{tabular}




\subsection{Moldagem, escarificação e cura}

As vigas VFC foram moldadas em duas etapas. Na primeira moldava-se o substrato da viga original VO e só posteriormente é que se realizava a segunda etapa de moldagem (execução do reforço) acrescentando-se uma camada de $3 \mathrm{~cm}$ de microconcreto à espessura da mesa da viga original. O intervalo de tempo entre a moldagem do substrato da viga e a execução do reforço foi apresentado na Tabela 7.2 .

O concreto do substrato foi preparado em uma betoneira com capacidade de $0,15 \mathrm{~m}^{3}$, sendo colocado na fôrma com o auxílio de pás e adensado em mesa vibratória. O microconcreto do reforço foi preparado em uma argamassadeira de $0,05 \mathrm{~m}^{3}$ e não foi preciso vibrá-lo, pois já foi dosado para ser um material autoadensável.

Após a cura do substrato, iniciou-se a preparação da superfície para receber o reforço através de sua escarificação com jato de água e antes de executar o reforço, limpou-se esta superfície com ar comprimido para retirar todo o material solto, umedecendo-a em seguida. Para evitar fuga da nata de cimento durante a moldagem do reforço foi aplicada uma argamassa de cimento e areia para vedar a ligação da forma com o substrato (ver Figura 7.13). Para que a argamassa do reforço não ficasse confinada pelos blocos de ancoragem nas extremidades da viga colocou-se pedaços de EPS (ver Figura 7.12) antes de sua concretagem para que durante o ensaio final das vigas VFC este material pudesse se deformar livremente. Tal procedimento não foi feito para a viga VFC-1.

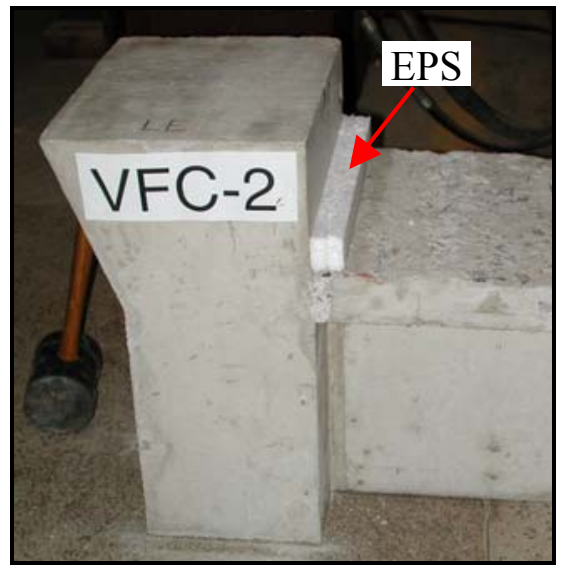

Figura 7.12 - Poliestireno fixado na extremidade da peça antes do reforço 


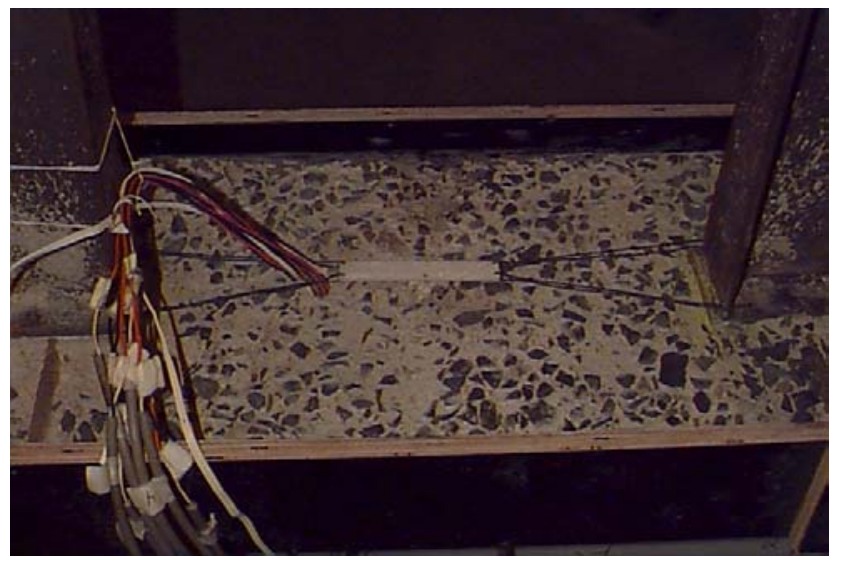

(a) aspecto da mesa da viga após sua escarificação

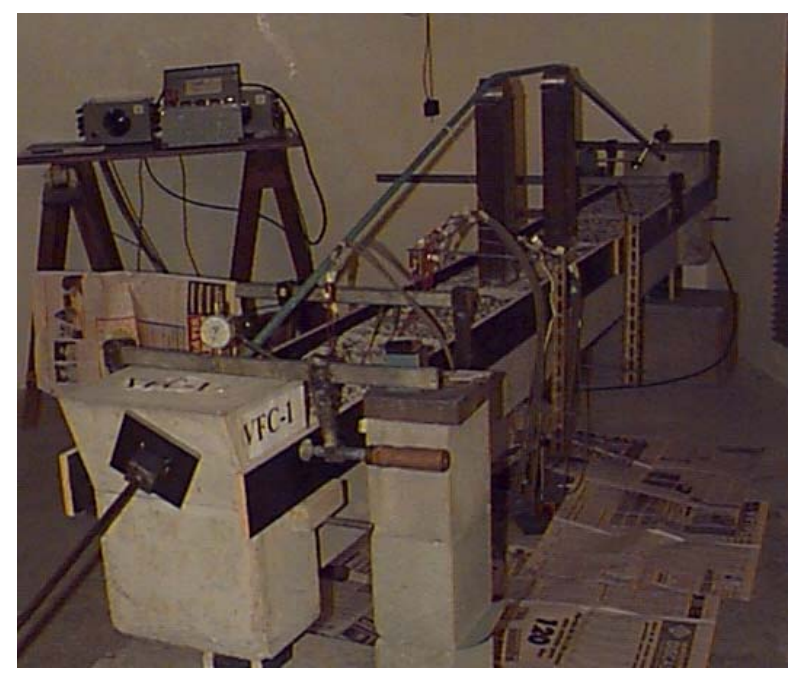

(b) esquema de fixação das fôrmas antes da execução do reforço

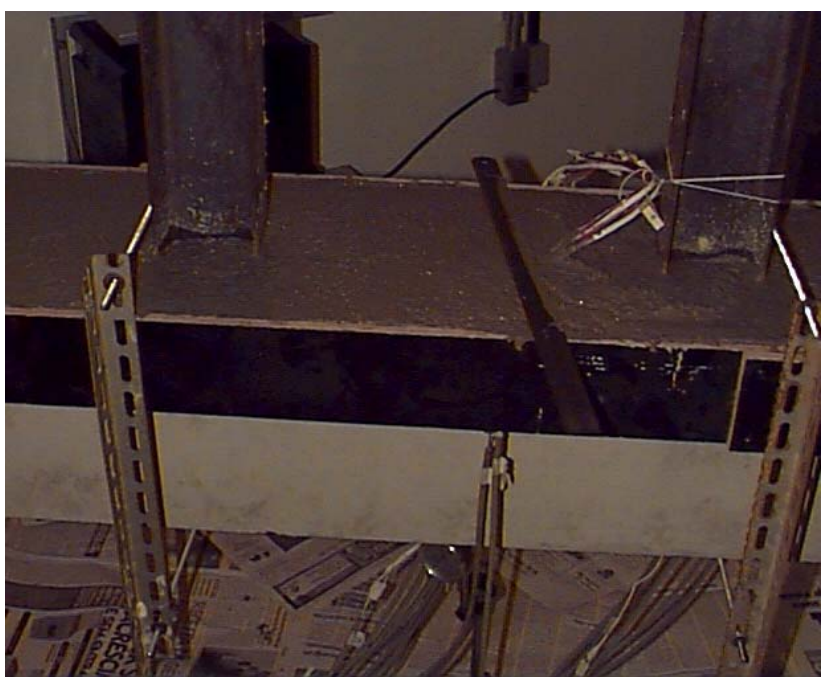

(c) viga após a execução do reforço

Figura 7.13 - Detalhes do reforço do bordo comprimido da viga 


\subsection{Apresentação e análise dos resultados}

Como os ensaios das vigas VFC foram subdivididos em duas fases (ensaio intermediário e ensaio final), os resultados obtidos foram apresentados e analisados separadamente.

\subsubsection{Ensaio intermediário (carregamento de longa duração)}

Os resultados experimentais descritos neste item referem-se apenas às vigas VFC-1 e VFC-3, que foram submetidas a um pré-carregamento para avaliação dos efeitos da fluência.

A análise dos resultados foi feita observando a evolução das deformações dos materiais em relação ao tempo e em relação à força atuante. A força atuante era crescente quando se aplicava ou aumentava o pré-carregamento por meio de protensão e era decrescente após a ancoragem do cabo protendido. Para facilitar a identificação de qual situação se encontrava a viga, subdividiu-se o ensaio intermediário em seis etapas tal como esquematizado na Figura 7.14 e na Tabela 7.6.
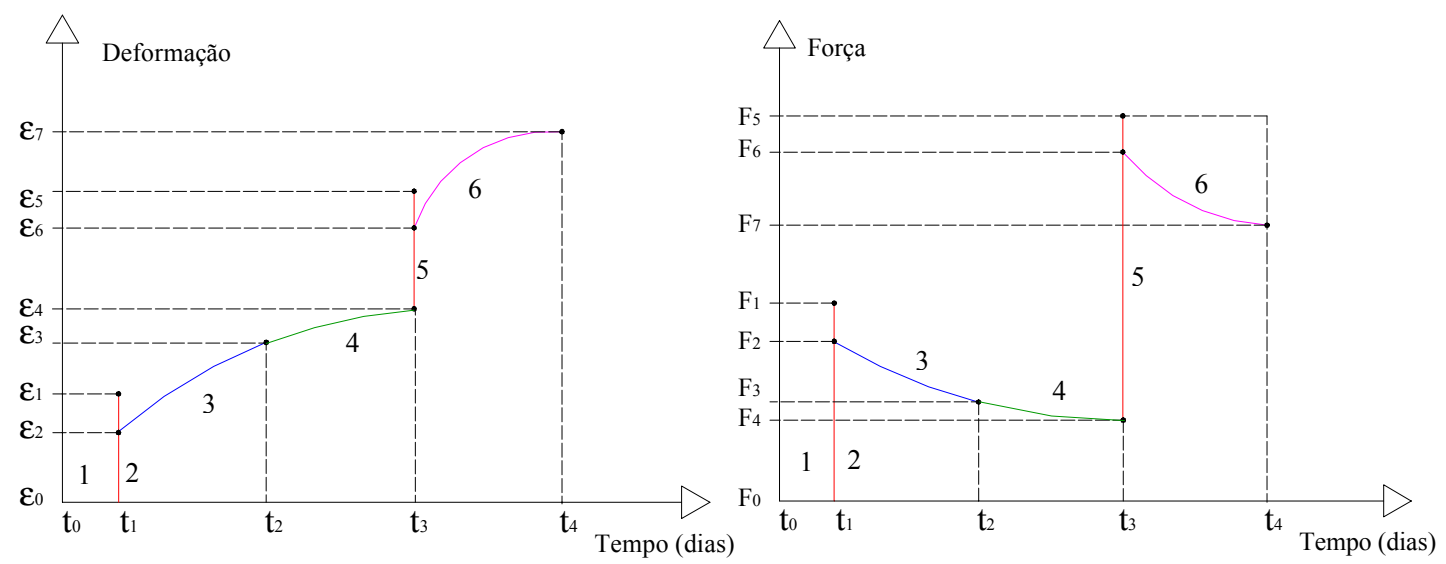

Legenda:

Etapa 1- Moldagem da viga até instantes antes da aplicação do $1^{\circ}$ pré-carregamento $\left(t_{0} \rightarrow t_{1}\right.$ e $\left.F=F_{0}\right)$

Etapa 2- Início da aplicação do $1^{\circ}$ pré-carregamento até ancoragem do cabo de protensão $\left(t=t_{1}\right.$ e $\left.F_{0} \rightarrow F_{1} \rightarrow F_{2}\right)$

Etapa 3- Final da aplicação do $1^{\circ}$ pré-carregamento até a execução do reforço da viga $\left(t_{1} \rightarrow t_{2}\right.$ e $\left.F_{2} \rightarrow F_{3}\right)$

Etapa 4- Execução do reforço até antes da aplicação do $2^{\circ}$ pré-carregamento $\left(t_{2} \rightarrow t_{3}\right.$ e $\left.F_{3} \rightarrow F_{4}\right)$

Etapa 5- Início da aplicação do $2^{\circ}$ pré-carregamento até ancoragem do cabo de protensão $\left(t=t_{3}\right.$ e $\left.F_{4} \rightarrow F_{5} \rightarrow F_{6}\right)$

Etapa 6- Final da aplicação do $2^{\circ}$ pré-carregamento até antes do início do ensaio final $\left(\mathrm{t}_{3} \rightarrow \mathrm{t}_{4}\right.$ e $\left.\mathrm{F}_{6} \rightarrow \mathrm{F}_{7}\right)$

Figura 7.14 - Etapas do ensaio a partir dos gráficos em função do tempo 
Tabela 7.6- Evolução da força vertical aplicada em função do tempo

\begin{tabular}{|c|c|c|c|c|c|}
\hline \multirow{2}{*}{\multicolumn{2}{|c|}{$\begin{array}{l}\text { Esquema de apresentação } \\
\text { dos resultados das vigas }\end{array}$}} & \multicolumn{4}{|c|}{ Valores obtidos a partir das etapas do ensaio de cada viga } \\
\hline & & \multicolumn{2}{|r|}{ VFC-1 } & \multicolumn{2}{|r|}{ VFC-3 } \\
\hline $\mathrm{t}$ (dias) & $F_{v}(k N)$ & $\mathbf{t}$ & $\mathbf{F}_{\mathbf{v}}$ & $\mathbf{t}$ & $\mathbf{F}_{\mathbf{v}}$ \\
\hline $\mathbf{t}_{0}$ & $\mathbf{F}_{\mathbf{0}}$ & 1 & 0 & 1 & 0 \\
\hline $\mathbf{t}_{1}$ & $F_{0} \rightarrow F_{1} \rightarrow F_{2}$ & 7 & $0 \rightarrow 21,6 \rightarrow 19,6$ & 7 & $0 \rightarrow 33,1 \rightarrow 32,0$ \\
\hline $\mathbf{t}_{2}$ & $\mathbf{F}_{3}$ & 40 & $12,6 \rightarrow 13,2$ & 75 & $22,5 \rightarrow 23,3$ \\
\hline$t_{3}$ & $F_{4} \rightarrow F_{5} \rightarrow F_{6}$ & 75 & $11,3 \rightarrow 37,7 \rightarrow 35,1$ & - & - \\
\hline $\mathbf{t}_{4}$ & $\mathbf{F}_{7}$ & 104 & 32,4 & 145 & 20,6 \\
\hline \multicolumn{6}{|l|}{ Obs. } \\
\hline \multicolumn{6}{|c|}{ A força vertical $F_{v}$ atuante na peça foi calculada por: $F_{v}=\operatorname{sen} 18^{\circ} . F_{\text {cabo }}$} \\
\hline \multicolumn{6}{|c|}{$\begin{array}{l}\text { Os gráficos apresentados a seguir e que mostram a relação força } \mathbf{F} \mathbf{X} \text { deslocamento, adotam o valor } \\
\text { da força } F_{v} \text { (eixo y) como sendo aquele referente ao de apenas uma das forças verticais atuantes nos } \\
\text { modelos durante a realização do ensaio intermediário. }\end{array}$} \\
\hline
\end{tabular}

Pela Figura 7.15, que mostra a evolução da força vertical aplicada durante todo o período do ensaio intermediário, percebe-se que esta se reduz com o tempo. Apesar desta redução não ser desejável, este fato já havia sido previsto em função das perdas de protensão do cabo por relaxação e por ancoragem. A força do cabo também se reduzia devido ao aumento da curvatura (aumento dos deslocamentos verticais) da viga por fluência porque isso deixava a cordoalha de protensão mais "frouxa" (menos tensionada).

A força vertical máxima aplicada em ambas vigas foram praticamente iguais (ver linhas pontilhadas vermelhas na Figura 7.15), só que ocorreram em datas diferentes porque na VFC-1 foram aplicados dois pré-carregamentos, enquanto que na VFC-3 foi aplicado apenas um. Como as deformações por fluência são maiores quanto menor a idade da peça em que se aplica o pré-carregamento, a redução da força vertical na VFC-3 foi muito mais acentuada. Por este motivo, a força vertical atuante na VFC-1 foi $36.5 \%$ maior que aquela atuante na VFC-3 no final do ensaio intermediário de longa duração. Além disso, o acompanhamento do comportamento de longa duração da VFC-3 foi feito por 41 dias a mais que o da VFC-1. 


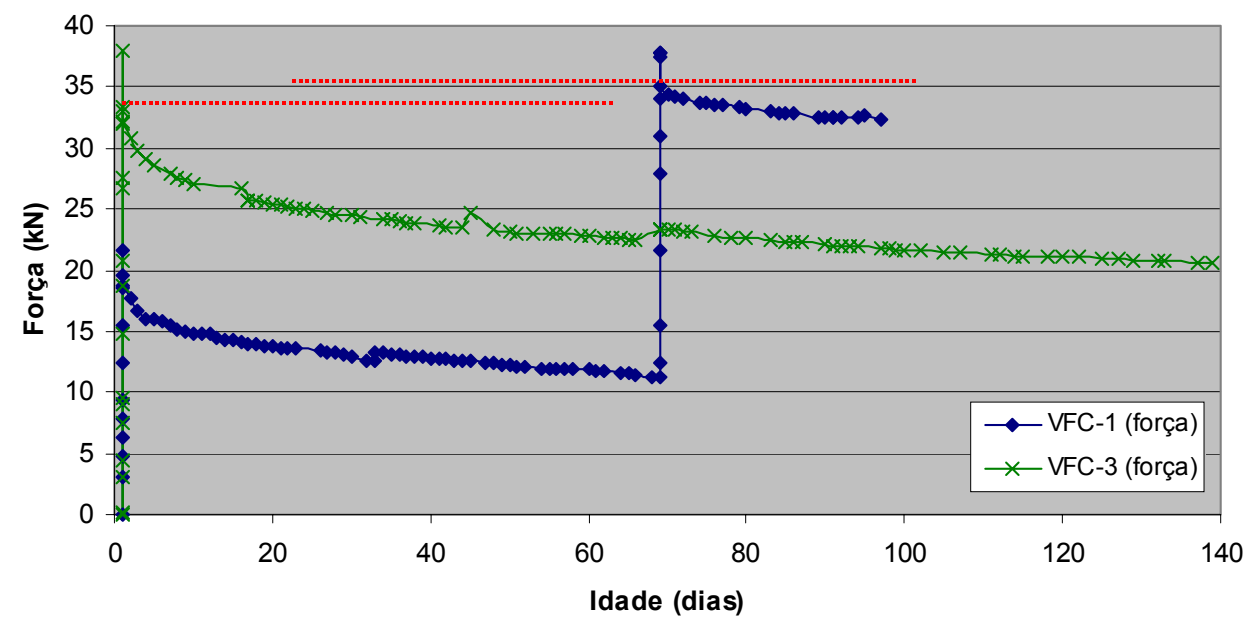

Figura 7.15- Evolução da força vertical nas peças ensaiadas

Mesmo tendo-se ajustado a câmara climatizada para ficar com uma temperatura de $\mathrm{T}=32^{\circ} \mathrm{C} \pm 2^{\circ} \mathrm{C}$ e umidade de $\mathrm{U}=38 \% \pm 4 \%$, nem sempre estes valores foram satisfeitos. Portanto para analisar as deformações dos materiais da viga ao longo do tempo foram observadas as variações ambientais durante todo o período em que os modelos permaneceram armazenados na câmara climatizada.
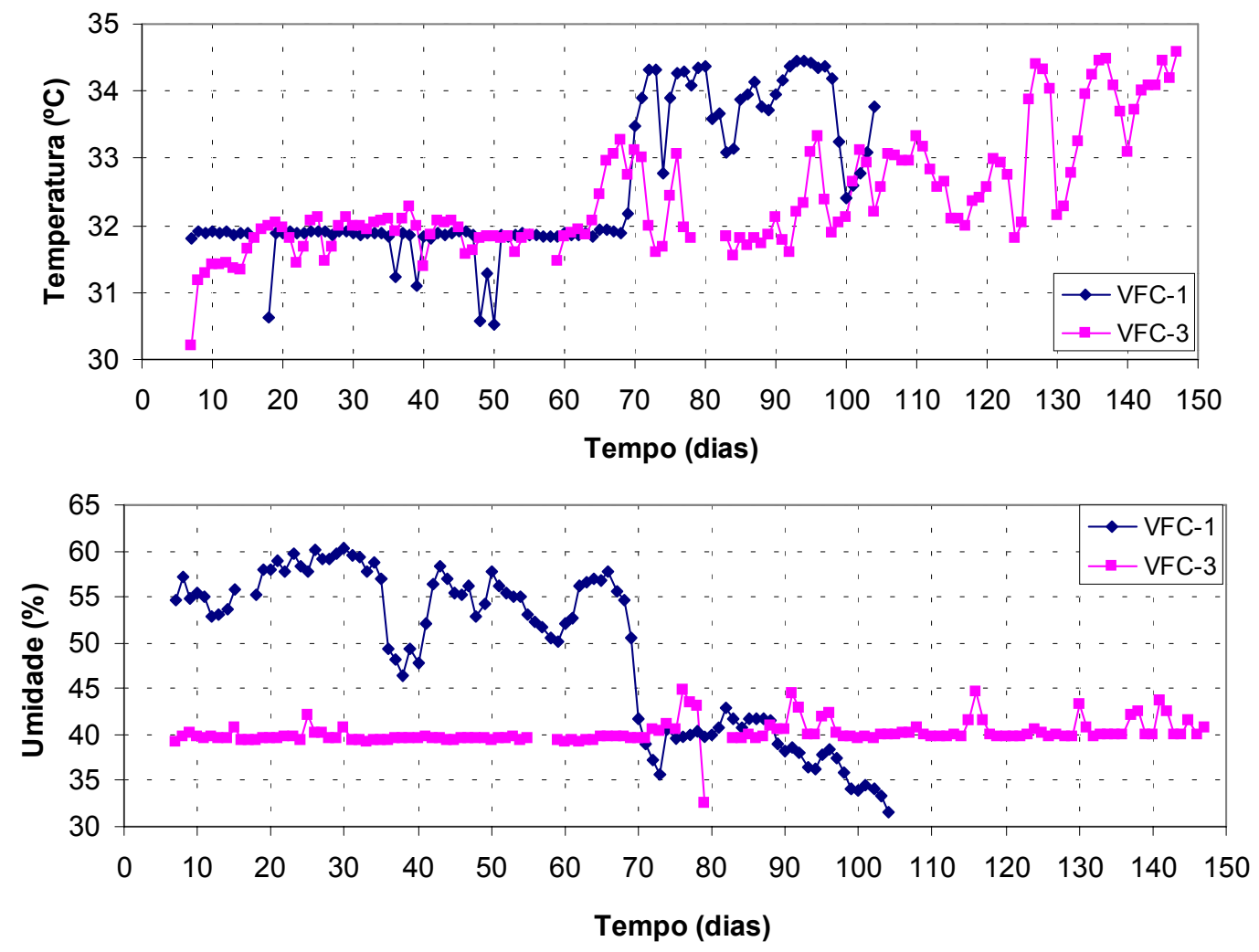

Figura 7.16- Gráficos da umidade e temperatura em função do tempo 
Observando a Figura 7.16 percebeu-se que, apesar da evolução da temperatura durante a realização dos ensaios das vigas apresentarem vários picos, as variações observadas ficaram praticamente dentro dos limites pré-estabelecidos de \pm $2^{\circ}$ C. Por outro lado, houve uma certa dificuldade de manter a umidade dentro dos limites desejados principalmente durante a realização dos ensaios da VFC-1. No ensaio intermediário da VFC-1 houve variações excessivamente altas da umidade que atingiu o valor máximo de $60,4 \%$ e o valor mínimo de $31,5 \%$. Para evitar que isso ocorresse no ensaio da VFC-2, trocou-se o desumidificador por outro mais eficiente.

\subsubsection{Esquema de fissuração}

Durante a aplicação do pré-carregamento por meio de protensão surgiram fissuras de flexão e de cisalhamento nas vigas. Estas permaneceram estabilizadas com o passar do tempo e nem mesmo com a execução do reforço observou-se alterações significativas em suas extensões e aberturas.

A VFC-3 apresentou uma fissuração bem mais significativa porque foi submetida a um pré-carregamento inicial maior que a VFC-1. Entretanto, ao aumentar o pré-carregamento na VFC-1 através da realização da segunda protensão, percebeu-se que a fissuração da VFC-1 ficou mais acentuada que a da VFC-3.

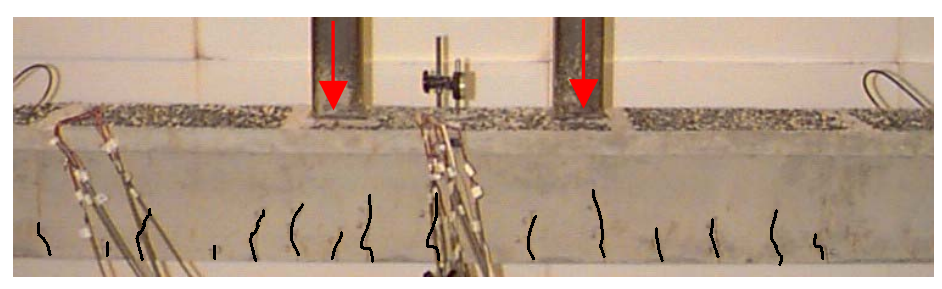

(a) Fissuração na VFC-1 $\left(1^{\circ}\right.$ pré-carregamento $\left.-\mathrm{F}_{\mathrm{v}}=19,6 \mathrm{kN}\right)$

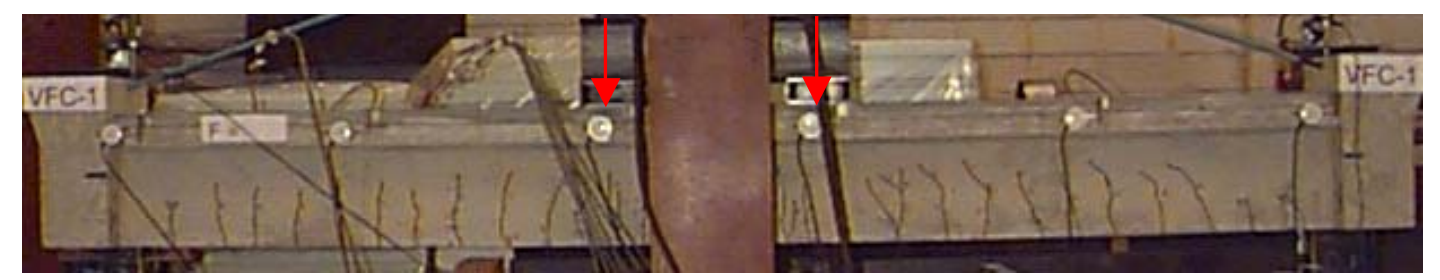

(b) Fissuração na VFC-1 ( $2^{\circ}$ pré-carregamento $\left.-\mathrm{F}_{\mathrm{v}}=35,1 \mathrm{kN}\right)$ 
Figura 7.17 - Esquema de fissuração durante o pré-carregamento da VFC-1

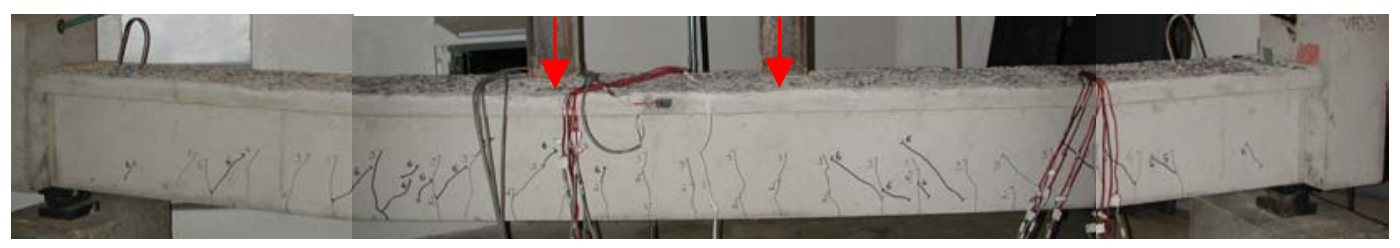

Fissuração na VFC-3 $\left(1^{\circ}\right.$ pré-carregamento $\left.-\mathrm{F}_{\mathrm{v}}=31,9 \mathrm{kN}\right)$

Figura 7.18 - Esquema de fissuração durante o pré-carregamento da VFC-3

\subsubsection{Deslocamentos verticais (flechas)}

Os deslocamentos verticais experimentais foram comparados tanto com os teóricos previstos analiticamente através das recomendações das normas brasileiras NBR-6118 (1978) e NBR-6118 (2003) quanto com os previstos numericamente por meio da simulação numérica realizada pelo programa CONSNOU.

As flechas teóricas imediatas, $\delta_{\text {imediata, foram avaliadas usando a formulação }}$ da Teoria das Estruturas (ver equação 3.75) e as flechas teóricas diferidas, $\delta_{\text {diferidas, }}$ foram avaliadas a partir das recomendações da norma NBR-6118 (1978) (ver equações 3.77 e 3.78) e da norma NBR-6118 (2003) (ver equações 3.79 a 3.83).

Como as vigas VFC estavam submetidas à flexão composta (flexocompressão de grande excentricidade) e a equação 3.75 é utilizada para avaliar as flechas de peças sujeitas à flexão simples, para estimar as flechas imediatas por esta equação foi necessário adotar uma força $\mathrm{F}$ equivalente que gerasse um momento fletor no meio do vão das vigas VFC igual ao provocado pela aplicação da força vertical e da força normal excêntrica em relação ao centro de gravidade do elemento estrutural. Portanto, a força $\mathrm{F}$ não correspondia efetivamente à força vertical aplicada nas vigas analisadas. Para a viga VFC-1 foram determinadas duas flechas imediatas em função dos dois pré-carregamentos aplicados em instantes distintos. Já para a VFC-3 foi determinada apenas uma flecha imediata.

Tanto para a NBR-6118 (1978) quanto para a NBR-6118 (2003) as flechas diferidas foram avaliadas multiplicando-se a flecha imediata por um determinado coeficiente $\gamma$. Para a NBR-6118 (1978) este coeficiente é determinado pela expressão (3.78) sendo $\gamma=\beta$. Já para a NBR-6118 (2003) o coeficiente $\gamma$ é determinado pela 
expressão (3.80) sendo $\gamma=\left(1+\alpha_{f}\right)$. Para obter o valor da flecha total em cada etapa analisada utilizou-se a expressão 7.1.

$$
\delta_{\text {total }}=\delta_{i 1} \cdot \gamma_{1}+\delta_{i 2} \cdot \gamma_{2}
$$

onde:

$\delta_{\text {total }}$ : flecha total;

$\delta_{\mathrm{ij}}$ : flecha imediata referente ao pré-carregamento $\mathrm{j}$ sendo $\mathrm{j}=1$ ou 2 ;

$\gamma_{\mathrm{j}}$ : coeficiente de majoração da flecha imediata referente ao pré-carregamento $\mathrm{j}$.

De acordo com a NBR-6118 (1978), para determinar o coeficiente $\gamma$ é necessário conhecer as deformações da fibra mais comprimida do concreto, $\varepsilon_{\mathrm{c}}$, e as deformações da armadura tracionada, $\varepsilon_{\mathrm{s}}$, tanto no instante de aplicação do précarregamento quanto ao longo do tempo. A fim de avaliar se esta expressão realmente era representativa do comportamento das vigas analisadas optou-se por utilizar os valores experimentais das deformações $\varepsilon_{\mathrm{c}}$ e $\varepsilon_{\mathrm{s}}$ coletados durante os ensaios das vigas VFC-1 e VFC-3.

Pelas Figuras 7.19 e 7.20 pode-se comparar as flechas reais e as flechas teóricas para cada uma das vigas ensaiadas em função do tempo. Comparando-se os valores das flechas totais, $\delta_{\text {total}}$, verificou-se que tanto as fornecidas pela simulação numérica quanto as obtidas pelas normas brasileiras foram subestimadas em relação aos valores experimentais. Entretanto como as flechas imediatas teóricas foram menores que as observadas experimentalmente, tentou-se eliminar a influência deste parâmetro na avaliação das flechas traçando-se os gráficos somente das flechas diferidas, $\delta_{\text {diferidas. }}$

Apesar da formulação usada na previsão das flechas diferidas das normas NBR-6118 (1978) e NBR-6118 (2003) serem distintas, estas forneceram valores bastante próximos de flechas teóricas tanto para a VFC-1 quanto para a VFC-3. Apesar de terem sido adotados poucos pontos para análise das flechas diferidas, verificou-se que as curvas finais obtidas tendem a representar o comportamento real das vigas.

Comparando as flechas diferidas experimentais com as obtidas teoricamente observou-se que a diferença entre estes valores foram muito pequenos (da ordem de 1 
$\mathrm{mm}$ ) indicando que tanto a simulação numérica feita pelo programa CONSNOU quanto pelas as normas brasileiras conseguiram avaliar de maneira bastante adequada as flechas diferidas das vigas estudadas. Conclui-se portanto que as flechas totais teóricas foram subestimadas quase que exclusivamente em função da subestimação das flechas imediatas.

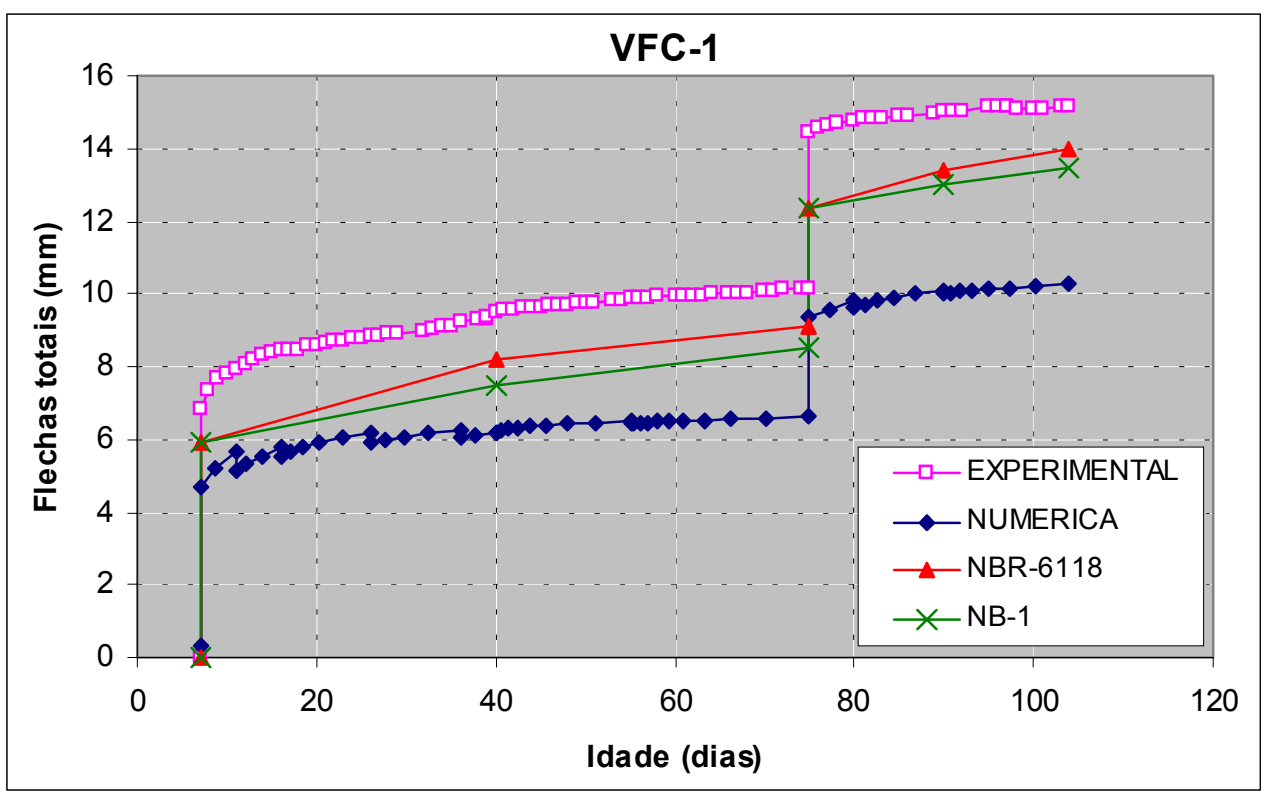

(a) flechas totais

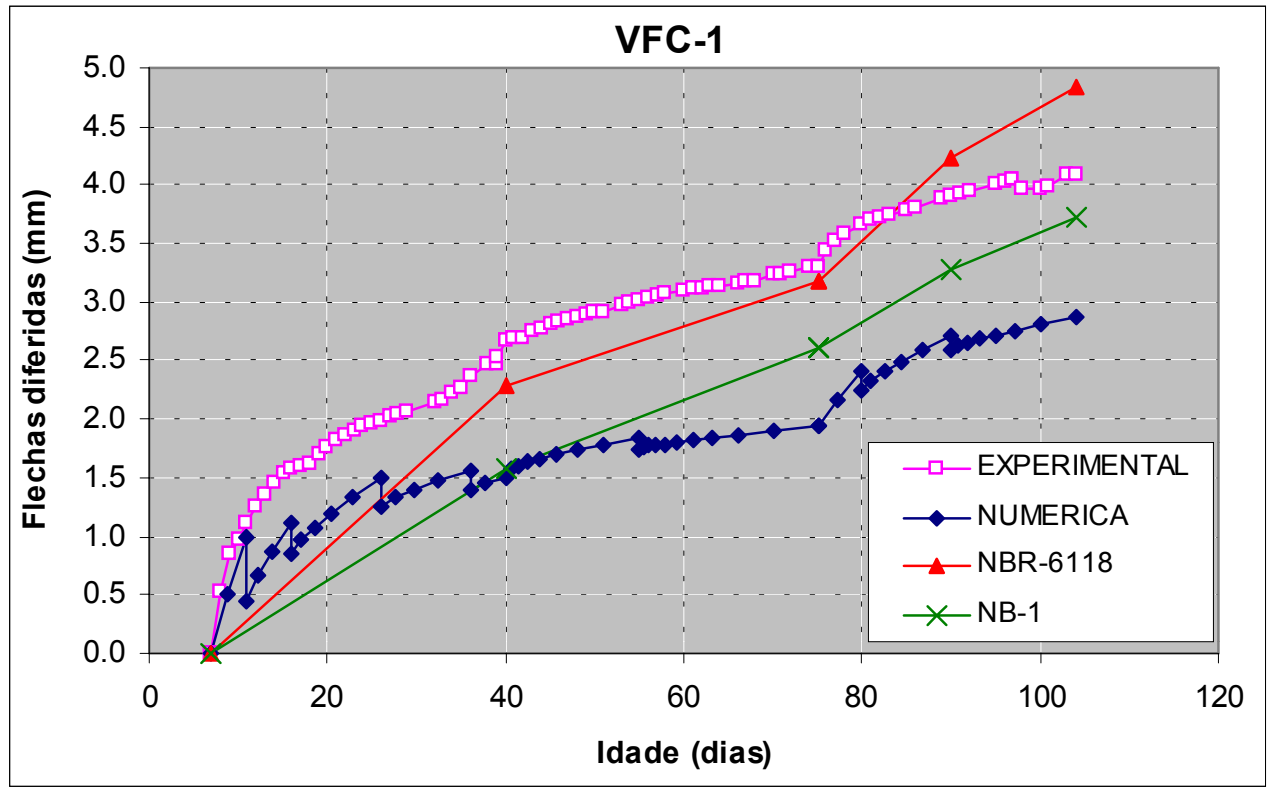

(b) flechas diferidas

Figura 7.19 - Flechas totais e diferidas na viga VFC-1 


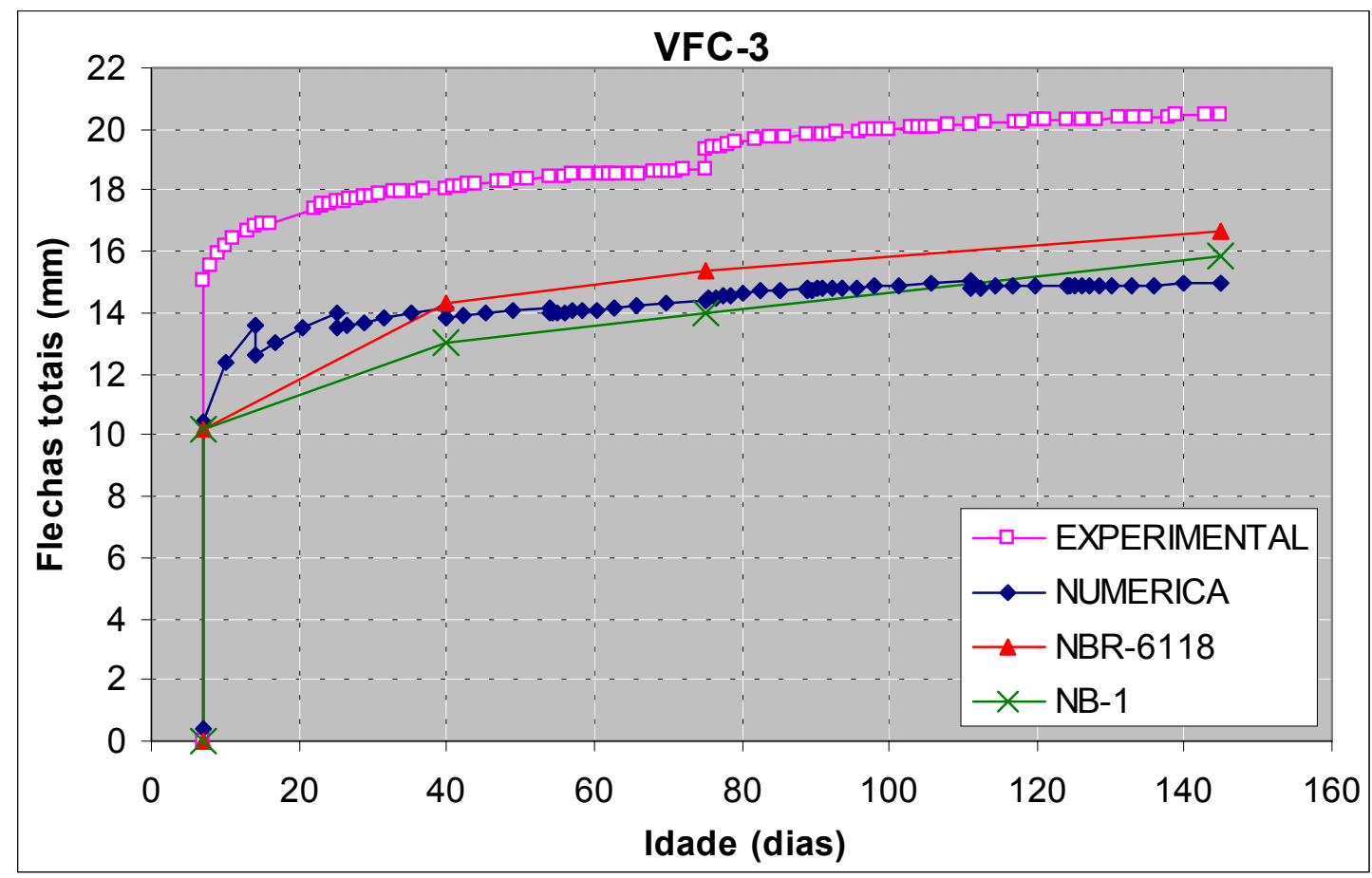

(a) flechas totais

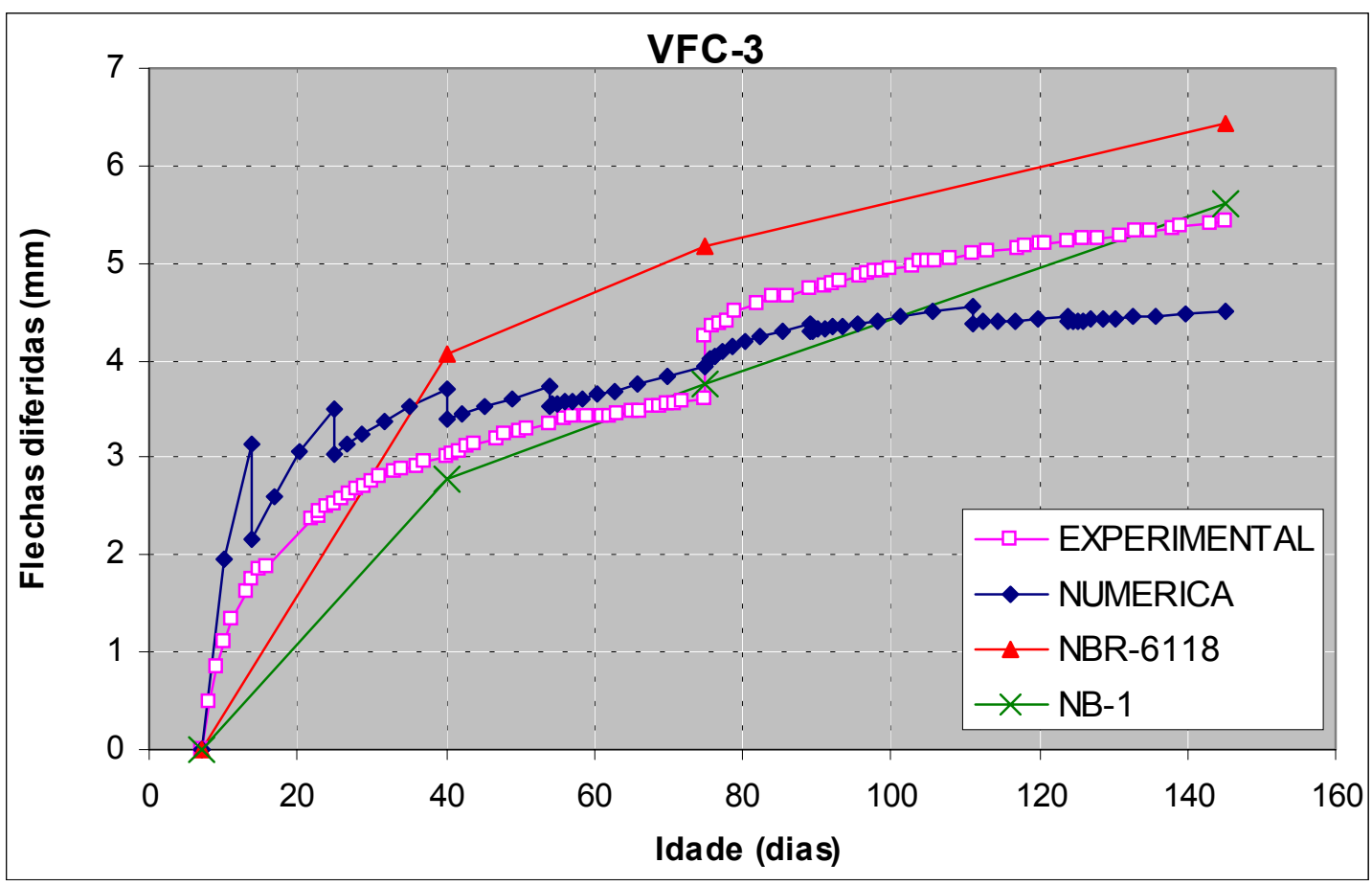

(b) flechas diferidas

Figura 7. 20 - Flechas totais e diferidas na viga VFC-3 
De acordo com alguns estudos realizados, a flecha diferida de elementos fletidos carregados ao longo do tempo pode ser até duas vezes maior que o valor da flecha total observada no instante de aplicação do carregamento. Entretanto, como o acompanhamento das flechas diferidas nos ensaios realizado foi feito por um período de tempo relativamente curto, a porcentagem das flechas diferidas em relação à flecha total foi pequena.

Fazendo uma análise aos 100 dias após a concretagem das vigas, observou-se que para a VFC-1 as flechas diferidas contribuíram com aproximadamente $25 \%$ no valor da flecha total, enquanto que na VFC-3 esta diferença foi de $22 \%$.

Tabela 7.7 - Valores experimentais das flechas totais e diferidas aos 100 dias

\begin{tabular}{|c|c|c|c|}
\hline \hline Vigas & $\begin{array}{c}\delta_{\text {total }} \\
(\mathrm{mm})\end{array}$ & $\begin{array}{c}\delta_{\text {diferida }} \\
(\mathrm{mm})\end{array}$ & $\delta_{\text {diferida }} / \delta_{\text {total }}$ \\
\hline \hline VFC-1 & 15,9 & 3,95 & 0,25 \\
\hline VFC-3 & 20,2 & 4,30 & 0,22 \\
\hline
\end{tabular}

\subsubsection{Deformações no concreto}

Conforme dito anteriormente, a deformação total $\varepsilon_{\mathrm{c}}(\mathrm{t})$ ao longo do tempo de um concreto comprimido (ver equação 3.35) é composta pela soma da deformação imediata, da deformação por fluência, da deformação por retração e da deformação por variação térmica. O valor experimental desta deformação em cada instante de tempo analisado foi obtido pelas leituras dos extensômetros colados ao concreto do substrato e ao microconcreto do reforço e estão apresentados nos gráficos das Figuras 7.23 e 7.24, juntamente com os respectivos valores teóricos.

As deformações totais dos concretos do substrato e do reforço foram avaliadas teoricamente de três maneiras distintas utilizando:

a) a simulação numérica feita através do programa CONSNOU;

b) as expressões matemáticas ajustadas às curvas experimentais (ver item 6.3.1),

c) as recomendações da norma NBR-6118 $(2003)^{*}$, que não foram apresentadas neste texto por serem bastante conhecidas do meio técnico.

\footnotetext{
* Recomendações iguais à da norma NBR-7197: "Projeto de Estruturas de Concreto Protendido".
} 
Antes de calcular a deformação $\varepsilon_{\mathrm{c}}(\mathrm{t})$ usando os ajustes das curvas experimentais ou as recomendações da NBR-6118 (2003) era preciso determinar o valor da deformação dependente da tensão $\left(\varepsilon_{\mathrm{c} \sigma}\right)$. Para obter esse valor era preciso multiplicar a curva da função fluência $J\left(t, t_{0}\right)$ pela tensão $\sigma_{c}$ atuante na fibra de concreto comprimido no instante $\mathrm{t}$ analisado, ou seja, $\varepsilon_{\mathrm{c} \sigma}=\sigma_{\mathrm{c}}\left(\mathrm{t}_{0}\right) \cdot \mathrm{J}\left(\mathrm{t}, \mathrm{t}_{0}\right)$.

Devido ao tipo de esquema de aplicação de força utilizado nas vigas VFC não foi possível manter constante o carregamento aplicado nas vigas ao longo do tempo. Conseqüentemente, com a diminuição do carregamento reduzia-se também os valores das tensões $\sigma_{\mathrm{c}}$ atuantes nas vigas. De qualquer maneira, a tensão $\sigma_{\mathrm{c}}$ do concreto variava não só por causa da redução do carregamento externo atuante nas vigas VFC, mas também em função dos efeitos da fluência e da retração desse material.

GHALI \& FAVRE (1986) apresentaram uma formulação algébrica simplificada que permitia avaliar as tensões e deformações diferidas de peças fissuradas em serviço submetidas à flexão normal ou composta (ver item 3.4.3.2) quando submetidas a um carregamento constante ao longo do tempo. Entretanto, ao tentar adaptar este método à situação real observada nas vigas VFC (caso de carregamento variável), percebeu-se que este método se tornava extremamente inviável devido à grande quantidade de cálculos necessários, a não ser que se implementasse um programa computacional usando esta formulação. Como neste trabalho não se tinha a pretensão de desenvolver nenhum programa computacional, buscou-se uma outra forma de avaliar as tensões aplicadas nas vigas em função do tempo. A alternativa encontrada foi calcular a deformação $\varepsilon_{\mathrm{c} \sigma}$ utilizando as tensões teóricas fornecidas pela simulação numérica feita usando o programa CONSNOU.

As Figuras 7.21 e 7.22 mostram a evolução das tensões e deformações teóricas dos materiais cimentícios obtidas pela simulação numérica indicando claramente que, conforme descrito no item 3.4.3, apesar das tensões se reduzirem com o tempo, a deformação permanece aumentando em função das propriedades reológicas dos concretos. 
O cálculo das deformações do substrato e do reforço utilizando as expressões matemáticas apresentadas no Capítulo 6 ou as recomendações da NBR-6118 (2003) foi feito somente para algumas idades (p.ex. idade de 7 dias, 40 dias, 75 dias e assim por diante conforme observado nas Figuras 7.23 e 7.24). Logo, para determinar as deformações dependentes das tensões $\left(\varepsilon_{\mathrm{c} \sigma}\right)$, foi preciso dividir o gráfico das tensões fornecidas pelo programa CONSNOU em um certo número de intervalos $i$ admitindo-se constante o valor da tensão entre os intervalos $i-1$ e $i$. Determinado os valores das tensões para cada intervalo de tempo em função do carregamento real atuante e dos efeitos viscoelásticos ocorridos no instante anterior, determinou-se a variação das tensões como sendo $\Delta \sigma\left(\tau_{\mathrm{k}}\right)=\sigma_{\mathrm{c}}\left(\mathrm{t}_{\mathrm{k}}\right)-\sigma_{\mathrm{c}}\left(\mathrm{t}_{\mathrm{k}-1}\right)$. A partir daí calculava-se as deformações $\varepsilon_{\mathrm{c} \sigma}$ admitindo-se o princípio da superposição de efeitos usando a equação 3.43 e adotando-se nesta equação as expressões da função fluência $J\left(t, \tau_{i}\right)$ determinadas através de cada um dos métodos teóricos usados.

Pelos gráficos das Figuras 7.23 e 7.24, pode-se comparar os resultados oferecidos pelas análises teóricas com os resultados experimentais. Por estes gráficos percebeu-se que apesar do pré-carregamento reduzir com o tempo, há um aumento das deformações do concreto comprimido provocado principalmente pela fluência e pela retração desses materiais. Este acréscimo de deformação conseguiu ser avaliado teoricamente de maneira bastante satisfatória através do programa CONSNOU para ambas as vigas, pois as curvas experimentais e numéricas foram praticamente coincidentes. A única exceção ocorreu em relação à deformação do microconcreto da VFC-1 após a aplicação do segundo pré-carregamento, mesmo assim a diferença observada foi pequena, ficando na ordem de 300 micro-strains apenas.

Os demais métodos teóricos usados na avaliação da deformação do concreto ao longo do tempo, apesar de não fornecerem resultados tão próximos dos reais quanto os obtidos pela simulação numérica, principalmente em função da pouca quantidade de pontos analisados, também podem ser considerados adequados. Podese afirmar portanto que tais procedimentos podem ser usados na avaliação da deformabilidade do concreto do bordo comprimido de vigas reabilitadas ao longo do 
tempo. Esta estimativa ficou um pouco prejudicada para o material do reforço talvez por não se levar em consideração a restrição da deformação por retração gerada pela aderência entre este material e o substrato.

As deformações experimentais do substrato da VFC-1 foram menores do que os da VFC-3 por causa da diferença do valor do pré-carregamento aplicado e também pelo fato da VFC-1 já estar reforçada durante a aplicação do $2^{\circ}$ pré-carregamento. Sendo assim, o material do reforço resistiu a uma parcela do pré-carregamento evitando que a deformação do substrato na VFC-1 fosse tão acentuada quanto na VFC-3.

Nos resultados experimentais da VFC-3 percebeu-se que houve uma ligeira redução das deformações do substrato da VFC-3 logo após a execução do reforço (idade $=75$ dias). Isso contrariou as expectativas, já que se acreditava que haveria um aumento das deformações do substrato em função do aumento do carregamento da viga devido ao peso próprio do reforço. Por outro lado, o processo de moldagem e cura do microconcreto do reforço aumenta a umidade superficial do material do substrato, fazendo com que ele sofra algum tipo de expansão e conseqüentemente causado a redução das deformações deste material ao invés do seu aumento.

Para avaliar a deformação da viga ao longo de sua seção transversal admitiuse, com base na compatibilidade de deformações, que as deformações da armadura comprimida seriam iguais à deformação do concreto em torno dela, e que as deformações da fibra mais comprimida do substrato seria igual à deformação do microconcreto do reforço aderia a ela. A partir daí, traçou-se os gráficos da Figura 7.25 , verificando-se que, ao contrário do que se esperava, as deformações da fibra do concreto do substrato mais comprimido ${ }^{\dagger}$ de ambas as vigas foram menores que as deformações em torno da armadura comprimida. Por estes gráficos, observou-se ainda que o início da participação do reforço na seção resistente da estrutura se deu basicamente devido ao aumento do carregamento aplicado, e que as deformações existentes neste material antes do aumento do pré-carregamento ocorreram basicamente em função de sua retração.

\footnotetext{
${ }^{\dagger}$ Fibra corresponde à face superior da viga antes da execução do reforço.
} 
Como a retração do material do reforço é parcialmente restringida pela aderência entre este material e o substrato, a deformação da fibra superior do reforço tende a ser menor que aquela que ocorreria se não houvesse tal restrição. Isso justificaria os resultados superestimados da deformação teórica obtidos usando a formulação paramétrica e as recomendações da NBR-6118 (2003), uma vez que tais formulações não consideram essa restrição.
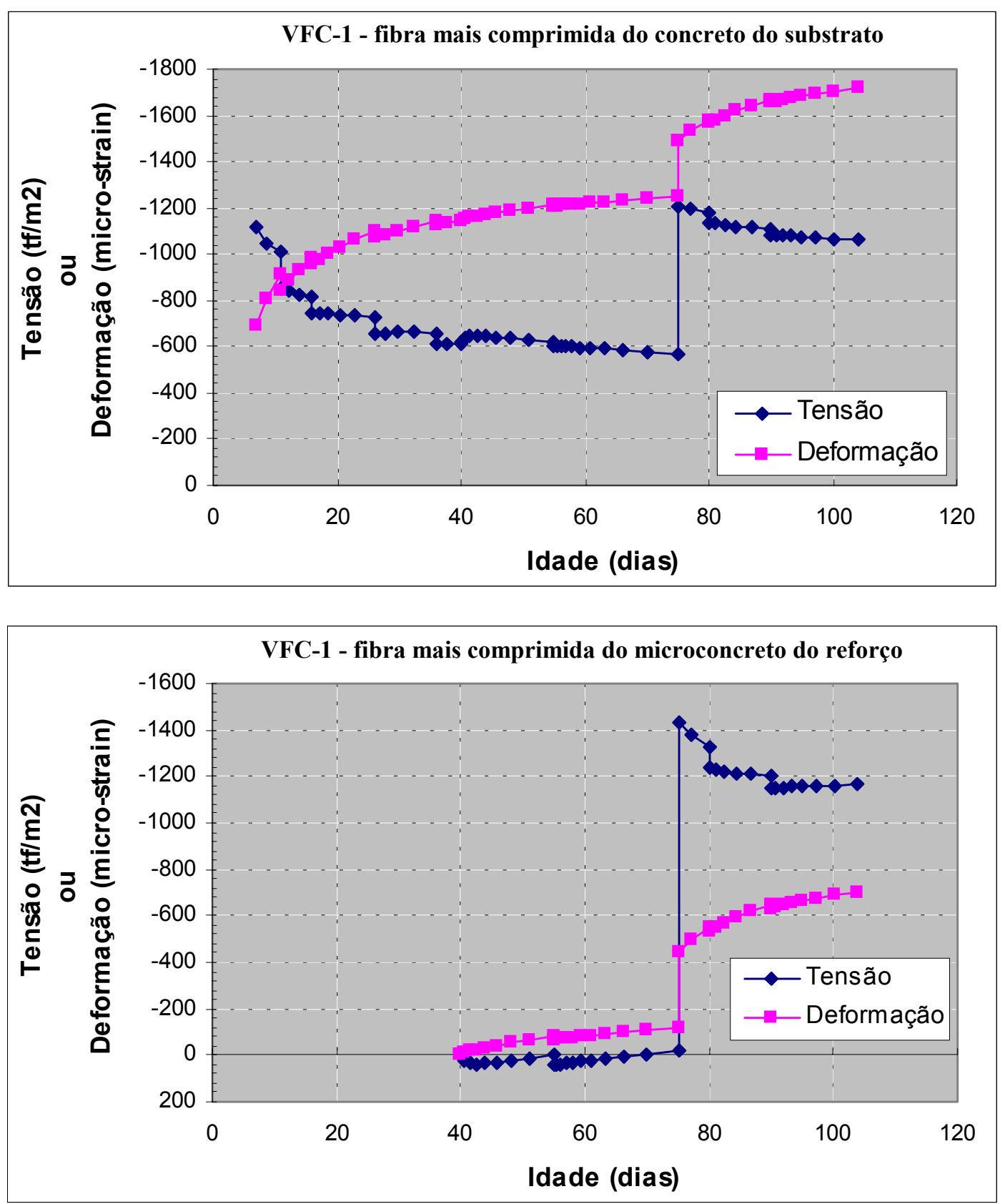

Figura 7.21 -Tensões e deformações teóricas obtidas pelo CONSNOU na VFC-1 

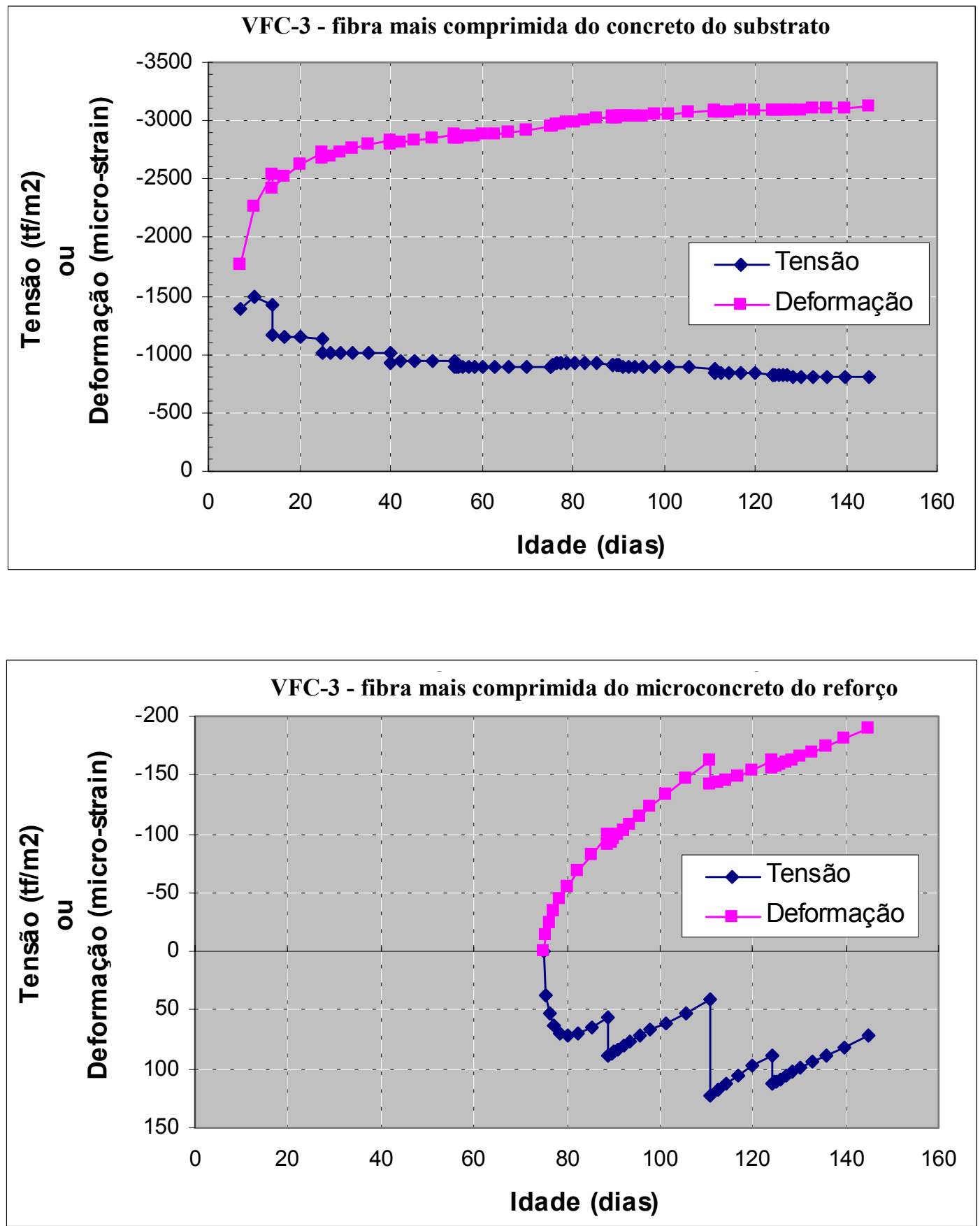

Figura 7.22- Tensões e deformações teóricas obtidas pelo CONSNOU na VFC-3 


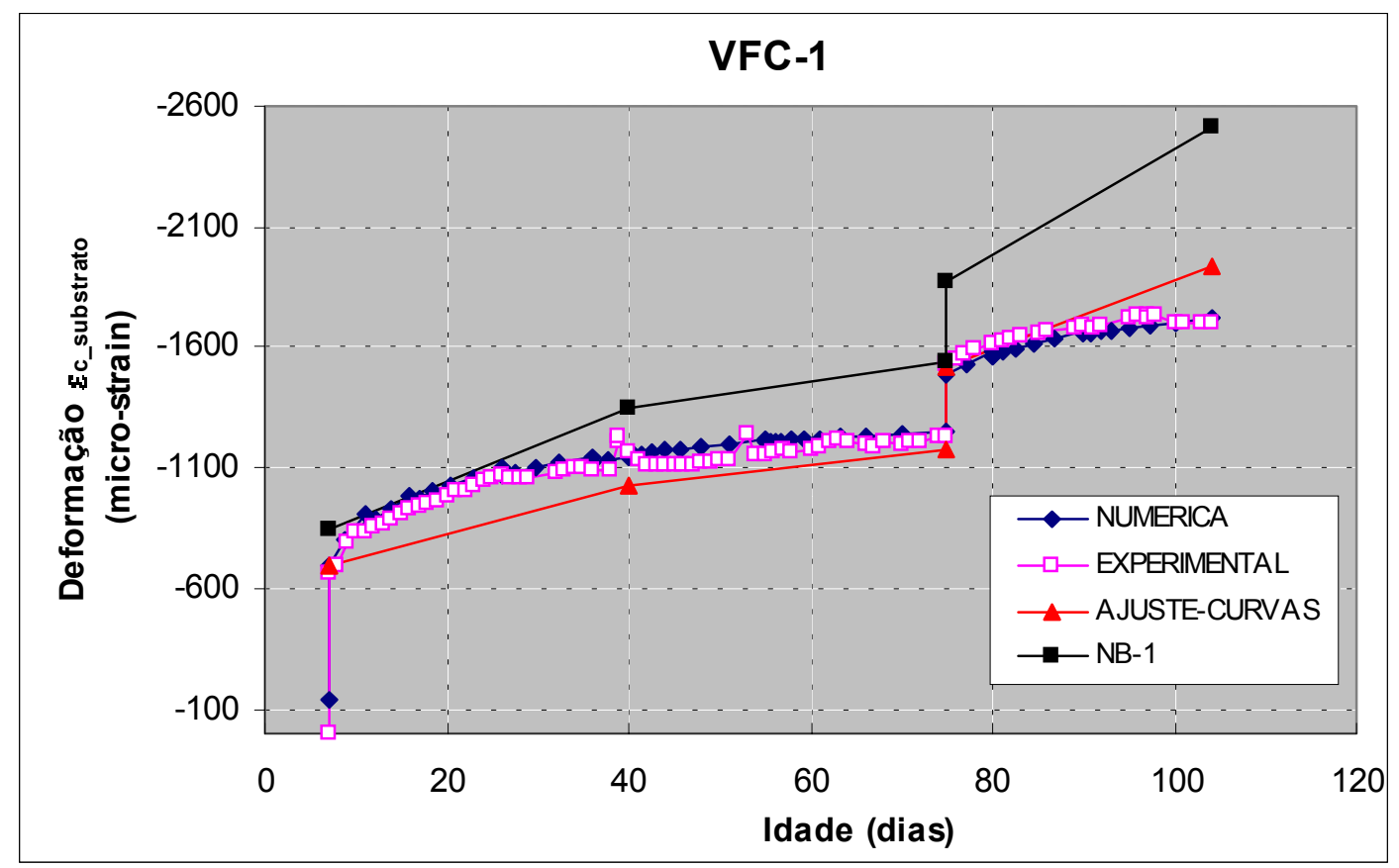

(a) substrato

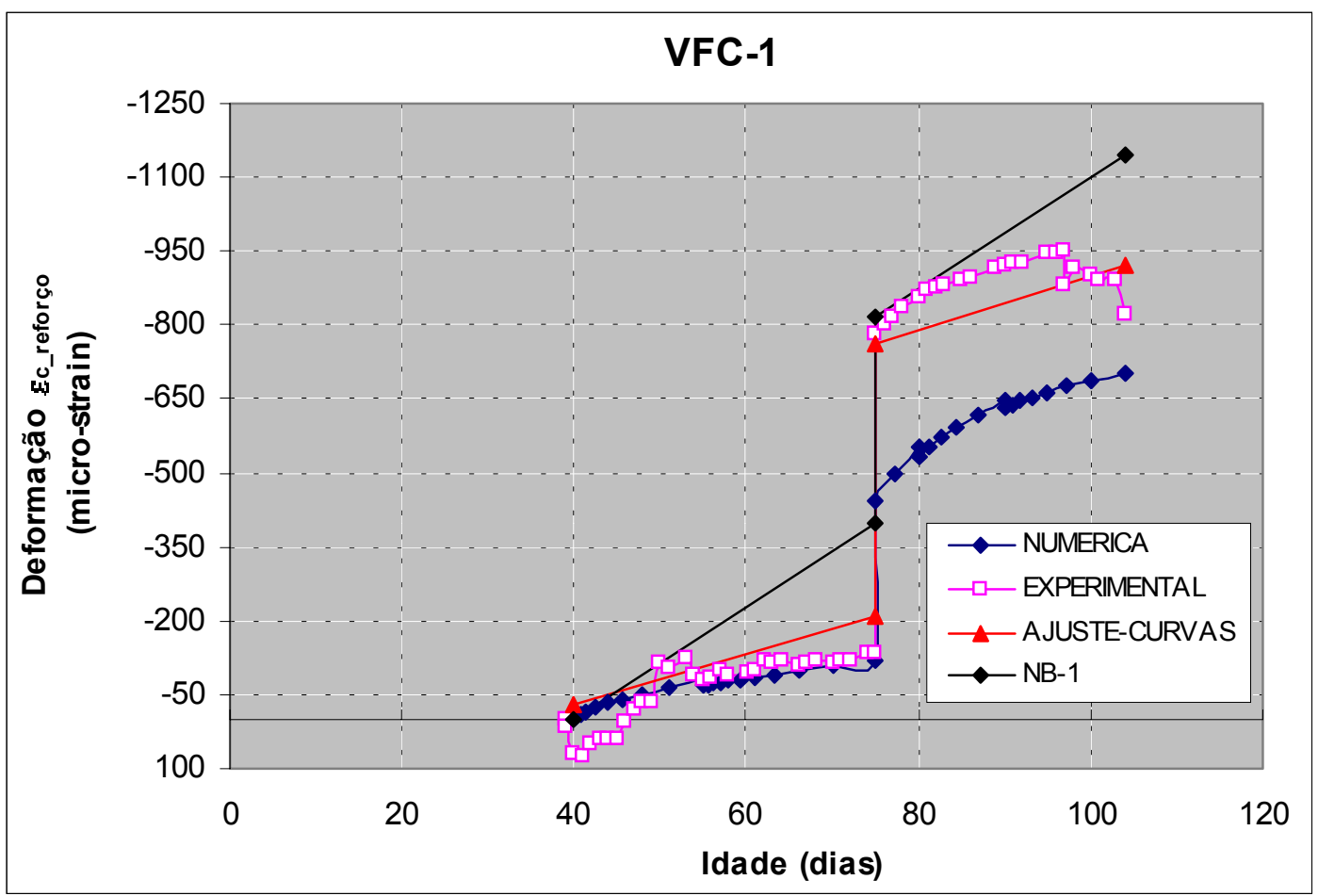

(b) reforço

Figura 7.23- Evolução das deformações na fibra mais comprimida do concreto e microconcreto da VFC-1 


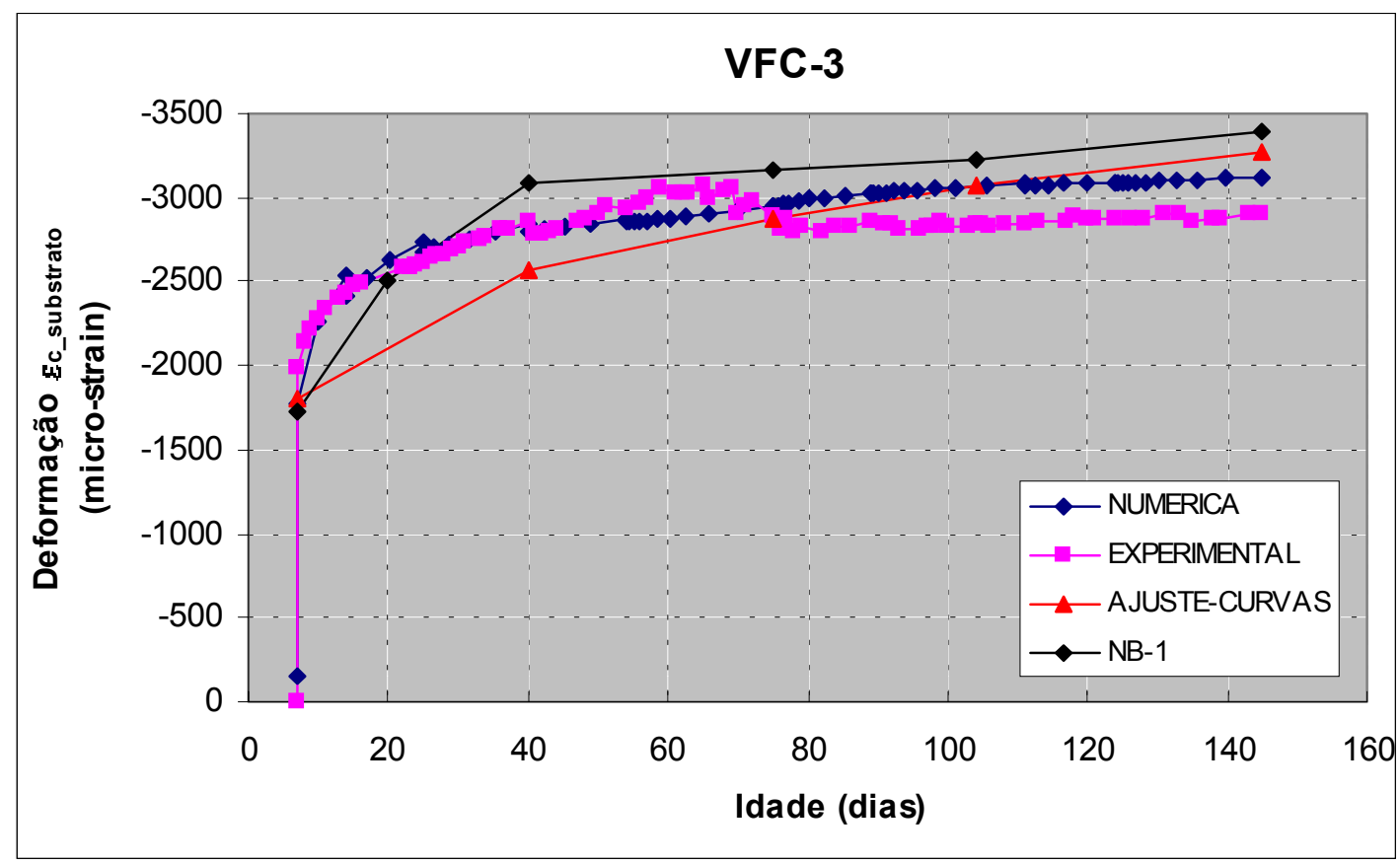

(a) substrato

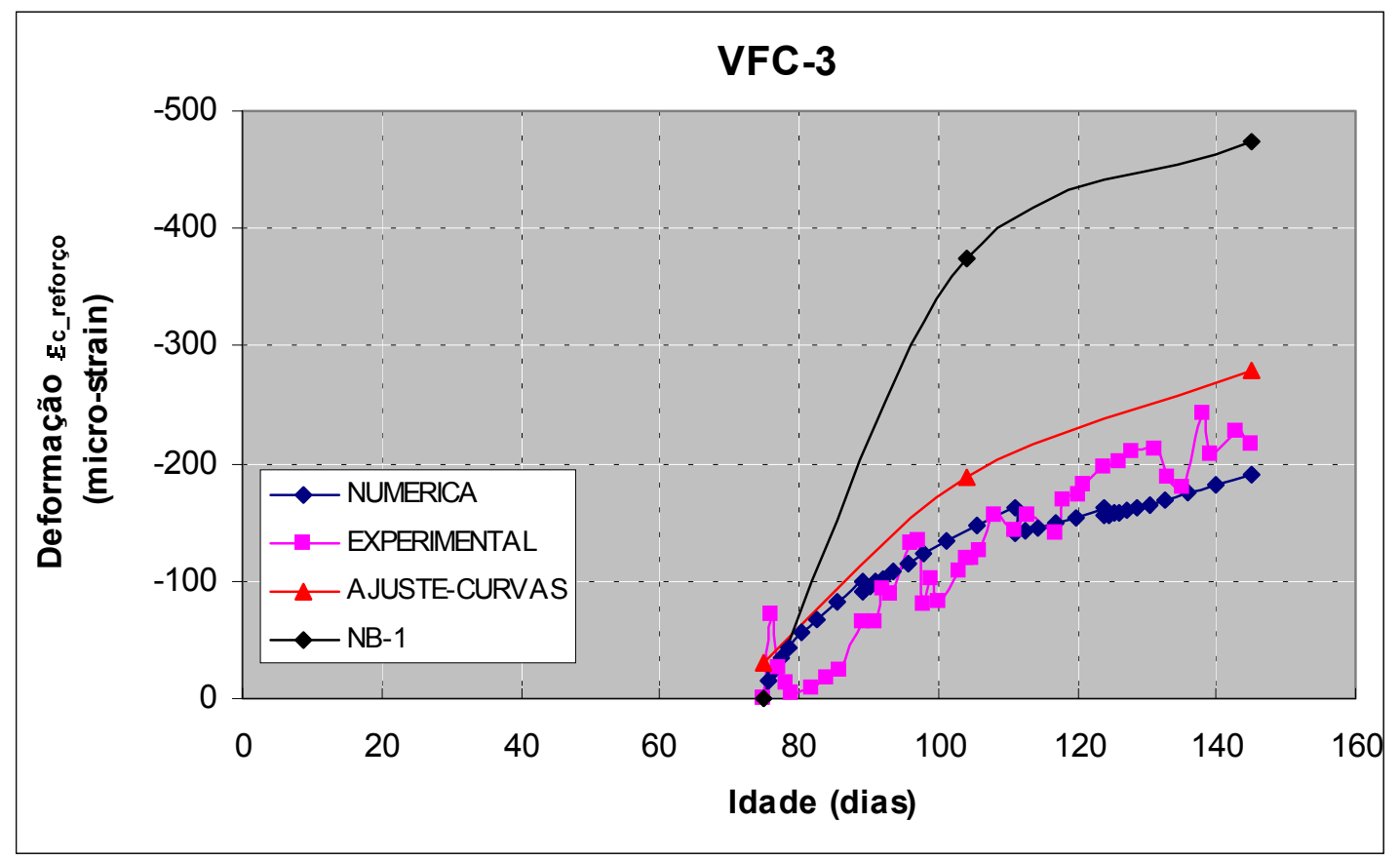

(b) reforço

Figura 7.24-Evolução das deformações na fibra mais comprimida do concreto e microconcreto da VFC-3 

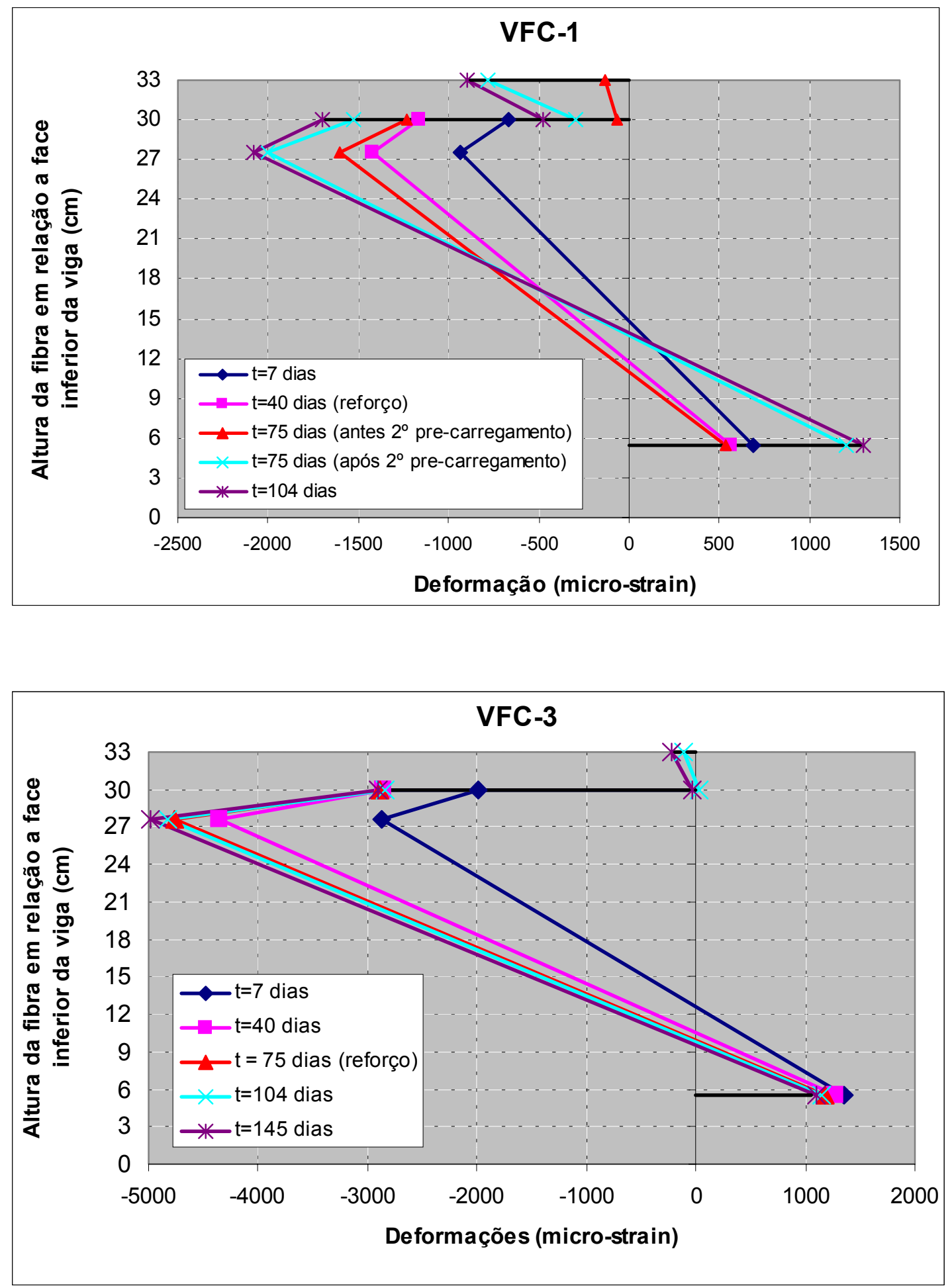

Figura 7.25-Evolução das deformações experimentais ao longo da seção transversal do elemento no meio do vão 


\subsubsection{Deformações da armadura comprimida $\left(A_{s l}{ }^{\prime}\right)$}

O aumento das deformações ao longo do tempo da armadura comprimida da VFC-3 foi mais acentuado que a da VFC-1, por ter sido ela submetida a um précarregamento inicial maior. Convém relembrar também que na VFC-1 o $2^{\circ}$ précarregamento (etapa 5 da Figura 7.14) foi aplicado após 35 dias da execução do reforço, ou seja, o reforço já estava contribuindo na resistência da viga durante esta etapa, ao contrário da VFC-3, na qual o valor máximo do pré-carregamento foi aplicado antes da execução do reforço, portanto as seções resistentes das vigas eram diferentes.

A Figura 7.26 indicou que apesar do valor do pré-carregamento atuante reduzir ao longo do tempo (ver Figura 7.15), foi possível observar o aumento das deformações da armadura comprimida devido à fluência do concreto comprimido que a envolve.

Tais deformações foram comparadas com os valores teóricos fornecidos pela simulação numérica realizada pelo programa CONSNOU, indicando que os valores experimentais foram maiores que os teóricos. Entretanto, as configurações das curvas experimentais e simuladas foram semelhantes e a diferença relativa entre tais curvas permaneceu praticamente constante ao longo do tempo, sugerindo que a diferença entre os valores reais e os teóricos se deu em função da estimativa da deformação imediata abaixo do valor experimental, tal como ocorreu na análise das flechas. Todavia, é importante dizer que nas vigas ensaiadas a hipótese de que as seções planas permanecem planas não foi satisfeita, pois as deformações da armadura comprimida foram maiores que as do concreto do substrato situado no topo (ver Figura 7.25), e que o programa CONSNOU admitia esta hipótese na avaliação do comportamento das vigas. 

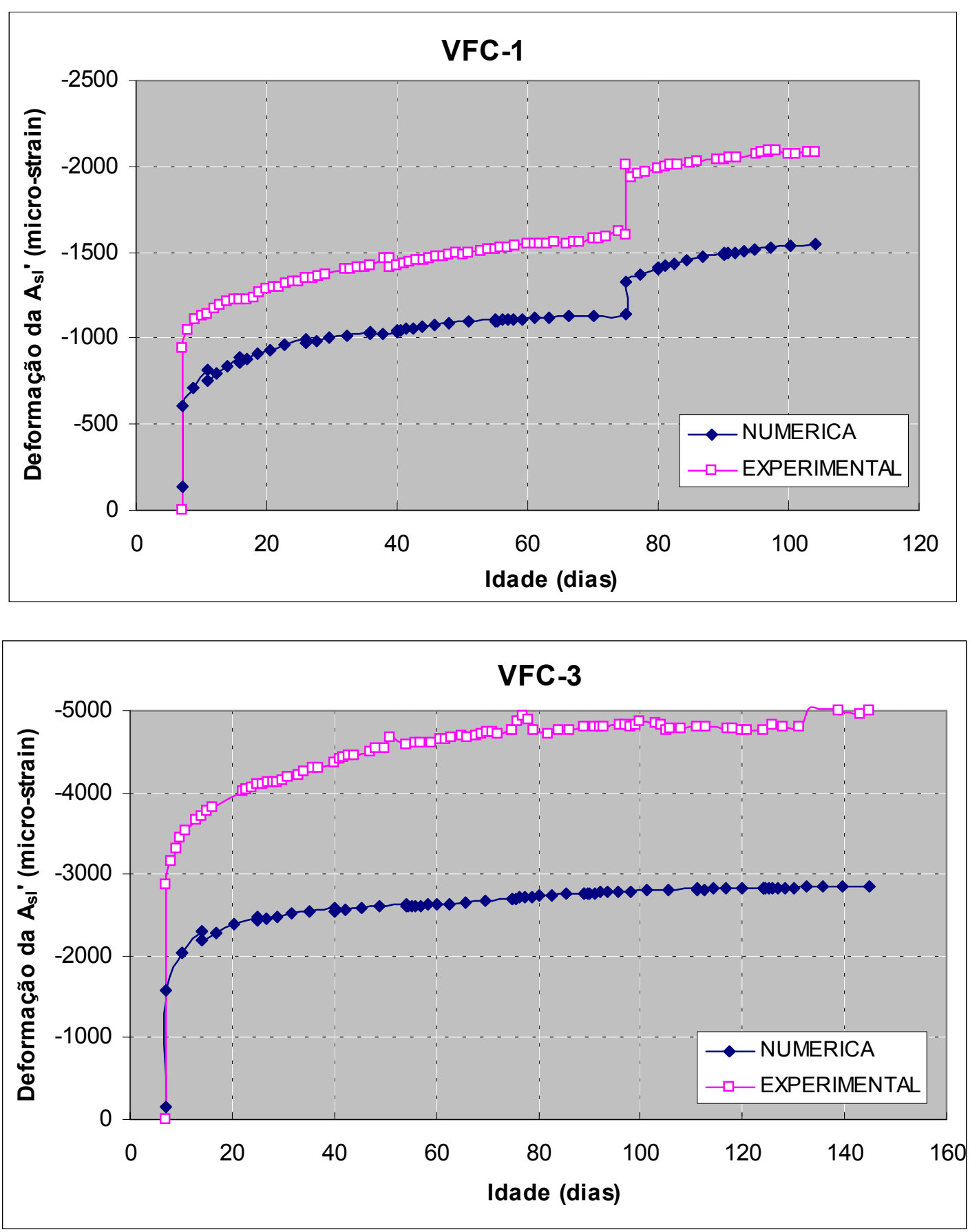

Figura 7.26 - Evolução da deformação das armaduras comprimidas

\subsubsection{Deformações da armadura tracionada $\left(\mathrm{A}_{\mathrm{sl}}\right)$}

Pela Figura 7.27 percebe-se que há uma tendência de redução das deformações das armaduras longitudinais tracionadas com o tempo por causa da redução gradual da força vertical aplicada nas vigas. Caso não houvesse esta 
redução, provavelmente a deformação nesta armadura seria praticamente constante ao longo do tempo. Este comportamento está coerente com a hipótese apresentada no item 3.4.3.1.
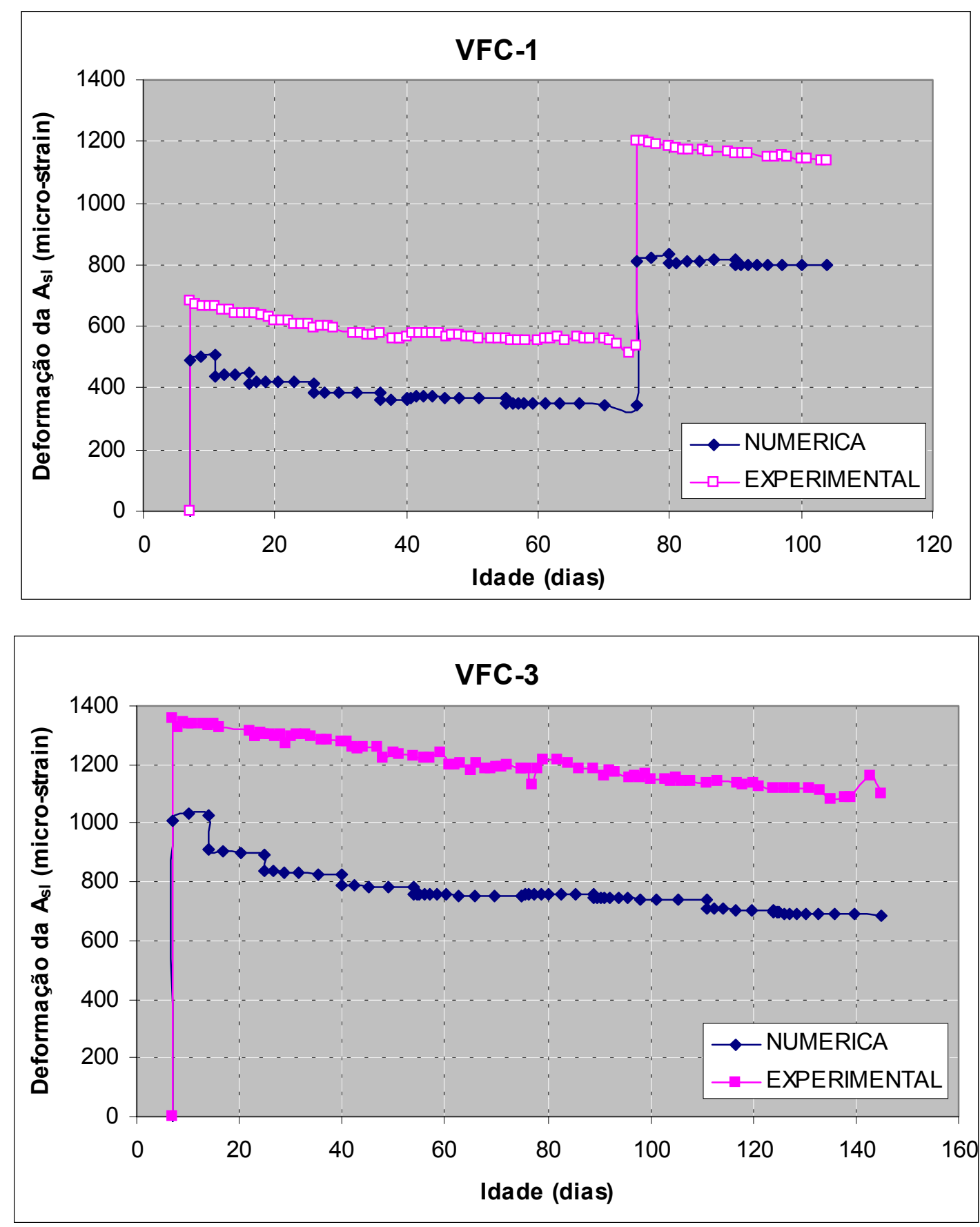

Figura 7.27 - Deformação da armadura longitudinal tracionada (meio do vão) 
A Figura 7.27 indica que as deformações experimentais da armadura tracionada foram maiores que as teóricas determinadas numericamente pelo programa CONSNOU. Entretanto, tal como ocorreu na análise das flechas e na análise das deformações da armadura comprimida, a configuração das curvas experimentais e simuladas da armadura tracionada foram semelhantes, sugerindo novamente que a diferença entre os valores reais e estimados ocorreu em função da estimativa da deformação imediata abaixo do valor experimental.

Comparando as deformações experimentais da VFC-1 com as da VFC-3 no último dia do ensaio intermediário percebe-se que ambas apresentaram valores de deformação em torno de $\varepsilon_{\mathrm{Asl}} \cong 1100$ micro-strain, ou seja, no início do ensaio final ambas as vigas estavam com um mesmo nível de deformação na armadura tracionada apesar das diferenças de pré-carregamento atuante (ver Tabela 7.6).

\subsubsection{Deformações nas armaduras transversais $\left(A_{s w}\right)$}

Como a taxa de armadura transversal das vigas foi superdimensionada para evitar o colapso por cisalhamento, as deformações nos estribos foram praticamente desprezíveis e, portanto não foram apresentadas aqui.

\subsubsection{Ensaio final (carregamento de curta duração)}

As curvas dos gráficos apresentados neste item nem sempre partiram da origem, pois se considerou tanto o valor do pré-carregamento quanto as deformações e os deslocamentos já existentes nas vigas reforçadas antes do início do ensaio de curta duração.

Deve-se relembrar também que a força $\mathrm{F}(\mathrm{kN})$, apresentada nos gráficos das vigas refere-se ao valor de apenas uma das forças verticais aplicadas. Durante a realização do ensaio intermediário esta força correspondia somente à solicitação gerada pela protensão e durante a realização do ensaio final esta força correspondia à solicitação gerada pelos macacos hidráulicos somada à força vertical gerada pela protensão. Ressalta-se que à medida que o carregamento aplicado pelos macacos 
hidráulicos aumentava, a força no cabo protendido diminuía pois este se afrouxava com o aumento das flechas da viga. A Figura 7.28 fornece o valor da força vertical total aplicada nas vigas obtida pela somatória entre as forças aplicadas pelo macaco hidráulico com as forças geradas pelo cabo protendido.

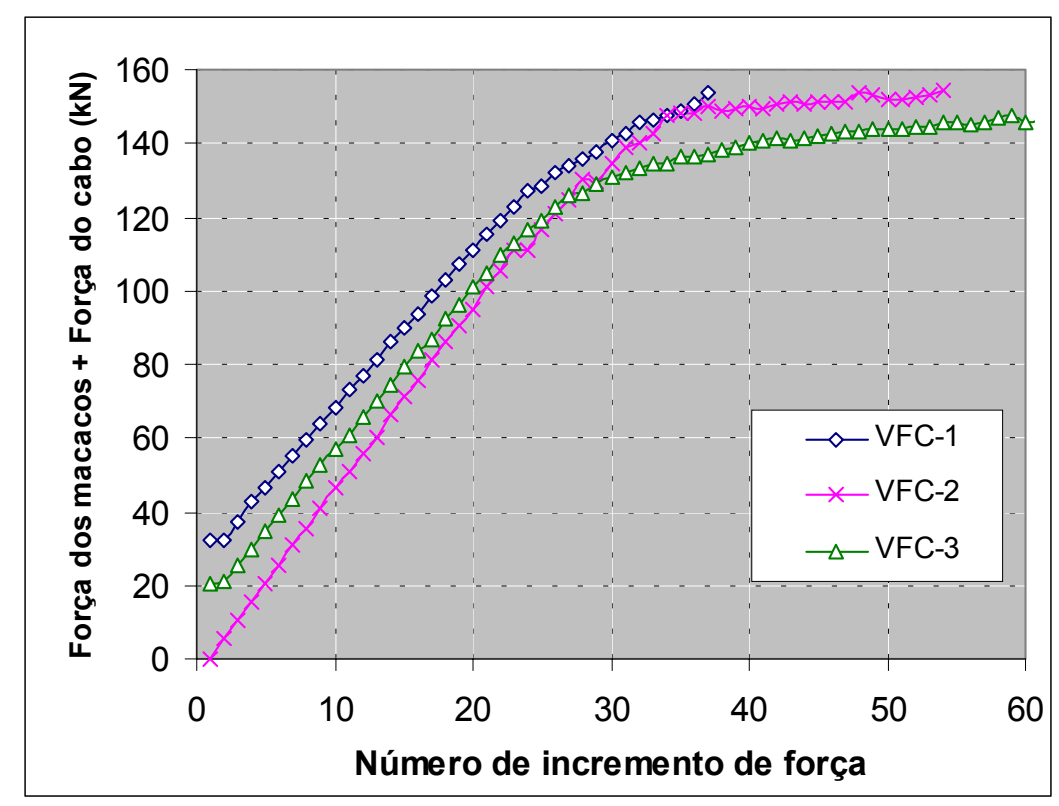

Figura 7.28 - Força vertical total aplicada nos ensaios de curta duração

\subsubsection{Esquema de fissuração, capacidade portante e modo de ruptura}

A configuração de fissuras observada em todos os modelos foi semelhante à de uma viga monolítica, indicando o bom desempenho do reforço, mesmo quando realizado com a peça submetida a um pré-carregamento. Nas vigas VFC-1 e VFC-3, as fissuras de cisalhamento se desenvolveram um pouco mais verticais que as da VFC-2 provavelmente por estarem submetidas a um esforço de compressão gerado pela protensão aplicada durante o ensaio intermediário.

O desempenho satisfatório das vigas reforçadas foi confirmado pelo modo de ruptura, que ocorreu sempre por deformação plástica excessiva da armadura longitudinal tracionada e esmagamento do concreto do reforço comprimido no meio do vão (ruptura no domínio 3). Instantes antes do esmagamento do concreto do reforço observou-se o aparecimento de fissuras horizontais na junta de ligação entre o 
substrato e o reforço indicando uma perda parcial de aderência, mas que não chegou a prejudicar a resistência das vigas. Imediatamente após o esmagamento do concreto do reforço, a fissuração horizontal da junta aumentava, provocando o esmagamento do concreto do substrato.

A capacidade portante teórica e real, a força de serviço de cada viga bem como as relações entre estes valores estão apresentadas na Tabela 7.8. Pelos resultados desta tabela verifica-se que as vigas reforçadas VFC apresentaram uma resistência média 93\% maior que a resistência da viga não reforçada VO. Isso foi conseguido acrescentando-se uma camada de $3 \mathrm{~cm}$ de concreto de alta resistência ao bordo comprimido, indicando que a técnica de reforço realmente é eficiente.

\section{Tabela 7.8- Força de serviço e força de ruptura}

\begin{tabular}{|c|c|c|c|c|c|c|c|}
\hline & $\begin{array}{l}\mathrm{F}_{\text {real }} \\
(\mathrm{kN})\end{array}$ & $\begin{array}{c}\mathrm{F}_{\text {servico }} \\
(\mathrm{kN})\end{array}$ & $\begin{array}{c}F_{\text {térico }} \\
(\mathrm{kN})\end{array}$ & $\mathrm{F}_{\text {real }} / \mathrm{F}_{\text {teórico }}$ & $\mathrm{F}_{\text {real }} / \mathrm{F}_{\text {real-VFC-2 }}$ & $\mathrm{F}_{\text {real }} / \mathrm{F}_{\text {teórico-Vo }}$ & $\begin{array}{c}\text { Modo de } \\
\text { ruptura }\end{array}$ \\
\hline $\mathrm{VO}$ & - & 54,5 & 78,6 & - & - & - & domínio 4 \\
\hline VFC-1 & 153,0 & 90,9 & 146,4 & 1,05 & 0,99 & 1,95 & domínio 3 \\
\hline VFC-2 & 154,4 & 90,9 & 146,4 & 1,05 & 1,00 & 1,96 & domínio 3 \\
\hline \begin{tabular}{|l|} 
VFC-3 \\
\end{tabular} & 147,2 & 90,9 & 146,4 & 1,00 & 0,95 & 1,87 & domínio 3 \\
\hline \multicolumn{8}{|c|}{$\begin{array}{ll}\begin{array}{l}\mathrm{F}_{\text {real }} \\
\mathrm{F}_{\text {serviço }} \text { e } \mathrm{F}_{\text {teórico }}\end{array} & \text { - força real de ruptura observada nos ensaios das vigas; } \\
& \text { da NBR-6118 (1978) utilizando os valores característicos de resistência dos materiais; } \\
\mathrm{F}_{\text {real-VFC-2 }} & \text { - força real de ruptura observada no ensaio da viga VFC-2 (viga sem pré-carregamento); } \\
\mathrm{F}_{\text {térico-Vo }} & \text { - força estimada de ruptura da viga original antes do reforço VO; }\end{array}$} \\
\hline
\end{tabular}

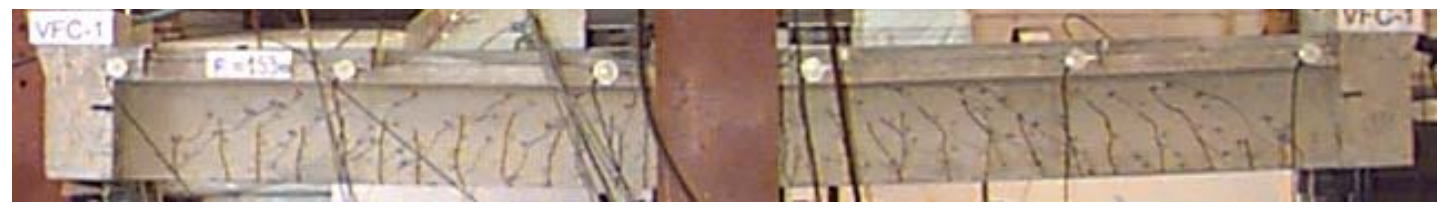

a) VFC-1

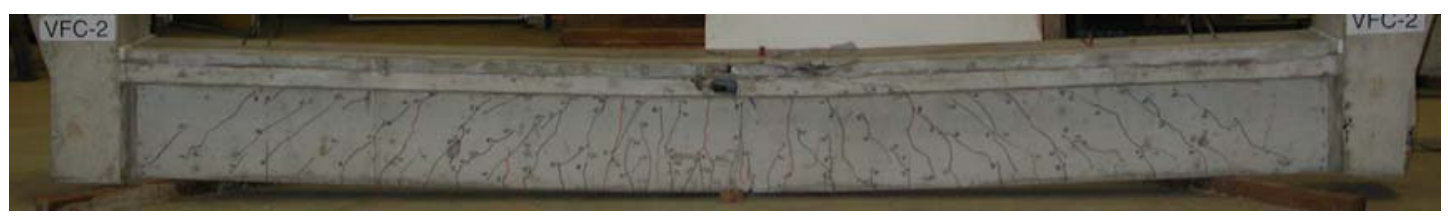

b) VFC-2

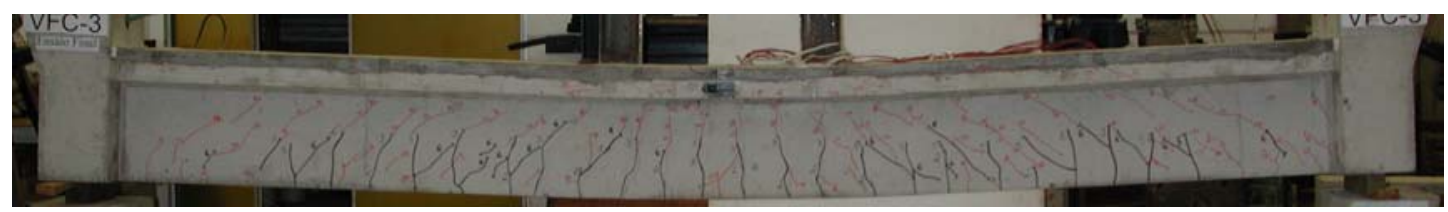

c) VFC-3

Figura 7.29 - Panorama geral de fissuração das vigas VFC 


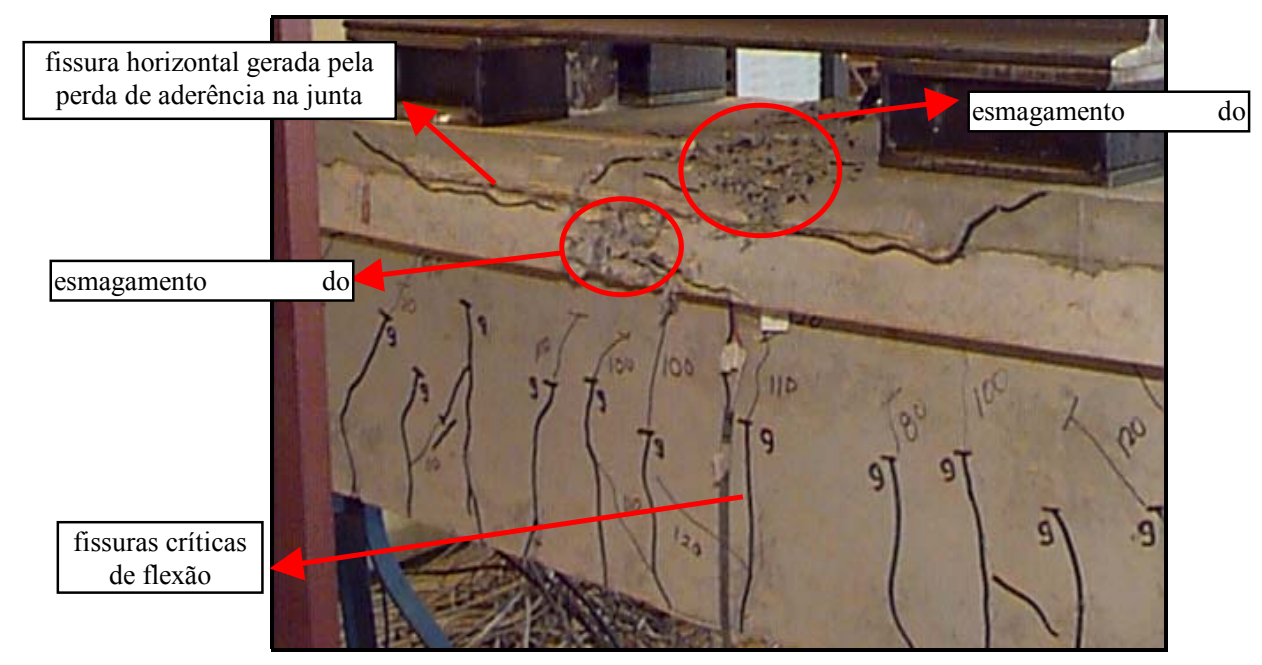

Figura 7.30 - Detalhe da ruptura da VFC-1 (semelhante às demais vigas)

\subsubsection{Deslocamentos verticais (flechas)}

Segundo a norma NBR-6118 (1978), em vigas de edifícios as flechas devem ser limitadas a $\delta_{\text {serviço }} \leq \ell / 300$ (para cargas permanentes + acidentais em serviço), logo a flecha máxima permitida para as vigas VFC é de $10 \mathrm{~mm}$. Fazendo a análise das flechas para o Estado Limite de Utilização, ou seja, admitindo a ação da força em serviço $\left(\mathrm{F}_{\text {serviço }}=90,9 \mathrm{kN}\right)$, constatou-se que a viga VFC-2 (sem pré-carregamento) foi a que apresentou menor flecha, sendo esta de $\delta_{\text {serviço }} \cong 10,2 \mathrm{~mm}$, seguida pela VFC-1 que apresentou uma flecha de $\delta_{\text {serviço }} \cong 21,7 \mathrm{~mm}$, e posteriormente pela VFC-3 que apresentou uma flecha de $\delta_{\text {serviço }} \cong 28,9 \mathrm{~mm}$. Portanto pode-se dizer que somente a viga VFC-2 está de acordo com o limite imposto pela norma.

A norma NBR-6118 (1978), que tece recomendações somente sobre o projeto de estruturas novas, limita o valor das flechas por considerá-las anti-estéticas, por causarem danos aos revestimentos da obra - tais como caixilhos e portas - e para evitar o projeto de estruturas excessivamente flexíveis, sujeitas a vibrações que podem incomodar o usuário. Contudo, quando se tem uma estrutura que já está pronta e que precisa ser reabilitada, nem sempre as limitações impostas pela norma são adequadas. Isso porque o elemento a ser reforçado já foi submetido a um carregamento e portanto apresentará uma flecha. Mesmo que se faça o descarregamento total dessa peça antes de reforçá-la, o que nem sempre é possível, 
sempre existirá uma flecha residual que foi gerada devido ao comportamento viscoelástico do concreto e que deverá ser somada às novas flechas que surgirão ao se colocar o elemento reabilitado novamente em serviço. É importante esclarecer que não se deve tentar eliminar a flecha residual por levantamento com auxílio de macacos hidráulicos, pois isso pode danificar ainda mais o elemento estrutural, já que provocará o aparecimento de tensões de tração no bordo superior da peça que foi projetado para resistir basicamente à compressão.

Como o valor da flecha residual é um dado de projeto conhecido, e como é possível prever as novas flechas que surgirão no elemento reabilitado usando os princípios básicos válidos para estruturas novas, mesmo que se atinja o limite da flecha especificado pela NBR-6118 (1978), isso não significa que ser tenha nem um elemento excessivamente flexível, nem que exista a possibilidade de gerar danos aos revestimentos da obra, já que se pode adotar procedimentos para evitar que isso ocorra. Além disso, quanto à questão estética, dependendo do local da viga, é possível inclusive escondê-la na alvenaria dando-se um acabamento adequado.

De qualquer maneira é preciso avaliar tanto as flechas imediatas quanto às flechas diferidas que surgirão no elemento estrutural após sua reabilitação e depois somá-las com as flechas residuais já existentes na peça, principalmente quando se optar pela reabilitação sob pré-carregamento.

Para avaliar as rigidezes das vigas traçou-se o gráfico da Figura $7.31 \mathrm{~b}$ que apresenta a evolução da força versus a flecha corrigida. No caso, a flecha corrigida refere-se à flecha das vigas reforçadas sob pré-carregamento (VFC-1 e VFC-3) menos um valor fixo de correção, que é determinado pela diferença entre a flecha obtida no início do ensaio final e a flecha da peça monolítica (VFC-2) para o correspondente pré-carregamento aplicado. Por este gráfico percebe-se que todas as vigas VFC apresentaram praticamente a mesma rigidez, pois as curvas têm inclinações semelhantes. Isso sugere que a camada de microconcreto adicionada ao bordo comprimido (material do reforço) estava perfeitamente aderida ao substrato conferindo à peça reabilitada um comportamento monolítico, apesar de não ter sido utilizada nenhuma armadura de costura para melhorar a aderência entre concreto novo e concreto antigo ao longo da junta de ligação. 


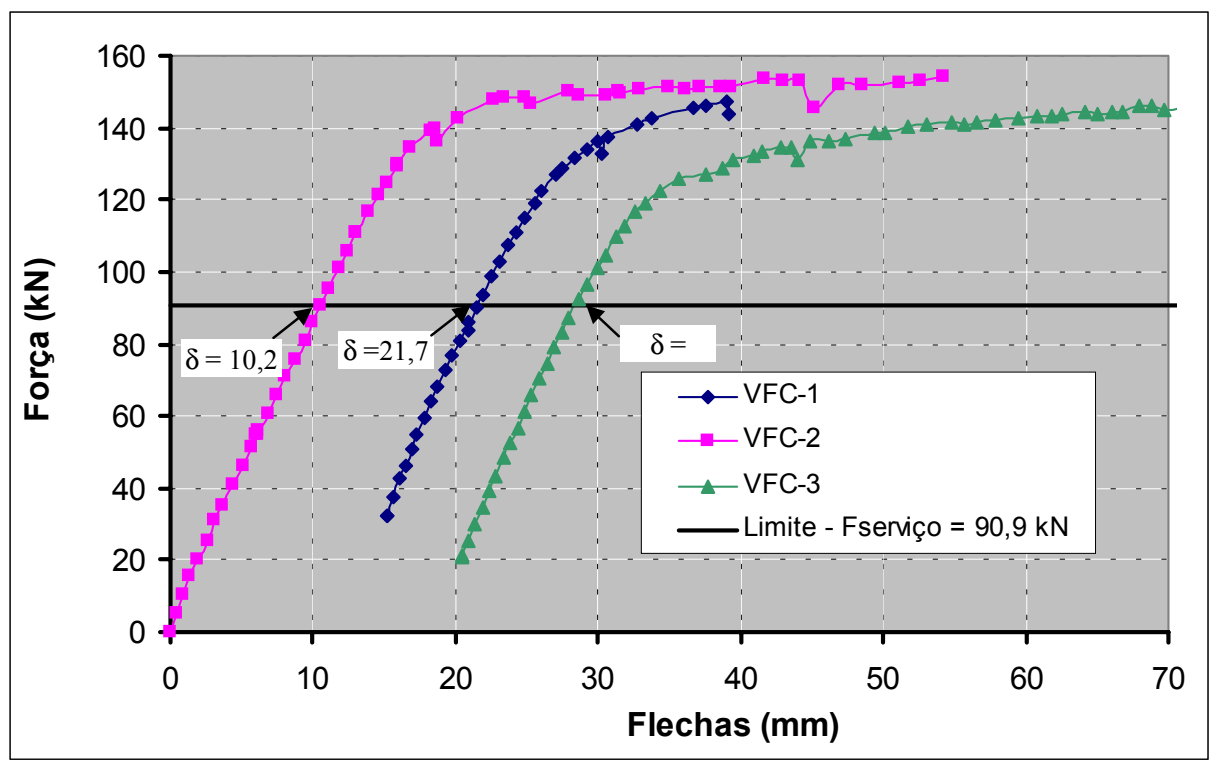

(a) flechas reais

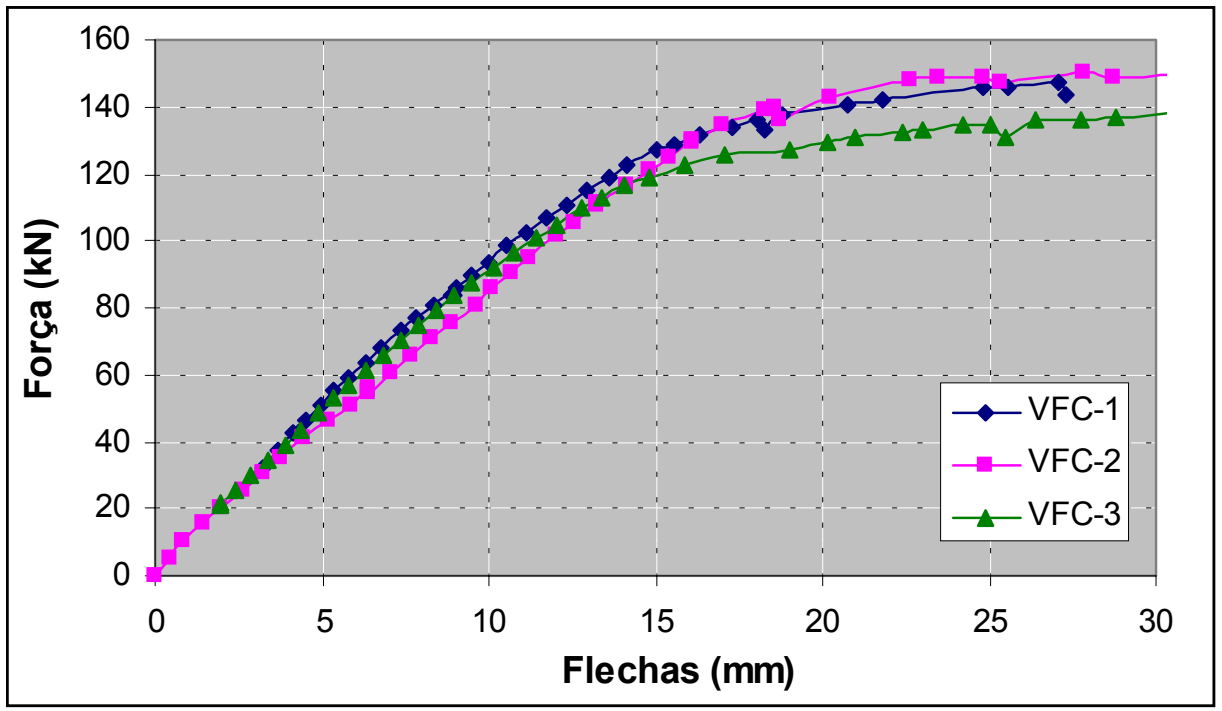

(b) flechas corrigidas

Figura 7.31- Deslocamentos verticais (flechas)

Os gráficos da Figura 7.32 mostram as diferenças entre as flechas experimentais e as flechas teóricas obtidas pela simulação numérica feita pelo programa CONSNOU descontando-se, no caso das vigas VFC-1 e VFC-3, o valor da flecha de longa duração observada no ensaio intermediário devido à aplicação do précarregamento. Por tais gráficos percebeu-se que as flechas teóricas correspondiam aproximadamente a $76 \%$ da flecha real para a força de serviço de $90,9 \mathrm{kN}$ em todas as vigas analisadas, ou seja, as flechas teóricas foram subestimadas. 

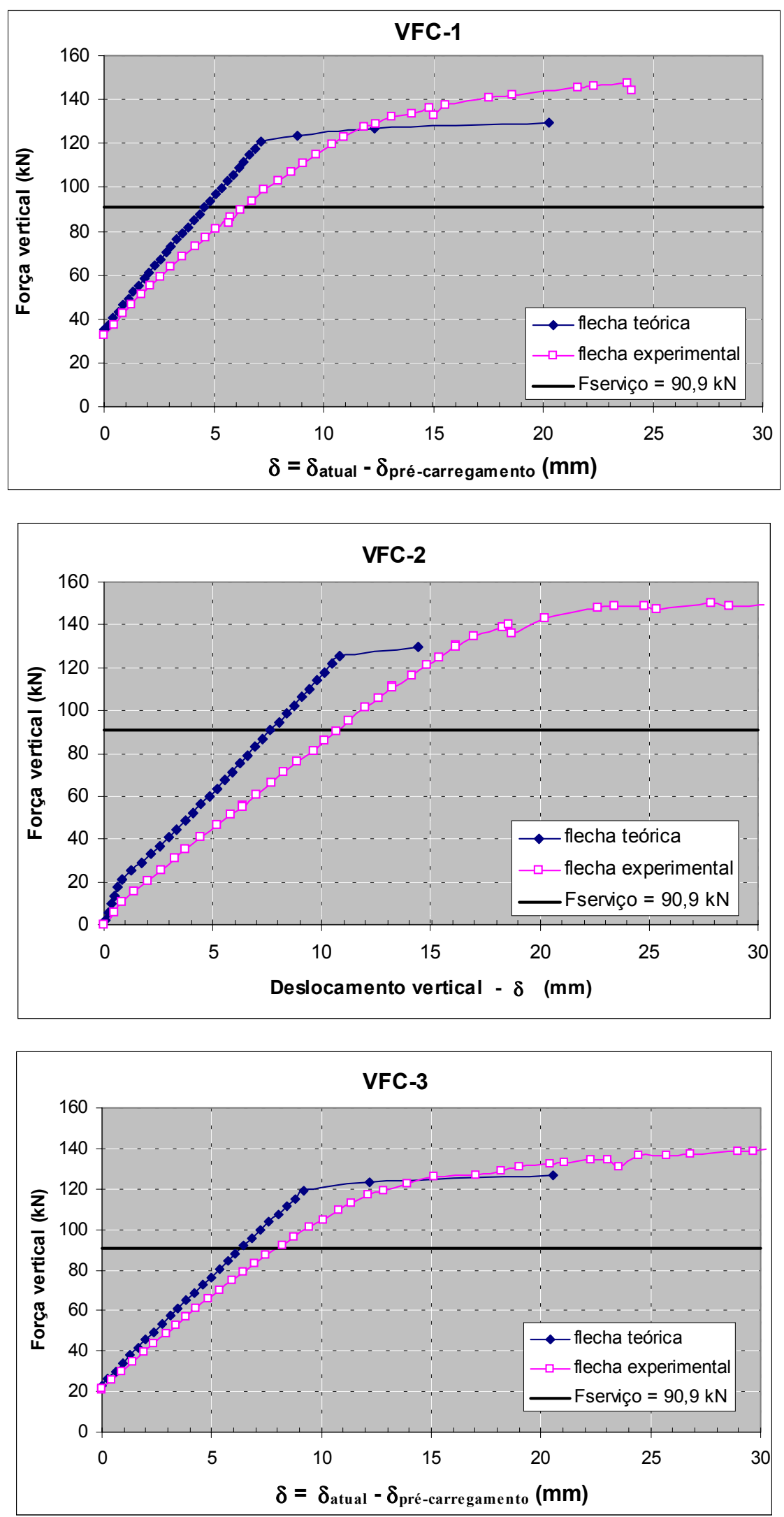

Figura 7.32 - Comparação entre as flechas experimentais e as simuladas 


\subsubsection{Deslocamentos horizontais na região da junta}

Para verificar se haveria perda de aderência na região da junta entre o material do reforço e o substrato, acompanhou-se os deslocamentos horizontais relativos através de relógios comparadores fixados ao longo desta junta (ver Figura 7.3b).

A partir das leituras coletadas pelo relógio comparador $n^{0} 25$ traçou-se o gráfico da Figura 7.33 que mostra o deslocamento horizontal relativo entre o concreto do substrato e o microconcreto do reforço para o meio do vão em função do aumento do carregamento aplicado. As leituras dos demais relógios não foram apresentadas ou por fornecerem resultados muito pequenos (caso dos relógios 28 a 31), ou por fornecerem resultados inconsistentes devido à interferência da fissuração gerada pelo esmagamento do concreto sob as forças concentradas (caso dos relógios 26 e 27$)$.

Por este gráfico nota-se que os deslocamentos horizontais foram praticamente desprezíveis até uma força vertical de aproximadamente $120 \mathrm{kN}$, ou seja, somente a partir deste instante é que se iniciava a fissuração na junta. Ressalta-se que é justamente para este nível de carregamento que a linha neutra cruza a região da junta, passando a situar-se acima dela e conseqüentemente fazendo com que todo concreto do substrato passe a ser tracionado assim como parte do concreto do reforço. Quando as tensões de tração no local ultrapassam a resistência a tração do material surgem as fissuras. Como a resistência à tração do reforço é bem maior que a do substrato, uma fissura de flexão qualquer que tentar cruzar a junta, acaba encontrando um material mais resistente. A partir daí, a fissura tende a se propagar na direção do caminho mais fraco, que no caso dos ensaios realizados, foi de se propagar na direção horizontal na região da junta provocando o deslizamento parcial entre os materiais do reforço e do substrato. Isso ocorreu porque não havia nenhuma armadura cruzando a interface que impedisse tal deslocamento, ficando a resistência da junta dependente somente da resistência por adesão entre os concretos do substrato e do reforço. Tal comportamento também foi observado em ensaios de vigas compostas pré-moldadas realizados por ARAÚJO (2002). Contudo, observa-se que a fissuração da junta ocorreu para um carregamento muito próximo da capacidade portante da viga e que 
mesmo assim o elemento ainda suportou acréscimos de força, indicando que apesar da ocorrência da fissuração na junta, esta não determinou o tipo de ruptura da peça.

De acordo com a formulação apresentada no item 3.2.1 determinou-se teoricamente as tensões tangenciais solicitantes e resistentes da junta formada pelos concretos do substrato e do reforço para as normas ACI, FIP e NBR-9062 (ver Tabela 7.9). Os resultados obtidos indicaram que a tensão resistente da junta é menor que a tensão solicitante no Estado Limite Último, portanto realmente haveria a necessidade de se utilizar uma armadura de costura para impedir o deslizamento relativo entre os materiais quando a peça estiver próxima da carga de ruptura.

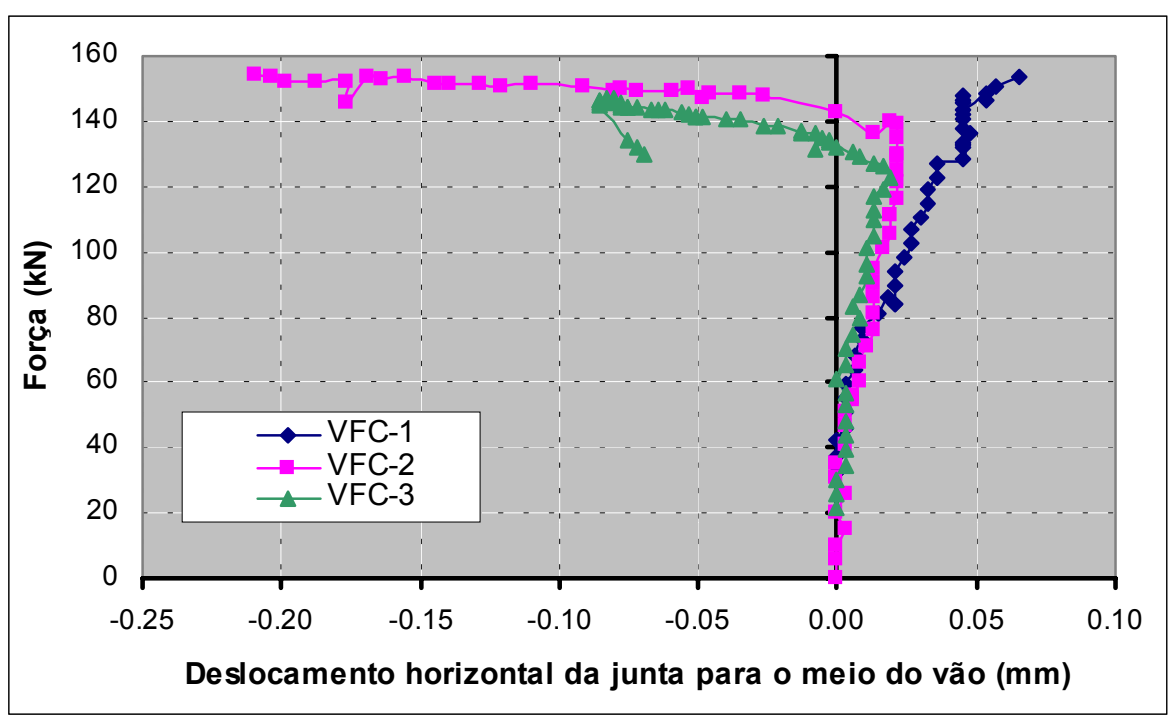

Figura 7.33 - Deslocamentos horizontais relativos entre o material do substrato e o material de reforço para a região da junta

Tabela 7.9 - Avaliação das tensões tangenciais na região da junta

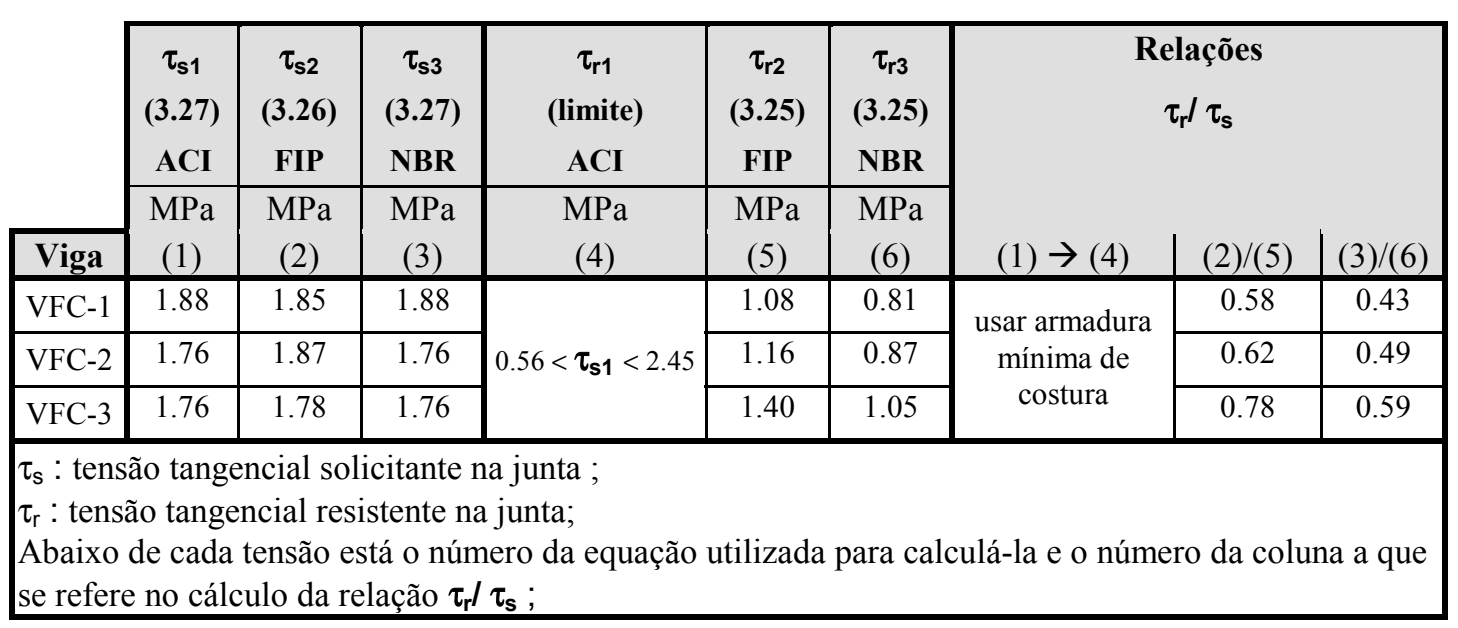




\subsubsection{Deformações no concreto do substrato e do reforço}

A ruptura real das vigas VFC-1, VFC-2 e VFC-3 ocorreu por deformação plástica excessiva do aço e o esmagamento da fibra de concreto mais comprimida (material do reforço), estando de acordo com o dimensionamento adotado (ruptura no domínio 3) que admitia a utilização máxima dos materiais, com deformações na armadura tracionada variando de 2,07\% até $10 \%$ e deformações no concreto de até 3,5\% . Como o início do escoamento da armadura tracionada faz com que a linha neutra da seção se desloque em direção à face comprimida, praticamente no mesmo instante em que houve o escoamento desta armadura, a linha neutra cruzou a junta formada pela ligação entre substrato e reforço. Desta maneira, a linha neutra situavase acima da junta fazendo com que o material do substrato e parte do material do reforço passasse a ser tracionado ao invés de comprimido.

Os gráficos da Figura 7.34, nos quais estão apresentados simultaneamente os resultados experimentais das deformações obtidos tanto para o concreto do substrato quanto para o microconcreto do reforço, permitem identificar o valor da força a partir da qual a linha neutra cruzava a junta de ligação sendo este valor aproximadamente igual ao que proporcionava o escoamento da armadura tracionada.

Pela Figura 7.35 verificou-se que a variação das deformações experimentais da fibra do concreto do substrato mais comprimido - fibra situada $3 \mathrm{~cm}$ abaixo da face superior da viga reforçada - em função do acréscimo de força foi relativamente pequena para todas as vigas ensaiadas, sendo inclusive menores do que as deformações teóricas obtidas pela simulação numérica tanto para as vigas reforçadas sob pré-carregamento quanto para a viga reforçada sem carregamento. Além disso, depois de determinado valor de força (que variou entre $120 \mathrm{kN}$ e $140 \mathrm{kN}$ ) verificouse o início da redução nas deformações de compressão deste material, indicando que a linha neutra havia cruzado a junta formada pela ligação entre o concreto do substrato e o microconcreto do reforço. Esta redução não conseguiu ser avaliada pelo programa CONSNOU devido a problemas de convergência, mas de qualquer maneira, através da simulação numérica foi possível determinar o instante em que esta redução teria início, uma vez que esta praticamente coincidia com o instante em que a armadura tracionada iniciava o escoamento. 

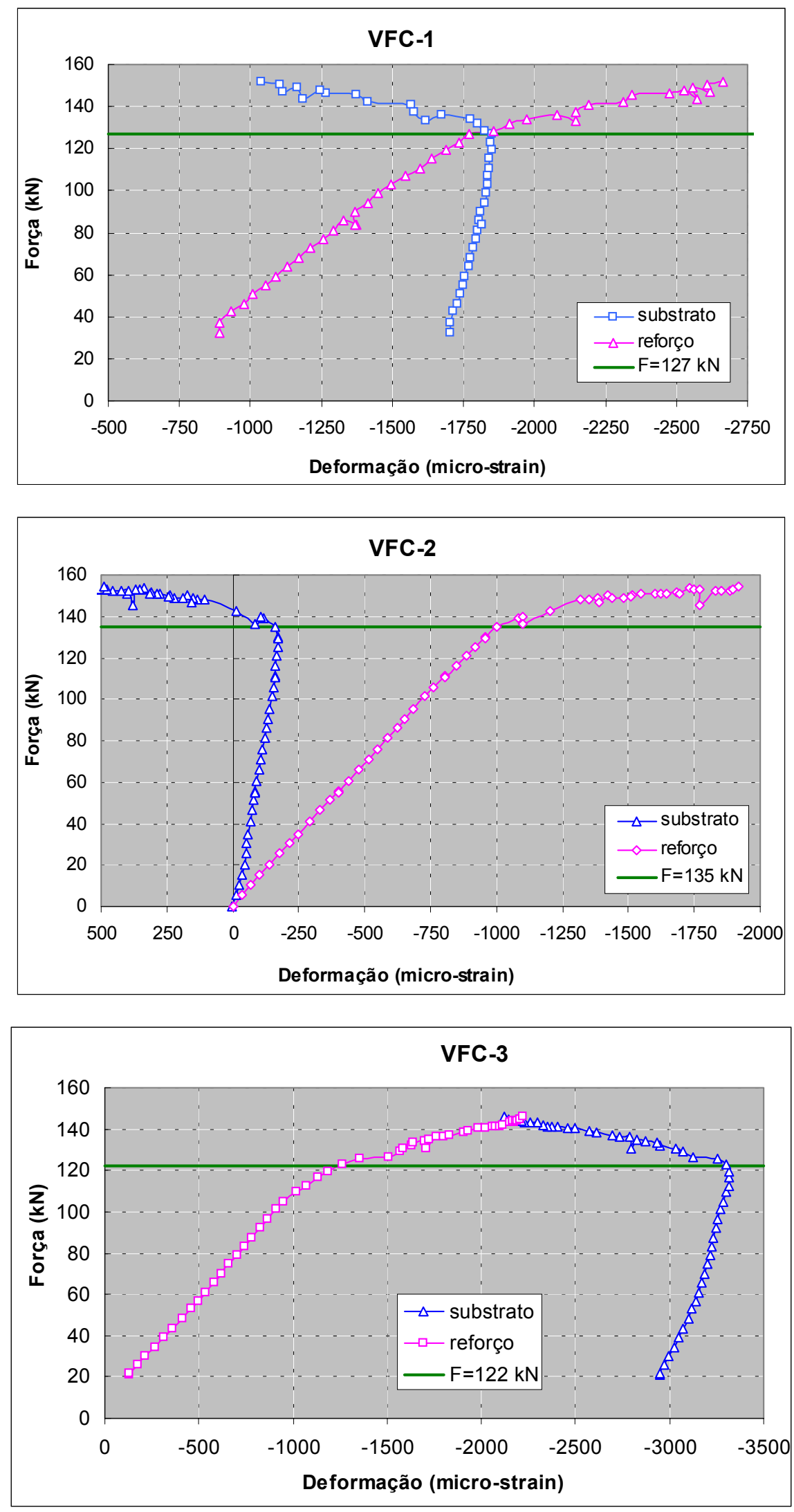

Figura 7.34 - Comparação entre as deformações reais do substrato e do reforço 
Conforme dito no item 7.6.2.1 e observado na Figura 7.30, também ocorreu a plastificação do concreto do substrato assim que houve o esmagamento do concreto do reforço e o aumento da perda de aderência na região da junta. Entretanto as deformações experimentais referentes a este esmagamento não conseguiram ser coletadas pelos extensômetros elétricos fixados neste material.

Quanto à fibra mais comprimida do microconcreto do reforço - situada na face superior da viga - esta apresentou deformações de compressão bem mais significativas, indicando inclusive sua plastificação logo após o início do escoamento da armadura tracionada, independentemente da deformação existente no material imediatamente antes do escoamento. Pela Figura 7.36 verifica-se que, ao contrário das curvas teóricas das deformações do concreto do substrato, as curvas das deformações do microconcreto do reforço fornecidas pela simulação numérica praticamente coincidiram com os resultados experimentais. A única exceção foi observada na viga VFC-1, para a qual a curva teórica ficou um pouco distante da curva real devido à subestimação do valor da deformação obtida na fase do ensaio intermediário (ensaio de longa duração). Todavia, a configuração da curva teórica foi coerente com a da curva experimental.

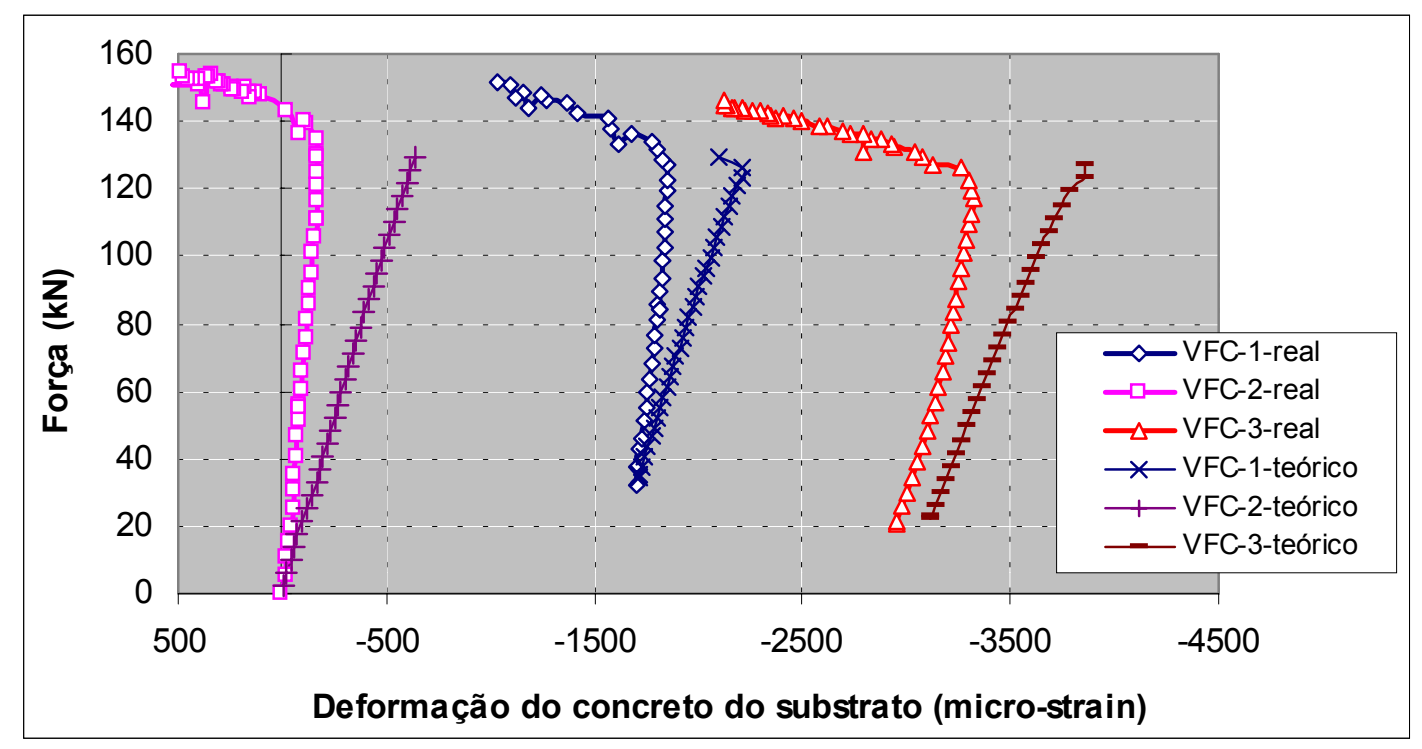

Figura 7.35 - Deformação no concreto do substrato - seção do meio do vão 


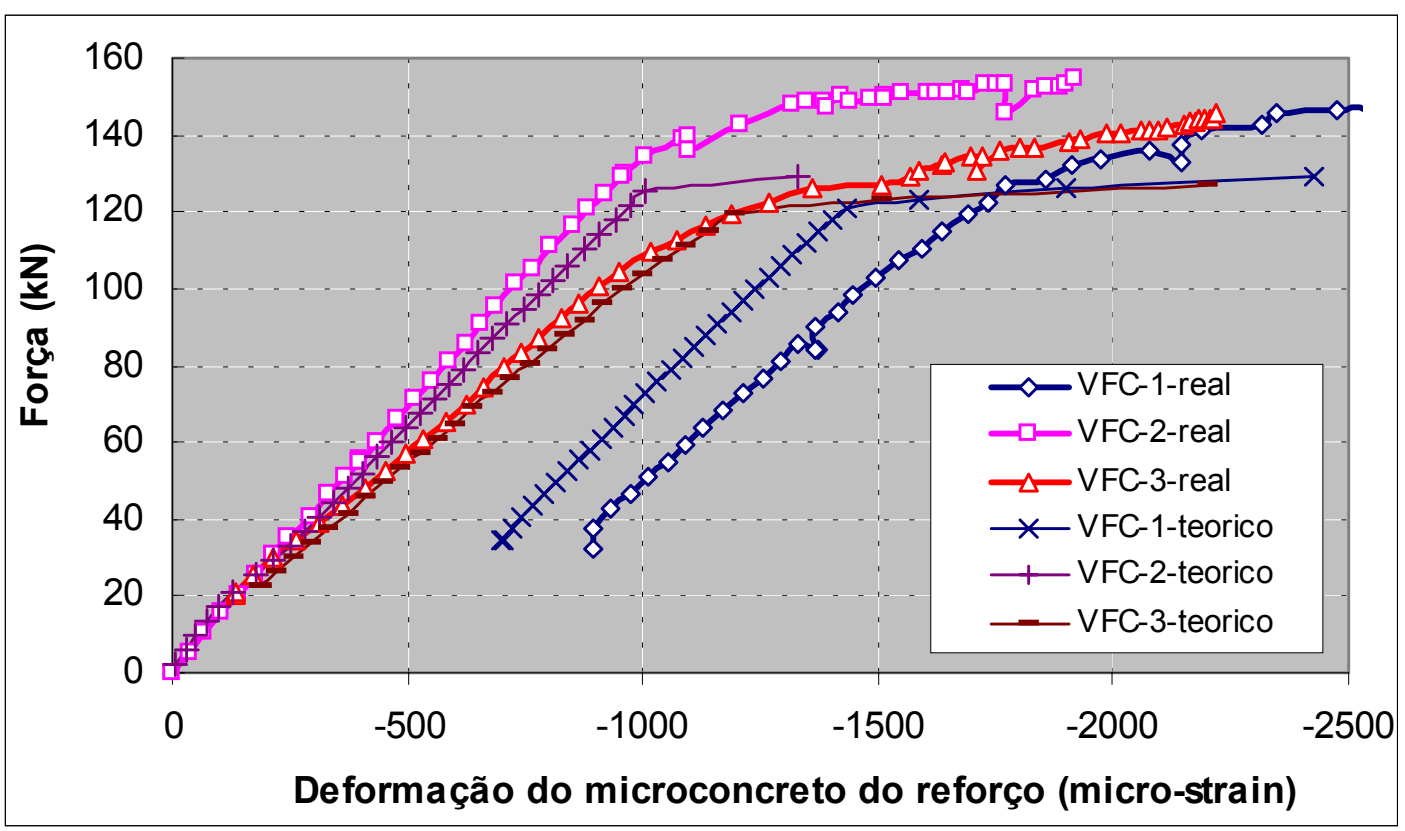

Figura 7.36 - Deformação no microconcreto do reforço - seção do meio do vão

Os gráficos das Figuras 7.35 e 7.36 apresentam os valores das deformações dos materiais em função da força aplicada. Entretanto, para realizar o dimensionamento da estrutura reabilitada, deve-se conhecer não só as deformações mas principalmente as tensões atuantes em cada material a fim de identificar o patamar de carregamento que causará o esmagamento do concreto do bordo comprimido. Entretanto, o método de avaliação das tensões em materiais cimentícios que sofreram os efeitos da fluência e da retração é bastante complexo já que, conforme descrito no item 3.4.3, para um carregamento mantido constante, apesar das deformações dos materiais aumentarem ao longo do tempo, as tensões tendem a se reduzir em função do deslocamento da linha neutra.

No item 3.4.3.2 está descrito uma formulação algébrica simplificada, proposta por GHALI \& FAVRE (1986), que utiliza o módulo de deformação efetivo ajustado na avaliação das tensões e deformações diferidas em peças fissuradas em serviço submetidas à flexão normal ou composta. Este método é relativamente fácil de ser utilizado quando se tem um carregamento constante ao longo do tempo, que corresponde à maior parte das situações práticas. Porém, nos ensaios realizados não foi possível manter o carregamento constante ao longo do tempo, o que tornava inviável o uso deste método, pois seria necessário realizar uma grande quantidade de 
cálculo a fim de se conseguir avaliar teoricamente as tensões nos elementos geradas simultaneamente pela fluência e pela redução do carregamento.

Como a simulação numérica realizada pelo programa CONSNOU permitia determinar os valores teóricos das tensões considerando simultaneamente os efeitos viscoelásticos dos materiais e a redução do carregamento com o tempo, e como os resultados teóricos das deformações fornecidos por esta simulação foram relativamente próximos dos experimentais, acredita-se que as tensões estimadas pelo programa CONSNOU estejam coerentes com os valores experimentais existentes nas vigas. Assim, fez-se a análise das tensões nas vigas em função dos resultados teóricos fornecidos pela simulação numérica e não utilizando o método simplificado apresentado por GHALI \& FAVRE (1986).

Pelos gráficos da Figura 7.37, que mostram a evolução das tensões e deformações teóricas fornecidas pela simulação numérica durante o acréscimo de carregamento referente ao ensaio de curta duração, verificou-se que o fato do substrato apresentar uma deformação maior que o reforço nem sempre significa que ele está submetido a uma tensão maior.

Analisando as curvas da tensão e deformação da viga VFC-2, que representam o comportamento de uma peça reforçada na qual nem o substrato nem o reforço sofreram os efeitos da fluência, percebeu-se que sempre a tensão e a deformação do substrato foram menores que as do reforço.

Já para a viga VFC-1, na qual o substrato sofreu os efeitos da fluência devida à aplicação do $1^{\circ}$ pré-carregamento e o reforço sofreu os efeitos da fluência em função da aplicação do $2^{\circ}$ pré-carregamento, observou-se que a deformação do substrato sempre foi maior que a do reforço. Isso decorre do fato do substrato ter sido submetido a um carregamento por mais tempo e também do fato do material do reforço ter sido dosado para apresentar uma deformação por fluência menor. Contudo, a tensão do substrato sempre foi menor que a tensão existente no reforço ao longo da execução do ensaio de curta duração. 

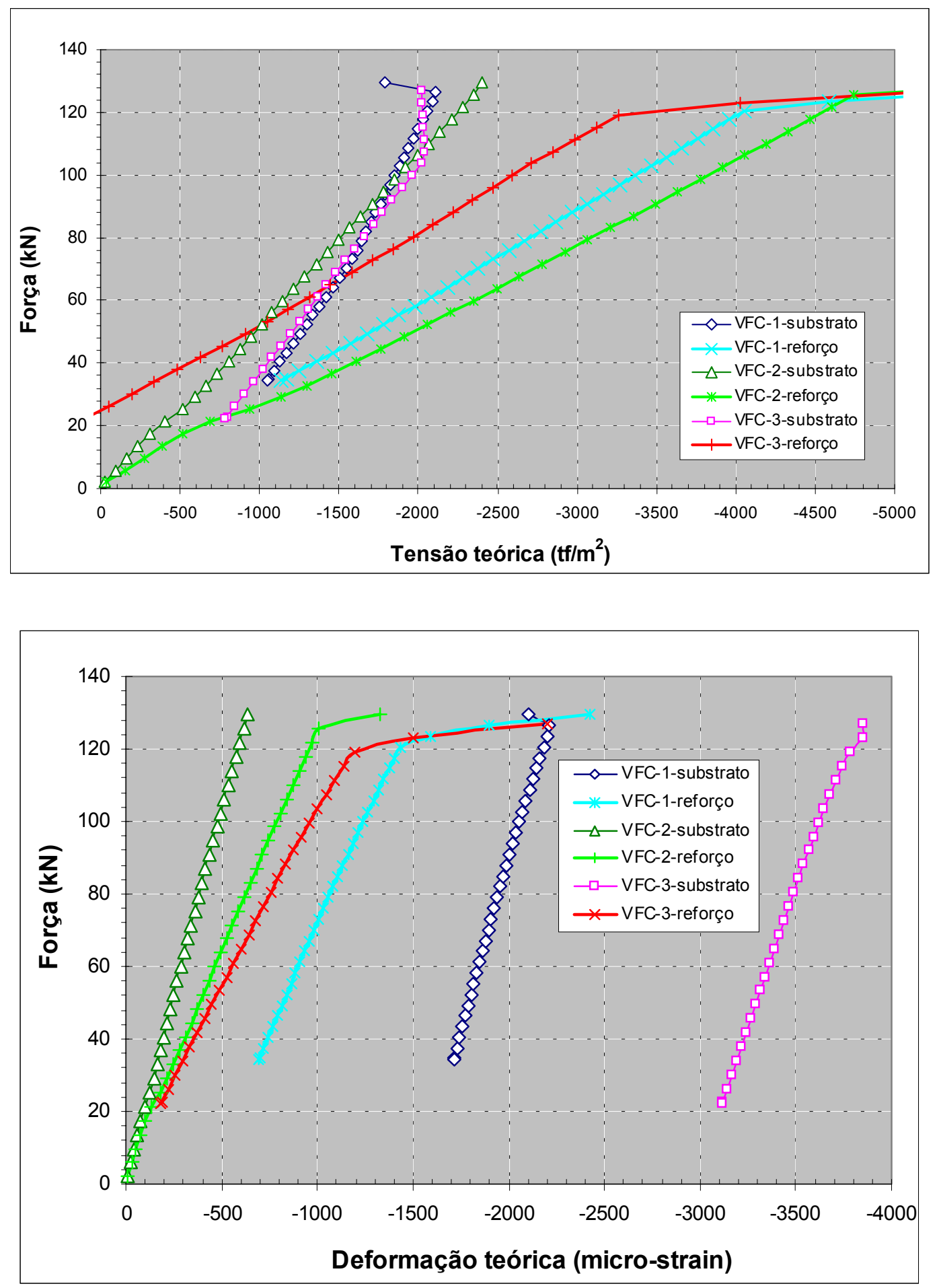

Figura 7.37 - Tensões e deformações teóricas do substrato e do reforço

Para a VFC-3, na qual somente o substrato sofreu os efeitos da fluência, observou-se que a deformação deste sempre foi maior que a do reforço. Quanto à tensão do substrato, esta foi inicialmente maior que a do reforço pois o carregamento 
atuante na viga antes do ensaio de curta duração não havia sido aumentado, ou seja, o concreto do reforço ainda não estava participando da seção resistente da viga, sendo o pré-carregamento atuante resistido somente pelo concreto do substrato. A partir do instante em que se aumentava o valor do carregamento (início do ensaio de curta duração), a tensão no reforço começou a aumentar a uma taxa bem maior que a tensão do substrato por causa da diferença na altura das fibras comprimidas destes materiais em relação à linha neutra da seção. Logo, para uma força de aproximadamente $65 \mathrm{kN}$, a tensão do reforço superou o valor da tensão do substrato permanecendo assim até a ruptura da viga. Ressalta-se que a deformação do reforço observada no início do ensaio da curta duração foi causada somente pelo efeito da retração deste material.

Desta forma pode-se dizer que o uso de programas computacionais que permitam simular o comportamento das vigas ao longo do tempo é uma ferramenta extremamente útil, pois através dele se tem condições de estimar tanto as tensões quanto as deformações dos materiais, possibilitando ao projetista realizar o dimensionamento do reforço de vigas pré-carregadas por longos períodos de tempo, de maneira mais econômica e segura.

\subsubsection{Deformações da armadura longitudinal comprimida $-\mathbf{A}_{\mathrm{sl}}$,}

Assim como o observado para as deformações do concreto do substrato, verificou-se que a variação das deformações da armadura comprimida $\left(\mathrm{A}_{\mathrm{sl}}{ }^{\prime}\right)$ foi relativamente pequena em função do aumento do carregamento aplicado e que, depois de determinado valor de força (entre $120 \mathrm{kN}$ e $140 \mathrm{kN}$ ), as deformações começavam a se reduzir com o acréscimo do carregamento, pois a linha neutra passava a ficar posicionada acima desta armadura (ver Figura 7.38).

Os gráficos da Figura 7.39 apresentam as deformações teóricas obtidas pela simulação numérica feita pelo programa CONSNOU. Por estes gráficos verifica-se que as curvas teóricas apresentaram a mesma configuração das curvas experimentais. Entretanto, conforme dito no item 7.6.1.4, os valores teóricos das deformações da armadura comprimida das vigas VFC-1 e VFC-3 foram subestimados em relação aos 
valores reais principalmente em função da subestimação das deformações imediatas. O mesmo não ocorreu para a viga VFC-2, na qual os valores teóricos praticamente coincidiram com os valores experimentais.

Convém esclarecer que na simulação numérica das vigas pré-carregadas (VFC-1 e VFC-3), o carregamento foi simulado aplicando-se duas forças verticais distanciadas $125 \mathrm{~cm}$ de cada apoio, além de um momento e de uma força normal em cada uma de suas extremidades, pois o sistema de aplicação do pré-carregamento implicava no surgimento destas ações (ver Figuras 3.25, 7.6 e 7.10). Tais ações não ocorriam na VFC-2 pois esta viga estava submetida à flexão simples em que o carregamento atuante correspondia somente às duas forças verticais. Conseqüentemente pode-se imaginar que o programa CONSNOU consiga avaliar melhor o desempenho de vigas submetidas à flexão simples ao invés das peças submetidas à flexo-compressão. De qualquer maneira, antes de questionar o desempenho deste programa, é preciso realizar outras simulações numéricas a partir de novos dados experimentais.

Por outro lado, mesmo observando-se a subestimação nos valores teóricos das deformações desta armadura, foi possível prever adequadamente o instante em que estas começavam a se reduzir em função da modificação da posição da linha neutra com o acréscimo do carregamento aplicado.

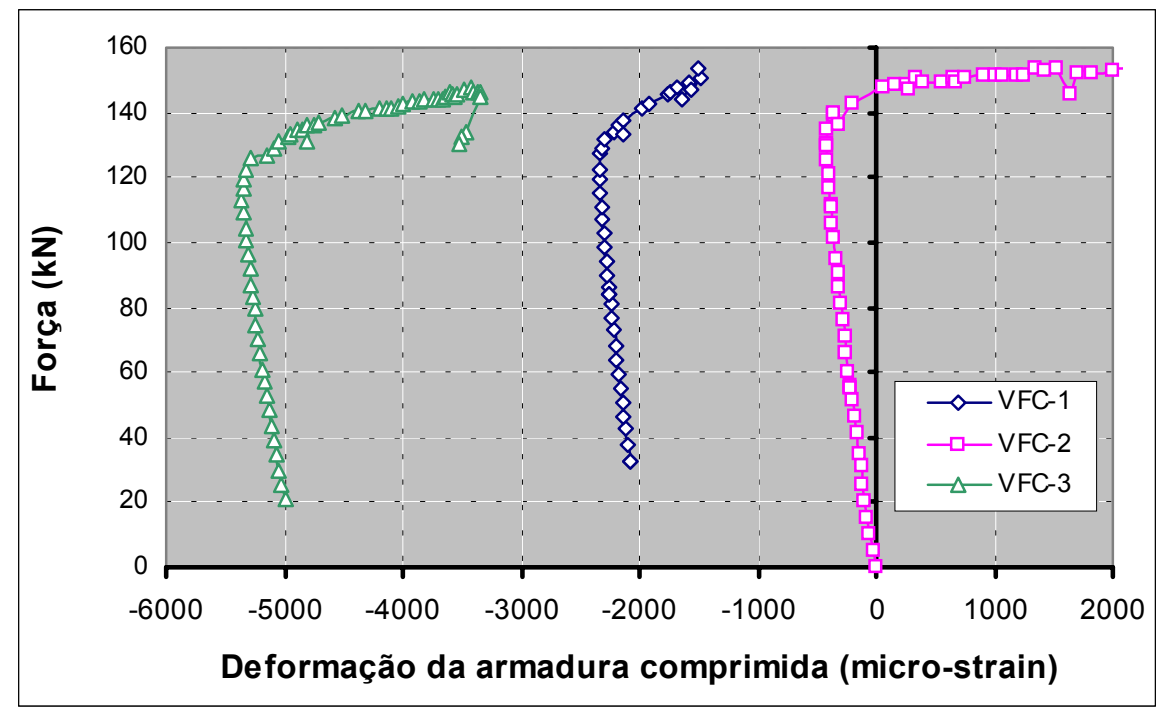

Figura 7.38- Deformação na armadura longitudinal comprimida no meio do vão 

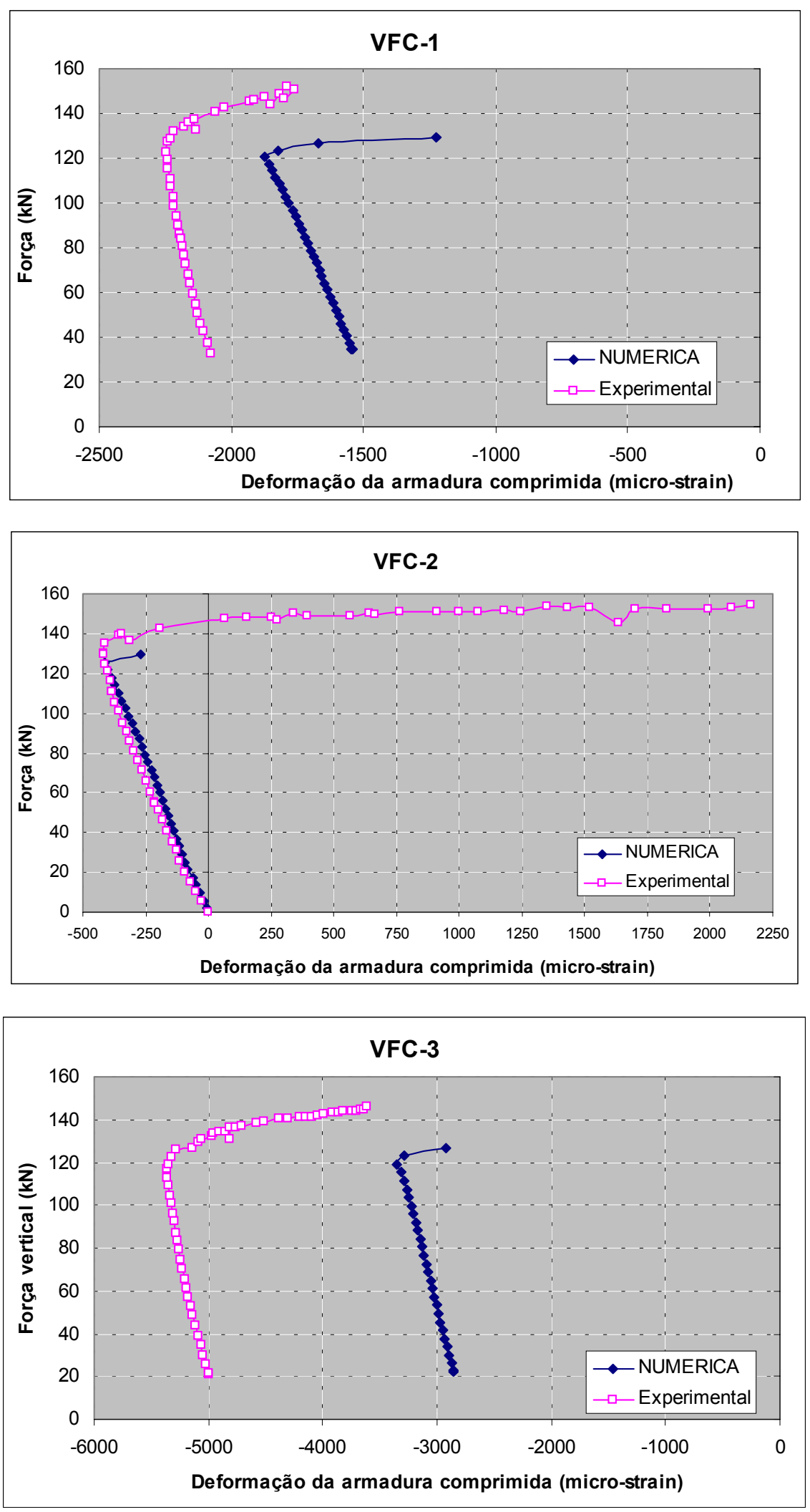


\section{Figura 7.39- Deformação na armadura longitudinal comprimida no meio do} vão

\subsubsection{Deformações da armadura longitudinal tracionada $-\mathbf{A}_{s l}$}

Pela Figura 7.40 confirma-se que as armaduras tracionadas atingiram o escoamento para a seção transversal do meio do vão para todas as vigas ensaiadas. Observando o gráfico desta figura percebe-se que a deformação que caracterizou o início do escoamento da armadura tracionada foi de aproximadamente 3,5\% em todas as vigas, sendo portanto maior que a deformação experimental média de início de escoamento $\left(\varepsilon_{\mathrm{s}}>2,6 \%\right.$ ) obtida nos ensaios de tração axial do aço dessa armadura. Como a armadura da viga VFC-2 não possuía nenhuma deformação antes do início do ensaio (viga reforçada sem pré-carregamento), esta foi capaz de suportar um carregamento maior antes de atingir a deformação de início de escoamento.

Apesar das armaduras tracionadas estarem escoando, todas as vigas VFC ainda suportaram acréscimos de carga até antes do inicio do esmagamento do concreto do reforço, confirmando o modo de ruptura no domínio 3 (deformação plástica excessiva da armadura tracionada e esmagamento do concreto comprimido) descrito na Tabela 7.8.

Como na verificação e no dimensionamento de estruturas deve-se utilizar os parâmetros de cálculo, traçou-se no gráfico da Figura 7.40 os limites referentes à força de serviço $\left(\mathrm{F}_{\text {serviço }}=90,9 \mathrm{kN}\right)$ da viga reabilitada bem como a deformação de início de escoamento de cálculo do aço $\left(\varepsilon_{\mathrm{yd}}=2,07 \%\right)$. A partir daí verificou-se que no caso da VFC-2, as deformações da armadura tracionada ainda não haviam atingido a deformação de escoamento de cálculo para a força de serviço, ao contrário das vigas VFC-1 e VFC-3, cujas deformações ultrapassaram este limite para o mesmo patamar de carregamento, não estando portanto atendendo aos critérios de dimensionamento adotados pelo processo dos Estados Limites, uma vez que tal limite de deformação só poderia ser alcançado para a força teórica de ruptura de cálculo

$\left(\mathrm{F}_{\text {ruptura }}=1,4 \cdot \mathrm{F}_{\text {serviço }} \rightarrow \mathrm{F}_{\text {ruptura }}=127,3 \mathrm{kN}\right)$. Este fato ressalta a importância de se 
avaliar as deformações existentes nas armaduras tracionadas da viga antes de sua reabilitação para que se possa elaborar um projeto de reforço adequado aos critérios de dimensionamento recomendado pelas normas.

O valor da deformação inicial da armadura tracionada das vigas VFC-1 e VFC-3 pode ser estimado com relativa precisão através dos métodos analíticos convencionais utilizando o valor do pré-carregamento atuante nas vigas para a respectiva seção resistente (antes ou depois do reforço). Isso porque, ao contrário do concreto, a deformação nesta armadura praticamente não se altera em função dos efeitos da fluência.

Quanto aos resultados obtidos pela simulação numérica, pode-se repetir as mesmas observações já descritas em relação ao comportamento teórico observado para a armadura longitudinal comprimida. Resumindo, as curvas teóricas foram semelhantes às experimentais, sendo que no caso das vigas pré-carregadas estes valores foram menores que os reais devido à subestimação das deformações iniciais desta armadura pelo programa CONSNOU provavelmente por causa do tipo de esquema de carregamento utilizado. Entretanto, mesmo com a subestimação dos valores teóricos das deformações desta armadura, foi possível prever adequadamente o instante em que estas começavam a escoar (ver Figura 7.41).

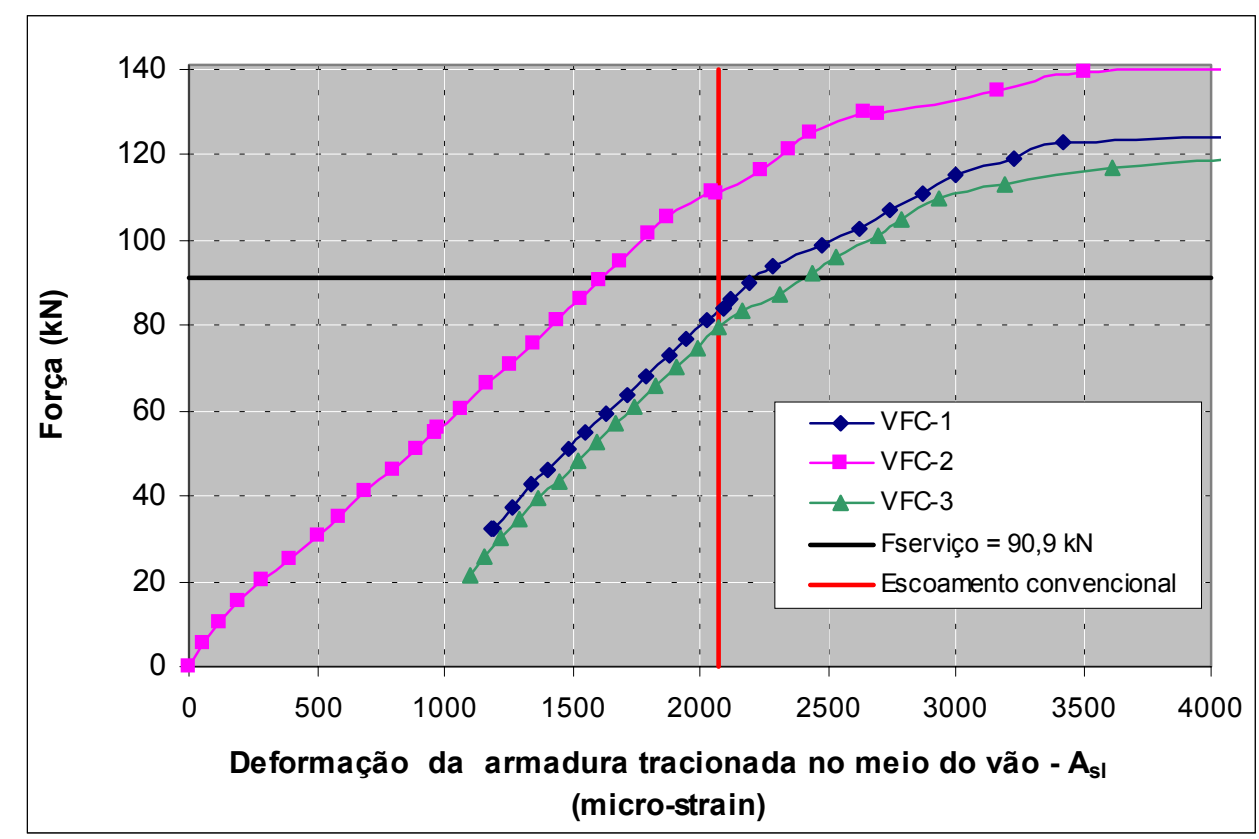


Figura 7.40 - Deformação na armadura longitudinal tracionada
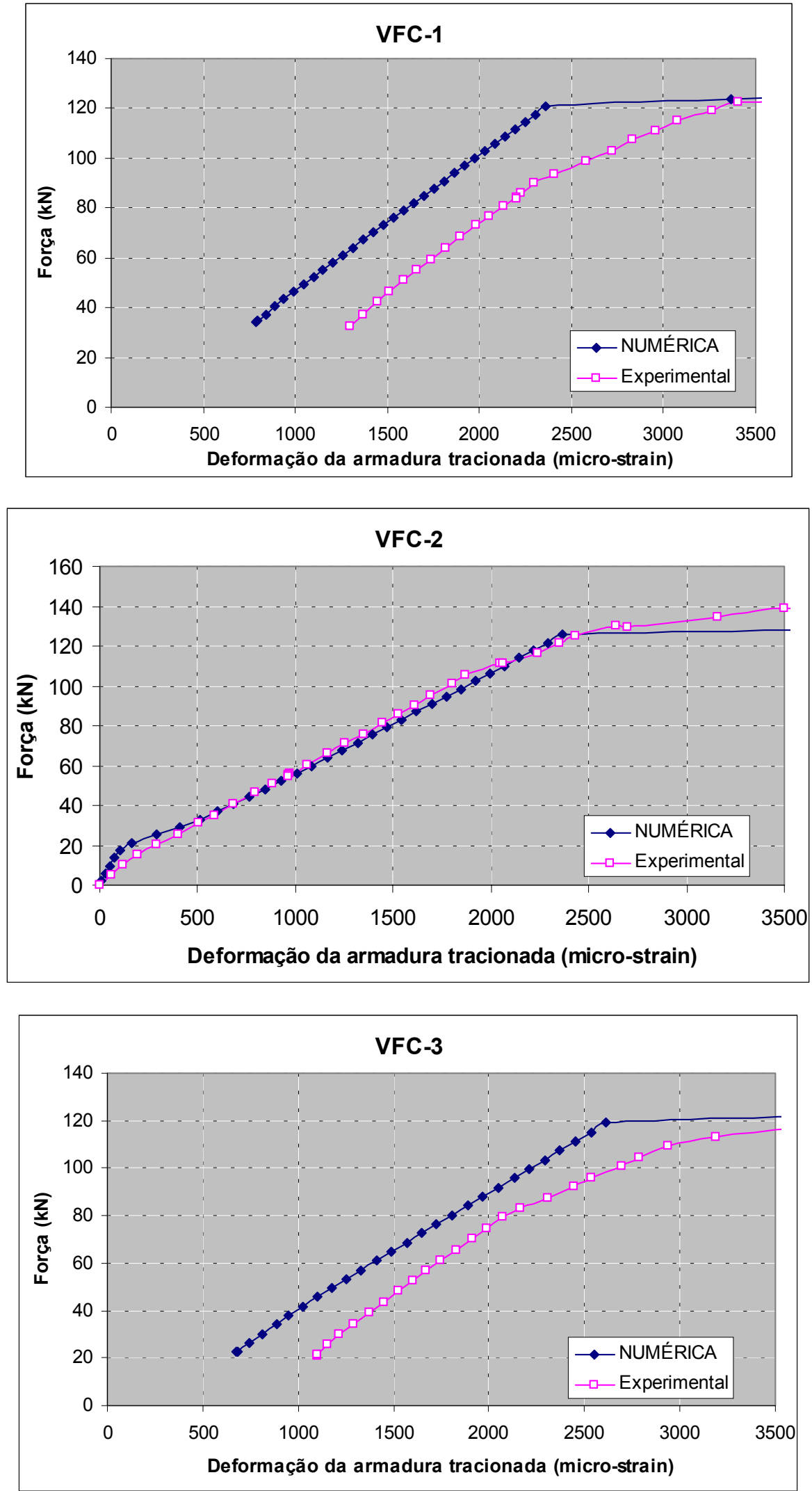

Figura 7.41 - Estimativa numérica da deformação da armadura tracionada 


\subsubsection{Deformações nas armaduras transversais}

Para evitar a ruptura por cisalhamento e permitir a verificação do comportamento das vigas devido somente à ação do momento fletor, adicionou-se uma taxa de armadura transversal maior que a necessária. Sendo assim, as deformações dos estribos foram pequenas e portanto não foram apresentadas aqui.

\section{7 - Dificuldades encontradas}

As principais dificuldades encontradas na realização deste tipo de ensaio refere-se à:

a) desenvolvimento de um sistema de aplicação de carga que conseguisse ao mesmo tempo manter a carga constante e permitisse o transporte da viga da câmara climatizada (local em que a peça ficava armazenada durante a realização dos ensaios de longa duração) para o galpão de ensaios onde seria realizado o ensaio de curta duração. No caso, o sistema adotado utilizava um cabo protendido que passavam externamente à viga e que apresentava perdas de protensão - conseqüentemente a redução da carga ao longo do tempo - em função do aumento das flechas, das perdas por relaxação do cabo e das perdas por ancoragem;

b) fazer a cura adequada do material de reforço dentro da câmara climatizada uma vez que ao tentar manter úmida esta superfície, a câmara acionava automaticamente o desumidificador.

c) desenvolver um sistema de aplicação de carga específico para o ensaio de curta duração que não interferisse no sistema usado para aplicar o précarregamento.

d) não danificar os extensômetros colados ao concreto em função da fixação das fôrmas durante a execução do reforço da viga. Além disso, a cola usada na fixação destes extensômetros se ressecavam com facilidade tornando necessário a substituição destes instrumentos de leitura por outros a fim de se conseguir leituras corretas das deformações dos materiais. 


\section{8 - Conclusões}

A meta principal desta pesquisa foi elaborar subsídios para estabelecer estratégias, métodos e procedimentos de projeto para reabilitação de estruturas de concreto, particularmente no que se refere ao reforço de vigas. Para alcançar tal meta inicialmente foi feita uma revisão bibliográfica, na qual se descreveu os principais estudos desenvolvidos sobre o reforço de vigas mediante adição de concreto simples ou armado. Esta pesquisa teórica permitiu identificar as lacunas de conhecimento existentes a respeito desta técnica de reforço e serviu de base para a definição dos parâmetros analisados no estudo experimental desenvolvido sobre:

$>$ reforço de vigas pela aplicação de argamassa com fibras de aço e armadura convencional ao bordo tracionado;

$>$ reforço de vigas pela aplicação de microconcreto ao bordo comprimido.

Para avaliar a eficiência destas duas técnicas de reforço e estudar as possibilidades de sua aplicação prática, realizou-se uma investigação experimental e uma investigação teórica do comportamento das vigas avaliando-se a influência dos seguintes parâmetros:

- $\quad$ a atuação de um pré-carregamento na viga durante a execução do reforço;

- o efeito da fluência e da retração diferencial existente entre os materiais novos e antigos;

- os mecanismos de resistência mobilizados nas vigas reforçadas por estas técnicas.

Após a avaliação e interpretação dos resultados obtidos neste trabalho apresentou-se as conclusões julgadas de maior importância nos itens a seguir. 


\subsection{Sobre as técnicas de reforço de vigas por meio de adição de concreto e o comportamento geral dos ensaios experimentais realizados}

A partir dos cuidadosos estudos prévios e da avaliação global da pesquisa experimental realizada, pode-se concluir que:

O reforço de vigas por meio da adição de concreto e armaduras suplementares constitui uma estratégia eficiente, atual e coerente no campo dos materiais à base de cimento. Ela pode se valer de materiais de alto desempenho, como os concretos com fibras e concretos de alta resistência, além de se mostrar adequada técnica e economicamente em grande parte dos casos. Pode-se afirmar também que as técnicas de reforço analisadas nesta pesquisa, apesar de serem um pouco diferentes das usuais, têm plenas condições de serem aplicadas na reabilitação de elementos fletidos uma vez que todas as vigas de seção T reforçadas apresentaram esquema de fissuração, modos de ruptura e capacidade portante semelhante àquelas de peças monolíticas.

Essa afirmação justifica-se pelas considerações seguintes:

$>$ Embora sempre sejam necessárias mais pesquisas para consolidar o conhecimento nesta área, foi possível reunir, na revisão bibliográfica, um conjunto consistente de informações extremamente úteis para se fazer adequadamente a reavaliação do comportamento estrutural da peça antes e após a reabilitação. Dentre estas informações pode-se citar: o estágio de conhecimento disponível sobre o assunto, as características que o material do reforço deve ter, a forma de preparo do substrato, métodos de previsão do comportamento de peças reforçadas e os resultados de estudos experimentais realizados por diversos pesquisadores.

$>$ Conseguiu-se, a partir de uma série de estudos teóricos nem sempre relacionados diretamente à área de reabilitação de estruturas, compatibilizar, integrar e sistematizar alguns dos conhecimentos teóricos existentes e fim de se estabelecer os fundamentos necessários às análises teóricas das vigas reforçadas, em função dos parâmetros analisados no programa experimental. 
$>$ Os ensaios complementares, necessários ao dimensionamento das vigas reforçadas pelas técnicas propostas, forneceram informações importantes tanto sobre as características das fibras de aço a serem adicionadas à argamassa de reforço das vigas VFT, quanto à deformabilidade do concreto do substrato e do reforço usada na avaliação da retração e fluência das vigas VFC.

Os resultados dos ensaios experimentais foram consistentes e de boa qualidade, constituindo-se em um conjunto de informações valiosas tanto sobre as características dos materiais usados no reforço, quanto ao comportamento estrutural das vigas reforçadas. Tais resultados podem ser utilizados inclusive na calibração e aferição de modelos teóricos a serem desenvolvidos em trabalhos futuros.

> Apesar dos casos investigados nesta pesquisa se restringirem a ensaios de vigas biapoiadas sujeitas à forças concentradas, acredita-se que algumas das conclusões obtidas possam, até certo ponto, ser úteis na avaliação do comportamento de estruturas reabilitadas em edifícios, assim como em pontes e viadutos.

\subsection{Sobre os ensaios complementares ao estudo da Técnica de Reforço $n^{0} 1$}

A realização de ensaios complementares ao estudo da Técnica de Reforço $\mathrm{n}^{\circ} 1$ permitiu concluir que:

Ensaios de flexão em prismas e ensaios de vigas retangulares de pequenas dimensões possibilitam conhecer melhor mecanismos resistentes específicos, como o de transmissão de esforços de cisalhamento, sem a necessidade de testar modelos físicos completos, maiores e de custo mais elevado. Com ensaios mais simples, é possível identificar, dentre as várias fibras disponíveis comercialmente, qual a que apresentaria um melhor desempenho para ser usada na confecção do material compósito empregado 
na reconstrução do bordo tracionado das vigas. Entretanto, uma metodologia mais precisa e detalhada merece ser desenvolvida.

A partir dos resultados obtidos, comentários mais detalhados podem ser feitos:

> Os ensaios à flexão de prismas de material compósito indicaram que foi a fibra RC-65/35 que proporcionou maior ductilidade ao material compósito, mas que foi a fibra RL-45/30 que proporcionou maiores aumentos de resistência à tração na flexão. Observou-se ainda que a resistência à tração na flexão aumentava linearmente com o aumento da taxa de fibras usada no compósito. Ressalta-se que a resistência à tração na flexão de um compósito atinge seu valor máximo quando se utiliza o volume crítico de fibras.

> A influência do tipo e do teor de fibras de aço na resistência à tração de materiais compósitos deve ser avaliada através de ensaios de prismas à flexão e não através de ensaios de tração por compressão diametral. Isso porque esse último é mais suscetível a erros de execução e moldagem, além das solicitações aplicadas no corpo-de-prova do compósito serem diferentes das que atuam nas aplicações práticas.

Os ensaios de vigas retangulares de pequenas dimensões confirmaram que o uso de um material compósito realmente aumenta a capacidade portante de peças que romperiam por cisalhamento horizontal pelo fato das barras de aço tracionadas não estarem envolvidas por estribos. Pode-se dizer então que as fibras de aço adicionadas ao compósito afetam os mecanismos resistentes mobilizados no local, aumentando a resistência desta região em função do tipo e da taxa de fibra utilizada. Dependendo das características da viga verificou-se que existe um limite máximo a partir do qual o aumento da taxa de fibra não mais eleva a capacidade portante da peça devido à alteração de seu modo de 
ruptura. Por estes ensaios, verificou-se que a fibra de aço mais eficiente no combate a este tipo de ruptura foi a RL-45/30.

Os ensaios realizados não possibilitaram identificar qual o teor mais adequado de fibras a ser adicionado ao compósito. Por outro lado, isso depende não apenas do material compósito usado mas também das características da peça reforçada (p. ex. bitola das armaduras longitudinais, espaçamento entre as barras da primeira e segunda camada e outros). Sendo assim, ainda são necessários mais estudos a fim de desenvolver uma metodologia que permita avaliar os efeitos das fibras de aço nos mecanismos de resistência mobilizados na transmissão de esforços de cisalhamento entre barras de aço tracionadas não envolvidas por estribos.

\subsection{Sobre o comportamento das vigas reforçadas pela Técnica de Reforço $\mathrm{n}^{0} 1$}

Os resultados desta série de ensaios permitiram concluir que:

A técnica proposta mostrou ser potencialmente viável, independentemente da viga ter sido ou não reforçada sob pré-carregamento. Para esta técnica de reforço ser eficiente, é preciso que os estribos existentes na viga antes da intervenção permaneçam ancorados ao banzo tracionado reconstituido - desta forma estes funcionam como armadura de costura evitando a ruptura na junta - e que a ruptura interna por cisalhamento longitudinal entre as camadas de barras de aço tracionadas não envolvidas por estribos, seja evitada pela adição adequada de fibras de aço ao material compósito.

Isso pode ser confirmado a partir das seguintes considerações:

O pré-carregamento aplicado durante a execução do reforço não foi suficiente para afetar a capacidade portante das vigas VFT. Entretanto, dependendo do valor deste pré-carregamento e das características da viga a ser reforçada, há a 
possibilidade de ruptura prematura da peça. Como o valor do pré-carregamento geralmente corresponde à parcela de carga permanente, nos elementos a serem reforçados cuja sobrecarga seja preponderante ao peso próprio, o risco de ocorrer ruptura prematura do material do substrato é menor.

> É possível avaliar teoricamente as flechas e os estados de tensão e deformação de peças reforçadas sob carga. Esta avaliação pode ser feita usando métodos numéricos, baseados no método dos elementos finitos, ou usando métodos simplificados propostos por normas, desde que devidamente adaptados. Este tipo de análise é essencial para que se possa dimensionar o reforço de maneira segura e econômica, evitando que seja atingido algum estado limite precocemente ao aumentar o carregamento após o reforço.

A verificação do uso dos estribos como armadura de costura pode ser feita comparando-se as tensões tangenciais solicitantes na junta, com sua resistência ao cisalhamento longitudinal. Estes parâmetros podem ser calculados utilizando-se normas específicas para estruturas compostas pré-moldadas.

A necessidade de se ter estribos cruzando a junta é mais crítica nos trechos submetidos a maiores esforços cortantes, conseqüentemente pode-se ter vigas reforçadas com juntas de alturas diferentes, conforme a necessidade ou não da armadura de costura. Isso facilita o processo executivo do reforço uma vez que não é necessário demolir todo o bordo tracionado da peça mas apenas aqueles trechos onde as tensões tangenciais são críticas.

Nas vigas reabilitadas sob carga, a substituição de parte do material do banzo tracionado antigo - provavelmente já fissurado - por um material novo, beneficiou a resistência ao cisalhamento da peça. Isso porque o novo banzo tracionado, constituído por concreto íntegro, não está sujeito aos esforços gerados pelo pré-carregamento, sendo seu reinício de fissuração ao 
cisalhamento determinado em função da diferença entre a força total aplicada na viga após o reforço e força atuante no instante da reabilitação.

\subsection{Sobre os ensaios complementares ao estudo da Técnica de Reforço $\mathrm{n}^{\circ} 2$}

A partir dos ensaios complementares ao estudo da técnica de reforço $n^{0} 2$ concluiu-se que:

É possível determinar expressões matemáticas representativas da deformabilidade do concreto ao longo do tempo através do ajuste de curvas experimentais, obtidas em ensaios de fluência, retração, coeficiente de dilatação térmica, módulo de elasticidade e resistência à compressão. A caracterização desta deformabilidade é especialmente interessante quando se deseja analisar os efeitos das deformações dependentes do tempo no desempenho de peças reforçadas no bordo comprimido.

A seguir destaca-se alguns comentários a respeito da análise da deformabilidade:

As deformações experimentais, coletadas durante a caracterização da deformabilidade do concreto ao longo do tempo, são muito pequenas. Logo, para se ter confiabilidade nos resultados obtidos é preciso que os corpos-deprova sejam armazenados em condições controladas de temperatura e umidade, além de ser necessário dispor de equipamentos específicos e de um corpo técnico bem treinado.

Os resultados experimentais podem ser usados para identificar, dentre uma série de normas técnicas pré-selecionadas, aquela que possibilita avaliar, com maior precisão, a deformabilidade ao longo do tempo dos materiais cimentícios analisados. Os resultados desta pesquisa mostraram que, dentre as várias formulações teóricas analisadas, foi a da NBR-6118 (2003) que apresentou 
resultados mais adequados, sendo portanto a usada na avaliação teórica da deformabilidade do concreto das vigas VFC.

\subsection{Sobre o comportamento das vigas reforçadas pela Técnica de Reforço $n^{0} 2$}

Os resultados desta série de ensaios permitiram concluir que:

Estando ou não a viga pré-carregada durante a execução do reforço, $e$ independentemente do período de tempo em que esta solicitação permaneceu atuando, a reabilitação de vigas por meio da técnica de reforço $n^{\circ} 2$ mostrou ser eficiente e viável. Esta técnica é particularmente interessante para vigas com falhas na resistência do banzo comprimido (vigas superarmadas), pois o acréscimo de uma camada de microconcreto de pequena espessura a este banzo pode aumentar a resistência da peça em até 90\%. Para dimensionar esse tipo de reforço, pode-se contar com a redução das tensões do concreto comprimido do substrato em função da fluência do material.

Isso pode ser confirmado a partir das seguintes considerações:

Os pré-carregamentos aplicados nas vigas VFC-1 e VFC-2 aparentemente não afetaram suas resistências, pois ambas romperam para uma força próxima à da peça reforçada sem carregamento (VFC-2), apresentando o mesmo modo de ruptura e o mesmo panorama de fissuração.

Apesar de terem aparecido fissuras horizontais na junta de ligação entre o substrato e o reforço, indicando uma perda parcial de aderência neste local, isso não chegou a prejudicar a resistência das vigas. Esta perda de aderência pode ser facilmente evitada utilizando-se uma armadura de costura dimensionada utilizando as mesmas normas usadas em peças pré-moldadas compostas. 
$>$ Para estimar a deformação do concreto ao longo do tempo, $\varepsilon_{\mathrm{c}}(\mathrm{t})$, é preciso conhecer o valor da tensão $\sigma_{\mathrm{c}}$ atuante na fibra do concreto comprimido no instante $t$ analisado. Para vigas com carregamento constante, existem métodos relativamente simples capazes de estimar a variação desta tensão com o tempo, uma vez que esta ocorre basicamente por causa da fluência do concreto comprimido. Entretanto, para vigas com carregamento variável, a avaliação dessa tensão é mais complexa, sendo necessário usar programas computacionais, semelhantes ao CONSNOU, já que sua variação ao longo do tempo ocorre simultaneamente por causa da fluência e da alteração do carregamento aplicado.

Apesar das vigas ensaiadas na EESC estarem sujeitas a condições ambientais mais severas que os corpos-de-prova ensaiados em FURNAS - e que foram usados na obtenção de expressões matemáticas representativas da deformabilidade dos concretos - a determinação teórica das deformações diferidas dos concretos comprimidos das vigas VFC usando este método foi bastante satisfatória.

As deformações diferidas dos concretos comprimidos do substrato e do reforço das vigas VFC foram avaliadas adequadamente, independentemente do método teórico usado (formulação da NBR-6118[2003], simulação numérica ou expressões matemáticas obtidas a partir do ajuste de curvas experimentais).

$>$ Durante a realização do ensaio final (acréscimo de carregamento) verificou-se que, por causa dos efeitos da fluência do substrato nas vigas VFC reforçadas sob carga, o fato do concreto comprimido do substrato ter uma deformação maior que o microconcreto do reforço, não significava necessariamente que ele tivesse submetido a uma tensão maior. 
$>$ Como a fluência do concreto comprimido do substrato provoca uma redução da tensão neste material com o tempo, parece ser possível contar com o efeito benéfico dessa redução no redimensionamento de peças reforçadas précarregadas sujeitas a ações de longa duração, pois isso pode gerar economia durante o projeto da intervenção.

Foi possível prever satisfatoriamente as flechas de longa duração, observadas nas vigas VFC-1 e VFC-3, seguindo as recomendações das normas brasileiras NBR-6118 (1978) e NBR-6118 (2003), e por meio da simulação numérica realizada pelo programa CONSNOU.

O programa CONSNOU mostrou ser uma ferramenta extremamente útil na avaliação teórica do comportamento de vigas reforçadas pré-carregadas submetidas a ações de longa duração. Apesar dos valores teóricos (deformações dos materiais ou flechas) nem sempre estarem próximos dos experimentais, as curvas teóricas obtidas, tanto em função do tempo quanto em função da força aplicada, possuíam trajetórias semelhantes às das curvas experimentais, uma vez que as diferenças foram causadas principalmente pela subestimação dos valores iniciais, observados imediatamente após a aplicação de um carregamento. Isso pode ter ocorrido em função da adoção do módulo de elasticidade do concreto aos 28 dias, na avaliação do comportamento das estruturas. Em estudos futuros talvez seja possível verificar a influência desta propriedade mecânica nos resultados teóricos, e assim recomendar algum tipo de ajuste nesta propriedade antes de se realizar a simulação numérica.

\subsection{Sugestões para pesquisas futuras}

Em função das observações, estudos e análises feitas ao longo do trabalho é possível propor vários temas para a continuidade desta pesquisa tais como: 
$>$ Realização de estudos similares destinados a avaliar o comportamento e o desempenho das vigas reabilitadas pelas Técnicas de Reforço $\mathrm{n}^{\mathrm{o}} 1$ e $\mathrm{n}^{\mathrm{o}} 2$ quando se tem situações de carregamento cíclico, já que este tipo de solicitação é usual em casos de vigas de pontes ou passarelas;

> Identificação de mecanismos de resistência e desenvolvimento de ensaios experimentais que permitam o estabelecimento de correlações entre $o$ comportamento de prismas compósitos ensaiados à flexão, de vigas retangulares de pequenas dimensões confeccionadas com o material compósito e as vigas de tamanho real à serem reforçadas no bordo tracionado utilizando tal compósito, para o estabelecimento e calibração de modelos teóricos;

$>$ Realização de mais estudos experimentais, variando-se a taxa de armadura longitudinal, o teor de fibra adicionado à argamassa, a resistência do concreto, o efeito da espessura do cobrimento, e a distância entre as camadas das armaduras tracionadas a fim de desenvolver um processo empírico no qual se possa identificar qual o teor e o tipo de fibras mais adequado a ser adicionado à argamassa do reforço (material compósito) em função das características da viga a ser reabilitada pela Técnica de Reforço $\mathrm{n}^{\mathrm{o}} 1$;

Realização de estudos similares ao executados no bordo comprimido de elementos fletidos (Técnica de Reforço $n^{\circ} 2$ ), deixando-se os modelos por mais tempo armazenados na câmara climatizada, para que a diferença de idade entre o substrato e o reforço seja maior de maneira a evidenciar ainda mais o efeito da fluência no comportamento do elemento reabilitado;

Realização de novos ensaios experimentais utilizando as Técnicas de Reforço $\mathrm{n}^{\mathrm{o}} 1$ e $\mathrm{n}^{\mathrm{o}} 2$ variando-se o valor do pré-carregamento aplicado a fim de obter mais dados sobre sua influência no desempenho de elementos fletidos reabilitados; 


\section{Bibliografia}

ALMEIDA, T.G.M. (2001). Reforço de vigas de concreto armado por meio de cabos externos protendidos. São Carlos. Dissertação (Mestrado) - Escola de Engenharia de São Carlos, Universidade de São Paulo.

AMERICAN CONCRETE INSTITUTE (1983). ACI 318M/83 - Building code requirements for reinforced concrete. Manual of concrete practice. Detroit, USA.

AMERICAN CONCRETE INSTITUTE (1992). ACI 209R/92 - Prediction of creep, shrinkage, and temperature effects in concrete structures. Detroit, USA.

ARAÚJO, D.L. (1997). Cisalhamento na interface entre concreto pré-moldado e concreto moldado no local em elementos submetidos à flexão. São Carlos. Dissertação (Mestrado) - Escola de Engenharia de São Carlos, Universidade de São Paulo.

ARAÚJO, D.L.; EL DEBS, M.K. (1997). Cisalhamento na interface entre concreto pré-moldado e concreto moldado no local em vigas submetidas à flexão: comparação de valores teóricos e experimentais. In: XXVIII JORNADAS SUL AMERICANAS DE ENGENHARIA ESTRUTURAL. Anais. São Carlos, SP, Brasil, 1997.

ASSOCIAÇÃO BRASILEIRA DE NORMAS TÉCNICAS - (1980). NBR 5739 Ensaio de compressão de corpos-de-prova cilíndricos de concreto - Método de ensaio. Rio de Janeiro.

ASSOCIAÇÃO BRASILEIRA DE NORMAS TÉCNICAS - (1978). NBR 6118 Projeto e execução de obras em concreto armado. Rio de Janeiro.

ASSOCIAÇÃO BRASILEIRA DE NORMAS TÉCNICAS - (2003). NBR 6118 Projeto de estruturas de concreto - Procedimento. Rio de Janeiro. 
ASSOCIAÇÃO BRASILEIRA DE NORMAS TÉCNICAS - (1980). NBR 6152 Material metálico - determinação das propriedades mecânicas à tração - método de ensaio . Rio de Janeiro.

ASSOCIAÇÃO BRASILEIRA DE NORMAS TÉCNICAS - (1989). NBR 7197 Projeto de estruturas de concreto protendido - Procedimento. Rio de Janeiro.

ASSOCIAÇÃO BRASILEIRA DE NORMAS TÉCNICAS - (1983). NBR 7222 Argamassa e concreto - determinação da resistência à tração por compressão diametral de corpos-de-prova cilíndricos - Método de ensaio. Rio de Janeiro.

ASSOCIAÇÃO BRASILEIRA DE NORMAS TÉCNICAS - (1985). NBR 7480 Barras e fios de aço destinados a armaduras para concreto armado Especificação. Rio de Janeiro.

ASSOCIAÇÃO BRASILEIRA DE NORMAS TÉCNICAS - (1983). NBR 8224 Concreto endurecido - determinação da fluência. Rio de Janeiro.

ASSOCIAÇÃO BRASILEIRA DE NORMAS TÉCNICAS - (1984). NBR 8522 Concreto - Determinação do módulo de deformação estático e diagrama tensãodeformação - Método de ensaio. Rio de Janeiro.

ASSOCIAÇÃO BRASILEIRA DE NORMAS TÉCNICAS - (1985). NBR 9062 Projeto e execução de estruturas de concreto pré-moldado. Rio de Janeiro.

ASSOCIAÇÃO BRASILEIRA DE NORMAS TÉCNICAS - (1991). NBR 12142 Concreto - Determinação da resistência à tração na flexão em corpos-de-prova prismáticos - Método de Ensaio. Rio de Janeiro.

ASSOCIAÇÃO BRASILEIRA DE NORMAS TÉCNICAS - (1994). NBR 12815 Concreto endurecido - Determinação do coeficiente de dilatação térmica linear Método de Ensaio. Rio de Janeiro.

AMERICAN SOCIETY FOR TESTING AND MATERIALS (1994). ASTM C78/94 - Standard test method for Flexural Strength of Concrete (using simple beam with third-point loading). Philadelphia.

AMERICAN SOCIETY FOR TESTING AND MATERIALS (1994). ASTM C1018/94b - Standard test method for flexural toughness and first-crack strength of fiber-reinforced concrete (using beam with third-point loading). Philadelphia. 
AMERICAN SOCIETY FOR TESTING AND MATERIALS (1995). ASTM C1116 - Standard specification for fiber-reinforced concrete and shotcrete. Philadelphia.

BALAGURU, P.N.; SHAH, S.P. (1992). Fiber reinforced cement composites. New York, McGraw-Hill International Editions.

BENTUR, A.; MINDESS, S. (1990). Fibre reinforced cementitious composites. New York, Elsevier Applied Science.

BERNAT, A.R.M. (1998). Programa CONSNOU - Para el análisis no lineal en el tiempo de estructuras de hormigón estructural construidas evolutivamente. (Manual de utilização do programa CONSNOU). Barcelona, Espanha.

BRITISH STANDARDS INSTITUTION (1985). BS 8110 - Structural use of concrete. part.1, p. 101; part.2, p.41. London.

CAIRNS, J. (1996). Alternative strategies for temporary support during structural repair of reinforced-concrete beams Journal of Structural Engineering, p.238-246, march.

CAIRNS, J.; ZHAO, Z. (1993). Behavior of concrete beams with exposed reinforcement Proceedings Institute of Civil Engineering - Structures and Buildings, v.99, p.141-154, maio.

CAMPOS, C. O. (2000). Análise experimental de lajes de concreto armado reforçadas pela face superior. Goiânia. Dissertação (Mestrado) - Escola de Engenharia Civil, Universidade Federal de Goiás.

CAMPOS FILHO, A. et al. (2000). Análise de peças reforçadas de concreto armado através do método dos elementos finitos. In: XXIX JORNADAS SUDAMERICANAS DE INGENIERIA ESTRUCTURAL. Anais (CD-ROM). Punta Del Este, Uruguay, 2000.

CÁNOVAS, M.F.(1988). Patologia e Terapia do Concreto Armado. São Paulo, Pini.

CARBONARI, G.; AGUADO, A.; GETTU, R. (1997). Proposta de uma metodologia para a obtenção do comportamento de longa duração de estruturas de concreto: estudo de caso para vigas com $\mathrm{f}_{\mathrm{c}}=65 \mathrm{MPa}$. In: XXVIII JORNADAS SULAMERICANAS DE ENGENHARIA ESTRUTURAL. Anais. São Carlos, SP, Brasil, 1997. 
CARBONARI, G.; AGUADO, A.; GETTU, R. (1997). Redução das deformações de longa duração utilizando C.A.D. e proteção de secagem. In: IV CONGRESSO IBEROAMERICANO DE PATOLOGIA DAS CONSTRUÇÕES / VI CONGRESSO DE CONTROLE DE QUALIDADE. Anais. Porto Alegre, Brasil, 1997.

CASTRO, C. H.; NASCIMENTO, J. F. F.; PINTO, R. S. P.; ANDRADE, W. P. (1999). Reparos em estruturas de concreto - avaliação da eficiência de resinas epóxi. In: $41^{\circ}$ CONGRESSO BRASILEIRO DO CONCRETO - IBRACON. Anais (CD-ROM). Salvador, Brasil, 1999.

CATELLI JR., C.A. (1998). Determinação de propriedades mecânicas de concreto com fibras de aço. São Paulo. Relatório de Iniciação Científica - Escola de Engenharia de São Carlos, Universidade de São Paulo.

CLÍMACO, J.C.T. (1990). Repair of Structural Concrete Involving the Addition of New Concrete. Londres. Tese (Doutorado) - Polytechnic of Central London, U.K.

CLÍMACO, J.C.T. (1991). Uma análise crítica dos métodos de avaliação de aderência e do uso de agentes adesivos no reparo de estruturas de concreto. In: XXV JORNADAS SUL-AMERICANAS DE ENGENHARIA ESTRUTURAL. Anais. Porto Alegre, Brasil, 1991.

CLÍMACO, J.C.T. (1995). Reforço à flexão de vigas de concreto armado envolvendo a adição de concreto novo. In: XXVII JORNADAS SUDAMERICANAS DE INGENIERIA ESTRUCTURAL. Anais. Tucumán, Argentina, 1995.

COMITE EURO-INTERNATIONAL DU BETON (1991). CEB-FIP model code 1990 - final draft. Bulletin d'Information $n^{\circ}$ 203/205.

COMITE EURO-INTERNATIONAL DU BETON (1983). Assessment of concrete structures and design procedures for upgrading (redesign). Bulletin d'Information $n^{\circ} .162$.

CUSSON, D.; MAILVAGANAM, N. (1996). Durability of repair materials. Concrete International, v.18, n.3, p.34-38, mar.

DAL MOLIN, D.C.; VIEIRA, F.M.P.; WOLF, J (1997). Concreto de Alta Resistência. Artigo apresentado em palestra na EESC-USP, São Carlos, 1997.

DIAB, Y. G. (1998). Strengthening of RC beams by using sprayed concrete: experimental approach. Engineering Structures, v.20, n.7, p.631-643. 
EL DEBS, M.K. (2000). Concreto Pré-moldado: Fundamentos e Aplicações. São Carlos, publicação EESC-USP.

EMBERSON, N.K. ; MAYS, G.C. (1996). Significance of property mismatch in the patch repair of structural concrete. Part 3: Reinforced concrete members in flexure. Magazine of Concrete Research, v. 48, no 174, p. 45-57, march. 1996.

EUROCÓDIGO No 2 (1993). Proyecto de estructuras de hormigón. Parte-1: Reglas generales y reglas para edificación. UNE ENV 1992-1-1.

EYRE, J. R.; NOKHASTEH, M. A. (1992). Strength assessment of corrosion damaged reinforced concrete slabs and beams. Proceedings Institute of Civil Engineering - Structures and Buildings, v.94, p.197-203, maio.

FÉDÉRATION INTERNATIONA DE LA PRÉCONTRAINTE (1982). Shear at the interface of precast and in situ concrete: FIP guide to good practice. Wexham Springs, Cement and Concrete Association.

FÉDÉRATION INTERNATIONA DU BÉTON - FIB (1999). Structural concrete. Updated knowledge of the CEB/FIP model code 1990. Textbook on behavior, design and performance. fib Bulletin, Lausanne, Switzerland, n.1-3. (3 volumes).

FIGUEIREDO, D.C.C. (1995). Parâmetros de Controle e Dosagem de Concreto projetado com fibras de aço. São Paulo. 342p. Tese (Doutorado) - Escola Politécnica, Universidade de São Paulo .

FONTOURA, J.T; GAMBALE, E. A. (1994). Modelos matemáticos para representar a fluência do concreto. Revista IBRACON, v 4, n.11, dezembro.

FURLAN JR, S. (1995). Vigas de concreto com taxas reduzidas de armadura de cisalhamento: influência do emprego de fibras curtas e de protensão. São Carlos. Tese (Doutorado) - Escola de Engenharia de São Carlos, Universidade de São Paulo.

FURNAS CENTRAIS ELÉTRICAS S.A. (1997). ANDRADE, W.P. Concretos: Massa, Estrutural, Projetado e Compactado com rolo - Ensaios e Propriedades. São Paulo, Pini.

GHALI, A.; FAVRE, R. (1989). Concrete Structures: Stresses and Deformations. London/New York, Chapman and Hall. 351p. 
GUTIÉRREZ, S. E.; CUDMANI, R. O.; DANESI, R. F. (1996). Time-dependent analysis of reinforced and prestressed concrete members. ACI Structural Journal, v.93, n.4, p.420-427, julho-agosto.

HARAJLI, M.H (1994). Development splice strength of reinforcing bars embedded in plain and fiber reinforced concrete. ACI Structural Journal, v.91, n.5, p.511520, setembro-outubro.

HARAJLI, M.H.; HOUT, M.; JALKH, W. (1995). Local bond stress-slip behavior of reinforcing bars embedded in plain and fiber concrete. ACI Materials Journal, v.92, n.4, p.343-354, julho-agosto.

HARAJLI, M.H.; SALLOUKH, K. A. (1997). Effect of fibers on development splice strength of reinforcing bars in tension. ACI Materials Journal, v.92, n.4, p.317324 , julho-agosto.

HELENE, P.R.L. (1992). Manual para Reparo, Reforço e Proteção de Estruturas de Concreto. São Paulo, Pini.

HSU, T.T.C.; MAU, S.T.; CHEN, B. (1987). Theory of shear transfer strength of reinforced concrete. ACI Structural Journal, v.84, n.2, p.149-160, maio-abril.

JAPAN SOCIETY OF CIVIL ENGINEERS (1984). JSCE-SF4 - part III-2 - Method of tests for steel fiber reinforced concrete.

KALINTZIS, C.A. (2000). Estudo da fluência do concreto de elevado desempenho, São Paulo. Dissertação (Mestrado) - Escola Politécnica, Universidade de São Paulo.

KOH, C.G.; ANG K.K.; ZHANG L. (1997). Effects of repeated loading on creep deflection of reinforced concrete beams. Engineering Structures, v. 19 n ${ }^{\circ}$, p. 2-18, 1997.

MARÍ, A.R.; SERRA, I. (1994). Métodos simplificados para el cálculo de flechas diferidas. Trabalho desenvolvido pelo Grupo Español del Hormigón - Grupo de trabajo: GT III-1 - Flechas. Barcelona, Espanha.

MARÍ, A.R.(1994). Simplified method for the calculation of deflections in reinforced concrete beams and one way slabs. Informe interno - Departamento de Ingeniería de la Construcción, Universitat Politecnica de Catalunya. Barcelona, Espanha.

MATTOCK, A.H. (1987). Anchorage of stirrups in a thin cast-in-place topping. PCI Journal, v.32, n.1, p.70-85, nov-dec. 
MATTOCK, A.H. (1988). Comments of "Influence of concrete strength and load history on the shear friction capacity of concrete members". PCI Journal, v.33, n.1, p.166-168, jan-feb. / paper by J. Walraven, et al. PCI Journal, v.32, n.1, p.6684 , jan-feb.

MATTOCK, A.H. (1994). Comments of "Horizontal shear strength of composite concrete beams with a rough interface" PCI Journal, v.39, n.5, p.106-108, september-october / paper by R.E. Loov. A.K. Patnaik, PCI Journal, v.39, n.1, p.48-69, january-february

MEHTA, P.K.; MONTEIRO, P.J.M.(1994). Concreto: estrutura, propriedades e materiais. São Paulo, Pini.

MENDES, J. A. (1993). Cálculo automático de perdas progressivas em peças de concreto protendido. São Carlos. Tese (Doutorado) - Escola de Engenharia de São Carlos, Universidade de São Paulo.

MORAES, A.F. (1985). Técnicas e procedimentos para serviços de recuperação e reforço de estruturas em concreto armado - aspectos práticos. Niterói. Dissertação (Mestrado) - Universidade Federal Fluminense.

MORAIS, M. C. (1997). Reforço de vigas de concreto. Rio de Janeiro. Dissertação (Mestrado) - COPPE, Universidade Federal do Rio de Janeiro.

MOREIRA, M.M.M. (2002). Análise interativa de situações de reforço e recuperação de peças de concreto armado, empregando o método dos elementos finitos. Porto Alegre. Dissertação (Mestrado) - PPGEC, Universidade Federal do Rio Grande do Sul.

MURCIA, J. (2000). Cálculo prático de flechas diferidas en estructuras de hormigón armado. Hormigón y Acero, n.215, p.103-108, $1^{\circ}$ trimestre, 2000.

NEVILle, A. M. (1997). Concreto de Alto Desempenho - Visão Atual. Artigo apresentado no $39^{\circ}$ Congresso Brasileiro do Concreto - IBRACON. São Paulo.

NUNES, N. L. (1998). Estudo da influência da geometria da fibra de aço na tenacidade à flexão dos compósitos de matriz de concreto. São Paulo. 193p. Dissertação (Mestrado) - Escola Politécnica, Universidade de São Paulo.

NUNES, N.L.; TANESI, J.; FIGUEIREDO, A.D. (1997). Aplicação do concreto reforçado com fibras de aço na recuperação de estruturas e pavimentos. In: IV CONCRESSO IBEROAMERICANO DE PATOLOGIA DAS CONSTUÇÕES E 
VI CONGRESSO DE CONTROLE DE QUALIDADE. Anais. Porto Alegre, Brasil, 1997.

OLIVEIRA, R.S. (2000). Análise de pavimentos de edifícios de concreto armado com a consideração da não-linearidade física - modelagem e metodologia de aplicação a projetos. São Carlos. Tese (Doutorado) - Escola de Engenharia de São Carlos, Universidade de São Paulo.

ONG, K.C.G.; PARAMASIVAM, P.; LIM C.T.E. (1992). Flexural strengthening of reinforced concrete beams using ferrocement laminates. Journal of Ferrocement, v.22, n. 4, p. 331-342, outubro.

PARAMASIVAM, P.; LIM, C.T.E.; ONG, K.C.G. (1998). Strengthening of RC beams with ferrocement laminates. Cement and Concrete Composites, v.20, p. 5365 .

PARAMASIVAM, P.; ONG, K.C.G.; LIM C.T.E. (1994). Ferrocement laminates for strengthening of RC T-beams. Cement \& Concrete Composites, v.16, p. 143-152.

PATNAIK, A.H. (1992). Horizontal shear strength of composite concrete beams with a rough interface. Calgary, Canada. Tese (Doutorado) - University of Calgary.

PIANCASTELLI, E.M.; CALIXTO, J.M.F. (1995). Comportamento estrutura, a baixa idade, de vigas de concreto armado reforçadas através do aumento das seções de concreto e aço. In: XXVII JORNADAS SUDAMERICANAS DE INGENIERIA ESTRUCTURAL. Anais. Tucumán, Argentina, 1995.

PIANCASTELLI, E.M.; CALIXTO, J.M.F. (1997). Dimensionamento de reforço à flexão, executado sob carga, de vigas de concreto armado: aplicabilidade dos critérios da NBR-6118. In: XXVIII JORNADAS SUL-AMERICANAS DE ENGENHARIA ESTRUTURAL. Anais. São Carlos, Brasil, 1997.

PIANCASTELLI, E.M. (1997). Comportamento e desempenho do reforço à flexão de vigas de concreto armado, solicitado a baixa idade e executado inclusive sob carga. Belo Horizonte. Dissertação (Mestrado) - Departamento de Engenharia de Estruturas, Universidade Federal de Minas Gerais.

PINHEIRO, L.M.; FERNANDES, S.A.(1993). Estudo comparativo do cálculo da retração e da fluência. In: III SIMPÓSIO EPUSP SOBRE ESTRUTURAS DE CONCRETO. Anais. São Paulo, SP.

PRECAST / PRESTRESSED CONCRETE INSTITUTE (1992). PCI Design Handbook: Precast and Prestressed Concrete. 4ed. PCI. Chicago, USA. 
RAHMAN, M.A. ; AYANO, T.; SAKATA, K. (1998). The use of physical phenomena to predict time effects in cracked reinforced concrete beams. Magazine of Concrete Research, v.50, n.3, p.219-227, september.

REIS, A.P.A., (1998) Reforço de vigas de concreto armado por meio de barras de aço adicionais ou chapas de aço e argamassa de alto desempenho. São Carlos. Dissertação (Mestrado) - Escola de Engenharia de São Carlos, Universidade de São Paulo.

REIS, A.P.A.; HANAI, J.B. (2002) Reforço do banzo tracionado de vigas de concreto armado pré-carregadas por adição de armadura e argamassa com fibras de aço. In: XXX JORNADAS SUL-AMERICANAS DE ENGENHARIA ESTRUTURAL. Anais (CD-ROM). Brasília, Brasil, 2002.

ROCHA, C.C (1995). Compatibilizando o novo material com o local da recuperação. Recuperar, $\mathrm{n}^{\mathrm{o}}$ 6. p 23-25. jul/ago.

ROCHA, C.C (1996). Compatibilidade. Recuperar, p 22-26. nº 11. maio/jun.

RODRIGUES, F.L. (1996). Estudo do dimensionamento do reforço por encamisamento aplicado a vigas de concreto armado. Niterói, RJ. Dissertação (Mestrado) - Universidade Federal Fluminense.

SÁ, M.A. (1993). Verificação da eficiência da ligação entre dois concretos sem o emprego de adesivos em elementos estruturais fletidos. Niterói, RJ. Dissertação (Mestrado) - Universidade Federal Fluminense.

SAIIDI, M.; VRONTINOS, S.; DOUGLAS, B. (1990). Model for the response of reinforced concrete beams strengthened by concrete overlays. ACI Structural Journal. v.87, $\mathrm{n}^{\circ}$ 6, p. 687-695, november-december.

SALLES, M.T. (1992). Estudo da ligação concreto novo-concreto velho para aplicação ao reforço de peças fletidas. Niterói, RJ. Dissertação (Mestrado) Universidade Federal Fluminense.

SAMEN EZELDIN, A.; BALAGURU, P. N. (1989). Bond behavior of normal and high-strength fiber reinforced concrete. ACI Materials Journal, v.86, n.6, p.515524, setembro-outubro.

SAMRA, R. M. (1997). Renewed assessment of creep and shrinkage effects in reinforced concrete beams. ACI Structural Journal, v.94, n.6, p.745-751, november-december, 1997. 
SAMRA, R. M. (1997). Time-dependent deflections of reinforced concrete beams revisited. Journal of Structural Engineering, p.823-830, june, 1997.

SHARMA, A. K. (1992). Test of reinforced concrete continuous beams repaired with and without fibro-ferrocrete. Concrete International, p.36-40, march, 1992.

SILFWERBRAND, J. (1997). Stresses and strains in composite concrete beams subjected to differential shrinkage. ACI Structural Journal, no 94-S31, july-august 1997.

SOUZA, R.H.F. (1990). Análise do Comportamento de vigas de betão armado reforçadas à flexão e ao esforço transverso. Lisboa. Tese (Doutorado) Universidade Técnica de Lisboa.

SOUZA, V.C.M.; RIPPER, T (1998). Patologia recuperação e reforço de estruturas de concreto. São Paulo, $1^{\mathrm{a}}$ edição, Pini.

SUMIE, A.E.; LOPES, M. A. (2000). Reforço à flexão de vigas em concreto armado pelo acréscimo de altura na região comprimida, utilizando-se concreto de alta resistência. In: $42^{\circ}$ CONGRESSO BRASILEIRO DO CONCRETO - IBRACON. Anais (CD-ROM). Fortaleza, Brasil.

SWAMY, R.N.; BAHIA, H.M. (1979). Influence of fiber reinforcement on the dowel resistance to shear. ACI Journal, Proceedings, v.76, n.2, p.327-355, february.

TAN K.H., PARAMASIVAM P.; TAN K.C.(1995). Cracking Characteristics of Reinforced Steel Fiber Concrete Beams under Short- and Long-Term Loadings. Advn. Cem. Bas. Mat.., n 2, p.127-137.

TASSIOS, T.P.; VINTZELEOU, E.N. (1990). Shear crack stability along a precast reinforced concrete joint. In: CARPINTERI, A., ed. Applications of fracture mechanics to reinforced concrete. Essex, Elsevier Applied Science. p.365-486.

TASSIOS,T.P.; VINTZELEOU, E.N. (1987). Concrete-to-concrete friction. Journal of Structural Engineering, ASCE, v.113, n.4, p.832-849, april.

TIMOSHENKO; GERE (1984). Mecânica dos Sólidos. v.1. $1^{\text {a }}$ edição. Rio de Janeiro, Livros Técnicos e Científicos.

TOMAZ, E.(1989). Trincas em Edifícios - Causas, Prevenção e recuperação. $1^{\mathrm{a}}$ edição. São Paulo, Pini. 
TRIKHA, D.N.; JAIN, S.C.; HALI, S.K. (1991). Repair and strengthening of damaged concrete beams. Concrete International, p.53-59, june, 1991.

TSOUKANTAS, S.G.; TASSIOS, T.P. (1989). Shear resistance of connections between reinforced concrete linear precast elements. ACI Structural Journal, v.86, n.3, p.242-249, may-june.

VASAN, R.M.; KAUSHIK, S.K.; SINGH, G. (1991). Performance Evaluation fo Ferro-Fibrocrete Composite overlays. Journal of Ferrocement, v.21, n ${ }^{\mathbf{0}} 3$, july.

VELA, J. M. (1991). Análisis aproximado em el tiempo de secciones de hormigón armado em servicio - Proposta de un nuevo factor de cálculo de flechas diferidas. Hormigón y Acero, n. 181, p. 6-16, 4º trimestre, 1991.

VIJAYA R.B. (1998). High-performance high-strength concrete: design recommendations. Concrete International, november, 1998.

WALRAVEN, J.; FRÉNAY, J.; PRUIJSSERS, A. (1987). Influence of concrete strength and load history on the shear friction capacity of concrete members. PCI Journal, v.32, n.1, p.66-84, january-february.

YUAN, Y.; MAROSSZEKY, M. (1994). Restrained shrinkage in repaired reinforced concrete elements. Materials and Structures, v.27, n. 171, p.375-382, augustseptember, 1994.

ZHANG, S.; RAOOF, M. (1995). Prediction of the behavior of RC beams with exposed reinforcement. Magazine of Concrete Research, v.47, n¹73, p.335-344, december. 


\section{APÊNDICE A}

(Resultados dos ensaios dos prismas de argamassa com fibras) 


\section{A.1 - Gráficos com os resultados dos ensaios dos prismas}

Tabela A.1 - Relação dos prismas ensaiados

\begin{tabular}{|c|c|c|c|}
\hline Série & Prismas & Volume (\%) & Observações \\
\hline \multirow{4}{*}{ série 1} & P1-RL-A & 1 & \multirow{10}{*}{$\begin{array}{l}1 \text { ) Para cada um dos tipos de prismas foram ensaiados três corpos- } \\
\text { de-prova denominados A, B e C. Alguns destes corpos-de-prova } \\
\text { não forneceram bons resultados e portanto não foram traçados } \\
\text { gráficos destes ensaios. }\end{array}$} \\
\hline & P2-RL-A & 2 & \\
\hline & P1-RC-A & 1 & \\
\hline & P2-RC-A & 2 & \\
\hline \multirow{6}{*}{ série 2} & P05-RL & 0,5 & \\
\hline & P1-RL & 1 & \\
\hline & P2-RL & 2 & \\
\hline & P05-RC & 0,5 & \\
\hline & P1-RC & 1 & \\
\hline & P2-RC & 2 & \\
\hline
\end{tabular}

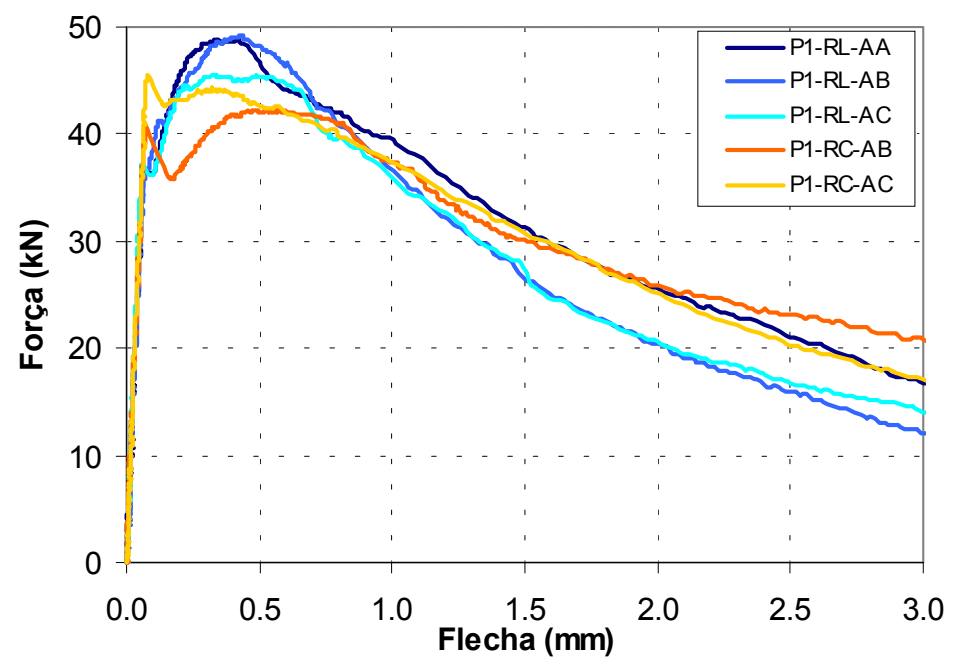

a) Gráfico dos prismas ensaiados com $1 \%$ de fibras para o traço da série 1

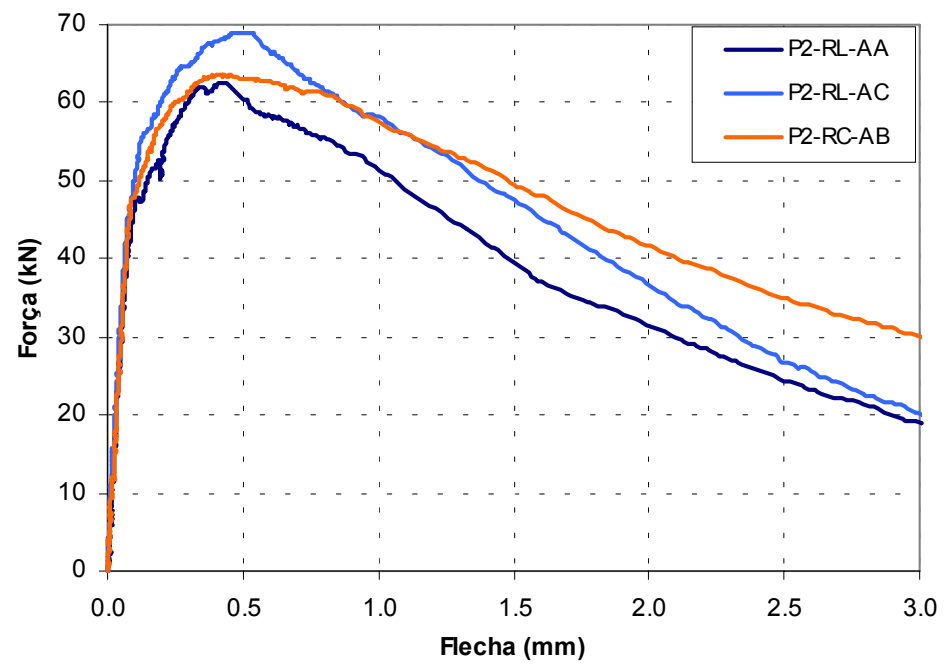

b) Gráfico dos prismas ensaiados com $2 \%$ de fibras para o traço da série 1 


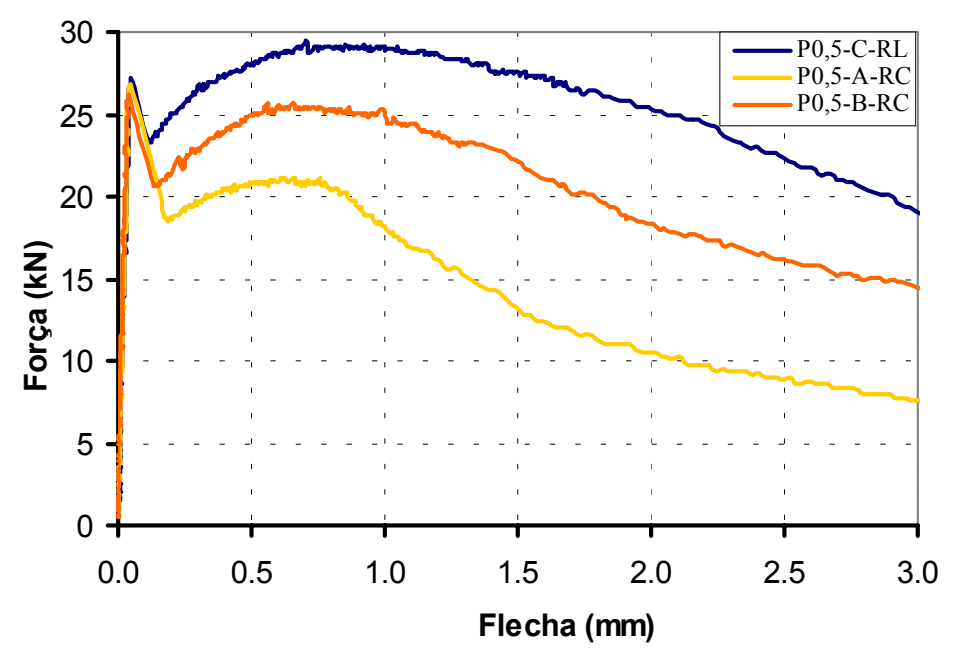

c) Gráfico dos prismas ensaiados com $0,5 \%$ de fibras para o traço da série 2

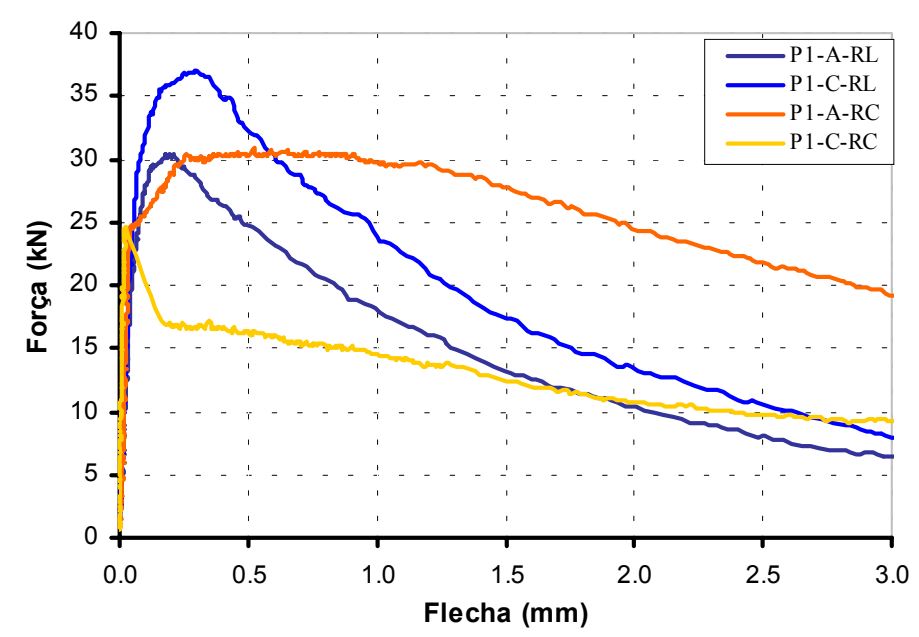

d) Gráfico dos prismas ensaiados com $1 \%$ de fibras para o traço da série 2

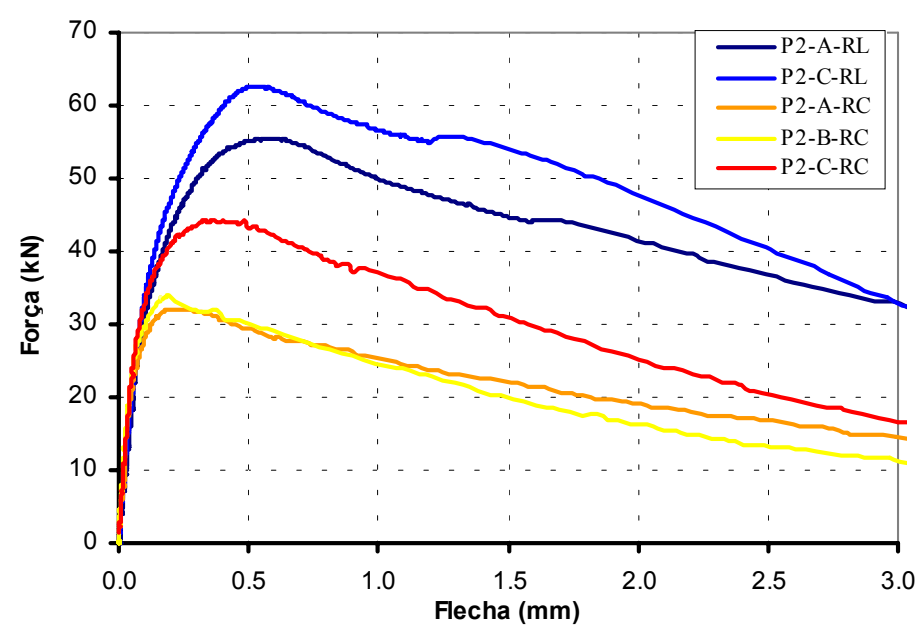

e) Gráfico dos prismas ensaiados com $2 \%$ de fibras para o traço da série 2 


\section{APÊNDICE B}

(Resultados dos ensaios das vigas retangulares - séries 1 e 2) 
B.1 - Ensaios das vigas retangulares - série 1

B.1.1 - Gráficos das deformações das armaduras longitudinais tracionadas $\boldsymbol{x}$ força
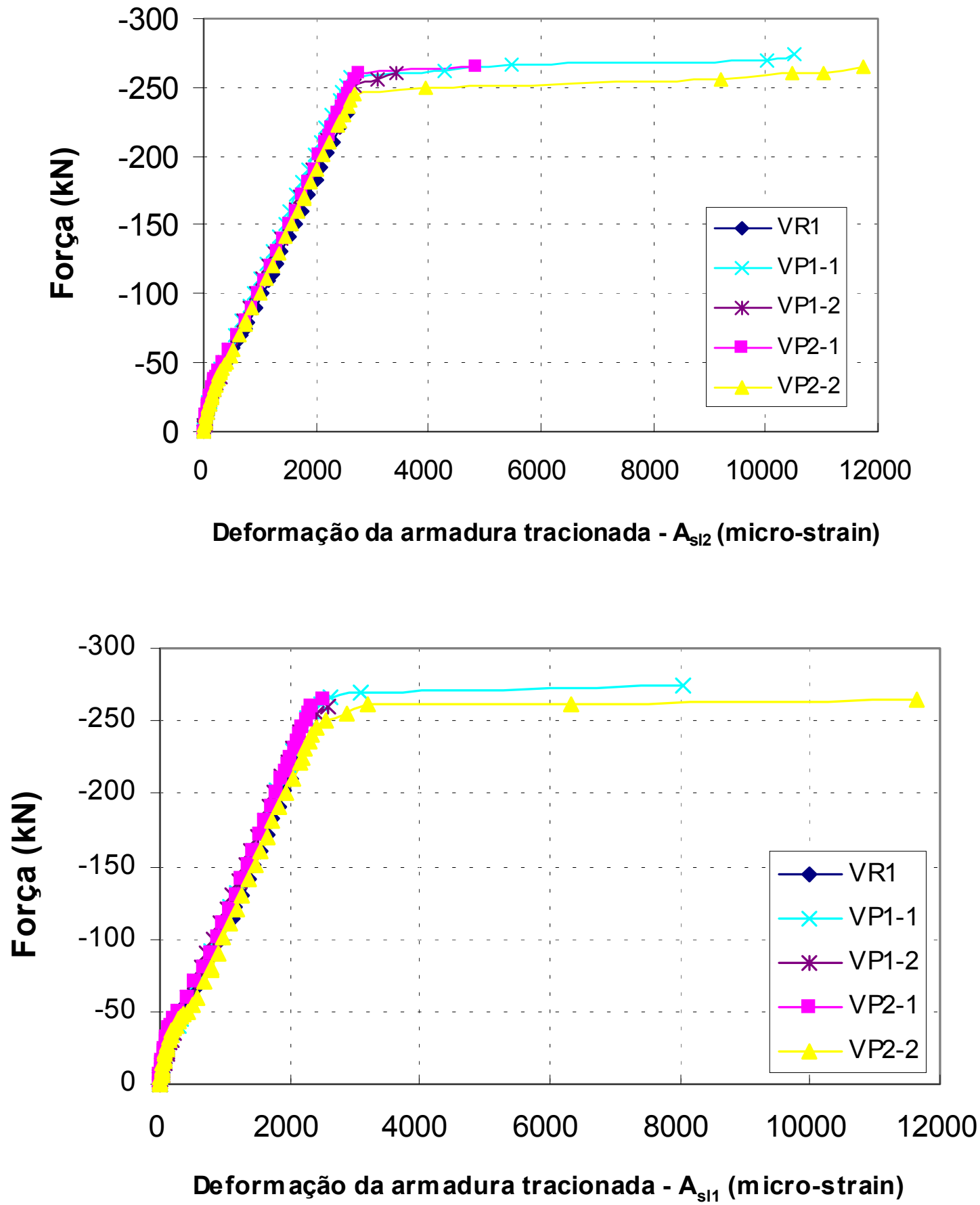
B.1.2 - Gráficos das flechas $\boldsymbol{x}$ força

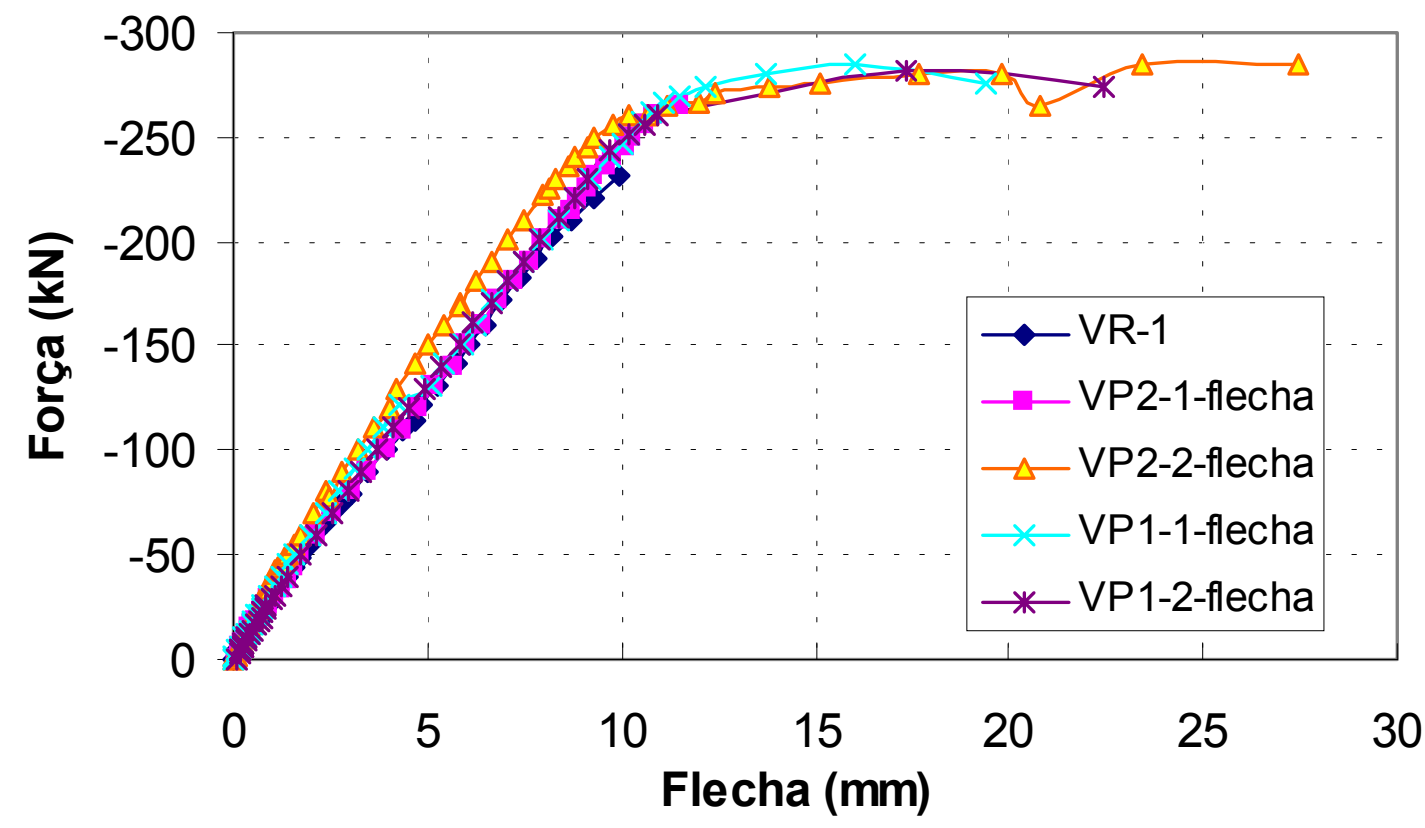

B.1.3 - Gráficos das deformações dos estribos $x$ força

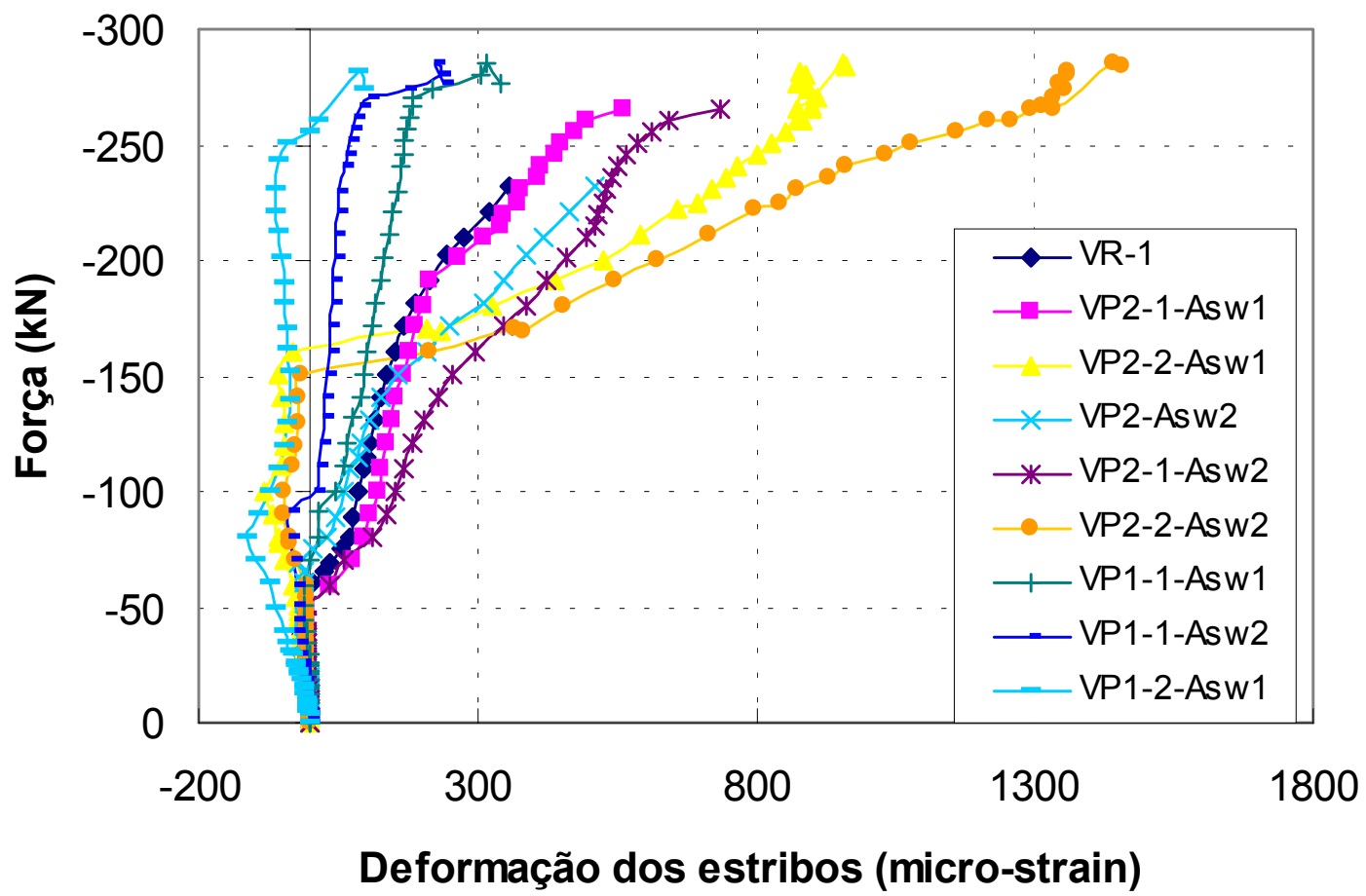


B.1.4 - Gráficos do concreto comprimido $x$ força

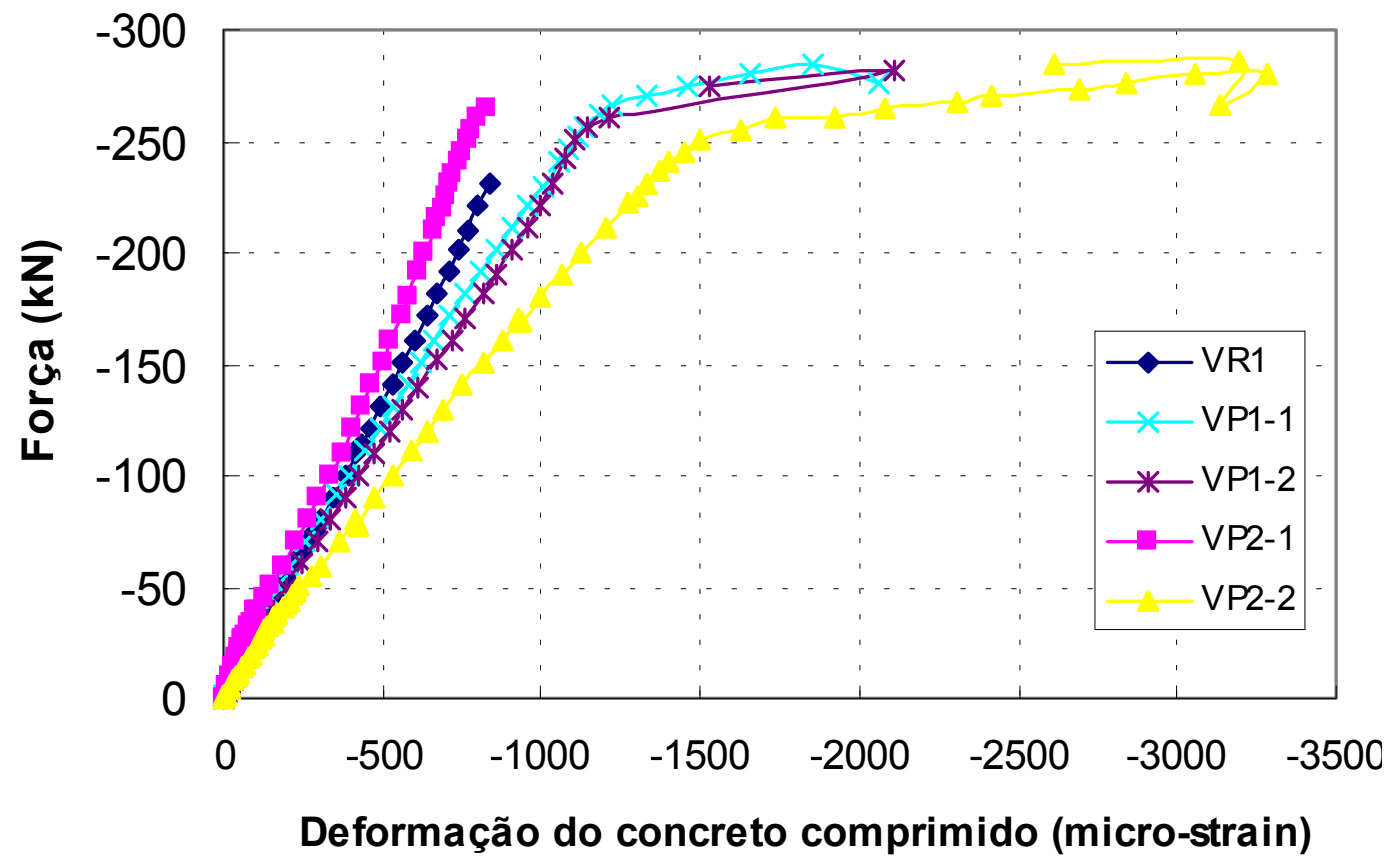

B.2 - Ensaios das vigas retangulares - série 2

B.2.1 - Gráficos das flechas $\boldsymbol{x}$ força

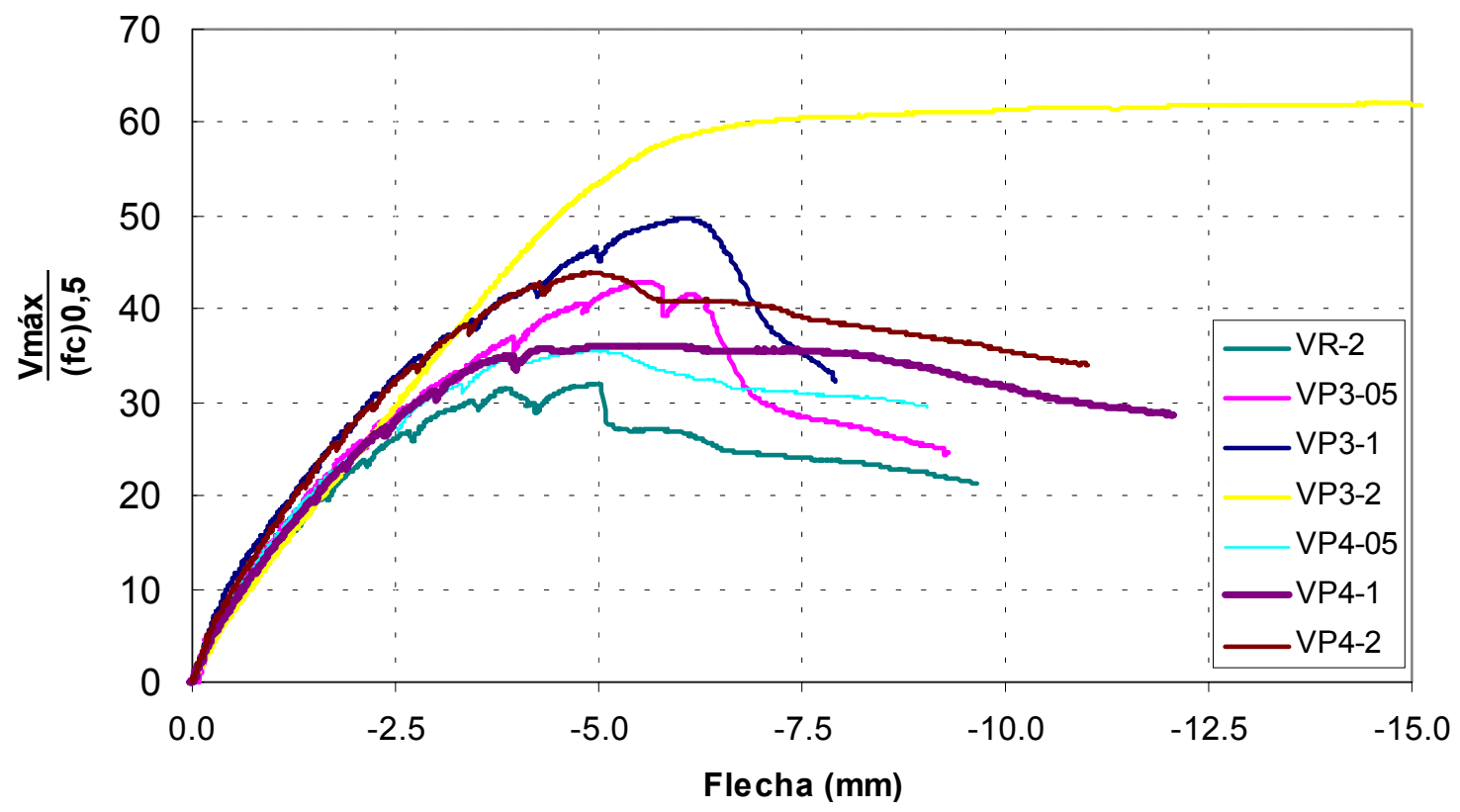


B.2.2 - Gráficos das deformações das armaduras longitudinais tracionadas $\boldsymbol{x}$ força

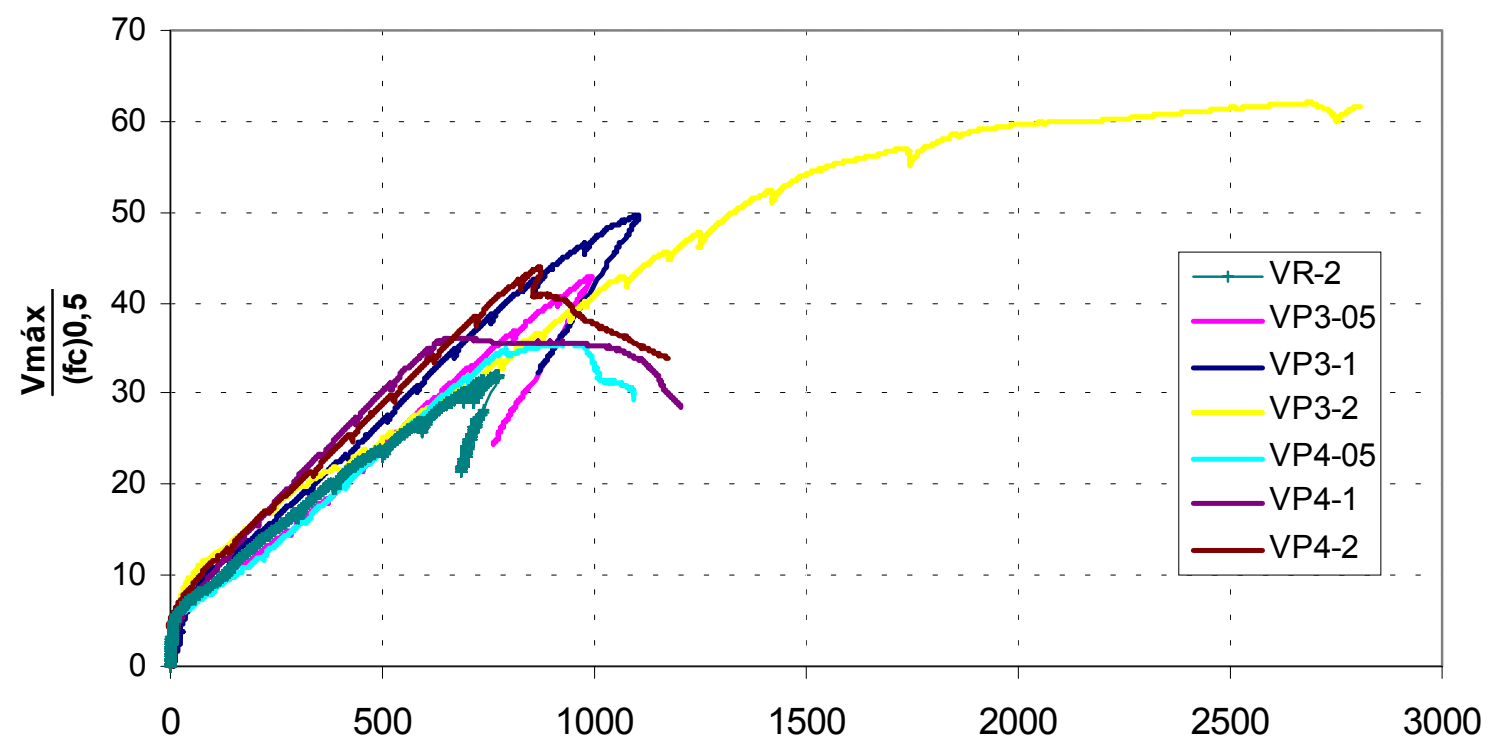

Deformação da armadura tracionada - $A_{s \mid 1}$ (micro-strain)

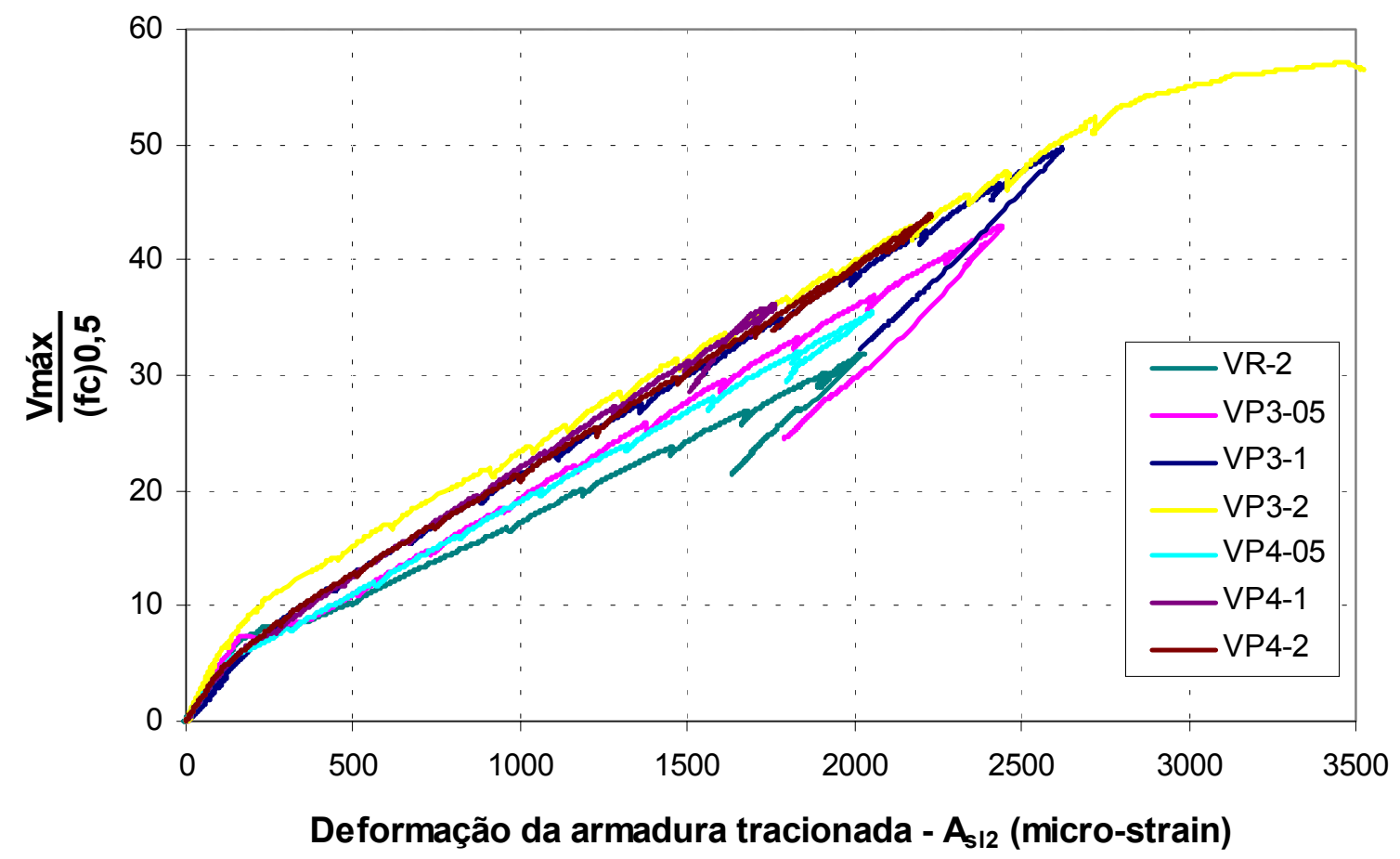


B.2.3 - Gráficos das deformações dos estribos $x$ força

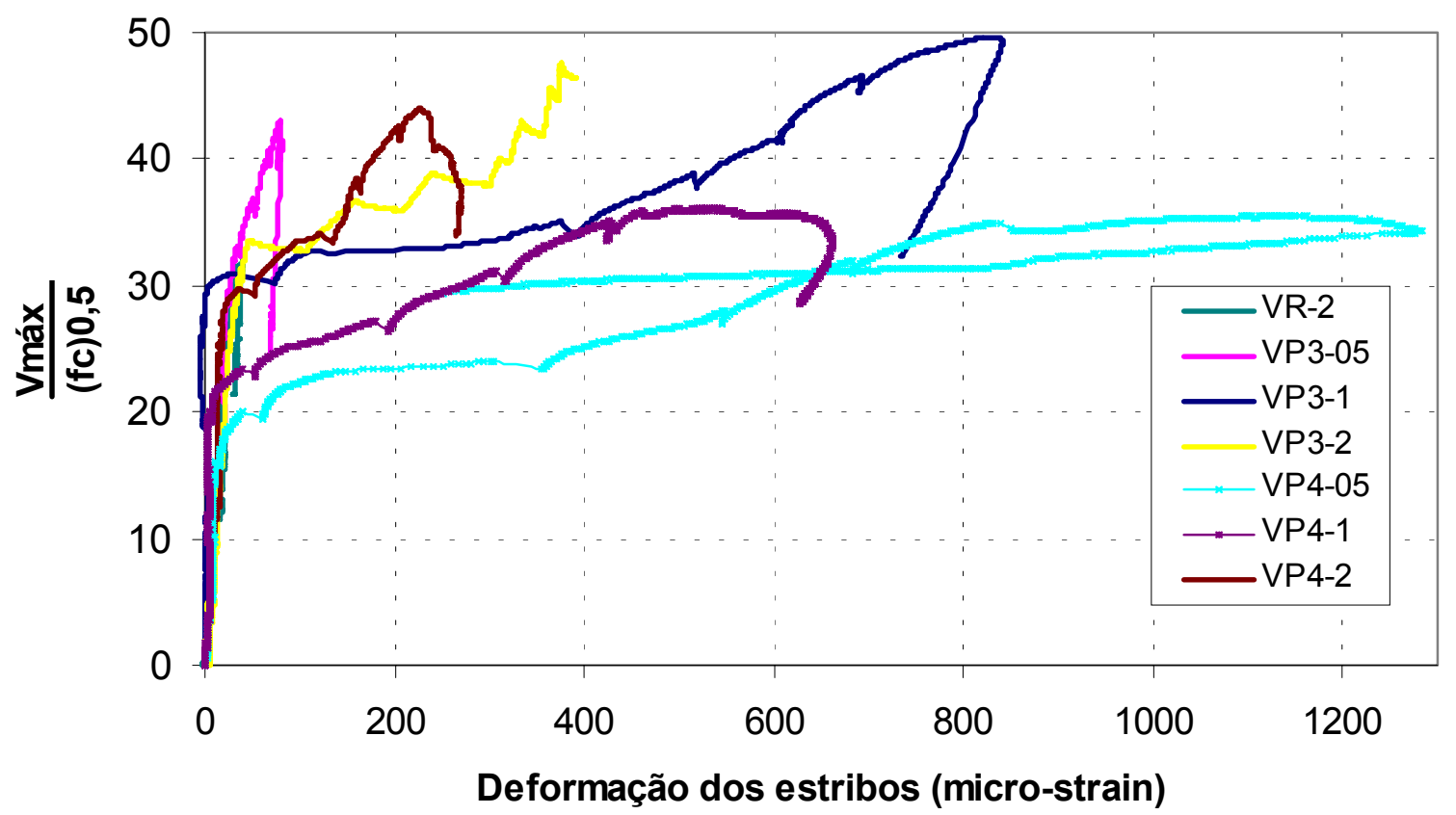

B.2.4 - Gráficos do concreto comprimido $x$ força

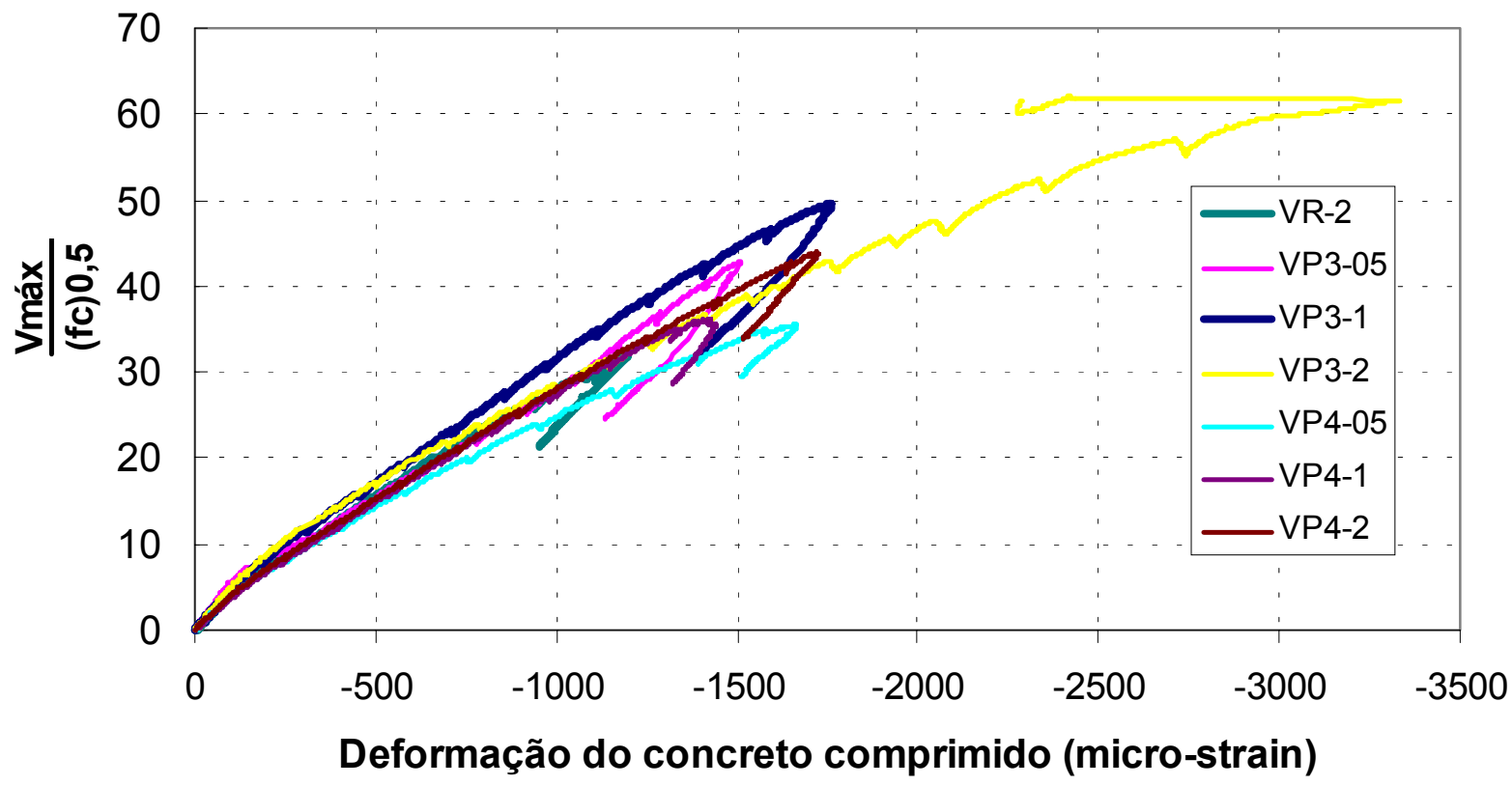




\section{APÊNDICE C}

(Resultados dos ensaios das vigas reforçadas no bordo tracionado) 


\section{C.1 Tabela com os resultados do ensaio da viga VFT-1}

\begin{tabular}{|c|c|c|c|c|c|c|c|c|}
\hline $\mathbf{F}$ & $\mathbf{A}_{\mathrm{s1}}$ & 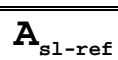 & $\mathbf{A}_{\mathrm{s} 11}$ & $\mathbf{A}_{\text {s1-ref }}$ & $\mathbf{A}_{\mathrm{s} 1}$ & $\overline{\mathbf{A}_{\mathrm{sw}}}$ & concreto & flecha \\
\hline & \multicolumn{2}{|c|}{$\frac{1}{(1)}$} & \multicolumn{2}{|c|}{$\frac{1}{(2)}$} & (3) & (4) & (5) & (6) \\
\hline$(\mathrm{kN})$ & \multicolumn{5}{|c|}{ (micro-strain) } & & & $(\mathrm{mm})$ \\
\hline \multicolumn{9}{|c|}{ Ensaio para aplicac } \\
\hline 0 & 0 & - & 0 & - & 0 & 0 & 0 & 0.01 \\
\hline 3 & 21 & - & 41 & - & -11 & -3 & -12 & -0.23 \\
\hline 4 & 29 & - & 77 & - & -16 & -5 & -16 & -0.44 \\
\hline 5 & 41 & - & 154 & - & -22 & -8 & -21 & -0.79 \\
\hline 6 & 53 & - & 211 & - & -27 & -8 & -27 & -1.14 \\
\hline 8 & 66 & - & 264 & - & -34 & -8 & -34 & -1.46 \\
\hline 8 & 76 & - & 300 & - & -40 & -8 & -41 & -1.67 \\
\hline 11 & 94 & - & 369 & - & -51 & -7 & -53 & -2.08 \\
\hline 13 & 134 & - & 448 & - & -68 & -6 & -71 & -2.59 \\
\hline 15 & 218 & - & 535 & - & -89 & -5 & -94 & -3.29 \\
\hline 17 & 295 & - & 599 & - & -103 & $\overline{-6}$ & -112 & -3.80 \\
\hline 21 & 414 & - & 704 & - & -128 & -7 & -142 & -4.67 \\
\hline 24 & 542 & - & 808 & - & -153 & -11 & -173 & -5.54 \\
\hline 30 & 758 & - & 1003 & - & -192 & -11 & -223 & -7.16 \\
\hline 29 & 768 & - & 983 & - & -188 & -19 & -220 & -7.12 \\
\hline 28 & 768 & - & 980 & - & -188 & -21 & -221 & -7.12 \\
\hline \multicolumn{9}{|c|}{ Ensaio final } \\
\hline 8 & 4484 & $\overline{-176}$ & 2698 & -151 & -265 & -117 & $\overline{-271}$ & -5.80 \\
\hline 10 & 505 & -152 & 717 & -125 & -251 & -101 & -262 & -5.88 \\
\hline 10 & 508 & -149 & 719 & -121 & -249 & -99 & -260 & -5.91 \\
\hline 11 & 520 & -135 & 734 & 480 & -244 & -92 & -257 & -5.93 \\
\hline 15 & 546 & -100 & 744 & 494 & -256 & -92 & -270 & -6.09 \\
\hline 20 & 574 & -61 & 756 & 509 & -272 & -93 & -287 & -6.27 \\
\hline 26 & 612 & -13 & 768 & 525 & -291 & -95 & -307 & -6.48 \\
\hline 28 & 634 & 13 & 775 & 534 & -301 & -96 & -317 & -6.58 \\
\hline 30 & 650 & 33 & 783 & 543 & -306 & -95 & -323 & -6.67 \\
\hline 35 & 691 & 91 & 794 & 557 & -323 & -97 & -341 & -6.89 \\
\hline 39 & 724 & 139 & 807 & 431 & -335 & -97 & -355 & -7.06 \\
\hline 41 & 750 & 171 & 813 & 499 & -344 & -98 & -365 & -7.20 \\
\hline 46 & 804 & 237 & 828 & 1192 & -364 & -99 & -387 & -7.51 \\
\hline 51 & 864 & 317 & 843 & 2041 & -383 & -100 & -410 & -7.85 \\
\hline 61 & 986 & 464 & 875 & - & -424 & -106 & -457 & -8.57 \\
\hline 66 & 1060 & 557 & 897 & 402 & -447 & -107 & -485 & -9.07 \\
\hline 71 & 1126 & 639 & 918 & 414 & -467 & -109 & -510 & -9.63 \\
\hline 75 & 1193 & 723 & 941 & 624 & -489 & -111 & -537 & -10.25 \\
\hline 79 & 1246 & 793 & 963 & 789 & -508 & -112 & -559 & -10.66 \\
\hline 82 & 1275 & 831 & 974 & 819 & -519 & -112 & -572 & -10.86 \\
\hline 85 & 1329 & 899 & 1007 & 1061 & -536 & -108 & -595 & -11.19 \\
\hline 91 & 1403 & 995 & 1054 & 1007 & -561 & -106 & -625 & -11.65 \\
\hline
\end{tabular}




\begin{tabular}{|c|c|c|c|c|c|c|c|c|}
\hline \multirow[t]{2}{*}{$\bar{F}$} & $\mathbf{A}_{\mathrm{s1}}$ & $A_{\text {sl-ref }}$ & $\mathbf{A}_{\mathrm{s} 11}$ & $\mathbf{A}_{\text {s1-re }}$ & $\mathbf{A}_{\mathrm{s} 1}$ & $\mathbf{A}_{\mathrm{sw}}$ & concreto & \multirow{2}{*}{\begin{tabular}{|c|} 
flecha \\
$(6)$
\end{tabular}} \\
\hline & \multicolumn{2}{|c|}{ (1) } & \multicolumn{2}{|c|}{$(2)$} & (3) & $(4)$ & (5) & \\
\hline (kN) & \multicolumn{7}{|c|}{ (micro-strain) } & (mm) \\
\hline \multicolumn{9}{|c|}{ Ensaio final (continuação) } \\
\hline 92 & 1430 & 1030 & 1079 & $\overline{-}$ & -571 & -105 & $\overline{-640}$ & -11.84 \\
\hline 96 & 1477 & 1091 & 1100 & - & -588 & -106 & -661 & $-12 \cdot 11$ \\
\hline 101 & 1541 & 1176 & 1143 & - & -610 & -102 & -689 & -12.52 \\
\hline 106 & 1613 & 1272 & 1274 & 2094 & -636 & -61 & -727 & -13.01 \\
\hline 111 & 1667 & 1344 & 1326 & 2146 & -656 & -45 & -751 & -13.36 \\
\hline 116 & 1741 & 1441 & 1383 & 764 & -685 & -23 & -794 & -13.90 \\
\hline 122 & 1812 & 1536 & 1436 & 819 & -712 & 8 & -828 & $-14 \cdot 36$ \\
\hline 124 & 1856 & 1595 & 1470 & 871 & -731 & 52 & -859 & -14.69 \\
\hline 129 & 1909 & 1666 & 1507 & 911 & -751 & 105 & -885 & -15.04 \\
\hline 132 & 1962 & 1735 & 1544 & 954 & -773 & 171 & -916 & -15.43 \\
\hline 138 & 2034 & 1829 & 1591 & 1014 & -801 & 243 & -954 & -15.94 \\
\hline 141 & 2092 & 1905 & 1617 & 1158 & -832 & 294 & -1005 & -16.36 \\
\hline 148 & 2178 & 2017 & 1673 & 1223 & -864 & 347 & -1047 & -16.95 \\
\hline 152 & 2236 & 2094 & 1716 & 1269 & -888 & 386 & -1082 & -17.36 \\
\hline 158 & 2310 & 2191 & 1767 & 1328 & -921 & 439 & -1132 & -17.88 \\
\hline 163 & 2390 & 2299 & 1817 & 1177 & -967 & 487 & -1202 & -18.50 \\
\hline 168 & 2455 & 2384 & 1857 & 1238 & -993 & 527 & -1238 & -18.96 \\
\hline 173 & 2531 & 2484 & 1900 & 1309 & -1028 & 567 & -1288 & -19.54 \\
\hline 180 & 2619 & 2601 & 1952 & 1395 & -1068 & 609 & -1346 & -20.22 \\
\hline 185 & 2739 & 2728 & 1999 & 1488 & -1134 & 639 & -1445 & -21.04 \\
\hline 191 & 2858 & 2847 & 2044 & 1564 & -1166 & 674 & -1492 & -21.62 \\
\hline 194 & 2977 & 3021 & 2073 & 1631 & -1198 & 691 & -1544 & -22.19 \\
\hline 200 & 3349 & 3380 & 2125 & 1717 & -1254 & 722 & -1637 & -23.19 \\
\hline 202 & 3494 & 3531 & 2167 & 1765 & -1322 & 715 & -1746 & -23.93 \\
\hline 205 & 3680 & 3691 & 2186 & 1798 & -1346 & 728 & -1782 & -24.38 \\
\hline 207 & 3984 & 4073 & 2205 & 1834 & -1380 & 734 & -1833 & -24.90 \\
\hline 203 & 4342 & 4384 & 2190 & 1819 & -1400 & 708 & -1872 & -24.99 \\
\hline 209 & 7189 & 7484 & 2223 & 1885 & -1457 & 737 & -1963 & -25.86 \\
\hline 205 & 11612 & 3962 & 2200 & 1856 & -1588 & 718 & -2223 & -26.57 \\
\hline 208 & & 4077 & 2219 & 1886 & -1640 & 728 & -2314 & -27.15 \\
\hline 210 & & 4393 & 2225 & 1907 & -1803 & 730 & -2611 & -28.27 \\
\hline 211 & & 5170 & 2230 & 1917 & -1853 & 735 & -2723 & -28.91 \\
\hline 210 & & 7925 & 2225 & 1912 & -1880 & 733 & -2782 & -29.16 \\
\hline 212 & & & 2237 & 1933 & -2038 & 740 & -3099 & -30.61 \\
\hline 214 & & & 2249 & 1965 & -2361 & 745 & -2942 & -33.21 \\
\hline 213 & & & 2249 & 1973 & -2668 & 741 & -2682 & -37.44 \\
\hline 212 & & & 2246 & 1968 & -2823 & 737 & -2507 & -40.03 \\
\hline 206 & & & 2217 & 1928 & -2950 & 716 & -2144 & -40.37 \\
\hline 204 & & & 2213 & 3041 & -2909 & 709 & -2084 & -40.44 \\
\hline
\end{tabular}




\section{C.2 Tabela com os resultados do ensaios da viga VFT-2}

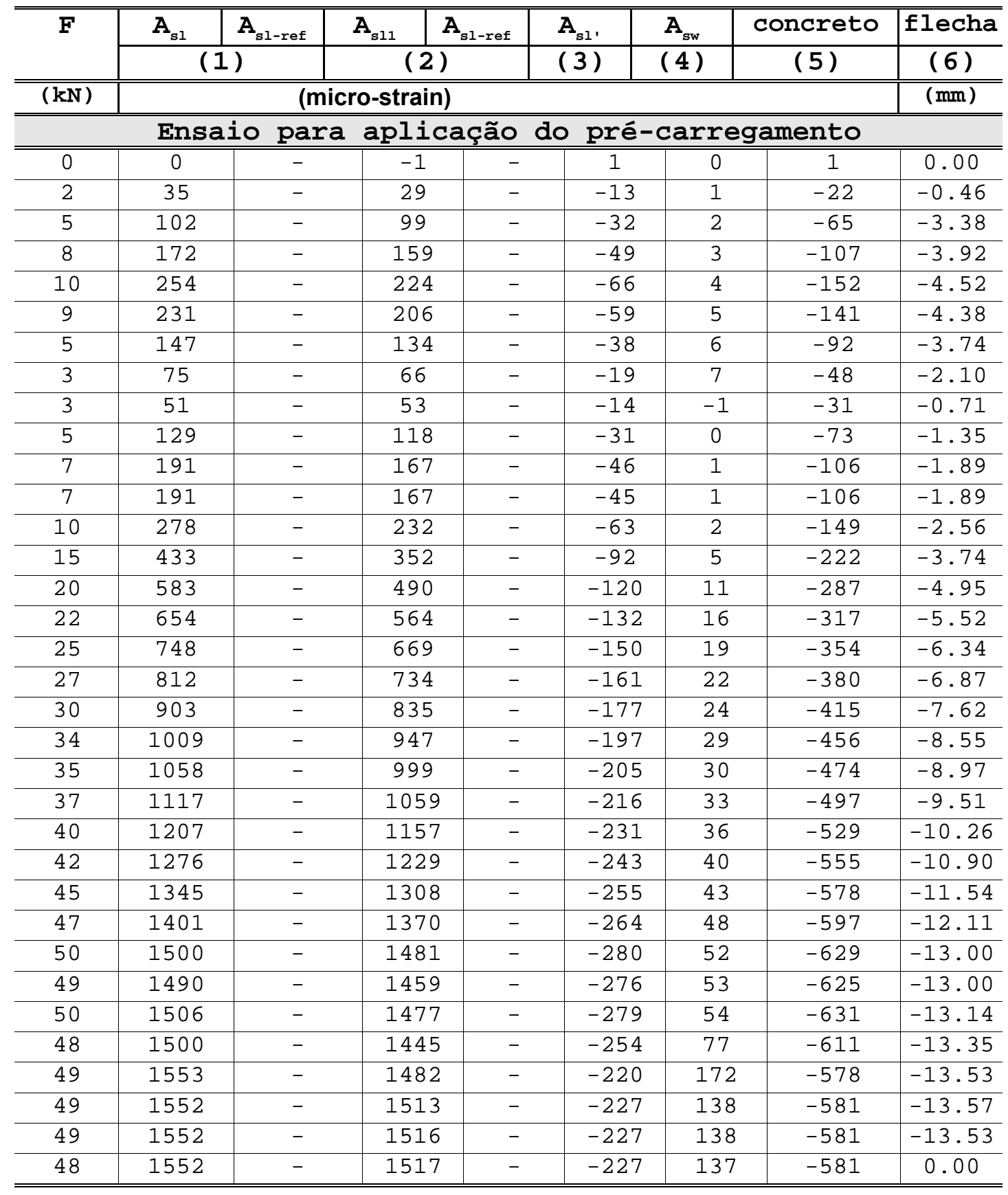




\begin{tabular}{|c|c|c|c|c|c|c|c|c|}
\hline 41 & 1369 & -144 & 13398 & -74 & -320 & 32 & -651 & 0.43 \\
\hline 45 & 1398 & -117 & 1596 & -64 & -334 & 31 & -670 & 0.25 \\
\hline 45 & 1404 & -113 & 1370 & -63 & -329 & 38 & -666 & 0.25 \\
\hline 45 & 1404 & -112 & 1370 & -63 & -329 & 38 & -666 & 0.25 \\
\hline 45 & 1407 & -110 & 1372 & -61 & -327 & 40 & -664 & 0.25 \\
\hline 50 & 1444 & -76 & 1385 & -47 & -343 & 40 & -685 & 0.00 \\
\hline \multirow[t]{2}{*}{$\mathbf{F}$} & $\mathbf{A}_{\mathrm{s} 1}$ & $\mathbf{A}_{\text {s1-ref }}$ & $\mathbf{A}_{\mathrm{s} 11}$ & $A_{s 1-x}$ & $\mathbf{A}_{\mathrm{s} 1}$, & $\mathbf{A}_{\mathrm{sw}}$ & concreto & flecha \\
\hline & \multicolumn{2}{|c|}{ (1) } & \multicolumn{2}{|c|}{ (2) } & $(3)$ & $(4)$ & $(5)$ & (6) \\
\hline$(\mathrm{kN})$ & \multicolumn{7}{|c|}{ (micro-strain) } & (mm) \\
\hline \multicolumn{9}{|c|}{ Ensaio final (continuação) } \\
\hline 0 & 1443 & -75 & 1385 & -46 & -344 & 37 & -686 & 0.00 \\
\hline 50 & 1443 & -74 & 1385 & -46 & -343 & 37 & -686 & 0.00 \\
\hline 52 & 1521 & -6 & 1436 & -21 & -296 & 98 & -651 & -0.18 \\
\hline 39 & 1428 & -92 & 1403 & -55 & -254 & 100 & -597 & 0.36 \\
\hline 51 & 1507 & -19 & 1431 & -26 & -289 & 99 & -642 & -0.11 \\
\hline 52 & 1541 & 8 & 1452 & -19 & -267 & 126 & -627 & -0.18 \\
\hline 52 & 1558 & 24 & 1461 & -14 & -258 & 140 & -619 & -0.21 \\
\hline 30 & 1409 & -114 & 1409 & -67 & -191 & 142 & -531 & 0.71 \\
\hline 49 & 1536 & 4 & 1454 & -21 & -248 & 140 & -607 & -0.11 \\
\hline 49 & 1540 & 8 & 1456 & -21 & -244 & 145 & -603 & -0.07 \\
\hline 49 & 1541 & 10 & 1456 & -20 & -245 & 145 & -603 & -0.07 \\
\hline 49 & 1515 & -13 & 1439 & -26 & -274 & 119 & -625 & 0.00 \\
\hline 52 & 1538 & 9 & 1446 & -19 & -285 & 119 & -639 & -0.14 \\
\hline 53 & 1527 & 2 & 1438 & -20 & -305 & 103 & -657 & -0.18 \\
\hline 45 & 1379 & -122 & 1354 & -65 & -386 & -14 & -721 & 0.21 \\
\hline 50 & 1410 & -92 & 1365 & -54 & -400 & -13 & -740 & 0.00 \\
\hline 50 & 1414 & -90 & 1366 & -53 & -397 & -14 & -740 & 0.00 \\
\hline 51 & 1441 & -65 & 1386 & -45 & -371 & 16 & -720 & -0.11 \\
\hline 52 & 1455 & -56 & 1795 & -43 & -361 & 29 & -713 & -0.14 \\
\hline 52 & 1456 & -57 & 1797 & -43 & -361 & 29 & -713 & -0.14 \\
\hline 52 & 1456 & -56 & 1834 & -43 & -360 & 30 & -712 & -0.14 \\
\hline 53 & 1481 & -37 & 1868 & -37 & -341 & 51 & -699 & -0.21 \\
\hline 57 & 1567 & 38 & 1772 & -14 & -292 & 118 & -660 & -0.43 \\
\hline 57 & 1563 & 36 & 1799 & -14 & -292 & 115 & -661 & -0.43 \\
\hline 57 & 1563 & 35 & 1832 & -14 & -291 & 119 & -658 & -0.43 \\
\hline 50 & 1429 & -85 & 2232 & -59 & -364 & 17 & -713 & -0.07 \\
\hline 50 & 1435 & -77 & 2240 & -57 & -359 & 24 & -710 & -0.11 \\
\hline 48 & 1372 & -135 & 2329 & -78 & -388 & -25 & -728 & 0.11 \\
\hline 50 & 1385 & -123 & 2334 & -74 & -394 & -25 & -737 & 0.00 \\
\hline 50 & 1358 & -153 & 2364 & -88 & -409 & -52 & -745 & 0.82 \\
\hline 50 & 1349 & -127 & 2363 & -81 & -410 & -49 & -747 & 0.14 \\
\hline 50 & 1349 & -152 & 2374 & -88 & -408 & -59 & -750 & 0.39 \\
\hline 50 & 1358 & -152 & 2386 & -81 & -389 & -59 & -744 & 0.14 \\
\hline 49 & 1368 & -152 & 2367 & -79 & -404 & -59 & -742 & 0.14 \\
\hline 52 & 1369 & -134 & 2402 & -83 & -387 & -36 & -733 & 0.04 \\
\hline 52 & 1369 & -134 & 2402 & -83 & -388 & -36 & -733 & 0.04 \\
\hline 51 & 1330 & -167 & 2401 & -94 & -417 & -71 & -754 & 0.18 \\
\hline 51 & 1332 & -166 & 2405 & -93 & -414 & -73 & -752 & 0.18 \\
\hline 51 & 1334 & -163 & 2406 & -93 & -412 & -71 & -751 & 0.14 \\
\hline 52 & 1365 & -140 & 2432 & -87 & -383 & -39 & -725 & 0.07 \\
\hline 53 & 1383 & -127 & 2445 & -84 & -372 & -25 & -718 & 0.00 \\
\hline 55 & 1416 & -97 & 2475 & -75 & -344 & 16 & -695 & -0.14 \\
\hline
\end{tabular}




\begin{tabular}{|c|c|c|c|c|c|c|c|c|}
\hline 56 & 1439 & -79 & 2499 & -69 & -330 & 38 & -682 & -0.18 \\
\hline 51 & 1317 & -177 & 2451 & -107 & -422 & -71 & -754 & 0.21 \\
\hline \multirow[t]{2}{*}{$\mathbf{F}$} & $\mathbf{A}$ & $\mathbf{A}$ & A & $\mathbf{A}$ & A. & $\mathbf{A}$ & concreto & flecha \\
\hline & \multicolumn{2}{|c|}{ (1) } & \multicolumn{2}{|c|}{ (2) } & (3) & $(4)$ & (5) & (6) \\
\hline$(\mathrm{kN})$ & \multicolumn{7}{|c|}{ (micro-strain) } & $(\mathrm{mm})$ \\
\hline \multicolumn{9}{|c|}{ Ensaio final (continuação) } \\
\hline 51 & 1327 & -169 & 2461 & -104 & -410 & -58 & -744 & 0.18 \\
\hline 51 & 1336 & -163 & 2469 & -102 & -400 & -48 & -736 & 0.14 \\
\hline 51 & 1339 & -161 & 2471 & -103 & -397 & -44 & -733 & 0.00 \\
\hline 51 & 1339 & -161 & 2471 & -103 & -397 & -45 & -734 & 0.00 \\
\hline 51 & 1346 & -157 & 2476 & -102 & -390 & -37 & -729 & 0.00 \\
\hline 51 & 1346 & -157 & 2476 & -102 & -389 & -37 & -729 & 0.00 \\
\hline 56 & 1375 & -129 & 2488 & -90 & -403 & -37 & -746 & -0.18 \\
\hline 56 & 1375 & -129 & 2488 & -90 & -403 & -37 & -746 & -0.18 \\
\hline 62 & 1416 & -91 & 2503 & -76 & -421 & -37 & -769 & -0.43 \\
\hline 66 & 1455 & -40 & 2514 & -65 & -434 & -36 & -787 & -0.64 \\
\hline 71 & 1521 & 23 & 2526 & -53 & -452 & -36 & -815 & -1.07 \\
\hline 75 & 1575 & 70 & 2538 & -43 & -466 & -35 & -837 & -1.50 \\
\hline 73 & 1567 & 64 & 2536 & -47 & -461 & -34 & -832 & -1.53 \\
\hline 80 & 1644 & 133 & 2553 & -30 & -484 & -33 & -865 & -2.03 \\
\hline 79 & 1641 & 129 & 2552 & -31 & -481 & -33 & -863 & -2.03 \\
\hline 86 & 1719 & 196 & 2571 & -14 & -505 & -33 & -897 & -2.46 \\
\hline 91 & 1785 & 257 & 2590 & 2 & -524 & -30 & -928 & -2.85 \\
\hline 95 & 1842 & 310 & 2624 & 31 & -534 & -20 & -948 & -3.21 \\
\hline 101 & 1916 & 373 & 2656 & 77 & -556 & -17 & -981 & -3.60 \\
\hline 106 & 1987 & 426 & 2687 & 108 & -586 & -5 & -1025 & -4.06 \\
\hline 110 & 2049 & 477 & 2730 & 140 & -605 & 10 & -1055 & -4.45 \\
\hline 115 & 2109 & 533 & 2761 & 168 & -627 & 22 & -1093 & -4.84 \\
\hline 120 & 2183 & 595 & 2810 & 218 & -651 & 30 & -1129 & -5.27 \\
\hline 125 & 2246 & 652 & 2856 & 278 & -677 & 43 & -1173 & -5.70 \\
\hline 130 & 2310 & 709 & 2901 & 320 & -702 & 71 & -1213 & -6.16 \\
\hline 135 & 2379 & 770 & 2948 & 368 & -751 & 94 & -1290 & -6.70 \\
\hline 140 & 2451 & 837 & 3006 & 422 & -780 & 121 & -1337 & -7.19 \\
\hline 145 & 2513 & 894 & 3060 & 464 & -810 & 149 & -1388 & -7.62 \\
\hline 150 & 2587 & 962 & 3132 & 537 & -845 & 202 & -1448 & -8.16 \\
\hline 155 & 2665 & 1039 & 3199 & 599 & -907 & 254 & -1548 & -8.83 \\
\hline 161 & 2761 & 1114 & 3268 & 662 & -939 & 316 & -1601 & -9.37 \\
\hline 166 & 2925 & 1179 & 3321 & 713 & -975 & 380 & -1663 & -9.86 \\
\hline 171 & 3083 & 1251 & 3371 & 767 & -1010 & 435 & -1726 & -10.40 \\
\hline 174 & 3171 & 1326 & 3411 & 814 & -1081 & 485 & -1846 & -11.08 \\
\hline 182 & 3366 & 1431 & 3469 & 878 & -1117 & 536 & -1906 & -11.75 \\
\hline 185 & 3439 & 1500 & 3506 & 923 & -1158 & 574 & -1975 & -12.29 \\
\hline 191 & 3581 & 1602 & 3557 & 982 & -1198 & 618 & -2046 & -12.96 \\
\hline 194 & 3666 & 1664 & 3578 & 1021 & -1276 & 652 & -2167 & -13.60 \\
\hline 200 & 3955 & 1750 & 3625 & 1074 & -1308 & 685 & -2220 & -14.17 \\
\hline 205 & 4677 & 1851 & 3666 & 1138 & -1353 & 724 & -2297 & -14.92 \\
\hline 210 & 7065 & 2075 & 3700 & 1200 & -1436 & 765 & -2423 & -15.81 \\
\hline 211 & 8910 & 2280 & 3704 & 1228 & -1506 & 798 & -2529 & -16.42 \\
\hline \multirow[t]{2}{*}{$\mathbf{F}$} & $\overline{A_{s 1}}$ & $\mathrm{~s}_{\mathrm{s}}$ & $\mathbf{A}_{\mathbf{s 1 1}}$ & $\overline{A_{s 1}}$ & $\overline{\mathbf{A}_{\mathrm{s}}}$ & $\overline{\mathbf{A}_{\mathrm{sw}}}$ & concreto & flecha \\
\hline & \multicolumn{2}{|c|}{ (1 } & \multicolumn{2}{|c|}{ (2) } & (3) & $(4)$ & (5) & (6) \\
\hline
\end{tabular}




\begin{tabular}{|c|c|c|c|c|c|c|c|c|}
\hline$(\mathbf{k N})$ & \multicolumn{6}{|c|}{ (micro-strain) } & & \multirow[t]{2}{*}{$(\mathrm{mm})$} \\
\hline \multicolumn{8}{|c|}{ Ensaio final (continuação) } & \\
\hline 214 & - & 2438 & 3720 & 1251 & -1529 & 814 & -2578 & -16.84 \\
\hline 218 & - & 2692 & 3750 & 1295 & -1580 & 849 & -2679 & $-17 \cdot 74$ \\
\hline 220 & - & 2934 & 3763 & 1316 & -1632 & 877 & -2763 & $-18 \cdot 34$ \\
\hline 219 & - & - & 3760 & 1322 & -1737 & 904 & -2968 & $-19 \cdot 37$ \\
\hline 219 & - & - & 3761 & 1330 & -1901 & 918 & -3155 & $-20 \cdot 23$ \\
\hline 221 & - & - & 3768 & 1339 & -1917 & 925 & -3188 & -20.48 \\
\hline 221 & - & - & 3769 & 1342 & -1937 & 931 & -3239 & $-20 \cdot 80$ \\
\hline 221 & - & - & 3763 & 1337 & -1967 & 933 & -3283 & -21.19 \\
\hline 221 & - & - & 3772 & 1352 & -2136 & 944 & -3346 & $-21 \cdot 40$ \\
\hline 222 & - & - & 3773 & 1353 & -2175 & 950 & -3368 & $-21 \cdot 40$ \\
\hline 222 & - & - & 3777 & 1354 & -2198 & 952 & -3309 & -21.40 \\
\hline 223 & - & - & 3774 & 1349 & -2227 & 953 & -3264 & $-21 \cdot 44$ \\
\hline 222 & - & - & 3781 & 1357 & -2261 & 957 & -3252 & -21.40 \\
\hline 222 & - & - & 3780 & 1355 & -2278 & 957 & -3241 & -21.40 \\
\hline 222 & - & - & 3779 & 1356 & -2293 & 958 & -3244 & -21.40 \\
\hline 221 & - & - & 3776 & 1352 & -2309 & 958 & -3230 & $-21 \cdot 40$ \\
\hline 222 & - & - & 3783 & 1358 & -2331 & 961 & -3227 & -21.40 \\
\hline 208 & - & - & 3724 & 1300 & -2434 & 931 & -3080 & -21.83 \\
\hline 222 & - & - & 3783 & 1367 & -2530 & 969 & -3207 & -21.79 \\
\hline 222 & - & - & 3782 & 1366 & -2551 & 973 & -3185 & -21.83 \\
\hline 221 & - & - & 3779 & 1364 & -2567 & 974 & -3192 & -21.83 \\
\hline 221 & - & - & 3777 & 1361 & -2592 & 974 & -3182 & -21.83 \\
\hline 220 & - & - & 3778 & 1364 & -2638 & 976 & -3144 & -21.83 \\
\hline 221 & - & - & 3785 & 1369 & -2667 & 981 & -3165 & -21.79 \\
\hline 220 & - & - & 3778 & 1364 & -2704 & 980 & -3166 & -21.83 \\
\hline 220 & - & - & 3788 & 1361 & -2727 & 980 & -3125 & -21.83 \\
\hline 221 & - & - & 3796 & 1366 & -2761 & 982 & -3112 & -21.79 \\
\hline 221 & - & - & 3802 & 1372 & -2777 & 985 & -3104 & -21.83 \\
\hline 221 & - & - & 3802 & 1371 & -2790 & 985 & -3089 & -21.83 \\
\hline 211 & - & - & 3766 & 1331 & -5133 & 966 & -2891 & -21.83 \\
\hline
\end{tabular}




\section{APÊNDICE D}




\section{D.2 Ensaios de caracterização do cimento e da sílica ativa utilizada}

Tabela D.2.1- Resultados do cimento Ribeirão tipo CP II-F 32

\begin{tabular}{|c|c|c|c|c|}
\hline \multicolumn{3}{|c|}{$\begin{array}{l}\text { PROPRIEDADES DETERMINADAS } \\
\text { CP II F-32 }\end{array}$} & $\begin{array}{c}\text { Registro } \\
\mathbf{1 . 1 2 3 3 . 2 0 0 1} \\
\end{array}$ & \begin{tabular}{|c|} 
Limite \\
NBR 11578/91 \\
\end{tabular} \\
\hline \multicolumn{3}{|l|}{ Massa específica $\left(\mathrm{g} / \mathrm{cm}^{3}\right)$} & 3,10 & --- \\
\hline \multirow{3}{*}{ Finura } & \multicolumn{2}{|c|}{ Resíduo na peneira $200(\%)$} & 3,6 & $\leq 12$ \\
\hline & \multicolumn{2}{|c|}{ Resíduo na peneira $325(\%)$} & 15,1 & --- \\
\hline & \multicolumn{2}{|c|}{ Área específica $\left(\mathrm{cm}^{2} / \mathrm{g}\right)$} & 3.340 & $\geq 2600$ \\
\hline \multirow{2}{*}{$\begin{array}{l}\text { Tempos de } \\
\text { Pega } \\
\end{array}$} & \multicolumn{2}{|c|}{ Início de Pega (h:min) } & $3: 10$ & $\geq 1: 00$ \\
\hline & \multicolumn{2}{|c|}{ Fim de Pega (h:min) } & $4: 30$ & $\leq 10: 00$ \\
\hline \multicolumn{3}{|c|}{ Água de Consistência - Pasta (\%) } & 25,0 & --- \\
\hline \multicolumn{3}{|c|}{ Expansão em Autoclave (\%) } & & --- \\
\hline \multirow{4}{*}{$\begin{array}{l}\text { Resistência à } \\
\text { Compressão } \\
(\mathrm{MPa})\end{array}$} & \multicolumn{2}{|l|}{3 dias } & 22,2 & $\geq 10$ \\
\hline & \multicolumn{2}{|l|}{7 dias } & 29,0 & $\geq 20$ \\
\hline & \multicolumn{2}{|l|}{28 dias } & 34,4 & $\geq 3 \overline{2} \mathrm{e}<49$ \\
\hline & \multicolumn{2}{|l|}{90 dias } & & --- \\
\hline \multirow{2}{*}{$\begin{array}{c}\text { Calor de } \\
\text { Hidratação }(\mathrm{J} / \mathrm{g})\end{array}$} & \multicolumn{2}{|l|}{ 7dias } & 327,1 & --- \\
\hline & \multicolumn{2}{|l|}{28 dias } & 351,9 & --- \\
\hline \multirow{16}{*}{$\begin{array}{l}\text { Componentes Químicos } \\
\qquad(\%)\end{array}$} & \multicolumn{2}{|c|}{ Perda ao fogo } & 4,83 & $\leq 6,5$ \\
\hline & \multicolumn{2}{|c|}{ Resíduo insolúvel } & 0,67 & $\leq 2,5$ \\
\hline & \multicolumn{2}{|c|}{ Trióxido de enxofre $\left(\mathrm{SO}_{3}\right)$} & 1,98 & $\leq 4,0$ \\
\hline & \multicolumn{2}{|c|}{ Óxido de magnésio (MgO) } & 2,73 & $\leq 6,5$ \\
\hline & \multicolumn{2}{|c|}{ Dióxido de silício $\left(\mathrm{SiO}_{2}\right)$} & 18,88 & --- \\
\hline & \multicolumn{2}{|c|}{ Oxido de ferro $\left(\mathrm{Fe}_{2} \mathrm{O}_{3}\right)$} & 2,92 & $\overline{---}$ \\
\hline & \multicolumn{2}{|c|}{ Óxido de alumínio $\left(\mathrm{Al}_{2} \mathrm{O}_{3}\right)$} & 5,40 & --- \\
\hline & \multicolumn{2}{|c|}{ Óxido de cálcio $(\mathrm{CaO})$} & 62,27 & --- \\
\hline & \multicolumn{2}{|c|}{ Óxido de cálcio livre $(\mathrm{CaO})$} & 1,76 & --- \\
\hline & & Oxido de sódio $\left(\mathrm{Na}_{2} \mathrm{O}\right)$ & 0,08 & --- \\
\hline & Totais & Óxido de potássio $\left(\mathrm{K}_{2} \mathrm{O}\right)$ & 0,70 & --- \\
\hline & & Equivalente alcalino em $\mathrm{Na}_{2} \mathrm{O}$ & 0,54 & \\
\hline & Álcalis & Óxido de sódio $\left(\mathrm{Na}_{2} \mathrm{O}\right)$ & - & \\
\hline & Solúveis & Óxido de potássio $\left(\mathrm{K}_{2} \mathrm{O}\right)$ & - & \\
\hline & em Água & Equivalente alcalino em $\mathrm{Na}_{2} \mathrm{O}$ & - & --- \\
\hline & Sulfato de & cálcio $\left(\mathrm{CaSO}_{4}\right)$ & 3,56 & $\begin{array}{l}-- \\
\end{array}$ \\
\hline & Sílicato tr & icálcico $\left(\mathrm{C}_{3} \mathrm{~S}\right)$ & 56,75 & --- \\
\hline Composição Potencial & Silicato d & cálcico $\left(\mathrm{C}_{2} \mathrm{~S}\right)$ & 11,32 & --- \\
\hline Método & Aluminat & tricálcico $\left(\mathrm{C}_{3} \mathrm{~A}\right)$ & 9,37 & --- \\
\hline Bogue $(\%)$ & Ferro alur & ninato tetracálcico $\left(\mathrm{C}_{4} \mathrm{AF}\right)$ & 8,89 & \\
\hline
\end{tabular}


Tabela D.2.2 - Resultados do cimento Ciminas tipo CP V - ARI PLUS

\begin{tabular}{|c|c|c|c|c|}
\hline \multicolumn{3}{|c|}{$\begin{array}{l}\text { PROPRIEDADES DETERMINADAS } \\
\text { CP V ARI }\end{array}$} & $\begin{array}{c}\text { Registro } \\
1.1234 .2001\end{array}$ & $\begin{array}{c}\text { Limite } \\
\text { NBR 5733/91 }\end{array}$ \\
\hline \multicolumn{3}{|c|}{ Massa específica $\left(\mathrm{g} / \mathrm{cm}^{3}\right)$} & 3,10 & \\
\hline \multirow{3}{*}{ Finura } & \multicolumn{2}{|c|}{ Resíduo na peneira $200(\%)$} & 0,3 & $\leq 6,0$ \\
\hline & \multicolumn{2}{|c|}{ Resíduo na peneira $325(\%)$} & 3,1 & --- \\
\hline & \multicolumn{2}{|c|}{ Área específica $\left(\mathrm{cm}^{2} / \mathrm{g}\right)$} & 4.590 & $\geq 3000$ \\
\hline \multirow{2}{*}{$\begin{array}{c}\text { Tempo de Pega } \\
\text { (h:min) }\end{array}$} & \multicolumn{2}{|c|}{ Início } & $1: 50$ & $\geq 1: 00 \mathrm{~h}$ \\
\hline & \multicolumn{2}{|l|}{ Fim } & $2: 50$ & $\leq 10: 00 \mathrm{~h}$ \\
\hline \multicolumn{3}{|c|}{ Água de Consistência - Pasta (\%) } & 26,8 & $\begin{array}{ll}-- \\
\end{array}$ \\
\hline \multirow{4}{*}{$\begin{array}{l}\text { Resistência à } \\
\text { Compressão } \\
(\mathrm{MPa})\end{array}$} & \multicolumn{2}{|l|}{1 dia } & - & $\geq 14,0$ \\
\hline & \multicolumn{2}{|l|}{3 dias } & 27,5 & $\geq 24,0$ \\
\hline & \multicolumn{2}{|l|}{7 dias } & 35,4 & $\geq 34,0$ \\
\hline & \multicolumn{2}{|l|}{28 dias } & 40,0 & --- \\
\hline \multirow{2}{*}{$\begin{array}{c}\text { Calor de Hidratação } \\
(\mathrm{J} / \mathrm{g})\end{array}$} & \multicolumn{2}{|l|}{7 dias } & 403,8 & --- \\
\hline & \multicolumn{2}{|l|}{28 dias } & 442,7 & $\begin{array}{ll}-- \\
--\end{array}$ \\
\hline \multirow{16}{*}{$\begin{array}{c}\text { Componentes } \\
\text { Químicos } \\
(\%)\end{array}$} & \multicolumn{2}{|c|}{ Perda ao fogo } & 2,70 & $\leq 4,5$ \\
\hline & \multicolumn{2}{|c|}{ Resíduo insolúvel } & 0,21 & $\leq 1,0$ \\
\hline & \multicolumn{2}{|c|}{ Trióxido de enxofre $\left(\mathrm{SO}_{3}\right)$} & 2,83 & 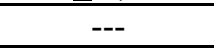 \\
\hline & \multicolumn{2}{|c|}{ Óxido de magnésio (MgO) } & 1,50 & $\leq 6,5$ \\
\hline & \multicolumn{2}{|c|}{ Dióxido de silício $\left(\mathrm{SiO}_{2}\right)$} & 18,60 & --- \\
\hline & \multicolumn{2}{|c|}{ Óxido de ferro $\left(\mathrm{Fe}_{2} \mathrm{O}_{3}\right)$} & 2,85 & --- \\
\hline & \multicolumn{2}{|c|}{ Óxido de alumínio $\left(\mathrm{Al}_{2} \mathrm{O}_{3}\right)$} & 5,68 & $\begin{array}{ll}-- \\
\end{array}$ \\
\hline & \multicolumn{2}{|c|}{ Óxido de cálcio $(\mathrm{CaO})$} & 63,66 & $\begin{array}{ll}-- \\
\end{array}$ \\
\hline & \multicolumn{2}{|c|}{ Óxido de cálcio livre $(\mathrm{CaO})$} & 1,69 & $\begin{array}{ll}-- \\
\end{array}$ \\
\hline & \multirow{3}{*}{$\begin{array}{l}\text { Álcalis } \\
\text { Totais }\end{array}$} & Óxido de sódio $\left(\mathrm{Na}_{2} \mathrm{O}\right)$ & 0,04 & --- \\
\hline & & $\begin{array}{l}\text { Óxido de potássio } \\
\left(\mathrm{K}_{2} \mathrm{O}\right)\end{array}$ & 0,58 & --- \\
\hline & & Equiv. alcalino & 0,42 & --- \\
\hline & \multirow{3}{*}{$\begin{array}{l}\text { Álcalis } \\
\text { Solúveis em } \\
\text { Água }\end{array}$} & Óxido de sódio $\left(\mathrm{Na}_{2} \mathrm{O}\right)$ & - & --- \\
\hline & & $\begin{array}{l}\text { Óxido de potássio } \\
\left(\mathrm{K}_{2} \mathrm{O}\right)\end{array}$ & - & --- \\
\hline & & Equiv. alcalino & - & --- \\
\hline & \multicolumn{2}{|c|}{ Sulfato de cálcio $\left(\mathrm{CaSO}_{4}\right)$} & 4,82 & --- \\
\hline
\end{tabular}


Tabela D.2.3 - Resultados da sílica ativa marca SILMIX

\begin{tabular}{|c|c|c|c|c|}
\hline \multicolumn{3}{|c|}{$\begin{array}{l}\text { PROPRIEDADES DETERMINADAS } \\
\text { Silica Ativa }\end{array}$} & $\begin{array}{l}\text { Registro } \\
1.1236 .2001\end{array}$ & $\begin{array}{l}\text { Limite } \\
\text { NBR 13956/97 }\end{array}$ \\
\hline \multicolumn{3}{|c|}{ Massa específica $\left(\mathrm{g} / \mathrm{cm}^{3}\right)$} & 2,21 & - \\
\hline \multirow{3}{*}{ Finura } & \multicolumn{2}{|c|}{ Resíduo na peneira $200(\%)$} & & - \\
\hline & \multicolumn{2}{|c|}{\begin{tabular}{|l|l} 
Resíduo na peneira $325(\%)$ \\
\end{tabular}} & & - \\
\hline & \multicolumn{2}{|c|}{ Área específica $\left(\mathrm{cm}^{2} / \mathrm{g}\right)$} & * & - \\
\hline & \multicolumn{2}{|c|}{ Perda ao fogo } & 1,96 & $\leq 6,0$ \\
\hline & \multicolumn{2}{|c|}{ Resíduo insolúvel } & - & - \\
\hline & \multicolumn{2}{|c|}{ Trióxido de enxofre $\left(\mathrm{SO}_{3}\right)$} & - & - \\
\hline & \multicolumn{2}{|c|}{\begin{tabular}{|c|} 
Óxido de magnésio $(\mathrm{MgO})$ \\
\end{tabular}} & 0,65 & - \\
\hline & \multicolumn{2}{|c|}{ Dióxido de silício $\left(\mathrm{SiO}_{2}\right)$} & 94,08 & $\geq 85,0$ \\
\hline $\begin{array}{l}\text { Componentes } \\
\text { Oú́micos }\end{array}$ & \multicolumn{2}{|c|}{\begin{tabular}{|l|} 
Óxido de ferro $\left(\mathrm{Fe}_{2} \mathrm{O}_{3}\right)$ \\
\end{tabular}} & 0,08 & - \\
\hline Qumings & \multicolumn{2}{|c|}{ Óxido de alumínio $\left(\mathrm{Al}_{2} \mathrm{O}_{3}\right)$} & 0,06 & - \\
\hline & \multicolumn{2}{|c|}{ Óxido de cálcio $(\mathrm{CaO})$} & 0,78 & - \\
\hline & \multicolumn{2}{|c|}{ Óxido de cálcio livre $(\mathrm{CaO})$} & - & - \\
\hline & \multirow[t]{3}{*}{ Álcalis totais } & Óxido de sódio $\left(\mathrm{Na}_{2} \mathrm{O}\right)$ & 0,18 & - \\
\hline & & Óxido de potássio $\left(\mathrm{K}_{2} \mathrm{O}\right)$ & 0,24 & - \\
\hline & & Equivalente alcalino em $\mathrm{Na}_{2} \mathrm{O}$ & 0,34 & $\leq 1,5$ \\
\hline \multicolumn{3}{|c|}{ Teor de Umidade (\%) } & - & $\leq 3,0$ \\
\hline
\end{tabular}

\section{D.3 Ensaios de caracterização dos agregados}

Tabela D.3.1 - Resultados da caracterização da areia, brita 1 e brita 0

\begin{tabular}{|c|c|c|c|c|c|}
\hline \multicolumn{2}{|c|}{$\begin{array}{c}\text { Data da solicitação } \\
17 / 05 / 01\end{array}$} & $\begin{array}{l}\text { Programa: } 1314 \\
\text { Eng. Responsável: Elcio Guerra }\end{array}$ & \multicolumn{3}{|c|}{ Elcio Guerra } \\
\hline \multicolumn{2}{|c|}{$\begin{array}{l}\text { METODO } \\
\text { UTILIZADO }\end{array}$} & $\begin{array}{c}\text { ENSAIOS } \\
\text { REALIZADOS }\end{array}$ & $\begin{array}{l}\text { MATERIAL } \\
\text { Areia Natural }\end{array}$ & $\begin{array}{c}\text { MATERIAL } \\
\text { Basalto } 19 \mathrm{~mm}\end{array}$ & $\begin{array}{c}\text { MATERIAL } \\
\text { Basalto } 9,5 \mathrm{~mm}\end{array}$ \\
\hline \multicolumn{2}{|c|}{ NO ENSAIO } & NO BLOCO 08 & REGISTRO & REGISTRO & REGISTRO \\
\hline NORMA & PROCED. & (AGREGADOS) & 1.1230 .01 & 1.1231 .01 & 1.1232 .01 \\
\hline NBR-9777/87 & 1.02 .04 & - Absorção (\%) & 0,48 & $\overline{-----}$ & $\overline{---_{--}}$ \\
\hline NBR-7217/87 & 1.02 .44 & - Granulometria (M.F.) & 2,40 & $-\cdots$ & 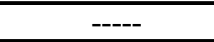 \\
\hline NBR-9776/87 & 1.02 .02 & - M. Específica - Chapman- $\left(\mathrm{g} / \mathrm{cm}^{3}\right)$ & 2,62 & $-\cdots$ & $-\cdots$ \\
\hline NBR-7220/87 & 1.02.11 & - Teor de Matéria Orgânica (+/- Clara) & + Clara & ---- & ---- \\
\hline NBR-6465/84 & 1.02 .16 & - Abrasão Los Ângeles(\%) & $\begin{array}{ll}---- \\
--\end{array}$ & $13(\mathrm{~B})$ & 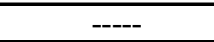 \\
\hline NBR-9937/87 & 1.02 .03 & - Absorção (\%) & $-\cdots$ & 1,0 & 1,60 \\
\hline NBR-7217/87 & 1.02 .09 & - Granulometria (M.F.) & 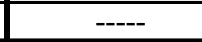 & 6,67 & 4,14 \\
\hline NBR-9937/87 & 1.02 .03 & - Massa Específica S.S.S.(g/cm³) & 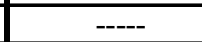 & 2,88 & 2,84 \\
\hline NBR-7251/82 & 1.02 .05 & - Massa Unit. - Estado Solto $\left(\mathrm{kg} / \mathrm{dm}^{3}\right)$ & 1,54 & 1,49 & 1,48 \\
\hline NBR-7218/87 & 1.02 .13 & - T. de Arg. em Torr. e Mat. Friáveis (\%) & 0,10 & ----- & 0,00 \\
\hline NBR-7219/87 & 1.02 .12 & - Teor de Material pulverulento (\%) & 1,12 & $-\cdots$ & 6,47 \\
\hline
\end{tabular}




\section{D.4 Resultado das propriedades mecânicas dos materiais}

Tabela D.4.1 - Resistências à compressão axial e à tração por compressão diametral

\begin{tabular}{|c|c|c|c|c|c|}
\hline & Idade & $\mathbf{f}_{\mathrm{cj}}$ & $\mathbf{f}_{\mathrm{cj}}-$ média & $\mathbf{f}_{\mathrm{tj}}$ & $f_{\mathrm{tj}}-$ média \\
\hline & (dia) & ( Мра) & ( Мра) & ( Мpa) & ( Мpa) \\
\hline \multirow{14}{*}{ Substrato } & \multirow[t]{2}{*}{3} & 11,8 & \multirow[t]{2}{*}{12,3} & 1,5 & \multirow[t]{2}{*}{1,5} \\
\hline & & 12,8 & & - & \\
\hline & \multirow[t]{2}{*}{7} & 17,1 & \multirow[t]{2}{*}{16,6} & 2,1 & \multirow[t]{2}{*}{2,1} \\
\hline & & 16,0 & & 2,1 & \\
\hline & \multirow[t]{2}{*}{14} & 20,9 & \multirow[t]{2}{*}{20,9} & 2,9 & \multirow[t]{2}{*}{2,6} \\
\hline & & 20,9 & & 2,4 & \\
\hline & \multirow[t]{2}{*}{21} & 26,7 & \multirow[t]{2}{*}{25,8} & 2,6 & \multirow[t]{2}{*}{2,7} \\
\hline & & 25,0 & & 2,7 & \\
\hline & \multirow[t]{2}{*}{28} & 26,7 & \multirow[t]{2}{*}{26,4} & 3,3 & \multirow[t]{2}{*}{3,3} \\
\hline & & 25,9 & & & \\
\hline & \multirow[t]{2}{*}{50} & 30,6 & \multirow[t]{2}{*}{30,9} & 3,12 & \multirow[t]{2}{*}{3,15} \\
\hline & & 31,3 & & 3,18 & \\
\hline & \multirow[t]{2}{*}{$130 *$} & 28,7 & \multirow[t]{2}{*}{26,8} & - & - \\
\hline & & 25,0 & & - & - \\
\hline \multirow{14}{*}{ Reforço } & \multirow[t]{2}{*}{3} & - & \multirow[t]{2}{*}{-} & - & \multirow[t]{2}{*}{ - } \\
\hline & & - & & - & \\
\hline & \multirow[t]{2}{*}{7} & 53,5 & \multirow[t]{2}{*}{54,9} & 5,0 & \multirow[t]{2}{*}{4,7} \\
\hline & & 56,3 & & 4,3 & \\
\hline & \multirow[t]{2}{*}{14} & 75,1 & \multirow[t]{2}{*}{75,1} & 5,0 & \multirow[t]{2}{*}{4,8} \\
\hline & & - & & 4,5 & \\
\hline & 21 & 77,7 & 77,4 & 5,5 & 6,0 \\
\hline & & 77,2 & & 6,6 & \\
\hline & 28 & 78,9 & 80,6 & 5,9 & 5,7 \\
\hline & & 82,3 & & 5,5 & \\
\hline & 50 & 95,4 & 84,6 & 6,0 & 6,0 \\
\hline & & 73,8 & & - & \\
\hline & $115^{*}$ & 69,5 & 72,7 & - & - \\
\hline & & 76,2 & & - & \\
\hline
\end{tabular}


Tabela D.4.2 - Módulos de elasticidade

\begin{tabular}{|c|c|c|c|c|c|}
\hline & Idade & Ext. Carlson & \begin{tabular}{|c} 
Ext. Carlson - \\
média
\end{tabular} & Ext. LVDT & $\begin{array}{c}\text { Ext. LVDT - } \\
\text { média }\end{array}$ \\
\hline & (dia) & ( GPa) & ( GPa) & ( GPa) & ( GPa) \\
\hline \multirow{14}{*}{ Substrato } & \multirow[t]{2}{*}{3} & - & \multirow[t]{2}{*}{-} & 22,57 & \multirow[t]{2}{*}{22,52} \\
\hline & & - & & 22,47 & \\
\hline & \multirow[t]{2}{*}{7} & 24,38 & \multirow[t]{2}{*}{24,83} & 26,33 & \multirow[t]{2}{*}{25,67} \\
\hline & & 25,28 & & 25,02 & \\
\hline & \multirow[t]{2}{*}{14} & - & \multirow[t]{2}{*}{-} & 29,77 & \multirow[t]{2}{*}{29,71} \\
\hline & & - & & 29,66 & \\
\hline & \multirow[t]{2}{*}{21} & 34,52 & \multirow[t]{2}{*}{32,27} & 29,71 & \multirow[t]{2}{*}{29,68} \\
\hline & & 30,03 & & 29,66 & \\
\hline & \multirow[t]{2}{*}{28} & 32,15 & \multirow[t]{2}{*}{34,43} & 34,51 & \multirow[t]{2}{*}{34,61} \\
\hline & & 36,72 & & 34,71 & \\
\hline & \multirow[t]{2}{*}{50} & 38,72 & \multirow[t]{2}{*}{36,05} & 35,85 & \multirow[t]{2}{*}{33,94} \\
\hline & & 33,38 & & 32,08 & \\
\hline & \multirow[t]{2}{*}{$130 *$} & - & \multirow[t]{2}{*}{-} & 34,36 & \multirow[t]{2}{*}{39,78} \\
\hline & & - & & 45,12 & \\
\hline \multirow{14}{*}{ Reforço } & \multirow[t]{2}{*}{3} & - & \multirow[t]{2}{*}{-} & - & \multirow[t]{2}{*}{-} \\
\hline & & - & & - & \\
\hline & \multirow[t]{2}{*}{7} & 36,20 & \multirow[t]{2}{*}{35,66} & 31,67 & \multirow[t]{2}{*}{31,68} \\
\hline & & 35,13 & & 31,69 & \\
\hline & \multirow[t]{2}{*}{14} & - & \multirow[t]{2}{*}{-} & 31,14 & 34,06 \\
\hline & & - & & 36,99 & \\
\hline & 21 & 41,12 & 40,09 & 33,81 & 34,08 \\
\hline & & 39,06 & & 34,35 & \\
\hline & 28 & 39,89 & 40,42 & 35,00 & 34,96 \\
\hline & & 41,34 & & 34,93 & \\
\hline & 50 & 42,29 & 42,21 & 36,63 & 36,57 \\
\hline & & 43,22 & & 36,51 & \\
\hline & $115^{*}$ & - & - & 35,45 & 35,47 \\
\hline & & - & & 35,51 & \\
\hline
\end{tabular}




\section{D.5 Ensaios de fluência}

Tabela D.5.1 - Função Fluência para o traço do substrato - Dosagem E-9091 (TS-2)

\begin{tabular}{|c|c|c|c|c|c|c|c|}
\hline \multicolumn{2}{|c|}{$t_{o}=7$ dias } & \multicolumn{2}{|c|}{$t_{0}=14$ dias } & \multicolumn{2}{|c|}{$t_{0}=50$ dias } & \multicolumn{2}{|c|}{$t_{o}=103$ dias } \\
\hline Idade & fluência & Idade & fluência & Idade & fluência & Idade & fluência \\
\hline (dias) & $\left(\times 10^{-6} / \mathrm{MPa}\right)$ & (dias) & $\left(\times 10^{-6} / \mathrm{MPa}\right)$ & (dias) & $\left(\times 10^{-6} / \mathrm{MPa}\right)$ & (dias) & $\left(\times 10^{-6} / \mathrm{MPa}\right)$ \\
\hline 7 & 0.00 & 14 & 0.00 & 50 & 0.00 & 103 & 0.00 \\
\hline 7 & 39.18 & 14 & 35.83 & 50 & 27.75 & 103 & 26.13 \\
\hline 7 & 39.82 & 14 & 36.07 & 50 & 27.75 & 103 & 26.49 \\
\hline 7 & 39.81 & 14 & 36.07 & 50 & 27.76 & 103 & 26.48 \\
\hline 7 & 39.82 & 14 & 36.07 & 50 & 27.75 & 103 & 26.49 \\
\hline 7 & 39.81 & 14 & 36.32 & 50 & 28.57 & 103 & 26.58 \\
\hline 7 & 40.13 & 14 & 37.02 & 50 & 28.58 & 103 & 26.73 \\
\hline 7 & 41.17 & 14 & 37.26 & 50 & 28.93 & 103 & 27.07 \\
\hline 7 & 41.37 & 14 & 37.74 & 50 & 29.17 & 103 & 27.07 \\
\hline 7 & 41.89 & 14 & 37.72 & 50 & 29.63 & 103 & 27.32 \\
\hline 7 & 42.41 & 14 & 38.67 & 50 & 29.81 & 103 & 27.32 \\
\hline 8 & 48.05 & 15 & 42.70 & 51 & 31.20 & 104 & 28.17 \\
\hline 11 & 57.80 & 18 & 48.87 & 54 & 34.11 & 105 & 28.87 \\
\hline 12 & 59.55 & 19 & 49.88 & 55 & 34.83 & 106 & 29.11 \\
\hline 13 & 61.33 & 20 & 50.83 & 56 & 35.29 & 109 & 30.19 \\
\hline 14 & 63.66 & 21 & 51.80 & 58 & 36.33 & 110 & 30.42 \\
\hline 15 & 64.21 & 25 & 54.15 & 60 & 37.03 & 111 & 30.76 \\
\hline 18 & 66.80 & 26 & 54.62 & 61 & 37.61 & 112 & 30.77 \\
\hline 19 & 67.92 & 27 & 55.35 & 62 & 37.96 & 116 & 31.76 \\
\hline 20 & 68.97 & 28 & 55.31 & 63 & 38.20 & 117 & 32.07 \\
\hline 21 & 69.01 & 29 & 55.77 & 64 & 38.45 & 118 & 32.30 \\
\hline 25 & 69.53 & 32 & 56.76 & 67 & 39.35 & 119 & 32.31 \\
\hline 26 & 70.05 & 33 & 56.73 & 68 & 39.67 & 120 & 32.56 \\
\hline 27 & 70.60 & 34 & 57.22 & 69 & 39.61 & 123 & 33.06 \\
\hline 28 & 70.77 & 35 & 57.48 & 70 & 40.00 & 124 & 33.31 \\
\hline 29 & 71.28 & 36 & 57.70 & 71 & 40.05 & 125 & 33.42 \\
\hline 32 & 71.63 & 39 & 58.31 & 74 & 40.69 & 130 & 33.93 \\
\hline 33 & 71.59 & 40 & 58.86 & 75 & 40.93 & 131 & 34.21 \\
\hline 34 & 71.84 & 41 & 58.85 & 76 & 41.27 & 132 & 34.34 \\
\hline 35 & 72.38 & 42 & 59.31 & 77 & 41.49 & 133 & 34.34 \\
\hline 36 & 73.10 & 43 & 58.96 & 78 & 41.73 & 134 & 34.44 \\
\hline 39 & 73.30 & 46 & 59.34 & 81 & 42.42 & 137 & 34.98 \\
\hline 40 & 73.39 & 47 & 59.56 & 82 & 42.37 & 138 & 35.18 \\
\hline 41 & 73.37 & 48 & 59.79 & 83 & 42.60 & 139 & 35.08 \\
\hline 42 & 73.35 & 49 & 60.03 & 85 & 43.00 & 140 & 35.09 \\
\hline 43 & 73.38 & 50 & 60.50 & 88 & 43.46 & 141 & 35.39 \\
\hline 46 & 74.00 & 54 & 61.77 & 89 & 43.56 & 144 & 35.76 \\
\hline 47 & 74.31 & 55 & 62.06 & 90 & 43.80 & 145 & 35.70 \\
\hline 48 & 74.50 & 56 & 62.30 & 91 & 43.98 & 146 & 35.67 \\
\hline 49 & 75.33 & 60 & 62.75 & 95 & 44.67 & 147 & 35.90 \\
\hline 50 & 75.34 & 61 & 63.20 & 96 & 44.96 & 148 & 36.03 \\
\hline
\end{tabular}




\begin{tabular}{|c|c|c|c|c|c|c|c|}
\hline 54 & 76.68 & 62 & 63.43 & 97 & 45.02 & 151 & 36.14 \\
\hline 55 & 76.72 & 63 & 63.68 & 98 & 45.03 & 152 & 36.25 \\
\hline 56 & 76.71 & 64 & 63.70 & 99 & 45.04 & 153 & 36.26 \\
\hline 60 & 77.40 & 67 & 63.91 & 102 & 45.27 & 154 & 36.49 \\
\hline 61 & 77.92 & 68 & 64.33 & 103 & 45.37 & 155 & 36.74 \\
\hline 62 & 78.21 & 69 & 64.27 & 104 & 45.54 & 158 & 36.94 \\
\hline 63 & 78.44 & 70 & 64.62 & 105 & 45.61 & 159 & 37.02 \\
\hline 64 & 78.48 & 71 & 64.69 & 106 & 45.72 & 160 & 37.13 \\
\hline 67 & 79.00 & 74 & 65.30 & 109 & 45.94 & 161 & 37.25 \\
\hline 68 & 79.54 & 75 & 65.53 & 110 & 46.15 & 162 & 37.24 \\
\hline 69 & 79.45 & 76 & 65.98 & 111 & 46.39 & 165 & 37.29 \\
\hline 70 & 79.59 & 77 & 65.96 & 112 & 46.41 & 168 & 37.71 \\
\hline 71 & 79.67 & 78 & 66.45 & 116 & 46.90 & 169 & 38.04 \\
\hline 74 & 79.78 & 81 & 66.72 & 117 & 47.08 & 172 & 38.14 \\
\hline 75 & 80.28 & 82 & 66.82 & 118 & 47.17 & 175 & 38.30 \\
\hline 76 & 80.57 & 83 & 66.83 & 119 & 47.30 & 176 & 38.33 \\
\hline 77 & 80.56 & 85 & 67.20 & 120 & 47.30 & 179 & 38.56 \\
\hline 78 & 80.80 & 88 & 68.13 & 123 & 47.55 & 180 & 38.56 \\
\hline 85 & 81.05 & 89 & 67.79 & 124 & 47.79 & 181 & 38.80 \\
\hline 88 & 81.35 & 90 & 68.04 & 125 & 48.04 & 182 & 39.10 \\
\hline 89 & 81.76 & 91 & 68.19 & 130 & 48.29 & 183 & 39.15 \\
\hline 90 & 81.78 & 95 & 68.75 & 131 & 48.33 & 186 & 39.39 \\
\hline 91 & 81.88 & 96 & 69.30 & 132 & 48.60 & 187 & 39.33 \\
\hline 95 & 82.81 & 97 & 69.21 & 133 & 48.61 & 188 & 39.32 \\
\hline 96 & 82.92 & 98 & 69.08 & 134 & 48.66 & 189 & 39.36 \\
\hline 97 & 82.81 & 99 & 69.08 & 137 & 48.84 & 190 & 39.57 \\
\hline 98 & 82.96 & 102 & 69.54 & 138 & 49.00 & 193 & 39.59 \\
\hline \multirow[t]{3}{*}{99} & 82.97 & 103 & 69.51 & 139 & 48.89 & 194 & 39.81 \\
\hline & & 104 & 69.42 & 140 & 49.16 & & \\
\hline & & 105 & 69.58 & 141 & 49.22 & & \\
\hline
\end{tabular}

Tabela D.5.2 - Função Fluência para o traço do reforço - Dosagem E-9121 (TR-2)

\begin{tabular}{|c|c|c|c|c|c|c|c|}
\hline \multicolumn{2}{|c|}{$t_{o}=7$ dias } & \multicolumn{2}{|c|}{$t_{o}=14$ dias } & \multicolumn{2}{|c|}{$t_{o}=126$ dias } & \multicolumn{2}{|c|}{$t_{o}=176$ dias } \\
\hline Idade & Fluência & Idade & fluência & Idade & fluência & Idade & fluência \\
\hline (dias) & $\left(\times 10^{-6} / \mathrm{MPa}\right)$ & (dias) & $\left(\times 10^{-6} / \mathrm{MPa}\right)$ & (dias) & $\left(\times 10^{-6} / \mathrm{MPa}\right)$ & (dias) & $\left(\times 10^{-6} / \mathrm{MPa}\right)$ \\
\hline 7 & 0.00 & 14 & 0.00 & 126 & 0.00 & 176 & 0.00 \\
\hline 7 & 28.20 & 14 & 14.67 & 126 & 25.52 & 176 & 23.86 \\
\hline 7 & 28.33 & 14 & 15.05 & 126 & 25.52 & 176 & 23.86 \\
\hline 7 & 28.33 & 14 & 15.04 & 126 & 25.52 & 176 & 24.06 \\
\hline 7 & 28.33 & 14 & 15.05 & 126 & 25.82 & 176 & 24.06 \\
\hline 7 & 29.10 & 14 & 15.23 & 126 & 25.82 & 176 & 24.16 \\
\hline 7 & 29.36 & 14 & 15.41 & 126 & 26.05 & 176 & 24.26 \\
\hline 7 & 29.61 & 14 & 15.42 & 126 & 26.20 & 176 & 24.26 \\
\hline 7 & 30.52 & 14 & 15.41 & 126 & 26.36 & 176 & 24.30 \\
\hline 7 & 30.77 & 14 & 15.78 & 126 & 26.51 & 176 & 24.50 \\
\hline 7 & 31.41 & 14 & 15.97 & 126 & 26.66 & 176 & 24.64 \\
\hline 11 & 43.80 & 15 & 29.17 & 126 & 26.81 & 176 & 24.82 \\
\hline 12 & 45.23 & 16 & 30.83 & 127 & 27.60 & 178 & 25.36 \\
\hline
\end{tabular}




\begin{tabular}{|c|c|c|c|c|c|c|c|}
\hline 13 & 46.27 & 18 & 33.26 & 130 & 28.37 & 179 & 26.18 \\
\hline 14 & 47.42 & 19 & 33.99 & 131 & 28.58 & 180 & 26.26 \\
\hline 15 & 48.56 & 20 & 34.57 & 132 & 28.79 & 181 & 26.54 \\
\hline 18 & 50.51 & 21 & 35.13 & 133 & 28.93 & 182 & 26.69 \\
\hline 19 & 51.27 & 22 & 35.68 & 134 & 29.10 & 183 & 26.80 \\
\hline 20 & 51.55 & 25 & 36.77 & 137 & 29.62 & 186 & 26.86 \\
\hline 21 & 51.95 & 26 & 37.35 & 138 & 29.62 & 187 & 27.33 \\
\hline 22 & 52.45 & 27 & 37.35 & 139 & 29.62 & 188 & 27.54 \\
\hline 25 & 53.70 & 28 & 37.72 & 140 & 29.77 & 189 & 27.64 \\
\hline 26 & 54.25 & 29 & 37.72 & 141 & 30.00 & 190 & 27.77 \\
\hline 27 & 54.50 & 32 & 38.62 & 144 & 30.25 & 193 & 27.77 \\
\hline 28 & 54.88 & 33 & 38.81 & 145 & 30.25 & 194 & 27.92 \\
\hline 29 & 54.89 & 34 & 38.98 & 146 & 30.38 & 195 & 27.84 \\
\hline 32 & 56.14 & 35 & 39.36 & 147 & 30.39 & 196 & 28.01 \\
\hline 33 & 56.40 & 36 & 39.55 & 148 & 30.54 & 197 & 28.01 \\
\hline 34 & 56.64 & 40 & 40.74 & 151 & 30.70 & 198 & 28.07 \\
\hline 35 & 57.04 & 41 & 40.94 & 154 & 30.98 & 201 & 29.19 \\
\hline 36 & 57.30 & 42 & 41.12 & 155 & 31.10 & 203 & 29.21 \\
\hline 40 & 58.68 & 46 & 41.87 & 158 & 31.29 & 204 & 29.08 \\
\hline 41 & 58.96 & 47 & 42.06 & 161 & 31.48 & 207 & 29.37 \\
\hline 42 & 59.22 & 48 & 42.24 & 162 & 31.53 & 208 & 29.32 \\
\hline 46 & 60.26 & 49 & 42.43 & 165 & 31.68 & 209 & 29.38 \\
\hline 47 & 60.52 & 50 & 42.62 & 166 & 31.75 & 214 & 29.74 \\
\hline 48 & 60.76 & 53 & 42.97 & 167 & 31.75 & 221 & 30.15 \\
\hline 49 & 60.90 & 54 & 43.28 & 168 & 31.77 & 228 & 30.28 \\
\hline 50 & 61.17 & 55 & 43.45 & 169 & 31.80 & 235 & 30.46 \\
\hline 53 & 61.52 & 56 & 43.88 & 172 & 32.02 & 242 & 31.48 \\
\hline 54 & 61.96 & 57 & 43.90 & 173 & 31.99 & 249 & 31.70 \\
\hline 55 & 61.92 & 60 & 44.34 & 174 & 32.14 & 256 & 32.12 \\
\hline 56 & 62.14 & 61 & 44.43 & 175 & 32.16 & 263 & 32.06 \\
\hline 57 & 62.43 & 62 & 44.62 & 176 & 32.30 & 267 & 32.18 \\
\hline 60 & 62.78 & 63 & 44.80 & 179 & 32.38 & & \\
\hline 61 & 63.16 & 64 & 44.80 & 180 & 32.45 & & \\
\hline 62 & 63.69 & 67 & 45.21 & 181 & 32.42 & & \\
\hline 63 & 63.68 & 68 & 45.14 & 182 & 32.42 & & \\
\hline 64 & 63.81 & 69 & 45.33 & 183 & 32.59 & & \\
\hline 67 & 64.00 & 71 & 45.57 & 186 & 32.69 & & \\
\hline 68 & 64.03 & 74 & 45.83 & 187 & 32.73 & & \\
\hline 69 & 64.03 & 75 & 45.99 & 188 & 32.88 & & \\
\hline 71 & 64.37 & 76 & 45.98 & 189 & 32.88 & & \\
\hline 74 & 64.48 & 77 & 46.13 & 190 & 32.88 & & \\
\hline 75 & 64.83 & 81 & 46.50 & 193 & 32.96 & & \\
\hline 76 & 64.96 & 82 & 46.62 & 194 & 33.05 & & \\
\hline 77 & 64.91 & 83 & 46.67 & 195 & 33.11 & & \\
\hline 81 & 65.30 & 84 & 46.73 & 196 & 33.23 & & \\
\hline 82 & 65.45 & 85 & 46.82 & 197 & 33.23 & & \\
\hline 83 & 65.54 & 88 & 47.01 & 198 & 33.26 & & \\
\hline 84 & 65.76 & 89 & 47.09 & 201 & 33.38 & & \\
\hline 85 & 65.76 & 90 & 47.16 & 203 & 33.40 & & \\
\hline 88 & 66.01 & 91 & 47.14 & 207 & 33.36 & & \\
\hline
\end{tabular}




\begin{tabular}{||l|l|l|l|l|l|l|l||}
89 & 66.14 & 92 & 47.22 & 208 & 33.55 & & \\
\hline 90 & 66.10 & 95 & 47.41 & 209 & 33.67 & & \\
\hline 91 & 66.32 & 96 & 47.49 & 214 & 33.69 & & \\
\hline 92 & 66.31 & 97 & 47.49 & 221 & 33.84 & & \\
\hline 95 & 66.60 & 98 & 47.59 & & & & \\
\hline 96 & 66.71 & 102 & 47.96 & & & & \\
\hline 97 & 66.85 & 103 & 47.94 & & & & \\
\hline 98 & 66.86 & 104 & 47.93 & & & & \\
\hline & & 105 & 48.03 & & & & \\
\hline
\end{tabular}

\section{D.6 Ensaios de retração autógena}

Tabela D.6.1 - Retração autógena para os traços do substrato e do reforço

\begin{tabular}{|c|c|c|c|}
\hline \multicolumn{2}{|c|}{ Dosagem E-9091 - substrato } & \multicolumn{2}{|c|}{ Dosagem E-9121 - reforço } \\
\hline Idade & retração autógena & Idade & retração autógena \\
\hline (dias) & $\left(\mathrm{x10}^{-6}\right)$ & (dias) & $\left(\mathrm{x10}^{-6}\right)$ \\
\hline 5 & -2.65 & 6 & -5.97 \\
\hline 6 & -3.89 & 7 & -6.45 \\
\hline 7 & -5.48 & 11 & -12.65 \\
\hline 8 & -9.76 & 12 & -12.90 \\
\hline 11 & -17.15 & 13 & -14.23 \\
\hline 12 & -20.36 & 14 & -17.18 \\
\hline 13 & -27.06 & 15 & -19.98 \\
\hline 14 & -25.91 & 18 & -26.10 \\
\hline 15 & -28.51 & 19 & -25.97 \\
\hline 18 & -34.95 & 20 & -26.07 \\
\hline 19 & -36.59 & 21 & -27.50 \\
\hline 20 & -37.84 & 22 & -30.45 \\
\hline 21 & -39.14 & 25 & -32.73 \\
\hline 25 & -40.50 & 26 & -37.40 \\
\hline 26 & -41.79 & 27 & -37.46 \\
\hline 27 & -42.08 & 28 & -40.54 \\
\hline 28 & -41.91 & 29 & -41.54 \\
\hline 29 & -41.79 & 32 & -48.32 \\
\hline 32 & -41.91 & 33 & -49.58 \\
\hline 33 & -41.74 & 34 & -51.23 \\
\hline 34 & -41.85 & 35 & -55.23 \\
\hline 35 & -42.02 & 36 & -55.51 \\
\hline 36 & -41.97 & 40 & -63.85 \\
\hline 39 & -41.16 & 41 & -67.09 \\
\hline 40 & -41.74 & 42 & -70.11 \\
\hline 42 & -41.51 & 46 & -77.15 \\
\hline 43 & -41.28 & 47 & -80.10 \\
\hline 46 & -42.06 & 48 & -80.01 \\
\hline 48 & -43.19 & 49 & -83.22 \\
\hline 49 & -44.31 & 50 & -84.29 \\
\hline 50 & -44.83 & 53 & -90.96 \\
\hline
\end{tabular}




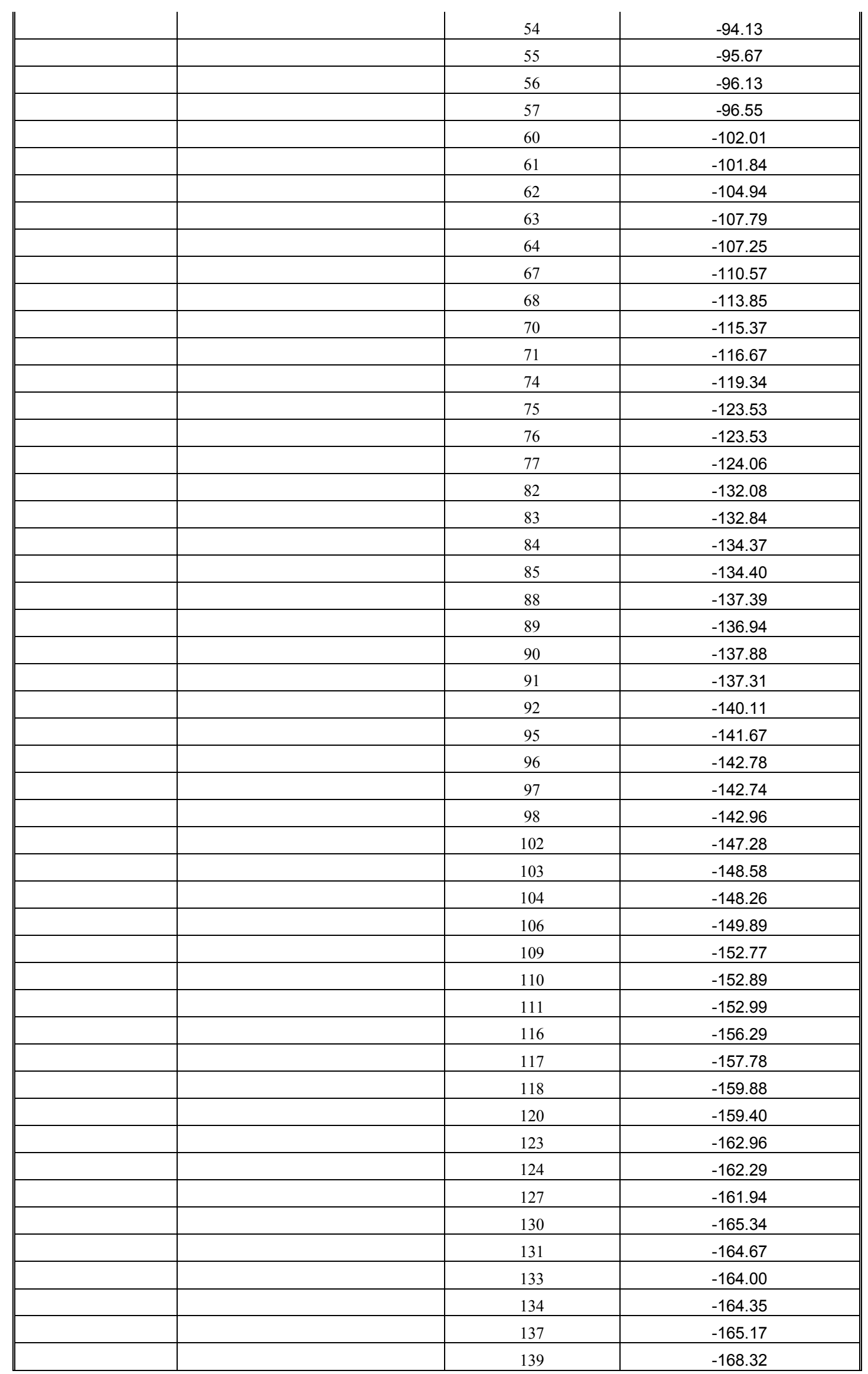




\begin{tabular}{|l|l|l|l|}
\hline & & 144 & -170.19 \\
\hline & & 146 & -169.94 \\
\hline & & 148 & -171.36 \\
\hline & & 154 & -174.03 \\
\hline & & 158 & -179.27 \\
\hline & & 161 & -178.29 \\
\hline & & 162 & -177.36 \\
\hline & & 165 & -177.14 \\
\hline & & 167 & -177.14 \\
\hline & & 173 & -180.48 \\
\hline & & 175 & -181.99 \\
\hline & & 176 & -183.61 \\
\hline
\end{tabular}

\section{D.7 Ensaios de retração por secagem}

Tabela D.7.1 - Retração por secagem para os traços do substrato e do reforço

\begin{tabular}{|c|c|c|c|}
\hline \multicolumn{2}{|c|}{ Dosagem E-9091 - substrato } & \multicolumn{2}{|c|}{ Dosagem E-9121 - reforço } \\
\hline Idade & retração por secagem & Idade & retração por secagem \\
\hline (dias) & $\left(\times 10^{-6}\right)$ & (dias) & $\left(\mathbf{x 1 0}^{-6}\right)$ \\
\hline 0 & 0 & 0 & 0 \\
\hline 1 & -10 & 1 & -30 \\
\hline 3 & -30 & 2 & -35 \\
\hline 4 & -30 & 3 & -50 \\
\hline 5 & -40 & 4 & -55 \\
\hline 6 & -40 & 5 & -60 \\
\hline 8 & -50 & 6 & -70 \\
\hline 11 & -70 & 7 & -70 \\
\hline 12 & -75 & 9 & -70 \\
\hline 13 & -80 & 12 & -75 \\
\hline 14 & -80 & 13 & -80 \\
\hline 15 & -80 & 14 & -85 \\
\hline 16 & -90 & 18 & -90 \\
\hline 17 & -90 & 19 & -100 \\
\hline 18 & -90 & 21 & -100 \\
\hline 19 & -95 & 22 & -100 \\
\hline 20 & -100 & 25 & -100 \\
\hline 21 & -100 & 26 & -115 \\
\hline 23 & -95 & 27 & -120 \\
\hline 26 & -110 & 28 & -120 \\
\hline 27 & -105 & 29 & -125 \\
\hline 28 & -105 & 32 & -125 \\
\hline 32 & -110 & 33 & -125 \\
\hline 33 & -120 & 34 & -130 \\
\hline 35 & -115 & 35 & -130 \\
\hline
\end{tabular}




\begin{tabular}{|c|c|c|c|}
\hline 36 & -120 & 39 & -145 \\
\hline 39 & -120 & 40 & -150 \\
\hline 40 & -125 & 46 & -155 \\
\hline 41 & -125 & 49 & -155 \\
\hline 42 & -130 & 53 & -160 \\
\hline 43 & -130 & 57 & -160 \\
\hline 46 & -135 & 60 & -160 \\
\hline 47 & -135 & 64 & -165 \\
\hline 48 & -140 & 67 & -165 \\
\hline 49 & -140 & 70 & -170 \\
\hline 53 & -165 & 74 & -180 \\
\hline 54 & -160 & 78 & -180 \\
\hline 60 & -160 & 81 & -180 \\
\hline 63 & -160 & 88 & -160 \\
\hline 67 & -165 & 96 & -170 \\
\hline 71 & -165 & 102 & -170 \\
\hline 74 & -175 & 109 & -170 \\
\hline 78 & -175 & 116 & -180 \\
\hline 81 & -180 & & \\
\hline 84 & -185 & & \\
\hline 88 & -200 & & \\
\hline 92 & -205 & & \\
\hline 95 & -205 & & \\
\hline 102 & -210 & & \\
\hline 110 & -220 & & \\
\hline 116 & -220 & & \\
\hline 123 & -220 & & \\
\hline 130 & -230 & & \\
\hline
\end{tabular}

Obs. A idade indicada na tabela corresponde à idade da peça após a moldagem menos o período em que a peça permaneceu sendo curada $\left(\mathrm{t}_{\mathrm{s}}\right)$.

\section{D.8 Ensaios para determinação do coeficiente de dilatação térmica linear}

Foram feitos ensaios para determinar o coeficiente de dilatação térmica, $\alpha_{\mathrm{t}, \mathrm{T}}$, para as idades de 7, 28, 50 e 100 dias. Entretanto, optou-se por apresentar aqui apenas os resultados obtidos para a idade de 28 dias. O valor do coeficiente $\alpha_{\mathrm{t}, \mathrm{T}}$ adotado no Capítulo 6 corresponde ao valor médio obtido por todos os ensaios realizados. 


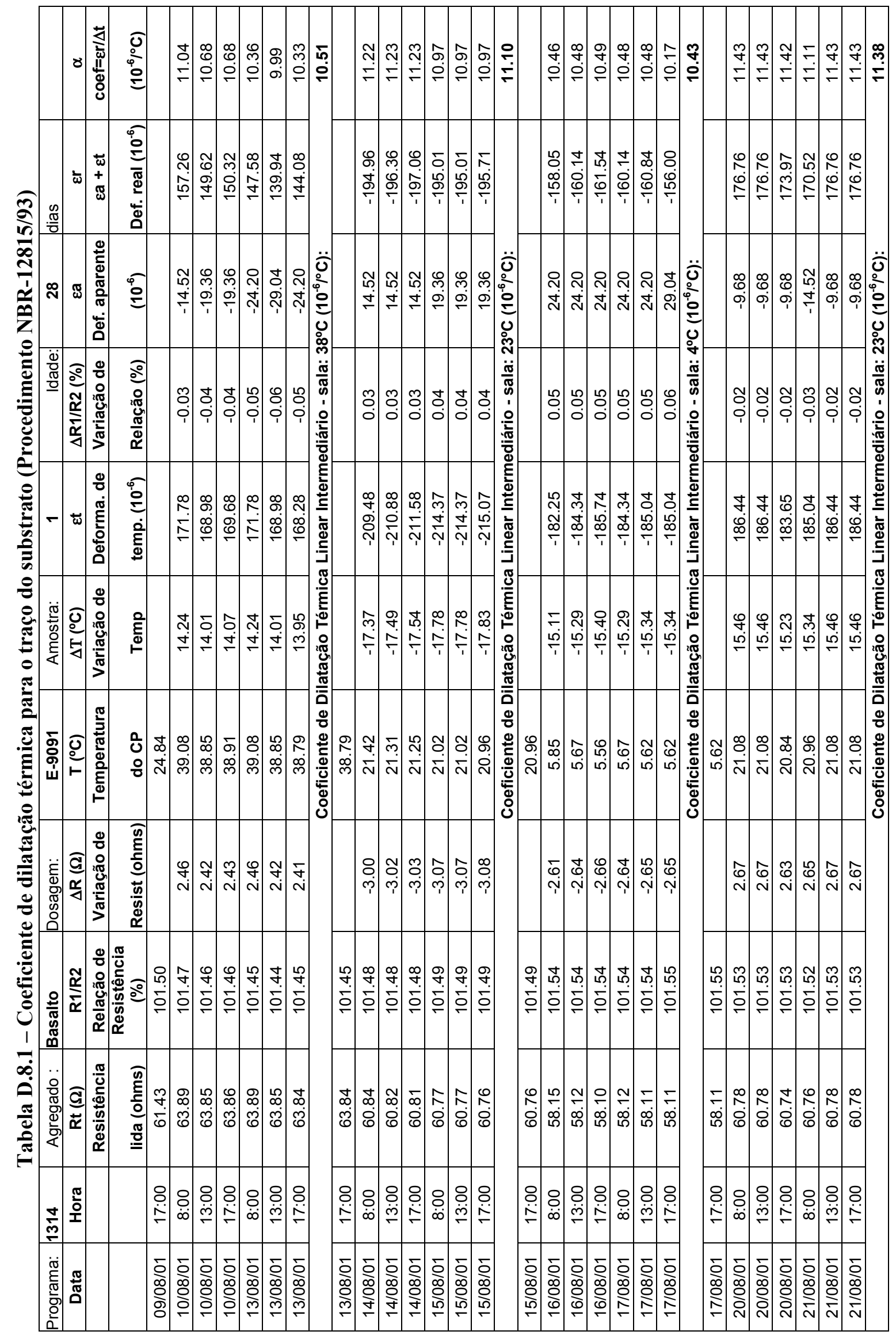




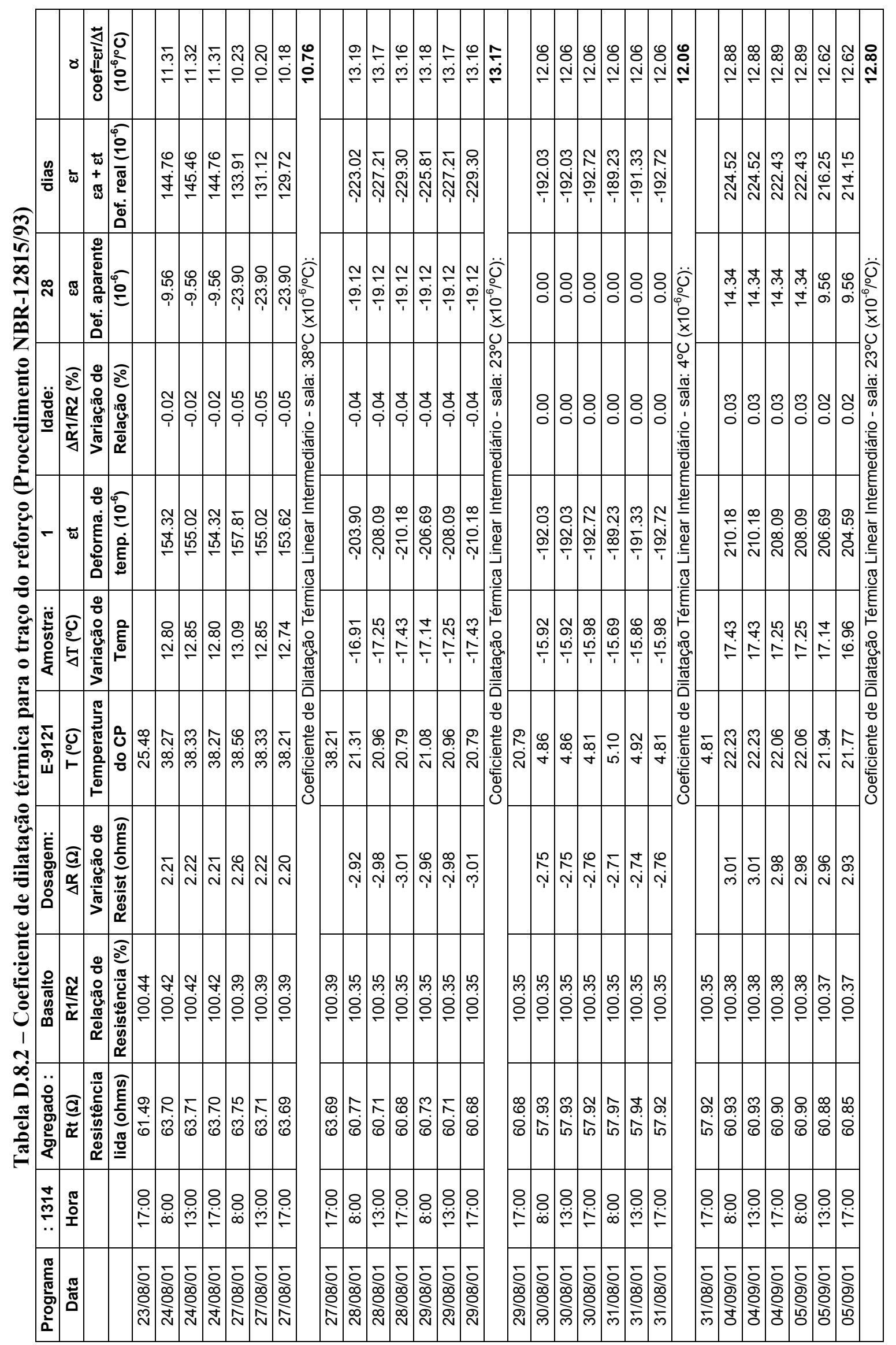





\section{APÊNDICE E}




\section{E.1 Tabela com os resultados dos ensaios viga VFC-1}

\begin{tabular}{|c|c|c|c|c|c|c|c|c|c|c|c|c|c|}
\hline \multirow[b]{2}{*}{ Idade } & \multirow[b]{2}{*}{ Fv } & \multicolumn{4}{|c|}{$\begin{array}{c}\text { Deformações médias das } \\
\text { armaduras }\end{array}$} & \multicolumn{7}{|c|}{ Deformações do concreto do substrato e do reforço } & \multirow[b]{2}{*}{ flecha } \\
\hline & & Asl1 & Asl2 & Asl' & Asw & \begin{tabular}{|l|} 
ext.15 \\
\end{tabular} & ext.16 & ext.17 & ext.18 & \begin{tabular}{|l|l|} 
ext.19 \\
\end{tabular} & ext.20 & \begin{tabular}{|l|} 
ext.21 \\
\end{tabular} & \\
\hline (dias) & $(\mathrm{kN})$ & \multicolumn{4}{|c|}{ (micro-strain) } & \multicolumn{7}{|c|}{ (micro-strain) } & $(\mathrm{mm})$ \\
\hline \multicolumn{14}{|c|}{ Início do ensaio intermediário - etapa 2} \\
\hline 1 & 0.0 & 0 & 0 & 0 & 0 & 0 & 0 & 0 & 0 & 0 & - & - & 0.00 \\
\hline 1 & 3.1 & 50 & 84 & $\begin{array}{l}-79 \\
\end{array}$ & 1 & -53 & -65 & -52 & -71 & $\begin{array}{l}-68 \\
\end{array}$ & - & - & 0.82 \\
\hline 1 & 4.7 & 90 & 144 & -127 & 3 & -84 & -99 & -82 & -113 & $\begin{array}{l}-107 \\
\end{array}$ & - & - & 1.23 \\
\hline 1 & 6.2 & 140 & 210 & -180 & -3 & -120 & $\begin{array}{l}-142 \\
\end{array}$ & -117 & $\begin{array}{l}-161 \\
\end{array}$ & \begin{tabular}{|c|}
-148 \\
\end{tabular} & - & - & 1.62 \\
\hline 1 & 7.8 & 197 & 269 & -217 & -2 & $\begin{array}{l}-143 \\
\end{array}$ & -175 & $\begin{array}{l}-139 \\
\end{array}$ & -195 & -181 & - & - & 2.01 \\
\hline 1 & 9.3 & 262 & 358 & -285 & 4 & -182 & -223 & -180 & -254 & $\begin{array}{l}-232 \\
\end{array}$ & - & - & 2.55 \\
\hline 1 & 12.4 & 361 & 488 & -403 & -1 & -255 & -319 & -247 & -361 & -327 & - & - & 3.67 \\
\hline 1 & 15.5 & 464 & 630 & -530 & -1 & -329 & -425 & -313 & -475 & -427 & - & - & 4.86 \\
\hline 1 & 18.6 & 569 & 780 & -680 & -5 & -422 & -579 & $\begin{array}{l}-388 \\
\end{array}$ & $\begin{array}{l}-624 \\
\end{array}$ & -560 & - & - & $\begin{array}{l}6.04 \\
\end{array}$ \\
\hline 1 & 21.6 & 663 & 931 & -859 & -13 & -532 & -765 & -463 & $\begin{array}{l}-798 \\
\end{array}$ & -715 & - & - & 7.26 \\
\hline 1 & 19.6 & 606 & 853 & -810 & -17 & -510 & -743 & -429 & -759 & -682 & - & - & 6.85 \\
\hline 1 & 18.7 & 568 & 825 & -939 & -136 & -611 & -712 & -505 & -830 & 338 & - & - & 6.85 \\
\hline \multicolumn{14}{|c|}{ Etapa 3} \\
\hline 2 & 17.6 & 532 & 829 & -1051 & -148 & -678 & 173 & -529 & -866 & 130 & - & - & 7.37 \\
\hline 3 & 16.7 & 504 & 867 & -1107 & -185 & -802 & 541 & -627 & $\begin{array}{l}-967 \\
\end{array}$ & -494 & - & - & 7.70 \\
\hline 4 & 16.0 & 498 & 854 & -1127 & -177 & -853 & 558 & -670 & \begin{tabular}{|c|}
-1005 \\
\end{tabular} & -896 & - & - & 7.82 \\
\hline 5 & 16.0 & 489 & 843 & -1145 & 52 & -642 & 823 & -446 & \begin{tabular}{|l|}
-798 \\
\end{tabular} & -931 & - & - & 7.96 \\
\hline 6 & 15.8 & 470 & 865 & -1171 & 61 & -669 & 817 & -460 & -819 & -967 & - & - & 8.10 \\
\hline 7 & 15.5 & 462 & 851 & -1191 & 81 & -682 & 822 & -470 & -835 & -990 & - & - & 8.20 \\
\hline 8 & 15.2 & 447 & 898 & -1211 & 88 & -708 & 814 & -488 & -861 & \begin{tabular}{|l|}
-1011 \\
\end{tabular} & - & - & 8.31 \\
\hline 9 & 15.0 & 441 & 930 & -1223 & 99 & -724 & 810 & -500 & -879 & -1024 & - & - & 8.39 \\
\hline 10 & 14.9 & 439 & 866 & -1222 & 119 & $\begin{array}{l}-744 \\
\end{array}$ & 783 & -512 & -909 & \begin{tabular}{|l|l|}
-1049 \\
\end{tabular} & - & - & 8.43 \\
\hline 11 & $\begin{array}{l}14.8 \\
\end{array}$ & 437 & 888 & -1227 & 132 & -760 & 775 & $\begin{array}{l}-520 \\
\end{array}$ & -931 & \begin{tabular}{|l|}
-1061 \\
\end{tabular} & - & - & 8.45 \\
\hline 12 & 14.7 & 430 & 855 & -1237 & 135 & -777 & 767 & -528 & -950 & \begin{tabular}{|l|l|}
-1077 \\
\end{tabular} & - & - & 8.47 \\
\hline 13 & 14.5 & 420 & 980 & \begin{tabular}{|c|}
-1269 \\
\end{tabular} & 128 & -781 & 796 & -539 & \begin{tabular}{|l|}
-959 \\
\end{tabular} & \begin{tabular}{|l|}
-1082 \\
\end{tabular} & - & - & 8.56 \\
\hline 14 & 14.3 & 407 & 946 & \begin{tabular}{|l|l|}
-1283 \\
\end{tabular} & 123 & -805 & 783 & $\begin{array}{l}-558 \\
\end{array}$ & -985 & -1090 & - & - & 8.62 \\
\hline 15 & 14.2 & 400 & 1072 & -1294 & 123 & -825 & 778 & -574 & -1011 & -1103 & - & - & 8.66 \\
\hline 16 & 14.1 & 398 & 1080 & \begin{tabular}{|c|}
-1299 \\
\end{tabular} & 134 & -817 & 777 & -571 & \begin{tabular}{|c|}
-1010 \\
\end{tabular} & \begin{tabular}{|l|}
-1106 \\
\end{tabular} & - & - & 8.70 \\
\hline 17 & 14.0 & 389 & 1079 & \begin{tabular}{|l|}
-1315 \\
\end{tabular} & 134 & -840 & 772 & -585 & -1030 & -1116 & - & - & 8.74 \\
\hline 18 & 13.9 & 385 & 1092 & \begin{tabular}{|l|}
-1326 \\
\end{tabular} & 122 & $\begin{array}{l}-856 \\
\end{array}$ & 758 & -600 & -1058 & \begin{tabular}{|l|l|}
-1130 \\
\end{tabular} & - & - & 8.78 \\
\hline 19 & 13.8 & 385 & 1139 & -1333 & 120 & $\begin{array}{l}-874 \\
\end{array}$ & 743 & -615 & \begin{tabular}{|l|}
-1075 \\
\end{tabular} & \begin{tabular}{|l|}
-1148 \\
\end{tabular} & - & - & 8.81 \\
\hline 20 & 13.7 & 371 & 829 & \begin{tabular}{|l|}
-1348 \\
\end{tabular} & 134 & $\begin{array}{l}-874 \\
\end{array}$ & 753 & $\begin{array}{l}-612 \\
\end{array}$ & \begin{tabular}{|l|l|}
-1088 \\
\end{tabular} & \begin{tabular}{|l|}
-1141 \\
\end{tabular} & - & - & 8.84 \\
\hline 21 & 13.6 & 372 & 856 & -1352 & 134 & -880 & 749 & -616 & \begin{tabular}{|l|l|}
-1072 \\
\end{tabular} & -1150 & - & - & 8.86 \\
\hline 22 & 13.6 & 371 & 858 & \begin{tabular}{|c|}
-1359 \\
\end{tabular} & 132 & -893 & 743 & -621 & \begin{tabular}{|c|}
-1070 \\
\end{tabular} & \begin{tabular}{|l|l|}
-1159 \\
\end{tabular} & - & - & 8.89 \\
\hline 23 & 13.5 & 363 & 845 & \begin{tabular}{|c|}
-1369 \\
\end{tabular} & 135 & $\begin{array}{l}-898 \\
\end{array}$ & 743 & $\begin{array}{l}-624 \\
\end{array}$ & $\mid-1065$ & \begin{tabular}{|l|}
-1167 \\
\end{tabular} & - & - & 8.92 \\
\hline 26 & 13.4 & 340 & 932 & $\begin{array}{l}-1402 \\
\end{array}$ & 126 & -931 & 723 & -647 & \begin{tabular}{|l|l|}
-1082 \\
\end{tabular} & \begin{tabular}{|l|}
-1201 \\
\end{tabular} & - & - & 8.98 \\
\hline 27 & 13.3 & 340 & 970 & -1406 & 131 & -929 & 724 & -647 & \begin{tabular}{|l|}
-1104 \\
\end{tabular} & \begin{tabular}{|l|}
-1203 \\
\end{tabular} & - & - & 9.01 \\
\hline 28 & 13.2 & 335 & 965 & -1415 & 129 & -939 & 721 & $\begin{array}{l}-658 \\
\end{array}$ & -1107 & \begin{tabular}{|l|}
-1216 \\
\end{tabular} & - & - & 9.08 \\
\hline 29 & 13.2 & 335 & 969 & $\begin{array}{l}-1417 \\
\end{array}$ & 131 & $\begin{array}{l}-946 \\
\end{array}$ & 723 & -660 & $\mid-1105$ & \begin{tabular}{|l|}
-1215 \\
\end{tabular} & - & - & 9.11 \\
\hline 30 & 13.0 & 337 & 976 & \begin{tabular}{|l|}
-1426 \\
\end{tabular} & 112 & $\begin{array}{l}-946 \\
\end{array}$ & 700 & -666 & \begin{tabular}{|l|l|}
-1082 \\
\end{tabular} & \begin{tabular}{|l|l|}
-1190 \\
\end{tabular} & - & - & 9.21 \\
\hline 32 & 12.7 & 323 & 948 & -1465 & 125 & -966 & 696 & -670 & \begin{tabular}{|l|}
-1082 \\
\end{tabular} & \begin{tabular}{|l|}
-1186 \\
\end{tabular} & - & - & 9.31 \\
\hline \multicolumn{14}{|c|}{ Etapa 4} \\
\hline 33 & 12.6 & 324 & 818 & -1463 & 115 & -975 & 683 & -677 & \begin{tabular}{|l|}
-1306 \\
\end{tabular} & \begin{tabular}{|l|}
-1220 \\
\end{tabular} & 0 & - & 9.31 \\
\hline 33 & 13.2 & 332 & 799 & \begin{tabular}{|c|}
-1416 \\
\end{tabular} & 105 & -937 & 721 & -637 & -1398 & -1020 & 15 & - & 9.37 \\
\hline 34 & 13.2 & 328 & 877 & \begin{tabular}{|l|l|}
-1426 \\
\end{tabular} & 105 & -939 & 693 & $\begin{array}{l}-582 \\
\end{array}$ & $\mid-1312$ & -832 & 71 & - & 9.52 \\
\hline 35 & 13.1 & 345 & 901 & \begin{tabular}{|l|}
-1428 \\
\end{tabular} & 115 & $\mid-1048$ & 682 & -567 & \begin{tabular}{|l|l|}
-1272 \\
\end{tabular} & -742 & 74 & - & 9.54 \\
\hline 36 & 13.1 & 341 & 845 & \begin{tabular}{|c|}
-1441 \\
\end{tabular} & 108 & $\begin{array}{l}-961 \\
\end{array}$ & 669 & -545 & -1250 & -605 & 48 & - & 9.55 \\
\hline 37 & 13.0 & 335 & 795 & -1455 & 109 & -968 & 678 & -554 & \begin{tabular}{|l|}
-1245 \\
\end{tabular} & $\begin{array}{l}-332 \\
\end{array}$ & 40 & - & 9.60 \\
\hline 38 & 12.9 & 340 & 833 & \begin{tabular}{|l|}
-1453 \\
\end{tabular} & 109 & -968 & 676 & -553 & \begin{tabular}{|l|l|}
-1239 \\
\end{tabular} & -285 & 38 & - & 9.63 \\
\hline 39 & 12.9 & 337 & 828 & -1460 & 113 & -965 & 673 & -550 & \begin{tabular}{|l|}
-1235 \\
\end{tabular} & -1226 & 38 & - & 9.65 \\
\hline 40 & 12.8 & 323 & 794 & \begin{tabular}{|l|}
-1479 \\
\end{tabular} & $\begin{array}{l}-114 \\
\end{array}$ & $\begin{array}{l}-974 \\
\end{array}$ & 686 & $\begin{array}{l}-553 \\
\end{array}$ & -1232 & \begin{tabular}{|l|}
-1239 \\
\end{tabular} & 10 & 0 & 9.68 \\
\hline 41 & 12.8 & 329 & 807 & -1475 & -113 & -981 & 687 & -564 & -1238 & \begin{tabular}{|l|l|}
-1242 \\
\end{tabular} & 8 & -51 & 9.70 \\
\hline 42 & 12.7 & 328 & 803 & $\begin{array}{l}-1490 \\
\end{array}$ & -107 & $\begin{array}{l}-988 \\
\end{array}$ & 678 & -573 & \begin{tabular}{|l|}
-1245 \\
\end{tabular} & -1254 & -3 & -68 & 9.72 \\
\hline 43 & 12.6 & 320 & 828 & -1500 & -120 & -989 & 675 & -574 & -1246 & -1255 & -3 & -69 & 9.75 \\
\hline
\end{tabular}




\begin{tabular}{|c|c|c|c|c|c|c|c|c|c|c|c|c|c|}
\hline 44 & 12.6 & 318 & 833 & -1489 & -108 & -995 & 648 & -582 & -1255 & -1274 & -10 & -219 & 9.76 \\
\hline 45 & 12.6 & 318 & 813 & -1492 & $\begin{array}{l}-104 \\
\end{array}$ & $\begin{array}{l}-994 \\
\end{array}$ & 688 & $\begin{array}{l}-583 \\
\end{array}$ & \begin{tabular}{|l|l|}
-1253 \\
\end{tabular} & -1258 & -6 & $\begin{array}{l}-199 \\
\end{array}$ & 9.76 \\
\hline 47 & 12.5 & 312 & 809 & -1510 & $\begin{array}{l}-79 \\
\end{array}$ & \begin{tabular}{|l|l|}
-1027 \\
\end{tabular} & 653 & -727 & $\begin{array}{l}-1317 \\
\end{array}$ & -1315 & -67 & -186 & 9.82 \\
\hline 48 & 12.4 & 311 & 820 & -1515 & -94 & \begin{tabular}{|l|l|}
-1013 \\
\end{tabular} & 667 & -607 & $\begin{array}{l}-1279 \\
\end{array}$ & -1281 & -30 & -146 & 9.84 \\
\hline 49 & 12.3 & 313 & 816 & -1518 & -95 & \begin{tabular}{|l|l|}
-1017 \\
\end{tabular} & 661 & -605 & -1280 & -1280 & -31 & -130 & 9.86 \\
\hline 50 & 12.2 & 306 & 869 & -1526 & -95 & \begin{tabular}{|l|l|}
-1020 \\
\end{tabular} & 658 & -610 & -1285 & -1283 & -37 & -132 & 9.88 \\
\hline 51 & 12.2 & 308 & 967 & -1526 & -89 & \begin{tabular}{|l|}
-1028 \\
\end{tabular} & 648 & -620 & -1294 & -1293 & -50 & $\begin{array}{l}-147 \\
\end{array}$ & 9.90 \\
\hline 52 & 12.1 & 303 & 937 & -1536 & $\begin{array}{l}-97 \\
\end{array}$ & $\mid-1024$ & 656 & -619 & -1293 & -1288 & -45 & -134 & 9.92 \\
\hline 54 & 12.0 & 302 & 727 & -1544 & -93 & $\mid-1032$ & 648 & -625 & -1306 & -1299 & -50 & -140 & 9.95 \\
\hline 55 & 12.0 & 309 & 731 & -1545 & -89 & \begin{tabular}{|l|l|}
-1037 \\
\end{tabular} & 648 & -630 & -1311 & -1300 & $\begin{array}{l}-54 \\
\end{array}$ & -142 & 9.97 \\
\hline 56 & 12.0 & 305 & 735 & -1547 & -78 & \begin{tabular}{|l|l|}
-1036 \\
\end{tabular} & 643 & -652 & -1335 & -1315 & $\begin{array}{l}-67 \\
\end{array}$ & -170 & 9.97 \\
\hline 57 & 11.9 & 308 & 737 & -1544 & -86 & \begin{tabular}{|l|l|}
-1049 \\
\end{tabular} & 647 & -665 & $\begin{array}{l}-1349 \\
\end{array}$ & -1315 & -63 & -170 & 9.98 \\
\hline 58 & 11.9 & 294 & 732 & -1554 & -82 & \begin{tabular}{|l|l|}
-1052 \\
\end{tabular} & 650 & -650 & -1335 & -1314 & -62 & -173 & 9.98 \\
\hline 60 & 11.9 & 306 & 742 & \begin{tabular}{l|l|}
-1546 \\
\end{tabular} & -97 & \begin{tabular}{|l|}
-1044 \\
\end{tabular} & 668 & -643 & -1331 & -1303 & -54 & -167 & 10.00 \\
\hline 61 & 11.8 & 301 & 738 & -1563 & $\begin{array}{l}-93 \\
\end{array}$ & $\mid-1051$ & 675 & -646 & -1307 & -1308 & -62 & -171 & 10.02 \\
\hline 62 & 11.8 & 299 & 737 & -1564 & -88 & \begin{tabular}{|l|l|}
-1037 \\
\end{tabular} & 651 & -645 & \begin{tabular}{|l|}
-1338 \\
\end{tabular} & -1313 & -62 & -172 & 10.03 \\
\hline 64 & 11.6 & 296 & 735 & -1575 & -89 & \begin{tabular}{|l|l|}
-1048 \\
\end{tabular} & 636 & -633 & -1328 & -1310 & $\begin{array}{l}-63 \\
\end{array}$ & -162 & 10.08 \\
\hline 65 & 11.6 & 292 & 729 & -1585 & -76 & \begin{tabular}{|l|l|}
-1056 \\
\end{tabular} & 627 & -640 & $\begin{array}{l}-1337 \\
\end{array}$ & -1315 & -74 & -165 & 10.09 \\
\hline 66 & 11.4 & 284 & 720 & -1591 & -75 & \begin{tabular}{|l|l|}
-1061 \\
\end{tabular} & 623 & -647 & -1343 & -1315 & -77 & -166 & 10.11 \\
\hline 68 & 11.2 & 252 & 695 & -1620 & -69 & \begin{tabular}{|l|l|}
-1086 \\
\end{tabular} & 585 & -663 & \begin{tabular}{l|l}
-1366 \\
\end{tabular} & -1338 & $\begin{array}{l}-88 \\
\end{array}$ & -181 & 10.16 \\
\hline \multicolumn{14}{|c|}{ Etapa 5} \\
\hline 69 & 11.3 & 276 & 715 & -1600 & -68 & \begin{tabular}{|l|l|}
-1071 \\
\end{tabular} & 607 & -658 & -1362 & -1327 & -87 & -179 & 10.16 \\
\hline 69 & 12.5 & 313 & 757 & \begin{tabular}{l|l}
-1626 \\
\end{tabular} & -55 & \begin{tabular}{|l|l|}
-1096 \\
\end{tabular} & 600 & -695 & \begin{tabular}{|c|}
-1393 \\
\end{tabular} & -1355 & -125 & -238 & 10.35 \\
\hline 69 & 15.5 & 388 & 845 & -1664 & -56 & \begin{tabular}{|l|l|}
-1116 \\
\end{tabular} & 594 & -720 & -1432 & -1384 & -171 & -329 & 10.82 \\
\hline 69 & 21.6 & 542 & 1034 & -1741 & -53 & $\mid-1163$ & 573 & -785 & -2422 & -1446 & -282 & -538 & 11.87 \\
\hline 69 & 28.0 & 699 & 1230 & -1817 & -58 & \begin{tabular}{|l|}
-1203 \\
\end{tabular} & 557 & -841 & -1606 & -1507 & -394 & -757 & 12.98 \\
\hline 69 & 30.9 & 782 & 1333 & -1857 & -67 & -1221 & 554 & -868 & $\begin{array}{ll}-1648 \\
\end{array}$ & -1528 & -449 & -862 & 13.56 \\
\hline 69 & 34.0 & 860 & 1427 & -1897 & -77 & \begin{tabular}{|l|l|}
-1248 \\
\end{tabular} & 545 & -900 & -1696 & -1564 & -507 & -975 & 14.11 \\
\hline 69 & 37.5 & 946 & 1535 & -1936 & -108 & \begin{tabular}{|l|l|}
-1270 \\
\end{tabular} & 539 & -913 & -1744 & -1594 & -568 & -1086 & 14.75 \\
\hline 69 & 37.7 & 956 & 1550 & -1942 & -130 & \begin{tabular}{|l|}
-1269 \\
\end{tabular} & 537 & -925 & -1757 & -1595 & -577 & -1104 & 14.79 \\
\hline 69 & 37.7 & 956 & 1550 & -1942 & -130 & \begin{tabular}{|l|l|}
-1269 \\
\end{tabular} & 537 & -925 & -1757 & -1595 & -577 & -1104 & 14.90 \\
\hline 69 & 35.1 & 874 & 1451 & -2005 & -135 & \begin{tabular}{|l|l|}
-1249 \\
\end{tabular} & 545 & -902 & -1724 & -1567 & -527 & -1032 & 14.41 \\
\hline \multicolumn{14}{|c|}{ Etapa 6} \\
\hline 70 & 34.4 & 872 & 1449 & -1932 & -144 & \begin{tabular}{|l|}
-1264 \\
\end{tabular} & 539 & -902 & \begin{tabular}{|l|}
-1768 \\
\end{tabular} & -1576 & -552 & -1054 & 14.56 \\
\hline 71 & 34.2 & 864 & 1446 & -1953 & -147 & \begin{tabular}{|l|l|}
-1279 \\
\end{tabular} & 534 & -914 & -1800 & -1587 & -564 & -1074 & 14.63 \\
\hline 72 & 34.0 & 857 & 1441 & \begin{tabular}{|c|}
-1966 \\
\end{tabular} & -144 & \begin{tabular}{|l|}
-1292 \\
\end{tabular} & 525 & -921 & \begin{tabular}{l|l}
-1826 \\
\end{tabular} & -1600 & -579 & -1091 & 14.68 \\
\hline 74 & 33.7 & 850 & 1436 & -1989 & -140 & \begin{tabular}{|l|l|}
-1312 \\
\end{tabular} & 523 & -937 & \begin{tabular}{|c|}
-1863 \\
\end{tabular} & -1613 & -598 & -1113 & 14.76 \\
\hline 75 & 33.6 & 845 & 1436 & -1996 & -136 & \begin{tabular}{|l|l|}
-1326 \\
\end{tabular} & 510 & -946 & -1879 & -1626 & -608 & -1132 & 14.80 \\
\hline 76 & 33.6 & 841 & 1430 & -2006 & -140 & \begin{tabular}{|l|l|}
-1314 \\
\end{tabular} & 513 & -948 & -1890 & -1627 & -613 & -1137 & 14.83 \\
\hline 77 & 33.5 & 837 & 1426 & $\begin{array}{l}-2013 \\
\end{array}$ & -144 & \begin{tabular}{|l|}
-1338 \\
\end{tabular} & 518 & $\begin{array}{l}-956 \\
\end{array}$ & \begin{tabular}{l|l}
-1904 \\
\end{tabular} & -1631 & -616 & -1145 & 14.84 \\
\hline 79 & 33.3 & 835 & 1426 & -2024 & -140 & \begin{tabular}{|l|l|}
-1352 \\
\end{tabular} & 511 & -960 & $\begin{array}{l}-1926 \\
\end{array}$ & -1643 & -620 & -1162 & 14.89 \\
\hline 80 & 33.2 & 832 & 1424 & -2028 & -137 & $\mid-1360$ & 511 & -965 & -1936 & -1647 & -626 & -1171 & 14.92 \\
\hline 83 & 33.0 & 830 & 1423 & -2042 & -139 & \begin{tabular}{|l|l|}
-1371 \\
\end{tabular} & 491 & -970 & -1954 & -1663 & -642 & -1192 & 14.99 \\
\hline 84 & 32.9 & 824 & 1418 & -2043 & -139 & \begin{tabular}{|l|l|}
-1373 \\
\end{tabular} & 493 & -980 & -1964 & -1665 & -644 & -1194 & 15.02 \\
\hline 85 & 32.9 & 823 & 1417 & -2049 & $\begin{array}{l}-139 \\
\end{array}$ & \begin{tabular}{|l|l|}
-1377 \\
\end{tabular} & 486 & $\begin{array}{l}-987 \\
\end{array}$ & $\begin{array}{l}-1944 \\
\end{array}$ & -1671 & -650 & -1200 & 15.04 \\
\hline 86 & 32.9 & 823 & 1418 & -2052 & -140 & \begin{tabular}{|l|l|}
-1381 \\
\end{tabular} & 496 & -984 & -1972 & -1667 & -648 & -1201 & 15.06 \\
\hline 89 & 32.6 & 809 & 1410 & -2075 & -133 & \begin{tabular}{|l|l|}
-1401 \\
\end{tabular} & 478 & -1008 & -2006 & -1686 & -664 & -1227 & 15.12 \\
\hline 90 & 32.5 & 811 & 1414 & $\begin{array}{l}-2078 \\
\end{array}$ & -132 & \begin{tabular}{|l|l|}
-1408 \\
\end{tabular} & 482 & -1017 & -2016 & -1690 & -667 & -1229 & 15.14 \\
\hline 91 & 32.5 & 813 & 1416 & -2080 & -132 & \begin{tabular}{|l|l|}
-1409 \\
\end{tabular} & 475 & -1017 & -2017 & -1694 & -669 & -1235 & 15.16 \\
\hline 91 & 32.4 & 837 & 1471 & -2093 & -150 & \begin{tabular}{|l|l|}
-1391 \\
\end{tabular} & 503 & -1034 & -1972 & -1708 & -627 & -1135 & 15.16 \\
\hline 92 & 32.5 & 830 & 1519 & -2087 & -191 & \begin{tabular}{|l|l|}
-1378 \\
\end{tabular} & 551 & -997 & -2034 & -1825 & -601 & -1233 & 15.07 \\
\hline 94 & 32.6 & 836 & 1538 & -2075 & -211 & \begin{tabular}{|l|l|}
-1336 \\
\end{tabular} & 622 & -960 & -2007 & -1828 & -578 & -1224 & 15.06 \\
\hline 95 & 32.6 & 838 & 1531 & -2068 & -215 & \begin{tabular}{|l|}
-1334 \\
\end{tabular} & 655 & $\begin{array}{c}-964 \\
\end{array}$ & -2006 & -1821 & -555 & -1229 & 15.09 \\
\hline 97 & 32.4 & 824 & 1552 & -2078 & -203 & \begin{tabular}{|l|l|}
-1398 \\
\end{tabular} & 544 & -956 & -2018 & -1878 & -578 & -1207 & 15.19 \\
\hline \multicolumn{14}{|c|}{ Início do ensaio final } \\
\hline 98 & 32.4 & 825 & 1552 & -2077 & -203 & \begin{tabular}{|l|}
-1398 \\
\end{tabular} & 544 & -956 & -2017 & -1878 & -473 & -1175 & 15.19 \\
\hline 98 & 37.4 & 894 & 1633 & -2091 & -209 & \begin{tabular}{|l|l|}
-142 \\
\end{tabular} & 528 & $\begin{array}{l}-993 \\
\end{array}$ & -2062 & -1879 & -474 & -1175 & 15.62 \\
\hline 98 & 42.5 & 966 & 1719 & -2105 & -214 & \begin{tabular}{|l|l|}
-1449 \\
\end{tabular} & 512 & -1033 & -2109 & -1881 & -476 & -1175 & 16.06 \\
\hline 98 & 46.2 & 1022 & 1786 & $\begin{array}{l}-2116 \\
\end{array}$ & -217 & \begin{tabular}{|l|l|}
-1468 \\
\end{tabular} & 500 & -1061 & \begin{tabular}{l|l}
-2148 \\
\end{tabular} & -1882 & -477 & $\begin{array}{l}-1176 \\
\end{array}$ & 16.45 \\
\hline 98 & 50.9 & 1096 & 1873 & -2125 & -218 & \begin{tabular}{|l|l|}
-1489 \\
\end{tabular} & 490 & -1096 & -2196 & -1884 & -479 & -1177 & 16.91 \\
\hline 98 & 55.0 & 1159 & 1949 & -2135 & -220 & \begin{tabular}{|l|l|}
-1506 \\
\end{tabular} & 480 & -1127 & -2238 & -1886 & -481 & -1177 & 17.30 \\
\hline 98 & 59.4 & 1229 & 2034 & -2145 & -223 & \begin{tabular}{|l|l|}
-1528 \\
\end{tabular} & 467 & -1162 & -2286 & -1888 & -483 & -1178 & 17.78 \\
\hline
\end{tabular}




\begin{tabular}{|c|c|c|c|c|c|c|c|c|c|c|c|c|c|}
\hline 98 & 63.9 & 1303 & 2121 & -2154 & -225 & \begin{tabular}{l|l|}
-1549 \\
\end{tabular} & 457 & -1198 & -2333 & \begin{tabular}{|l|l|}
-1890 \\
\end{tabular} & -485 & -1178 & 18.25 \\
\hline 98 & $\begin{array}{ll}68.3 \\
\end{array}$ & 1376 & 2211 & -2164 & -227 & -1570 & 446 & -1233 & -2381 & -1893 & -488 & -1179 & $\begin{array}{l}18.76 \\
\end{array}$ \\
\hline 98 & $\begin{array}{l}73.0 \\
\end{array}$ & 1454 & 2305 & -2171 & -227 & -1592 & 437 & -1270 & -2429 & -1895 & -490 & -1180 & 19.35 \\
\hline 98 & 76.7 & 1516 & 2379 & -2179 & -229 & -1609 & 430 & -1301 & -2469 & \begin{tabular}{l|l}
-1897 \\
\end{tabular} & -492 & -1180 & 19.79 \\
\hline 98 & 81.0 & 1589 & 2466 & -2186 & -229 & -1628 & 422 & -1334 & -2512 & \begin{tabular}{|l|l|}
-1899 \\
\end{tabular} & -494 & -1181 & 20.31 \\
\hline 98 & 86.0 & 1674 & 2569 & -2196 & -231 & -1650 & 411 & -1374 & $\begin{array}{l}-2566 \\
\end{array}$ & $\mid-1902$ & -497 & -1182 & 20.95 \\
\hline 98 & 84.0 & 1648 & 2542 & -2188 & -228 & -1652 & 419 & -1363 & -2563 & -1902 & -497 & -1182 & 20.90 \\
\hline 98 & 83.9 & 1649 & 2542 & -2188 & -227 & -1651 & 420 & -1361 & -2561 & -1902 & -497 & -1182 & 20.86 \\
\hline 98 & 89.8 & 1738 & 2648 & -2200 & -229 & -1674 & 406 & -1403 & -2612 & -1904 & -499 & -1183 & 21.44 \\
\hline 98 & 93.8 & 1807 & 2767 & -2208 & -230 & -1691 & 398 & -1434 & -2652 & $\mid-1906$ & -501 & -1183 & 21.95 \\
\hline 98 & $\begin{array}{l}98.6 \\
\end{array}$ & 1914 & 3038 & -2216 & -227 & -1711 & 393 & -1474 & -2706 & -1909 & -504 & -1184 & 22.45 \\
\hline 98 & 102.7 & 2032 & 3210 & -2220 & -220 & -1724 & 393 & -1514 & -2764 & 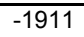 & -506 & -1185 & 23.10 \\
\hline 98 & 107.2 & 2135 & 3359 & -2227 & -215 & -1748 & 389 & -1556 & -2824 & \begin{tabular}{|l|l|}
-1914 \\
\end{tabular} & -509 & -1186 & 23.73 \\
\hline 98 & 110.7 & 2234 & 3505 & -2231 & -210 & -1758 & 389 & -1591 & -2872 & \begin{tabular}{|l|l|}
-1916 \\
\end{tabular} & -511 & -1186 & 24.26 \\
\hline 98 & 115.2 & 2337 & 3656 & -2239 & -209 & -1781 & 382 & -1634 & -2932 & -1919 & -514 & -1187 & 24.86 \\
\hline 98 & 119.3 & 2463 & 3995 & -2241 & -200 & -1792 & 386 & -1673 & -2988 & -1922 & -517 & -1188 & 25.60 \\
\hline 98 & 122.7 & 2547 & 4293 & -2243 & -196 & -1807 & 386 & -1702 & -3028 & -1924 & -519 & -1189 & 26.09 \\
\hline 98 & 127.3 & 3229 & 10195 & -2238 & $\begin{array}{l}-160 \\
\end{array}$ & -1804 & 420 & -1767 & -3133 & -1928 & -523 & -1190 & 27.02 \\
\hline 98 & 128.6 & 3922 & 16019 & -2227 & $\begin{array}{l}-131 \\
\end{array}$ & -1800 & 455 & -1807 & -3201 & -1930 & -525 & -1191 & 27.54 \\
\hline 98 & 131.9 & 5536 & 17919 & -2217 & -95 & -1792 & 494 & -1856 & -3283 & -1933 & -528 & -1191 & 28.29 \\
\hline 98 & 133.7 & 9257 & 18683 & -2180 & 6 & -1735 & 637 & -1927 & -3421 & $\begin{array}{l}-1936 \\
\end{array}$ & -531 & -1193 & 29.25 \\
\hline 98 & 136.1 & 7605 & 18563 & -2160 & 62 & -1714 & 726 & -1974 & -3505 & \begin{tabular}{|l|}
-1939 \\
\end{tabular} & -534 & -1193 & 30.04 \\
\hline 98 & 132.9 & 6640 & 15202 & -2134 & 105 & -1685 & 793 & -1966 & -3512 & -1939 & -535 & -1194 & 30.21 \\
\hline 98 & 137.6 & 6628 & 15255 & -2138 & 116 & -1696 & 806 & -2004 & -3564 & -1942 & -537 & -1194 & 30.75 \\
\hline 98 & 140.9 & 6572 & 15170 & -2059 & 223 & -1589 & 1069 & -2084 & -3732 & -1949 & -544 & -1197 & 32.73 \\
\hline 98 & 142.4 & 6557 & 15150 & -2025 & 200 & -1552 & 1184 & -2109 & -3772 & -1953 & -548 & -1198 & 33.78 \\
\hline 98 & 145.6 & 6491 & 15191 & -1932 & 171 & -1396 & 1385 & -2186 & -3952 & -1964 & -559 & -1201 & 36.75 \\
\hline 98 & 146.1 & 6523 & 15126 & -1914 & 185 & -1363 & 1407 & -2239 & -3999 & -1966 & $\begin{array}{l}-561 \\
\end{array}$ & -1202 & 37.53 \\
\hline 98 & 147.5 & 6521 & 15140 & -1873 & 215 & -1303 & 1503 & -2274 & -4056 & -1972 & -567 & -1204 & 39.01 \\
\hline 98 & 143.8 & 6457 & 15051 & -1850 & 220 & -1267 & 1538 & -2270 & -4035 & -1972 & -567 & -1204 & 39.25 \\
\hline 98 & 148.8 & 6514 & 15114 & -1816 & 238 & -1233 & 1635 & -2323 & -4106 & \begin{tabular}{|l|l|}
-1979 \\
\end{tabular} & -574 & -1206 & \\
\hline 98 & 146.6 & 6475 & 15074 & -1802 & 240 & -1214 & 1660 & -2316 & -4087 & \begin{tabular}{|l|l|}
-1979 \\
\end{tabular} & -574 & -1206 & \\
\hline 98 & 150.7 & 6501 & 15146 & -1763 & 284 & -1155 & 1773 & -2369 & -4148 & \begin{tabular}{|l|}
-1985 \\
\end{tabular} & -580 & -1208 & \\
\hline 98 & 151.9 & 6526 & 15209 & -1790 & 284 & -1052 & 1719 & -2489 & -4045 & \begin{tabular}{|l|}
-1988 \\
\end{tabular} & -583 & -1209 & \\
\hline
\end{tabular}

\begin{tabular}{|c|c|c|c|c|c|c|c|}
\hline \multicolumn{7}{|c|}{ Relógios - deslocamentos horizontais } & \multicolumn{1}{l|}{ Fv } \\
\hline relógio & relógio & relógio & relógio & relógio & relógio & relógio & \\
\hline prox. Apoio & 62.5 apoio & $\mathrm{F} \mathrm{v-1}$ & meio & $\mathrm{Fv}-2$ & 62.5 apoio & prox. Apoio & Fmacaco + Fvcabo \\
\hline$(\mathrm{mm})$ & $(\mathrm{mm})$ & $(\mathrm{mm})$ & $(\mathrm{mm})$ & $(\mathrm{mm})$ & $(\mathrm{mm})$ & $(\mathrm{mm})$ & $(\mathrm{kN})$ \\
\hline \multicolumn{7}{|c|}{ Início do ensaio final } \\
\hline 0.000 & 0.000 & 0.000 & 0.000 & 0.000 & 0.000 & 0.000 & 32 \\
\hline 0.000 & 0.000 & 0.003 & 0.000 & 0.000 & 0.000 & 0.000 & 37 \\
\hline 0.000 & 0.000 & 0.000 & 0.000 & 0.000 & 0.000 & 0.000 & 43 \\
\hline 0.000 & 0.000 & 0.003 & 0.003 & 0.000 & 0.000 & -0.004 & 46 \\
\hline 0.000 & 0.003 & 0.003 & 0.003 & 0.000 & 0.000 & 0.000 & 51 \\
\hline 0.000 & 0.003 & 0.003 & 0.003 & 0.003 & 0.000 & 0.000 & 55 \\
\hline-0.003 & 0.003 & 0.005 & 0.003 & 0.003 & 0.000 & 0.000 & 59 \\
\hline-0.003 & 0.003 & 0.005 & 0.006 & 0.003 & 0.000 & 0.000 & 64 \\
\hline-0.003 & 0.006 & 0.005 & 0.006 & 0.006 & 0.000 & 0.000 & 68 \\
\hline-0.005 & 0.006 & 0.005 & 0.009 & 0.006 & 0.000 & 0.000 & 73 \\
\hline-0.005 & 0.006 & 0.005 & 0.009 & 0.006 & 0.000 & 0.000 & 77 \\
\hline-0.005 & 0.006 & 0.005 & 0.015 & 0.003 & 0.000 & 0.004 & 81 \\
\hline-0.005 & 0.006 & 0.005 & 0.018 & 0.003 & 0.000 & 0.004 & 86 \\
\hline-0.008 & 0.006 & 0.005 & 0.021 & 0.003 & 0.003 & 0.004 & 84 \\
\hline-0.008 & 0.006 & 0.005 & 0.021 & 0.003 & 0.003 & 0.004 & 84 \\
\hline-0.008 & 0.009 & 0.005 & 0.021 & 0.003 & 0.000 & 0.004 & 90 \\
\hline-0.008 & 0.009 & 0.008 & 0.021 & 0.003 & 0.000 & 0.004 & 94 \\
\hline
\end{tabular}




\begin{tabular}{|l|l|l|l|l|l|l|l|}
\hline-0.008 & 0.009 & 0.005 & 0.024 & 0.003 & 0.000 & 0.004 & 99 \\
\hline-0.008 & 0.009 & 0.008 & 0.027 & 0.003 & 0.000 & 0.004 & 103 \\
\hline-0.008 & 0.009 & 0.008 & 0.027 & 0.003 & 0.000 & 0.004 & 107 \\
\hline-0.011 & 0.012 & 0.011 & 0.030 & 0.003 & 0.000 & 0.004 & 111 \\
\hline-0.011 & 0.012 & 0.011 & 0.033 & 0.006 & 0.000 & 0.004 & 115 \\
\hline-0.011 & 0.012 & 0.011 & 0.033 & 0.006 & 0.000 & 0.004 & 119 \\
\hline-0.013 & 0.009 & 0.011 & 0.036 & 0.006 & 0.003 & 0.004 & 123 \\
\hline-0.013 & 0.012 & 0.011 & 0.036 & 0.009 & 0.003 & 0.008 & 127 \\
\hline-0.016 & 0.012 & 0.011 & 0.045 & 0.009 & 0.003 & 0.008 & 129 \\
\hline-0.016 & 0.012 & 0.013 & 0.045 & 0.009 & 0.003 & 0.008 & 132 \\
\hline-0.018 & 0.012 & 0.011 & 0.045 & 0.000 & 0.006 & 0.011 & 134 \\
\hline-0.018 & 0.012 & 0.013 & 0.048 & -0.003 & 0.006 & 0.011 & 136 \\
\hline-0.021 & 0.012 & 0.013 & 0.045 & -0.003 & 0.006 & 0.011 & 133 \\
\hline-0.021 & 0.015 & 0.013 & 0.045 & -0.003 & 0.006 & 0.011 & 138 \\
\hline-0.021 & 0.012 & 0.013 & 0.045 & -0.003 & 0.006 & 0.011 & 141 \\
\hline-0.024 & 0.015 & 0.013 & 0.045 & -0.003 & 0.006 & 0.011 & 142 \\
\hline-0.026 & 0.012 & 0.013 & 0.045 & -0.003 & 0.006 & 0.011 & 146 \\
\hline-0.029 & 0.012 & 0.013 & 0.045 & -0.003 & 0.009 & 0.011 & 146 \\
\hline-0.034 & 0.012 & 0.008 & 0.045 & -0.003 & 0.009 & 0.011 & 147 \\
\hline-0.034 & 0.012 & 0.008 & 0.045 & -0.006 & 0.009 & 0.011 & 144 \\
\hline-0.040 & 0.012 & 0.003 & 0.054 & -0.003 & 0.012 & 0.011 & 149 \\
\hline-0.042 & 0.012 & 0.003 & 0.054 & -0.006 & 0.012 & 0.015 & 147 \\
\hline-0.053 & 0.012 & 0.032 & 0.057 & -0.003 & 0.012 & 0.015 & 151 \\
\hline-0.061 & 0.012 & 0.098 & 0.066 & -0.006 & 0.015 & 0.015 & 152 \\
\hline
\end{tabular}

\section{E.2 Tabela com os resultados do ensaio da viga VFC-2}

\begin{tabular}{|c|c|c|c|c|c|c|c|c|c|c|c|c|c|}
\hline & & Deforma & média & das ar & duras & Deforn & ções do & concr & to do st & bstrato & do refo & rço & \\
\hline Idade & Fv & Asl1 & Asl2 & Asl' & Asw & ext. 17 & ext. 18 & ext. 15 & ext. 16 & ext. 19 & ext. 20 & ext. 21 & flecha \\
\hline (dias) & $(\mathrm{kN})$ & \multicolumn{4}{|c|}{ (micro-strain) } & \multicolumn{7}{|c|}{ (micro-strain) } & $(\mathrm{mm})$ \\
\hline \multicolumn{14}{|c|}{ INICIOO DO ENSAIO FINAL } \\
\hline 86 & -0.1 & 0 & 0 & 1 & 1 & 1 & 1 & 2 & 1 & 1 & -1 & 1 & 0.00 \\
\hline 87 & 5.4 & 50 & 67 & -16 & 0 & -1 & -12 & -12 & -2 & -28 & -41 & -39 & 0.47 \\
\hline 88 & 10.4 & 101 & 134 & -31 & 1 & 2 & -25 & -22 & -4 & -51 & -77 & -73 & 0.85 \\
\hline 89 & 15.4 & 169 & 224 & -48 & 4 & 0 & -38 & -27 & -5 & $\begin{array}{l}-73 \\
\end{array}$ & -114 & -112 & 1.40 \\
\hline 90 & 20.2 & 251 & 327 & -63 & 18 & 1 & -49 & -31 & -2 & -89 & -151 & -153 & 1.98 \\
\hline 91 & 25.5 & 344 & 451 & -81 & 44 & 1 & -60 & -33 & 1 & -108 & -193 & -198 & 2.64 \\
\hline 92 & 30.9 & 441 & 571 & -93 & 68 & 6 & -67 & -33 & 8 & -117 & -232 & -241 & 3.22 \\
\hline 93 & 35.1 & 511 & 658 & -102 & 89 & 7 & -74 & -34 & 10 & -130 & -262 & -273 & 3.73 \\
\hline 94 & 40.9 & 616 & 756 & -115 & 115 & 8 & -86 & -40 & 11 & -147 & -307 & -320 & 4.47 \\
\hline 95 & 46.3 & 713 & 875 & -123 & 145 & 8 & -94 & -41 & 15 & -163 & -348 & -363 & 5.21 \\
\hline 96 & 51.2 & 796 & 976 & -129 & 174 & 8 & -103 & -42 & 19 & -178 & -383 & -401 & 5.83 \\
\hline 97 & 55.8 & 875 & 1070 & -126 & 202 & 8 & -111 & -43 & 21 & -191 & -416 & -436 & 6.37 \\
\hline 98 & 55.0 & 869 & 1063 & \begin{tabular}{|l|}
-123 \\
\end{tabular} & 206 & 8 & -109 & -43 & 22 & -188 & -414 & -434 & 6.37 \\
\hline 99 & 54.8 & 868 & 1062 & \begin{tabular}{|l|}
-123 \\
\end{tabular} & 208 & 8 & -108 & -42 & 22 & -188 & -414 & -434 & 6.37 \\
\hline 100 & 60.4 & 954 & 1168 & -128 & 230 & 8 & -121 & -45 & 24 & -206 & -452 & -474 & 7.03 \\
\hline 101 & 66.1 & 1043 & 1280 & $\begin{array}{l}-137 \\
\end{array}$ & 259 & 11 & -133 & -49 & 24 & -224 & -495 & -517 & 7.69 \\
\hline 102 & 71.0 & 1125 & 1385 & -142 & 292 & 10 & -143 & -52 & 25 & -241 & -529 & -554 & 8.28 \\
\hline 103 & 75.8 & 1205 & 1488 & -147 & 343 & 10 & -154 & -54 & 25 & -255 & -563 & -590 & 8.90 \\
\hline 104 & 81.1 & 1293 & 1596 & $\begin{array}{l}-153 \\
\end{array}$ & 403 & 10 & -164 & -55 & 27 & -270 & -600 & -630 & 9.60 \\
\hline 105 & 85.9 & 1367 & 1690 & $\begin{array}{l}-162 \\
\end{array}$ & 447 & 11 & -175 & -58 & 26 & -287 & -636 & -668 & 10.10 \\
\hline 106 & 90.5 & 1439 & 1776 & -168 & 487 & 10 & -185 & -60 & 27 & -300 & -665 & -700 & 10.68 \\
\hline 107 & 95.1 & 1512 & 1866 & -175 & 557 & 10 & -194 & -60 & 28 & -314 & -697 & -734 & 11.23 \\
\hline 108 & 101.4 & 1613 & 1988 & \begin{tabular}{|c|}
-183 \\
\end{tabular} & 634 & 10 & -207 & -61 & 30 & -332 & -741 & -780 & 12.00 \\
\hline 109 & 105.5 & 1675 & 2065 & -190 & 681 & 11 & -217 & -66 & 27 & -346 & $\begin{array}{l}-773 \\
\end{array}$ & -814 & 12.59 \\
\hline 110 & 111.1 & 1775 & 2314 & -196 & 738 & 10 & -229 & -65 & 28 & -361 & -812 & -857 & 13.25 \\
\hline 111 & 110.9 & 1775 & 2347 & -195 & 741 & 11 & -229 & -65 & 29 & -361 & -812 & -856 & 13.25 \\
\hline 112 & 116.5 & 1919 & 2556 & $\begin{array}{l}-198 \\
\end{array}$ & 805 & 11 & -236 & -53 & 38 & -369 & -855 & -905 & 14.10 \\
\hline
\end{tabular}




\begin{tabular}{|c|c|c|c|c|c|c|c|c|c|c|c|c|c|}
\hline 113 & \begin{tabular}{|l}
121.2 \\
\end{tabular} & 2025 & 2675 & -199 & 855 & 9 & -243 & -47 & 41 & -378 & -890 & $\begin{array}{c}-943 \\
\end{array}$ & 14.84 \\
\hline 114 & \begin{tabular}{|l|l}
124.9 \\
\end{tabular} & 2099 & 2762 & $\begin{array}{l}-198 \\
\end{array}$ & 909 & 12 & -252 & -48 & 42 & -390 & $\begin{array}{l}-924 \\
\end{array}$ & -977 & 15.38 \\
\hline 115 & $\mid 130.1$ & 2340 & 2945 & -201 & 962 & 12 & -258 & -41 & 49 & -396 & -961 & -1021 & 16.12 \\
\hline 116 & 129.5 & 2383 & 3018 & -197 & 966 & 13 & -256 & -37 & 51 & -393 & -961 & -1019 & 16.12 \\
\hline 117 & \begin{tabular}{|l|l}
134.7 \\
\end{tabular} & 2512 & 3809 & -193 & 1025 & 13 & -257 & -18 & 67 & -391 & -1001 & -1070 & 16.98 \\
\hline 118 & \begin{tabular}{|l|l}
139.1 \\
\end{tabular} & 3501 & & -187 & 1075 & 16 & -223 & 57 & 127 & -331 & -1069 & -1172 & 18.30 \\
\hline 119 & \begin{tabular}{|l|l}
140.1 \\
\end{tabular} & 4401 & & -186 & 1084 & 16 & -217 & 69 & 136 & -320 & -1082 & -1192 & 18.57 \\
\hline 120 & \begin{tabular}{|l|}
136.1 \\
\end{tabular} & 7973 & & -168 & 1075 & 19 & -195 & 92 & 150 & -280 & -1081 & -1203 & 18.73 \\
\hline 121 & 142.8 & & & -174 & 1120 & 23 & -132 & 144 & 189 & -155 & -1165 & -1346 & 20.20 \\
\hline 122 & \begin{tabular}{|l|l}
147.9 \\
\end{tabular} & & & -172 & 1157 & 26 & 220 & 123 & 171 & 52 & -1248 & -1517 & 22.65 \\
\hline 123 & \begin{tabular}{|l|l}
148.4 \\
\end{tabular} & & & -170 & 1171 & 27 & 255 & 115 & 178 & 114 & -1269 & -1568 & 23.43 \\
\hline 124 & \begin{tabular}{|l|l}
148.5 \\
\end{tabular} & & & -165 & 1180 & 25 & 259 & 99 & 184 & 163 & -1291 & -1619 & 24.83 \\
\hline 125 & \begin{tabular}{|l|l}
147.0 \\
\end{tabular} & & & $\begin{array}{l}-164 \\
\end{array}$ & 1184 & 25 & 271 & 99 & 186 & 177 & -1297 & -1629 & 25.37 \\
\hline 126 & 150.2 & & & -163 & 1192 & 25 & 290 & 93 & 192 & 223 & -1319 & -1674 & 27.86 \\
\hline 127 & \begin{tabular}{|l|l}
148.9 \\
\end{tabular} & & & -164 & 1200 & 26 & 294 & 89 & 198 & 259 & -1332 & -1704 & 28.71 \\
\hline 128 & 149.2 & & & -163 & 1206 & 26 & 282 & 73 & 220 & 368 & -1358 & -1782 & 30.50 \\
\hline 129 & 150.3 & & & $\begin{array}{l}-163 \\
\end{array}$ & 1210 & 26 & 275 & 65 & 238 & 417 & -1379 & -1828 & 31.47 \\
\hline 130 & \begin{tabular}{|l|l|}
149.4 \\
\end{tabular} & & & -162 & 1208 & 27 & 275 & 64 & 241 & 431 & -1375 & -1828 & 31.55 \\
\hline 131 & 150.8 & & & -164 & 1216 & 28 & 268 & 57 & 320 & 493 & -1400 & -1890 & 32.83 \\
\hline 132 & 151.0 & & & -161 & 1221 & 25 & 257 & 39 & 914 & 585 & -1434 & -1981 & 34.93 \\
\hline 133 & 151.0 & & & -160 & 1223 & 25 & 252 & 33 & 1566 & 650 & -1443 & -2020 & 36.09 \\
\hline 134 & 151.2 & & & -158 & 1228 & 26 & 240 & 28 & & 703 & -1458 & -2063 & 37.18 \\
\hline 135 & \begin{tabular}{|l}
151.6 \\
\end{tabular} & & & -158 & 1234 & 28 & 225 & 18 & & 775 & -1476 & -2123 & 38.62 \\
\hline 136 & 151.3 & & & -156 & 1232 & 29 & 213 & 10 & & 817 & -1480 & -2147 & 39.36 \\
\hline 137 & 153.6 & & & -155 & 1238 & 29 & 200 & 6 & & 888 & -1498 & -2205 & 41.45 \\
\hline 138 & \begin{tabular}{|l}
152.9 \\
\end{tabular} & & & -154 & 1241 & 30 & 191 & 2 & & 943 & -1509 & -2241 & 42.77 \\
\hline 139 & 153.3 & & & -153 & 1243 & 31 & 182 & -2 & & 998 & -1519 & -2275 & 43.98 \\
\hline 140 & \begin{tabular}{|l|l}
145.6 \\
\end{tabular} & & & -147 & 1207 & 24 & 143 & $\begin{array}{l}-7 \\
\end{array}$ & & 1058 & -1506 & -2280 & 44.95 \\
\hline 141 & 152.1 & & & -153 & 1243 & 25 & 148 & -6 & & 1106 & -1557 & -2355 & 46.78 \\
\hline 142 & \begin{tabular}{|l}
152.2 \\
\end{tabular} & & & -152 & 1245 & 38 & 142 & -8 & & 1186 & $\begin{array}{l}-1569 \\
\end{array}$ & -2400 & 48.33 \\
\hline 143 & \begin{tabular}{|l}
152.5 \\
\end{tabular} & & & -150 & 1249 & 41 & 134 & -5 & & 1285 & -1582 & -2456 & 50.93 \\
\hline 144 & 153.3 & & & -148 & 1246 & 42 & 127 & -3 & & 1347 & $\begin{array}{l}-1584 \\
\end{array}$ & -2478 & 52.41 \\
\hline 145 & \begin{tabular}{|l|l}
154.4 \\
\end{tabular} & & & -147 & 1248 & 42 & 122 & -2 & & 1393 & -1590 & -2502 & 54.04 \\
\hline 146 & \begin{tabular}{|l|l}
113.4 \\
\end{tabular} & & & -107 & 1012 & 7 & -314 & 84 & & -194 & -1083 & -1235 & 57.85 \\
\hline 147 & \begin{tabular}{|l|l}
112.5 \\
\end{tabular} & & & -108 & 1006 & 10 & -321 & 80 & & -210 & -1068 & -1213 & 57.89 \\
\hline 148 & 81.2 & & & $\begin{array}{l}-73 \\
\end{array}$ & 809 & 16 & -256 & 92 & & -126 & \begin{tabular}{c|}
-904 \\
\end{tabular} & -1062 & 54.74 \\
\hline 149 & \begin{tabular}{|l|}
19.6 \\
\end{tabular} & & & 9 & 418 & 30 & -48 & 99 & & 151 & -404 & -618 & 46.58 \\
\hline 150 & 0.0 & & & 61 & 299 & 37 & -5 & 58 & & 344 & -178 & -357 & 42.54 \\
\hline 151 & 0.0 & & & 63 & 293 & 33 & -3 & 56 & & 357 & -171 & -342 & 42.39 \\
\hline
\end{tabular}

\begin{tabular}{|c|c|c|c|c|c|c|c|}
\hline \multicolumn{7}{|c|}{ Relógios - deslocamentos horizontais } & \multicolumn{2}{c|}{ Fv } \\
\hline relógio & relógio & relógio & relógio & relógio & relógio & relógio & \\
\hline prox. Apoio & 62.5 apoio & $\mathrm{F} \mathrm{v}-1$ & meio & $\mathrm{F} \mathrm{v} \mathrm{-}$ & 62.5 apoio & prox. Apoio & Fmacaco + Fvcabo \\
\hline$(\mathrm{mm})$ & $(\mathrm{mm})$ & $(\mathrm{mm})$ & $(\mathrm{mm})$ & $(\mathrm{mm})$ & $(\mathrm{mm})$ & $(\mathrm{mm})$ & $(\mathrm{kN})$ \\
\hline \multicolumn{7}{|c|}{ Início do ensaio final } \\
\hline 0.000 & 0.000 & 0.000 & 0.000 & 0.000 & 0.000 & 0.000 & -0.1 \\
\hline 0.000 & 0.000 & 0.000 & 0.000 & 0.000 & 0.000 & 0.000 & 5.4 \\
\hline 0.000 & 0.000 & 0.000 & 0.000 & 0.000 & 0.000 & 0.000 & 10.4 \\
\hline 0.003 & 0.000 & 0.003 & 0.003 & 0.003 & 0.003 & 0.003 & 15.4 \\
\hline 0.003 & 0.000 & 0.006 & 0.000 & 0.006 & 0.003 & 0.003 & 20.2 \\
\hline 0.003 & 0.003 & 0.009 & 0.003 & 0.009 & 0.006 & 0.003 & 25.5 \\
\hline 0.000 & 0.018 & 0.009 & 0.000 & 0.009 & 0.006 & 0.000 & 30.9 \\
\hline-0.003 & 0.018 & 0.012 & 0.000 & 0.012 & 0.006 & 0.000 & 35.1 \\
\hline 0.000 & 0.018 & 0.012 & 0.003 & 0.012 & 0.006 & 0.000 & 40.9 \\
\hline 0.000 & 0.018 & 0.015 & 0.003 & 0.014 & 0.009 & 0.000 & 46.3 \\
\hline 0.000 & 0.018 & 0.018 & 0.003 & 0.014 & 0.009 & 0.000 & 51.2 \\
\hline-0.003 & 0.018 & 0.018 & 0.005 & 0.014 & 0.009 & 0.000 & 55.8 \\
\hline-0.003 & 0.018 & 0.021 & 0.005 & 0.014 & 0.009 & 0.000 & 55.0 \\
\hline 0.000 & 0.018 & 0.021 & 0.005 & 0.014 & 0.009 & 0.000 & 54.8 \\
\hline 0.000 & 0.018 & 0.021 & 0.008 & 0.017 & 0.009 & 0.000 & 60.4 \\
\hline 0.000 & 0.018 & 0.021 & 0.008 & 0.014 & 0.009 & 0.000 & 66.1 \\
\hline 0.003 & 0.018 & 0.024 & 0.011 & 0.017 & 0.012 & 0.003 & 71.0 \\
\hline 0.003 & 0.021 & 0.027 & 0.013 & 0.017 & 0.012 & 0.005 & 75.8 \\
\hline
\end{tabular}




\begin{tabular}{|c|c|c|c|c|c|c|c|}
\hline 0.003 & 0.021 & 0.027 & 0.013 & 0.020 & 0.012 & 0.003 & 81.1 \\
\hline-0.003 & 0.021 & 0.027 & 0.013 & 0.020 & 0.012 & 0.000 & 85.9 \\
\hline 0.000 & 0.021 & 0.027 & 0.013 & 0.020 & 0.012 & 0.003 & 90.5 \\
\hline 0.000 & 0.024 & 0.027 & 0.013 & 0.020 & 0.015 & 0.000 & 95.1 \\
\hline-0.003 & 0.024 & 0.027 & 0.016 & 0.023 & 0.015 & 0.000 & 101.4 \\
\hline 0.003 & 0.026 & 0.030 & 0.019 & 0.026 & 0.018 & 0.003 & 105.5 \\
\hline 0.000 & 0.026 & 0.030 & 0.019 & 0.026 & 0.018 & 0.003 & 111.1 \\
\hline 0.003 & 0.026 & 0.030 & 0.019 & 0.026 & 0.018 & 0.003 & 110.9 \\
\hline 0.003 & 0.026 & 0.033 & 0.021 & 0.029 & 0.018 & 0.003 & 116.5 \\
\hline 0.003 & 0.029 & 0.033 & 0.021 & 0.029 & 0.021 & 0.005 & 121.2 \\
\hline 0.000 & 0.029 & 0.033 & 0.021 & 0.026 & 0.021 & 0.003 & 124.9 \\
\hline 0.000 & 0.032 & 0.033 & 0.021 & 0.026 & 0.021 & 0.000 & 130.1 \\
\hline 0.000 & 0.032 & 0.030 & 0.021 & 0.026 & 0.021 & 0.003 & 129.5 \\
\hline 0.000 & 0.032 & 0.033 & 0.021 & 0.026 & 0.021 & 0.003 & 134.7 \\
\hline 0.000 & 0.034 & 0.033 & 0.021 & 0.026 & 0.024 & 0.003 & 139.1 \\
\hline 0.000 & 0.034 & 0.033 & 0.019 & 0.026 & 0.024 & 0.000 & 140.1 \\
\hline 0.000 & 0.032 & 0.030 & 0.013 & 0.026 & 0.021 & 0.003 & 136.1 \\
\hline 0.000 & 0.034 & 0.033 & 0.000 & 0.032 & 0.024 & 0.003 & 142.8 \\
\hline 0.000 & 0.032 & 0.033 & -0.027 & 0.032 & 0.024 & 0.003 & 147.9 \\
\hline 0.000 & 0.034 & 0.030 & -0.035 & 0.032 & 0.024 & 0.003 & 148.4 \\
\hline-0.003 & 0.032 & 0.027 & -0.046 & 0.032 & 0.024 & 0.000 & 148.5 \\
\hline 0.000 & 0.032 & 0.012 & -0.048 & 0.032 & 0.024 & 0.003 & 147.0 \\
\hline-0.003 & 0.034 & -0.009 & -0.054 & 0.029 & 0.024 & 0.000 & 150.2 \\
\hline-0.003 & 0.034 & -0.012 & -0.059 & 0.026 & 0.024 & 0.000 & 148.9 \\
\hline-0.003 & 0.034 & -0.018 & -0.072 & 0.012 & 0.024 & 0.003 & 149.2 \\
\hline 0.000 & 0.034 & -0.018 & -0.078 & 0.006 & 0.024 & 0.003 & 150.3 \\
\hline 0.000 & 0.034 & -0.021 & -0.080 & 0.006 & 0.024 & 0.003 & 149.4 \\
\hline-0.003 & 0.034 & -0.027 & -0.091 & 0.000 & 0.024 & 0.003 & 150.8 \\
\hline-0.003 & 0.037 & -0.036 & -0.110 & -0.012 & 0.024 & 0.000 & 151.0 \\
\hline-0.003 & 0.037 & -0.048 & -0.121 & -0.017 & 0.024 & 0.000 & 151.0 \\
\hline-0.003 & 0.037 & -0.060 & -0.129 & -0.023 & 0.024 & 0.000 & 151.2 \\
\hline-0.003 & 0.037 & -0.069 & -0.139 & -0.029 & 0.024 & 0.003 & 151.6 \\
\hline 0.000 & 0.037 & -0.075 & -0.145 & -0.035 & 0.024 & 0.003 & 151.3 \\
\hline-0.003 & 0.037 & -0.090 & -0.156 & -0.049 & 0.024 & 0.000 & 153.6 \\
\hline-0.003 & 0.037 & -0.099 & -0.164 & -0.058 & 0.024 & 0.000 & 152.9 \\
\hline-0.003 & 0.037 & -0.105 & -0.169 & -0.061 & 0.024 & 0.003 & 153.3 \\
\hline 0.000 & 0.040 & -0.117 & -0.177 & -0.078 & 0.027 & -0.003 & 145.6 \\
\hline 0.000 & 0.040 & -0.117 & -0.177 & -0.078 & 0.027 & -0.003 & 152.1 \\
\hline 0.000 & 0.040 & -0.120 & -0.188 & -0.084 & 0.027 & -0.003 & 152.2 \\
\hline 0.003 & 0.040 & -0.129 & -0.198 & -0.095 & 0.030 & 0.000 & 152.5 \\
\hline
\end{tabular}

\section{E.3 Tabela com os resultados dos ensaios da viga VFC-3}

\begin{tabular}{|c|c|c|c|c|c|c|c|c|c|c|c|c|c|}
\hline \multirow[b]{2}{*}{ Idade } & \multirow[b]{2}{*}{$\mathrm{Fv}$} & \multicolumn{5}{|c|}{$\begin{array}{l}\text { Deformações médias das armaduras } \\
\text { reforço }\end{array}$} & \multicolumn{6}{|c|}{ Deformações do concreto do substrato e do } & \multirow[b]{2}{*}{ flecha } \\
\hline & & Asl1 & Asl2 & Asl' & Asw & ext.15 & ext.16 & ext.17 & ext.18 & ext.18 & ext.18 & ext.18 & \\
\hline (dias) & $(\mathrm{kN})$ & \multicolumn{4}{|c|}{ (micro-strain) } & \multicolumn{7}{|c|}{ (micro-strain) } & $(\mathrm{mm})$ \\
\hline 1 & 0.0 & 0.0 & 0 & 0 & 0 & 0 & 0 & 0 & 0 & 0 & - & - & 0.000 \\
\hline 1 & 3.1 & 90.0 & 111.5 & -81 & 4.5 & -54 & -43 & -54 & -34 & -76 & - & - & 0.070 \\
\hline 1 & 4.5 & 123.0 & 160.5 & -126 & 4.5 & -92 & -73 & -89 & -64 & -118 & - & - & 0.380 \\
\hline 1 & 7.4 & 205.5 & 282.5 & -217.5 & 0.5 & -179 & -135 & -163 & -116 & -205 & - & - & 1.170 \\
\hline 1 & 8.9 & 253.0 & 350.5 & -264 & -3.5 & -227 & -168 & -195 & -141 & -247 & - & - & 2.640 \\
\hline 1 & 14.8 & 437.0 & 615 & -453 & -2 & -406 & -304 & -339 & -242 & -400 & - & - & 3.330 \\
\hline 1 & 20.8 & 629.5 & 889.5 & -700 & 9 & -648 & -480 & -530 & -472 & -600 & - & - & 5.221 \\
\hline 1 & 26.7 & 816.0 & 1162 & $\begin{array}{l}-1006 \\
\end{array}$ & 26.5 & -945 & -666 & -764 & -518 & -827 & - & - & 7.482 \\
\hline 1 & 32.1 & 1001.5 & 1468.5 & -1537.5 & 72 & -1516 & -943 & -1098 & -769 & -1219 & - & - & 10.328 \\
\hline 1 & 0.2 & 117.0 & 183 & -293.5 & 44.5 & -291 & -213 & -179 & -120 & -216 & - & - & 1.129 \\
\hline 1 & 9.5 & 369.0 & 562.5 & -730 & -107.5 & -626 & -364 & -463 & -332 & -551 & - & - & 4.972 \\
\hline
\end{tabular}




\begin{tabular}{|c|c|c|c|c|c|c|c|c|c|c|c|c|c|}
\hline 1 & 18.8 & 647.0 & 967.5 & -618.5 & 56 & $\begin{array}{l}-1054 \\
\end{array}$ & -618 & -759 & -540 & -867 & - & - & 7.862 \\
\hline 1 & 27.6 & 895.0 & 1321.5 & \begin{tabular}{|l}
-1453.5 \\
\end{tabular} & 74.5 & -1414 & -861 & $\begin{array}{l}-1014 \\
\end{array}$ & -715 & -1144 & - & - & 9.359 \\
\hline 1 & 33.4 & 1063.5 & 1570 & $\mid-1764.5$ & 100 & $\begin{array}{l}-1696 \\
\end{array}$ & -1027 & -1196 & -855 & -1359 & - & - & 11.317 \\
\hline 1 & 38.0 & 1214.5 & 1871 & \begin{tabular}{|l|}
-2728 \\
\end{tabular} & 139 & -3035 & -1303 & $\begin{array}{l}-2926 \\
\end{array}$ & -1300 & -1973 & - & - & 14.754 \\
\hline 1 & 33.1 & 1088.0 & 1703.5 & \begin{tabular}{|l}
-2672.5 \\
\end{tabular} & 133 & $\begin{array}{l}-3103 \\
\end{array}$ & -1227 & $\begin{array}{l}-2844 \\
\end{array}$ & -1275 & -1915 & - & - & $\begin{array}{l}13.774 \\
\end{array}$ \\
\hline 1 & 31.9 & 1043.0 & 1674 & -2865 & 154 & -3226 & -1250 & -2913 & -1329 & -1991 & - & - & 15.068 \\
\hline 2 & 30.7 & 995.0 & 1657.5 & \begin{tabular}{|l|}
-3163 \\
\end{tabular} & 154 & $\begin{array}{l}-3354 \\
\end{array}$ & -1330 & -3069 & -1418 & -2136 & - & - & 15.558 \\
\hline 3 & 29.9 & 1001.0 & 1688.5 & \begin{tabular}{|l}
-3307 \\
\end{tabular} & 182 & -3127 & -1378 & $\begin{array}{l}-3136 \\
\end{array}$ & -1451 & -2210 & - & - & 15.905 \\
\hline 4 & 29.2 & 984.0 & 1693 & \begin{tabular}{|l}
-3439.5 \\
\end{tabular} & 185 & -3500 & -1439 & -3190 & -1489 & $\begin{array}{l}-2274 \\
\end{array}$ & - & - & 16.163 \\
\hline 5 & 28.6 & 973.5 & 1703.5 & -3536 & 194.5 & -3565 & -1495 & -3254 & -1533 & -2335 & - & - & 16.395 \\
\hline 7 & 27.9 & 963.5 & 1714 & -3670.5 & 216 & -3668 & -1580 & -3330 & -1585 & -2404 & - & - & 16.690 \\
\hline 8 & 27.6 & 952.5 & 1714 & \begin{tabular}{|l|}
-3717 \\
\end{tabular} & 231 & -3705 & -1606 & -3353 & -1605 & -2429 & - & - & 16.805 \\
\hline 9 & 27.4 & 953.5 & 1718.5 & \begin{tabular}{|l}
-3765.5 \\
\end{tabular} & 224 & -3769 & -1664 & -3411 & -1646 & -2478 & - & - & 16.911 \\
\hline 10 & 27.1 & 942.0 & 1717 & \begin{tabular}{|l}
-3807.5 \\
\end{tabular} & 246.5 & $\begin{array}{l}-3794 \\
\end{array}$ & -1680 & -3425 & -1660 & -2487 & - & - & 16.935 \\
\hline 17 & 25.7 & 878.0 & 1719 & \begin{tabular}{|l|}
-4039 \\
\end{tabular} & 278.5 & $\begin{array}{l}-3987 \\
\end{array}$ & -1825 & -3555 & -1786 & -2587 & - & - & $\begin{array}{l}17.458 \\
\end{array}$ \\
\hline 17 & 25.7 & 878.0 & 1719 & \begin{tabular}{|l|}
-4039 \\
\end{tabular} & 278.5 & $\begin{array}{l}-3987 \\
\end{array}$ & -1825 & -3555 & -1786 & -2587 & - & - & 17.516 \\
\hline 18 & 25.6 & 885.0 & 1727 & \begin{tabular}{|l|}
-4064 \\
\end{tabular} & 278 & -4002 & -1832 & -3564 & -1792 & -2592 & - & - & 17.564 \\
\hline 19 & 25.5 & 884.0 & 1724.5 & -4094.5 & 274 & -4028 & -1851 & -3588 & -1802 & -2609 & - & - & 17.598 \\
\hline 20 & 25.4 & 878.5 & 1721.5 & \begin{tabular}{|l|l|l|}
-4.5 \\
\end{tabular} & 257 & -4059 & -1880 & -3616 & -1827 & -2638 & - & - & 17.642 \\
\hline 21 & 25.3 & 875.5 & 1722 & \begin{tabular}{|l|l|}
-4122 \\
\end{tabular} & 251 & -4080 & -1897 & $\begin{array}{l}-3637 \\
\end{array}$ & -1846 & -2656 & - & - & 17.685 \\
\hline 22 & 25.2 & 875.0 & 1732 & \begin{tabular}{|l|}
-4124 \\
\end{tabular} & 253.5 & -4086 & -1895 & -3641 & -1849 & -2661 & - & - & 17.732 \\
\hline 23 & 25.1 & 836.5 & 1704 & -4117.5 & 228.5 & -4129 & -1934 & -3675 & -1887 & -2688 & - & - & 17.775 \\
\hline 24 & 25.0 & 866.5 & 1724 & -4151.5 & 223 & -4157 & -1956 & -3700 & -1903 & -2709 & - & - & 17.820 \\
\hline 25 & 24.9 & 872.0 & 1735 & \begin{tabular}{|l|}
-4190 \\
\end{tabular} & 221 & -4174 & -1975 & -3704 & -1920 & -2729 & - & - & 17.866 \\
\hline 27 & 24.7 & 866.0 & 1734 & \begin{tabular}{|l|}
-4218 \\
\end{tabular} & 214.5 & -4203 & -1995 & -3740 & -1948 & -2757 & - & - & 17.920 \\
\hline 28 & 24.6 & 859.5 & 1728 & \begin{tabular}{|l}
-4245.5 \\
\end{tabular} & 204.5 & -4224 & -2016 & -3755 & -1963 & $\begin{array}{l}-2768 \\
\end{array}$ & - & - & 17.941 \\
\hline 30 & 24.4 & 848.0 & 1715.5 & \begin{tabular}{|l|}
-4303 \\
\end{tabular} & 190 & -4276 & -2058 & -3807 & -1998 & -2807 & - & - & 17.985 \\
\hline 31 & 24.3 & 844.0 & 1722 & \begin{tabular}{|l}
-4308.5 \\
\end{tabular} & 200.5 & -4269 & -2053 & -3802 & -2005 & $\begin{array}{l}-2814 \\
\end{array}$ & - & - & 18.022 \\
\hline 34 & 24.1 & 838.0 & 1714 & \begin{tabular}{|l}
-4357.5 \\
\end{tabular} & 194 & -4311 & -2089 & -3849 & -2034 & -2862 & - & - & 18.077 \\
\hline 35 & 24.1 & 842.0 & 1717 & \begin{tabular}{|l|}
-4416 \\
\end{tabular} & 203.5 & $\begin{array}{l}-4253 \\
\end{array}$ & -2028 & $\begin{array}{l}-3776 \\
\end{array}$ & -1974 & -2778 & - & - & 18.113 \\
\hline 36 & 24.0 & 820.0 & 1702.5 & \begin{tabular}{|l|}
-4435.5 \\
\end{tabular} & 201.5 & -4259 & -2033 & -3783 & -1989 & -2780 & - & - & 18.138 \\
\hline 37 & 23.9 & 809.0 & 1691.5 & -4452.5 & 195.5 & -4271 & -2042 & -3789 & -2003 & -2795 & - & - & 18.170 \\
\hline 38 & 23.8 & 820.0 & 1702.5 & -4450.5 & 198.5 & $\begin{array}{l}-4274 \\
\end{array}$ & -2041 & $\begin{array}{l}-3797 \\
\end{array}$ & -2005 & -2812 & - & - & 18.202 \\
\hline 41 & 23.6 & 819.0 & 1700 & \begin{tabular}{|l|}
-4492.5 \\
\end{tabular} & 181 & $\begin{array}{l}-4308 \\
\end{array}$ & -2075 & -3831 & -2023 & -2856 & - & - & 18.265 \\
\hline 42 & 23.6 & 781.5 & 1666 & \begin{tabular}{|l}
-4535.5 \\
\end{tabular} & 170 & -4320 & -2079 & -3757 & -2029 & -2873 & - & - & 18.314 \\
\hline 44 & 23.5 & 801.0 & 1686.5 & -4537 & 160.5 & -4326 & -2098 & -3769 & -2053 & -2910 & - & - & 18.335 \\
\hline 45 & 24.6 & 786.0 & 1689.5 & -4676.5 & 212.5 & $\begin{array}{l}-4397 \\
\end{array}$ & -2095 & -3603 & -2061 & -2951 & - & - & 18.350 \\
\hline 48 & 23.3 & 784.0 & 1670.5 & \begin{tabular}{|l|}
-4590.5 \\
\end{tabular} & 153 & -4365 & -2120 & \begin{tabular}{|c|}
-3569 \\
\end{tabular} & -2074 & -2935 & - & - & 18.404 \\
\hline 50 & 23.1 & 775.0 & 1664.5 & \begin{tabular}{|l|}
-4603 \\
\end{tabular} & 144.5 & -4377 & -2140 & \begin{tabular}{|l|}
-3529 \\
\end{tabular} & -2087 & -2958 & - & - & 18.459 \\
\hline 51 & 23.0 & 779.5 & 1664.5 & -4614.5 & 126.5 & -4404 & -2164 & \begin{tabular}{|l|}
-3554 \\
\end{tabular} & -2105 & -2991 & - & - & 18.486 \\
\hline 53 & 23.0 & 799.0 & 1684.5 & \begin{tabular}{|l}
-4607.5 \\
\end{tabular} & 97 & -4450 & -2214 & -3576 & -2141 & -3060 & - & - & 18.495 \\
\hline 55 & 23.0 & 757.0 & 1645.5 & \begin{tabular}{|l}
-4648.5 \\
\end{tabular} & 100.5 & -4438 & -2196 & \begin{tabular}{|l|}
-3544 \\
\end{tabular} & -2146 & -3019 & - & - & 18.483 \\
\hline 56 & 22.9 & 754.0 & 1643 & \begin{tabular}{|c|}
-4660 \\
\end{tabular} & 95.5 & -4443 & -2198 & -3527 & -2148 & -3024 & - & - & 18.499 \\
\hline 57 & 22.9 & 760.0 & 1648 & \begin{tabular}{|l|}
-4663 \\
\end{tabular} & 94 & -4452 & -2208 & -3530 & -2153 & -3027 & - & - & 18.515 \\
\hline 59 & 22.8 & 738.0 & 1627.5 & \begin{tabular}{|l|}
-4691 \\
\end{tabular} & 60.5 & -4491 & -2245 & -3554 & -2193 & -3078 & - & - & 18.543 \\
\hline 60 & 22.8 & 755.5 & 1648.5 & -4680.5 & 143.5 & -4409 & -2161 & \begin{tabular}{|c|}
-3438 \\
\end{tabular} & -2108 & -2996 & - & - & 18.552 \\
\hline 62 & 22.7 & 739.5 & 1631.5 & $\begin{array}{l}-4702 \\
\end{array}$ & 110.5 & -4447 & -2202 & \begin{tabular}{|l|}
-3466 \\
\end{tabular} & -2151 & -3039 & - & - & 18.596 \\
\hline 63 & 22.6 & 742.0 & 1631.5 & -4708.5 & 99.5 & -4460 & -2211 & -3416 & -2163 & -3053 & - & - & 18.605 \\
\hline 64 & 22.6 & 749.0 & 1638 & -4738.5 & 173 & -4379 & -2080 & \begin{tabular}{|l|}
-3347 \\
\end{tabular} & -2106 & -2910 & - & - & 18.610 \\
\hline 65 & 22.5 & 749.0 & 1638 & -4727 & 141.5 & -4371 & -2084 & \begin{tabular}{|c|}
-3464 \\
\end{tabular} & -2134 & -2953 & - & - & 18.626 \\
\hline
\end{tabular}




\begin{tabular}{|c|c|c|c|c|c|c|c|c|c|c|c|c|c|}
\hline 66 & 22.5 & 755.5 & 1645.5 & -4722.5 & 99 & -4403 & -2100 & \begin{tabular}{|l|}
-3466 \\
\end{tabular} & -2151 & -2984 & - & - & 18.655 \\
\hline 69 & 23.3 & 749.0 & 1622.5 & -4766.5 & 155.5 & -3415 & \begin{tabular}{|c|}
-1886 \\
\end{tabular} & \begin{tabular}{|l|}
-3389 \\
\end{tabular} & -2069 & -2882 & 0 & - & 18.664 \\
\hline 69 & 23.3 & 749.0 & 1622.5 & -4766.5 & 155.5 & -3415 & \begin{tabular}{|l|}
-1886 \\
\end{tabular} & \begin{tabular}{|l|}
-3389 \\
\end{tabular} & -2069 & -2882 & 0 & - & 19.312 \\
\hline 70 & 23.3 & 756.5 & 1621 & -4859 & 173 & $\begin{array}{l}-1605 \\
\end{array}$ & -1688 & \begin{tabular}{|l|}
-3389 \\
\end{tabular} & -1975 & -2809 & $\begin{array}{l}-72 \\
\end{array}$ & - & 19.420 \\
\hline 71 & 23.3 & 697.5 & 1565 & $\begin{array}{l}-4943 \\
\end{array}$ & 113.5 & $\begin{array}{l}-1389 \\
\end{array}$ & -1681 & \begin{tabular}{|l|}
-1054 \\
\end{tabular} & -2027 & -2878 & -25 & - & 19.433 \\
\hline 72 & 23.1 & 755.0 & 1623 & -4881.5 & 181 & -454 & \begin{tabular}{|c|}
-639 \\
\end{tabular} & -497 & -1962 & -2804 & 13 & - & 19.456 \\
\hline 73 & 23.1 & 786.0 & 1647 & -4750 & 156 & -423 & -539 & -413 & -1999 & -2832 & -4 & 0 & 19.563 \\
\hline 76 & 22.8 & 784.5 & 1649.5 & $\mid-4725.5$ & 182.5 & -337 & -355 & -165 & $\begin{array}{l}-1958 \\
\end{array}$ & -2800 & 8 & 821 & 19.649 \\
\hline 78 & 22.7 & 768.0 & 1637 & -4756.5 & 175 & -359 & -365 & -859 & -1987 & -2835 & -17 & 882 & 19.717 \\
\hline 80 & 22.6 & 753.5 & 1623.5 & -4765.5 & 159 & -380 & -364 & -545 & $\begin{array}{l}-1996 \\
\end{array}$ & -2831 & -23 & 935 & 19.736 \\
\hline 83 & 22.5 & 750.0 & 1620 & -4803.5 & 142.5 & -427 & -384 & -535 & $\begin{array}{l}-2016 \\
\end{array}$ & -2856 & -64 & 980 & 19.811 \\
\hline 85 & 22.4 & 746.0 & 1572 & -4792 & 159.5 & -426 & -376 & -529 & -2008 & -2836 & -64 & 942 & 19.841 \\
\hline 86 & 22.3 & 748.0 & \begin{tabular}{|l|l}
1616.5 \\
\end{tabular} & -4797 & 150.5 & -448 & -390 & $\begin{array}{l}-574 \\
\end{array}$ & -2015 & -2848 & $\begin{array}{l}-94 \\
\end{array}$ & 963 & 19.848 \\
\hline 87 & 22.3 & 732.0 & 1611.5 & -4792.5 & 167.5 & -430 & -368 & -630 & -2003 & $\begin{array}{l}-2817 \\
\end{array}$ & -88 & 1007 & 19.877 \\
\hline 90 & 22.1 & 718.5 & 1593 & -4822 & 158 & -471 & -393 & -689 & -2027 & -2818 & -132 & 968 & 19.921 \\
\hline 91 & 22.0 & 722.0 & 1595.5 & -4821.5 & 156.5 & -495 & -397 & $\begin{array}{l}-802 \\
\end{array}$ & $\begin{array}{l}-2024 \\
\end{array}$ & -2826 & -134 & 990 & 19.951 \\
\hline 92 & 22.0 & 717.0 & 1590 & -4812 & $\begin{array}{l}156.5 \\
\end{array}$ & -519 & \begin{tabular}{|l|}
-410 \\
\end{tabular} & -787 & -2026 & \begin{tabular}{|l|}
-2834 \\
\end{tabular} & -80 & 1025 & 19.977 \\
\hline 93 & 21.9 & 731.0 & 1603.5 & -4819.5 & 146 & -541 & -444 & $\begin{array}{l}-882 \\
\end{array}$ & $\begin{array}{l}-2046 \\
\end{array}$ & -2861 & -102 & 1038 & 19.986 \\
\hline 94 & 21.9 & 712.0 & 1586 & -4860.5 & 161.5 & -534 & -415 & -748 & -2029 & -2824 & -83 & 1010 & 20.004 \\
\hline 97 & 21.8 & 713.5 & \begin{tabular}{|l|}
1588.5 \\
\end{tabular} & -4843.5 & 155 & -547 & -435 & -739 & -2042 & -2827 & -109 & 1015 & 20.046 \\
\hline 98 & 21.7 & 705.0 & 1580 & -4819.5 & $\begin{array}{l}153.5 \\
\end{array}$ & -594 & -450 & -756 & -2052 & -2847 & -119 & 1011 & 20.074 \\
\hline 99 & 21.7 & 718.0 & 1588.5 & $\mid-4761.5$ & 147 & $\begin{array}{l}-613 \\
\end{array}$ & -459 & $\begin{array}{l}-784 \\
\end{array}$ & -2052 & $\begin{array}{l}-2844 \\
\end{array}$ & -118 & 1000 & 20.077 \\
\hline 100 & 21.7 & 708.5 & 1582.5 & -4752 & 154.5 & -610 & -455 & $\begin{array}{l}-780 \\
\end{array}$ & -2050 & -2835 & -126 & 1000 & 20.095 \\
\hline 102 & 21.6 & 707.0 & 1578.5 & -4747.5 & 142 & -640 & -481 & -743 & -2065 & -2849 & $\begin{array}{c}-156 \\
-15\end{array}$ & 985 & 20.113 \\
\hline 105 & 21.5 & 700.0 & \begin{tabular}{|l|l}
1571.5 \\
\end{tabular} & -4811.5 & 157 & -646 & -481 & -729 & -2061 & -2836 & -143 & 992 & 20.167 \\
\hline 107 & 21.4 & 706.5 & 1578 & -4802.5 & 140.5 & -689 & -515 & -787 & -2079 & $\begin{array}{l}-2864 \\
\end{array}$ & -155 & 989 & 20.191 \\
\hline 111 & 21.3 & 701.5 & 1569.5 & $\mid-4713.5$ & 156.5 & -690 & -524 & $\begin{array}{l}-747 \\
\end{array}$ & -2067 & -2856 & -141 & 928 & 20.221 \\
\hline 112 & 21.3 & 696.0 & 1566.5 & -4770 & 144 & -719 & -555 & -835 & -2091 & -2883 & -168 & 978 & 20.250 \\
\hline 114 & 21.2 & 703.5 & 1575 & \begin{tabular}{|l|}
-4769.5 \\
\end{tabular} & 139.5 & -729 & -556 & -752 & -2093 & -2881 & -173 & 966 & 20.264 \\
\hline 115 & 21.2 & 694.0 & 1559.5 & -4660 & 145 & -725 & -560 & -524 & -2093 & -2880 & -181 & 965 & 20.273 \\
\hline 118 & 21.1 & 686.0 & 1554 & -4702.5 & 145.5 & -739 & -568 & -549 & -2091 & -2880 & -197 & 942 & 20.304 \\
\hline 120 & 21.0 & 686.0 & 1551 & -4817.5 & 147 & -734 & -574 & -542 & -2096 & -2878 & -202 & 936 & 20.310 \\
\hline 122 & 21.0 & 683.5 & 1551.5 & -4590 & 150 & -736 & -575 & -547 & -2102 & -2872 & -210 & 910 & 20.321 \\
\hline 125 & 21.0 & 684.5 & 1553 & $\begin{array}{l}-4648 \\
\end{array}$ & 146.5 & -771 & -605 & -569 & -2112 & -2905 & -213 & 865 & 20.350 \\
\hline 127 & 20.8 & 676.0 & 1550.5 & -5012.5 & 132.5 & -779 & -604 & -647 & -2111 & -2900 & -188 & 871 & 20.395 \\
\hline 129 & 20.8 & 635.5 & 1532.5 & $\begin{array}{l}-5026 \\
\end{array}$ & 158.5 & -739 & -581 & -877 & -2098 & -2860 & -179 & 864 & 20.404 \\
\hline 132 & 20.8 & 638.0 & 1536 & $\begin{array}{l}-5028 \\
\end{array}$ & 148.5 & -747 & -598 & $\begin{array}{l}-879 \\
\end{array}$ & -2113 & -2874 & -242 & 761 & 20.422 \\
\hline 133 & 20.7 & 638.0 & 1535 & -4998.5 & 156 & -749 & -595 & -10813 & -2104 & -2875 & -208 & 855 & 20.446 \\
\hline 137 & 20.6 & 708.0 & 1612 & -4955 & 130.5 & -777 & \begin{tabular}{|l|}
-623 \\
\end{tabular} & -814 & $\begin{array}{l}-2134 \\
\end{array}$ & \begin{tabular}{|l|}
-2898 \\
\end{tabular} & -227 & 798 & 20.476 \\
\hline 139 & 20.6 & 653.5 & 1549 & -4999 & 126.5 & $\begin{array}{l}-792 \\
\end{array}$ & -640 & -790 & $\begin{array}{l}-2148 \\
\end{array}$ & -2909 & -217 & 906 & 20.493 \\
\hline \multicolumn{14}{|c|}{ INICIO DO ENSAIO FINAL } \\
\hline 4 & 0.7 & 0 & 0 & 1 & 1 & 0 & 1 & 0 & 1 & 1 & 0 & 1 & 0.0000 \\
\hline 5 & 5.3 & 46 & 60 & -22 & 2 & -1 & -5 & -9 & -12 & -22 & -38 & -78 & 0.3885 \\
\hline 6 & 10.2 & 103 & 132 & -47 & 5 & -1 & -9 & -17 & -26 & -48 & -82 & -167 & 0.8159 \\
\hline 7 & 15.2 & 171 & 218 & $\begin{array}{l}-73 \\
\end{array}$ & 15 & -2 & -9 & -23 & -38 & -73 & $\begin{array}{l}-130 \\
\end{array}$ & -284 & 1.3598 \\
\hline 8 & 20.6 & 242 & 304 & -99 & 28 & -2 & $\begin{array}{l}-10 \\
\end{array}$ & -25 & -50 & -99 & $\begin{array}{l}-181 \\
\end{array}$ & -404 & 1.8648 \\
\hline 9 & 25.6 & 311 & 388 & -123 & 44 & -2 & -14 & -29 & -62 & -123 & -228 & -521 & 2.3699 \\
\hline 10 & 31.0 & 383 & 476 & $\begin{array}{l}-147 \\
\end{array}$ & 62 & -3 & -18 & -33 & -72 & -149 & -277 & -634 & 2.9138 \\
\hline 11 & 36.0 & 452 & 559 & $\begin{array}{l}-167 \\
\end{array}$ & 86 & -1 & -5 & -33 & -81 & $\begin{array}{l}-168 \\
\end{array}$ & -322 & $\begin{array}{l}-733 \\
\end{array}$ & 3.3800 \\
\hline 12 & 40.7 & 517 & 638 & -185 & 112 & -2 & -9 & -36 & -89 & -186 & -364 & -822 & 3.8462 \\
\hline
\end{tabular}




\begin{tabular}{|c|c|c|c|c|c|c|c|c|c|c|c|c|c|}
\hline 13 & 45.4 & 584 & 718 & -202 & 138 & -2 & -11 & -37 & $\begin{array}{l}-96 \\
\end{array}$ & -203 & -402 & -905 & 4.3124 \\
\hline 14 & 50.7 & 661 & 811 & -221 & 172 & -2 & -14 & -38 & $\begin{array}{l}-103 \\
\end{array}$ & -222 & -447 & -991 & 4.8951 \\
\hline 15 & 55.9 & 736 & 899 & -239 & 211 & 1 & -11 & -35 & -108 & -238 & -489 & -1067 & 5.4390 \\
\hline 16 & 61.0 & 811 & 988 & -254 & 268 & 1 & -15 & -37 & -115 & -252 & -528 & -1134 & \begin{tabular}{|l|}
5.9829 \\
\end{tabular} \\
\hline 17 & 66.3 & 889 & 1070 & \begin{tabular}{|l|}
-273 \\
\end{tabular} & 317 & 0 & -17 & -39 & -119 & -266 & -570 & -1203 & \begin{tabular}{|l|}
6.5268 \\
\end{tabular} \\
\hline 18 & 71.0 & 979 & 1179 & -297 & 383 & 4 & -12 & -34 & -122 & -275 & -608 & -1282 & 7.0707 \\
\hline 19 & 75.3 & 1060 & 1353 & -308 & 429 & 4 & -14 & -33 & -118 & -285 & -644 & -1339 & \begin{tabular}{|l|}
7.5758 \\
\end{tabular} \\
\hline 20 & 81.3 & 1194 & 1504 & -325 & 495 & 4 & -17 & -32 & -113 & -297 & -695 & -1425 & \begin{tabular}{|l}
8.3139 \\
\end{tabular} \\
\hline 21 & 85.9 & 1294 & 1598 & -345 & 566 & 5 & -17 & -29 & -107 & -309 & $\begin{array}{l}-732 \\
\end{array}$ & -1453 & \begin{tabular}{|l|}
8.8967 \\
\end{tabular} \\
\hline 22 & 91.4 & 1412 & 1706 & -359 & 626 & 4 & -19 & -27 & -101 & -322 & -776 & -1477 & 9.5960 \\
\hline 23 & 95.7 & 1512 & 1761 & -363 & 686 & 7 & -21 & -25 & -97 & -335 & -815 & -1477 & 10.2176 \\
\hline 24 & 101.4 & 1645 & 1850 & -377 & 739 & 7 & -23 & -21 & -87 & -352 & \begin{tabular}{|l|}
-883 \\
\end{tabular} & -1597 & 10.9169 \\
\hline 25 & 105.4 & 1756 & 1872 & -397 & 799 & 7 & -22 & -17 & -78 & -364 & $\begin{array}{l}-937 \\
\end{array}$ & -1638 & 11.5385 \\
\hline 26 & 110.2 & 2227 & 1903 & -404 & 852 & 7 & -22 & $\begin{array}{l}-7 \\
\end{array}$ & -52 & -369 & -997 & -1686 & 12.2766 \\
\hline 27 & 113.3 & 2405 & 1898 & -430 & 932 & 13 & -13 & 7 & -25 & -366 & -1052 & -1667 & 13.0148 \\
\hline 28 & 117.8 & 3621 & 1883 & -411 & 979 & 12 & -11 & 29 & 30 & -349 & -1133 & -1719 & 14.0637 \\
\hline 29 & 122.4 & 4992 & 1886 & -371 & 1031 & 14 & -4 & 62 & 114 & -307 & -1225 & -1766 & 15.3458 \\
\hline 30 & 125.0 & 5377 & 4474 & -233 & 1053 & 14 & 15 & 120 & 348 & -174 & -1372 & -1918 & 17.2494 \\
\hline 31 & 128.4 & 5658 & & \begin{tabular}{|l|}
-179 \\
\end{tabular} & 1080 & 13 & 22 & 134 & 432 & -122 & -1433 & -2026 & 18.4149 \\
\hline 32 & 130.9 & 6576 & & -145 & 1106 & 14 & 25 & 141 & 477 & -85 & -1451 & -2135 & 19.2308 \\
\hline 33 & 132.4 & 9887 & & -55 & 1120 & 15 & 41 & 166 & 530 & 4 & -1499 & -2243 & 20.6682 \\
\hline 34 & 133.3 & 9392 & & $\begin{array}{l}-39 \\
\end{array}$ & 1134 & 16 & 36 & 164 & 539 & 19 & -1508 & -2263 & 21.2898 \\
\hline 35 & 134.4 & 10290 & & 17 & 1147 & 18 & 47 & 194 & 583 & 77 & -1564 & -2348 & 22.4942 \\
\hline 36 & 134.6 & 10016 & & 64 & 1152 & 18 & 54 & 220 & 610 & 122 & -1588 & -2392 & 23.2712 \\
\hline 37 & 131.0 & 9597 & & 103 & 1142 & 22 & 58 & 233 & 626 & 158 & -1575 & -2398 & 23.7762 \\
\hline 38 & 136.2 & 9717 & & 104 & 1176 & 20 & 57 & 245 & 638 & 159 & -1626 & -2448 & 24.6698 \\
\hline 39 & 136.4 & 9722 & & 166 & 1179 & 21 & 62 & 319 & 659 & 214 & -1666 & -2510 & 25.9907 \\
\hline 40 & 137.0 & 9705 & & 218 & 1191 & 19 & 62 & 365 & 687 & 252 & -1698 & -2563 & 27.0785 \\
\hline 41 & 138.5 & 9701 & & 338 & 1210 & 18 & 63 & 256 & 765 & 336 & -1770 & -2689 & 29.2152 \\
\hline 42 & 138.8 & 9690 & & 390 & 1213 & 19 & 62 & 251 & 829 & 374 & -1797 & -2734 & 29.9534 \\
\hline 43 & 140.3 & 9704 & & 510 & 1220 & 20 & 59 & 263 & 1062 & 451 & -1850 & -2823 & 31.5462 \\
\hline 44 & 140.7 & 9694 & & 581 & 1235 & 17 & 58 & 250 & 1179 & 491 & -1885 & -2846 & 32.7894 \\
\hline 45 & 141.3 & 9682 & & 678 & 1239 & 19 & 54 & 272 & 1305 & 545 & -1924 & -2900 & 34.4988 \\
\hline 46 & 141.0 & 9678 & & 735 & 1242 & 19 & 52 & 280 & 1394 & 574 & -1945 & -2929 & 35.3924 \\
\hline 47 & 141.5 & 9679 & & 787 & 1242 & 19 & 51 & 282 & 1467 & 598 & -1963 & -2948 & 36.3248 \\
\hline 48 & 142.1 & 9680 & & 846 & 1256 & 19 & 54 & 256 & 1547 & 622 & -1982 & -2958 & 37.6457 \\
\hline 49 & 142.9 & 9682 & & 899 & 1261 & 20 & 60 & 263 & 1574 & 656 & -2018 & -2996 & 39.1608 \\
\hline 50 & 143.3 & 9687 & & 975 & 1264 & 21 & 65 & 271 & 1594 & 693 & -2043 & -3063 & 40.4817 \\
\hline 51 & 143.2 & 9676 & & 1041 & 1264 & 21 & 69 & 274 & 1613 & 722 & -2030 & -3087 & 41.5695 \\
\hline 52 & 143.8 & 9673 & & 1083 & 1264 & 20 & 71 & 274 & 1620 & 739 & -2032 & -3090 & 42.3077 \\
\hline 53 & 144.1 & 9712 & & 1175 & 1279 & 18 & 70 & 256 & 1635 & 771 & -2047 & -3001 & 43.9005 \\
\hline 54 & 144.0 & 9691 & & 1217 & 1276 & 19 & 75 & 256 & 1639 & 793 & -2058 & -3014 & 44.7941 \\
\hline 55 & 144.4 & 9707 & & 1258 & 1281 & 19 & 77 & 256 & 1637 & 809 & -2073 & -3016 & 45.8042 \\
\hline 56 & 144.4 & 9705 & & 1292 & 1283 & 19 & 80 & 256 & 1634 & 821 & -2075 & -2987 & 46.5812 \\
\hline 57 & 146.0 & 9699 & & 1318 & 1286 & 19 & 80 & 255 & 1632 & 829 & -2085 & -2951 & 47.5524 \\
\hline 58 & 145.8 & 9705 & & 1343 & 1285 & 19 & 81 & 253 & 1630 & 840 & -2082 & -2925 & 48.4072 \\
\hline 59 & 145.0 & 9710 & & 1366 & 1286 & 19 & 82 & 249 & 1629 & 847 & -2086 & -2886 & 49.3007 \\
\hline 60 & 145.8 & 9726 & & 1394 & 1289 & 19 & 82 & 243 & 1629 & 858 & -2098 & -2831 & 50.5828 \\
\hline 61 & 147.2 & 9725 & & 1449 & 1287 & 19 & 85 & 237 & 1623 & 889 & -2113 & -2769 & 51.9814 \\
\hline 62 & 147.4 & 9721 & & 1509 & 1288 & 19 & 87 & 233 & 1617 & 915 & -2136 & -2703 & 53.3800 \\
\hline
\end{tabular}




\begin{tabular}{|l|l|l|l|l|l|l|l|l|l|l|l|l|l|}
\hline 63 & 146.0 & 9720 & & 1539 & 1281 & 19 & 89 & 232 & 1612 & 925 & -2196 & -2657 & 54.1570 \\
\hline 64 & 146.2 & 9730 & & 1579 & 1263 & 16 & 85 & 222 & 1612 & 931 & -2263 & -2561 & 55.7110 \\
\hline 65 & 146.6 & 9700 & & 1592 & 1254 & 16 & 85 & 216 & 1612 & 936 & -2312 & -2515 & 57.3815 \\
\hline 66 & 144.9 & 9682 & & 1596 & 1246 & 16 & 86 & 212 & 1609 & 937 & -2319 & -2462 & 57.9254 \\
\hline 67 & 134.1 & 9525 & & 1461 & 1329 & 14 & 81 & 152 & 1548 & 854 & -2256 & -2171 & 58.3528 \\
\hline 68 & 132.2 & 9503 & & 1425 & 1320 & 14 & 81 & 155 & 1530 & 834 & -2254 & -2112 & 58.4305 \\
\hline 69 & 130.2 & 9476 & & 1405 & 1311 & 15 & 75 & 155 & 1516 & 824 & -2252 & -2063 & 58.5082 \\
\hline 70 & 70.6 & 8553 & & 1617 & 826 & 19 & 86 & 171 & 1465 & 979 & -1685 & -1637 & 51.4763 \\
\hline 71 & 70.6 & 8555 & & 1618 & 826 & 19 & 85 & 171 & 1464 & 979 & -1685 & -1638 & 51.4763 \\
\hline 72 & 49.1 & 8287 & & 1711 & 684 & 20 & 88 & 179 & 1439 & 1041 & -1464 & -1518 & 48.7179 \\
\hline 73 & 32.3 & 7990 & & 1854 & 540 & 19 & 88 & 183 & 1406 & 1111 & -1234 & -1429 & 46.1538 \\
\hline 74 & 14.5 & 7718 & & 2041 & 419 & 20 & 91 & 182 & 1370 & 1202 & -937 & -1237 & 43.2012 \\
\hline 75 & 2.7 & 7492 & & 2286 & 324 & 21 & 98 & 177 & 1310 & 1325 & -606 & -416 & 40.4817 \\
\hline 76 & 2.1 & 7479 & & 2311 & 316 & 20 & 98 & 177 & 1300 & 1336 & -580 & -337 & 40.2875 \\
\hline 77 & -0.2 & 7437 & & 2416 & 280 & 19 & 98 & 176 & 1258 & 1383 & -477 & 26 & 39.2774 \\
\hline 78 & -0.2 & 7441 & & 2429 & 278 & 18 & 96 & 175 & 1253 & 1388 & -468 & 39 & 39.1997 \\
\hline
\end{tabular}

\begin{tabular}{|c|c|c|c|c|c|c|c|}
\hline \multicolumn{7}{|c|}{ Relógios - deslocamentos horizontais } & \multirow[t]{2}{*}{ Fv } \\
\hline relógio & relógio & relógio & relógio & relógio & relógio & relógio & \\
\hline prox. Apoio & 62.5 apoio & $\mathrm{Fv}-1$ & meio & $\mathrm{Fv}-2$ & 62.5 apoio & prox. Apoio & Fmacaco + Fvcabo \\
\hline$(\mathrm{mm})$ & $(\mathrm{mm})$ & $(\mathrm{mm})$ & $(\mathrm{mm})$ & $(\mathrm{mm})$ & $(\mathrm{mm})$ & $(\mathrm{mm})$ & $(\mathrm{kN})$ \\
\hline \multicolumn{8}{|c|}{ Início do ensaio final } \\
\hline-0.0031 & 0.0000 & 0.0000 & 0.0000 & 0.0000 & 0.0000 & 0.0000 & 0.7 \\
\hline 0.0000 & 0.0000 & 0.0000 & 0.0000 & 0.0000 & 0.0000 & 0.0000 & 5.3 \\
\hline 0.0000 & 0.0000 & 0.0030 & 0.0000 & 0.0000 & 0.0030 & 0.0027 & 10.2 \\
\hline 0.0031 & 0.0000 & 0.0030 & 0.0027 & 0.0058 & 0.0030 & 0.0027 & 15.2 \\
\hline 0.0031 & 0.0000 & 0.0000 & 0.0027 & 0.0087 & 0.0030 & 0.0053 & 20.6 \\
\hline 0.0031 & 0.0000 & 0.0000 & 0.0027 & 0.0116 & 0.0030 & 0.0053 & 25.6 \\
\hline 0.0031 & 0.0000 & 0.0000 & 0.0027 & 0.0145 & 0.0030 & 0.0053 & 31.0 \\
\hline 0.0000 & 0.0079 & 0.0000 & 0.0027 & 0.0145 & 0.0000 & 0.0027 & 36.0 \\
\hline 0.0000 & 0.0079 & -0.0030 & 0.0027 & 0.0173 & 0.0000 & 0.0000 & 40.7 \\
\hline-0.0031 & 0.0079 & -0.0030 & 0.0000 & 0.0173 & 0.0000 & 0.0000 & 45.4 \\
\hline-0.0031 & 0.0053 & -0.0030 & 0.0027 & 0.0202 & 0.0000 & 0.0027 & 50.7 \\
\hline 0.0000 & 0.0079 & 0.0000 & 0.0027 & 0.0231 & 0.0000 & 0.0027 & 55.9 \\
\hline 0.0000 & 0.0053 & 0.0000 & 0.0054 & 0.0231 & 0.0000 & 0.0027 & 61.0 \\
\hline-0.0031 & 0.0053 & 0.0000 & 0.0080 & 0.0231 & 0.0000 & 0.0027 & 66.3 \\
\hline-0.0031 & 0.0053 & -0.0030 & 0.0054 & 0.0405 & 0.0000 & 0.0027 & 71.0 \\
\hline-0.0062 & 0.0053 & -0.0030 & 0.0080 & 0.0405 & 0.0000 & 0.0027 & 75.3 \\
\hline-0.0031 & 0.0053 & 0.0000 & 0.0107 & 0.0405 & 0.0030 & 0.0053 & 81.3 \\
\hline-0.0062 & 0.0026 & -0.0030 & 0.0107 & 0.0405 & 0.0030 & 0.0027 & 85.9 \\
\hline-0.0092 & 0.0053 & -0.0030 & 0.0107 & 0.0376 & 0.0030 & 0.0027 & 91.4 \\
\hline-0.0092 & 0.0079 & -0.0060 & 0.0134 & 0.0405 & 0.0030 & 0.0027 & 95.7 \\
\hline-0.0123 & 0.0079 & -0.0090 & 0.0134 & 0.0405 & 0.0030 & 0.0027 & 101.4 \\
\hline-0.0154 & 0.0079 & -0.0090 & 0.0134 & 0.0376 & 0.0030 & 0.0027 & 105.4 \\
\hline-0.0216 & 0.0079 & -0.0120 & 0.0134 & 0.0376 & 0.0000 & -0.0027 & 110.2 \\
\hline-0.0277 & 0.0079 & -0.0181 & 0.0161 & 0.0376 & 0.0030 & -0.0080 & 113.3 \\
\hline-0.0277 & 0.0079 & -0.0151 & 0.0188 & 0.0434 & 0.0060 & -0.0027 & 117.8 \\
\hline-0.0431 & 0.0079 & -0.0211 & 0.0161 & 0.0405 & 0.0060 & -0.0027 & 122.4 \\
\hline-0.0585 & 0.0079 & -0.0271 & 0.0134 & 0.0405 & 0.0060 & -0.0027 & 125.0 \\
\hline-0.0708 & 0.0079 & -0.0331 & 0.0080 & 0.0405 & 0.0060 & 0.0000 & 128.4 \\
\hline
\end{tabular}




\begin{tabular}{|c|c|c|c|c|c|c|c|}
\hline-0.0862 & 0.0079 & -0.0391 & 0.0054 & 0.0376 & 0.0030 & -0.0053 & 130.9 \\
\hline-0.0985 & 0.0079 & -0.0482 & 0.0000 & 0.0376 & 0.0030 & -0.0053 & 132.4 \\
\hline-0.0954 & 0.0053 & -0.0602 & -0.0027 & 0.0347 & 0.0060 & -0.0053 & 133.3 \\
\hline-0.0954 & 0.0053 & -0.0632 & -0.0027 & 0.0347 & 0.0030 & -0.0053 & 134.4 \\
\hline $\begin{array}{c}-0.0954 \\
\end{array}$ & 0.0053 & -0.0692 & -0.0054 & 0.0347 & 0.0060 & -0.0053 & 134.6 \\
\hline-0.0954 & 0.0053 & -0.0783 & -0.0080 & 0.0318 & 0.0060 & -0.0053 & 131.0 \\
\hline-0.0985 & 0.0053 & -0.0783 & -0.0080 & 0.0318 & 0.0060 & -0.0053 & 136.2 \\
\hline-0.0985 & 0.0053 & -0.0963 & -0.0134 & 0.0318 & 0.0060 & -0.0053 & 136.4 \\
\hline-0.0985 & 0.0053 & -0.1054 & -0.0134 & 0.0318 & 0.0060 & -0.0053 & 137.0 \\
\hline-0.0985 & 0.0053 & -0.1325 & -0.0215 & 0.0318 & 0.0060 & -0.0053 & 138.5 \\
\hline-0.0985 & 0.0053 & -0.1355 & -0.0268 & 0.0318 & 0.0060 & -0.0053 & 138.8 \\
\hline-0.0954 & 0.0079 & -0.1475 & -0.0349 & 0.0318 & 0.0060 & -0.0053 & 140.3 \\
\hline-0.1016 & 0.0053 & -0.1626 & -0.0402 & 0.0289 & 0.0060 & -0.0053 & 140.7 \\
\hline-0.1016 & 0.0053 & -0.1746 & -0.0483 & 0.0289 & 0.0060 & -0.0053 & 141.3 \\
\hline-0.1016 & 0.0053 & -0.1806 & -0.0510 & 0.0289 & 0.0060 & -0.0053 & 141.0 \\
\hline-0.1016 & 0.0053 & -0.1836 & -0.0510 & 0.0376 & 0.0060 & -0.0053 & 141.5 \\
\hline-0.0985 & 0.0053 & -0.1927 & -0.0536 & 0.0723 & 0.0060 & -0.0027 & 142.1 \\
\hline-0.0985 & 0.0053 & -0.1957 & -0.0563 & 0.0723 & 0.0060 & -0.0027 & 142.9 \\
\hline-0.0985 & 0.0053 & -0.2077 & -0.0617 & 0.0751 & 0.0060 & -0.0027 & 143.3 \\
\hline-0.1016 & 0.0053 & -0.2228 & -0.0644 & 0.0751 & 0.0060 & -0.0027 & 143.2 \\
\hline-0.1016 & 0.0053 & -0.2318 & -0.0671 & 0.0751 & 0.0060 & -0.0027 & 143.8 \\
\hline-0.1016 & 0.0053 & -0.2468 & -0.0724 & 0.1069 & 0.0060 & -0.0027 & 144.1 \\
\hline-0.1016 & 0.0053 & -0.2589 & -0.0751 & 0.1069 & 0.0060 & -0.0053 & 144.0 \\
\hline-0.1016 & 0.0053 & -0.2679 & -0.0751 & 0.1069 & 0.0060 & -0.0053 & 144.4 \\
\hline-0.1016 & 0.0053 & -0.2739 & -0.0778 & 0.1069 & 0.0060 & -0.0027 & 144.4 \\
\hline-0.1016 & 0.0053 & -0.2769 & -0.0778 & 0.1069 & 0.0060 & -0.0027 & 146.0 \\
\hline-0.1047 & 0.0053 & -0.2800 & -0.0805 & 0.1069 & 0.0060 & -0.0027 & 145.8 \\
\hline-0.1047 & 0.0053 & -0.2860 & -0.0778 & 0.1069 & 0.0060 & -0.0027 & 145.0 \\
\hline-0.1047 & 0.0053 & -0.2860 & -0.0805 & 0.1098 & 0.0060 & -0.0027 & 145.8 \\
\hline-0.1047 & 0.0053 & -0.2950 & -0.0805 & 0.1185 & 0.0060 & -0.0053 & 147.2 \\
\hline-0.1047 & 0.0053 & -0.3040 & -0.0832 & 0.1329 & 0.0060 & -0.0053 & 147.4 \\
\hline-0.1047 & 0.0053 & -0.3070 & -0.0858 & 0.1445 & 0.0060 & -0.0053 & 146.0 \\
\hline-0.1078 & 0.0053 & -0.3101 & -0.0858 & 0.1763 & 0.0060 & -0.0053 & 146.2 \\
\hline-0.1078 & 0.0053 & -0.3131 & -0.0858 & 1.1329 & 0.0060 & -0.0053 & 146.6 \\
\hline-0.1078 & 0.0053 & -0.3131 & -0.0858 & 1.2370 & 0.0060 & -0.0053 & 144.9 \\
\hline-0.1139 & 0.0053 & -0.3251 & -0.0751 & 1.4422 & -0.6194 & -0.0133 & 134.1 \\
\hline-0.1139 & 0.0053 & -0.3281 & -0.0724 & 1.5491 & -0.7181 & -0.0160 & 132.2 \\
\hline-0.1139 & 0.0053 & -0.3251 & -0.0697 & 1.6301 & -0.7899 & -0.0133 & 130.2 \\
\hline-0.1139 & 0.0053 & -0.3402 & -0.0724 & 1.5347 & -0.7540 & -0.0160 & 70.6 \\
\hline-0.1139 & 0.0053 & -0.3402 & -0.0724 & 1.5347 & -0.7540 & -0.0133 & 70.6 \\
\hline-0.1139 & 0.0053 & -0.3462 & -0.0805 & 1.4682 & -0.7121 & -0.0133 & 49.1 \\
\hline-0.1108 & 0.0053 & -0.3522 & -0.0912 & 1.4017 & -0.6673 & -0.0160 & 32.3 \\
\hline-0.1078 & -0.0053 & -0.3552 & -0.0992 & 1.3584 & -0.6074 & -0.0160 & 14.5 \\
\hline-0.1047 & -0.0132 & -0.3552 & -0.1073 & 1.3353 & -0.5536 & -0.0160 & 2.7 \\
\hline-0.1078 & -0.0132 & -0.3552 & -0.1100 & 1.3324 & -0.5536 & -0.0160 & 2.1 \\
\hline-0.1047 & -0.0158 & -0.3552 & -0.1127 & 1.3208 & -0.5536 & -0.0160 & $\begin{array}{c}-0.2 \\
\end{array}$ \\
\hline-0.1047 & -0.0158 & -0.3552 & -0.1127 & 1.3208 & -0.5536 & -0.0160 & -0.2 \\
\hline
\end{tabular}

